\title{
Urbanização e Impactos Ambientais: Histórico de Inundações e Alagamentos na Bacia do Gregório, São Carlos - SP
}

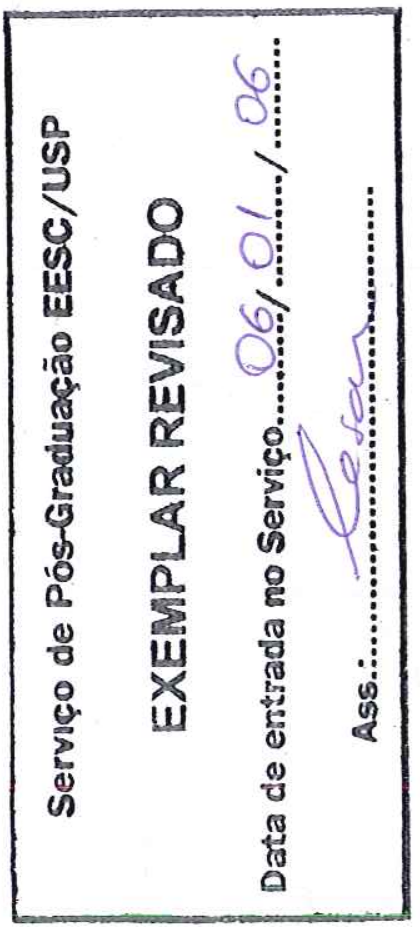

\section{Heloisa Ceccato Mendes}

Dissertação apresentada à Escola de Engenharia de São Carlos da Universidade de São Paulo, como parte dos requisitos para obtenção do título de Mestre em Ciências da Engenharia Ambiental

Orientador:

Prof. Dr. Eduardo Mario Mendiondo
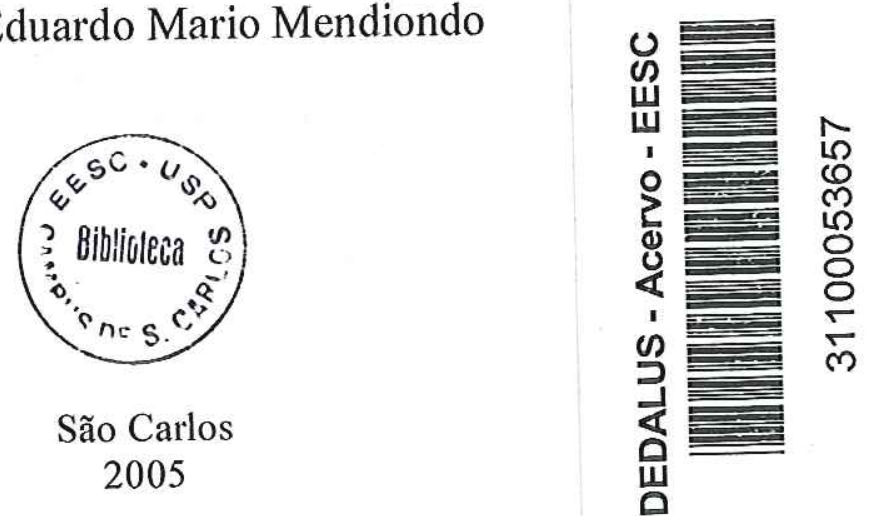

São Carlos 2005 


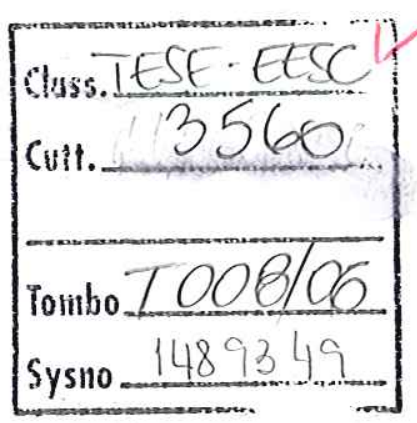

Ficha catalográfica preparada pela Seção de Tratamento da Informação do Serviço de Biblioteca - EESC/USP

1. Planejamento urbano. 2. Impactos ambientais. 3. Águas urbanas. 4. Histórico de inundações. 5. Bacias urbanas. I. Título. 


\section{AGRADECIMENTOS}

Ao Professor Eduardo Mario Mendiondo, pela orientação desse trabalho e pelo exemplo de generosidade como pesquisador e, sobretudo, como pessoa.

A Tatiana e Issac, pela freqüente disponibilidade em auxiliar na etapa de levantamento das notícias de jornal, contribuindo para a realização desse trabalho.

Aos professores responsáveis pelas disciplinas cursadas, pelo conhecimento compartilhado. Ao Prof. Marcelo Pereira, em especial, pelo apoio quando necessário.

Ao Prof. Evaldo Luiz Gaeta Espíndola, pelo empenho na coordenação do PPG-SEA.

Aos funcionários do PPG-SEA, pelo auxílio nos momentos necessários, em especial Claudete, Wellington, Achiles, Mara, Amândio e Marcelo.

Aos funcionários do SHS, em especial Rose e Bruno, pela gentileza.

Aos funcionários da Universidade de São Paulo, em especial às bibliotecárias da EESC-USP pela competência e disponibilidade em ajudar.

À Professora Daisy Rebelatto, pela ajuda no início da pesquisa.

Ao pesquisador Marcelo Montaño (Minduim), pela ajuda com alguns dados.

Ao Sr. Odo Primavesi, da Embrapa, e à engenheira Soraia Matsunaga, do DAEE, pelas informações fornecidas.

Ao Sr. José João (Alemão), pela paixão pelos registros históricos e pela inestimável atenção dispensada.

Aos funcionários da Fundação Pró Memória de São Carlos, pela auxílio durante a realização dos levantamentos.

Ao Professor e Secretário de Obras Renato Anelli, pela confiança profissional depositada e, principalmente, por ser o responsável por meu primeiro contato com a questão do histórico de inundações em São Carlos. 
A todos os companheiros da Prefeitura Municipal de São Carlos, com quem pude dividir a oportunidade de desenvolvimento profissional e pessoal. A toda a equipe de elaboração do Plano Diretor de São Carlos, pela convivência e enorme aprendizado, fazendo crescer os interesses pelas questões urbanas e ambientais que me levaram a este trabalho.

Aos colegas do NIBH Fred, Paulino, Pedro, Renata, Rodrigo Boldrin e Elisânea, pelo auxílio técnico à pesquisa.

A cada um dos colegas do NIBH, em especial Melissa, Fred, Paulino e Juliana Pontes pela convivência e oportunidade de nos tornarmos pessoas melhores a cada dia.

Aos/amigos queridos, por compartilharem comigo os leitos altos e baixos da vida.

Ao tio Armando, pelos jornais guardados e pelo interesse pelas coisas da minha vida.

À minha mãe Dolores e ao meu pai Cláudio, por contribuírem para cada uma das minhas conquistas, grandes ou pequenas, de maneira decisiva.

À minha avó Lola, pela torcida de todo dia.

À Marina, por ser minha irmã por opção, e não somente por parentesco.

Ao Francisco, por fazer com que tempo e distância sejam apenas palavras. 


\section{SUMÁRIO}

\section{LISTA DE FIGURAS - i}

LISTA DE TABELAS - vi

LISTA DE QUADROS - vii

LISTA DE SIGLAS - viii

RESUMO - ix

ABSTRACT - $\mathrm{x}$

1. INTRODUÇÃO - 01

2. OBJETIVOS - 02

2,1. Gerais - 02

2.2. Específicos -02

\section{REVISÃO BIBLIOGRÁFICA - 03}

3.1. Enchentes, Inundações e Alagamentos: Conceitos - 03

3.2. Impactos de Inundações - 05

3.2.1. Panorama Mundial - 05

3.2.2. Panorama Brasileiro - 09

3.3. Urbanização - 11

3.3.1. A Influência da urbanização nos impactos de inundações - 11

3.3.1.1. Impermeabilização do solo e aumento de escoamento por canais por diminuição do tempo de concentração da bacia - 12

3.3.1.2. Desorganização na implantação da infra-estrutura urbana - 13

3.3.1.3. Ocupação urbana e impermeabilização em áreas com risco de inundação - 16

3.3.2. Mitigação dos impactos de inundações urbanas - 17

3.3.3. O processo de urbanização no mundo -21

3.3.4. O processo de urbanização no Brasil - 23

\section{MATERIAIS E MÉTODOS - 33}

\subsection{Caracterização da Área de Estudo - 33}

4.1.1. Localização e Dinâmica Populacional do município de São Carlos - 33

4.1.2. As Bacias Hidrográficas em São Carlos - 35

4.1.3. A Sub-Bacia Hidrográfica do Córrego do Gregório - 36

4.2.Histórico da Expansão Urbana: São Carlos e Bacia do Gregório - 38

4.3.Levantamento de datas em que possivelmente ocorreram inundações ou alagamentos - 39

4.3.1. Datas indicadas por dados históricos monitorados - 39

4.3.2. Datas indicadas por fontes complementares - 45

4.4.Levantamento de Notícias de Jornais - 47

4.5.Organização e Análise das Notícias Encontradas - 48

4.6.Integração entre Métodos Utilizados, Resultados e Objetivos - 49 


\section{RESULTADOS E DISCUSSÃO - 50}

5.1. Histórico da expansão urbana de São Carlos - 50

5.2. Histórico da ocupação urbana da Bacia do Gregório - 55

5.3. Histórico da região do Mercado Municipal - 66

5.4. Avaliação dos métodos utilizados para o levantamento de notícias de jornal - 76

5.5. Notícias de jornal encontradas -77

5.6. Análise dos dados contidos nas notícias de jornal -81

5.6.1. Níveis Máximos atingidos - 83

5.7. Tempo de retorno médio de recorrência de eventos -84

5.8. Relações entre urbanização e ocorrência de inundações e alagamentos -85

5.9. Avaliação histórica dos tipos de medidas mitigadoras aplicadas na Bacia do Gregório - 90

\section{CONCLUSÕES - 95}

7. RECOMENDAÇÕES - 97

8. REFERÊNCIAS BIBLIOGRÁFICAS - 99

\section{ANEXO 01}

Fotos das Notícias: Evento específico de Inundação ou Alagamento na Bacia do Gregório - 105

ANEXO 02

Fotos das Notícias: Intervenções e Obras relacionadas à drenagem na Bacia do Gregório - 192

ANEXO 03

Fotos das Notícias: Inundações e alagamentos em demais pontos da cidade de São Carlos - 233

ANEXO 04

Fotos das Notícias: Notícias gerais sobre o tema - 256

ANEXO 05

Análise das Notícias: Evento específico de Inundação ou Alagamento na Bacia do Gregório - 287

ANEXO 06

Análise das Notícias: Intervenções e Obras relacionadas à drenagem na Bacia do Gregório - ver CD

ANEXO 07

Análise das Notícias: Inundações e alagamentos em demais pontos da cidade de São Carlos - ver CD

ANEXO 08

Análise das Notícias: Notícias gerais sobre o tema - ver CD

ANEXO 09

Gráficos sujeitos a complementação de dados - ver CD 
ANEXO 10

Tabelas de dados monitorados do SIGRH e EMBRAPA - ver CD

\section{ANEXO 11}

Vídeos de inundação ocorrida na Bacia do Gregório em 30/01/2004 - ver CD Fonte: Projeto FINEP/CT-HIDRO/EESC/USP-DAEE/SP - CNPq - 01.02.0086.00. 


\section{LISTA DE FIGURAS}

\section{Capítulo 3 - REVISÃO BIBLIOGRÁFICA}

Figura 3.1 - Esquemas ilustrativos de elevação do nível de um rio provocada pelas chuvas, do nível normal até o nível de uma inundação - 3

Figura 3.2 - Esquema ilustrativo sobre eventos de Alagamento - 4

Figura 3.3 - Alagamento na região do Mercado Municipal, em frente à Praça dos Voluntários, em $2002-5$

Figura 3.4 - Catástrofes Naturais no mundo 1985-1999-6

Figura 3.5 - Pessoas afetadas por desastres naturais - 7

Figura 3.6 - Ocorrência de secas, inundações e tempestades: uma visão geográfica dos últimos 30 anos -7

Figura 3.7 - Notícia do jornal Estado de São Paulo: protesto de moradores sobre veiculação de leptospirose por inundação urbana no bairro do Butantã, São Paulo - SP - 9

Figura 3.8 - Municípios atingidos por inundações com destaque para o estado de São Paulo (1998-1999) - 10

Figura 3.9 - Balanço da chuva de janeiro a março de 2004, com destaque para o Estado de São Paulo - 11

Figura 3.10 - Gráfico da variação das vazões de pico, variando a quantidade de áreas verdes (florestas e parques) em uma sub-bacia embutida na Bacia do Gregório, para uma chuva com $\mathrm{Tr}=25$ anos -12

Figura 3.11 - Localização das pontes da R. Episcopal e R. D. Alexandrina, sobre o Córrego do Gregório - 13

Figura 3.12 - Foto de preparação para o início das obras na ponte da R. Episcopal - 14

Figura 3.13 - Foto durante a realização das obras na ponte da R. Episcopal - 14

Figura 3.14 - Notícia de jornal publicada após a conclusão da obra - 15

Figura 3.15 - Notícia publicada sobre obra a ser realizada na ponte da R. D. Alexandrina para melhorar o escoamento das águas - 15

Figura 3.16 - Áreas de Preservação Permanente ocupadas pela urbanização em São Carlos 16 
Figura 3.17 - Evolução dos objetivos de obras de drenagem urbana - 19

Figura 3.18 - Comparação entre os conceitos de drenagem urbana: canalização e reservação $-20$

Figura 3.19 - Exemplo de variáveis de avaliação de cenários para a recuperação ambiental 21

Figura 3.20 - Evolução da População de grandes metrópoles da Europa e da América, com destaque para cidades de países em Desenvolvimento: São Paulo e Buenos Aires - 23

Figura 3.21 - Desenho do Vale do Anhangabaú em fins do séc. XIX - 25

Figura 3.22 - Vale do Anhangabau em 1954 - 25

Figura 3.23 - Rio Pinheiros antes e depois da retificação - 27

Figura 3.24 - Processo de retificação dos rios e ocupação das várzeas em São Paulo: confluência dos rios Tamanduateí e Tietê - 28

Figura 3.25 - Córrego do Monjolinho em 1970 e em 2003 - 29

Figura 3.26 - Córrego do Tijuco Preto em 1982 e em 2002 - 30

Figura 3.27 - Foto de inundação na Marginal Tietê, São Paulo - SP, em 25 de maio de 2005 $-32$

Figura 3.28 - Inundação na Marginal Tietê em 25 de maio de 2005: Caminhão em baixo da ponte das Bandeiras - 32

\section{Capítulo 4 - MATERIAIS E MÉTODOS}

Figura 4.1 - Localização do município de São Carlos - 33

Figura 4.2 - Taxa Geométrica de Crescimento de 1940 a 2000: São Carlos, Estado de São Paulo e Brasil - 34

Figura 4.3 - Evolução da porcentagem da População Urbana e Rural em São Carlos de 1940 a $2004-35$

Figura 4.4 - Bacias Hidrográficas no Município de São Carlos - 35

Figura 4.5 - Bacias Hidrográficas no Município de São Carlos, com destaque para o Córrego do Gregório - 36 
Figura 4.6 - Bacias Urbanas de São Carlos, com destaque para a Bacia do Gregório e região do Mercado Municipal - 37

Figura 4.7 - Inundações na região do Mercado Municipal, em 2001 e em 2002 - 37

Figura 4.8 - Localização aproximada das estações de monitoramento cujos dados foram utilizados -40

Figura 4.9 - Inundação na Bacia do Gregório em 30 de janeiro de 2004 - 43

Figura 4.10 - Notícia do jornal A Tribuna, sobre inundação de 30 de janeiro de 2004-43

Figura 4.11 - Localização da Padaria Caiçara - 47

\section{Capítulo 5 - RESULTADOS}

Figura 5.10 - Resultado da avaliação da Expansão Urbana de São Carlos e ocupação de margens de córregos urbanos - 51

Figura 5.2 - Resultado da Evolução de Área Loteada em São Carlos e Evolução da População, de 1940 a $2002-52$

Figura 5.11 - Resultado do Histórico da Taxa de Urbanização Percápita [m2/(hab.ano)] em São Carlos, no período de 1940 a 2002 - 53

Figura 5.4 - Proposta de anel viário para São Carlos, baseada na implantação de avenidas de fundo de vale -54

Figura 5.5 - Construção da avenida marginal ao Córrego do Gregório, em 1974, próximo à área atualmente ocupada pelo SESC - 55

Figura 5.6 - Expansão Urbana de São Carlos entre 1940 e 2002, com indicação do limite da Bacia do Gregório - 56

Figura 5.7 - Evolução de áreas loteadas em São Carlos e na Bacia do Gregório - 57

Figura 5.8 - Resultado da avaliação da ocupação urbana da Bacia do Gregório entre 1940 e 2004, com destaque para a região do Mercado Municipal - 58

Figura 5.9 - Resultado da avaliação do processo de ocupação urbana da Bacia do Gregório: urbanização em 1962 - 59

Figura 5.10 - Resultado da avaliação do processo de ocupação urbana da Bacia do Gregório: urbanização em 1998 - 60

Figura 5.11 - Interpretação de transformações na vista da Avenida São Carlos para o vale do Córrego do Gregório, a partir da margem esquerda: em 1898, 1929 e 2004 - 61 
Figura 5.12 - Resultado de Taxa de Urbanização (km2/ano) em São Carlos e na Bacia do Gregório no período de 1940 a 2002-62

Figura 5.13 - Foto de notícia de jornal sobre o desenvolvimento de projeto de canalização dos córregos do Gregório e Simeão, em 1972 - 64

Figura 5.14 - Vista aérea do fundo de vale do Córrego do Gregório em 2003 - 65

Figura 5.15 - Inauguração da Praça dos Voluntários, em 1934 - 66

Figura 5.16 - Interpretação de foto da região do Mercado Municipal em 1950, com indicação aproximada do curso do Córrego do Gregório - 67

Figura 5.17 - Interpretação de foto do Mercado Municipal antigo e Construção do Mercado atual em 1967, com indicação aproximada do curso do Córrego do Gregório - 68

Figura 5.18 - Interpretação de fotos da região do Mercado Municipal em 1962, 1972, 1998 e 2003-69

Figura 5.19 - Interpretação de fotos da década de 1960, com indicação de traçado do Córrego Simeão. Fonte das fotos: Casa da Agricultura e Foto Arte. Elaboração: Heloisa Ceccato Mendes - 70

Figura 5.20 - Avaliação de transformações área em frente ao local onde se situa atualmente o Mercado Municipal: canalização na década de 1970, e em 2004 - 71

Figura 5.21 - Avaliação de transformações entre Rua Episcopal e Rua 9 de Julho: em 1898, durante tamponamento, e em 2004-72

Figura 5.22 - Avaliação de transformações na vista para o Mercado Municipal a partir da esquina da Av. São Carlos com R. Geminiano Costa, localizada na margem esquerda: 1908 e $2004-73$

Figura 5.23 - Detalhe de notícia de jornal sobre inundação na Bacia do Gregório, em 1932 $-74$

Figura 5.24 - Avaliação de transformações na vista da Rua Geminiano Costa (margem esquerda) a partir da Av. São Carlos: 1940 e $2004-75$

Figura 5.25 - Foto de realização de limpeza do corredor que separava os dois edifícios do Mercado Municipal antigo, localizado na margem esquerda do córrego, após inundação em $1947-76$

Figura 5.26 - Detalhe de notícia sobre danos causados por evento em 1947 - 82

Figura 5.27 - Detalhe de notícia sobre danos causados por evento em 1974 - 82 
Figura 5.28 - Detalhe de notícia sobre danos causados por evento em 1998 - 83

Figura 5.29 - Níveis máximos atingidos por eventos históricos com base em informações de notícias de jornal -84

Figura 5.30 - Número de ocorrências nos anos em que foram encontrados registros de eventos entre 1940 e $2004-85$

Figura 5.31 - Evolução da População Urbana de São Carlos e do Número Acumulado de Inundações na Bacia do Gregório - 86

Figura 5.32 - Relação entre Área Urbanizada Acumulada e Número Acumulado de Ocorrências de inundações e alagamentos, com indicação de estágios de desenvolvimento urbano da bacia - 87

Figura 5.33 - Comparação entre 1) Evolução da Taxa de Urbanização (km2 / ano), 2) Número de Eventos ocorridos classificados por anos, e 3) Média de ocorrência dos períodos (no. de ocorrências / ano) para cada um dos estágios de urbanização da Bacia do Gregório. $-88$

Figura 5.34 - Interpretação para a Bacia do Gregório de diagrama de evolução histórica de objetivos das intervenções relacionadas à drenagem urbana -90

Figura 5.35 - Avaliação da aplicação de conceitos de Canalização e de Reservação na Bacia do Gregório - 91

Figura 5.36 - Requalificação de área central próxima ao Mercado Municipal, realizada em $2003-92$

Figura 5.37 - Projeto de recuperação ambiental e urbana para trecho do Córrego Tijuco Preto -93

Figura 5.38 - Foto de catálogo representando o aspecto final da requalificação - 93

Figura 5.39 - Foto de catálogo representando aspecto final dos degraus de dissipação - 93 


\section{LISTA DE TABELAS}

\section{Capítulo 3 - REVISÃO BIBLIOGRÁFICA}

Tabela 3.1 - Número de Inundações por Região no período de 1973 a 2002 - 08

Tabela 3.2 - Evolução da População Urbana 1955 a 2015 - 22

\section{Capítulo 4 - MATERIAIS E MÉTODOS}

Tabela 4.1 - Período de utilização de dados monitorados das estações do SIGRH e EMBRAPA - 41

Tabela 4.2 - Relações entre durações. Fonte: adaptado de CETESB apud Tucci (2002) - 42

Tabela 4.3 - Datas com ocorrência de Precipitação Diária maior ou igual a $70 \mathrm{~mm}$ no período de 1940 a 2004 - 45

Tabela 4.4 - Notícias de jornal de 1970 a 1988 sobre eventos na Bacia do Gregório (Dados: Rebelatto, 1991) - 46

Tabela 4.5 - Datas de eventos de inundações na região do Mercado Municipal de São Carlos, registradas pelo proprietário da Padaria Caiçara. Fonte: Barros, 2005-47

Tabela 4.6 - Modelo de tabela preenchido na etapa de análise das notícias encontradas - 49

\section{Capítulo 5 - RESULTADOS}

Tabela 5.1 - Número de notícias encontradas, classificadas de acordo com seu conteúdo - 77

Tabela 5.2 - Notícias encontradas em jornal sobre inundações na Sub-Bacia do Gregório entre 1940 e 2004 - 77

Tabela 5.3 - Número de eventos ocorridos na Bacia do Gregório, classificados por anos. - 79

Tabela 5.4: Notícias encontradas em jornal sobre inundações na Sub-Bacia do Gregório em 1932 - 80

Tabela 5.5: Notícias encontradas em jornal sobre inundações na Sub-Bacia do Gregório em 2005 - 81 


\section{LISTA DE QUADROS}

\section{Capítulo 3 - REVISÃO BIBLIOGRÁFICA}

Quadro 3.1 - Conceito de canalização x conceito de reservação - 18

\section{Capítulo 4 - MATERIAIS E MÉTODOS}

Quadro 4.1 - Estratégia metodológica da pesquisa relacionada com Fontes de Informação - 38

Quadro 4.2 - Síntese da Integração entre Métodos utilizados, Resultados e Objetivos - 49

\section{Capítulo 5 - RESUL'TADOS}

Quadro 5.1 - Caracterização de períodos de urbanização da Bacia do Gregório 


\section{LISTA DE SIGLAS}

SIGRH - Sistema Integrado de Gerenciamento de Recursos Hídricos de São Paulo P Diária - Precipitação Diária

APPs - Áreas de Preservação Permanente 


\section{RESUMO}

Com o objetivo de promover a reflexão sobre os impactos ambientais ocasionados pela urbanização, avalia-se a relação entre expansão urbana e histórico de ocorrência de inundações e alagamentos em uma cidade média brasileira: São Carlos - SP.

O levantamento de notícias históricas de jornal tem como objetivo resgatar informações sobre transformações físico-territoriais e ocorrência de inundações e alagamentos em uma bacia urbana sem sistematização de dados históricos. Os métodos utilizados relacionam dados sobre evolução da urbanização, população e de ocorrência de inundações e alagamentos na Bacia do Gregório, especificamente no período de 1940 a 2004.

Os resultados demonstram que a urbanização da bacia teve influência no aumento da freqüência de inundações se alagamentos, bem como no aumento da magnitude de seus impactos. Tais resultados indicam que a inclusão do histórico da ocupação territorial é um elemento crucial no processo de tomada de decisões para o planejamento territorial futuro. A abordagem histórica da drenagem urbana fornece subsídios para a implementação de políticas públicas que objetivem a recuperação ambiental e a redução dos impactos gerados por inundações e alagamentos.

Palavras Chave: planejamento urbano, impactos ambientais, águas urbanas, histórico de inundações, bacias urbanas. 


\section{ABSTRACT}

To promote reflections about environmental impacts caused by urban occupation, the history process of urban development and flood events at a scale of a medium Brazilian (São Carlos - SP) city is outlined.

Historic documentation, thereby retrieving past information, is included in order to show up territorial transformations related to inundation frequency increase in flood prone areas. The Methodology consists on the relation of data about the evolution of urbanized area, population and occurrence of flood events on the Gregorio basin, most specifically during the period between 1940 and 2002.

Results show that the urbanization of the basin has influence on the increase on flood events frequency, and on the increase of its impacts. The results also show that the inclusion of historical occupation is an asset for decision making towards future planning. Historic elements support public policies looking forward to either river recovering or flood mitigating devices.

Key-Words: urban planning, environmental impacts, urban waters, flood events history, urban basins. 


\section{INTRODUÇÃ̃}

Entre 1985 e 1999, as inundações foram responsáveis por 53\% das mortes causadas por catástrofes naturais no mundo, o correspondente a cerca de 302.084 mortes. No mesmo período, os prejuízos causados por inundações corresponderam a $29 \%$ dos prejuízos causados por catástrofes naturais, o equivalente a US\$ 275 bilhões (Berz, 2000).

A América Latina foi a terceira região do mundo com maior número de inundações entre 1973 e 2002, com registro de 240 eventos, o equivalente a $11,8 \%$ do total de inundações ocorridas no mundo nesse período (International Strategy For Disaster Reduction; United Nations, 2003).

A freqüente ocorrência de inundações em várias cidades de todo o mundo sinaliza para a necessidade de reflexão sobre seus processos históricos de expansão, gerando crescente impermeabilização do solo, ocupação de fundos de vale e de áreas alagáveis de rios e córregos urbanos.

Os prejuízos anuais causados por inundações no Brasil são provavelmente superiores a US\$ 1 bilhão (MCT/CGE, 2002). Entre janeiro e março de 2004, as inundações atingiram 1.224 municípios brasileiros, destruindo 17.510 casas, danificando 95.523 casas e atingindo 376.987 pessoas (FGTS..., 2004). Tais dados demonstram a necessidade de implementação de medidas mitigadoras dos impactos gerados por inundações e de reflexão sobre o modelo de ocupação territorial que tem sido adotado nas cidades brasileiras, preconizando a sobreposição do homem e da técnica ao meio. A realização de levantamentos históricos que relacionem o processo de expansão urbana com a incidência de inundações visa ao fornecimento de dados que subsidiem tal processo.

A comparação do crescimento demográfico de São Carlos com o do Estado de São Paulo e do Brasil, no período entre 1981 e 2000, demonstra que o município se destaca sob tal aspecto. Nesse período, a população de São Carlos cresceu mais do que a do Estado de São Paulo e a do Brasil, apresentando taxa geométrica de crescimento populacional superior à média do Estado de São Paulo e do Brasil (IBGE, 1981; 2000).

A cidade de São Carlos foi fundada em 4 de novembro de 1857. No entanto, a Seção de Cadastro, pertencente à SMHDU - Secretaria Municipal de Habitação e Desenvolvimento Urbano da Prefeitura Municipal de São Carlos foi criada somente na década de 1970. Desse modo, a administração pública conta com uma falta sistemática de registros históricos sobre a cidade. 
Esta pesquisa visa a contribuir para a reversão do processo de perda de memória pelo qual São Carlos tem passado, buscando estabelecer o reconhecimento da cidade a partir de sua história e fornecer subsídios para o planejamento urbano, tendo como objetivo resgatar e discutir o processo histórico de expansão urbana e sua relação com a incidência de inundações. Analisam-se as taxas de crescimento das áreas loteadas e da população local, visando avaliar a magnitude de inundações passadas em bacias sem registros de dados sistematizados (SIVAPALAN et al, 2003).

Como referência, é tomada uma bacia hidrográfica brasileira: a Bacia do Gregório, em São Carlos - SP, onde se situa um dos principais pontos de inundação da cidade de São Carlos, a área do Mercado Municipal. O processo histórico de ocupação urbana da bacia será apresentado de forma geral, envolvendo as áreas de drenagem, fora do alcance das inundações, e as áreas de fundo de vale, sujeitas às inundações. Neste trabalho são realizados levantamentos históricos de eventos que ocasionaram danos à região do Mercado Municipal de São Carlos, sejam estes de inundações ou de alagamentos.

\section{OBJETIVOS}

\subsection{Gerais}

- Analisar como o processo histórico de expansão urbana, por meio da ocupação dos fundos de vale e crescente impermeabilização do solo da bacia, se relaciona com as ocorrências de inundações e alagamentos;

- A partir da análise anterior, fornecer subsídios para a implementação de políticas públicas visando à mitigação das inundações urbanas.

\subsection{Específicos}

- Analisar o processo de expansão da cidade de São Carlos, SP, com especial atenção à ocupação de fundos de vale urbanos e aumento da impermeabilização do solo na Bacia do Gregório;Sistematizar informações de notícias de jornal sobre níveis máximos atingidos e danos causados por eventos históricos de inundações e alagamentos ocorridos entre 1940 e 2004 na Bacia do Gregório, de modo a constituir um banco de dados;Relacionar ocorrência de inundações e alagamentos com estágios de urbanização da bacia, fornecendo subsídios para implementação de medidas mitigadoras e para elaboração de cenários de planejamento futuro. 


\section{REVISÃO BIBLIOGRÁFICA}

\subsection{ENCHENTES, INUNDAÇÕES E ALAGAMENTOS: CONCEITOS}

Goerl e Kobyiama (2005) destacam que existem diversos termos relacionados ao fenômeno das inundações. Em função de traduções equivocadas e adaptações mal feitas de termos provenientes de línguas estrangeiras, esses termos são freqüentemente usados equivocadamente. As palavras "cheia" e "enchente" têm como origem o verbo encher, do latin implere, que significa "ocupar o vão, a capacidade ou a superfície", "tornar cheio ou repleto". Portanto, é correto dizer que ocorreu uma enchente quando as águas do rio elevam-se até a altura de suas margens, porém sem transbordar. Quando ocorre transbordamento, é correto dizer que ocorreu inundação. A Figura 3.1 demonstra a diferença entre as enchentes e inundações.

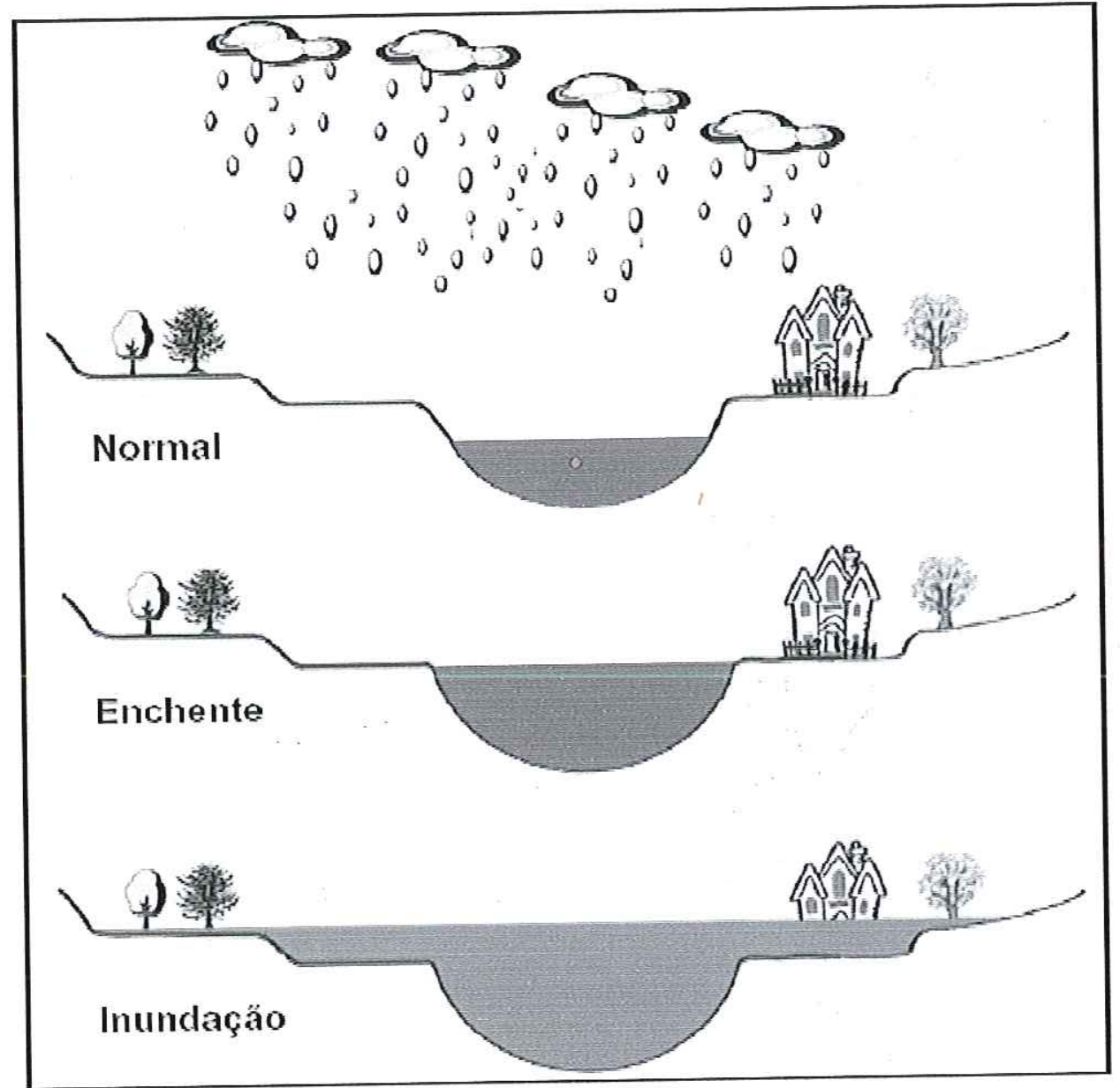

Figura 3.1 - Esquemas ilustrativos de elevação do nível de um rio provocada pelas chuvas, do nível normal até o nível de uma inundação. Fonte: Goerl \& Kobyiama (2005). 
Segundo Carlos Tucci (2003) ${ }^{3.1}$, o escoamento pluvial pode produzir Inundações de áreas ribeirinhas e Inundações devido à urbanização, dois processos que podem ocorrer isoladamente ou combinados. Geralmente os rios apresentam dois leitos: o leito menor, onde a água escoa a maior parte do tempo, e o leito maior, que é inundado com risco geralmente entre 1,5 e 2 anos. As inundações de áreas ribeirinhas ocorrem pelo processo natural no qual o rio escoa pelo seu leito maior, sendo uma decorrência natural do ciclo hidrológico. Com a ocupação urbana do leito maior, local caracterizado como área de risco, os impactos de inundações tornam-se freqüentes. Quanto à ocorrência dos dois tipos de inundações, o autor aponta que a ocorrência de inundações ribeirinhas tem sido registrada junto com a história do desenvolvimento humano, enquanto as inundações devido à urbanização têm sido mais freqüentes neste século, em função do aumento significativo da urbanização e da tendência dos engenheiros de drenarem o escoamento pluvial o mais rápido possível das áreas urbanizadas.

Além das enchentes e inundações, podem ocorrer também eventos de alagamentos, que são caracterizados pelo acúmulo de água nas margens, porém sem a ocorrência de extravasamento do rio. Nesses casos, o acúmulo de águas nas margens se dá, portanto, não em função do extravasamento do rio ou canal, mas sim da dificuldade de escoamento, que pode ser determinada pela topografia da área. A Figura 3.2 apresenta um esquema ilustrativo da ocorrência de um evento de alagamento.

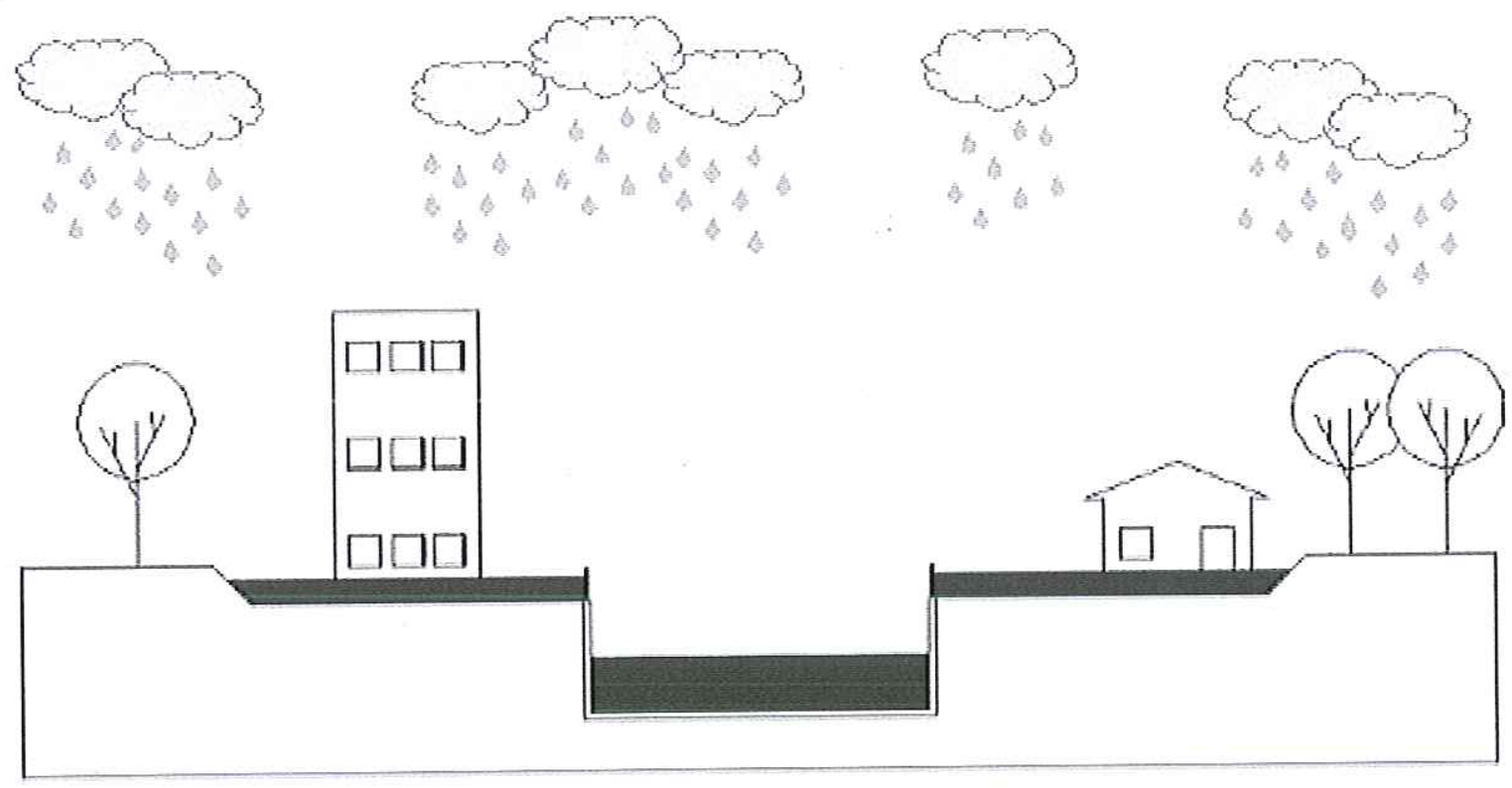

Figura 3.2 - Esquema ilustrativo sobre eventos de Alagamento. Elaboração: Heloisa Ceccato Mendes

${ }^{3,1}$ TUCCI, C. E. M. Águas Urbanas. In: TUCCI, C. E. M.; BERTONI, J. C. (org). Inundações urbanas na América do Sul. Porto Alegre:, Associação Brasileira de Recursos Hídricos, 2003, 471 p. 
Na Região do Mercado Municipal de São Carlos é freqüente a ocorrência de alagamentos. A Figura 3.3 retrata um exemplo de evento de alagamento ocorrido na área de estudo em 2002, na qual pode-se observar o acúmulo de água na margem do Córrego do Gregório associado à ausência de extravasamento do canal.

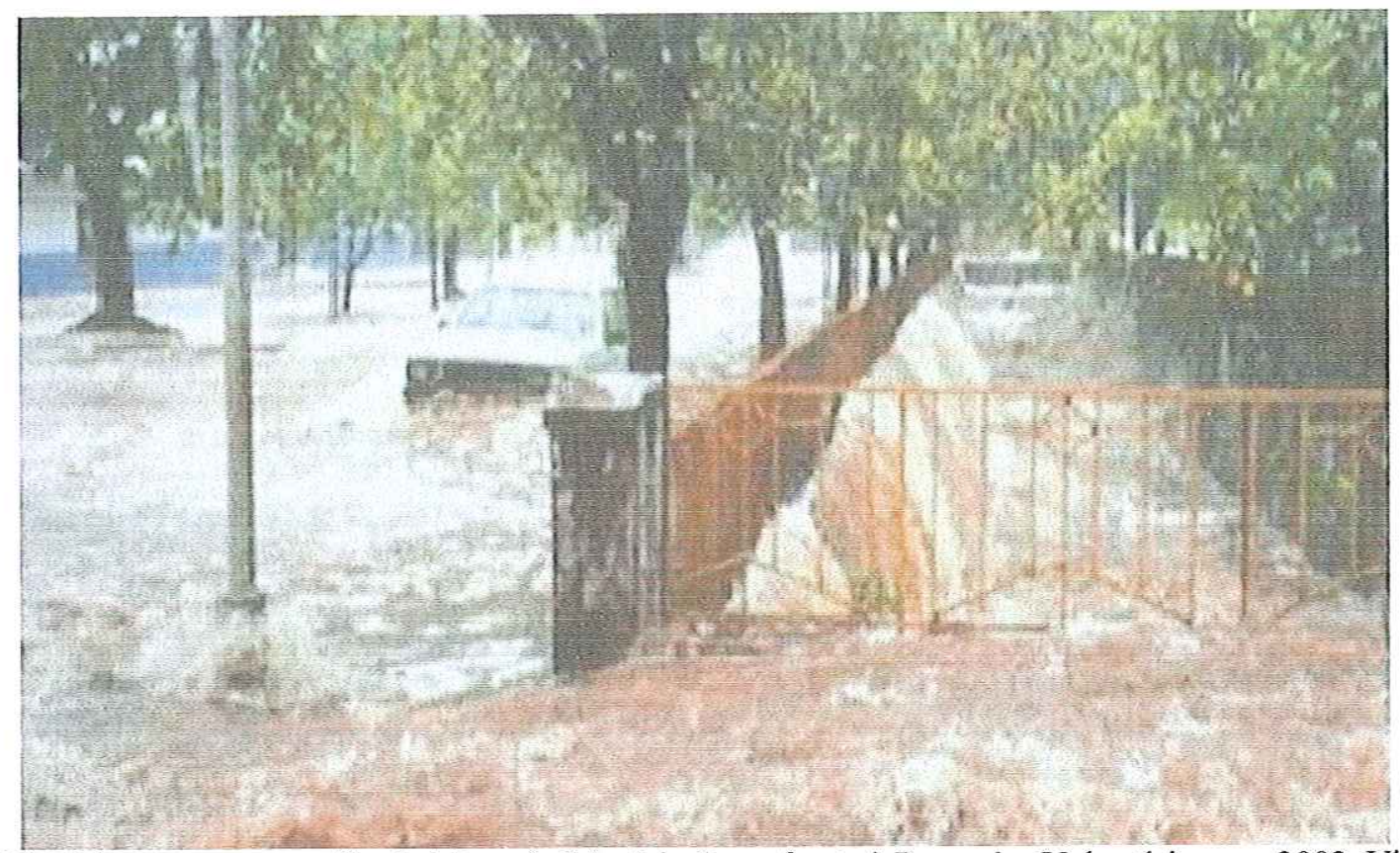

Figura 3.3 - Alagamento na região do Mercado Municipal, em frente à Praça dos Voluntários, em 2002. Vista para jusante. Fonte: CABALLERO (2004) ${ }^{32}$.

Os resultados apresentados neste trabalho correspondem a eventos que causaram algum tipo de dano na região do Mercado Municipal, sejam estes de inundações ou de alagamentos.

\subsection{IMPACTOS DE INUNDAÇÕES}

\subsubsection{Panorama Mundial}

Segundo Gerhard Berz (2000), mais de 250 bilhões de dólares foram empregados ,nos últimos dez anos, na compensação dos danos causados por inundações. Além disso, uma comparação entre as inundações e outros riscos naturais no período de 1985 a 1999, expressa na Figura 3.4, indica grande expressividade desses eventos:

\footnotetext{
${ }^{32}$ Informação fornecida por Caballero em São Carlos, em 2004. O Sr. Pedro Caballero é Coordenador Regional Adjunto de Defesa Civil do Estado de São Paulo da Central Redec I/12 e foi Chefe da Seção de Defesa Civil de São Carlos de 1992 a 2004.
} 


\section{(A) 8.737 eventos com perdas (B) Perdas economicas US\$ bn}

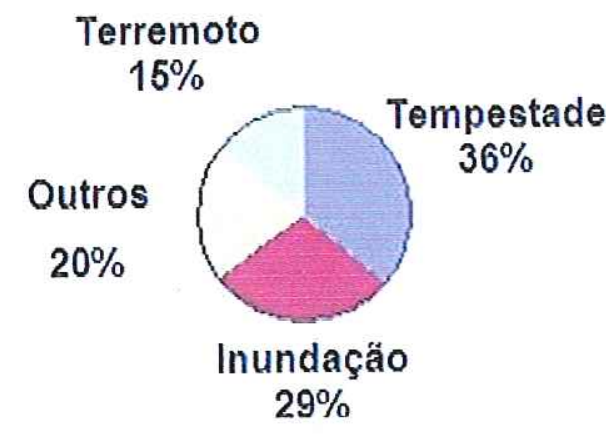

(C) $\underline{669.970 \text { mortes }}$

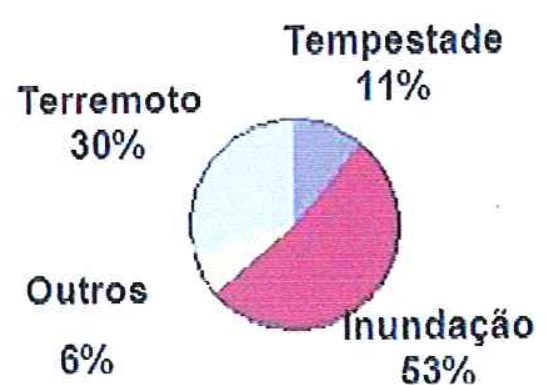

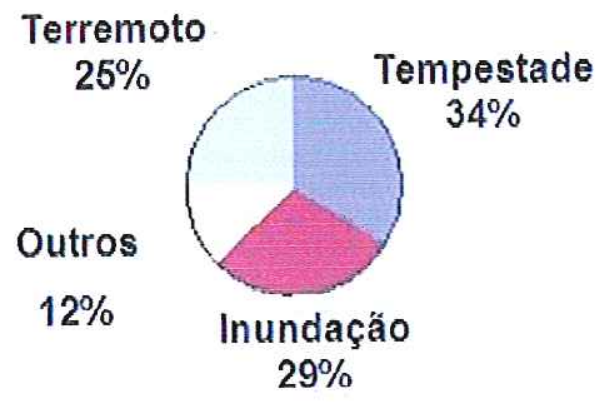

(D) Perdas asseguradas US $\$ 189 \mathrm{bn}$

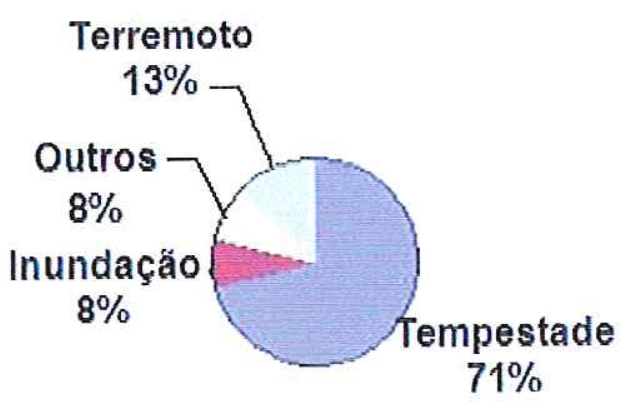

Figura 3.4 - Catástrofes Naturais no mundo 1985 - 1999. Fonte: adaptado de BERZ (2000)

Tais gráficos demonstram os seguintes dados sobre as inundações:

- Correspondem a cerca de um terço $29 \%$ das ocorrências de catástrofes naturais

- Causam mais da metade (53\%) das mortes causadas por catástrofes naturais, o correspondente a 382.085 mortes.

- São responsáveis por cerca de um terço (29\%) das perdas econômicas causadas às catástrofes naturais, o que corresponde a US\$275 bilhões.

- As perdas asseguradas relacionadas às inundações correspondem a apenas $10 \%$ do total de perdas asseguradas

O Gráfico D da Figura 3.4 indica que, dos prejuízos relacionados às inundações, apenas 8\% são asseguradas, o que corresponde a um valor de US\$15,12 bilhões. Portanto, relacionando esse valor aos US\$ 275 bilhões, correspondentes aos prejuízos causados por inundações no mundo entre 1985 e 1999 , verificamos que somente 5,5 \% das perdas econômicas causadas por inundações no mundo são asseguradas. 
Tal fato, associado à constatação de que o número de pessoas afetadas pelas inundações tem aumentado nos últimos tempos, de acordo com a Figura 3.5, constitui um quadro bastante preocupante.

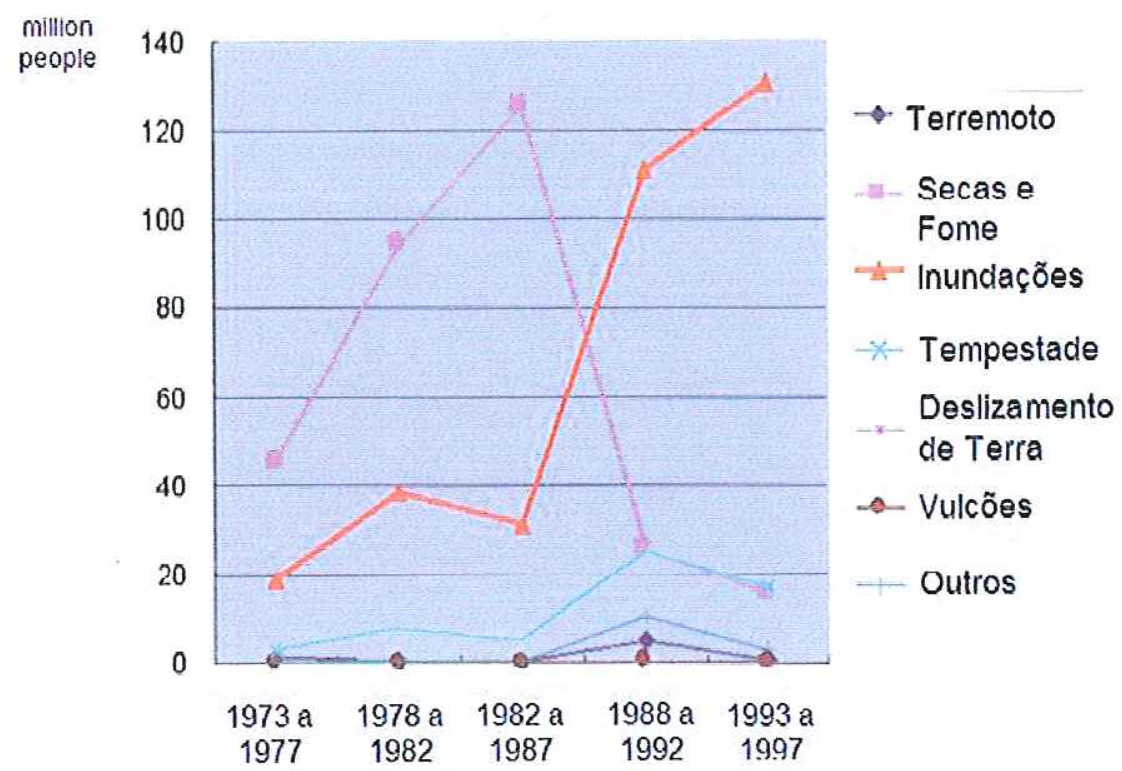

Figura 3.5 - Pessoas afetadas por desastres naturais. Fonte: INTERNATIONAL FLOOD NETWORK, (s/d)

Outro fato relevante é o de que as inundações atingem várias localidades do planeta, em maior ou menor grau (Figura 3.6).
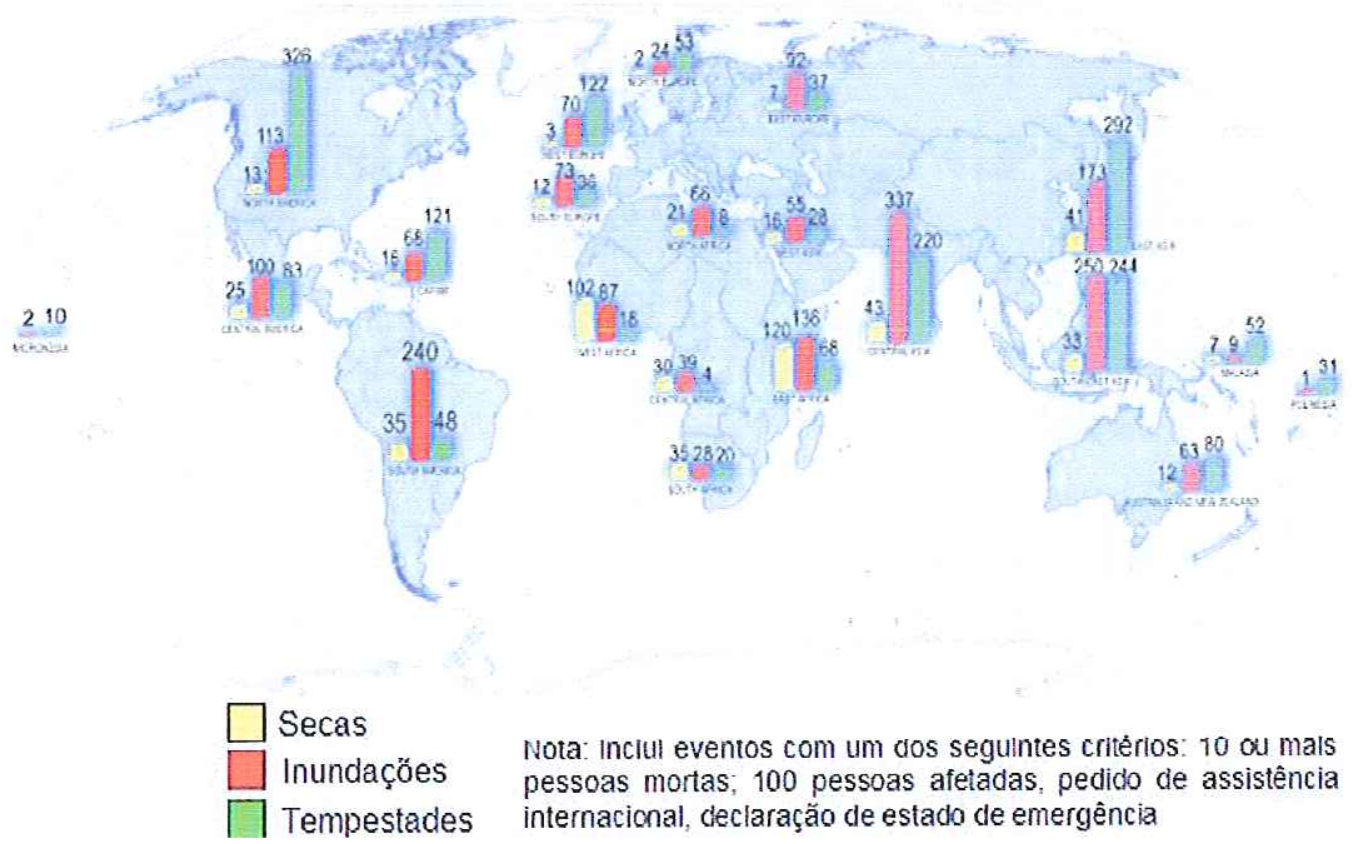

Nota: Inciul eventos com um dos seguintes critérios: 10 ou mals pessoas mortas; 100 pessoas afetadas, pedido de assistência internacional, declaraçăo de estado de emergência

Figura 3.6 - Ocorrência de secas, inundações e tempestades: uma visão geográfica dos últimos 30 anos. Fonte: adaptado de INTERNATIONAL STRATEGY FOR DISASTER REDUCTION; UNITED NATIONS (2003). 
A América do Sul foi a terceira região do mundo com maior número de incidência de inundações entre 1973 e 2002 (Tabela 3.1), com registro de 240 eventos, ou seja, 11,8\% do total de inundações ocorridas no mundo nesse período. Nesse período, a região com o maior registro de enchentes foi a Ásia Central, com 337 eventos, seguida pela Ásia do Sudeste, com 250 eventos), conforme a Tabela 3.1 .

Tabela 3.1 - Número de Inundações por Região no período de 1973 a 2002

\begin{tabular}{|c|c|c|}
\hline Regiăo & $\begin{array}{l}\text { Número de Inurdações } \\
\text { entre } 1973 \text { e } 2002\end{array}$ & $\begin{array}{l}\text { Porcentagem em re hção ao } \\
\text { Número Total de Inundaçóes no } \\
\text { Murdo entre } 1973 \text { e } 2002\end{array}$ \\
\hline América do Norte & 113 & $5,6 \%$ \\
\hline América Central & 100 & $4.9 \%$ \\
\hline América do Sul & 240 & $11,8 \%$ \\
\hline Canbe & 68 & $3,4 \%$ \\
\hline Europa do Leste & 92 & $4,5 \%$ \\
\hline Europa do Norte & 24 & $1,2 \%$ \\
\hline Europa do Oeste & 70 & $3,5 \%$ \\
\hline Europa do Sul & 73 & $3,6 \%$ \\
\hline Africa Central & 39 & $1.9 \%$ \\
\hline África do Leste & 136 & $6,7 \%$ \\
\hline Africa do Norte & 66 & $3,3 \%$ \\
\hline Africa do Oaste & 87 & $4,3 \%$ \\
\hline África do Sul & 28 & $1,4 \%$ \\
\hline Asia Central & 337 & $16,6 \%$ \\
\hline$\hat{A} \sin$ do Leste & 173 & $8,5 \%$ \\
\hline Ásin do Oeste & 55 & $2.7 \%$ \\
\hline Ásin do Sudeste & 250 & $12,3 \%$ \\
\hline Malásia & 9 & $0,4 \%$ \\
\hline Polinésia & 1 & $0,0 \%$ \\
\hline Austrália e Nova Zelândia & 63 & $3,1 \%$ \\
\hline Microrésia & 2 & $0,1 \%$ \\
\hline & 2026 & $100,0 \%$ \\
\hline
\end{tabular}

Dados: INTERNATIONAL STRATEGY FOR DISASTER REDUCTION; UNITED NATIONS (2003). Elaboração: Heloisa Ceccato Mendes. Nota: Inclui as inundações com um dos seguintes critérios: dez ou mais mortes, cem pessoas afetadas, pedido de assistência internacional e/ou declaração de estado de emergência.

Mendiondo (2005 a) compara os prejuízos causados por inundações em países da América Latina com os respectivos Produto Interno Bruto (PIB): em 1991 as perdas no Brasil e Argentina foram de 5 bilhões de dólares (2\% do PIB); em 1999 as perdas na Venezuela foram de 3,2 bilhões de dólares (3,3\% do PIB); e em 1998 em Honduras, o furacão Mitch causou perdas de aproximadamente 4 bilhões de dólares (100\% do PIB). 
Esses dados indicam a necessidade de implementação de medidas mitigadoras dos grandes impactos sociais e econômicos gerados pelas inundações em todo o mundo, assim como a necessidade de realização de levantamentos de dados que subsidiem tal processo.

\subsubsection{Panorama Brasileiro}

De acordo com as Diretrizes Estratégicas para o Fundo de Recursos Hídricos de Desenvolvimento Científico e Tecnológico (MCT/CGE, 2002), as inundações no Brasil causam prejuízos anuais de aproximadamente US\$ 1 bilhão.

Os principais impactos causados por inundações são as perdas materiais e humanas, interrupção de atividade econômica e social nas áreas inundadas, contaminação da água (pela inundação de depósitos de material tóxico e estações de tratamento, por exemplo) e contaminação por doenças de veiculação hídrica (leptospirose e cólera, por exemplo). Além disso, um fato relevante é o de que muitas cidades brasileiras apresentam ligações clandestinas de esgoto não tratado nas redes de águas pluviais, o que ocasiona, em uma situação de inundação, contato direto da população com a água misturada ao esgoto.

Em notícia publicada no jornal Estado de São Paulo, a faixa carregada em manifestação de moradores com os dizeres "Enchente causa doenças" exemplifica a preocupação da população em relação à disseminação de doenças com a ocorrência de inundações. De acordo com o texto da notícia, a leptospirose havia causado a morte de um dos moradores do bairro (Figura 3.7).

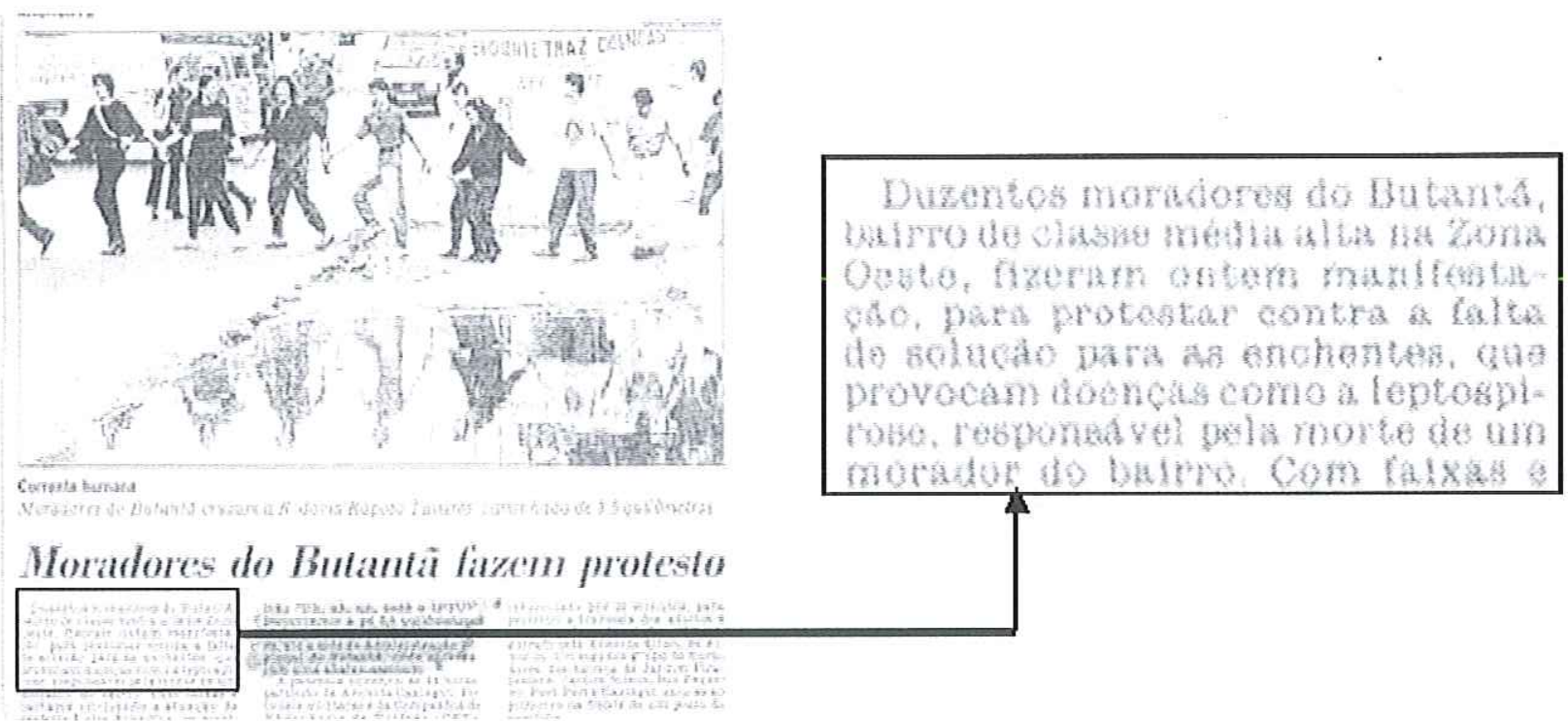

Figura 3.7 - Notícia do jornal Estado de São Paulo: protesto de moradores em São Paulo - SP. Fonte: adaptado de MORADORES...1992 ${ }^{3.3}$ apud Kahtouni, 2002.

${ }^{33}$ MORADORES do Butantã fazem protesto. (1992). Estado de São Paulo, São Paulo, 30 abr. 1992. Cidades. 
Segundo a ANA - Agência Nacional de Águas, vários municípios brasileiros foram atingidos por inundações de 1998 a 1999 (Figura 3.8). Nota-se uma relativa concentração nas regiões Sul e Sudeste, da qual destacamos no mapa o estado de São Paulo, que apresenta a marcação de vários municípios atingidos por inundações nesse período.

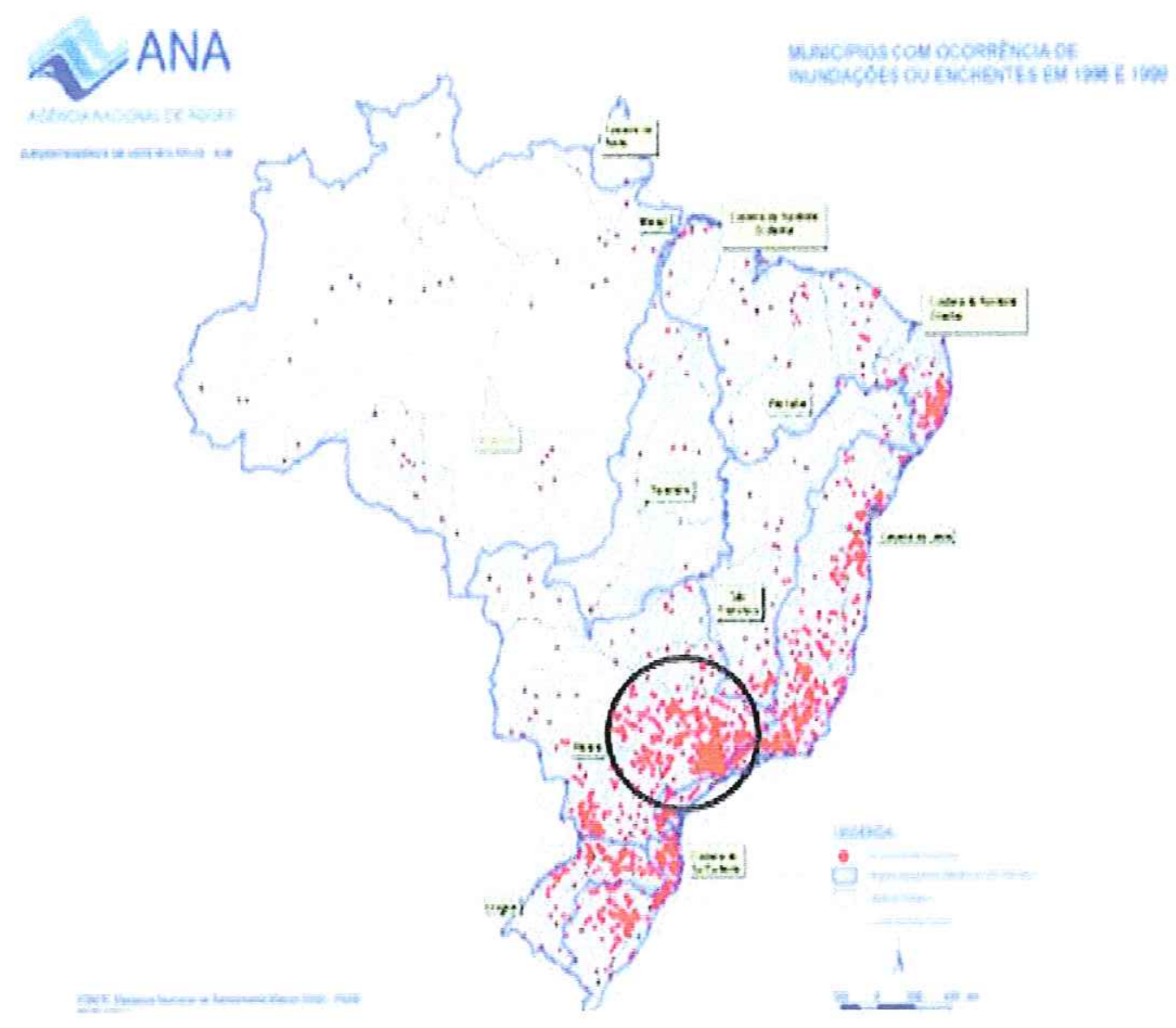

Figura 3.8 - Municipios atingidos por inundações com destaque para o estado de São Paulo (1998-1999). Fonte: adaptado de ANA apud TUCCI; BERTONI (2003)

As chuvas recentes de janeiro a março de 2004 atingiram 1.224 municípios brasileiros, sendo 64 deles localizados no estado de São Paulo. O balanço total dos prejuízos provocados pela sinundações nesse período foi de 17.510 casas destruídas, 95.523 casas danificadas e 376.987 pessoas atingidas (Figura 3.9). 


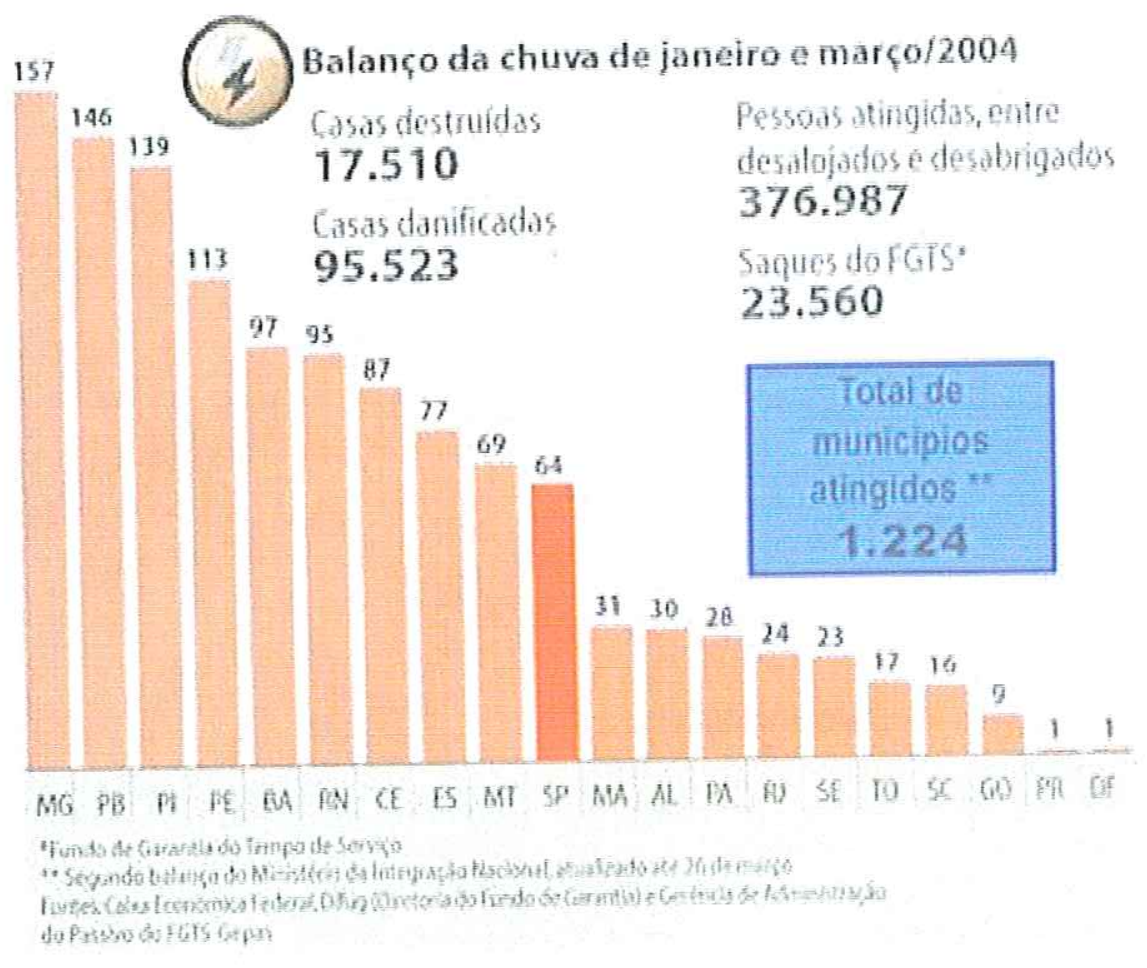

Figura 3.9 - Balanço da chuva de janeiro a março de 2004, com destaque para o Estado de São Paulo. Fonte: adaptado de FGTS...(2004)

\subsection{URBANIZAÇÃO}

\subsubsection{A influência da urbanização nos impactos de inundações}

Trabalhos relacionando o processo histórico de expansão urbana com a ocorrência de inundações (BAPTISTA et al., 1998; REBELATTO, 1991; ANTONIO, 1993; SANTOS, 2002) demonstram que o processo de urbanização ocorrido em Belo Horizonte - MG, São Carlos - SP, Santo André - SP e Bauru - SP, respectivamente, tiveram como conseqüência o agravamento dos impactos de inundações urbanas.

Alguns dos aspectos da urbanização que podem influenciar no aumento da freqüência e magnitude das inundações indicados por CarlosTucci (2003) $)^{3.4}$ são:

a) Impermeabilização do solo e aumento de escoamento dos canais por diminuição do tempo de concentração da bacia, produzindo aumento nas vazões máximas;

${ }^{3.4}$ TUCCI, C. E. M. Águas Urbanas. In: TUCCI, C. E. M.; BERTONI, J. C. (org). Inundações urbanas na América do Sul. Porto Alegre:, Associação Brasileira de Recursos Hídricos, 2003, 471 p. 
b) Desorganização na implantação da infra-estrutura urbana, como pontes, que podem obstruir o escoamento;

c) Ocupação urbana e impermeabilização em áreas com risco de inundação, promovendo a diminuição da capacidade de infiltração nas áreas alagáveis.

A seguir apresentam-se exemplos da cidade de São Carlos e da Bacia do Gregório para cada um desses aspectos.

\subsubsection{Impermeabilização do solo e aumento de escoamento por canais por} diminuição do tempo de concentração da bacia

Sobre esse tema destacam-se os trabalhos realizados por Boldrin (2005), Alves (2005), Barbassa (1991) e Queiroz (1996), sobre a Bacia do Gregório, e também o trabalho de Ohnuma Junior (2005), sobre a Bacia do Tijuco Preto, localizada próximo à Bacia do Gregório.

Alves (2005) e Boldrin (2005) avaliaram o efeito da existência de áreas verdes em uma sub-bacia embutida na Bacia do Gregório, utilizando simulação hidrológica. Os resultados apresentados demonstram que as vazões de pico sofrem reduções significativas com o aumento de áreas verdes (parques ou florestas) na sub-bacia em análise (Figura 3.10).

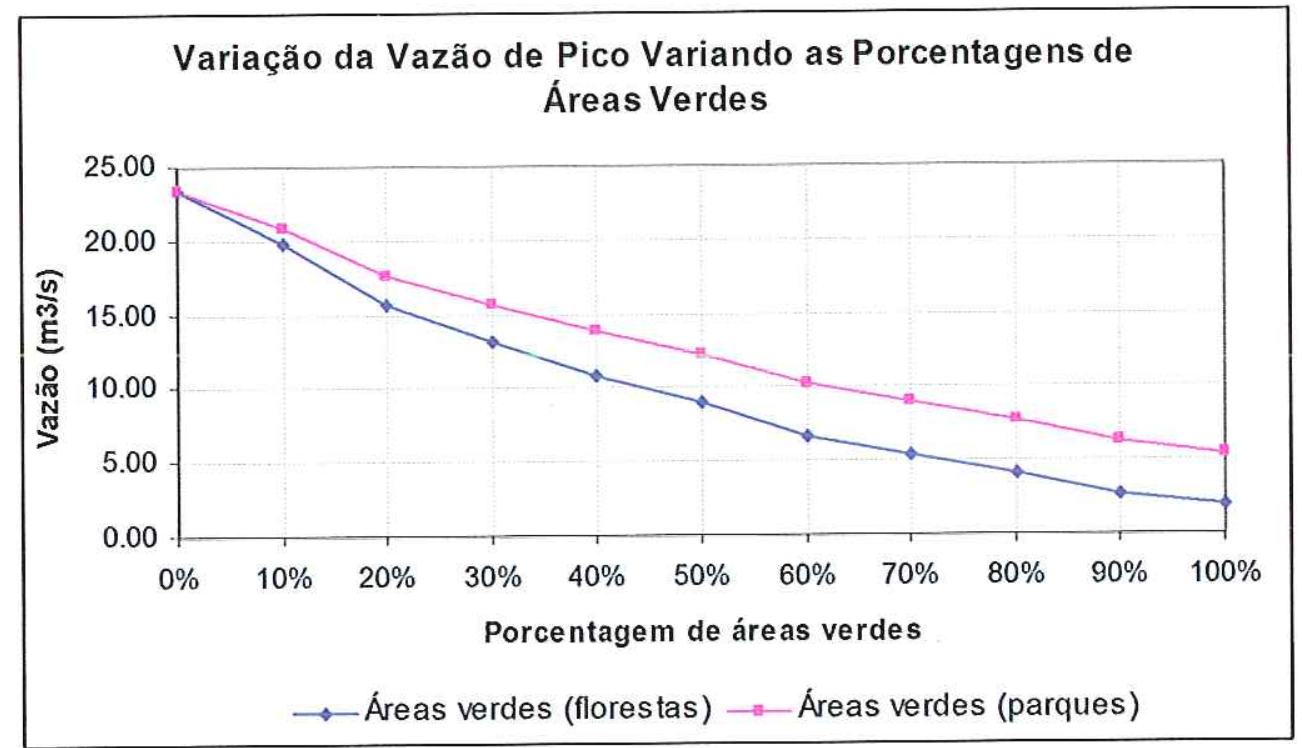

Figura 3.10 - Gráfico da variação das vazões de pico, variando a quantidade de áreas verdes (florestas e parques) em uma sub-bacia embutida na Bacia do Gregório, para uma chuva com $\mathrm{Tr}=25$ anos. Fonte: Boldrin (2005), p. 134. 
Também utilizando simulação hidrológica, Barbassa (1991) demonstrou a influência da ocupação urbana da Bacia do Gregório no aumento dos valores de vazão de pico na seção do Mercado Municipal. Os resultados indicam que uma vazão produzida por uma precipitação de 5 (cinco) anos de período de retorno em 1990 era produzida, em 1980, por uma precipitação com período de retorno duas vezes maior: de 10 (dez) anos. Os resultados indicam, portanto, que a urbanização da bacia tornou as áreas de várzea mais vulneráveis a danos causados por inundações.

Queiroz (1996) realizou simulação hidrológica considerando a implantação de medidas não estruturais de mitigação de impactos de inundações na Bacia do Gregório. Os resultados indicaram que o porcentual de área permeável foi um dos parâmetros mais determinantes nos resultados obtidos pelas simulações hidrológicas realizadas.

Ohnuma Junior (2005) utilizou simulações hidrológicas para a Bacia do Tijuco Preto, considerando cenários de evolução urbana com e sem implementação de medidas mitigadoras de impactos de inundações, sendo uma delas o controle distribuído da drenagem com maior poder de infiltração e percolação de água no solo. As simulações demonstraram que o processo de urbanização sem a implementação das medidas mitigadoras propostas tem como conseqüências grandes aumentos no volume escoado e na vazão de pico, além de diminuição do tempo de concentração da bacia.

\subsubsection{Desorganização na implantação da infra-estrutura urbana}

As pontes localizadas próximo ao Mercado Municipal, na R. Episcopal e na R. D. Alexandrina (Figura 3.11), são um exemplo desse aspecto, pois interrompiam o escoamento das águas do Córrego do Gregório. Em 2003, foi realizada obra de alargamento do vão da ponte da R. Episcopal para garantir o escoamento eficiente das águas (Figuras 3.12 e 3.13).
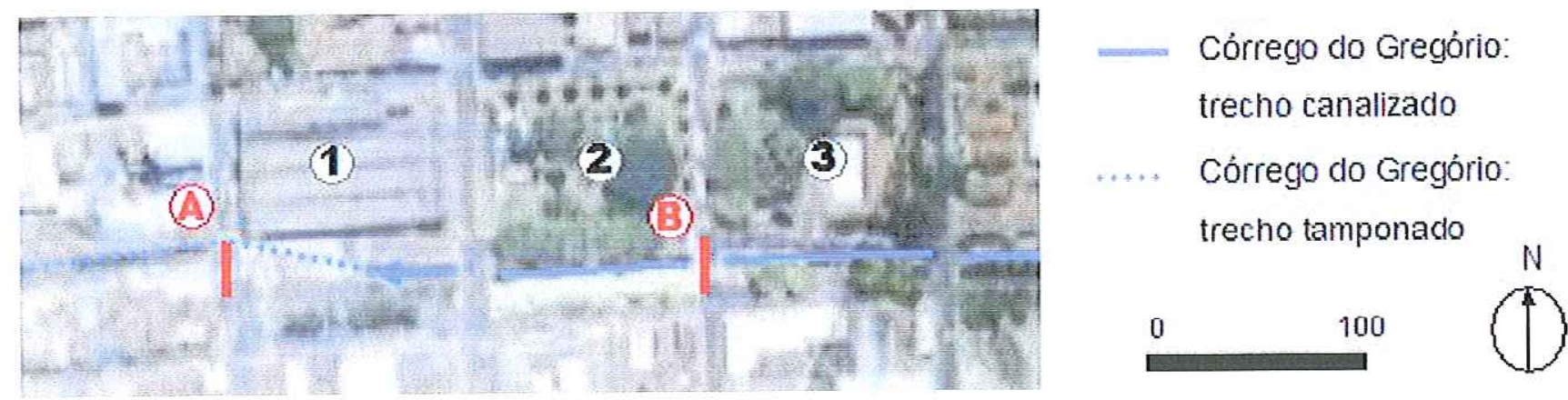

Figura 3.11 - Localização das pontes da R. Episcopal e R. D. Alexandrina, sobre o Córrego do Gregório. 1) Mercado Municipal, 2) Praça dos Voluntários, 3) Pìscina Municipal, A) Ponte da R. Episcopal, B) Ponte da R. D. Alexandrina. Fonte: adaptado de FIPAI/PMSC (2003). 


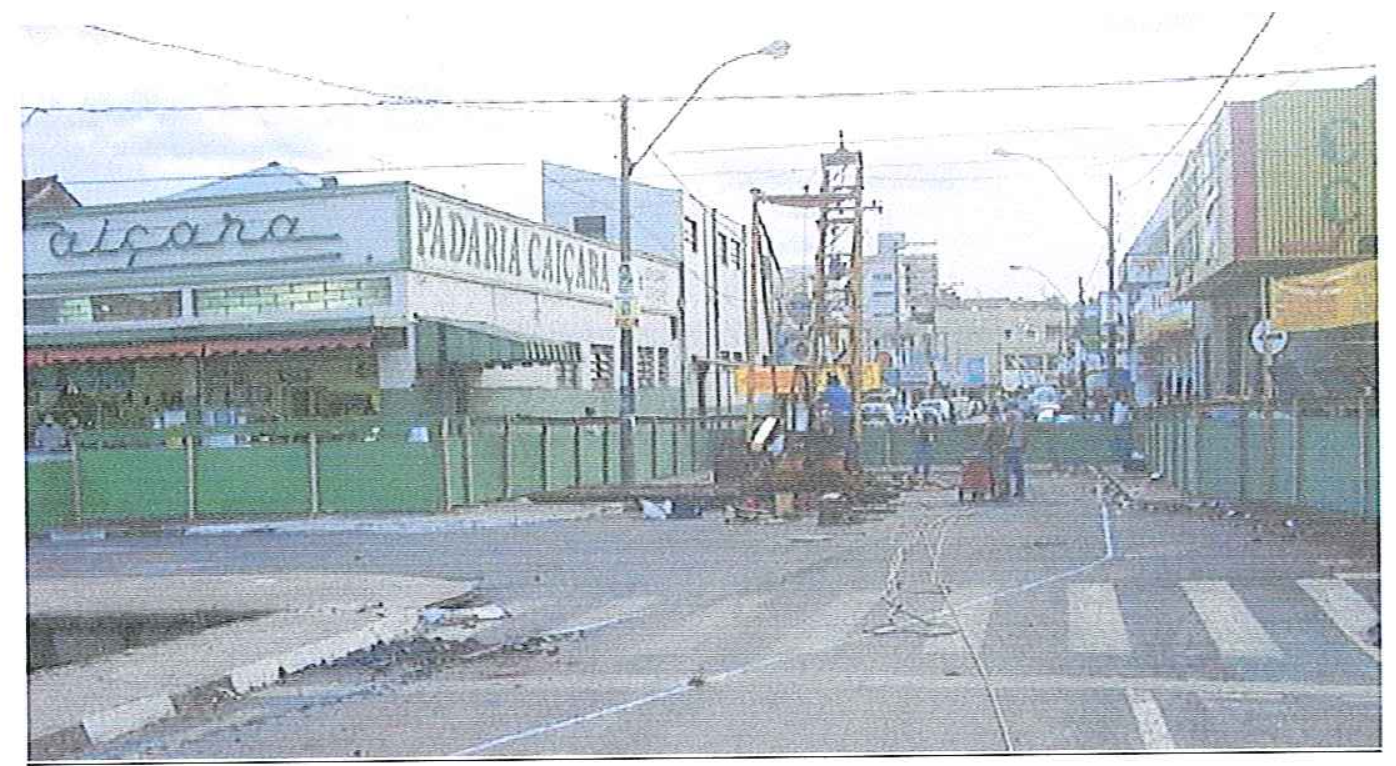

Figura 3.12 - Foto de preparação para o início das obras na ponte da R. Episcopal. Fonte: ANELLI (2005)

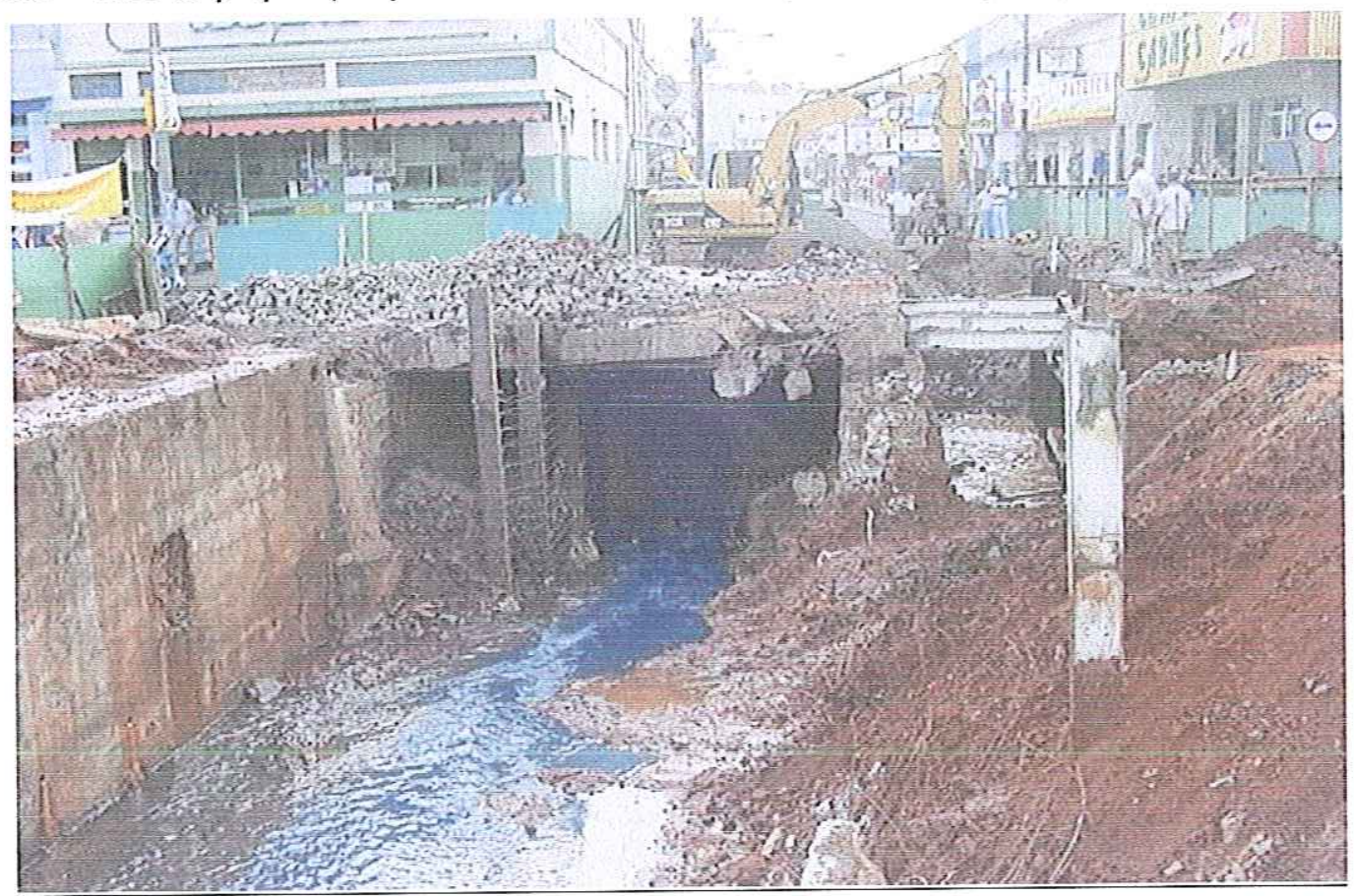

Figura 3.13 - Foto durante a realização das obras na ponte da R. Episcopal. Fonte: ANELLI, 2005

Em notícia de jornal publicada em 09 de janeiro de 2003 no jornal Primeira Página (Figura 3.14), o presidente da ACISC (Associação de Comerciantes de São Carlos) declara estar satisfeito com a realização da obra na região do Mercado Municipal, predominantemente ocupada por estabelecimentos comerciais. 


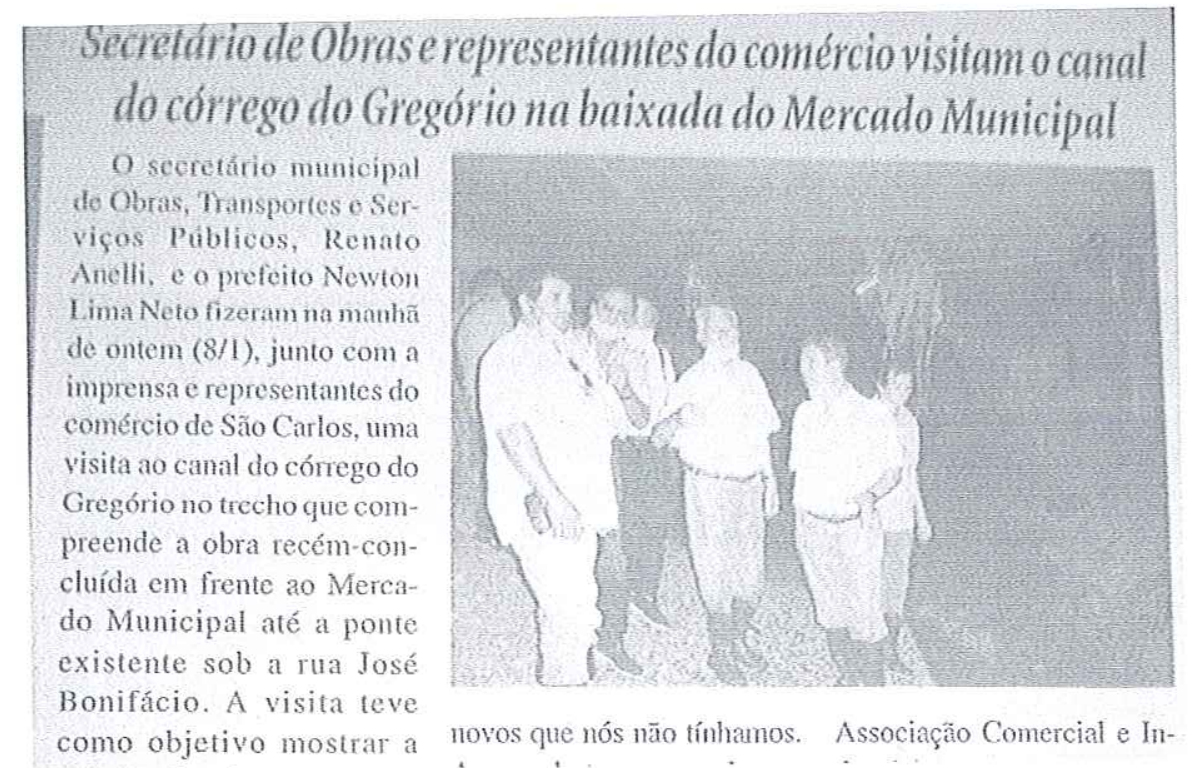

Figura 3.14 - Notícia de jornal publicada após a conclusão da obra. Fonte: (adaptado de SECRETÁRIO...2003)

As obras na ponte da R. D. Alexandrina são consideradas um próximo passo a ser realizado, de acordo também com notícia publicada em 09 de janeiro de 2003 no jornal Primeira Página (Figura 3.15).

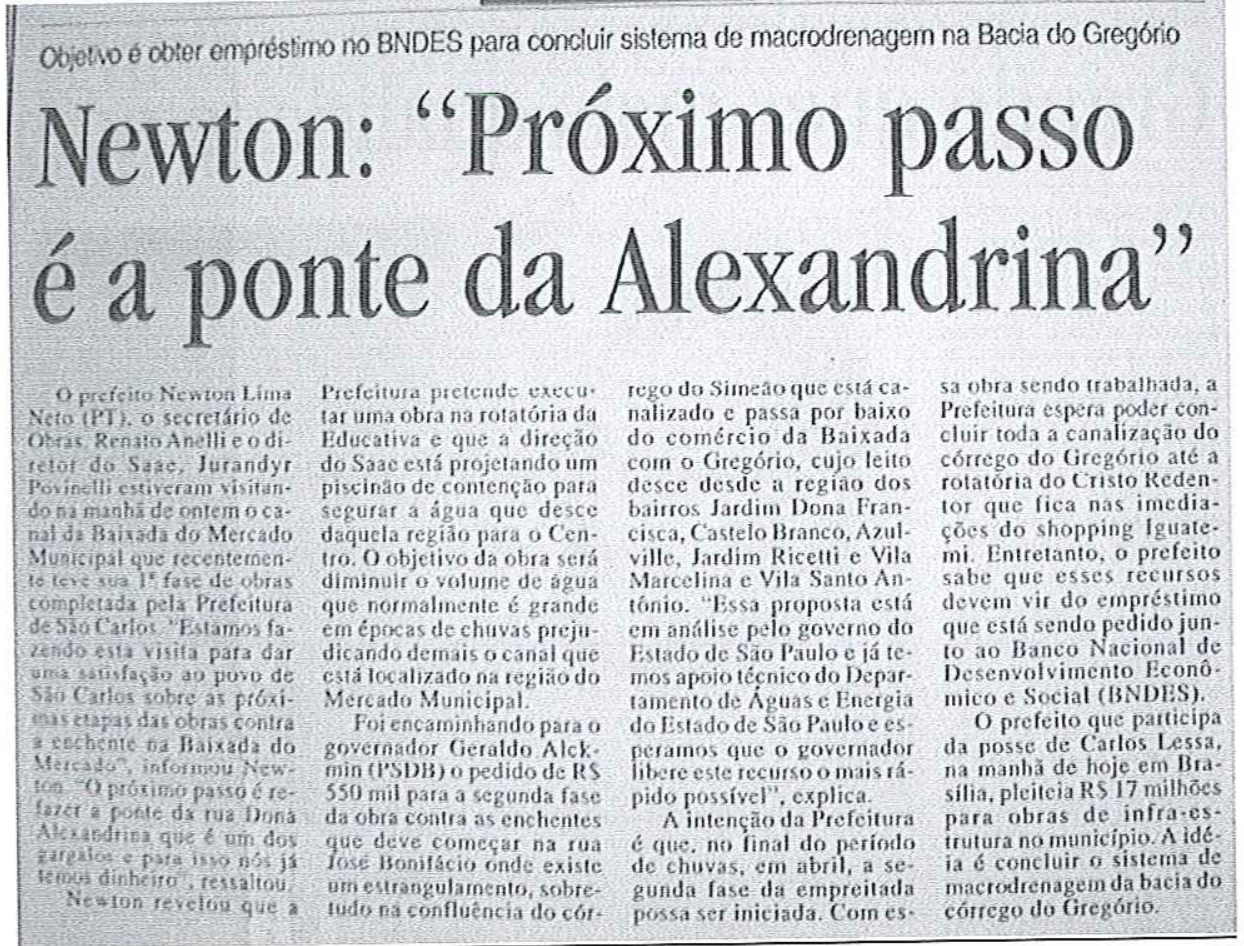

Figura 3.15 - Notícia publicada sobre obra a ser realizada na ponte da R. D. Alexandrina para melhorar o escoamento das águas. Fonte: (NEWTON...2003) 


\subsubsection{Ocupação urbana e impermeabilização em áreas com risco de inundação}

A Figura 3.16 demonstra a ocupação urbana das APPs - Áreas de Preservação Permanente ${ }^{3.5}$ dos córregos urbanos em São Carlos, com destaque para o Córrego do Gregório.

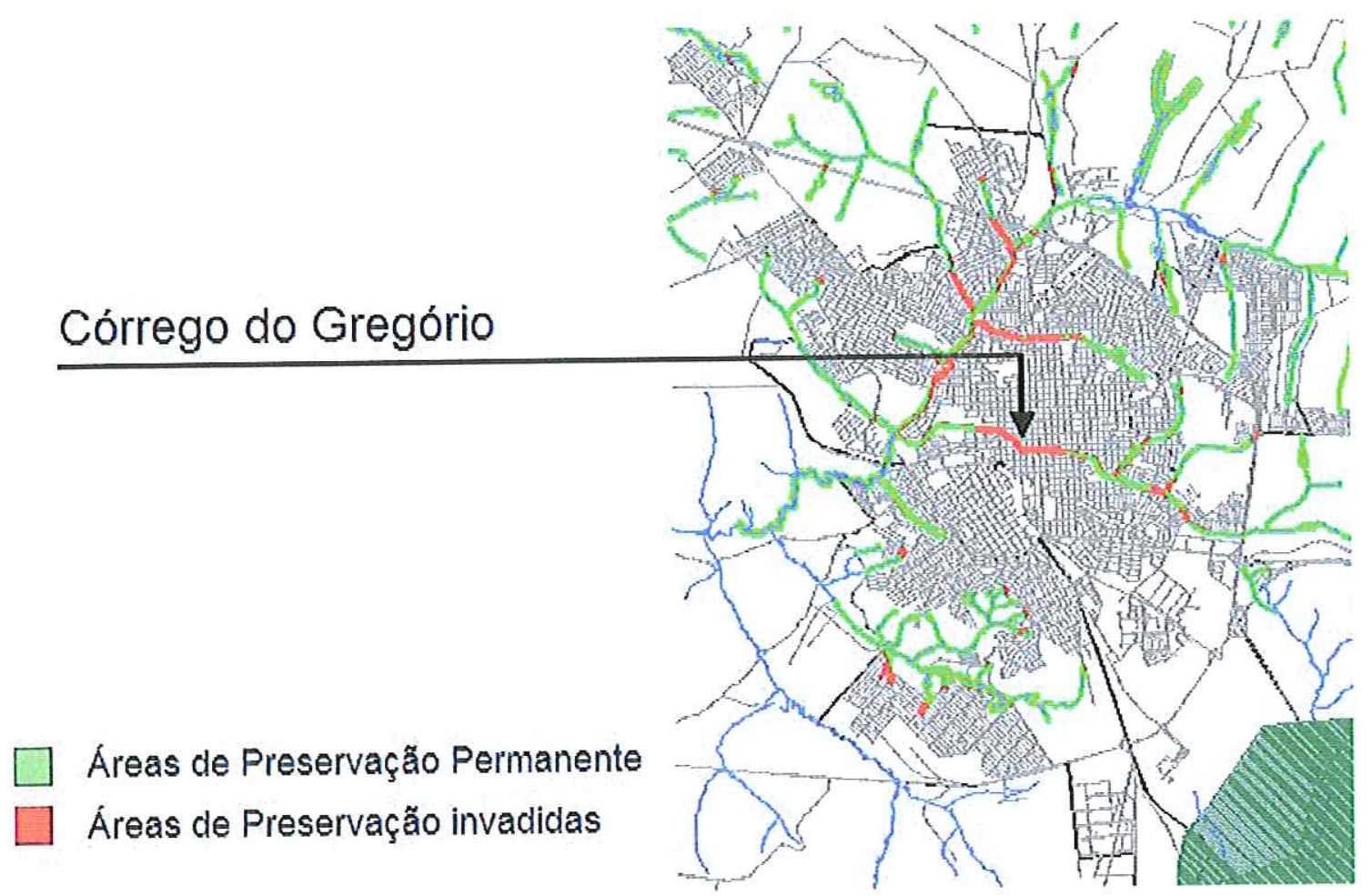

Figura 3.16 - Áreas de Preservação Permanente (APPs) ocupadas pela urbanização em São Carlos. Fonte: adaptado de PMSC, 2002

Sobre este assunto, destacam-se novamente os trabalhos desenvolvidos por Boldrin (2005) e Alves (2005), nos quais são considerados cenários distintos quanto aos seguintes parâmetros: a) preservação das faixas de proteção ao longo dos corpos d'água e nascentes, b) manutenção de uma parcela maior de áreas permeáveis e vegetadas nas áreas públicas dos loteamentos e c) arborização de vias para uma sub-bacia embutida na Bacia do Gregório.

Boldrin (2005) obteve hidrogramas que indicaram que a redução máxima do pico de vazão ocorre com a associação de todas as medidas. Com o objetivo de avaliar a eficácia de cada uma das medidas, foram elaborados cenários considerando somente a implantação de cada uma delas isoladamente. Alves (2005) concluiu que a medida de melhor desempenho na diminuição na vazão de pico é a preservação das APPs.

${ }^{5}$ As Áreas de Preservação Permanente são estabclecidas pela Lei Federal 4771/65, conhecida como Código Florestal. 


\subsubsection{Mitigação dos impactos de inundações urbanas}

As medidas mitigadoras dos impactos de inundações urbanas são classificadas em medidas estruturais e não estruturais.

As medidas estruturais são obras que podem ser implantadas para a correção e/ou prevenção dos impactos das inundações e são classificadas em extensivas e intensivas.

As medidas extensivas como aquelas que agem na bacia, procurando modificar as relações entre precipitação e vazão. Um exemplo de medida extensiva é o aumento da cobertura vegetal do solo, que reduz e retarda os picos de enchente. As medidas intensivas são as que agem no rio, sendo classificadas em três tipos (Simons et al, $1977^{3.6}$ apud Tucci, 2002): a) aceleram o escoamento (diques, por exemplo), b) retardam o escoamento (reservatórios e bacias de amortecimento, por exemplo), c) desviam o escoamento (canais de desvio, por exemplo). Dentre as medidas estruturais descritas, destacamos a seguir as de modificação de rios e a construção de reservatórios.

A modificação de rios tem como objetivo aumentar a velocidade de escoamento das águas pluviais. Para isso, é necessário reduzir a rugosidade do leito, tirando obstruções ao escoamento por meio da dragagem de rios, por exemplo. Além disso, o aumento da velocidade de escoamento pode ser obtido também com o aumento da declividade do rio, por meio da retificação de seus meandros.

Os reservatórios retêm parte do volume de água, amortecendo os picos de vazão. O volume retido nos reservatórios nos períodos de vazão alta é escoado quando os valores de vazão já estão reduzidos. Canholi (2005) indica que a tecnologia de detenção pode ser aplicada em cada lote, com pequenos reservatórios associados a áreas permeáveis, por exemplo, ou em bacias de detenção maiores, fechadas ou a céu aberto.

Graciosa (2005), Ohnuma Junior (2005) e FIPAI/PMSC (2003) desenvolveram trabalhos abordando a questão da aplicação de medidas estruturais na cidade de São Carlos, mais especificamente sobre trincheiras de infiltração, caixas de detenção na escala de micro-drenagem, e reservatórios de detenção na escala de macro-drenagem, respectivamente.

As medidas não estruturais são as que buscam a redução dos danos das inundações pela introdução de normas, regulamentos e programas de disciplinamento do uso e ocupação do solo, podendo ser classificadas em regulamentação do uso da terra, construções à prova de enchentes, seguro de enchentes e

${ }^{3.6}$ SIMONS, D. B. Et al. (1977) Flood flows, stages and damages. Fort Collins: Colorado State University. 
sistema de alerta de inundações.

Tucci (2002) destaca que para implementar a regulamentação do uso da terra, ou zoneamento de áreas inundáveis, é necessário determinar o risco de inundação das diferentes cotas das áreas ribeirinhas. A partir dessa determinação, devem ser estabelecidos critérios de ocupação das áreas, de acordo com o risco de inundação de cada uma delas. Nas áreas de maior risco não deve ser permitido uso habitacional, enquanto nas áreas com riscos menores devem ser permitidas construções com precauções especiais. Tais determinações devem ser contempladas no Plano Diretor da cidade.

A questão da aplicação de medidas não-estruturais na cidade de São Carlos tem sido abordada em alguns trabalhos, como Andrade et al (2005), Righetto (2005) e Benini (2005) sobre sistema de alerta, seguro contra inundações e plano diretor de recuperação ambiental, respectivamente. Mendiondo (2005 c) propõe a consideração do "peso ambiental" na definição da Planta Genérica de Valores de São Carlos, com implementação de IPTU ecológico. A proposta consiste, basicamente, em punição para os proprietários que promovam uma ocupação que diminua capacidade de armazenamento do lote em relação à capacidade de armazenamento do solo, ou premiação para os casos em que ocorra aumento de tal capacidade.

Canholi (2005) apresenta algumas considerações sobre medidas não convencionais que podem ser utilizadas para a mitigação dos impactos de inundações, destacando que as diretrizes gerais de projeto de drenagem urbana se classificam em "conceito de canalização" e "conceito de reservação" (Walesh, 1989 apud Canholi, 2005). O Quadro 3.1 compara as características dos dois conceitos.

\begin{tabular}{|l|l|l|}
\hline Característica & Canalização & Reservação \\
\hline Função & - Remoção rápida dos escoamentos & - Contenção temporária para subseqüente liberação \\
\hline $\begin{array}{l}\text { Componentes } \\
\text { Principais }\end{array}$ & - Canais abertos/ galerias & $\begin{array}{l}\text { - Reservatórios a superfície livre } \\
\text { - Reservatórios subterâneos } \\
\text { - Retenção sub-superficial }\end{array}$ \\
\hline Aplicabilidade & $\begin{array}{l}\text { - Instalação em áreas novas } \\
\text { - Construção por fases } \\
\text { - Ampliação de capacidade pode se tomar dificil } \\
\text { (centros urbanos) }\end{array}$ & $\begin{array}{l}\text { - Áreas novas (em implantação) } \\
\text { - Construção por fases } \\
\text { - Áreas existentes (à superficie ou subterrâneas) }\end{array}$ \\
\hline $\begin{array}{l}\text { Impacto nos trechos de } \\
\text { jusante (quantidade) }\end{array}$ & $\begin{array}{l}\text {-Aumenta significativamente os picos das } \\
\text { enchentes em relação à condição anterior } \\
\text { - Maiores obras nos sistemas de jusante }\end{array}$ & $\begin{array}{l}\text { - Áreas novas: podem ser dimensionadas para impacto zero } \\
\text { (Legislação EUA) } \\
\text { - Reabilitação de sistemas: podem tomar vazões a jusante } \\
\text { compativeis com capacidade disponível }\end{array}$ \\
\hline $\begin{array}{l}\text { Impacto nos trechos de } \\
\text { jusante (qualidade) }\end{array}$ & $\begin{array}{l}\text { - Transporta para o corpo receptor toda carga } \\
\text { poluente afluente }\end{array}$ & $\begin{array}{l}\text { - Facilita remoção de material flutuante por concentração em } \\
\text { áreas de recirculação dos reservatórios e dos sólidos em } \\
\text { suspensão, pelo processo natural de decantação }\end{array}$ \\
\hline Manutenção / operação & $\begin{array}{l}\text { - Manutenção em geral pouco freqüente (pode } \\
\text { ocorrer excesso de assoreamento de lixo) } \\
\text { - Manutenção nas galerias é dificil (condições de } \\
\text { acesso) }\end{array}$ & $\begin{array}{l}\text { - Necessária limpeza periódica } \\
\text { - Necessária fiscalização } \\
\text { - Sistemas de bombeamento requerem operação / manutenção } \\
\text { Desinfecção eventual (insetos) }\end{array}$ \\
\hline
\end{tabular}

Quadro 3.1 - Conceito de canalização x conceito de reservação. Fonte: adaptado de Canholi (2005) 
De acordo com Canholi (2005), o "conceito de canalização" definido por Walesh refere-se à prática da canalização convencional, exercida por décadas em vários lugares do mundo, e em partícular no Brasil. Tal conceito é voltado à implantação de galerias de concreto, tamponamento de córregos, retificação de traçados de rios e aumento de declividades de fundo, além de outras intervenções que tinham como objetivo promover o rápido escoamento das águas pluvial, principal preceito da visão higienista, ou sanitarista, da drenagem urbana (Silveira, 1998). Além disso, Canholi (2005) destaca que o conceito em questão tem como objetivo promover também o aproveitamento dos fundos de vale para a implantação de vias de tráfego, localizadas nas laterais dos canais ou sobre os mesmos.

A finalidade principal dos dispositivos vinculados à diretriz de reservação é promover a redução do pico das inundações por meio do armazenamento de parte do volume escoado. Porém, sua utilização pode ser associada também a outros usos, como recreação, lazer e melhoria da qualidade da água. A evolução da utilização das obras de detenção ao logo do tempo é representada na Figura 3.17. Atualmente, as obras desse tipo já aplicadas no Brasil situam-se na Fase 2: "Controle das Enchentes" e "Recreação, Paisagismo, outros usos" (CANHOLI, 2005).

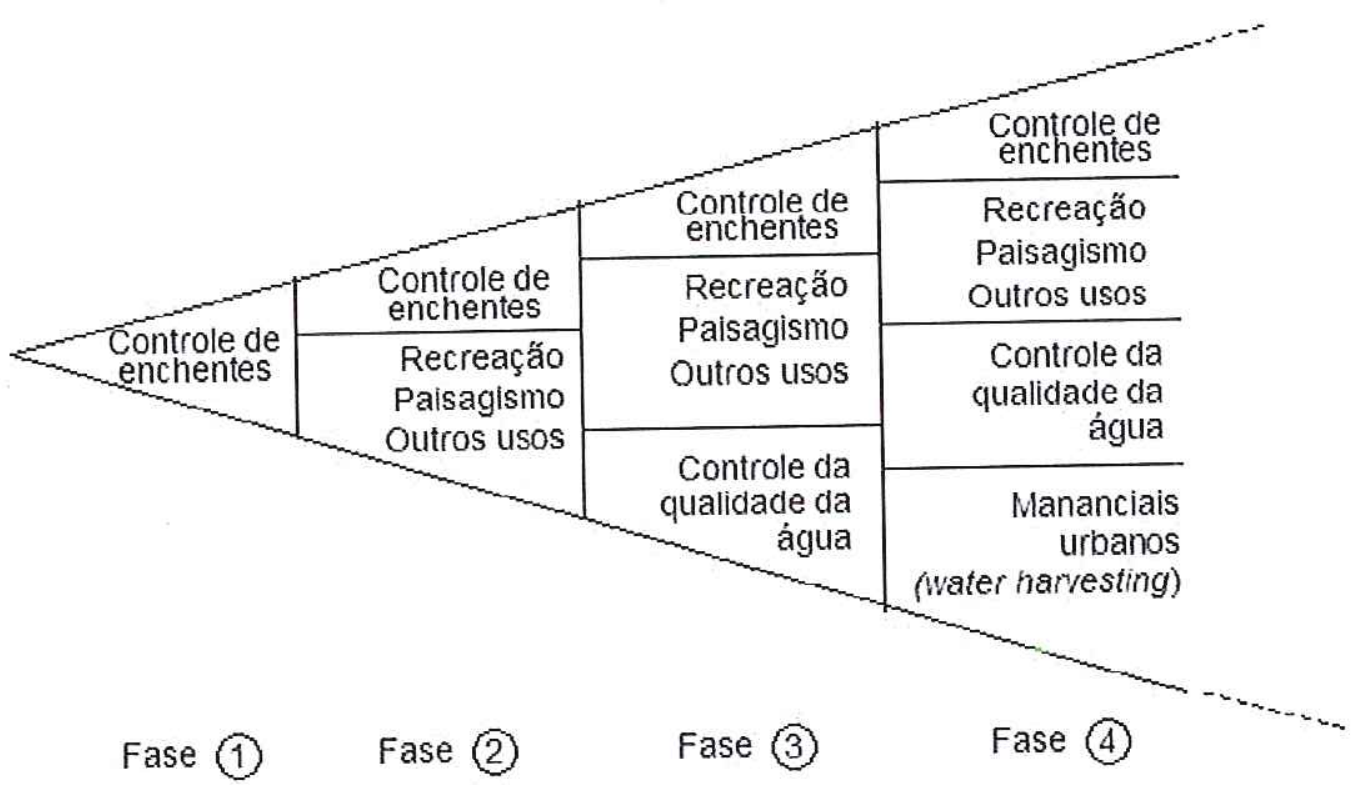

Figura 3.17 - Evolução dos objetivos de obras de drenagem urbana.

Fonte: adaptado de Walesh (1989) apud Canholi (2005)

A Figura 3.18 ilustra os principais dispositivos empregados seguindo o conceito conservacionista, ou de reservação, comparando-os à visão higienista, que envolve apenas obras de canalização. A análise da Figura 3.18 indica que o emprego de obras vinculadas ao conceito de canalização tem como conseqüência a ocorrência de picos elevados, enquanto o conceito de reservação está vinculado à ocorrência de picos reduzidos e mais prolongados. 


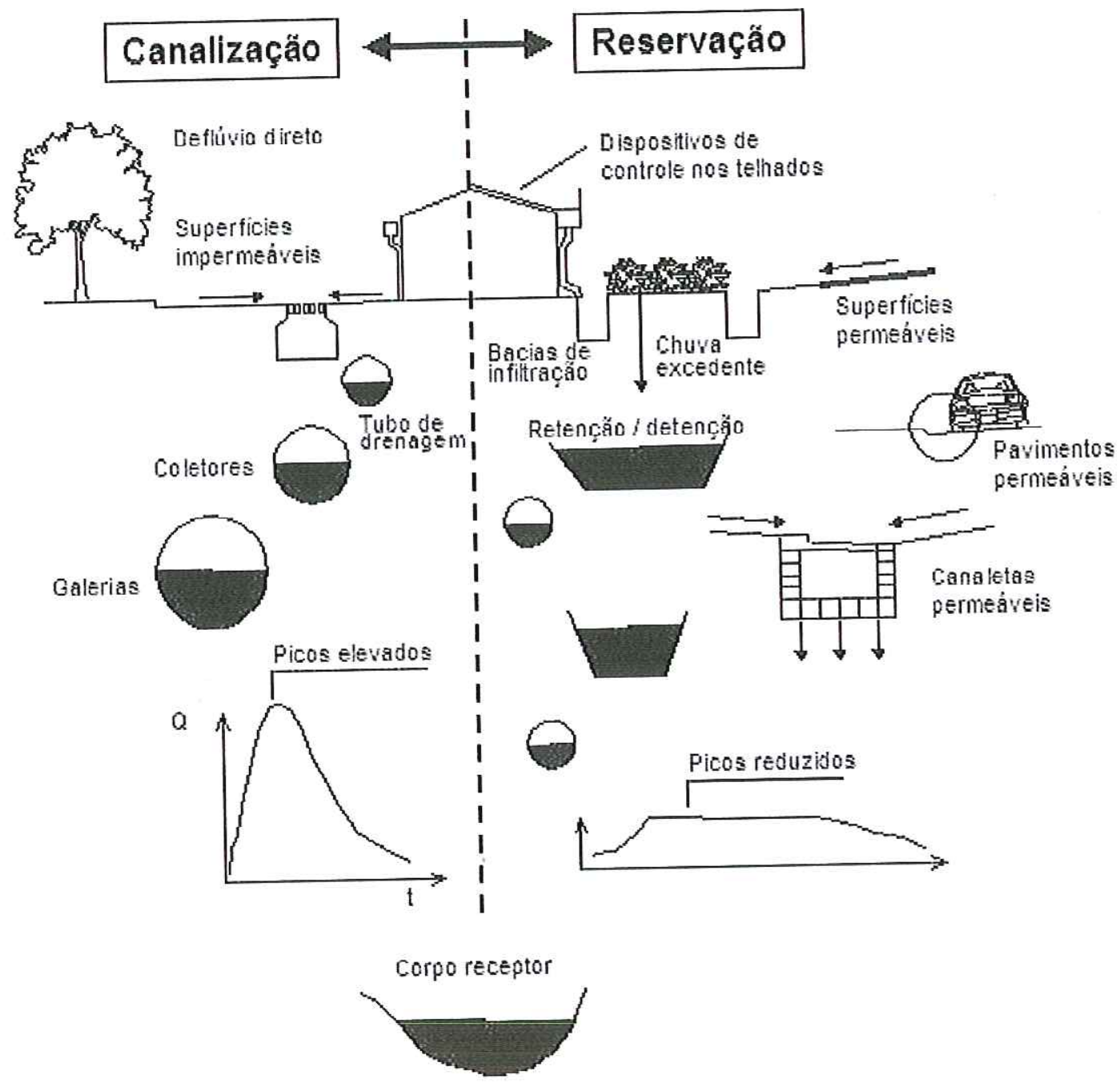

Figura 3.18 - Comparação entre os conceitos de drenagem urbana: canalização e reservação. Fonte: Urbonas e Sathre (1990) apud Canholi (2005).

Segundo Das Neves e Tucci (2003) ${ }^{3.7}$ apud Boldrin (2005), freqüentemente se pratica a fase sanitarista da drenagem nos países em desenvolvimento, como conseqüência das difíceis condições sócio-econômicas e tecnológicas. Nos países desenvolvidos, ao contrário, utilizam-se atualmente medidas ligadas à visão ambientalista ou conservacionista da drenagem urbana.

Macedo et al (2004), Mendiondo et al (2004) e Mendes et al (2004) abordam a questão da elaboração de cenários como importante instrumento para o planejamento da drenagem urbana. Mendiondo et al (2004) destacam a importância de discriminar as políticas de "recuperação" e de

3.7 DAS NEVES, M.G.F.P.; TUCCI, C.E.M. (2003). Gerenciamento Integrado em Drenagem Urbana: Quantificação e Controle de Resíduos Sólidos. In: XV Simpósio Brasileiro de Recursos Hídricos - Anais. 2003. Curitiba, PR, ABRH, Aquacon. 
"controle" na elaboração dos cenários. A Figura 3.19 apresenta o crescimento do coeficiente de escoamento ao longo do tempo em uma determinada bacia. São apresentados dois cenários, de maneira conceitual: sem recuperação ambiental, em que o coeficiente de escoamento continua aumentando, sem aplicação de nenhuma intervenção para impedir esse processo; e com recuperação ambiental, em que são aplicadas medidas de controle com objetivo de diminuir o coeficiente de escoamento.

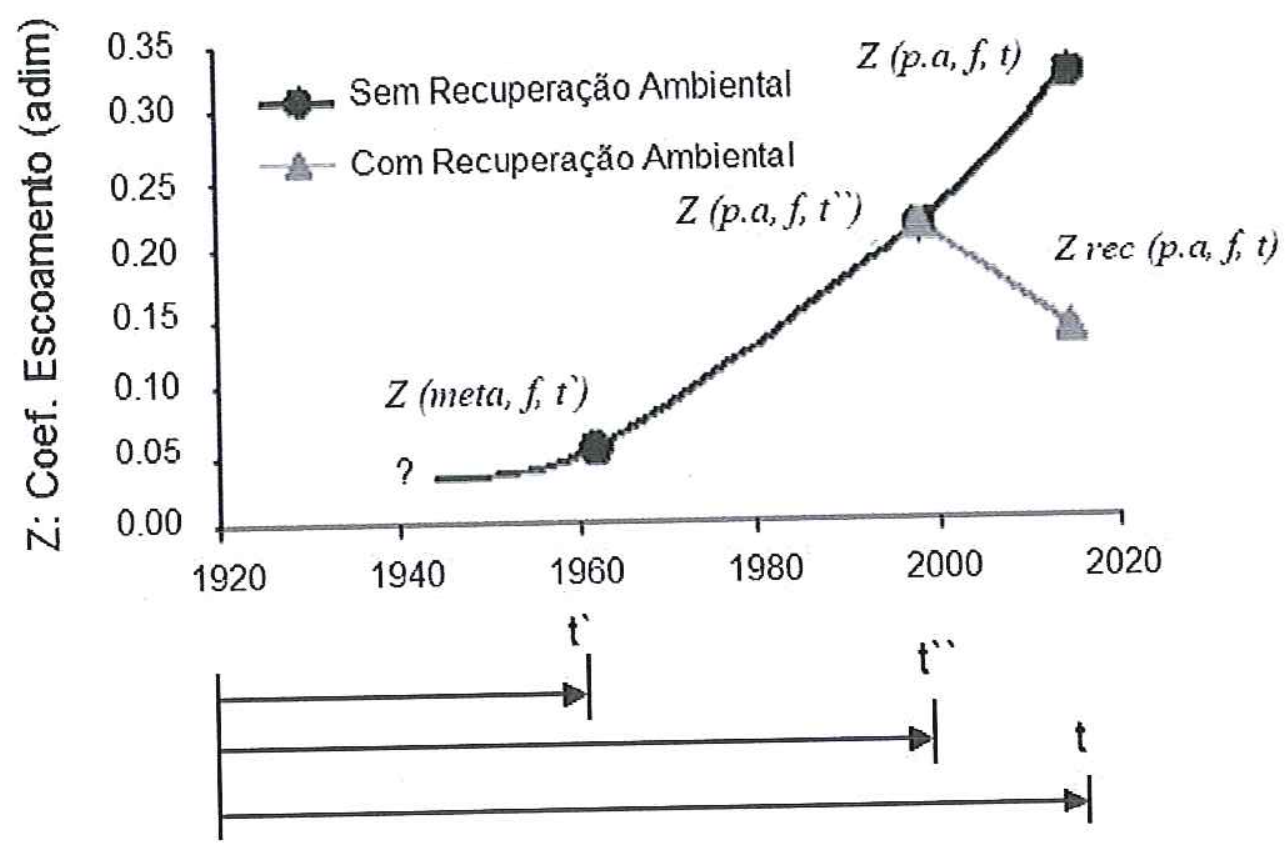

Figura 3.19 - Exemplo de variáveis de avaliação de cenários para a recuperação ambiental. Fonte: Mendiondo et al (2004)

\subsubsection{O processo de urbanização no mundo}

Segundo Carlos Tucci e Juan Carlos Bertoni (2003), no ano 1800 somente 1\% da população mundial vivia em cidades. A partir do século XVIII, a revolução industrial teve como efeito um processo mundial de urbanização muito intenso e cada vez mais acelerado. Segundo Guglielmo (1996) ${ }^{3.8}$ apud TUCCI; BERTONI (2003), durante a primeira metade do século XX a população total do mundo aumentou em $49 \%$ e a população urbana em $240 \%$. Na segunda metade do século essa evolução foi ainda mais expressiva, pois a população urbana passou de 1.520 milhões de habitantes em 1974 para 1.970 milhões em 1982. A Tabela 3.2 demonstra o crescimento da porcentagem da população urbana no mundo de 1955 a 1995, apresentado também uma estimativa para o período entre 1995 e 2015.

${ }^{3.8}$ GUGLIELMO, R. Les grande métropoles du monde et leur crise. Paris: A Colin, 1996, 268p. 
Tabela 3.2 - Evolução da População Urbana 1955 a 2015. Fonte: FNUAP apud TUCCI; BERTONI, 2003, p.2

\begin{tabular}{|l|l|l|l|l|}
\hline Año & $\mathbf{1 9 5 5}$ & $\mathbf{1 9 7 5}$ & $\mathbf{1 9 9 5}$ & $\mathbf{2 0 1 5}$ \\
\hline \% del total & 32 & 38 & 45 & 54 \\
\hline
\end{tabular}

Atualmente, a população mundial é de aproximadamente 6.100 milhões de habitantes, dos quais 2.850 milhões correspondem à população urbana. Portanto, $47 \%$ da população mundial é urbana na atualidade. Se o crescimento dos últimos tempos for mantido, em pouco tempo a população urbana terá superado a população rural mundial, pela primeira vez na história.

Em 1950, oito aglomerações urbanas alcançavam ou ultrapassavam a população de 5 milhões de habitantes: Nova York, Londres, La Ruhr, Tókio, Sahngai, Paris, Buenos Aires e Moscou, correpondendo a $7 \%$ da população mundial naquele momento. No ano 2000 , a população mundial do planeta concentrada em metrópoles com pelo menos 10 milhões de habitantes já correspondia a $15 \%$ da população mundial (UNESCO apud TUCCI; BERTONI, 2003, p.2).A tendência de crescimento urbano é liderada pela América do Sul, onde a concentração urbana nas principais cidades tem o crescimento mais alto das regiões do mundo e o maior de todos os tempos.

Segundo Guglielmo (1996) ${ }^{3.9}$ apud TUCCI; BERTONI (2003), na segunda metade do século XIX - ou na primeira metade do século XX, de acordo com o caso - as metrópoles dos países desenvolvidos passaram por um crescimento demográfico intenso associado à industrialização. $\mathrm{O}$ desenvolvimento industrial nos países em desenvolvimento foi mais intenso, pelo contrário, na segunda metade do século XX. Em 1950, das 8 grande metrópoles do mundo, 6 se situavam em países desenvolvidos (75\%) e em 1990, das 35 cidades com mais de 5 milhões de habitantes do mundo, somente 12 pertencem a países desenvolvidos (35\%), o que demonstra como o processo de urbanizaçấo nos países em desenvolvimento foi intenso nesse período.

É interessante ressaltar também que das 15 cidades mais povoadas do mundo, 4 se localizam na América Latina, sendo duas no Brasil. São elas: São Paulo, Cidade do México, Buenos Aires e Rio de Janeiro. O prognóstico é de que por volta do ano 2010 existirão 60 cidades com população superior a 5 milhões de habitantes, sendo a maioria em países em desenvolvimento.

3.9 GUGLIELMO, R. Les grande métropoles du monde et leur crise. Paris: A Colin, 1996, 68p. 
A partir de 1975, as cidades de países desenvolvidos (Paris, Londres e Nova York) apresentaram diminuição representativa do aumento da população, enquanto as cidades de países em desenvolvimento (São Paulo e Buenos Aires) apresentaram comportamento contrário: crescimento populacional acentuado (Figura 3.20). Esse fato se deve ao próprio aumento do crescimento da população e também ao êxodo rural intenso.

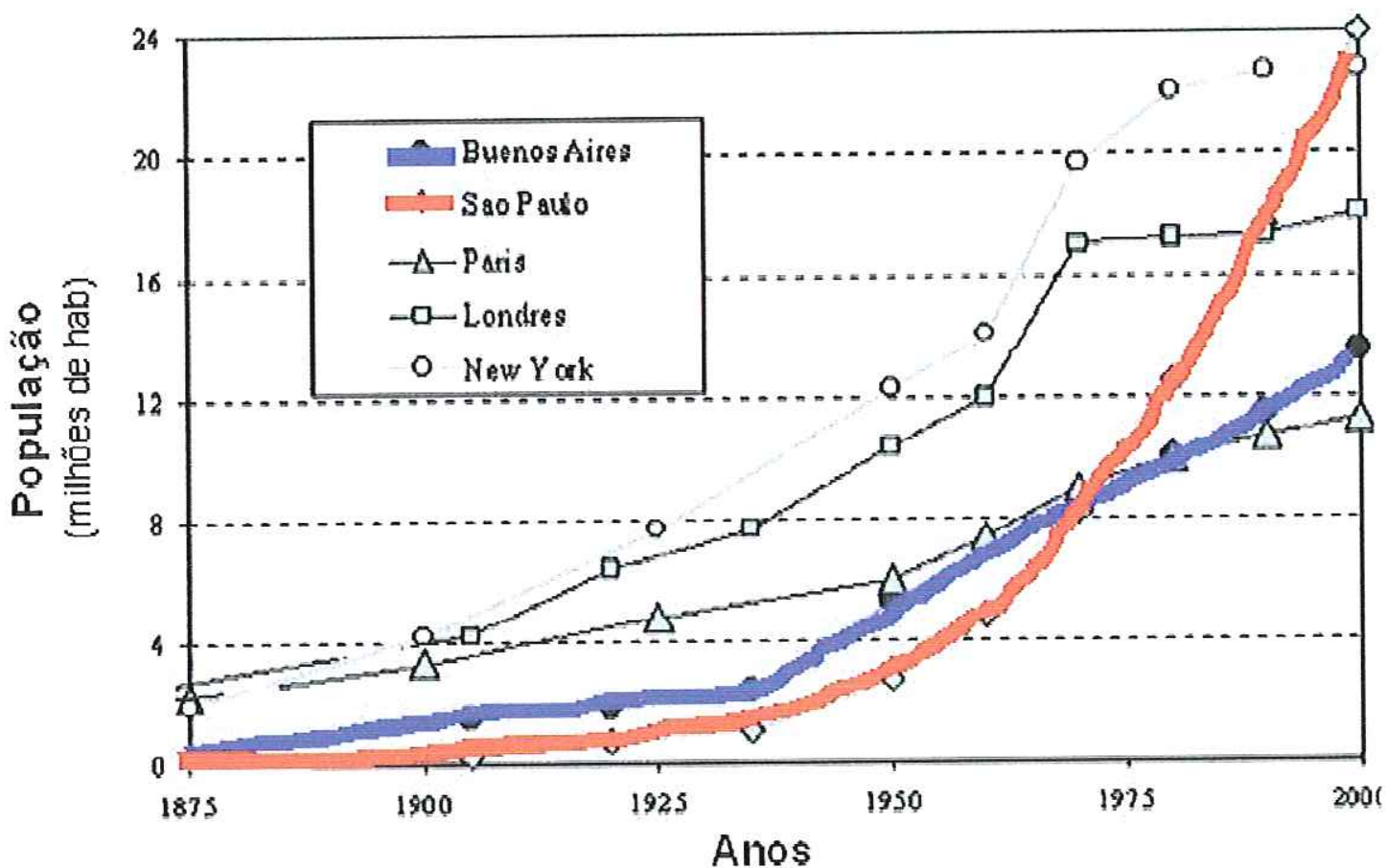

Figura 3.20 - Evolução da População de grandes metrópoles da Europa e da América, com destaque para cidades de países em Desenvolvimento: São Paulo e Buenos Aires. Fonte: Adaptado de GUGLIELMO,1996 ${ }^{3.10}$ ; INDEC, $1999^{3.11}$ apud TUCCI; BERTONI, 2003, p.4

\subsubsection{O processo de urbanização no Brasil}

As décadas de 1960 e 1970 foram caracterizadas no Brasil por um processo muito intenso de urbanização. Em 1960 a população total do Brasil era composta por 44,7\% de população urbana e 55,3\% de população rural (BRASIL. Estatuto da Cidade, 2001). Dez anos depois essa relação se inverteu, com números quase idênticos: $55,9 \%$ de população urbana e 44,1\% de população rural. Entre 1960 e 1996, a população urbana brasileira aumentou em mais do que quatro vezes, passando de 31 milhões de habitantes para 137 milhões, recebendo, portanto, 106 milhões de novos moradores nesses 36 anos.

3. 10 GUGLIELMO, R. Les grande métropoles du monde et leur crise. Paris: A Colin, 1996, 268p.

3.11 INDEC - Instituto Nacional de Estadística y Censos. Amuário Estadístico. Buenos Aires, 1999. 
Esse processo produziu uma ocupação urbana com infra-estrutura inadequada e gerou o surgimento de favelas e periferias situadas em áreas de risco. Tal processo fez com que as cidades brasileiras se caracterizassem pela existência de territórios urbanos legais e ilegais ou irregulares. Desse modo, passaram a existir no cenário urbano brasileiro a cidade legal e a cidade ilegal. De acordo com Rolnik (1995), as favelas e cidades precárias, irregulares e ilegais, existentes em todas as localidades brasileiras são fruto da grande e rápida transformação do país de majoritariamente rural para urbano. Além disso, a autora destaca que freqüentemente as áreas estabelecidas pelo mercado formal como impróprias para a implantação de loteamentos passam por um processo de desvalorização. Com a perda de valor para o mercado formal, tais áreas passam a ser reserva de terra do mercado clandestino. Como exemplos desse processo, a autora ressalta que a maioria das favelas brasileiras se encontra em áreas de maior declividade ou nas margens de córregos.

Segundo Carlos Tucci (2003) ${ }^{3.12}$, quase a totalidade das cidades da América do Sul não apresenta em seus planos diretores restrições que impeçam efetivamente o loteamento de áreas com risco de inundação, o que contribui para a exposição da população aos riscos das inundações urbanas. Complementarmente, é importante considerar também a dinâmica da cidade ilegal (Rolnik, 1995), pois nos casos em que se aplica uma restrição às áreas ribeirinhas - não permitindo o loteamento por tratarse de uma área com risco de inundação -, ou no caso de áreas ribeirinhas pertencentes ao poder público, é freqüente a ocorrência de invasões por população de baixa renda.

O pensamento amplamente difundido no Brasil, baseado na adaptação da hidrografia ao sistema de mobilidade urbana, fez com que vários rios urbanos sofressem intervenções drásticas de retificação de seus meandros. Tais ações tiveram como objetivo recuperar terrenos considerados impróprios para a ocupação. Assim, os meandros dos rios deram lugar à urbanização e os fundos de vale se transformaram em terras que poderiam ser loteadas e comercializadas, conformando as áreas de várzeas como são conhecidas atualmente. O processo ocorrido no Vale do Anhangabaú, em São Paulo - SP, é um exemplo representativo desse processo.

Em 1907 o córrego do Anhangabaú ainda corria no vale, pelos fundos de lotes residenciais, quando Augusto Carlos de Silva Telles publica um livro com o título Os melhoramentos em São Paulo, no qual destaca a circulação viária como o maior desafio a ser resolvido. As obras consideradas como urgentes são alargamento de alguns cruzamentos e transformação da Rua Libero Badaró, estreita, íngreme e ocupada por

${ }^{3.12}$ TUCCI, C. E. M. Águas Urbanas. In: TUCCI, C. E. M.; BERTONI, J. C. (org). Inundações urbanas na América do Sul. Porto Alcgre:; Associação Brasileira de Recursos Hídricos, 2003, 471 p. 
muitos cortiços. Telles indica as intenções das obras: "Daríamos ao centro da cidade um verdadeiro desafogo, dotaríamos São Paulo de uma bella (sic) avenida central, dominando esse vale sob os dois viadutos, hoje tão mal aproveitado e que poderá transformar-se em um sítio encantador." (Telles, $1907^{3.13}$ apud LEME, 1999).

Em 1912 Silva Telles apresenta na Câmara Municipal uma nova versão para esse projeto, contemplando toda a área que compreende o vale. Nesse projeto, além da intervenção na rua Libero Badaró, surge a proposta de implantação de uma avenida no fundo de vale, associada a um tratamento paisagístico da área. A idéia de utilizar um fundo de vale para uma ligação viária era inovadora, já que habitualmente a abertura de caminhos era realizada pelos pontos mais altos, onde não se apresentavam problemas de drenagem (SIMÕES JÚNIOR,1995 ${ }^{14}$ apud LEME, 1999). As Figuras 3.21 e 3.22 ilustram o Vale do Anhangabaú em 1954 e em 2002.

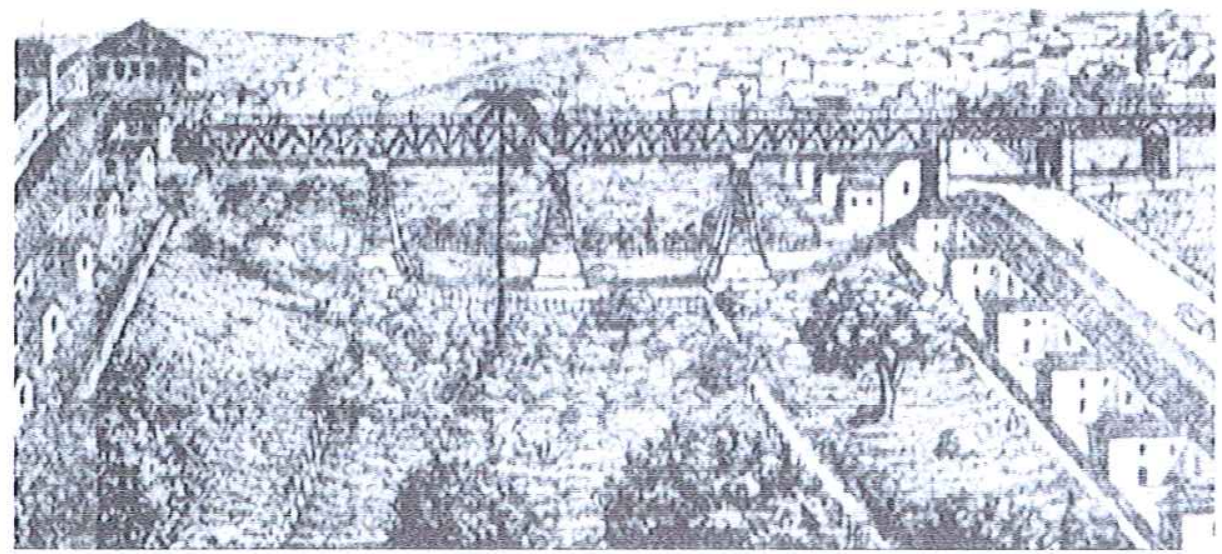

Figura 3.21 - Desenho do Vale do Anhangabau em fins do séc. XIX. Fonte: Museu Paulista apud Steinke, 2002, p.72

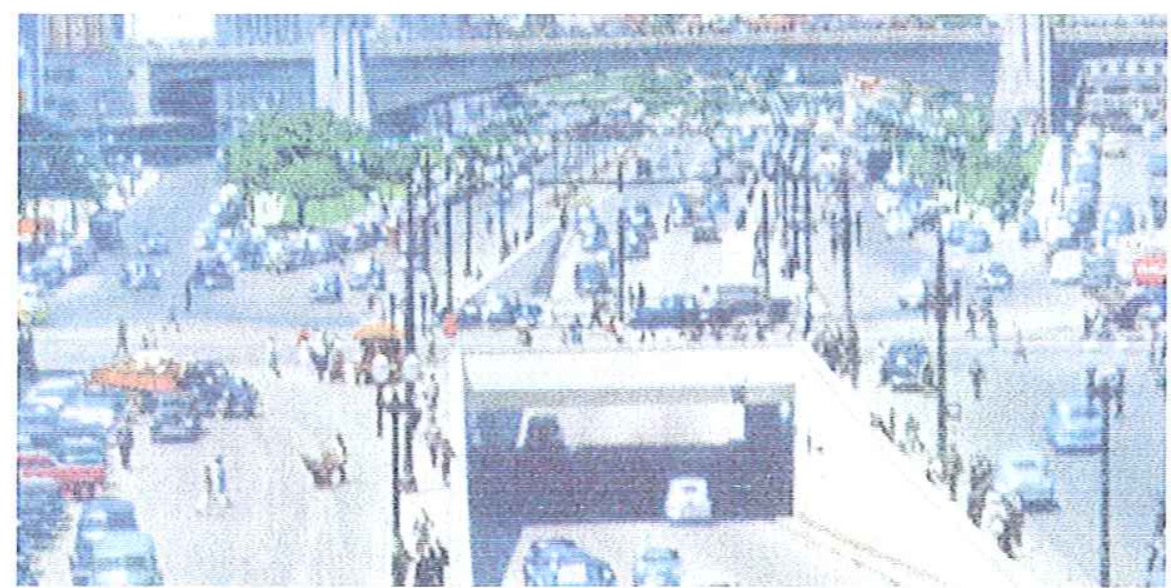

Figura 3.22 - Vale do Anhangabau em 1954. Fonte: Revista Cidade DPH/PMSP, 1996 apud Steinke, 2002, p. 72

${ }^{3.13}$ TELLES, Augusto Carlos da Silva. Os melhoramentos de São Paulo. São Paulo: Escolas Salesianas Profissionais, 1907.

${ }^{14}$ JR SIMÕES, J. G. Anhangabaú: História e Urbanismo: São Paulo. Tese (Doutorado) - Faculdade de Arquitetura e Urbanismo, Universidade de São Paulo, 1995. 
Como consequêencia da urbanização dos fundos de vale, a população passou a sofrer os impactos causados por inundações, que passaram a ser assunto freqüente em notícias de jornal. Segundo Baptista et al (1998), nota-se por parte da imprensa uma percepção inadequada do papel dos cursos d'água no ambiente urbano. Como exemplo, os autores destacam considerações feitas no jornal Estado de Minas sobre córregos da cidade de Belo Horizonte $-\mathrm{MG}^{3.15}$ :

“ (...) permeiam pelo noticiário acusações de que os córregos da cidade são "agentes de poluição" e "de destruição", sendo que o Ribeirão Arrudas, em especial, passou a constituir "um entrave ao desenvolvimento de algumas regiões", uma vez que, "percorrendo áreas densamente povoadas", jogava "suas águas poluídas para fora do leito, inundando ruas e invadindo lojas, deixando para trás um saldo de mortes e de desabrigados". " (BAPTISTA et al, 1998, p. )

Dois dos principais exemplos brasileiros desse tipo de processo são os ocorridos com o Rio Tietê e o Rio Pinheiros, em São Paulo - SP. As Figuras 3.23 e 3.24 ilustram o processo de retificação do Rio Pinheiros, que foi seguida pela implantação de avenidas marginais.

${ }^{3.15}$ ESTADO DE MINAS. Arquivos do período de 1938 a 1997 . Notícias de 12/12/1980 e de 30/12/1984. 

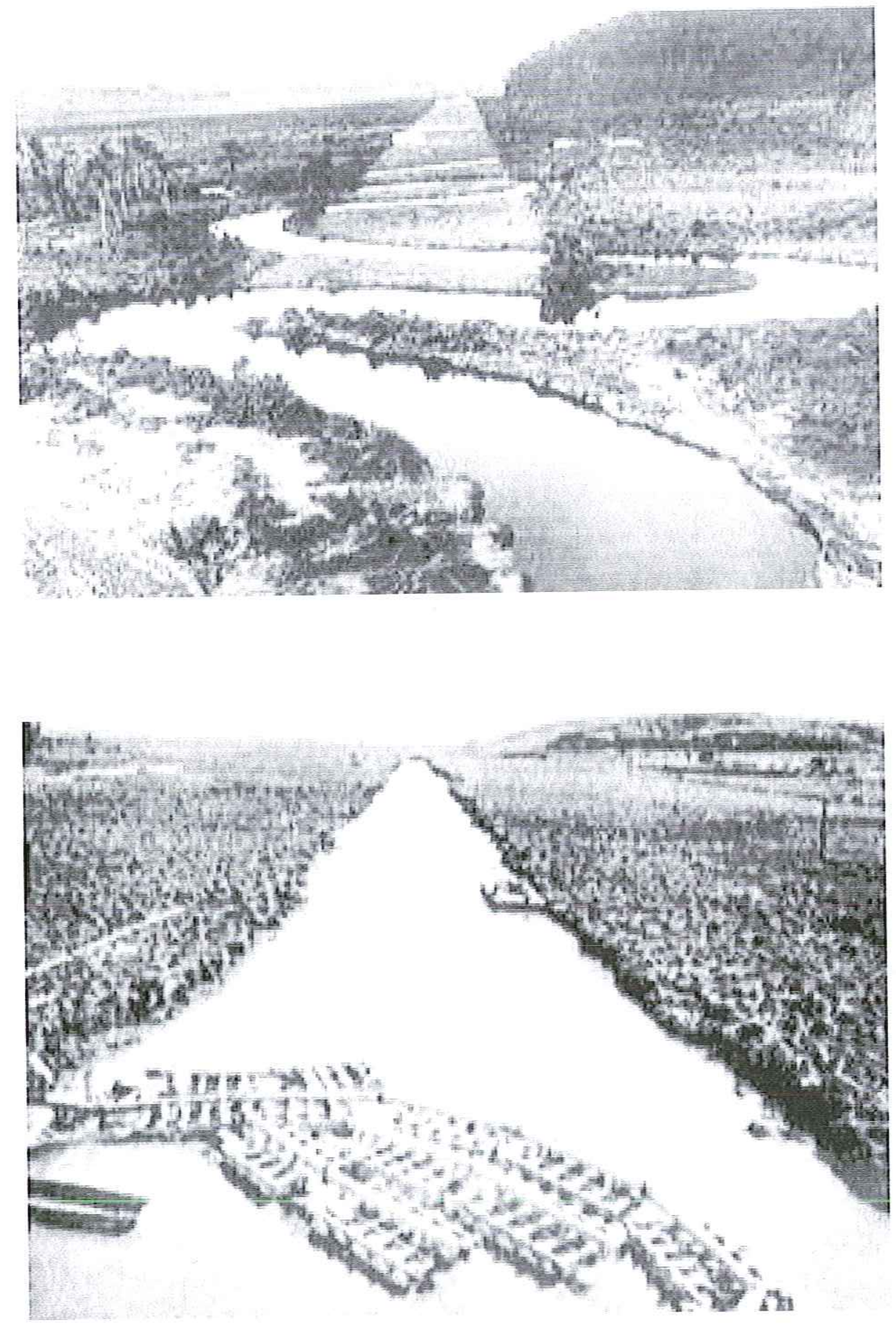

Figura 3.23 - Rio Pinheiros antes e depois da retificação. Fonte: WORKSHOP RIOS URBANOS, 2003, p. 32 e 33 

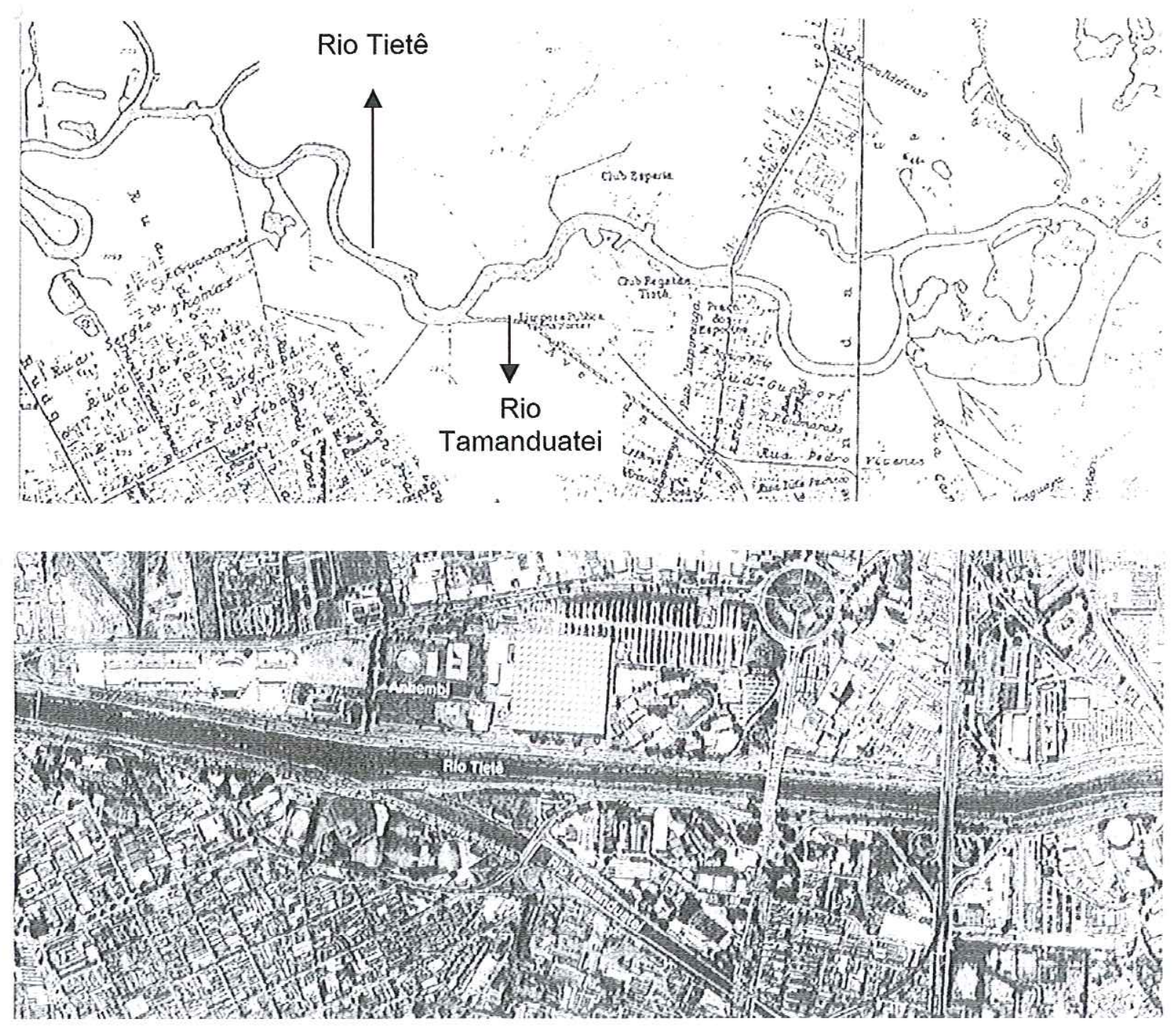

Figura 3.24 - Processo de retificação dos rios e ocupação das várzeas em São Paulo: confluência dos rios Tamanduateí e Tietê. Fonte: Canholi (2005)

O processo de retificação dos rios foi reproduzido em várias cidades brasileiras, sendo São Carlos uma delas. A Figura 3.25 demonstra a transformação do curso do Córrego do Monjolinho, entre 1970 e 2003. A Figura 3.26 indica o curso do Córrego do Tijuco Preto em 1982 e em 2002. 


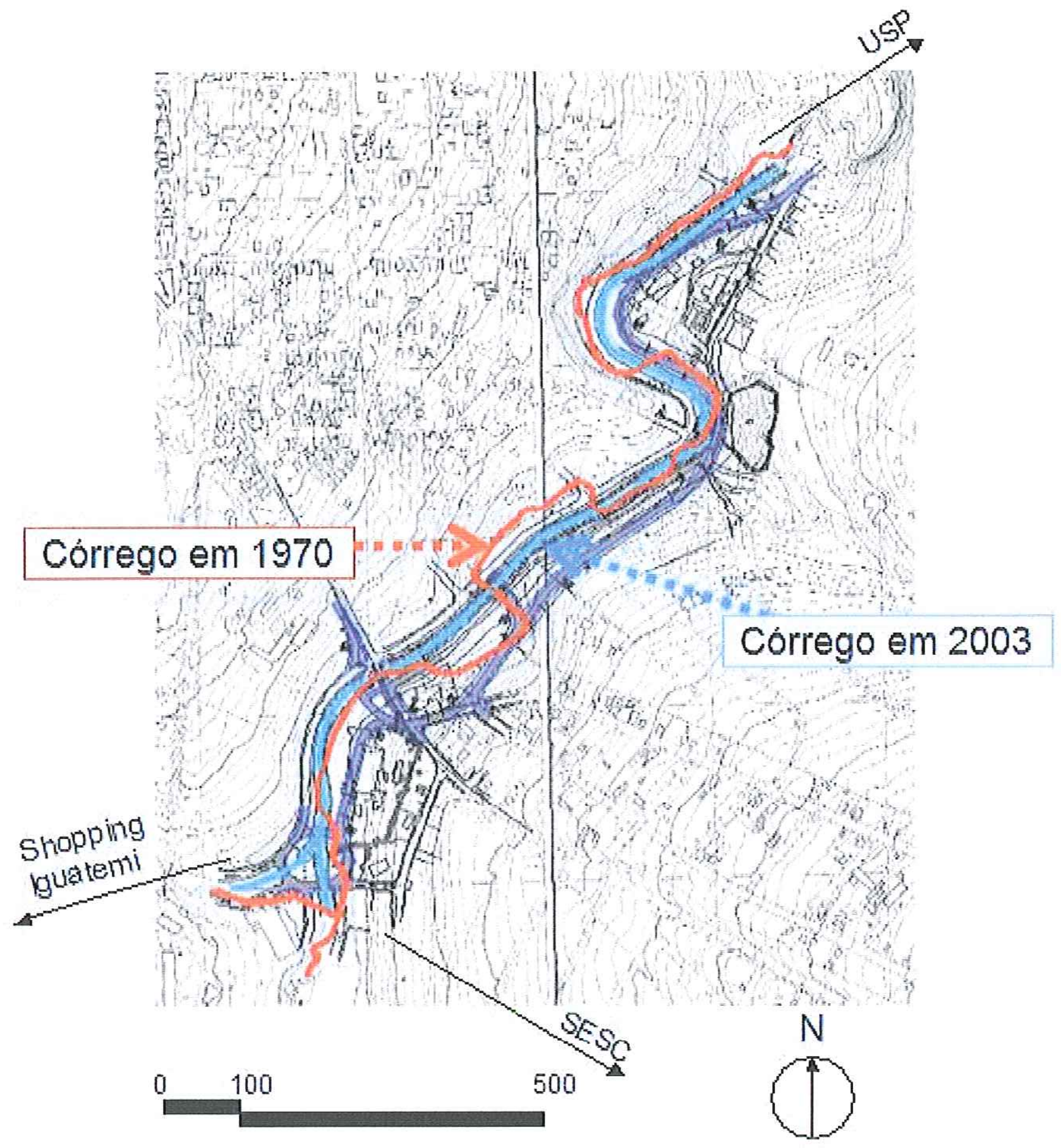

Figura 3.25 - Córrego do Monjolinho em 1970 e em 2003. Fonte: adaptado de ANELLI (2005). 


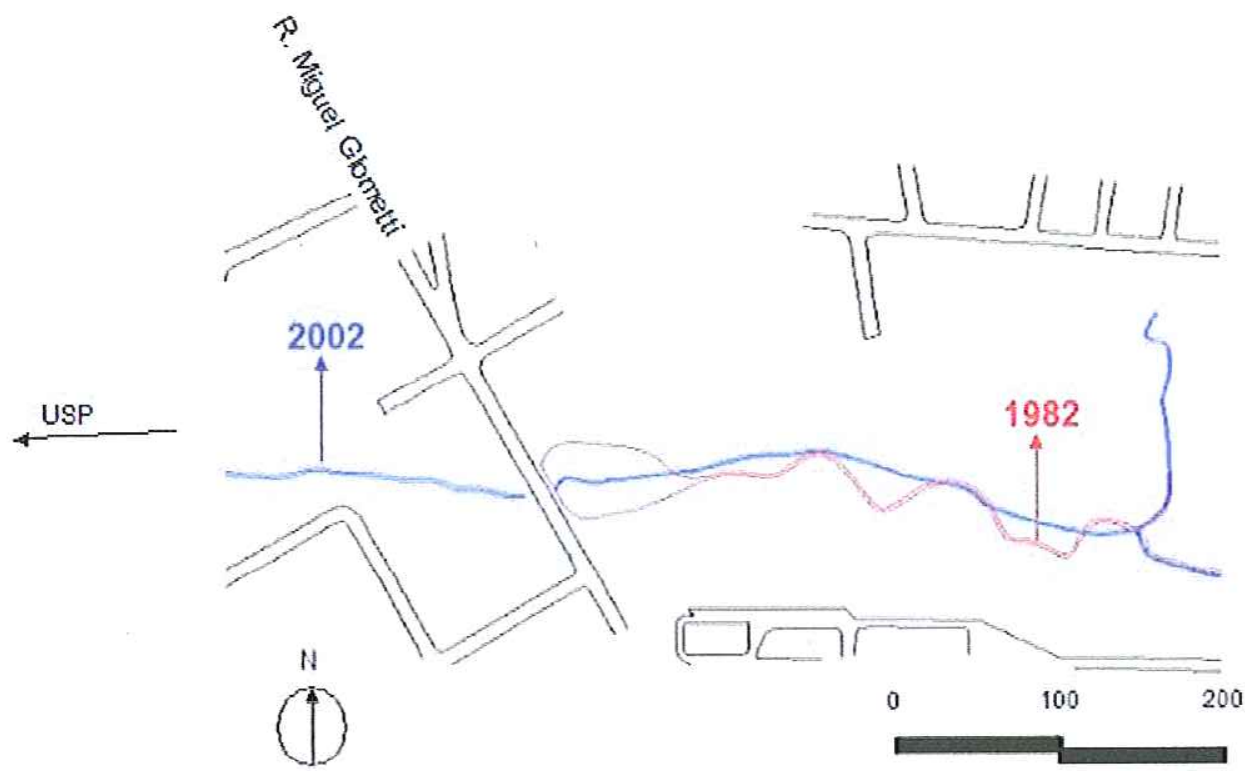

Figura 3.26 - Córrego do Tijuco Preto em 1982 e em 2002. Fonte: FIPAI / PMSC (2003)

Projetos e propostas para a canalização do Rio Tietê e o aproveitamento de suas várzeas foram realizados desde o final do século XIX., em função do agravamento das condições de saneamento de suas várzeas e da situação crítica ocasionada por freqüentes inundações. O primeiro estudo de retificação do Rio Tietê foi desenvolvido pelo Barão de Guarajá, em 1836. A partir de então, foram elaborados diversos projetos de retificação do Rio Tietê (LEME, 1999).

Destacamos a seguir algumas das idéias contidas nas propostas de Barry Parker, em 1919, e de Prestes Maia, em 1930, para a várzea do rio Tietê.

Barry Parker, arquiteto inglês que trabalhou para a Companhia City em São Paulo, propôs em 1919 a implantação de um cinturão de parques (parking) ao redor da área urbana que teria como objetivo conter o crescimento urbano. O cinturão articularia parques existentes e novos a serem criados. É essa mesma idéia que inspira Prestes Maia a propor um sistema de parques para a cidade, apresentado no seu Plano de Avenidas, em 1930.

O sistema de parques proposto por Prestes Maia não teria a função de conter o crescimento da cidade, como havia proposto Parker, mas também articularia parques já existentes e novos a serem criados. A proposta de Prestes Maia era baseada na implantação de avenidas-parque ao longo dos fundos de vale. Com a construção das marginais aos rios Tietê e Pinheiros seria concluído o círculo de avenidas perimetrais envolvendo a área urbana, um dos principais aspectos da proposta.

Prestes Maia observa que a avenida-parque perimetral (parkway) é "uma orientação americana, 
moderna e feliz, a de ligar entre si os parques de uma cidade por meio de avenidas amplas que conservem alguns caracteres que lembram os parques, taes (sic) como arborização ajardinamento, casas afastadas". (Maia, $1930{ }^{3.16}$ apud LEME, 1999, p. 347).

O Circuito de parkways de Prestes Maia era composto por principalmente pelas avenidas marginais aos Rios Tietê e Pinheiros. As linhas férreas seriam implantadas à margem direita do Tietê, enquanto a margem esquerda seria reservada à circulação, com calçamento, arborização e iluminação adequados. A proposta previa também implantação de conjuntos monumentais nas marginais, como a nova estação central, instalações esportivas e indústrias. O rio canalizado seria próprio à navegação e a atividades esportivas.

Segundo Yves Bruand (1997), o plano de Prestes Maia poderia ter sido uma solução satisfatória se tivesse sido colocado em prática imediatamente. Porém, embora não tenha deixado de servir como orientação e seu autor tenha sido prefeito da cidade por duas vezes, foram necessários 30 anos para que a proposta tomasse forma. Na gestão de Prestes Maia de 1938 a 1945, durante a ditadura de Getúlio Vargas, o autor teve de contentar-se com a abertura de somente uma parte do anel e a dupla pista da Av. 9 de julho. Na gestão de 1961 a 1965, em que foi eleito pela via direta, os recursos financeiros não permitiram realizar a maioria das grandes obras propostas. O autor destaca ainda que "A infelicidade de São Paulo é que as tentativas feitas vêm sempre muito tarde e visam remediar uma situação já superada no momento de sua realização". (BRUAND, 1997, p. 330)

Na gestão de Prestes Maia como prefeito de São Paulo, de 1938 a 1945, as obras de canalização do Tietê no trecho entre Osasco e Ponte Grande foram iniciadas. Segundo Maria Cristina da Silva Leme (1999), a partir de então, abandonam-se várias idéias desenvolvidas em projetos anteriores, como a possibilidade de navegação do rio. A prioridade passa a ser possibilitar a urbanização das áreas inundáveis ou antes ocupadas pelos meandros dos rios. A referida autora avalia que "caso iivessem prevalecido as idéias dos urbanistas, a várzea do Tietê poderia ter se tornado uma grande área de lazer da cidade, com parques, equipamentos de transporte rápido por via férrea e por via navegável”. (LEME, 1999, p. 347)

Com a retificação dos rios Tietê e Pinheiros, a ocupação urbana de suas várzeas foi iniciada, compondo um processo de transformação que teve como produto a configuração de um dos principais exemplos de áreas afetadas por inundações urbanas no Brasil (Figuras 3.27 e 3.28). Esse processo foi reproduzido em várias cidades brasileiras, sendo São Carlos uma delas.

${ }^{3.16}$ MAIA, Francisco Prestes. Introdução ao estudo de um plano de avenidas para a cidade de São Paulo. São Paulo: Editora Melhoramentos, 1930. 

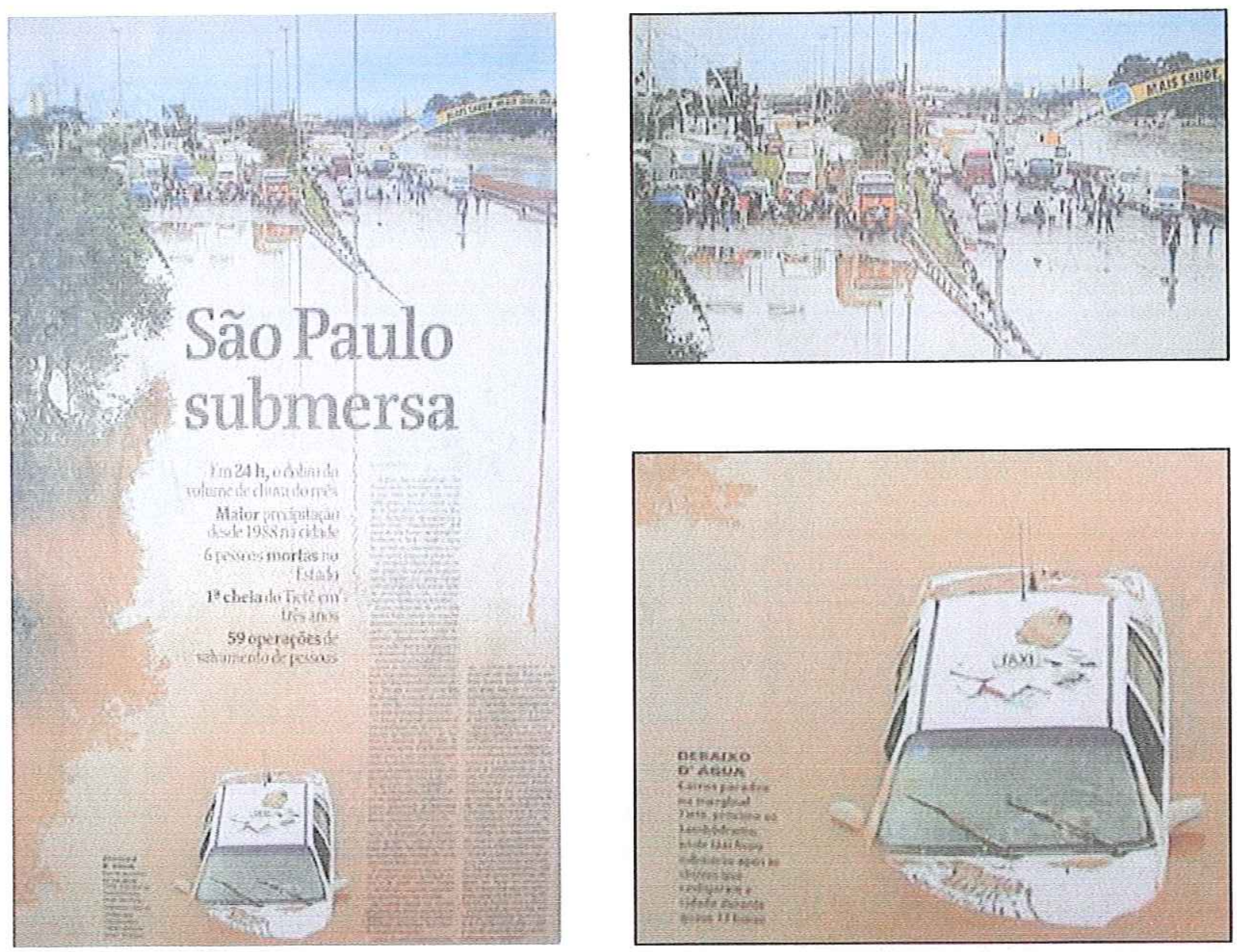

Figura 3.27 - Foto de inundação na Marginal Tietê, São Paulo - SP, em 25 de maio de 2005. Fonte: adaptado de SÃO PAULO..., 2005

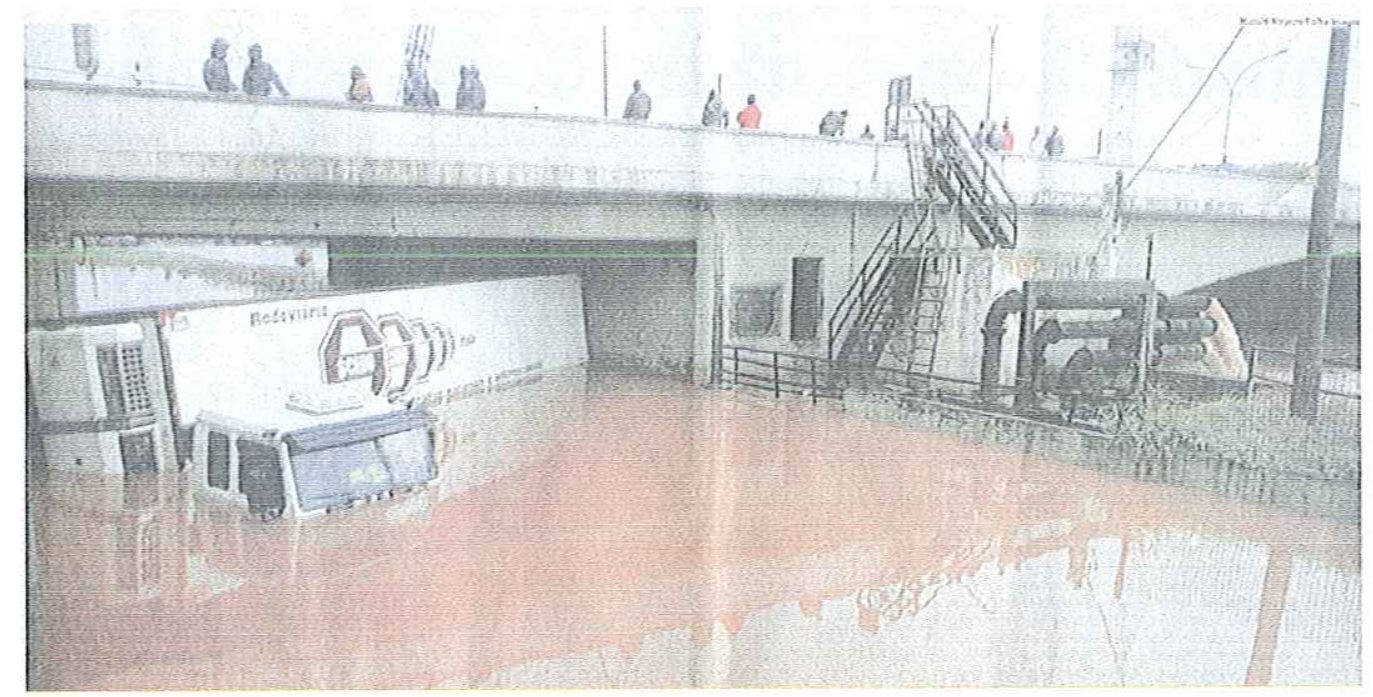

Figura 3.28 - Inundação na Marginal Tietê em 25 de maio de 2005: Caminhão em baixo da ponte das Bandeiras. Fonte: adaptado de INUNDAÇÃO..., 2005. 


\section{MATERIAIS E MÉTODOS}

\subsection{CARACTERIZAÇÃO DA ÁREA DE ESTUDO}

\subsubsection{Localização e Dinâmica Populacional do Município de São Carlos}

O município de São Carlos se localiza no centro do Estado de São Paulo (Figura 4.1). A população total do município, em 2000, era de 192.923 habitantes (IBGE, 2000).

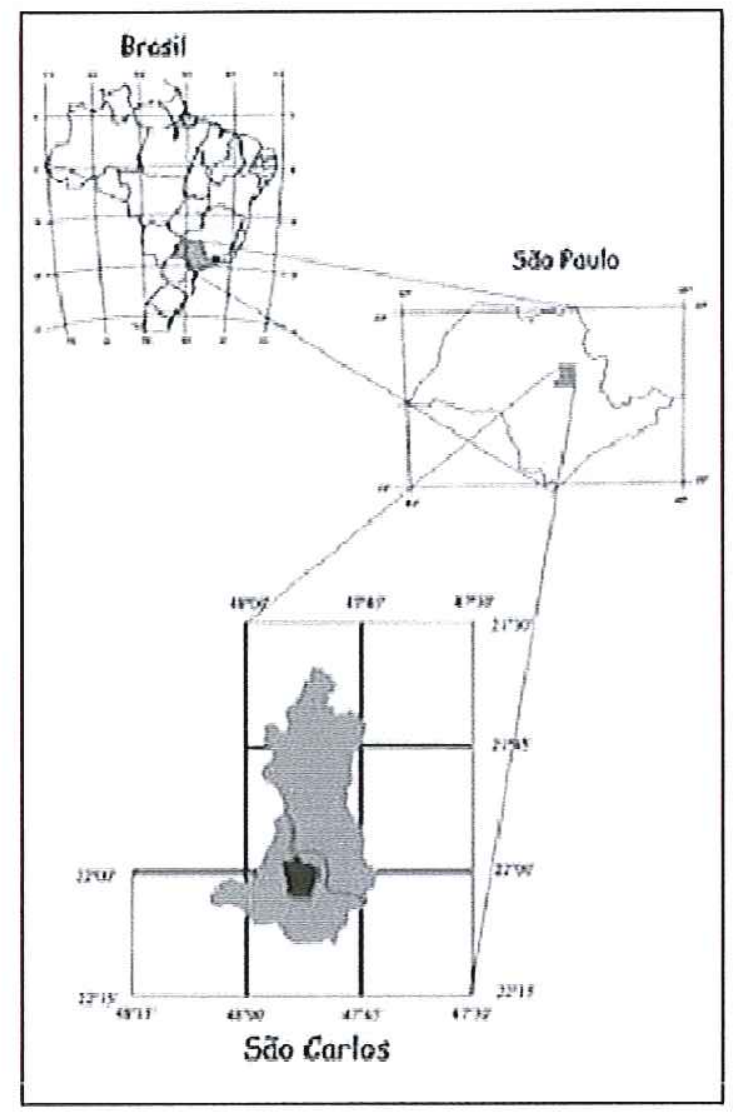

Figura 4.1 - Localização do município de São Carlos.

De acordo com Regina Devescovi (1987), a ocupação da região de São Carlos se deu em um contexto de conquista do território paulista pelo desenvolvimento da economia cafeeira, a partir do último quarto do século XIX e até a crise de 1929. A fixação antrópica na região foi determinada pela chegada da lavoura do café, por volta de 1840. A comercialização do café se fortaleceu de fato após 1860 e se tornou a principal atividade da região em 1884, com a construção da ferrovia e implementação de mão de obra estrangeira. 
O marco inicial da cidade se localiza entre a Avenida São Carlos e Rua Episcopal, onde atualmente se encontra a Catedral de São Carlos. Sua primeira ocupação se deu com a implantação da primeira capela, em 1856. A ocupação urbana se deu a partir da capela, em direção ao sul, alcançando o Córrego do Gregório.

A comparação do crescimento demográfico de São Carlos com o do Estado de São Paulo e do Brasil no período entre 1981 e 2000 (Figura 4.2) demonstra que o município se destaca sob tal aspecto. Nesse período, a população de São Carlos cresceu mais do que a do Estado de São Paulo e a do Brasil, apresentando taxa geométrica de crescimento populacional de 2,57\%, superior à média do Estado de São Paulo (2,13\%) e do Brasil (1,93\%) (IBGE, 1981; 2000).

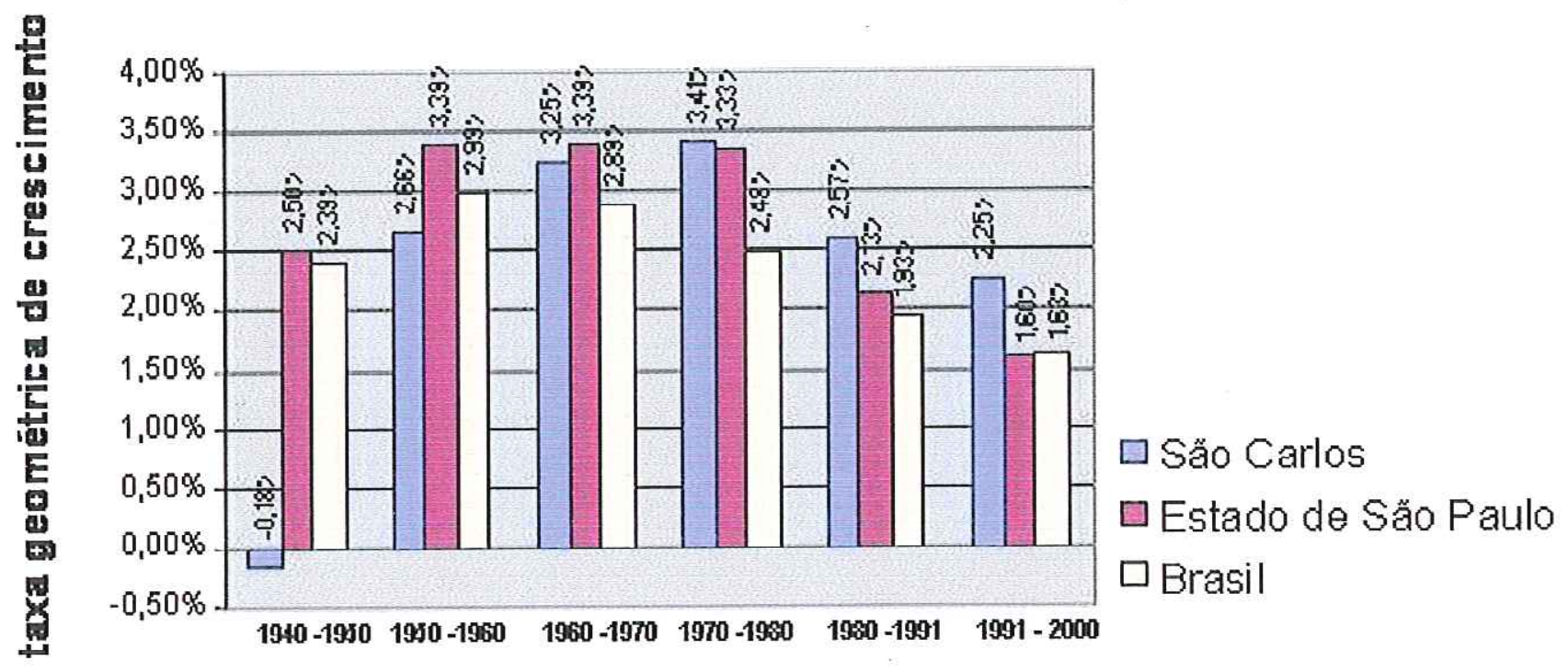

Figura 4.2 - Taxa Geométrica de Crescimento de 1940 a 2000: São Carlos, Estado de São Paulo e Brasil. Fonte: PMSC, 2002.

Entre 1940 e 2000, a população urbana de São Carlos aumentou aproximadamente sete vezes, passando de 25.746 habitantes em 1940 (IBGE, 1940), para 183.369 habitantes em 2000 (IBGE, 2000). No mesmo período, (Figura 4.3) a porcentagem da população urbana passou de 53\% para 93\%. Atualmente, a porcentagem da população urbana de São Carlos é de 95,8\% (SEADE, 2004). 


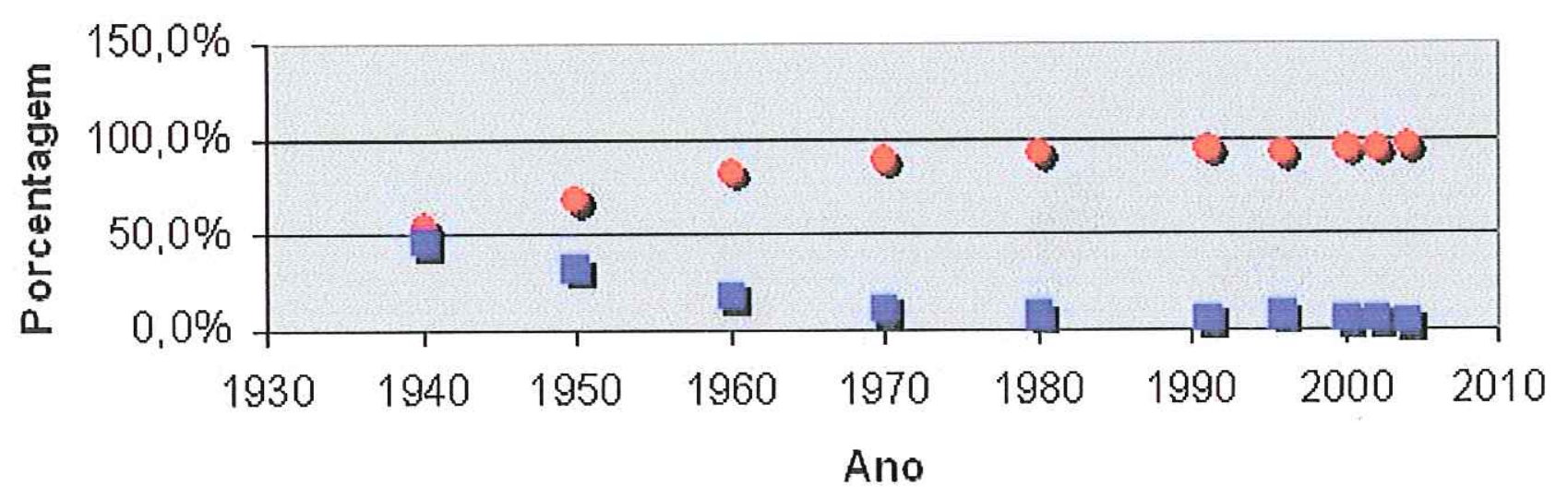

\% Pop. Urbana a Pop. Rural

Figura 4.3 - Evolução da porcentagem da População Urbana e Rural em São Carlos de 1940 a 2004. Dados: IBGE e SEADE

\subsubsection{As Bacias Hidrográficas em São Carlos}

O município de São Carlos se situa nas bacias hidrográficas Tietê-Jacaré e Mogi-Guaçu (Figura 4.4), que se dividem em dez bacias. A bacia do Monjolinho abrange praticamente toda a área urbana, que é atravessada pelo Córrego do Gregório (Figura 4.5).
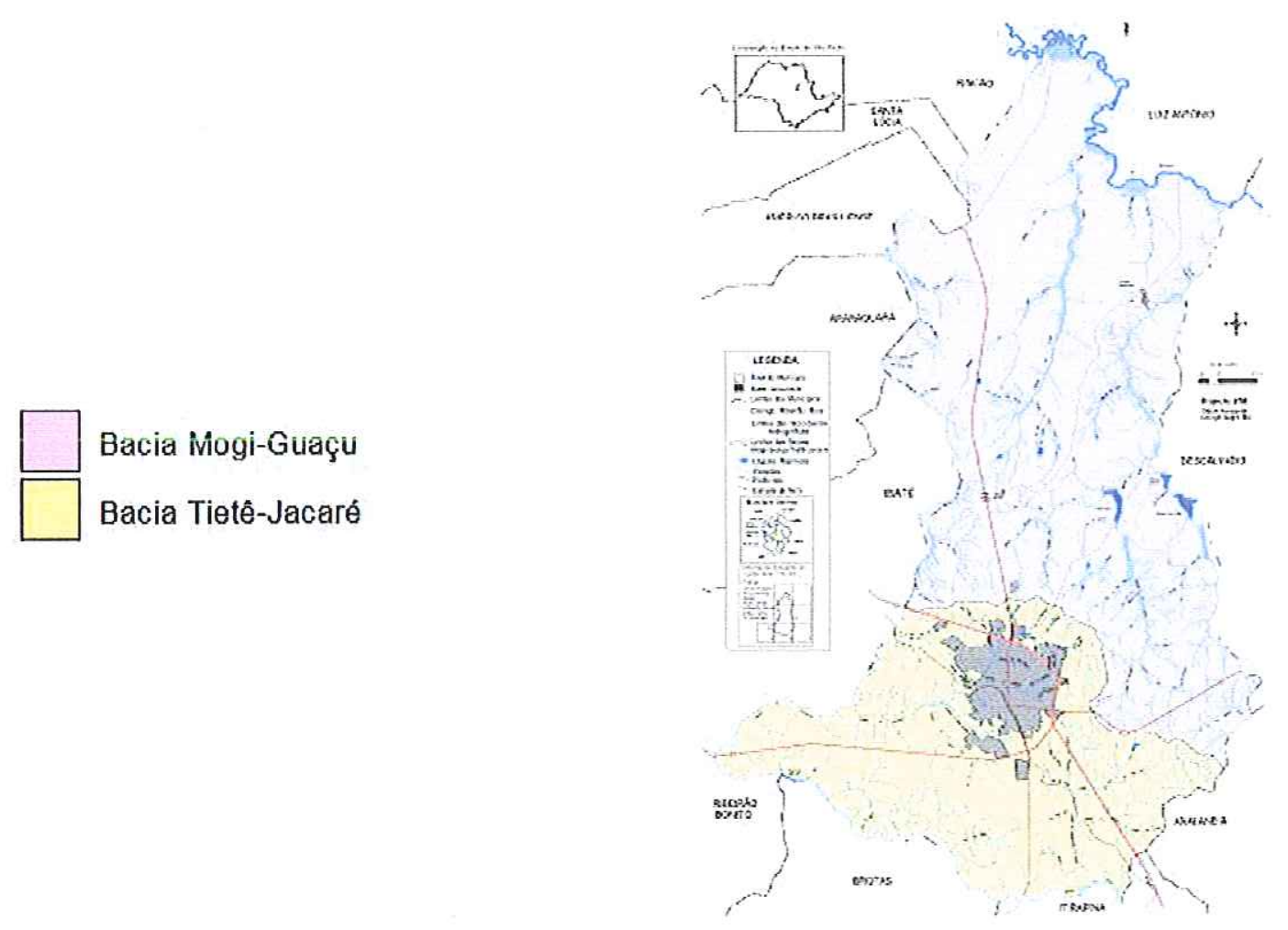

Figura 4.4 - Bacias Hidrográficas no Município de São Carlos. Fonte: PMSC, 2002. 


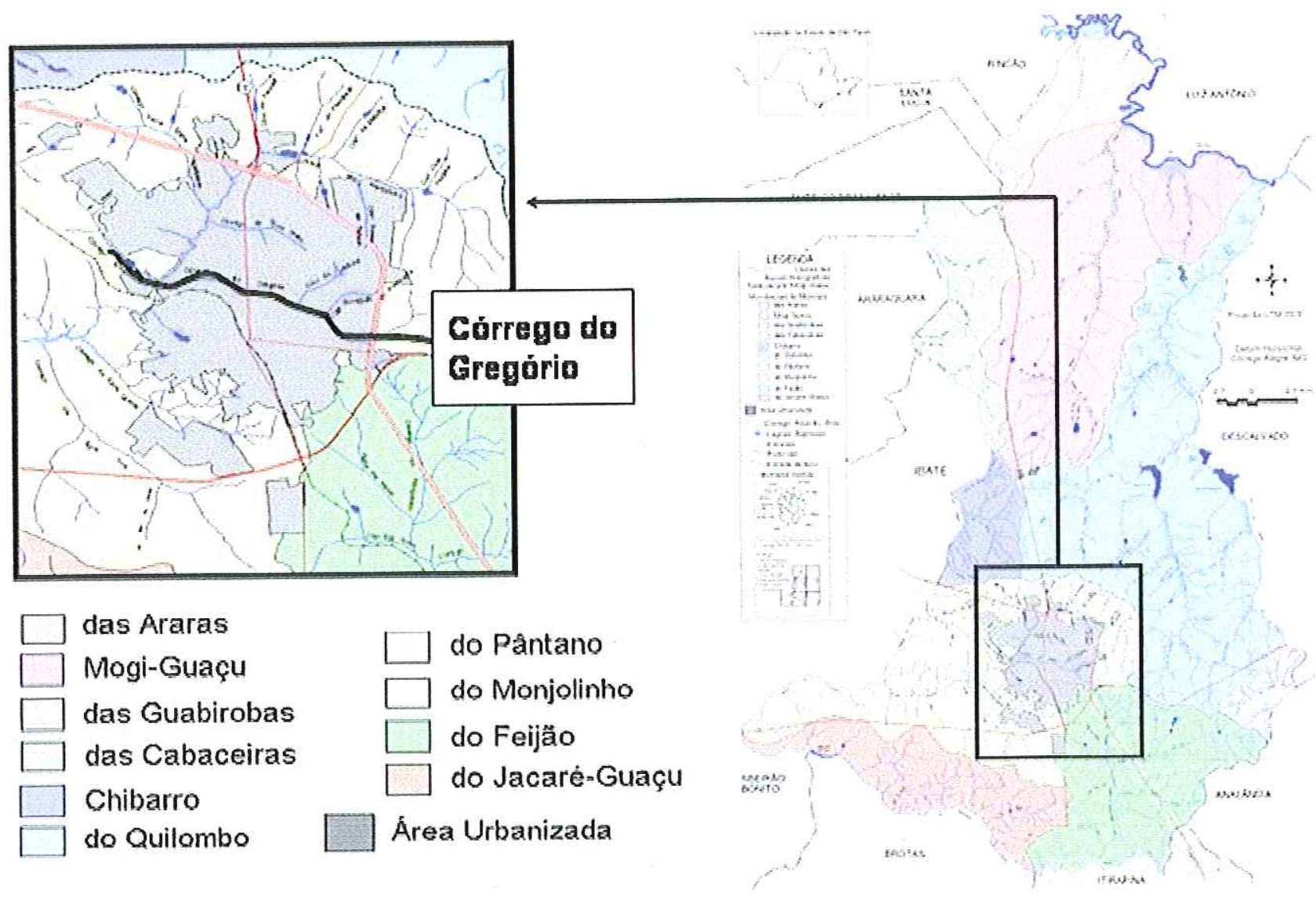

Figura 4.5 - Bacias Hidrográficas no Município de São Carlos, com destaque para o Córrego do Gregório.

Fonte: adaptado de PMSC,2002

\subsubsection{A Bacia Hidrográfica do Córrego do Gregório}

A Bacia do Gregório (Figura 4.6), onde se situa o Mercado Municipal tem extensão de 18,9 km2, perímetro de 22,4 km, desnível máximo de $166 \mathrm{~m}$ e $60 \%$ de área urbanizada (ESTEVES, 2003).

Nessa bacia, as inundações ocorrem rapidamente (Figura 4.7), de 15 a 30 minutos, atingindo cotas de $50 \mathrm{~cm}$ a $150 \mathrm{~cm}$. (RIGHETTO et al, 2003). As inundações mais freqüentes afetam a mais de 40 estabelecimentos comerciais, com perdas estimadas de até R $\$ 500.000$ por inundação (Projeto FINEP, 2002). 


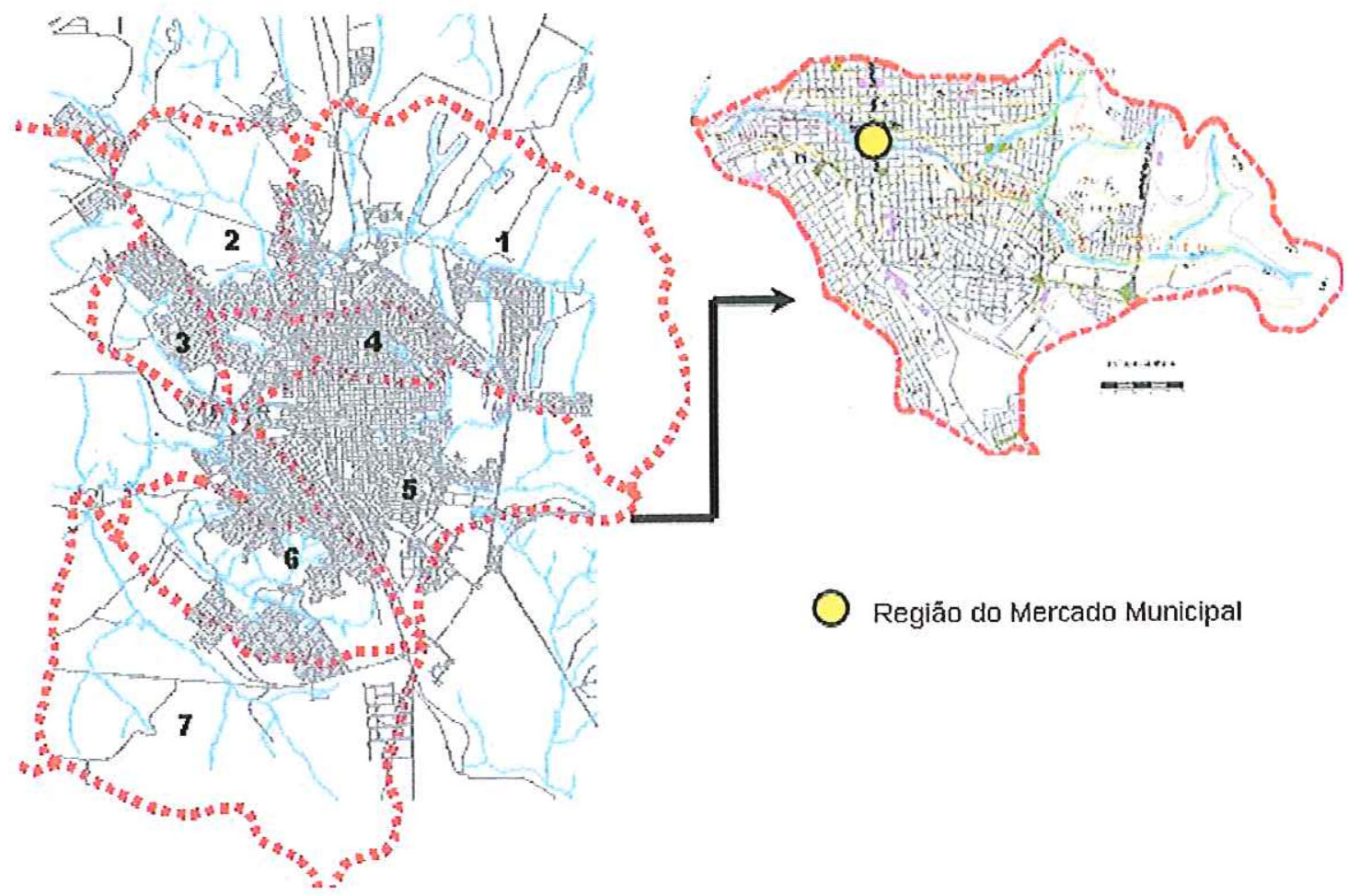

Figura 4.6 - Bacias Urbanas de São Carlos, com destaque para a Bacia do Gregório e região do Mercado Municipal. Dados: Projeto FINEP/CT-HIDRO/EESC/USP-DAEE/SP - CNPq- 01.02.0086.00

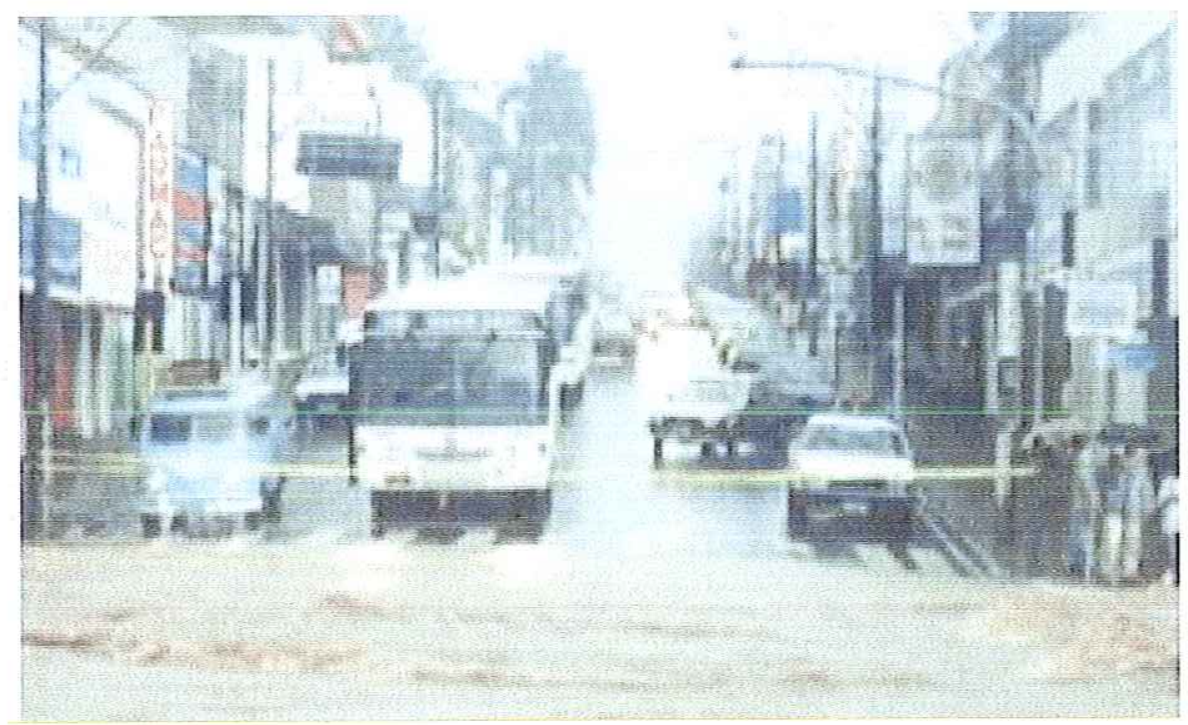

Figura 4.7 - Inundações na região do Mercado Municipal, em 2001 (esquerda) e em 2002 (direita). Fonte: PMSC e Pedro Caballero - Defesa Civil de São Carlos 


\subsection{HISTÓRICO DA EXPANSÃO URBANA: SÃO CARLOS E BACIA DO GREGÓRIO}

O levantamento dos dados utilizados na pesquisa foi realizado nas instâncias indicadas no Quadro 4.1.

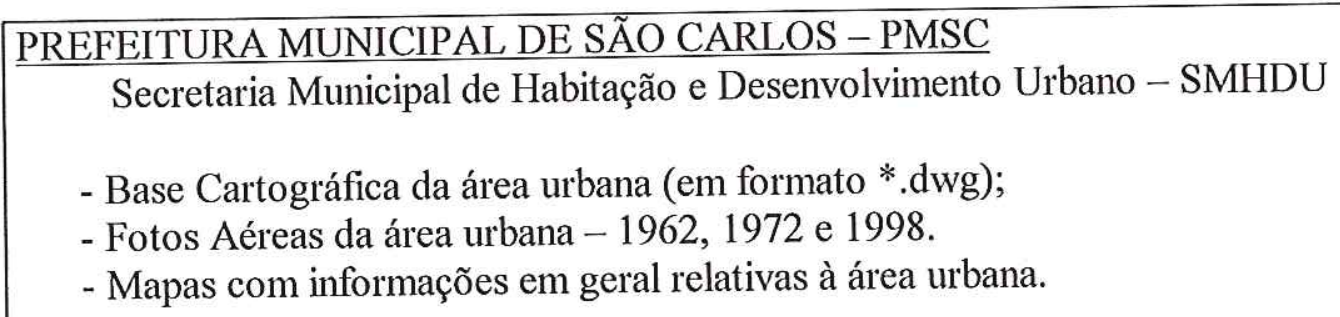

- Fotos de transformações na região do Mercado Municipal;

- Fotos históricas de inundações e alagamentos na Bacia do Gregório.

\section{EMPRESA FOTOARTE}

- Fotos de transformações na região do Mercado Municipal;

- Fotos históricas de inundações e alagamentos na Bacia do Gregório.

Quadro 4.1 - Estratégia metodológica da pesquisa relacionada com Fontes de Informação

O levantamento sobre o processo histórico de expansão urbana de São Carlos foi realizado em três etapas. A primeira delas se deu junto à Secretaria Municipal de Habitação e Desenvolvimento Urbano de São Carlos -SMHDU, no período em que a autora fez parte da equipe de elaboração do Plano Diretor de São Carlos (PMSC, 2004), de 2001 a 2004. No período entre 2001 e 2002, aproximadamente, foram realizados os levantamentos de dados que subsidiaram a proposta do Plano Diretor, atualmente em análise na Câmara Municipal. A elaboração do Mapa de Expansão Urbana de São Carlos de 1940 a 2002 (AMADOR, 1990; BISSINOTO, 1988, PMSC/SMHDU, 2001) fez parte desse processo e constitui a primeira etapa de elaboração deste trabalho. As seqüências históricas de áreas loteadas, calculadas na segunda e terceira etapa, foram obtidas a partir do Mapa de Expansão Urbana, em formato dwg, disponibilizado pela SMHDU.

A segunda etapa consistiu no cálculo das áreas loteadas em São Carlos para cada período. Foram traçadas poligonais indicando os limites da ocupação urbana nos anos 1950, 1970, 1980, 1990, 2000 e 2002. Com o cálculo das áreas das poligonais, foram obtidos os valores relativos à área total loteada para cada um dos referidos anos. 
$\mathrm{Na}$ terceira etapa, a indicação dos limites da Bacia do Gregório foi sobreposta ao mapa, possibilitando a aplicação do mesmo procedimento para a área da bacia.

As áreas totais loteadas em 1960, para a cidade de São Carlos e para a Bacia do Gregório, foram estimadas em função da tendência indicada pelos valores obtidos.

A partir da obtenção desses dados, foram calculadas taxas relacionando o crescimento de áreas loteadas com o crescimento da população urbana, visando à compreensão do processo de expansão urbana de São Carlos e de ocupação da Bacia do Gregório. Os cálculos das seqüências históricas de áreas loteadas e das taxas, para São Carlos e para a Bacia do Gregório, foram realizados em aproximadamente dois meses.

Realizou-se também, junto à empresa FotoArte e à Fundação Pró-Memória de São Carlos, o levantamento de fotos antigas que demonstrassem as transformações territoriais ocorridas na área próxima ao Mercado Municipal, desde o início de sua ocupação urbana até a atualidade. Algumas dessas fotos foram selecionadas e reproduzidas na atualidade, possibilitando comparações entre as ocupações estabelecidas em diferentes períodos para a mesma área.

\subsection{LEVANTAMENTO DE DATAS EM QUE POSSIVELMENTE OCORRERAM INUNDAÇÕES OU ALAGAMENTOS}

\subsubsection{Datas indicadas por dados históricos monitorados}

Para nortear a busca das notícias, foi realizado um levantamento sobre dados históricos monitorados de Precipitação Diária de algumas das estações do SIGRH (Sistema Integrado de Gerenciamento dos Recursos Hídricos de São Paulo) localizadas no município de São Carlos.

Dentre as estações do SIGRH, foram selecionadas as estações D4-045, D4-017 e D4-075, por serem Mais próximas à bacia de estudo. Os dados das estações selecionadas se referem somente até janeiro de 1996. Para o período de fevereiro de 1996 a dezembro de 2004, necessário para completar o período da pesquisa (1940 a 2004), foram utilizados os dados da estação da EMBRAPA (EMBRAPA, 2004 a) (Figura 4.8).

É importante destacar que a localização das estações foi elaborada com coordenadas com precisão máxima de minutos (disponibilizadas por SIGRH, 2004). Para manter um mesmo critério na aproximação para a localização das estações, foram utilizadas as coordenadas da estação da EMBRAPA também com 
precisão máxima de minutos. Portanto, a localização das estações sobre a base cartográfica da cidade de São Carlos com a demarcação da bacia do Gregório (Figura 4.8) é aproximada. As estações D4-017 e D4-075 ocupam a mesma posição, porém operaram em períodos diferentes.

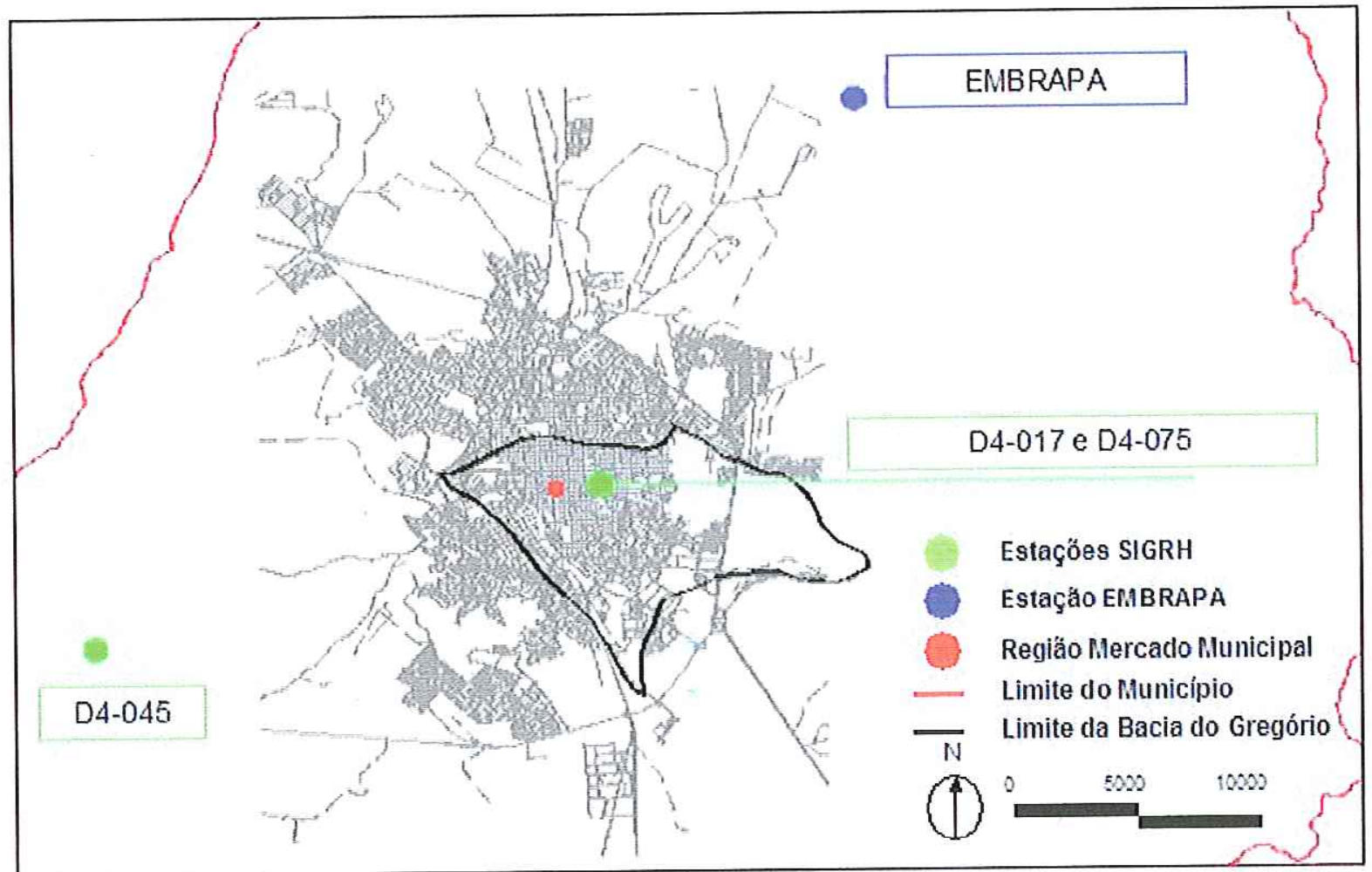

Figura 4.8 - Localização aproximada das estações de monitoramento cujos dados foram utilizados.

Foram utilizados os dados de todo o período de monitoramento da estação D4-017 (de janeiro de 1954 a dezembro de 1971), já que essa é a estação mais próxima da área de estudo. Para os sub-períodos restantes foram utilizados dados das estações D4-045 (de janeiro de 1940 a dezembro de 1953), D4-075 (de janeiro de 1972 a janeiro de 1996) e EMBRAPA (fevereiro de 1996 a dezembro de 2004). A Tabela 4.1 indica os dados disponíveis e os dados utilizados das estações D4-017, D4-045, D4-075 e EMBRAPA. 
Tabela 4.1 - Período de utilização de dados monitorados das estações do SIGRH e EMBRAPA

\begin{tabular}{|c|c|c|c|c|c|c|c|c|c|}
\hline \multirow[b]{2}{*}{ ANO } & \multicolumn{4}{|c|}{ ESTAÇÃO } & \multirow[b]{2}{*}{ ANO } & \multicolumn{4}{|c|}{ ESTAÇÃO } \\
\hline & D4-045 & D4-017 & D4-075 & Embrapa & & D4-045 & D4-017 & D4-075 & Embrapa \\
\hline 1936 & & & & & 1972 & & & $\mathrm{x}$ & \\
\hline 1937 & & & & & 1973 & & & $x$ & \\
\hline 1938 & & & & & 1974 & & & $x$ & \\
\hline 1939 & & & & & 1975 & & & $x$ & \\
\hline 1940 & $x$ & & & & 1976 & & & $x$ & \\
\hline 1941 & $x$ & & & & 1977 & & & $x$ & \\
\hline 1942 & $x$ & & & & 1978 & & & $x$ & \\
\hline 1943 & $x$ & & & & 1979 & & & $x$ & \\
\hline 1944 & $x$ & & & & 1980 & & & $x$ & \\
\hline 1945 & $x$ & & & & 1981 & & & $x$ & \\
\hline 1946 & $x$ & & & & 1982 & & & $x$ & \\
\hline 1947 & $x$ & & & & 1983 & & & $x$ & \\
\hline 1948 & $x$ & & & & 1984 & & & $x$ & \\
\hline 1949 & $x$ & & & & 1985 & & & $x$ & \\
\hline 1950 & $x$ & & & & 1986 & & & $x$ & \\
\hline 1951 & $x$ & & & & 1987 & & & $x$ & \\
\hline 1952 & $x$ & & & & 1988 & & & $x$ & \\
\hline 1953 & $x$ & & & & 1989 & & & $x$ & \\
\hline 1954 & & $x$ & & & 1990 & & & $x$ & \\
\hline 1955 & & $x$ & & & 1991 & & & $x$ & \\
\hline 1956 & & $x$ & & & 1992 & & & $x$ & \\
\hline 1957 & & $x$ & & & 1993 & & & $x$ & \\
\hline 1958 & & $x$ & & & 1994 & & & $x$ & \\
\hline 1959 & & $x$ & & & 1995 & & & $x$ & \\
\hline 1960 & & $x$ & & & 1996 & & & $x$ & $x$ \\
\hline 1961 & & $x$ & & & 1997 & & & & $x$ \\
\hline 1962 & & $x$ & & & 1998 & & & & $x$ \\
\hline 1963 & & $x$ & & & 1999 & & & & $x$ \\
\hline 1964 & & $x$ & & & 2000 & & & & $x$ \\
\hline 1965 & & $x$ & & & 2001 & & & & $x$ \\
\hline 1966 & & $x$ & & & 2002 & & & & $x$ \\
\hline 1967 & & $x$ & & & 2003 & & & & $x$ \\
\hline 1968 & & $x$ & & & 2004 & & & & $x$ \\
\hline 1969 & & $x$ & & & & & & & \\
\hline 1970 & & $x$ & & & & & & Dados & sponíveis \\
\hline 1971 & & $x$ & & & & & $x$ & Dados u & lizados \\
\hline
\end{tabular}

A seleção das datas para nortear a busca de notícias de jornal, se deu pela aplicação de um critério desenvolvido com baseado em uma análise considerando três aspectos:

- Tempo de concentração da bacia; 
- Relações entre lâminas de diferentes durações de precipitação;

- Experiência da Defesa Civil de São Carlos.

CETESB (1979) ${ }^{4.1}$ apud Tucci (2002) apresenta algumas relações entre durações de precipitações para o Brasil (Tabela 4.2).

Tabela 4.2 - Relações entre durações. Fonte: adaptado de CETESB apud Tucci (2002)

\begin{tabular}{|l|l|}
\hline Relação & BRASIL \\
\hline $5 \mathrm{~min} / 30 \mathrm{~min}$ & 0,34 \\
\hline $10 \mathrm{~min} / 30 \mathrm{~min}$ & 0,54 \\
\hline $15 \mathrm{~min} / 30 \mathrm{~min}$ & 0,70 \\
\hline $20 \mathrm{~min} / 30 \mathrm{~min}$ & 0,81 \\
\hline $25 \mathrm{~min} / 30 \mathrm{~min}$ & 0,91 \\
\hline $30 \mathrm{~min} / \mathrm{h}$ & 0,74 \\
\hline $1 \mathrm{~h} / 24 \mathrm{~h}$ & 0,42 \\
\hline $6 \mathrm{~h} / 24 \mathrm{~h}$ & 0,72 \\
\hline $8 \mathrm{~h} / 24 \mathrm{~h}$ & 0,78 \\
\hline $10 \mathrm{~h} / 24 \mathrm{~h}$ & 0,82 \\
\hline $12 \mathrm{~h} / 24 \mathrm{~h}$ & 0,85 \\
\hline $24 \mathrm{~h} / 1 \mathrm{dia}$ & 1,10 \\
\hline
\end{tabular}

Considerando que, de acordo com Esteves \& Mendiondo (2003), o tempo de concentração médio observado da bacia do Gregório é de $45 \pm 17$ minutos, foram consideradas duas possibilidades para estimar o valor de P Diária a partir do qual configura-se um quadro preocupante quanto a inundações na região do Mercado Municipal: a) tempo de concentração da bacia igual a 1 hora, b) tempo de concentração da bacia igual a 30 minutos.

a) Considerando tempo de concentração da bacia igual a 1 hora:

Obteve-se o coeficiente de relação entre $\mathrm{P}_{\text {Diária }} \mathrm{P}_{1 \mathrm{~h}}$ utilizando os valores da Tabela 4.2:

$$
1 \mathrm{~h} / 24 \mathrm{~h}=0,42 \quad 24 \mathrm{~h} / 1 \mathrm{dia}=1,10
$$

Multiplicando-se esses dois valores obteve-se $\mathrm{P}_{1 \mathrm{~h}} / \mathrm{P}_{\text {Diária }}=0,46$

b) Considerando tempo de concentração da bacia igual a 30 minutos:

Obteve-se o coeficiente de relação entre $\mathrm{P}_{\text {Diária }}$ e $\mathrm{P}_{30 \text { min }}$ utilizando os valores da Tabela 4.2:

$$
30 \min / 1 \mathrm{~h}=0,74 \quad 1 \mathrm{~h} / 24 \mathrm{~h}=0,42 \quad 24 \mathrm{~h} / 1 \mathrm{dia}=1,10
$$


Multiplicando-se esses três valores obteve-se $\mathrm{P}_{30 \mathrm{~min}} / \mathrm{P}_{\text {Diária }}=0,34$

Mendiondo (2005 b) estabeleceu quatro categorias de alerta para eventos de inundações na Bacia do Gregório. O evento ocorrido em 30/01/2004 foi classificado pelo referido autor na categoria mais alta. Tal evento foi tomado como exemplo para a aplicação dos coeficientes obtidos, no qual realmente ocorreu uma inundação da bacia do Gregório, com extravasamento do canal (Figura 4.9) e grandes danos à população (Figura 4.10).

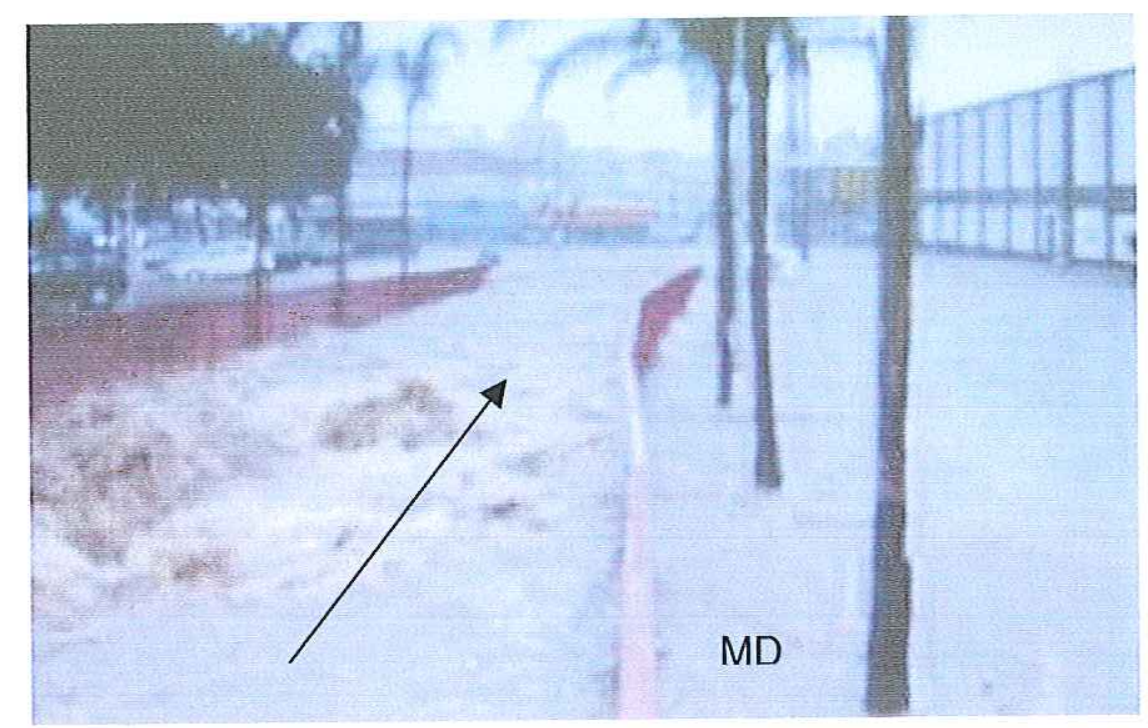

Figura 4.9 - Inundação na Bacia do Gregório em 30 de janeiro de 2004. À direita, Mercado Municipal inundado. Vista para jusante. Fonte: Projeto FINEP-CT-HIDRO, 2002. Área de drenagem aproximadamente 13 $\mathrm{km}^{2}$.

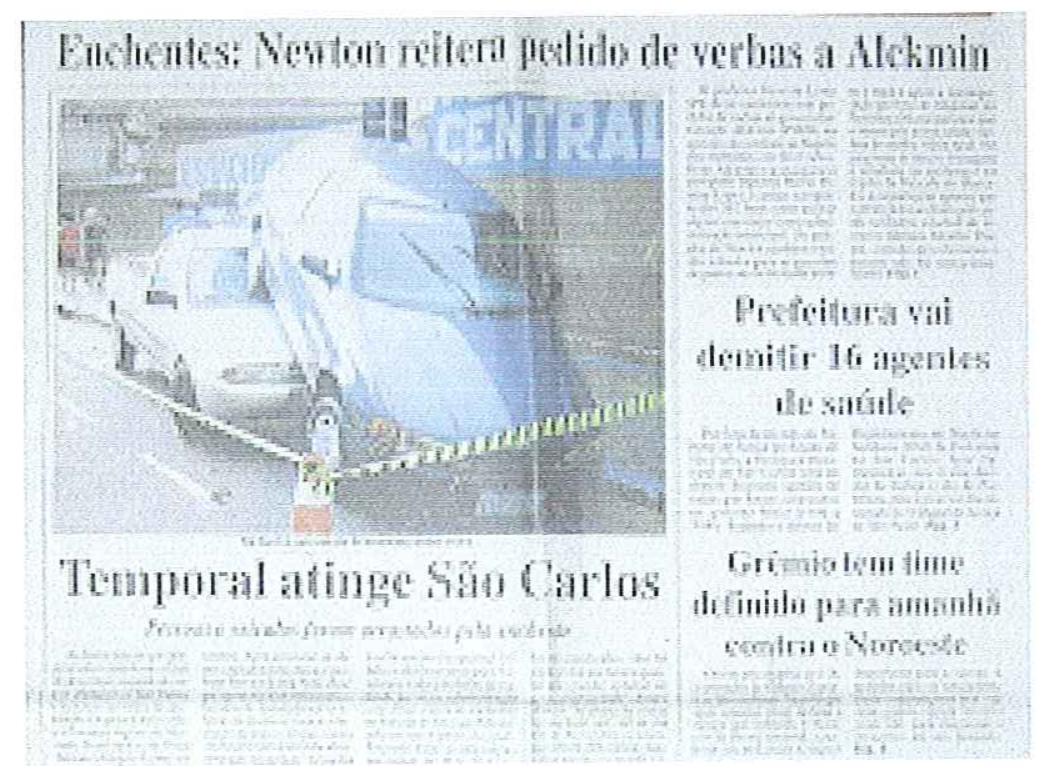

Figura 4.10 - Notícia do jornal A Tribuna, sobre inundação de 30 de janeiro de 2004. 
No evento de 30/01/2004, a precipitação foi de 43,6 mm em 45 minutos (Projeto FINEP-CTHIDRO, 2002). Realizou-se a aplicação dos coeficientes obtidos considerando tempo de concentração:

a) Considerando coeficiente entre $\mathrm{P} \underline{\underline{L}} / \mathrm{P}$ Diária $=0,46$ (admitindo tempo de concentração da bacia igual a 1 hora):

$$
\begin{aligned}
& P_{1 h} / P_{\text {Diária }}=0,46 \\
& 43,6 / P_{\text {Diária }}=0,46 \\
& P_{\text {Diária }}=43,6 / 0,46 \\
& P_{\text {Diária }}=\mathbf{9 4 , 3} \mathbf{~ m m}
\end{aligned}
$$

b) Considerando coeficiente entre $\mathrm{P}_{30 \mathrm{~min}} / \mathrm{P}$ Diária $=0,34$ (admitindo tempo de concentração da bacia igual a 30 minutos):

$$
\begin{aligned}
& \mathrm{P}_{30 \text { min }} / \mathrm{P}_{\text {Diária }}=0,34 \\
& 43,6 / \mathrm{P}_{\text {Diária }}=0,34 \\
& \mathrm{P}_{\text {Diária }}=43,6 / 0,34 \\
& \mathrm{P}_{\text {Diária }}=\mathbf{1 2 8 , 0} \mathbf{~ m m}
\end{aligned}
$$

Desse modo obteve-se uma faixa de valores de $\mathrm{P}$ Diária dentro do tempo de concentração da bacia, indicando datas em que ocorreram $\mathrm{P}$ Diárias a partir de $94,3 \mathrm{~mm}$ como base para a busca de notícias históricas sobre a ocorrência de inundações na região do Mercado Municipal.

Complementarmente, Caballero (2004) indica que eventos com precipitações a partir de $40 \mathrm{~mm}$ configuram um quadro preocupante quanto a inundações na região do Mercado Municipal. Com a ocorrência de precipitações a partir de $70 \mathrm{~mm}$, geralmente as lojas localizadas próximo ao Mercado Municipal são inundadas (informação verbal) ${ }^{4.3}$.

Com o objetivo de realizar um levantamento histórico abrangente de alagamento e inundações ocorridos na região de estudo, foram selecionadas datas em que a P Diária foi igual ou superior a $70 \mathrm{~mm}$ para nortear a busca de notícias de jornal.

\footnotetext{
${ }^{43}$ Informação fornecida por Caballero em São Carlos, em 2004. O Sr. Pedro Caballero é Coordenador Regional Adjunto de Defesa Civil do Estado de São Paulo da Central Redec V/12 e foi Chefe da Seção de Defesa Civil de São Carlos de 1992 a 2004.
} 
A seleção dessas datas foi realizada a partir dos dados monitorados de precipitação diária no período de 1940 a 2004 e são apresentadas na Tabela 4.3 e Figura 4.11.

Tabela 4.3 - Datas com ocorrência de Precipitação Diária maior ou igual a $70 \mathrm{~mm}$ no período de 1940 a 2004

\begin{tabular}{|c|c|c|c|c|c|}
\hline DATA & P Diária & Estação & DATA & P Diária & Estação \\
\hline $05 / 03 / 42$ & 100,8 & D4-045 & $14 / 03 / 70$ & 71,8 & D4-075 \\
\hline $12 / 03 / 42$ & 88,0 & D4-045 & $24 / 02 / 72$ & 109,8 & D4-075 \\
\hline $12 / 10 / 43$ & 99,0 & D4-045 & $13 / 07 / 72$ & 82,8 & D4-075 \\
\hline $16 / 01 / 45$ & 90,0 & D4-045 & $11 / 10 / 72$ & 72,5 & D4-075 \\
\hline $13 / 11 / 53$ & 81,4 & D4-045 & $05 / 02 / 73$ & 83,6 & D4-075 \\
\hline $01 / 12 / 53$ & 70,0 & D4-045 & $07 / 12 / 73$ & 93,3 & D4-075 \\
\hline $05 / 01 / 54$ & 91,2 & D4-017 & $01 / 01 / 74$ & 149,0 & D4-075 \\
\hline $02 / 05 / 56$ & 81,8 & D4-017 & $06 / 06 / 76$ & 94,0 & D4-075 \\
\hline $12 / 06 / 56$ & 80,0 & D4-017 & $14 / 09 / 76$ & 73,2 & D4-075 \\
\hline $15 / 01 / 57$ & 106,4 & D4-017 & $03 / 12 / 77$ & 70,5 & D4-075 \\
\hline $02 / 04 / 57$ & 104,2 & D4-017 & $18 / 01 / 80$ & 71,7 & D4-075 \\
\hline $20 / 01 / 58$ & 99,0 & D4-017 & $13 / 02 / 80$ & 122,4 & D4-075 \\
\hline $11 / 12 / 58$ & 70,4 & D4-017 & $18 / 02 / 80$ & 95,6 & D4-075 \\
\hline $09 / 01 / 60$ & 77,0 & D4-017 & $20 / 10 / 81$ & 93,2 & D4-075 \\
\hline $06 / 01 / 60$ & 71,6 & D4-017 & $06 / 03 / 83$ & 70,5 & D4-075 \\
\hline $16 / 12 / 60$ & 76,2 & D4-017 & $31 / 05 / 83$ & 78,5 & D4-075 \\
\hline $19 / 12 / 60$ & 72,6 & D4-017 & $14 / 12 / 83$ & 92,6 & D4-075 \\
\hline $21 / 12 / 60$ & 91,4 & D4-017 & $15 / 12 / 84$ & 70,9 & D4-075 \\
\hline $12 / 02 / 61$ & 75,2 & D4-017 & $03 / 11 / 85$ & 124,4 & D4-075 \\
\hline $30 / 12 / 62$ & 71,5 & D4-017 & $02 / 12 / 86$ & 86,5 & D4-075 \\
\hline $20 / 01 / 65$ & 76,6 & D4-017 & $28 / 01 / 87$ & 102,7 & D4-075 \\
\hline $01 / 02 / 65$ & 78,0 & D4-017 & $16 / 11 / 87$ & 78,8 & D4-075 \\
\hline $23 / 02 / 65$ & 110,1 & D4-017 & $05 / 12 / 87$ & 70,8 & D4-075 \\
\hline $27 / 02 / 65$ & 73,0 & D4-017 & $13 / 12 / 89$ & 70,5 & D4-075 \\
\hline $10 / 12 / 65$ & 86,4 & D4-017 & $04 / 01 / 90$ & 79,8 & D4-075 \\
\hline $23 / 12 / 66$ & 99,1 & D4-017 & $03 / 01 / 96$ & 135,7 & D4-075 \\
\hline $13 / 01 / 68$ & 75,2 & D4-017 & $28 / 02 / 96$ & 92,0 & D4-075 \\
\hline $27 / 11 / 68$ & 98,2 & D4-017 & $28 / 01 / 98$ & 75,6 & EMBRAPA \\
\hline $13 / 01 / 69$ & 75,2 & D4-017 & $26 / 01 / 99$ & 90,8 & EMBRAPA \\
\hline $16 / 01 / 70$ & 103,6 & D4-075 & $08 / 02 / 00$ & 70,4 & EMBRAPA \\
\hline $18 / 01 / 70$ & 102,0 & D4-075 & $25 / 01 / 04$ & 91,0 & EMBRAPA \\
\hline $17 / 01 / 70$ & 92,2 & D4-075 & & & \\
\hline
\end{tabular}

\subsubsection{Datas indicadas por fontes complementares}

Complementarmente aos dados de Precipitação Diária, foram utilizadas como fonte de informação recuperação de história oral e também trabalhos previamente desenvolvidos sobre o tema.

A recuperação pela história oral de informações sobre datas prováveis em que ocorreram inundações ou alagamentos na Bacia do Gregório foi realizada por meio de consultas ao Sr. José João 
${ }^{4.4}$, proprietário da Empresa FotoArte. Em consultas ao Sr. José João, foram indicados, de maneira aproximada, os anos de 1947, 1956, 1957, 1970, 1973 e 1993, por volta de janeiro e fevereiro, como base para a busca de notícias.

Rebellatto (1991) realizou levantamento de notícias sobre eventos ocorridos na área de estudo entre 1970 e 1988. A referida autora indica as datas de publicação, título do jornal e título da notícia (Tabela 4.4), porém o trabalho não apresenta um banco de dados sistematizado com análise das informações contidas nas notícias, nem documentação gráfica das mesmas.

Tabela 4.4 - Notícias de jornal de 1970 a 1988 sobre eventos na Bacia do Gregório (Dados: Rebelatto, 1991)

\begin{tabular}{|c|c|c|}
\hline DATA & JORNAL & TÍTULO DA NOTÍCIA \\
\hline $22 / 1 / 1970$ & A Folha & Chuvas danificam muro de arrimo \\
\hline $28 / 2 / 1971$ & A Folha & Gregório: fonte de perigo para a garotada \\
\hline $24 / 2 / 1972$ & A Folha & Chuvas inundam a cidade: prejuízos foram enormes \\
\hline $25 / 2 / 1972$ & A Folha & Ainda repercute em São Carlos os efeitos da última inundação. \\
\hline $23 / 4 / 1972$ & A Folha & Drenagem do Gregório: projeto já está nas mãos do interventor \\
\hline $16 / 12 / 1972$ & A Folha & Novo trecho do Gregório está sendo retificado \\
\hline $21 / 2 / 1973$ & A Folha & Chuvas causam estragos \\
\hline $13 / 1 / 1974$ & A Folha & As Chuvas continuam e com elas os estragos \\
\hline $14 / 3 / 1974$ & A Folha & Prefeitura constrói novas galerias pluviais em SC \\
\hline $15 / 2 / 1977$ & A Folha & Limpeza do Gregório continua problema \\
\hline $22 / 3 / 1977$ & A Folha & Chuva de ontem produziu novamente estragos na cidade \\
\hline 23/3/1977 & A Folha & $\begin{array}{l}\text { Câmara Municipal deseja comissão para estudar e resolver de vez o problema } \\
\text { das enchentes em São Carlos }\end{array}$ \\
\hline $28 / 1 / 1987$ & A Folha & Chuvas inundam lojas e o rio transborda \\
\hline $12 / 1 / 1988$ & A Folha & Tromba d'água causa estragos na cidade \\
\hline $1 / 3 / 1973$ & A Tribuna & Planejamento Urbano \\
\hline $12 / 1 / 1975$ & A Tribuna & Verdadeira tromba de água sobre São Carlos causa prejuízos \\
\hline $12 / 1 / 1975$ & A Tribuna & Em fase adiantada as obras do Córrego Gregório \\
\hline $22 / 1 / 1975$ & A Tribuna & Uma ponte sobre o Gregório facilita acesso \\
\hline $23 / 1 / 1975$ & A Tribuna & Obras de Retificação e Canalização do Córrego Gregório \\
\hline $8 / 3 / 1976$ & A Tribuna & Prefeitura Municipal vai acelerar obras \\
\hline $10 / 1 / 1978$ & A Tribuna & As Chuvas de ontem \\
\hline 14/1/1978 & A Tribuna & Enchentes: Prefeito mobiliza pessoal \\
\hline $12 / 3 / 1982$ & A Tribuna & Enchentes "perseguem" a administração Massei \\
\hline $5 / 3 / 1981$ & O Correio & Chuvas provocam estragos na cidade \\
\hline $12 / 3 / 1970$ & O Diário & Retificação do Gregório \\
\hline $14 / 3 / 1970$ & O Diário & Rua São Paulo tem "cascata" \\
\hline $20 / 3 / 1970$ & O Diário & Prefeito determina: imediata construção de galerias pluviais na Rua São Paulo \\
\hline $9 / 3 / 1980$ & O Diário & Inundações: consequências e causas \\
\hline $12 / 12 / 1980$ & O Diário & Chuvas não interrompem obras contra enchentes em São Carlos \\
\hline $31 / 12 / 1980$ & O Diário & São Carlos não tem mais problemas de enchentes \\
\hline
\end{tabular}

\footnotetext{
${ }^{4.4} \mathrm{O}$ Sr. José João trabalhou como fotógrafo autônomo para jornais antigos da cidade de São Carlos, o que lhe conferiu um conhecimento da história da cidade de extrema importância para o desenvolvimento deste trabalho. As consultas ao Sr. José João contribuíram para a compreensão e contextualização, a partir da recuperação da história oral, do processo de expansão da cidade de São Carlos e incidência de inundações. Atualmente o Sr. Josẻ João é proprietảrio da Empresa Foto Arte, que conta com um importante arquivo de fotos antigas da cidade, uma das principais fontes de levantamento de dados para esta pesquisa.
} 
Barros (2005) apresenta algumas datas de inundações ocorridas entre 2000 e 2002 (Tabela 4.5), indicadas pelo proprietário da Padaria Caiçara, localizada próximo ao Mercado Municipal (4.11).

Tabela 4.5 - Datas de eventos de inundações na região do Mercado Municipal de São Carlos, registradas pelo proprietário da Padaria Caiçara. Fonte: Barros, 2005

\begin{tabular}{|c|c|}
\hline Data & Horário \\
\hline $17 / 12 / 2000$ & $03: 05 \mathrm{~h}$ \\
\hline $14 / 9 / 2001$ & $17: 15 \mathrm{~h}$ \\
\hline $7 / 1 / 2002$ & $00: 15 \mathrm{~h}$ \\
\hline $9 / 1 / 2002$ & $01: 05 \mathrm{~h}$ \\
\hline $13 / 1 / 2002$ & $02: 35 \mathrm{~h}$ \\
\hline $28 / 1 / 2002$ & $20: 50 \mathrm{~h}$ \\
\hline $10 / 2 / 2002$ & $17: 00 \mathrm{~h}$ \\
\hline $10 / 11 / 2002$ & $18: 15 \mathrm{~h}$ \\
\hline
\end{tabular}
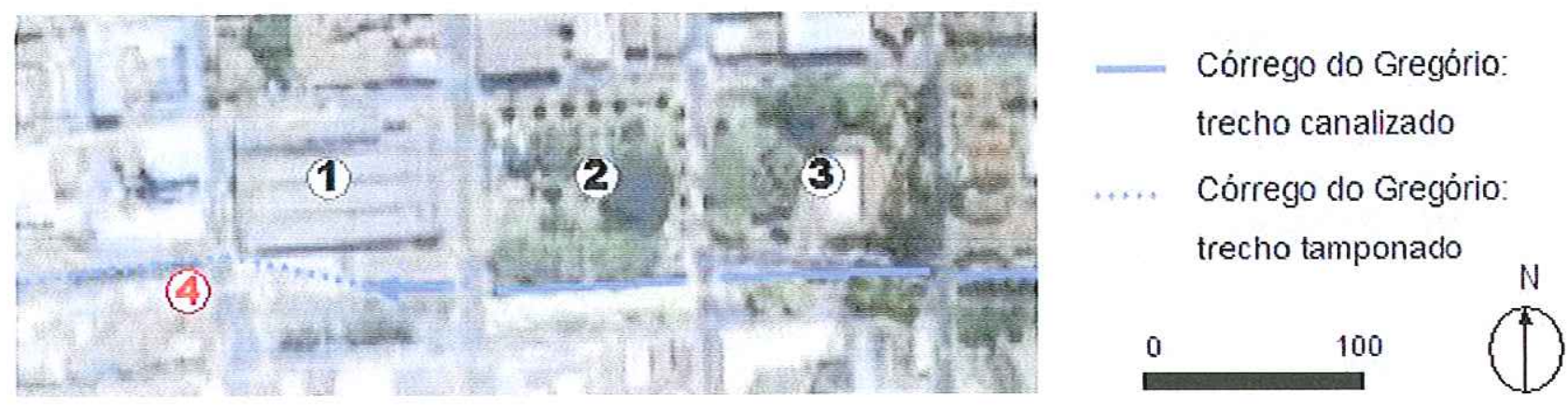

Figura 4.11 - Localização da Padaria Caiçara. 1) Mercado Municipal, 2) Praça dos Voluntários, 3) Pìscina Municipal, 4)Padaria Caiçara. Fonte: adaptado de FIPAI/PMSC (2003).

\subsection{LEVANTAMENTO DE NOTÍCIAS DE JORNAIS}

Por indicação do Sr. José João, priorizou-se a busca de notícias nos jornais Correio de São Carlos e $A$ Folha, por serem estes os jornais que mais abordavam as questões vinculadas às inundações na Região do Mercado Municipal. De acordo com o Sr. José João, o jornal A Folha circula em São Carlos desde a década de 1950 até a atualidade. O jornal Correio de São Carlos teve circulação desde a década de 1940 até a década de 1960. Porém, em alguns casos, a Fundação Pró Memória não possuía os exemplares dos referidos jornais nas datas solicitadas. Nesses casos, o levantamento foi realizado em outros jornais: $A$ Cidade, A Tribuna e $O$ Diário.

A busca pelas notícias foi realizada tendo como referência as datas obtidas em que a precipitação diária, de acordo com as estações do SIGRH, foram maiores ou iguais a $70 \mathrm{~mm}$ (Tabela 4.3). As 
notícias foram procuradas $10(\mathrm{dez})$ dias antes e depois das datas utilizadas para guiar a busca das notícias.

Complementarmente, buscou-se notícias de jornal para os meses de janeiro, fevereiro, novembro e dezembro dos 06 (seis) anos indicados em consultas ao Sr. José João - 1947, 1956, 1957, 1970, 1973 e 1993 - e também para as datas indicadas por Rebelatto (1991) e por Barros (2005).

Todas as notícias encontradas foram fotografadas com câmera digital, de modo a gerar um banco de dados gráfico do qual podem ser extraídas informações relevantes sobre a evolução histórica das inundações na área de estudo.

\subsection{ORGANIZAÇÃO E ANÁLISE DAS NOTÍCIAS ENCONTRADAS}

As notícias foram classificadas de acordo com seu conteúdo, compondo quatro grupos de notícias referentes a:
a) Evento específico de Inundação ou Alagamento na Bacia do Gregório;
b) Intervenções e Obras relacionadas à drenagem na Bacia do Gregório;
c) Inundações e alagamentos em demais pontos da cidade de São Carlos;
d) Notícias gerais sobre o tema.

Todas as notícias encontradas foram lidas e analisadas em busca dos seguintes dados:
a) Data da Chuva;
b) Nível atingido (especificando se mencionado da notícia ou aferido por observação de foto);
c) Danos causados;
d) Duração da Chuva;
e) Tempo de Permanência;
f) Área Inundada.

Foram analisados os textos e as imagens das notícias, de modo a extrair o máximo de informação possível destas. A análise das notícias foi sistematizada em uma tabela no mesmo modelo indicado pela Tabela 4.6, na qual consta também um resumo da notícia e indicação do arquivo com as fotos digitais da notícia. 
Tabela 4.6 - Modelo de tabela utilizado na etapa de análise das notícias encontradas

\begin{tabular}{|l|l|l|l|l|l|l|l|l|l|}
\hline $\begin{array}{l}\text { Data } \\
\text { da } \\
\text { chuva }\end{array}$ & $\begin{array}{l}\text { Data } \\
\text { da } \\
\text { notícia }\end{array}$ & Jornal & $\begin{array}{l}\text { Título } \\
\text { da } \\
\text { notícia }\end{array}$ & $\begin{array}{l}\text { Altura } \\
\text { Máxima } \\
\text { (especificar: } \\
\text { mencionado } \\
\text { no texto ou } \\
\text { aferido por } \\
\text { observação } \\
\text { de foto) }\end{array}$ & $\begin{array}{l}\text { Danos } \\
\text { causados }\end{array}$ & $\begin{array}{l}\text { Duração } \\
\text { da } \\
\text { chuva }\end{array}$ & $\begin{array}{l}\text { Tempo de } \\
\text { Permanência }\end{array}$ & $\begin{array}{l}\text { Área } \\
\text { Inundada }\end{array}$ & $\begin{array}{l}\text { Resumo } \\
\text { da Notícia }\end{array}$ \\
\hline & & & & & & & & & \\
\end{tabular}

\subsection{INTEGRAÇÃO ENTRE METODOS UTILIZADOS, RESULTADOS E OBJETIVOS}

A integração entre Métodos utilizados, Resultados e Objetivos da dissertação está sintetizada no Quadro 4.2.

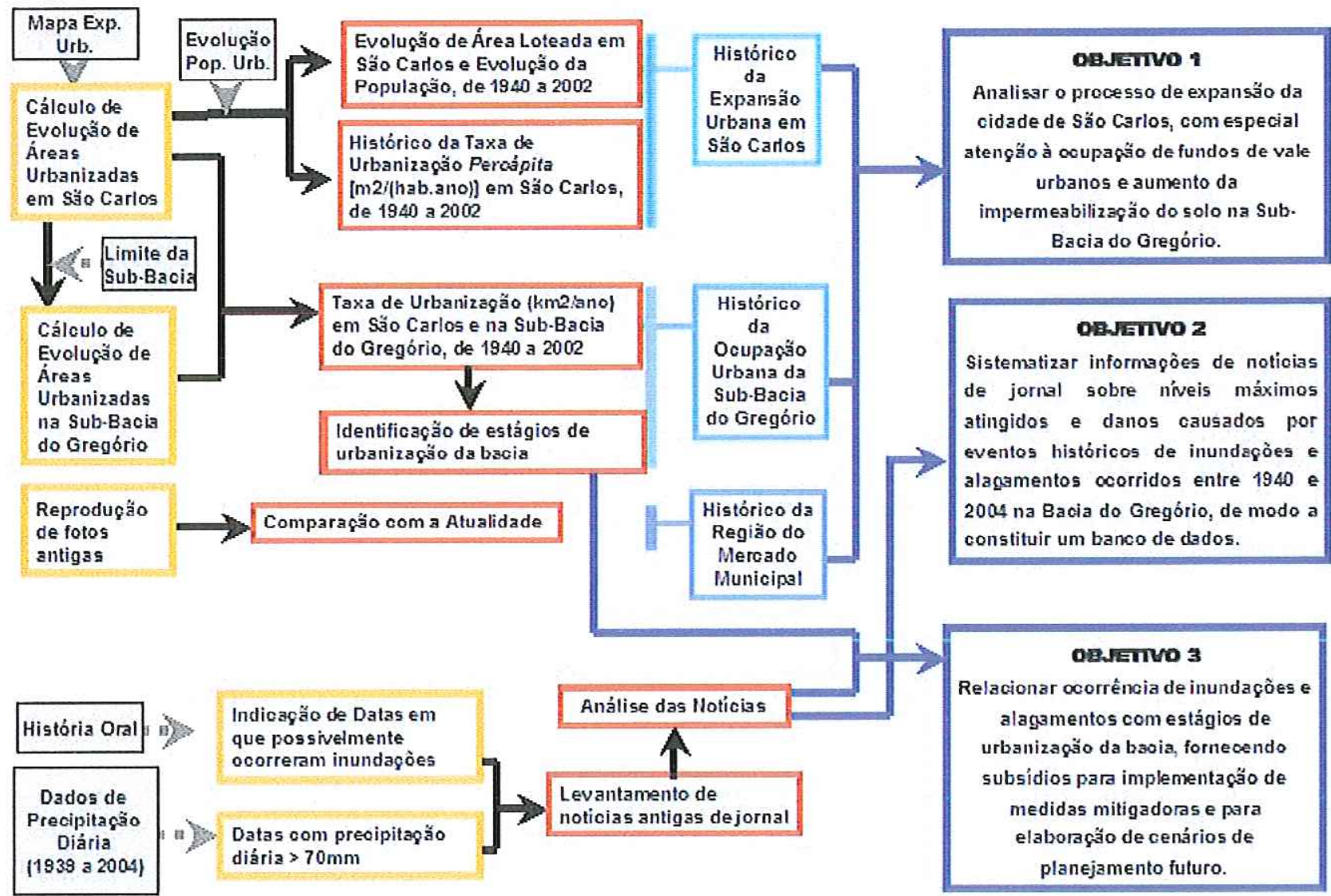

$\square$ Daclos

$\square$ Resultados Tipo 1

घResultados Tipo 2

Objetivos

Quadro 4.2 - Síntese da Integração entre Métodos utilizados, Resultados e Objetivos 


\section{RESULTADOS E DISCUSSÃO}

Os resultados relacionados ao Objetivo Específico 1 (Quadro 4.2) são apresentados nos itens:

5.1. Histórico da expansão urbana de São Carlos;

5.2. Histórico da ocupação urbana da Bacia do Gregório;

5.3. Histórico da região do Mercado Municipal.

Os resultados relacionados ao Objetivo Específico 2 (Quadro 4.2) são apresentados nos itens:

5.4.Análise dos métodos utilizados para o levantamento de notícias de jornal;

5.5. Notícias de jornal encontradas;

5.6. Análise dos dados contidos nas notícias de jornal;

Os resultados relacionados ao Objetivo Específico 3 (Quadro 4.2) são apresentados nos itens:

5.7. Tempo de retorno médio de recorrência de eventos;

5.8. Relações entre urbanização e ocorrência de inundações e alagamentos.

\subsection{HISTÓRICO DA EXPANSÃO URBANA DE SÃO CARLOS}

São Carlos foi fundada em 04 de novembro de 1857. De acordo com Regina Devescovi (1987), a ocupação da região de São Carlos se deu em um contexto de conquista do território paulista pelo desenvolvimento da economia cafeeira, a partir do último quarto do século XIX e até a crise de 1929. A fixação antrópica na região foi determinada pela chegada da lavoura do café, por volta de 1840 . A comercialização do café se fortaleceu de fato após 1860 e se tornou a principal atividade da região em 1884, com a construção da ferrovia e implementação de mão de obra estrangeira.

O marco inicial da cidade se localiza entre a Avenida São Carlos e Rua Episcopal, onde atualmente se encontra a Catedral de São Carlos. Sua primeira ocupação se deu com a implantação da primeira capela, em 1856. A ocupação urbana se deu a partir da capela, em direção ao sul, alcançando o Córrego do Gregório.

A análise do processo de expansão urbana da cidade (Figura 5.1) indica que os fundos de vale dos Córregos do Tijuco Preto e Monjolinho foram ocupados intensamente no período de 1950 a 1970 , enquanto o Córrego do Gregório já apresentava ocupação urbana representativa de suas margens em 
1940. O Gregório foi, portanto, o primeiro córrego de São Carlos a ter suas margens alcançadas pela expansão urbana.

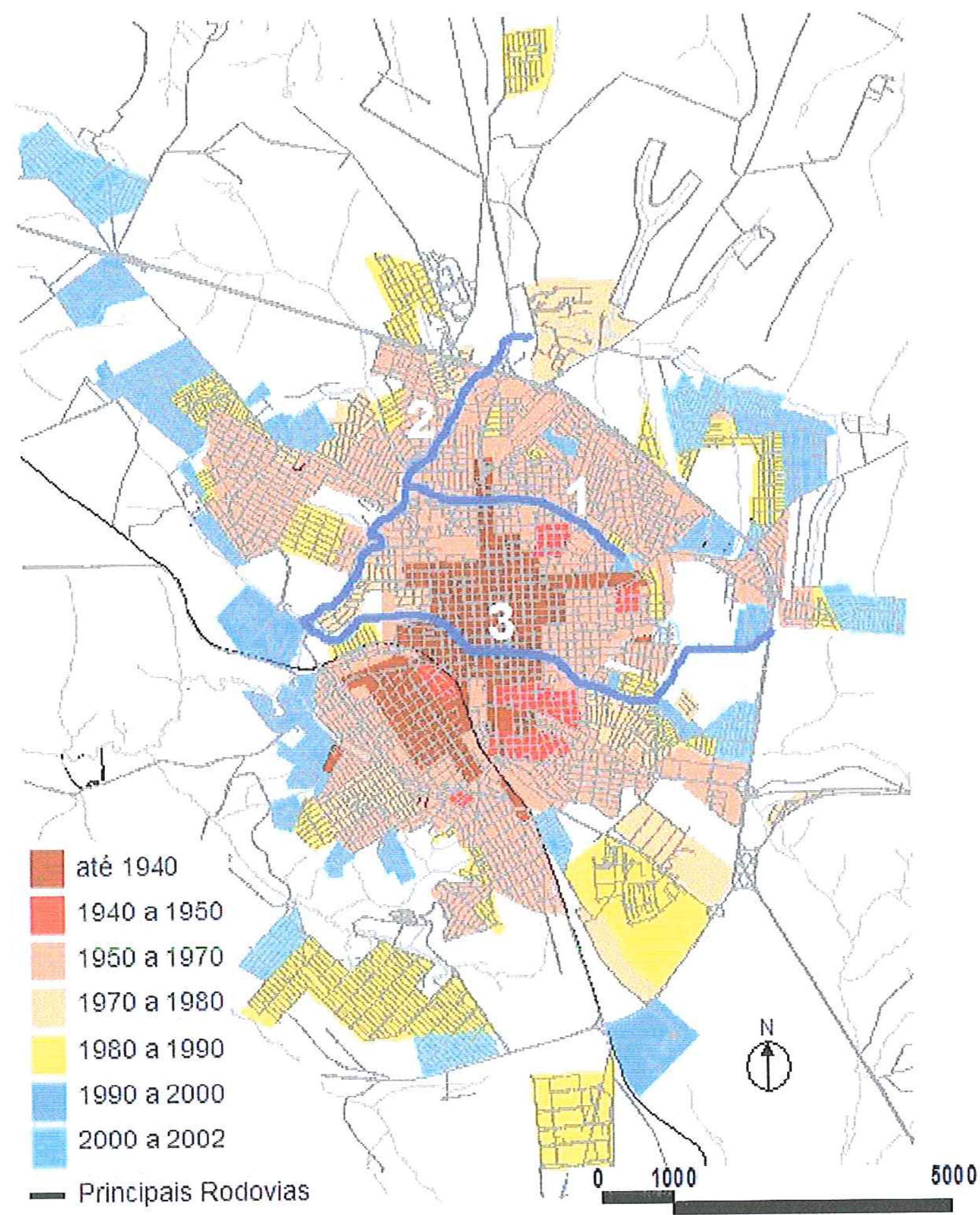

Figura 5.1 - Resultado da avaliação da Expansão Urbana de São Carlos e ocupação de margens de córregos urbanos 1: Tijuco Preto, 2: Monjolinho, 3: Gregório. Fonte: adaptado de PMSC/SMHDU, 2002 
Os resultados obtidos indicam que, entre 1940 e 2002, a área loteada de São Carlos aumentou aproximadamente em 8 vezes, passando de $4,4 \mathrm{~km}^{2}$ para $36,9 \mathrm{~km}^{2}$. No mesmo período, de acordo com dados do IBGE, a população urbana passou de 25.746 para 191.465 habitantes. Nesses 62 anos a área loteada aumentou em $32,5 \mathrm{~km}^{2}$, e a população urbana aumentou em 165.719 habitantes. Portanto, concluímos que, entre 1940 e 2002, a área urbana loteada de São Carlos aumentou em aproximadamente $3,2 \mathrm{~m}^{2}$ por habitante, por ano $\left(3,2 \mathrm{~m}^{2} /\right.$ hab $\mathrm{x}$ ano).

A evolução de áreas loteadas e do crescimento populacional em São Carlos (Figura 5.2) se divide, basicamente, em três períodos. O primeiro, de 1940 a 1950, se caracteriza por uma relação de semelhança entre o aumento da população e o de áreas loteadas. No segundo, entre 1950 e 1960 , notase o início de um processo de desvinculação entre os dois aspectos abordados. A partir de 1960 temos o terceiro período, caracterizado pela confirmação da desvinculação entre crescimento de áreas loteadas e da população. O terceiro período pode ser subdividido em quatro sub-períodos, caracterizados diferentemente quanto ao crescimento de áreas loteadas: de 1960 a 1970, apresentando crescimento bastante representativo; de 1970 a 1980, caracterizado por uma certa desaceleração do crescimento; de 1980 a 2000, em que o crescimento de áreas loteadas se acentuou novamente; e de 2000 a 2002, indicando um crescimento ainda maior do que o apresentado entre 1960 e 1970.

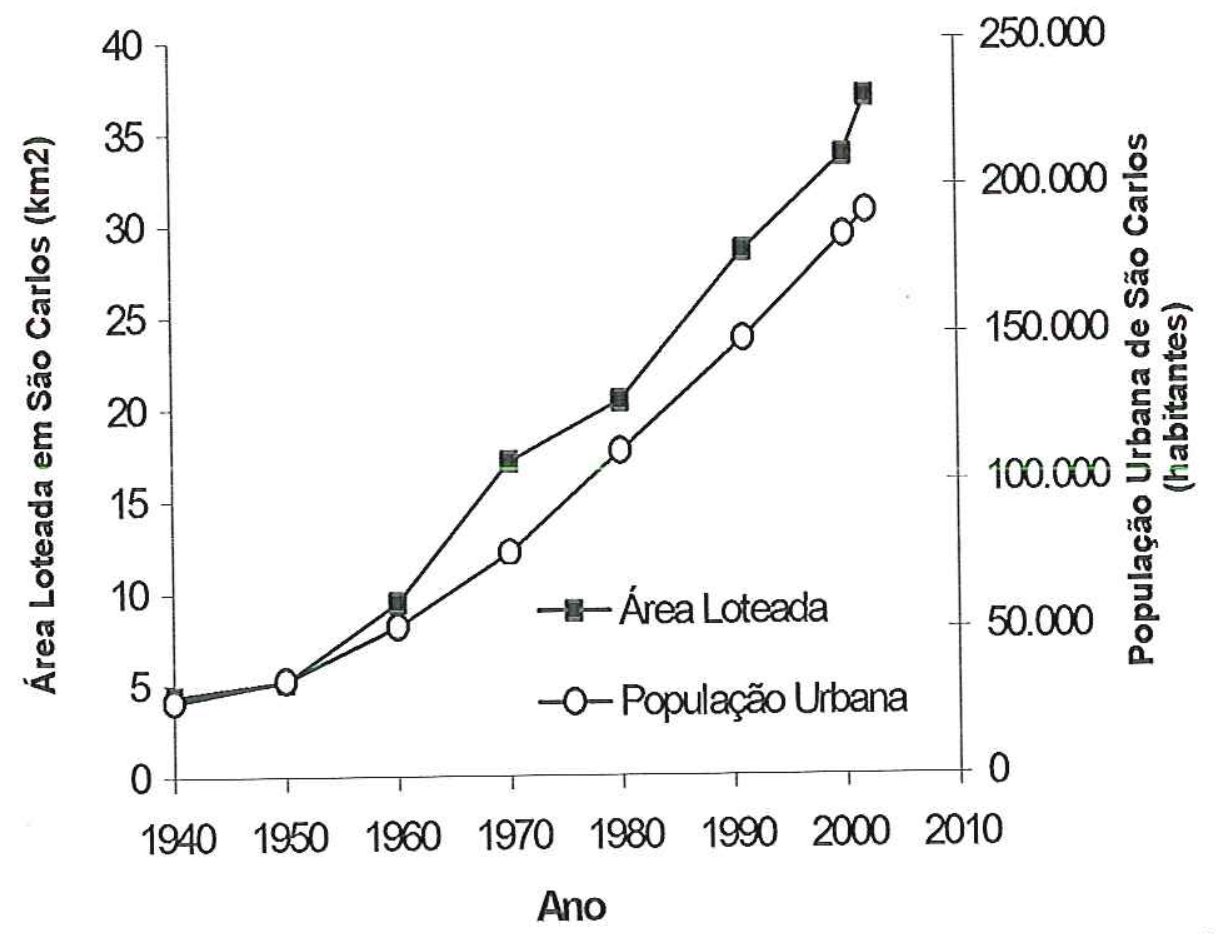

Figura 5.2 - Resultado da Evolução de Área Loteada em São Carlos e Evolução da População, de 1940 a 2002. Fonte dos dados de população: IBGE e SEADE. Cálculo de Áreas: Heloisa Ceccato Mendes 
Ao relacionarmos os dados de evolução de área loteada com os dados de crescimento populacional, por meio do cálculo da taxa de urbanização percápita [m2/(hab.ano)], constatamos que, desde 1940, o período que apresentou maior taxa foi o de 2000 a 2002 (Figura 5.3).

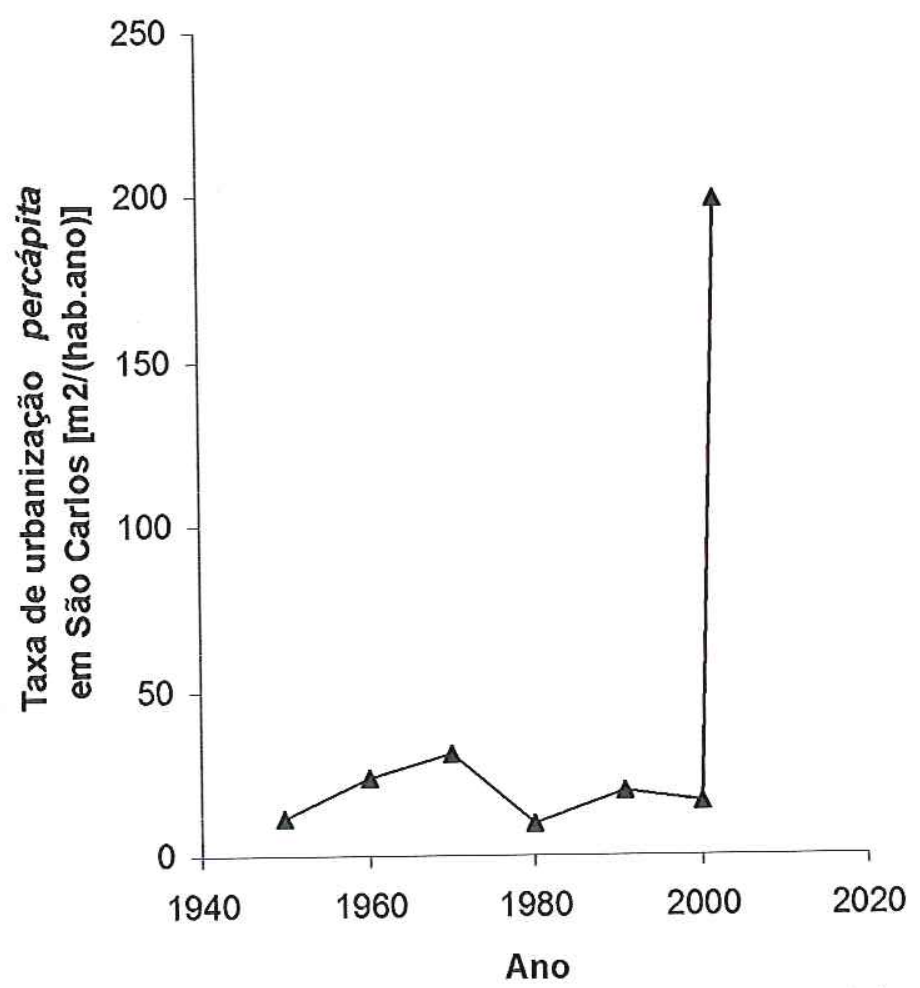

Figura 5.3 - Resultado do Histórico da Taxa de Urbanização Percápita [m2/(hab.ano)] em São Carlos, no período de 1940 a 2002. Fonte dos dados de população: IBGE e SEADE. Fonte dos dados de urbanização: Mapa de Evolução da Expansão Urbana - PMSC, 2002.

Uma explicação para tal fato é o surgimento de grandes condomínios residenciais nesse período, voltados para a população de alta renda e com pouca densidade demográfica. Atualmente, alguns desses condomínios encontram-se ainda em processo de ocupação, apresentando muitos lotes desocupados. É necessário ressaltar que, possivelmente, a ocupação a ser estabelecida nesses condomínios apresentará índice de impermeabilização menor do que o apresentado no centro da cidade. Para atender ao padrão de vida desejado por seus condôminos, a tendência é de que os lotes nesses condomínios sejam maiores do que os existentes no centro da cidade, o que aumenta a possibilidade de manutenção de áreas permeáveis nos lotes, e de que as áreas verdes sejam preservadas para lazer comum. Os fatos de que não houve grande aumento populacional em São Carlos entre 2000 e 2002 e de que os condomínios geralmente ocupam extensas áreas determinou o aumento da taxa de urbanização percápita na cidade, pois o aumento da área urbanizada foi mais representativo do que o acréscimo populacional. 
A análise do histórico da taxa de urbanização percápita (Figura 5.3) revela duas questões importantes. A primeira é a indicação da tendência de aumento da taxa de urbanização em São Carlos para o futuro, baseada no fato de que a taxa de 2000 e 2002 foi a maior desde 1950 . A segunda questão é a constatação de que o período de 1940 a 2000, mesmo apresentando taxas de urbanização muito inferiores à de 2000 a 2002, produziu impactos ambientais significativos, como as inundações na Bacia do Gregório.

A associação dessas duas questões indica a tendência de uma urbanização futura ainda mais impactante do que a ocorrida até a atualidade. Tal tendência demonstra a necessidade de implementação de um planejamento urbano visando à minimização dos impactos ambientais. $\mathrm{O}$ planejamento urbano deverá se opor, portanto, ao processo ocorrido historicamente na cidade de São Carlos, abordado por Dozena (2001) e Rebellato (1991), e também em várias outras cidades brasileiras, como demonstrado por Baptista et al (1998) e Silveira (1998).

A destinação dos fundos de vale à implantação de avenidas para solucionar os problemas de circulação urbana, prática bastante recorrente no Brasil, teve expressão em São Carlos com a proposta de construção do anel viário, na década de 1970 (Figura 5.4).

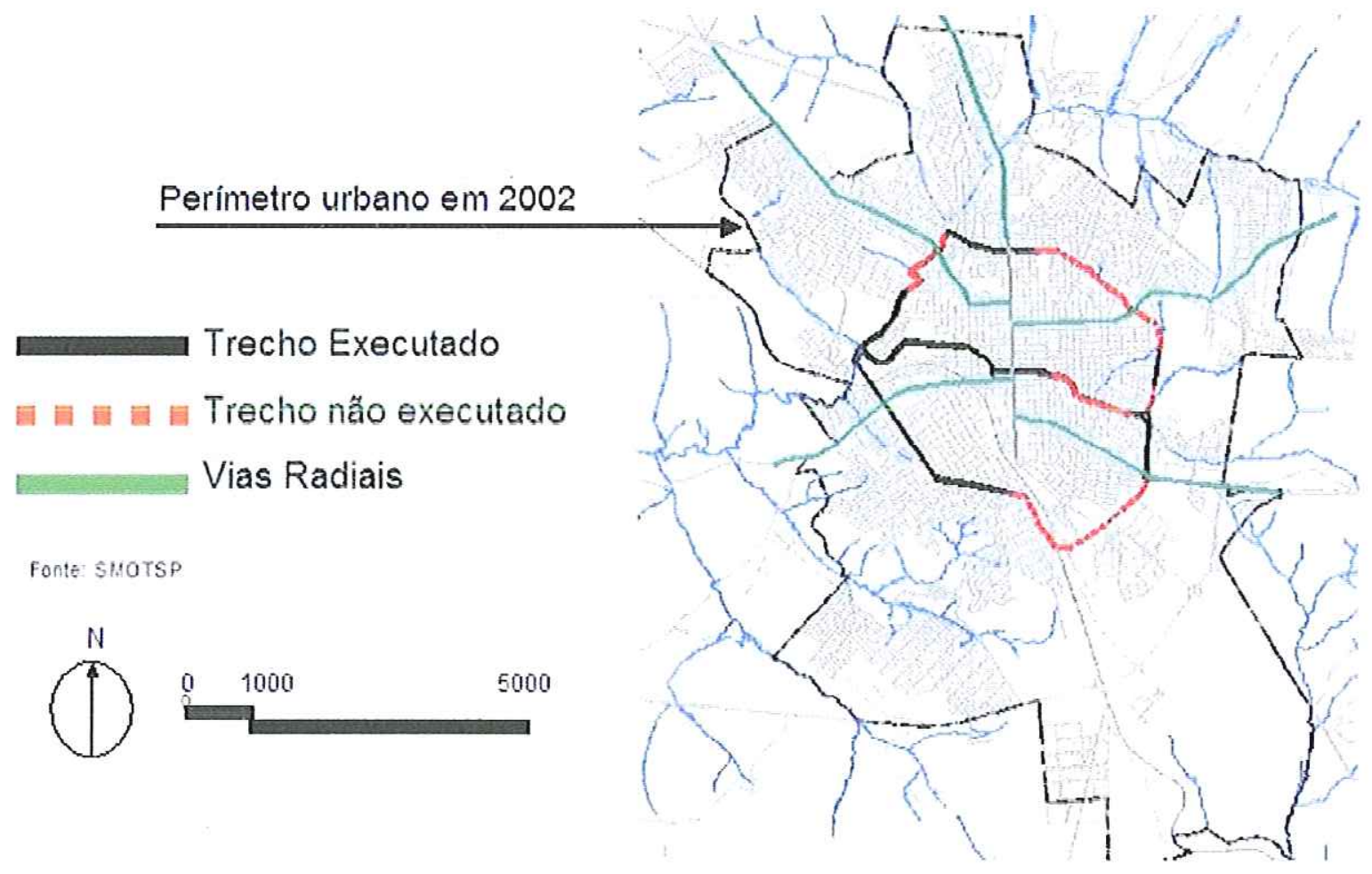

Figura 5.4 - Proposta de anel viário para São Carlos, baseada na implantação de avenidas de fundo de vale. Fonte: PMSC, 2002 
O pensamento amplamente difundido no Brasil, baseado na adaptação da hidrografia ao sistema de mobilidade urbana teve aplicação em São Carlos com a retificação e posterior construção de avenidas marginais aos córregos Tijuco Preto, Monjolinho e Gregório, sendo a construção desta última datada de 1974 (Figura 5.5). Em São Carlos, as intervenções nos fundos de vale foram motivadas principalmente pela promoção da eficiência da mobilidade urbana, com pouca consideração de questões paisagísticas ou intenções de criação de áreas de lazer ao longo dos córregos.

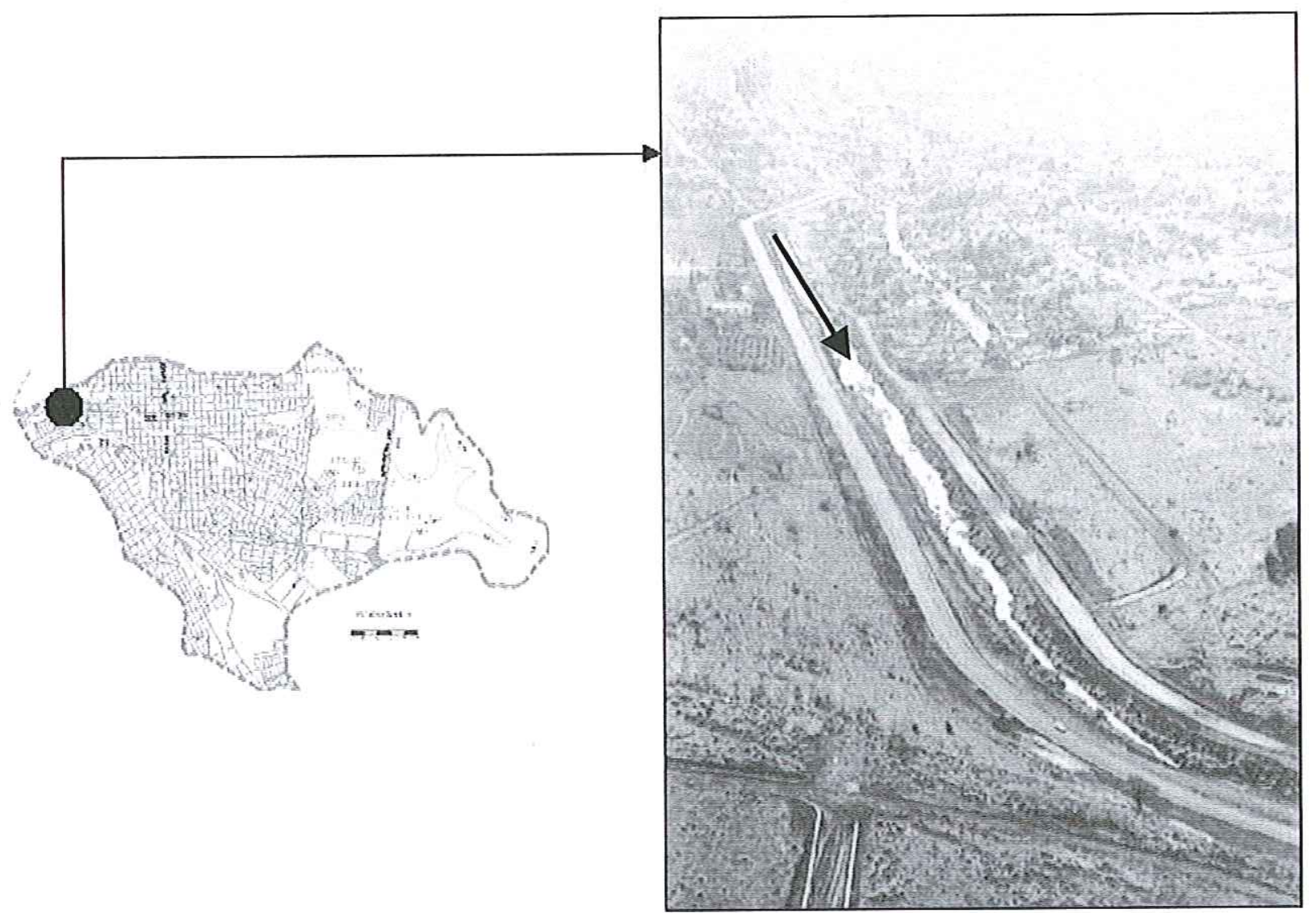

Figura 5.5 - Construção da avenida marginal ao Córrego do Gregório, em 1974, próximo à área atualmente ocupada pelo SESC. Fonte: adaptado de PMSC, 2002.

\subsection{HISTÓRICO DA OCUPACÃO URBANA DA BACIA DO GREGÓRIO}

De acordo com registros históricos, o Córrego do Gregório recebeu esse nome porque Gregório era um posseiro que vivia às suas margens, na região situada aproximadamente entre a R. Episcopal e a Avenida São Carlos. Na ocasião da fundação da cidade, o Conde do Pinhal determinou que essas terras fossem desocupadas, encarregando Jesuíno de Arruda dessa tarefa. Jesuíno de Arruda também 
foi morador dessa região, em uma casa construída sobre palafitas localizada no canto sudeste do Mercado Municipal, onde hoje se encontra uma estátua sua (ONG AMIGOS DO GREGÓRIO, 2005).

O primeiro núcleo urbano de São Carlos constituiu-se à margem do Córrego do Gregório, com a implantação da principal área de comércio da cidade e de seu primeiro Mercado Municipal. Até 1950 a área urbanizada de São Carlos se encontrava mais representativamente na Bacia do Gregório (Figuras 5.6 e 5.7$)$.

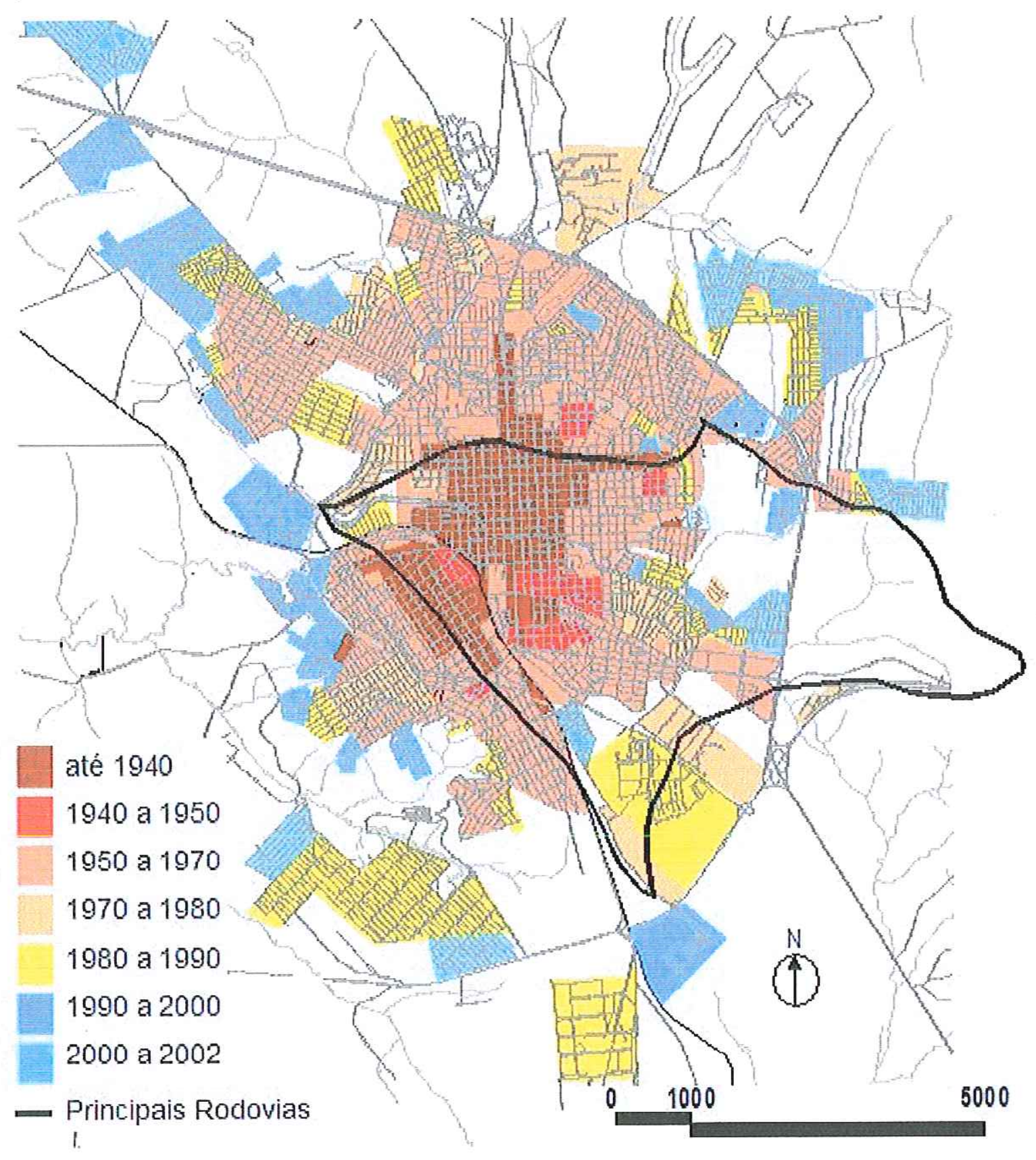

Figura 5.6 - Expansão Urbana de São Carlos entre 1940 e 2002, com indicação do limite da Bacia do Gregório. Fonte: adaptado de PMSC/SMHDU, 2002 


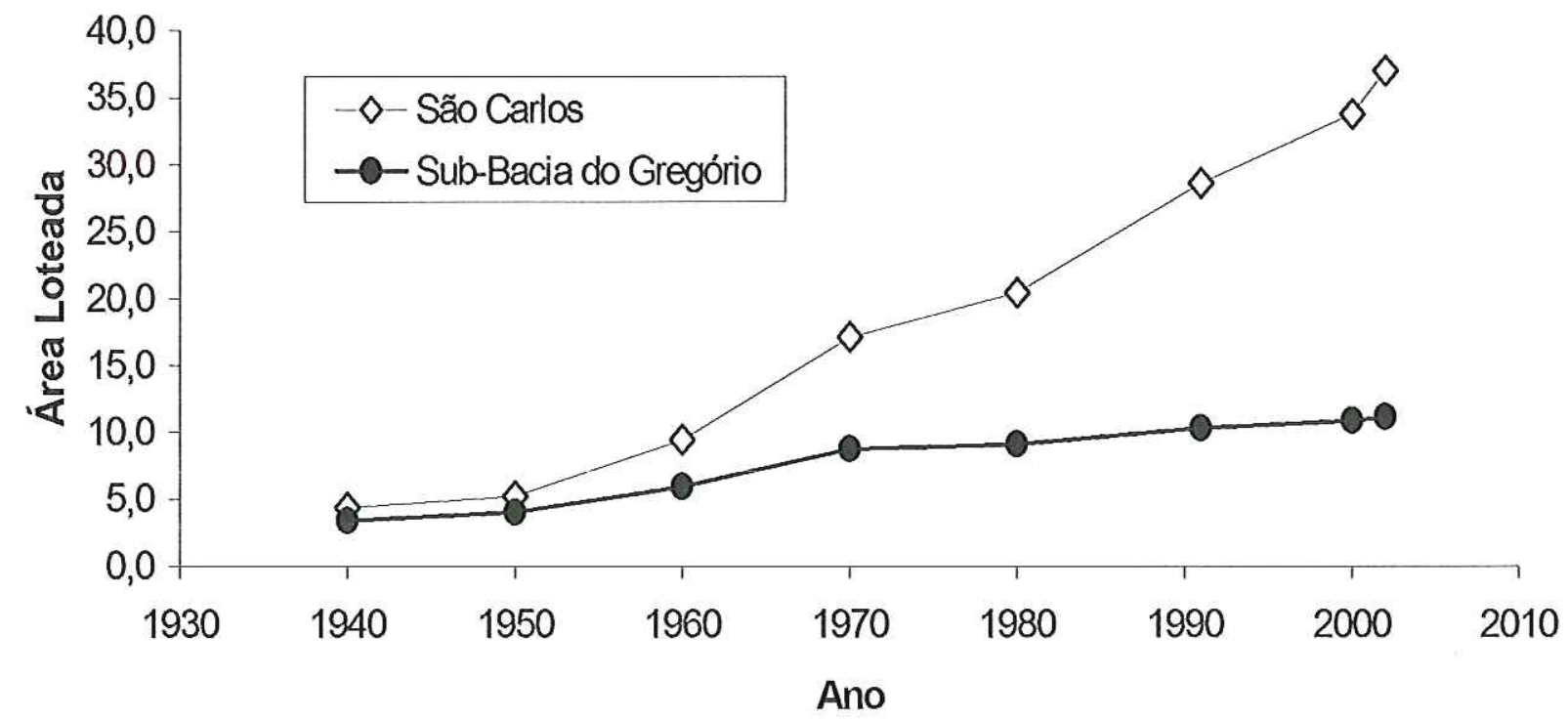

Figura 5.7 - Evolução de áreas loteadas em São Carlos e na Bacia do Gregório

A ocupação urbana da Bacia do Gregório se deu a partir do centro da cidade em direção ao leste, no sentido de montante para jusante (Figuras 5.8, 5.9 e 5.10). A Rodovia Washington Luiz constituiu uma barreira para a ocupação urbana, impedindo que tal processo alcançasse a região de nascentes da bacia.

Com a implantação da Companhia Paulista de Estrada de Ferro, em 1884, a urbanização se deu no sentido sul, para além do córrego do Gregório. Na região da Vila Prado, localizada ao sul do córrego, foram construídas as primeiras casas dos ferroviários, as indústrias Pereira Lopes e a Igreja Santo Antônio (ONG AMIGOS DO GREGÓRIO, 2005). 


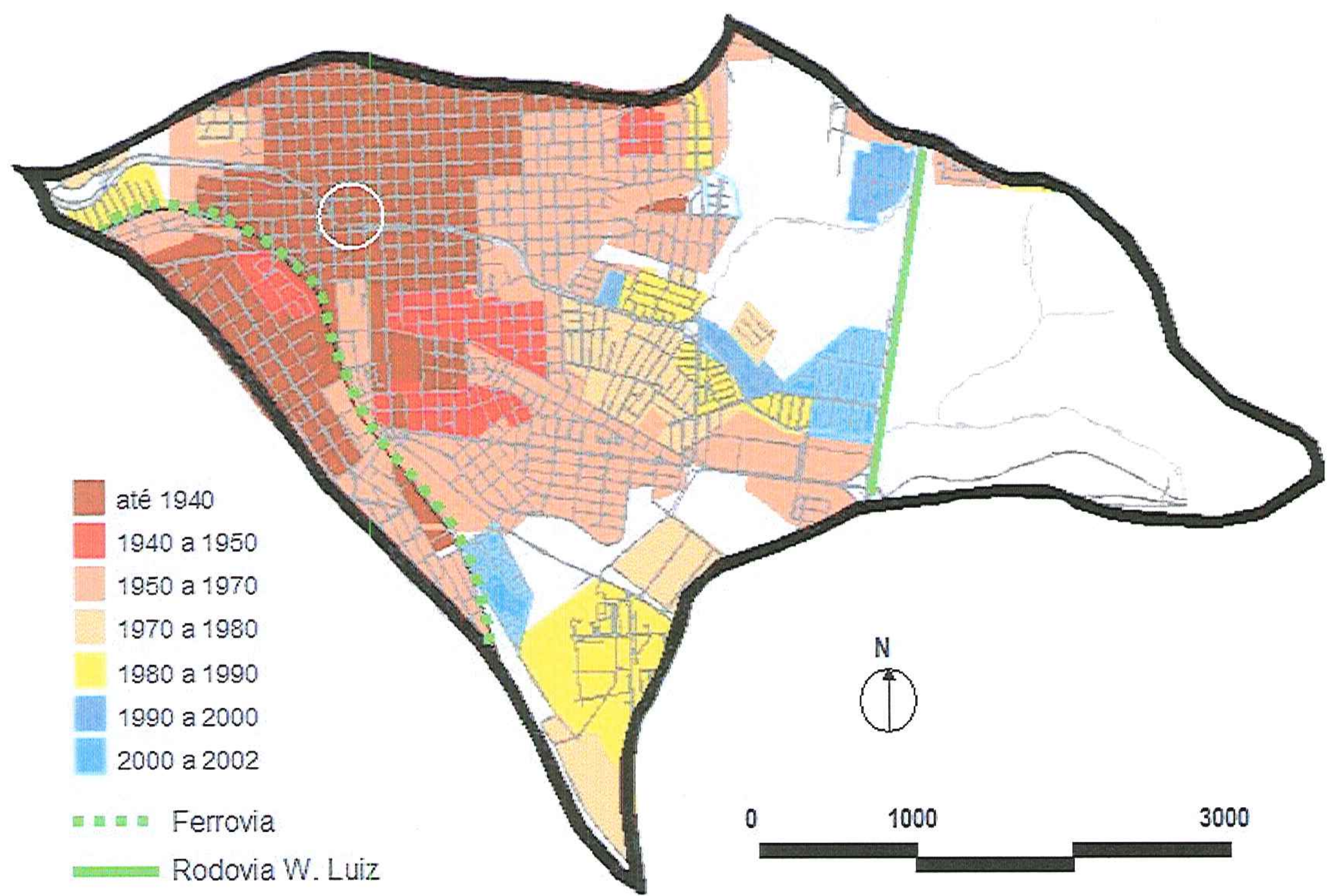

Figura 5.8 - Resultado da avaliação da ocupação urbana da Bacia do Gregório entre 1940 e 2004, com destaque para a região do Mercado Municipal. 


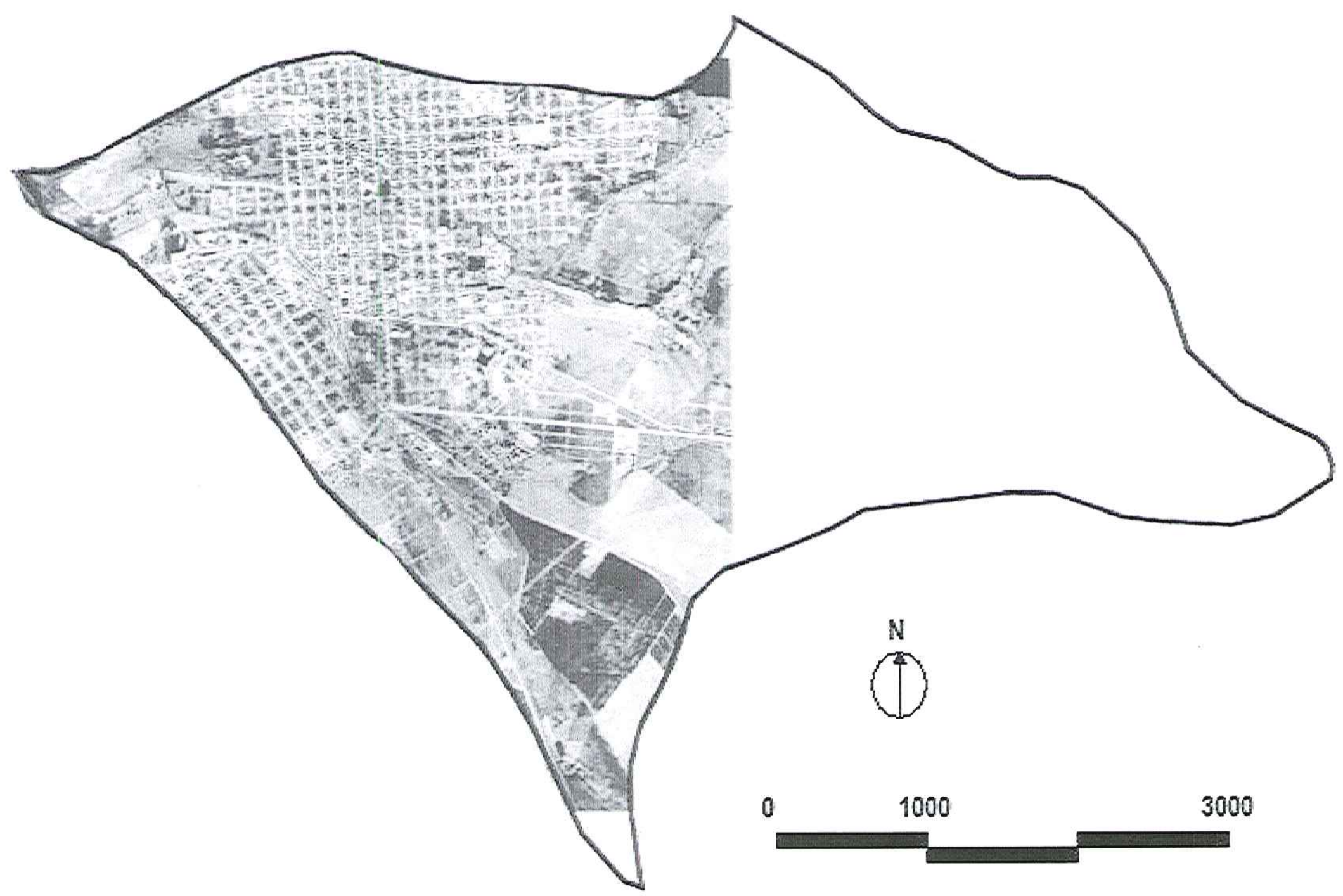

Figura 5.9 - Resultado da avaliação do processo de ocupação urbana da Bacia do Gregório: urbanização em 1962. Foto Aérea: Casa da Agricultura de São Carlos. Elaboração: Heloisa Ceccato Mendes 


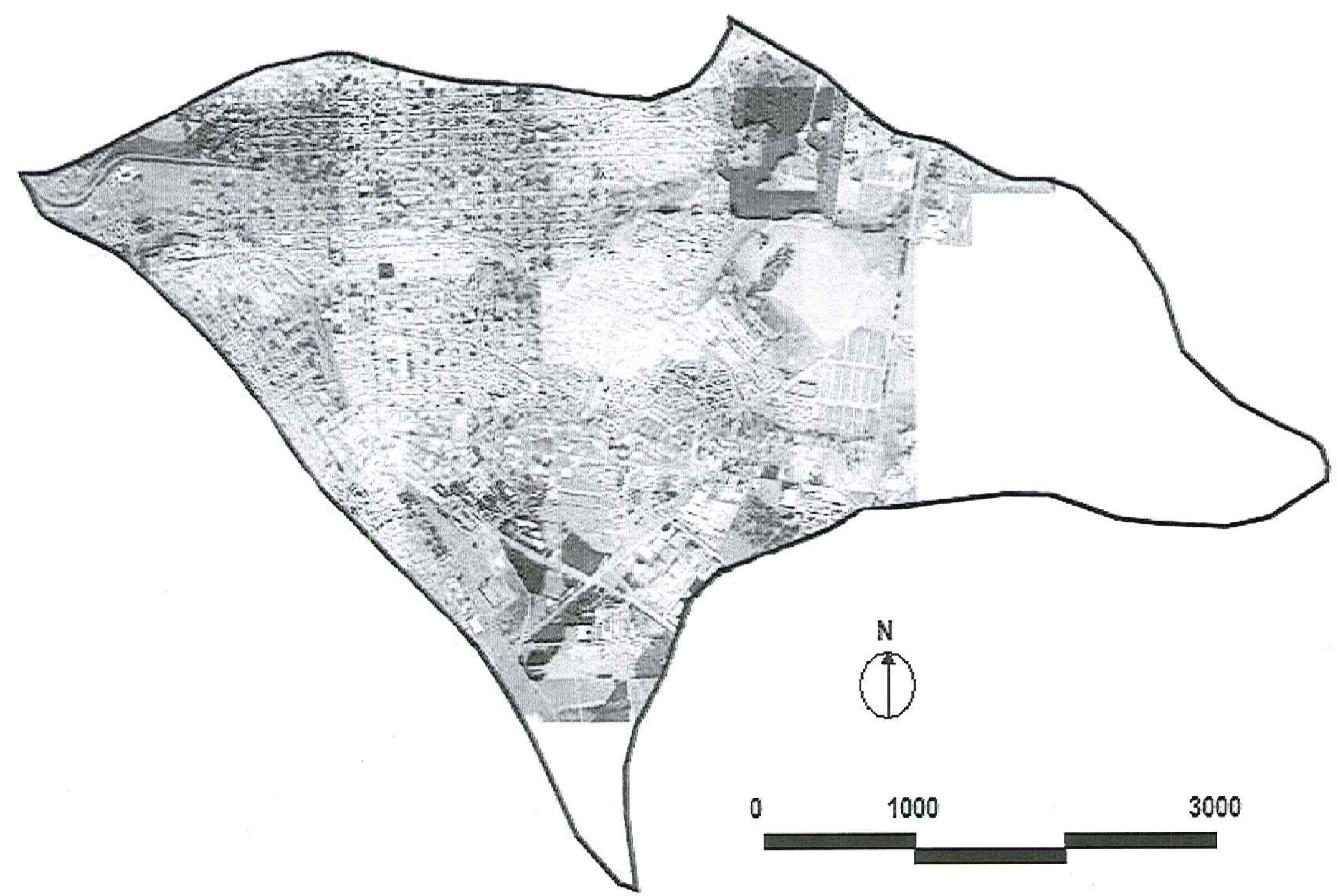

Figura 5.10 - Resultado da avaliação do processo de ocupação urbana da Bacia do Gregório: urbanização em 1998. Fotos Aéreas: PMSC - SMHDU. Elaboração: Heloisa Ceccato Mendes 
A Figura 5.11 ilustra a transformação ocorrida na região central de São Carlos ao longo do tempo, com fotos da Avenida São Carlos nos anos de 1898, 1929 e 2004, na qual pode-se observar a intensa impermeabilização do solo.
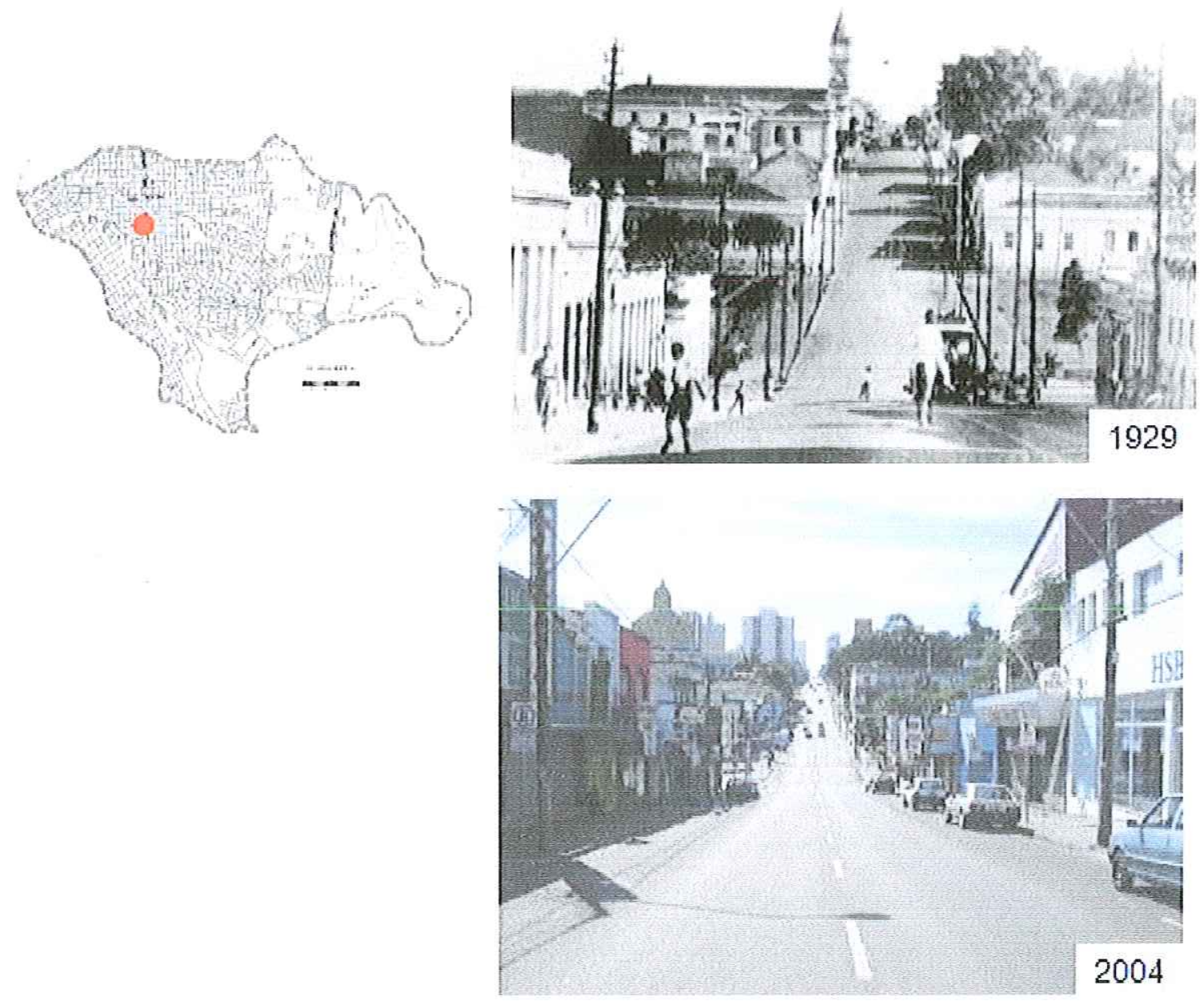

Figura 5.11 - Interpretação de transformações na vista da Avenida São Carlos para o vale do Córrego do Gregório, a partir da margem esquerda: em 1898, 1929 e 2004. Fonte das fotos: 19898 e 1929 - FotoArte, 2004 - foto da autora. Elaboração: Heloisa Ceccato Mendes. 
A Figura 5.12 demonstra a evolução da taxa de urbanização de São Carlos e da Bacia do Gregório. Nota-se que até aproximadamente 1980 as taxas da cidade e da bacia de estudo seguiram processos semelhantes: acréscimo de 1950 a 1970 e decréscimo de 1970 a 1980. A partir de 1990 os processos começaram a se diferenciar: a taxa de urbanização da bacia de estudo praticamente se estabilizou, enquanto a taxa da cidade aumentou, pois a expansão urbana passou a se dar com maior representatividade fora da bacia do Gregório (Figura 5.6).

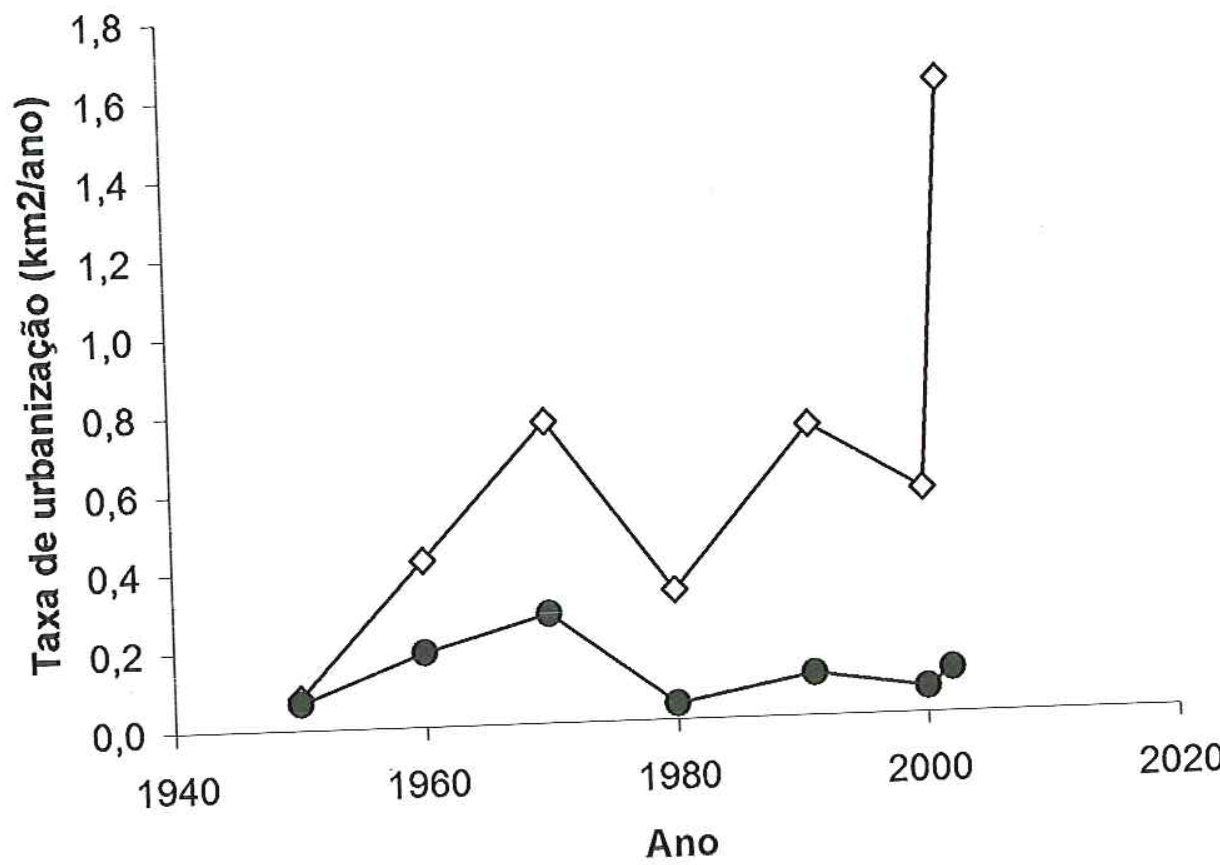

\section{$\diamond$ São Carlos $\quad-$-Bacia do Gregório}

Figura 5.12 - Resultado de Taxa de Urbanização (km2/ano) em São Carlos e na Bacia do Gregório no período de 1940 a 2002

A evolução entre 1950 e 2002 da taxa de urbanização (km2/ano) da Bacia do Gregório (Figura 5.12) pode ser dividida em três momentos.

O primeiro estágio, de 1950 a 1970, foi caracterizado por intenso aumento, atingindo o maior valor entre 1950 e 2000. Portanto, foi no primeiro estágio em que se deu o processo de urbanização mais rápido e intenso da bacia.

No segundo estágio, de 1970 a 1980, a bacia foi urbanizada com velocidade menor do que a do primeiro estágio, pois a taxa de urbanização sofieu diminuição representativa. 
O terceiro estágio, de 1980 a 2002, apresenta uma estabilização da tendência de urbanização da bacia.

A Figura 5.12 indica que os estágios nos quais ocorreram maiores oscilações da taxa de urbanização foram o primeiro, apresentando o maior aumento, e o segundo, apresentando a maior diminuição.

O Quadro 5.1 apresenta resumidamente as características de cada um dos estágios.

\begin{tabular}{|l|l|}
\hline Estágios & Característica \\
\hline I: 1950 a 1970 & - Intensa Urbanização \\
& - Em 1970: maior valor de taxa de urbanização do período de 1950 a 2000 \\
\hline II: 1970 a 1980 & - Desaceleração da urbanização \\
\hline III: 1980 a 2002 & - Estabilização da urbanização \\
\hline
\end{tabular}

Quadro 5.1 - Caracterização de períodos de urbanização da Bacia do Gregório

De acordo com registros históricos as retificações mais representativas do Córrego do Gregório ocorreram na década de 1970 (Figura 5.13), exatamente no momento em que a taxa de urbanização começou a diminuir. Esse fato vem reforçar a hipótese de que a intensa urbanização da bacia, de 1950 a 1970, gerou grandes impactos no seu sistema de escoamento. Para solucionar o problema, a solução adotada foi a canalização do Córrego do Gregório. Tal solução foi baseada na herança do conceito higienista, bastante presente no início do Século XX no Brasil, e que preconizava a eliminação sistemática de águas paradas ou empoçadas nas cidades como medida de saúde pública (SILVEIRA,1998). A partir de então, as medidas mitigadoras dos impactos de inundações aplicadas na Bacia do Gregório se caracterizaram predominantemente pela aplicação de medidas estruturais intensivas, orientadas pelo conceito higienista.

A Figura 5.13 retrata uma notícia de jornal, publicada no jornal A Folha, em 1972, sobre o projeto de canalização dos córregos do Gregório e Simeão. No Anexo 02, são apresentadas demais notícias históricas sobre obras e intervenções relacionadas a drenagem urbana realizadas na Bacia do Gregório. 


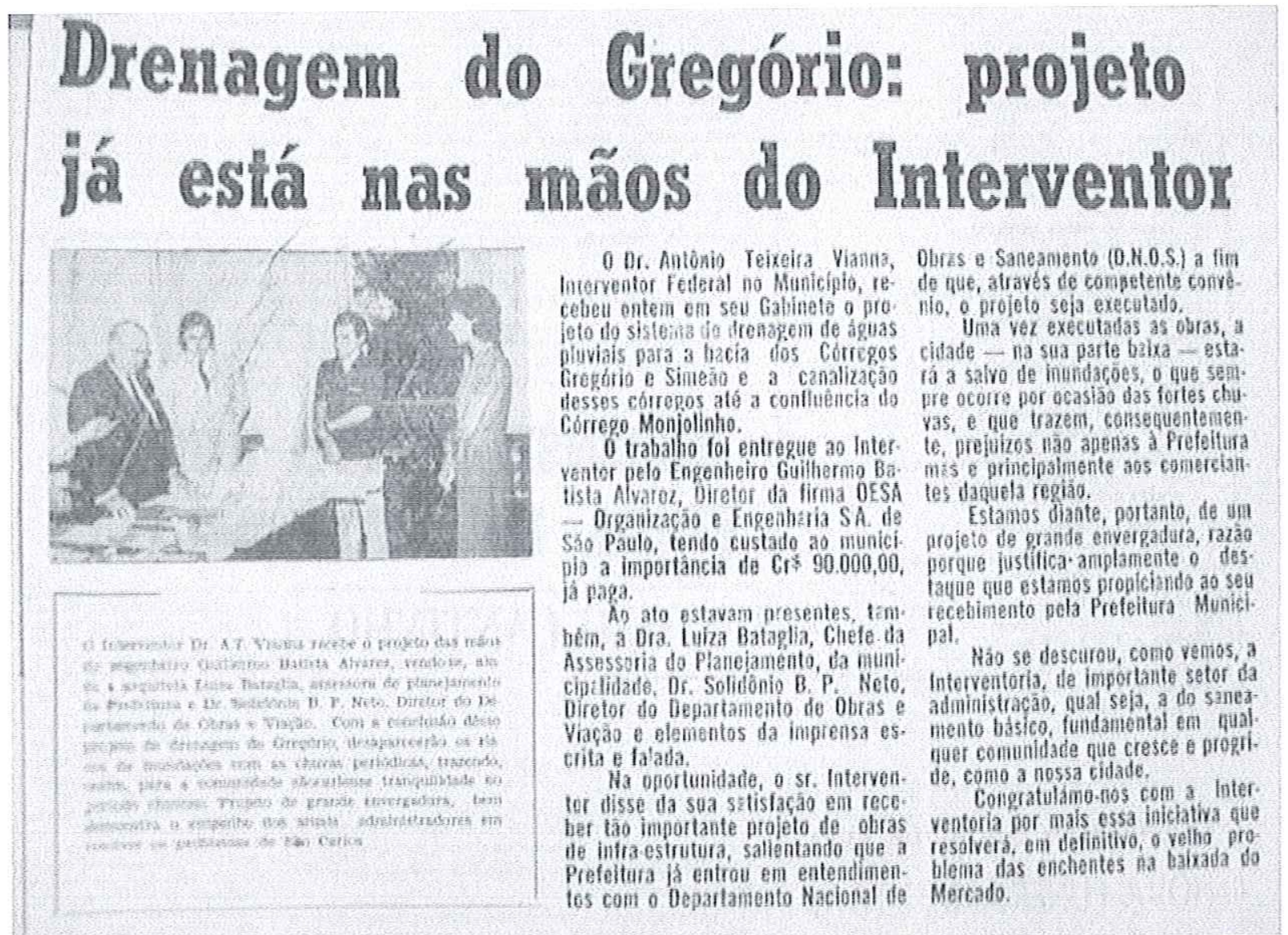

Figura 5.13 - Foto de notícia de jornal sobre o desenvolvimento de projeto de canalização dos córregos do Gregório e Simeão, em 1972. Fonte: adaptado de (DRENAGEM..., 1972)

Na Figura 5.14, com data de 2003, pode-se observar a conformação atual do fundo de vale do Córrego do Gregório na região próxima ao Mercado Municipal. Nota-se, pela observação da foto, o traçado bastante retificado do córrego nas proximidades do Mercado Municipal, principalmente no trecho a jusante deste. A foto ilustra também a intensa ocupação urbana e impermeabilização das áreas de várzea. 


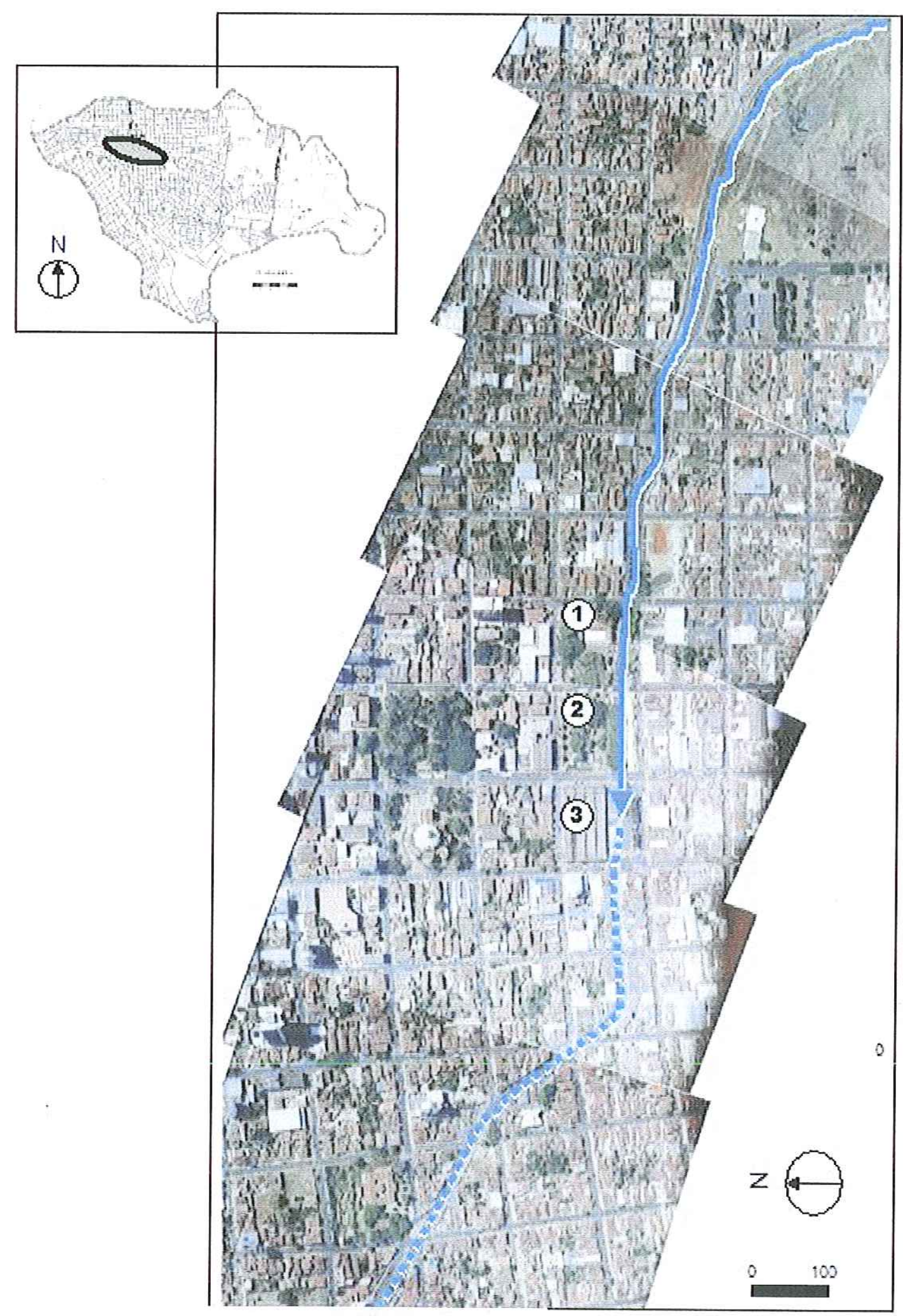

Figura 5.14 - Vista aérea do fundo de vale do Córrego do Gregório em 2003. 1) Piscina Municipal, 2) Praça dos Voluntários, 3) Mercado Municipal. Fonte da foto: Projeto FINEP/CT-HIDRO/EESC/USP-DAEE/SP - CNPq 01.02.0086.00. Elaboração: Heloisa Ceccato Mendes. Observação: cada quadra tem as dimensões aproximadas de $100 \mathrm{~m} \times 100 \mathrm{~m}$. 
O conceito higienista é indicado por Silveira (1998) como o princípio adotado pela primeira etapa de desenvolvimento da Hidrologia Urbana no Brasil. Em 1970, momento em que foram realizadas as canalizações mais expressivas do Córrego do Gregório como medida mitigadora dos impactos de inundação, o desenvolvimento da Hidrologia Urbana no Brasil passava, de acordo com o referido autor, pela etapa de Racionalização e Normatização. Porém, o autor ressalta que essa etapa não se desenvolveu de forma ideal no Brasil, pois foi caracterizada pela importação direta de métodos sem estudos de validação local, prejudicando e estabelecimento de normas nacionais e do planejamento, que poderia ter alertado para o impacto de certas práticas em um país de intensa urbanização.

\subsection{HISTÓRICO DA REGIÃO DO MERCADO MUNICIPAL}

O processo de urbanização da Bacia do Gregório promoveu transformações bastante representativas em algumas de suas regiões, das quais destacaremos a região do Mercado Municipal, por se tratar de um dos principais pontos de inundação e alagamentos da cidade.

A praça onde se localizou o primeiro Mercado Municipal de São Carlos, limitada pelas vias Avenida São Carlos, Rua Jesuíno de Arruda, Rua Episcopal e Rua Geminiano Costa, foi inaugurada na década de 1910. Embora o Mercado Municipal já se localizasse nessa região, a ocupação estabelecida nesse momento era bastante diferente da atual. A inauguração da praça do Mercado Municipal foi seguida por uma série de modificações na região. Entre elas, destaca-se a intervenção paisagística que criou um eixo composto por três praças. Com a inauguração da Praça dos Voluntários (Figura 5.15) e da Piscina Municipal, em 1934, essa região passou a ser caracterizada pela presença de áreas voltadas ao lazer (Figura 5.16).

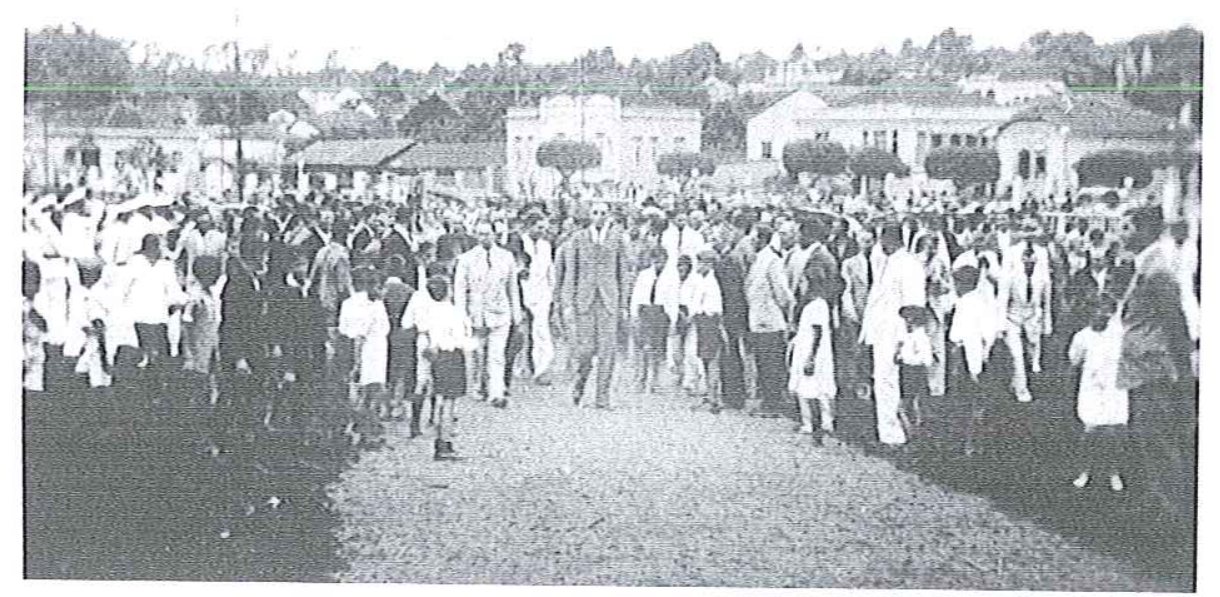

Figura 5.15 - Inauguração da Praça dos Voluntários, em 1934. Mercado Municipal antigo ao fundo, à direita. Fonte: Fundação Pró Memória de São Carlos. 


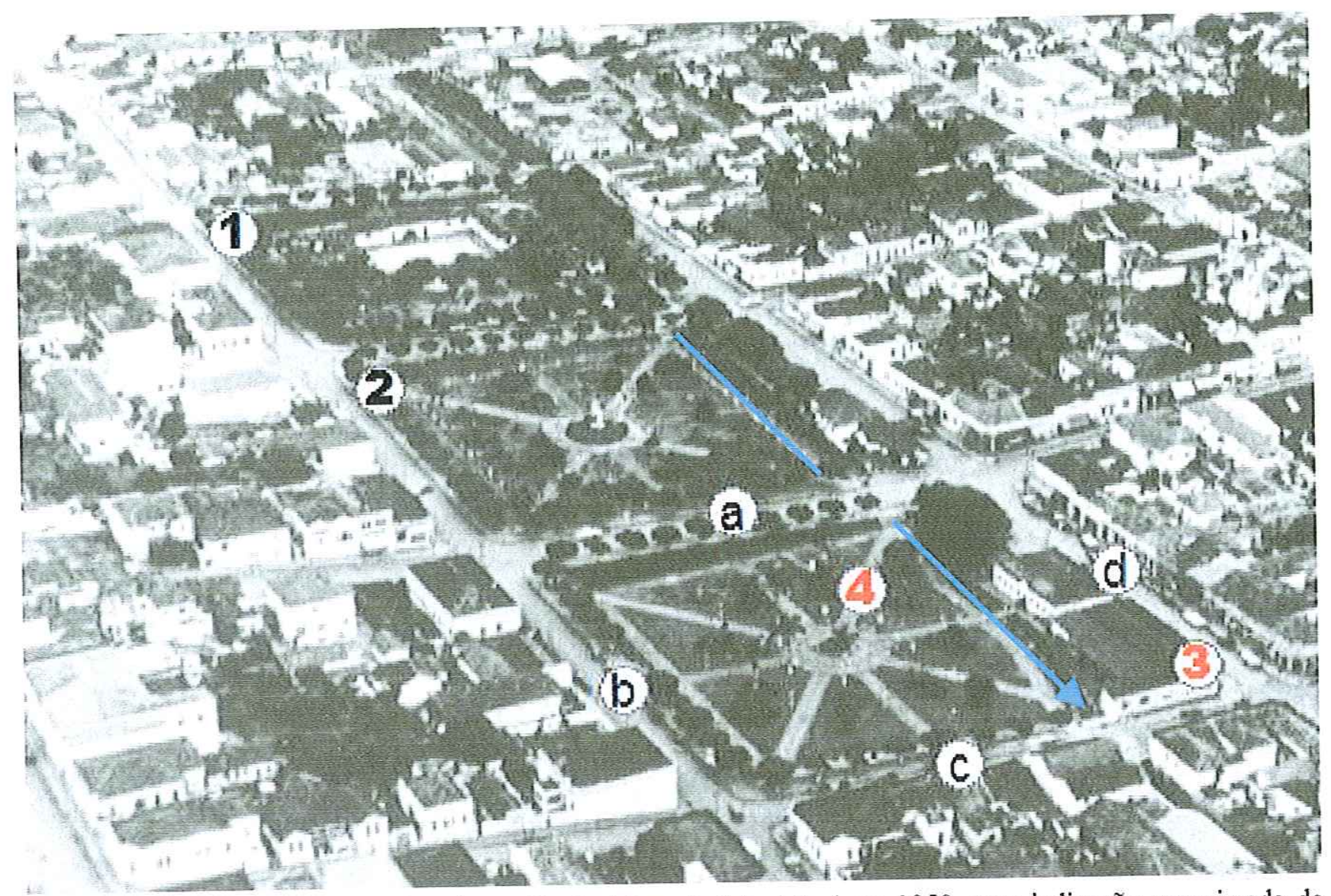

Figura 5.16 - Interpretação de foto da região do Mercado Municipal em 1950, com indicação aproximada do curso do Córrego do Gregório. 1) Piscina Municipal, 2) Praça dos Voluntários, 3) Mercado Municipal Antigo, 4) Praça onde o Mercado Municipal atual foi implantado, a) Av. São Carlos, b) R. Jesuíno de Arruda, c) R. Episcopal, d) R. Geminiano Costa. Fonte da foto: Fundação Pró Memória de São Carlos. Elaboração: Heloisa Ceccato Mendes. Observação: cada quadra tem as dimensões aproximadas de $100 \mathrm{~m}$ x $100 \mathrm{~m}$

As intervenções que deram origem à conformação da região de estudo em meados de 1950 (implantação de avenidas no fundo de vale e intervenção paisagística criando um eixo composto pelas três praças) podem ser analisadas como algo análogo às intervenções propostas para o Vale do Anhangabaú, em São Paulo - SP, entre 1907 e 1912 (Figuras 3.19 e 3.20, capítulo 3). Nos dois casos observa-se a existência associada de duas intenções para os fundos de vale: criação de espaços de lazer por meio da realização de tratamento paisagístico, e solução dos problemas de circulação urbana por meio da implantação de avenidas.

Em 1968 foi inaugurado o novo Mercado Municipal, localizado à margem direita do Córrego do Gregório (Figura 5.17). O fato de que o Mercado Municipal foi implantado em uma área que antes dava lugar a uma das três praças, que buscavam conferir ao fundo de vale um uso recreativo, indica que a intenção paisagística foi colocada em segundo plano a partir desse momento. A partir de então, as intenções que guiaram as intervenções no fundo do vale do Gregório foram se afastando de 
conceitos paisagísticos, buscando exclusivamente a solução dos problemas de inundações com base nos conceitos higienistas, além de promover a impermeabilização das áreas de várzea.

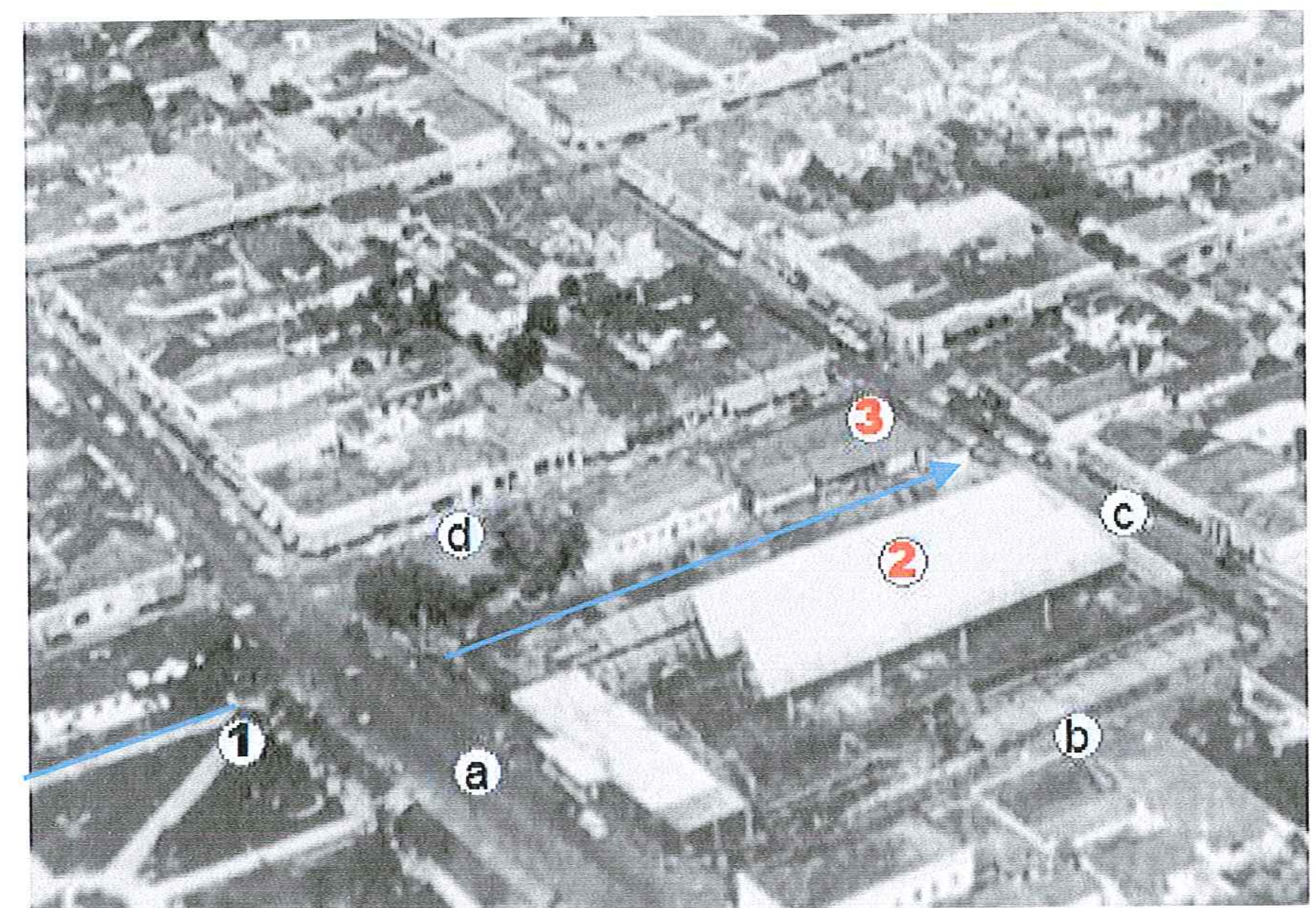

Figura 5.17 - Interpretação de foto do Mercado Municipal antigo e Construção do Mercado atual em 1967, com indicação aproximada do curso do Córrego do Gregório. 1) Praça dos Voluntários, 2) Mercado Municipal atual em construção, 3) Mercado Municipal Antigo, a) Av. São Carlos, b) R. Jesuíno de Arruda, c) R. Episcopal, d) R. Geminiano Costa. Fonte da foto: FotoArte. Elaboração: Heloisa Ceccato Mendes. Observação: cada quadra tem as dimensões aproximadas de $100 \mathrm{~m} \times 100 \mathrm{~m}$.

A seqüência histórica de imagens aéreas (Figura 5.18) demonstra a região do Mercado Municipal nas seguintes datas: 1962, quando a quadra de localização do Mercado Municipal antigo era composta em grande parte pela Praça Santos Dumont; em 1972, quando o Mercado Municipal atual já havia sido implantado; e, mais recentemente, em 1998 e 2003. 

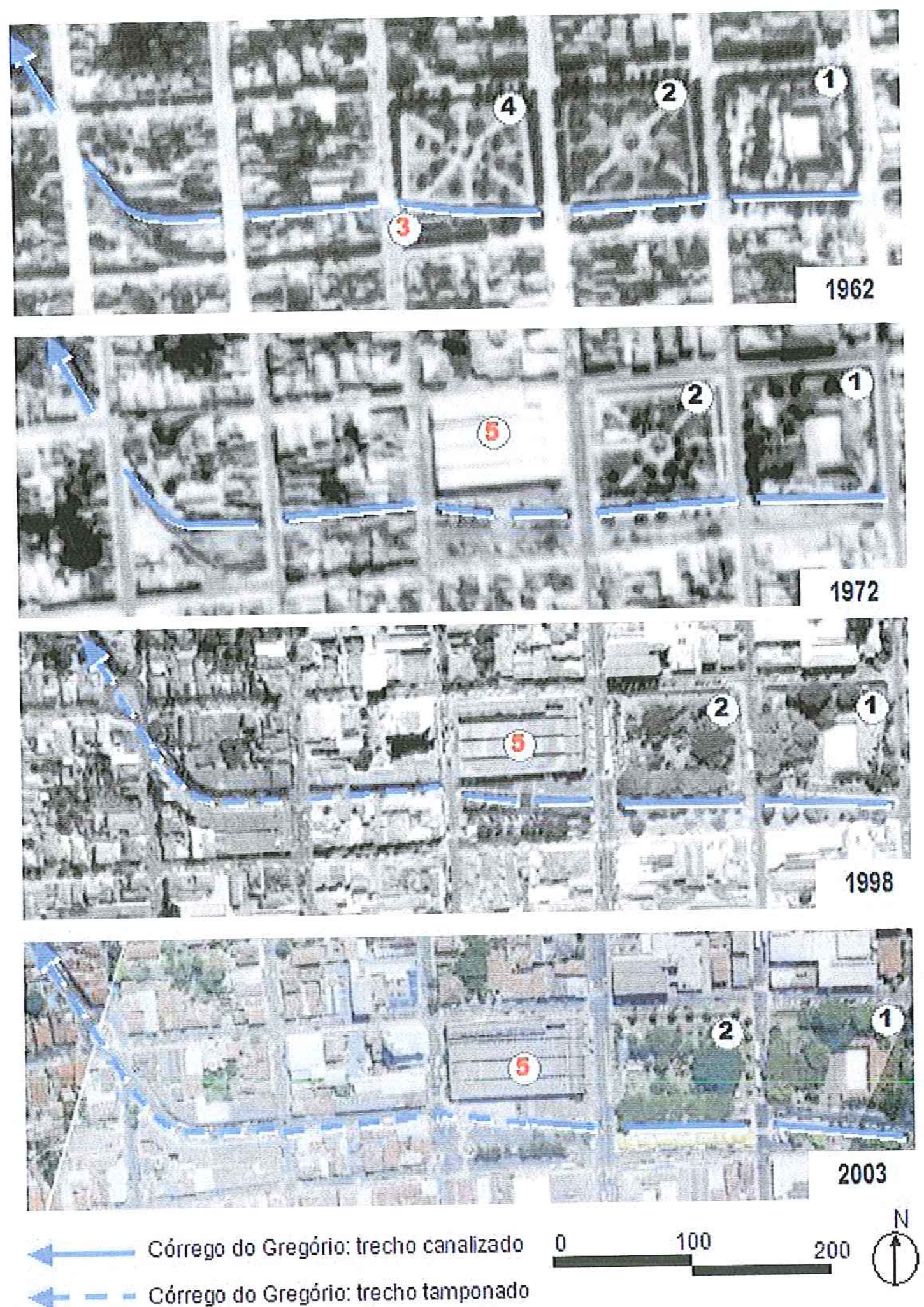

Figura 5.18 - Interpretação de fotos da região do Mercado Municipal em 1962, 1972, 1998 e 2003. 1) Piscina Municipal, 2) Pça dos Voluntários, 3) Mercado Municipal Antigo, 4) Praça onde o Mercado Municipal atual foi implantado, 5) Mercado Municipal atual. Fonte das fotos: 1962 e 1972 - Casa da Agricultura de São Carlos , 1998 - PMSC / SMHDU, 2003 - FIPAI/PMSC (2003). Elaboração: Heloisa Ceccato Mendes. 
Nas fotos de 1962 e de 1972 da Figura 5.18, pode-se observar o traçado do Córrego Simeão próximo ao encontro com o Córrego do Gregório. O Córrego do Simeão foi tamponado na década de 1970 (Figura 5.13), e seu leito atualmente ocupa áreas localizadas abaixo de estabelecimentos comerciais. A Figura 5.19 demonstra o traçado do Córrego do Simeão e do Córrego do Gregório em planta e em uma vista aérea da área próxima ao encontro dos dois córregos.
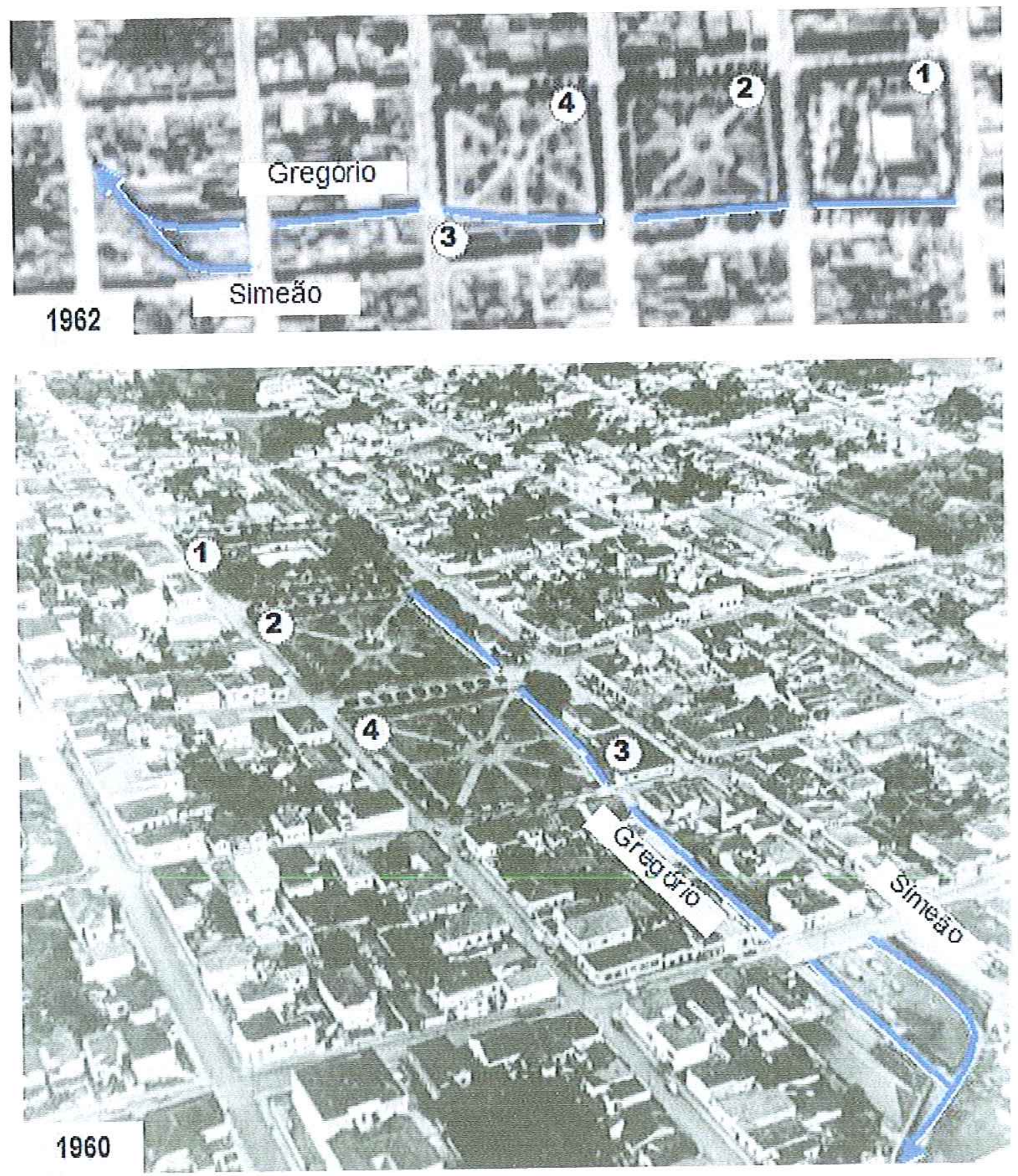

Figura 5.19 - Interpretação de fotos da década de 1960, com indicação de traçado do Córrego Simeão. Fonte das fotos: Casa da Agricultura e Foto Arte. Elaboração: Heloisa Ceccato Mendes 
A Figura 5.20 retrata a canalização do Córrego do Gregório, na década de 1970, na região onde atualmente se situa o Mercado Municipal, e também a mesma área em 2003.
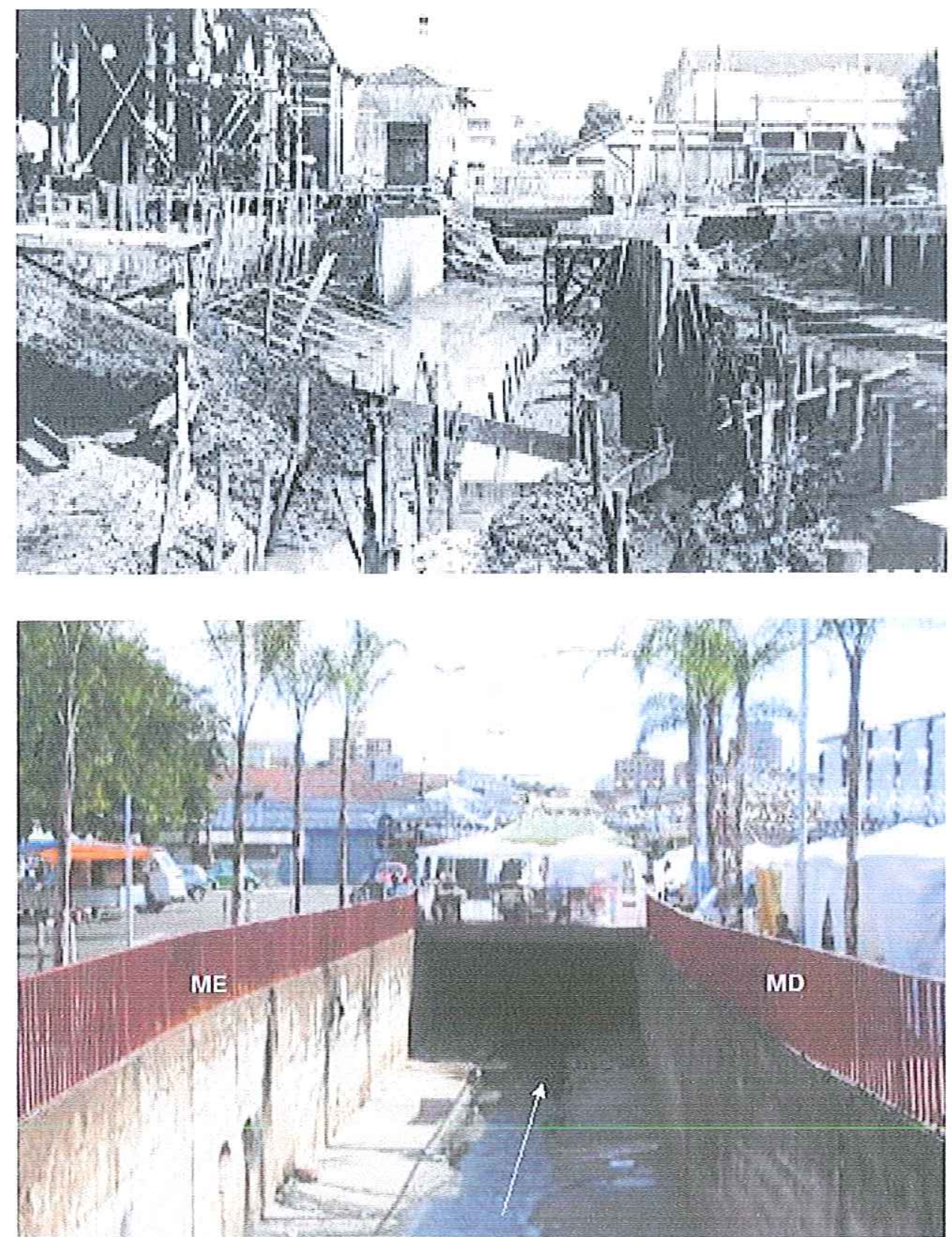

Figura 5.20 - Avaliação de transformações área em frente ao local onde se situa atualmente o Mercado Municipal: canalização na década de 1970, e em 2004. Fonte das fotos: 1970 - FotoArte, 2004 - foto da autora. Elaboração: Heloisa Ceccato Mendes.

A Figura 5.21 retrata a quadra entre a Ruas Episcopal e Rua 9 de julho, em 1898, durante a realização de obras de tamponamento do córrego, e atualmente, em 2004. 

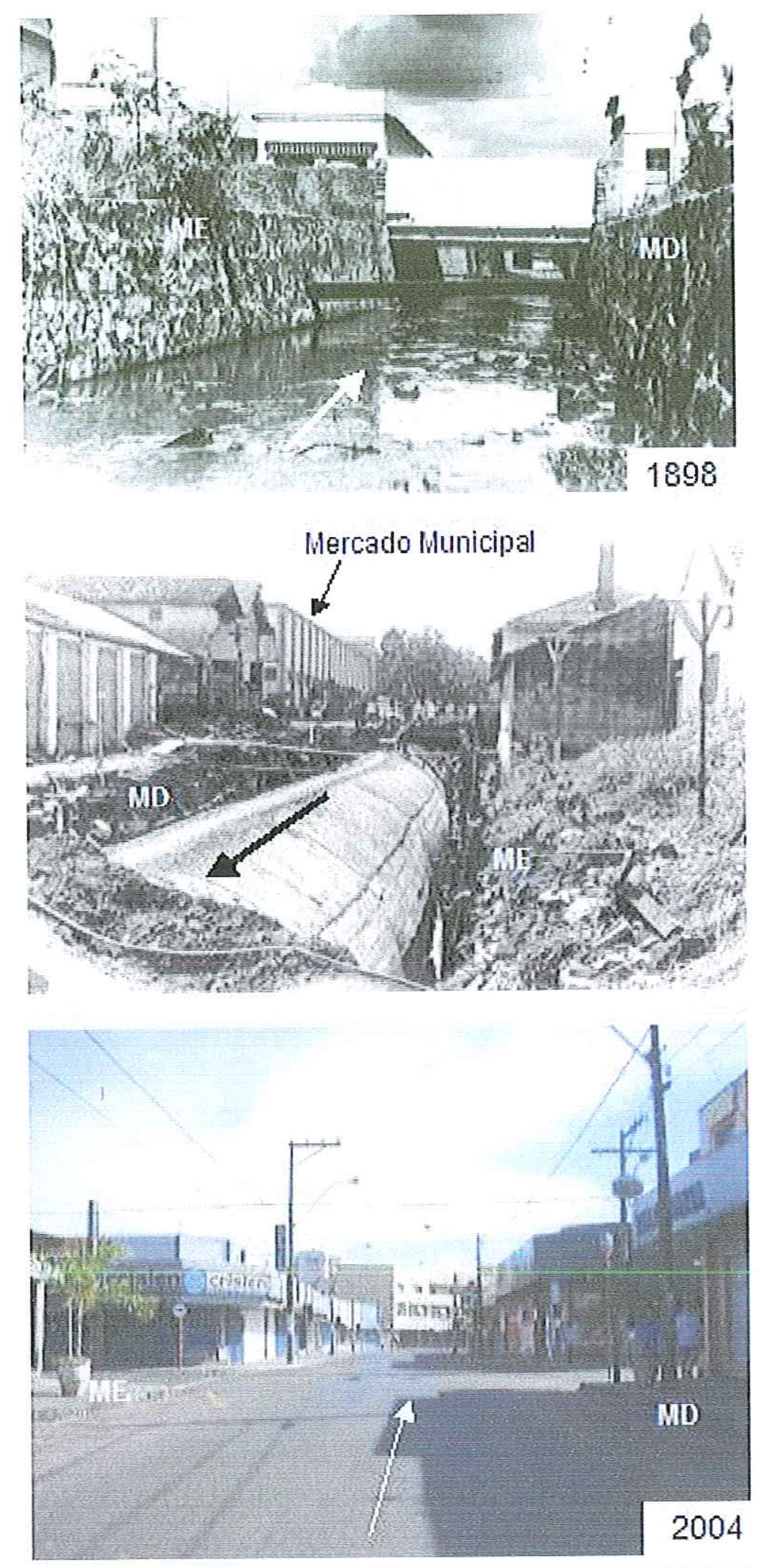

Figura 5.21 - Avaliação de transformações entre Rua Episcopal e Rua 9 de Julho: em 1898, durante tamponamento, e em 2004. Fonte das fotos: 1898 - FotoArte, 1970 - FotoArte, 2004 - foto da autora. Elaboração: Heloisa Ceccato Mendes. 
O primeiro Mercado Municipal de São Carlos (Figura 5.22) localizava-se à margem esquerda do Córrego do Gregório, sendo composto por dois edifícios: um destinado ao comércio de carnes, mais próximo da Avenida São Carlos, e outro para o comércio de frutas e verduras, mais próximo da Rua Episcopal.
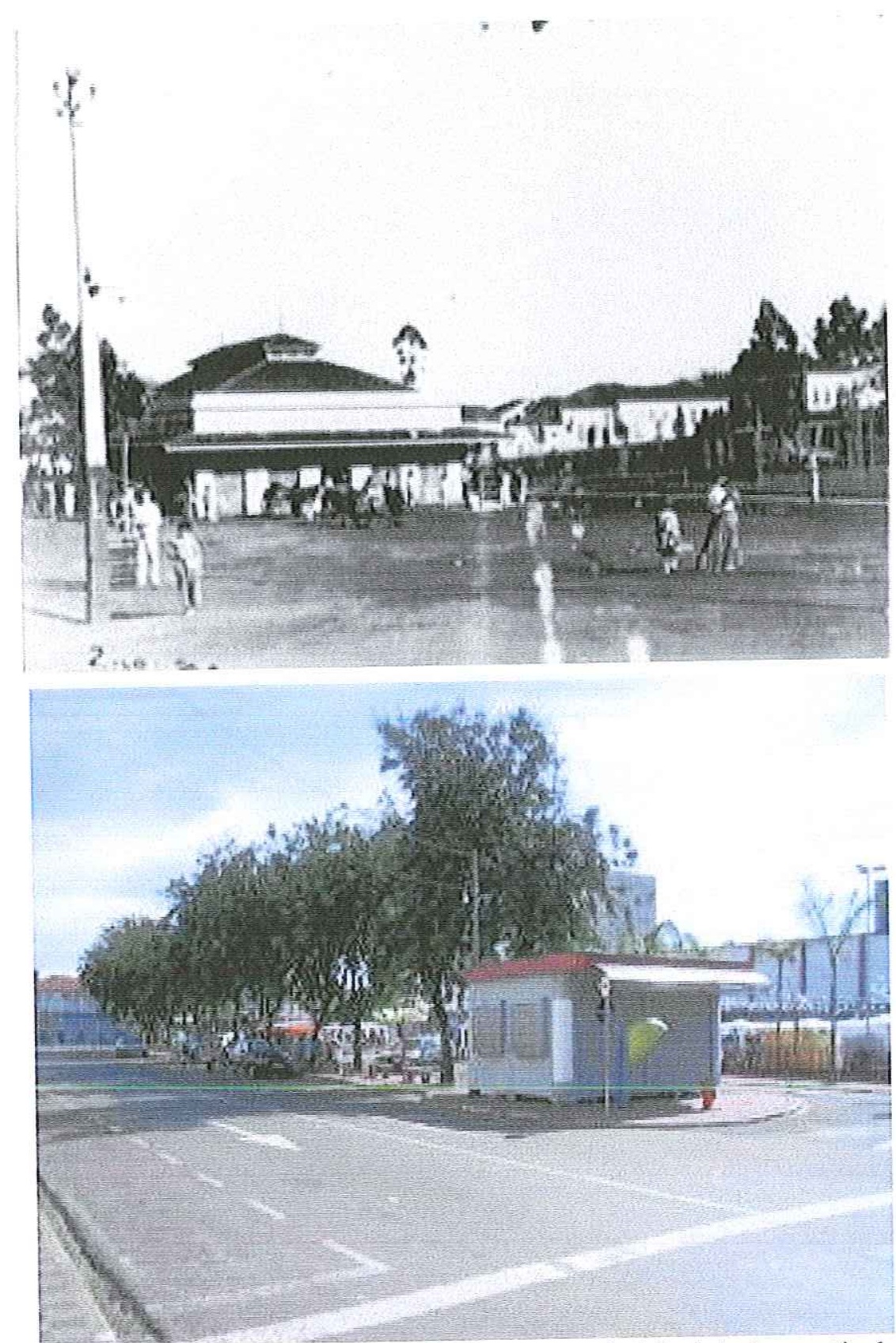

Figura 5.22 - Avaliação de transformações na vista para o Mercado Municipal a partir da esquina da Av. São Carlos com R. Geminiano Costa, localizada na margem esquerda: 1908 e 2004. Fontes das fotos: 1908 FotoArte, 2004 - foto da autora. Elaboração: Heloisa Ceccato Mendes. 
Os registros históricos indicam que a região do Mercado Municipal sofria impactos causados por inundações já na década de 1930 (Figura 5.23). O Anexo 01 apresenta demais notícias sobre inundações e alagamentos ocorridos na Bacia do Gregório de 1940 a 2004.

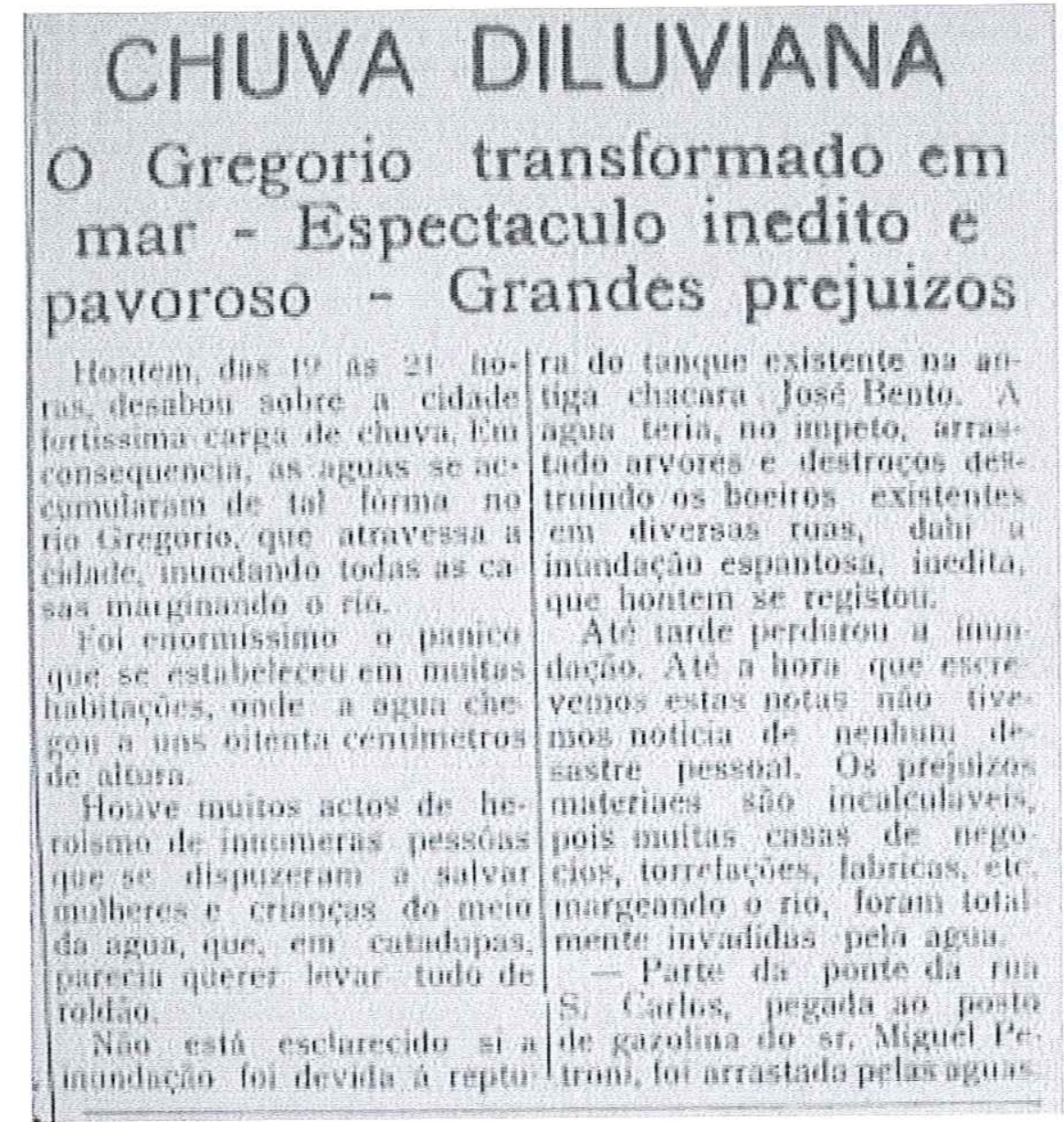

Figura 5.23 - Detalhe de notícia de jornal sobre inundação na Bacia do Gregório, em 1932. Fonte: adaptado de CHUVA...1932

A Figura 5.24 demonstra a destruição da pavimentação de paralelepípedos da Rua Geminiano Costa, ocasionada por uma inundação em 1940. A Figura 5.25 retrata a realização de limpeza do corredor que separava os dois edifícios do Mercado Municipal, após uma inundação em 1947. 

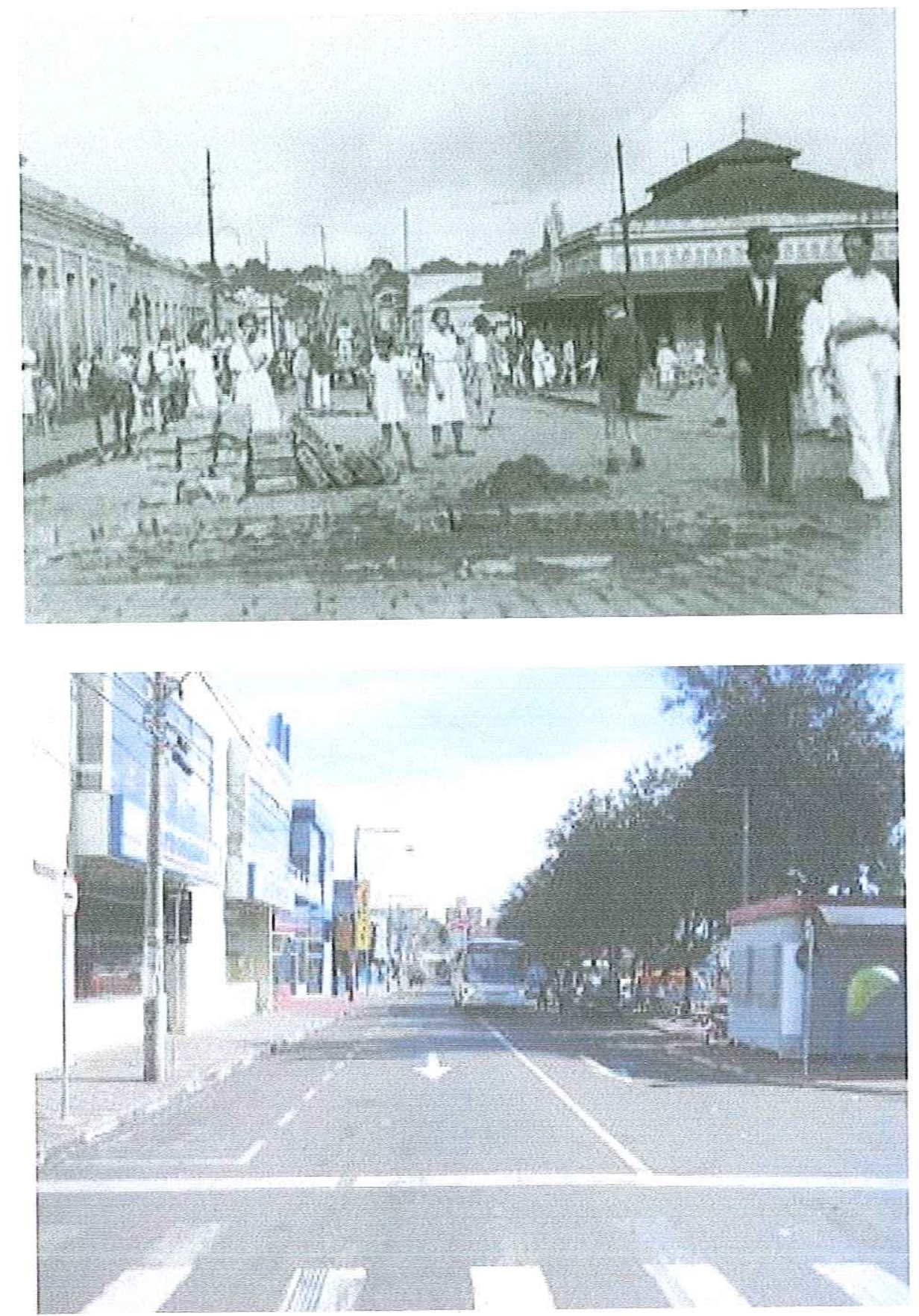

Figura 5.24 - Avaliação de transformações na vista da Rua Geminiano Costa (margem esquerda) a partir da Av. São Carlos: 1940 e 2004. Fontes das fotos: 1940 - FotoArte, 2004 - foto da autora. Elaboração: Heloisa Ceccato Mendes) 


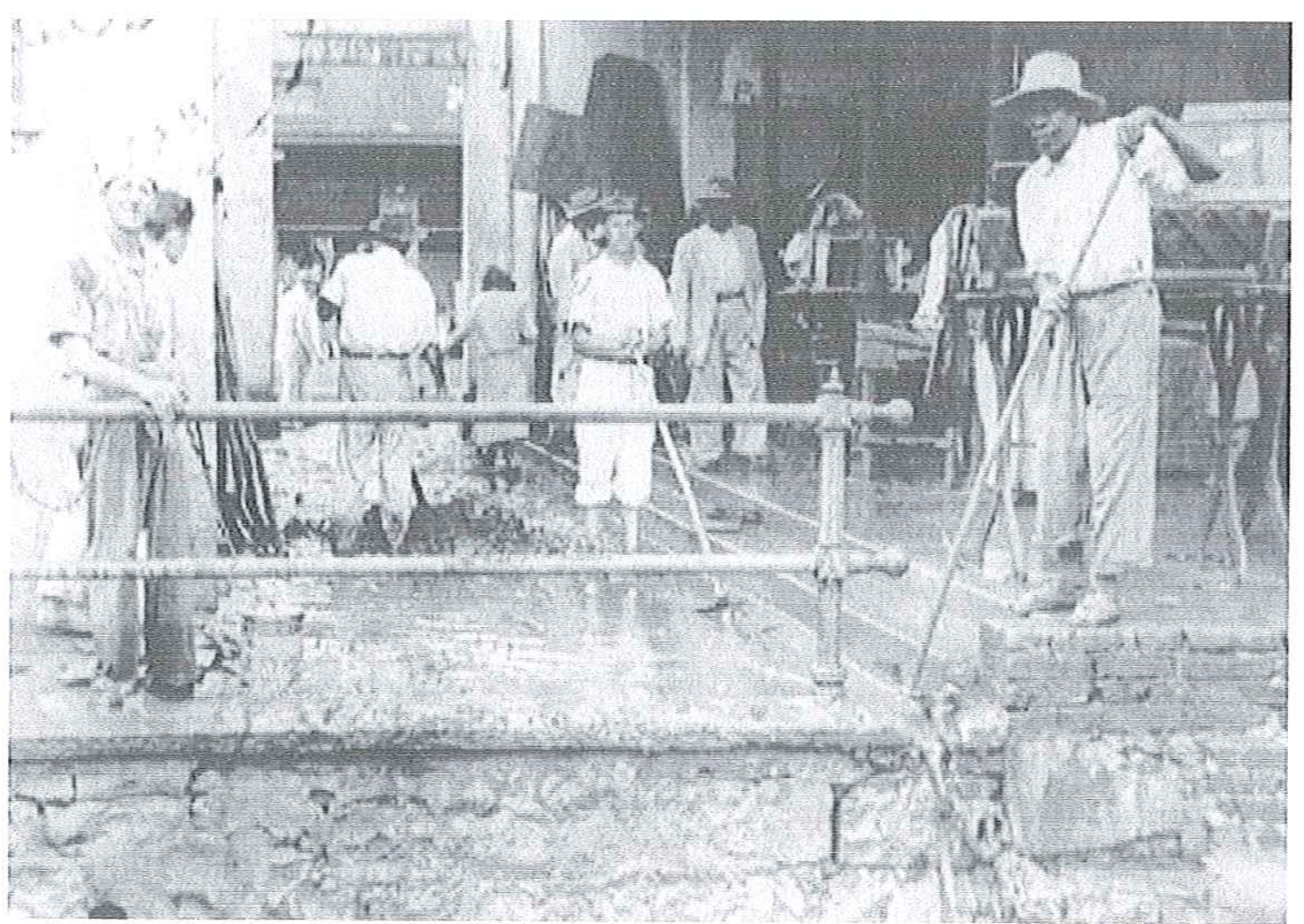

Figura 5.25 - Foto de realização de limpeza do corredor que separava os dois edifícios do Mercado Municipal antigo, localizado na margem esquerda do córrego, após inundação em 1947. Fonte: Foto Arte.

\subsection{AVALIAÇÃO DOS MÉTODOS UTILIZADOS PARA O LEVANTAMENTO DE NOTÍCIAS DE JORNAL}

Utilizando dados monitorados pelo SIGRH e EMBRAPA, foram selecionadas datas em que ocorreram PDiàrias a partir de $70 \mathrm{~mm}$. Com a utilização de 28 (vinte e oito) das 63 (sessenta e três) datas, não foram localizadas notícias relacionadas ao tema das inundações. Com a utilização de 11 (onze) das 63 (sessenta e três) datas utilizadas para o levantamento de notícias foram encontradas notícias somente sobre o tema das inundações em geral ou em outros pontos de São Carlos não localizados na bacia de estudo.

Com a utilização de 24 (vinte e quatro) das 63 (sessenta e três) datas utilizadas para o levantamento de notícias foram encontradas notícias sobre um evento específico de inundação ou alagamento ocorrido na bacia do Gregório. Portanto, a eficácia do método de consideração das datas em que ocorreu P Diária a partir de $70 \mathrm{~mm}$ para o levantamento de notícias de jornal sobre inundações na bacia do Gregório foi de aproximadamente $38 \%$. 
Das 38 (trinta e oito) notícias indicadas por fontes complementares (Rebelatto, 1991 e Barros, 2005), foram encontradas 36 (trinta e seis). Portanto, o método de consideração das indicações em trabalhos desenvolvidos anteriormente para busca de notícias de jornal sobre inundações teve eficácia de aproximadamente $95 \%$.

Em consulta Ao Sr. José João foram indicados, de maneira aproximada, os anos de 1947, 1956, 1957, 1970, 1973 e 1993, por volta de janeiro e fevereiro, como base para a busca de notícias. Dos 06 (seis) anos indicados pelo Sr. José João, somente não foram encontradas notícias sobre inundações na Bacia do Gregório para dois deles (1956 e 1993). Portanto, avaliou-se que a eficácia do método de consideração da história oral para o levantamento de notícias históricas sobre inundações foi de aproximadamente $67 \%$.

\subsection{NOTÍCIAS DE JORNAL ENCONTRADAS}

A Tabela 5.1 indica o número de notícias encontrado de acordo com o assunto.

Tabela 5.1 - Número de notícias encontradas, classificadas de acordo com seu conteúdo

\begin{tabular}{|l|r|}
\hline Tipo de notícia & No. de notícias encontradas \\
\hline Evento específico de Inundação ou Alagamento na Bacia do Gregório & 64 \\
\hline Intervenções e Obras relacionadas à drenagem na Bacia do Gregório & 38 \\
\hline Inundações e alagamentos em demais pontos da cidade de São Carlos & 18 \\
\hline Notícias gerais sobre o tema & 29 \\
\hline TOTAL & 149 \\
\hline
\end{tabular}

Foram encontradas 149 (setenta e duas) notícias de jornal sobre inundações entre 1940 e 2004 , sendo que 64 (sessenta e quatro) delas referem a um evento de inundação específico ocorrido na subbacia do Gregório, referentes a 54 (cinqüenta e quatro) datas de publicação em jornais (Tabela 5.2).

Tabela 5.2 - Notícias encontradas em jornal sobre inundações na Sub-Bacia do Gregório entre 1940 e 2004

\begin{tabular}{|r|l|l|}
\hline \multicolumn{1}{|c|}{ Data da Notícia } & \multicolumn{1}{|c|}{ Título da notícia } \\
\hline $23 / 2 / 1947$ & Correio de São Carlos & Conseqüências das Chuvas \\
\hline $23 / 2 / 1947$ & Correio de São Carlos & $\begin{array}{l}\text { Suspensas temporariamente as atividades das } \\
\text { piscinas }\end{array}$ \\
\hline $2 / 3 / 1947$ & Correio de São Carlos & Inundada a parte baixa da cidade \\
\hline $20 / 11 / 1947$ & Correio de São Carlos & Enchente \\
\hline $17 / 2 / 1953$ & Correio de São Carlos & As Ruas estão intransitáveis \\
\hline $2 / 2 / 1955$ & Correio de São Carlos & Novamente inundada a parte baixa da cidade \\
\hline $3 / 2 / 1955$ & Correio de São Carlos & O Córrego do Gregório \\
\hline
\end{tabular}




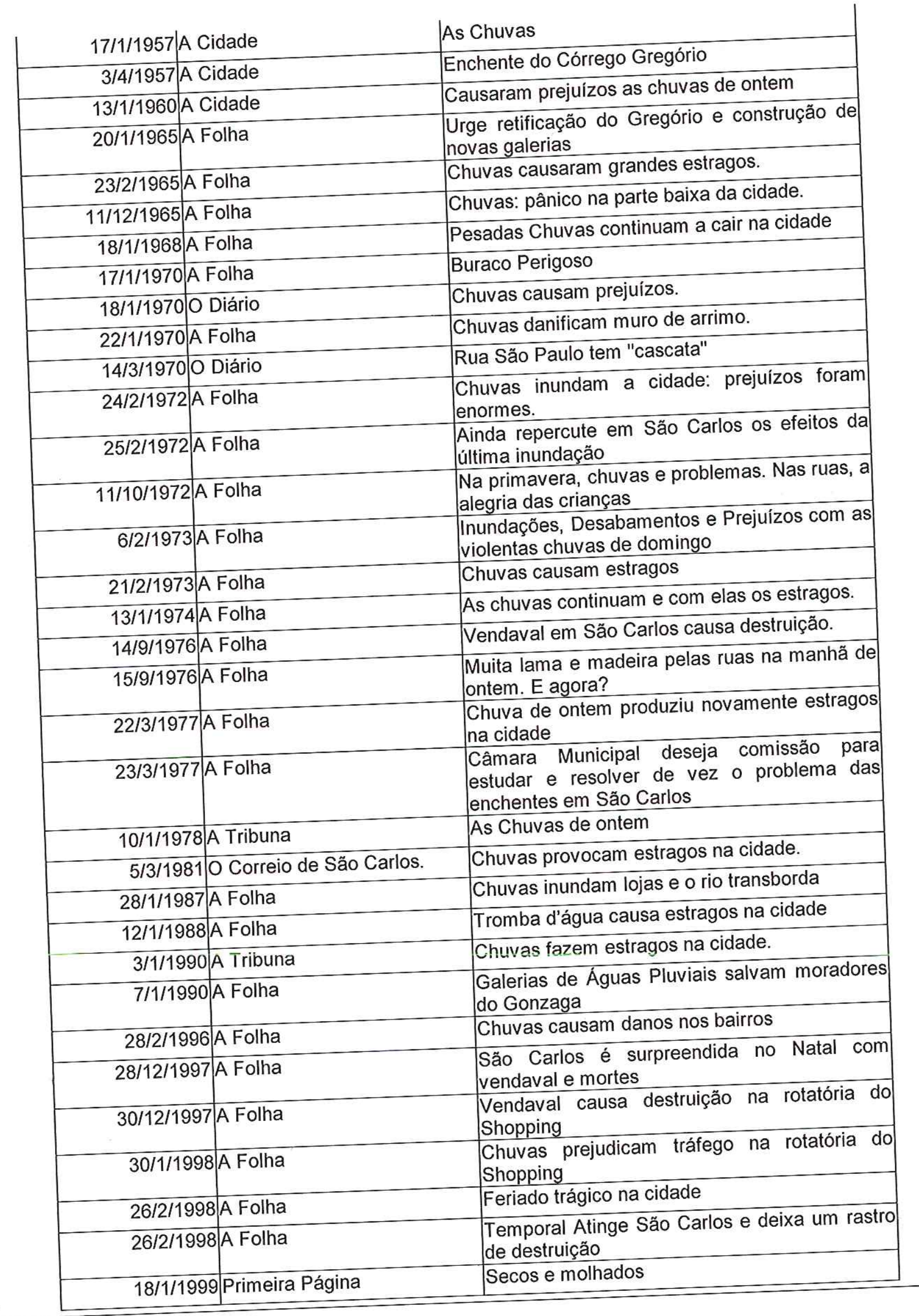




\begin{tabular}{|c|c|c|}
\hline 18/1/1999|Pri & Primeira Página & Enchentes viram rotina para comerciantes \\
\hline 19/2/1999/A & A Folha & $\begin{array}{l}\text { São Carlos é atingida por temporal no Carnaval } \\
\text { que causou muitos danos }\end{array}$ \\
\hline $10 / 1 / 2002 / A$ & A Folha & $\begin{array}{l}\text { Coletiva anuncia medidas emergenciais } \\
\text { tomadas pela PMSC sobre estragos causados } \\
\text { pela chuva }\end{array}$ \\
\hline $10 / 1 / 2002 / \mathrm{Pr}$ & Primeira Página & Chuva provoca acidente inédito em São Carlos \\
\hline $14 / 2 / 2002$ A & A Tribuna & Carnaval da animação ou da inundação \\
\hline $12 / 11 / 2002$ A & A Folha & Combate a enchente \\
\hline 12/11/2002 $\mathrm{Pl}$ & Primeira Página & Chuvas atormentam comerciantes da baixada \\
\hline $12 / 11 / 2002 / \mathrm{P}$ & Primeira Página & Ponte perfaz $10 \%$ das obras contra enchente \\
\hline $5 / 1 / 2003 \mathrm{Pr}$ & Primeira Página & Chuvas castigaram cidade na madrugada \\
\hline $5 / 1 / 2003 \mathrm{P}$ & Primeira Página & Chuvas em São Carlos \\
\hline $31 / 1 / 2004 \mid \mathrm{P}$ & Primeira página & Chuva inunda obra de Newton na baixada \\
\hline $31 / 1 / 2004 \mid \mathrm{P}$ & Primeira página & $\begin{array}{l}\text { Alkimin chega em São Carlos junto com } \\
\text { enchente }\end{array}$ \\
\hline $31 / 1 / 2004$ A & A Tribuna & Temporal Atinge São Carlos \\
\hline $3 / 2 / 2004 \mid A$ & A Folha & $\begin{array}{l}\text { Chuvas que atingem país deixam pessoas } \\
\text { desalojadas }\end{array}$ \\
\hline $16 / 12 / 2004 / \mathrm{F}$ & Primeira Página & $\begin{array}{l}\text { Temporal assusta, mas não causa estragos na } \\
\text { cidade }\end{array}$ \\
\hline $16 / 12 / 2004$ & Primeira Página & $\begin{array}{l}\text { Temporal de meia hora assusta moradores da } \\
\text { cidade }\end{array}$ \\
\hline $20 / 12 / 2004$ & EPTV Central & Chuva causa alagamentos em São Carlos \\
\hline
\end{tabular}

No total, encontraram-se notícias relacionadas ao tema das inundações urbanas em São Carlos para os anos de 1945, 1947, 1953, 1955, 1957, 1960, 1965, 1968, 1970, 1972, 1973, 1974, 1975, 1976, 1977, 1978, 1980, 1981, 1983, 1987, 1988, 1990, 1996, 1997, 1998, 1999, 2002, 2003, 2004. Destas notícias, as que fazem referência a eventos específicas ocorridos na Bacia do Gregório são dos anos de 1947, 1953, 1955, 1957, 1960, 1965, 1968, 1970, 1972, 1973, 1974, 1976, 1977, 1978, 1981, 1987 , 1988, 1989, 1990, 1996, 2002, 2003 e 2004. A Tabela 5.3 apresenta o número de eventos ocorridos em cada um desses anos.

Tabela 5.3 - Número de eventos ocorridos na Bacia do Gregório, classificados por anos.

\begin{tabular}{|c|c|}
\hline Ano & No. de eventos \\
\hline 1947 & 3 \\
\hline 1953 & 1 \\
\hline 1955 & 2 \\
\hline 1957 & 2 \\
\hline 1960 & 1 \\
\hline 1965 & 3 \\
\hline 1968 & 1 \\
\hline 1970 & 3 \\
\hline
\end{tabular}




\begin{tabular}{|c|c|}
\hline 1972 & 2 \\
\hline 1973 & 2 \\
\hline 1974 & 1 \\
\hline 1976 & 1 \\
\hline 1977 & 1 \\
\hline 1978 & 1 \\
\hline 1981 & 1 \\
\hline 1987 & 1 \\
\hline 1988 & 1 \\
\hline 1989 & 2 \\
\hline 1990 & 2 \\
\hline 1996 & 1 \\
\hline 2002 & 3 \\
\hline 2003 & 1 \\
\hline 2004 & 3 \\
\hline 2005 & 2 \\
\hline
\end{tabular}

Além do período de levantamento da pesquisa (1940 a 2004), foram encontradas também algumas notícias para os anos de 1932 e 2005.

Em notícia do jornal Primeira Página de 09/09/2005 (BALA, 2005) foi encontrada a indicação de uma notícia de 02/03/1932 sobre inundação na região do mercado municipal, que foi localizada e catalogada. As demais notícias do ano de 1932 foram localizadas por indicação de um pesquisador que se encontrava na Fundação Pró Memória durante o período de realização dos levantamentos (5.4).

Tabela 5.4: Notícias encontradas em jornal sobre inundações na Sub-Bacia do Gregório em 1932

\begin{tabular}{ccc|c|}
\hline $\begin{array}{c}\text { Data da } \\
\text { Chuva }\end{array}$ & Data da Notícia & Jornal & Título da notícia \\
\hline $25 / 2 / 1932$ & $26 / 2 / 1932$ & Correio de São Carlos & Chuva diluviana \\
\hline $25 / 12 / 1932$ & $27 / 2 / 1932$ & Correio de São Carlos & Chuva diluviana \\
\hline $25 / 2 / 1932$ & $2 / 3 / 1932$ & Correio de São Carlos & Cronica Hebdomadaria \\
\hline $12 / 6 / 1932$ & $14 / 6 / 1932$ & Correio de São Carlos & Chuva diluviana \\
\hline
\end{tabular}

Durante o período de realização da pesquisa, foram encontradas também duas notícias de 2005 (Tabela 5.5). 
Tabela 5.5: Notícias encontradas em jornal sobre inundações na Sub-Bacia do Gregório em 2005

\begin{tabular}{|c|c|c|c|}
\hline $\begin{array}{c}\text { Data da } \\
\text { Chuva }\end{array}$ & Data da Notícia & Jornal & Título da notícia \\
\hline $4 / 1 / 2005$ & $5 / 1 / 2005$ & Primeira Página & $\begin{array}{c}\text { Chuva causa alagamento e } \\
\text { transtorno no trânsito }\end{array}$ \\
\hline $16 / 3 / 2005$ & $17 / 3 / 2005$ & Site PMSC & $\begin{array}{c}\text { Chuvas provocam pontos de } \\
\text { alagamento }\end{array}$ \\
\hline
\end{tabular}

\subsection{ANÁLISE DOS DADOS CONTIDOS NAS NOTÍCIAS DE JORNAL}

Todas as notícias encontradas foram analisadas. A análise das notícias está sistematizada em Tabelas nos Anexos 05, 06, 07 e 08, sendo que a análise das notícias referentes a um evento específico de inundação ou alagamento na Bacia do Gregório se encontra no Anexo 05.

Observou-se que freqüentemente as notícias de jornal informam a data da chuva que ocasionou o evento na bacia de estudo. A obtenção da data da chuva se deu em alguns casos pela indicação explícita no texto, e em outros casos pela dedução a partir de informações indiretas. Um exemplo de dedução por informação indireta é ocorreu com a notícia publicada pelo jornal $A$ Cidade, em 13/01/1960, em que o título da notícia já sugere a data da chuva: "Causaram prejuízos as chuvas de ontem". Das 64 (sessenta e quatro) notícias classificadas como relativas a um evento específico de inundação ou alagamento na Bacia do Gregório, foi encontrada indicação das datas da chuva em 56 (cinqüenta e seis) delas. Ou seja, foi possível obter a data da chuva foi obtida para $87,5 \%$ dos casos.

Foi realizada uma análise qualitativa, por meio da descrição dos danos causados por cada um dos eventos na bacia (Anexos 05). Das 64 (sessenta e quatro) notícias classificadas como relativas a um evento específico de inundação ou alagamento na Bacia do Gregório, foi encontrada referência aos danos causados em 47 (quarenta e sete) delas. Ou seja, foi possível obter descrição dos danos causados para $73,4 \%$ dos casos.

Nota-se que os danos causados são os principais aspectos abordados pelas notícias de jornal. A seguir, destacamos três exemplos de notícias que demonstram alguns dos principais impactos ocorridos historicamente na região do Mercado Municipal. As Figuras 5.26, 5.27 e 5.28 descrevem, respectivamente, os danos causados por eventos em 1947, 1974 e 1998. As demais fotos de notícias podem ser consultadas nos Anexos 01 a 04. 


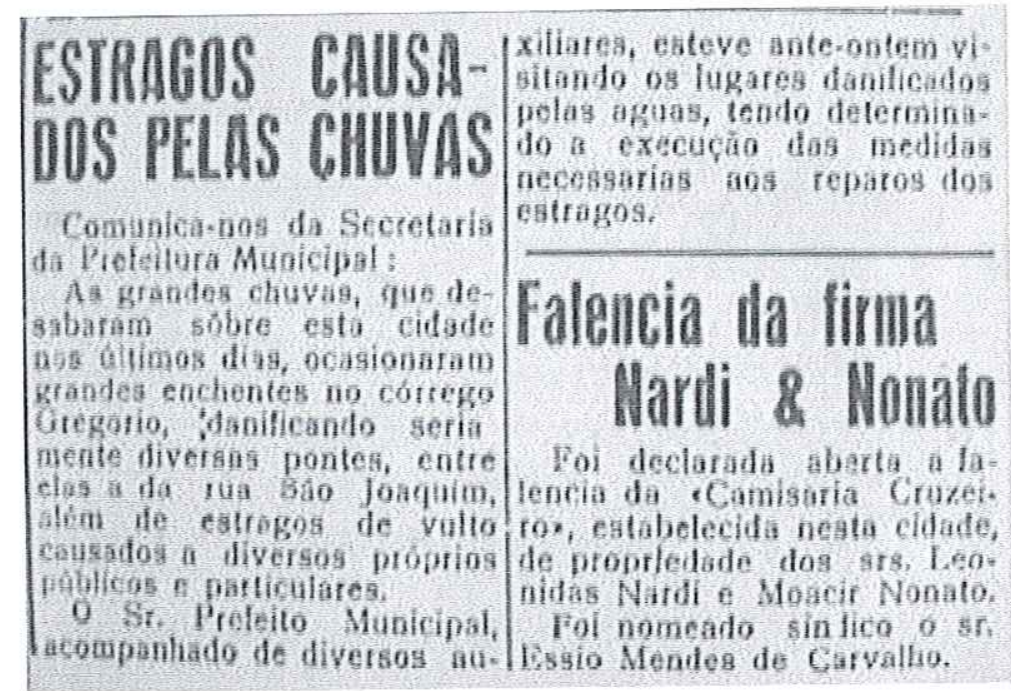

Figura 5.26 - Detalhe de notícia sobre danos causados por evento em 1947. Fonte: adaptado de ESTRAGOS...1947

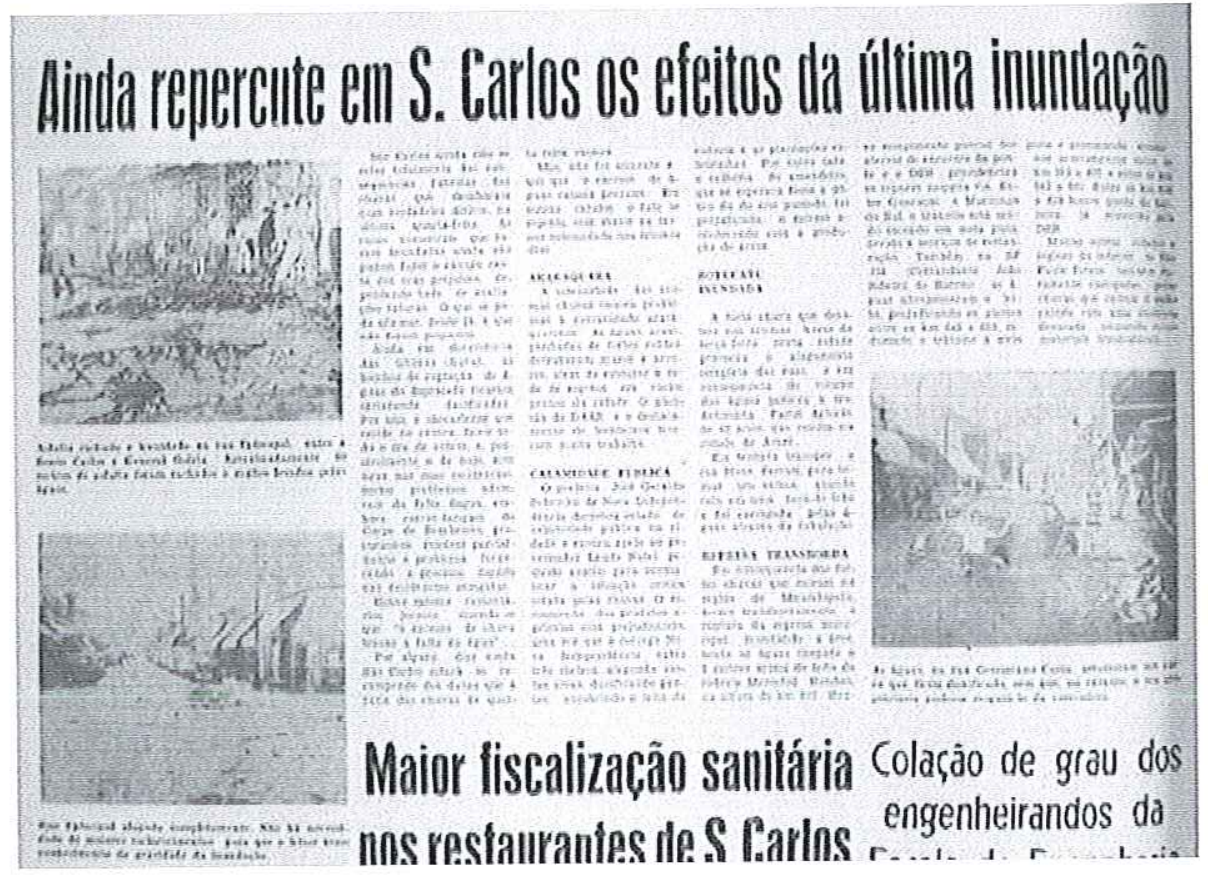

Figura 5.27 - Detalhe de notícia sobre danos causados por evento em 1974. Fonte: adaptado de AINDA...1974 


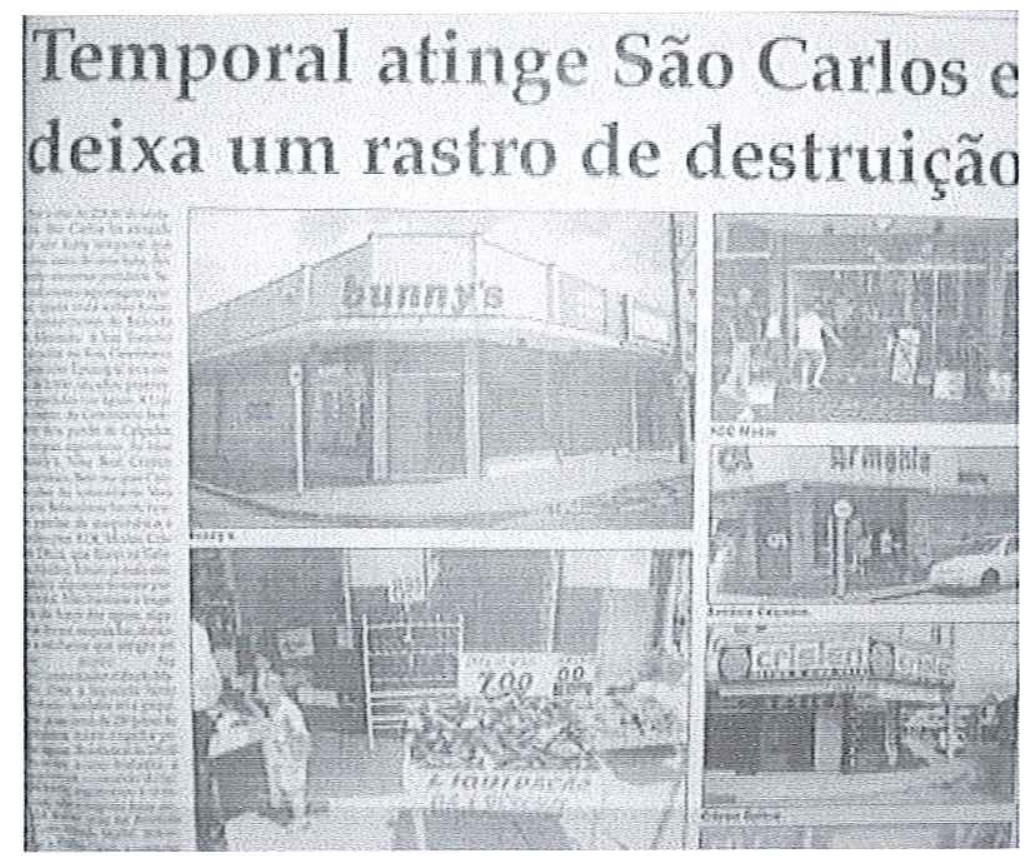

Figura 5.28 - Detalhe de notícia sobre danos causados por evento em 1998. Fonte: adaptado de TEMPORAL...1998

No processo de análise das notícias de jornal, observou-se que freqüentemente não há informações sobre tempo de permanência da inundação ou alagamento e duração da chuva. Com os dados encontrados sobre esses aspectos, foram elaborados dois gráficos (Anexo 09) que estão sujeitos à complementação de dados, uma vez que a disponibilidade dos dados é pouco frequente. Além disso, quando disponível, os dados sobre duração da chuva e tempo de permanência são muitas vezes imprecisos. Um exemplo é o dado da notícia publicada pelo jornal $A$ Folha, em 09/01/1965, que indica que a duração da chuva foi "A chuva começou de tarde, e foi até de manhã do dia seguinte" (Anexo 05). Com essa informação é possível estimar a duração da chuva somente de modo muito aproximado. Nesse caso, a duração da chuva foi admitida como de 06 (seis) horas. Em função da pouca precisão desses dados, os gráficos foram apresentados no Anexo 09, com a indicação de que a complementação dos dados é necessária.

\subsubsection{Níveis Máximos atingidos}

A partir das análises das notícias classificadas como referentes a um evento específico de inundação ou alagamento na Bacia do Gregório obteve-se a evolução histórica dos níveis máximos atingidos, que foram classificados em 4 (quatro) categorias (Figura 5.29). Das 64 (sessenta e quatro) notícias classificadas como relativas a um evento específico de inundação ou alagamento na Bacia do 
Gregório, foi encontrada indicação do nível máximo atingido para 16 (dezesseis) delas. Portanto, foi possível obter a data da chuva foi obtida para $25,0 \%$ dos casos.

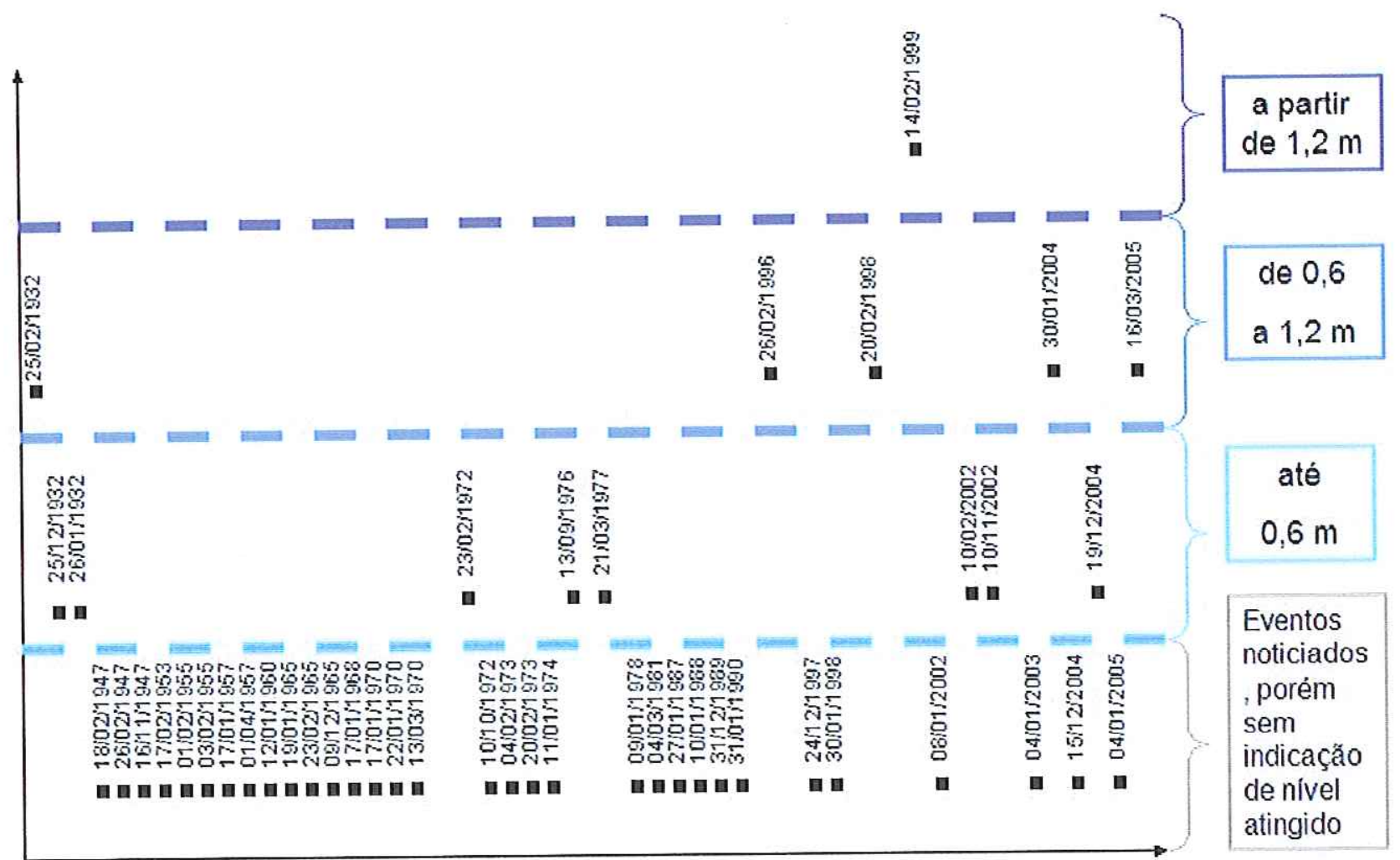

Figura 5.29 - Níveis máximos atingidos por eventos históricos com base em informações de notícias de jornal.

A Figura 5.29 demonstra que os níveis máximos atingidos foram maiores em eventos mais recentes do que nos eventos ocorridos nos primórdios da urbanização da bacia, o que indica que a urbanização teve influência no aumento dos níveis máximos atingidos e, portanto, na geração de maiores riscos de danos à população.

\subsection{TEMPO DE RETORNO MÉDIO DE RECORRÊNCIA DE EVENTOS}

A Figura 5.30 indica que as ocorrências variaram de 1 (um) a 3 (três) eventos nos anos em que foram encontrados registros de inundações ou alagamentos (1947, 1953, 1955, 1957, 1960, 1965, 1968, 1970, 1972, 1973, 1974, 1976, 1977, 1978, 1981, 1987, 1988, 1989, 1990, 1996, 2002, 2003, 2004). Nota-se que foram encontrados (três) registros de eventos já em 1947, quando a urbanização da bacia ainda era pouco representativa (Figura 5.8), o que reforça a suscetibilidade da área à ocorrência de inundações e alagamentos, característica que não foi considerada na ocupação urbana da bacia. 


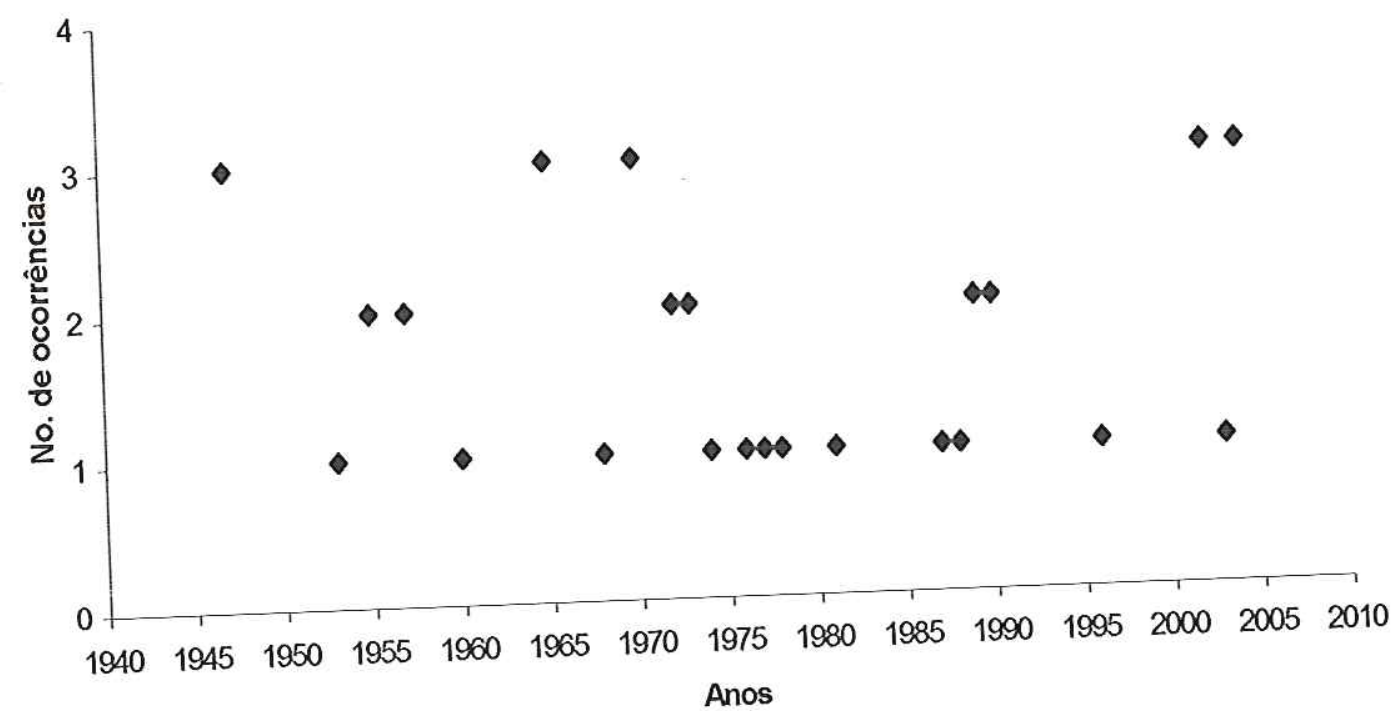

Figura 5.30 - Número de ocorrências nos anos em que foram encontrados registros de eventos entre $1940 \mathrm{e}$

Com base nos dados históricos de ocorrência de eventos entre 1940 e 2004, estimou-se que o tempo de retorno médio de ocorrência de eventos de inundação ou alagamento na Bacia do Gregório é de 0,65 eventos / ano com desvio padrão de 0,84. As notícias encontradas para os anos de 1932 e 2005 não foram consideradas nesse cálculo, pois são complementares ao período da pesquisa.

\subsection{RELAÇÕES ENTRE URBANIZAÇÃO E OCORRÊNCIA DE INUNDAÇÕES E ALAGAMENTOS}

A Figura 5.31 apresenta a relação entre ocorrência de eventos e evolução da população urbana de São Carlos (IBGE). A análise é realizada considerando os estágios de urbanização da bacia (Figura 5.12), indicados também na Figura 5.31. 


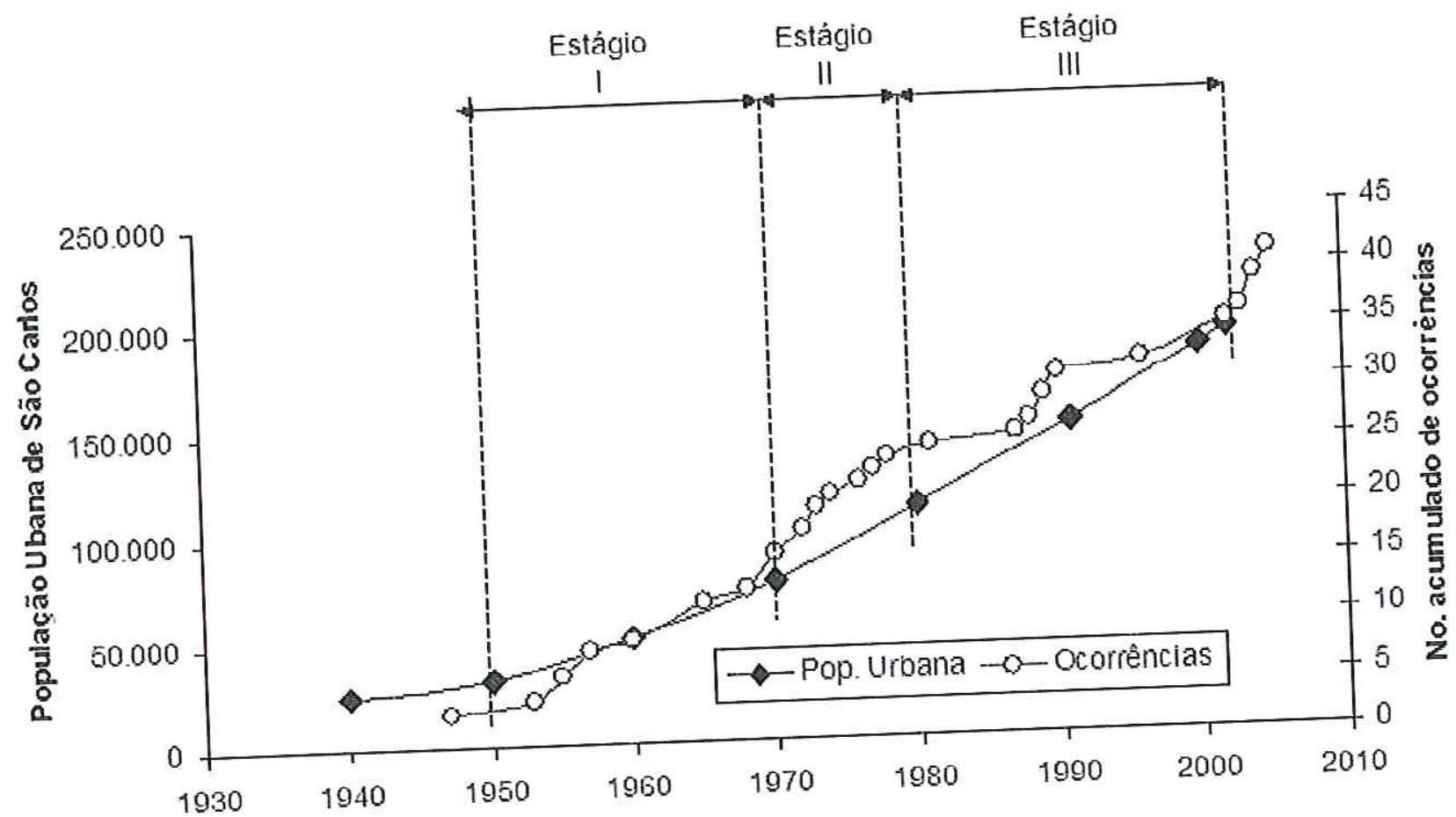

Figura 5.31 - Evolução da População Urbana de São Carlos e do Número Acumulado de Inundações na Bacia do Gregório

A análise da Figura 5.30 demonstra que foi no início do Estágio II, em 1970, que o número acumulado de ocorrências passou a aumentar mais representativamente do que a população urbana. Destacase que a maior dissociação entre aumento populacional e número acumulado de ocorrências foi verificada no Estágio II.. Tal fato já indica que esse foi um período bastante marcante na história da ocorrência de inundações e alagamentos na bacia, constatação que será reforçada com as demais análises, desenvolvidas a seguir.

Os dados obtidos sobre ocorrência de eventos entre 1940 e 2004 foram também relacionados ao histórico de urbanização da bacia (Figura 5.12). Os resultados indicam que o número acumulado de ocorrências aumentou com a urbanização da bacia (Figura 5.32), sendo que ocorreram processos diferentes em cada um dos estágios. 


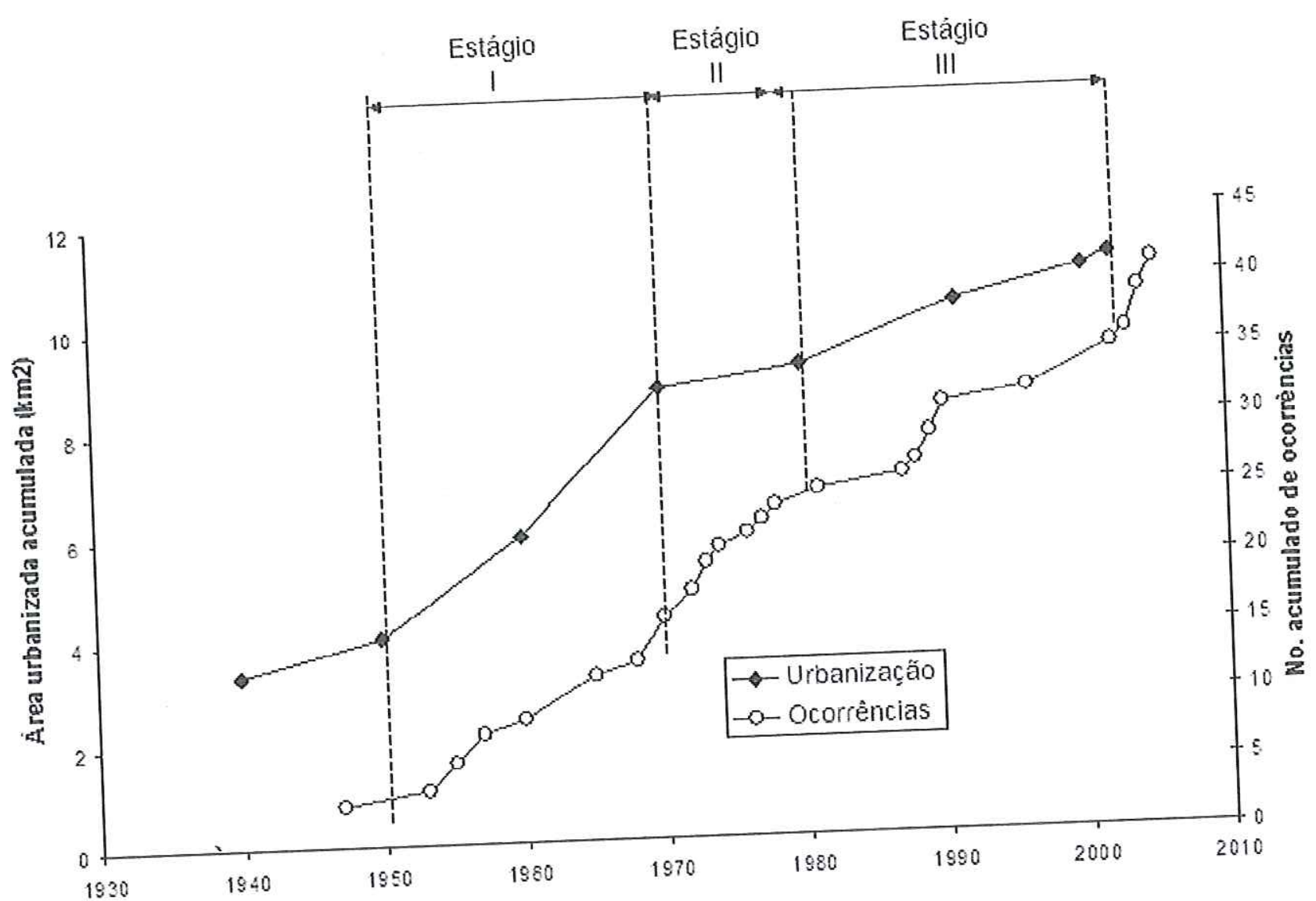

Figura 5.32 - Relação entre Área Urbanizada Acumulada e Número Acumulado de Ocorrências de inundações e alagamentos, com indicação de estágios de desenvolvimento urbano da bacia.

As áreas urbanizadas acumuladas e o número acumulado de ocorrências aumentaram de maneira semelhante durante o Estágio I. Nos Estágio II e III nota-se uma tendência de aproximação da extremidade das duas curvas, ou seja, o número de ocorrências acumulado continua aumentando, enquanto a urbanização já não aumenta com a mesma velocidade. Destaca-se particularmente o Estágio II, em que as duas curvas indicam processos bastante diferentes, ou seja, o número acumulado de ocorrências continuou aumentando, embora a urbanização não tenha sido tão intensa nesse período.

A Figura 5.33 compara três aspectos de cada um dos estágios de urbanização da bacia:

- Evolução da Taxa de urbanização (km2 / ano, Figura 5.11);

- Número acumulado de ocorrências;

- Média de ocorrência dos períodos (no. de ocorrências / ano); 


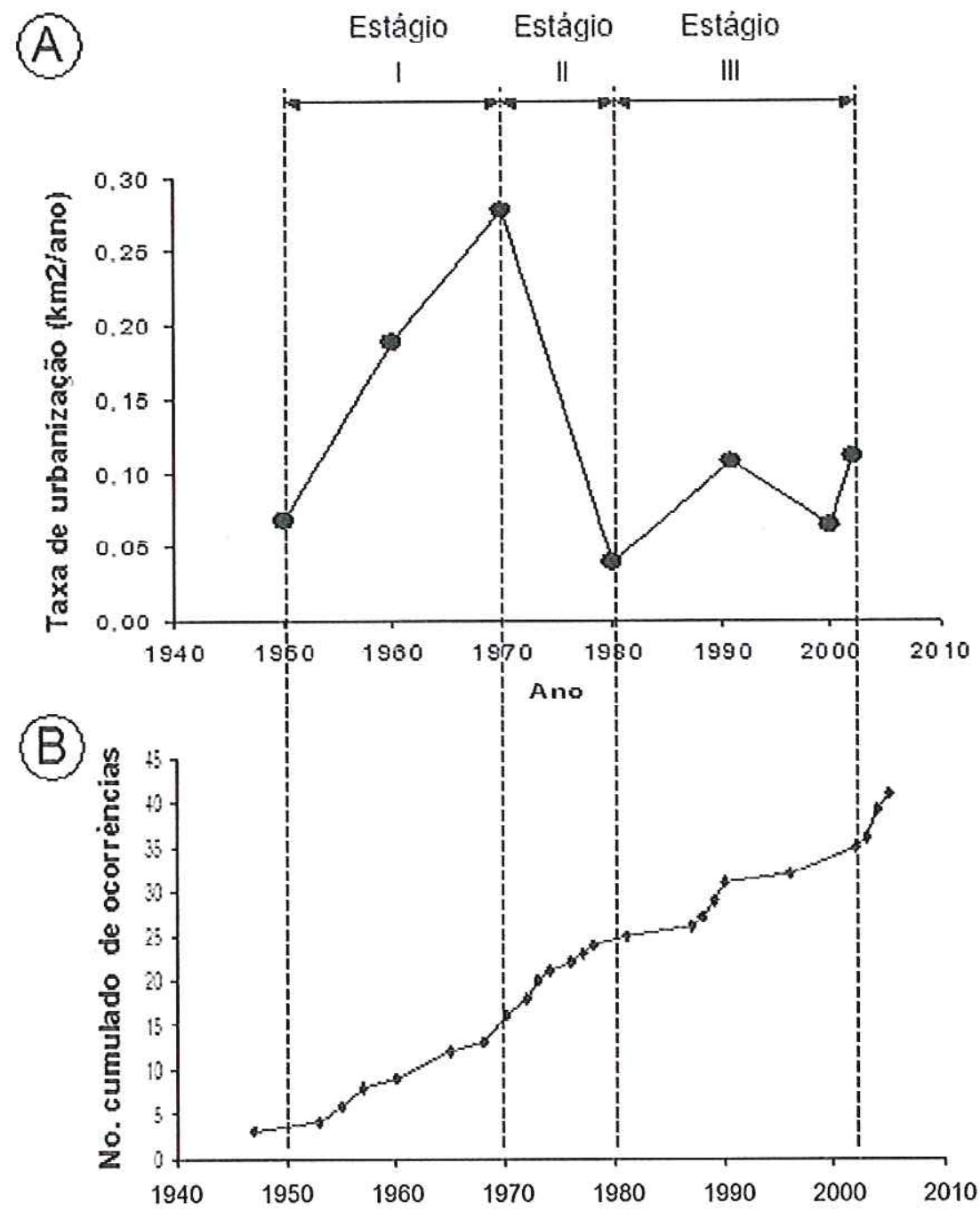

(C)

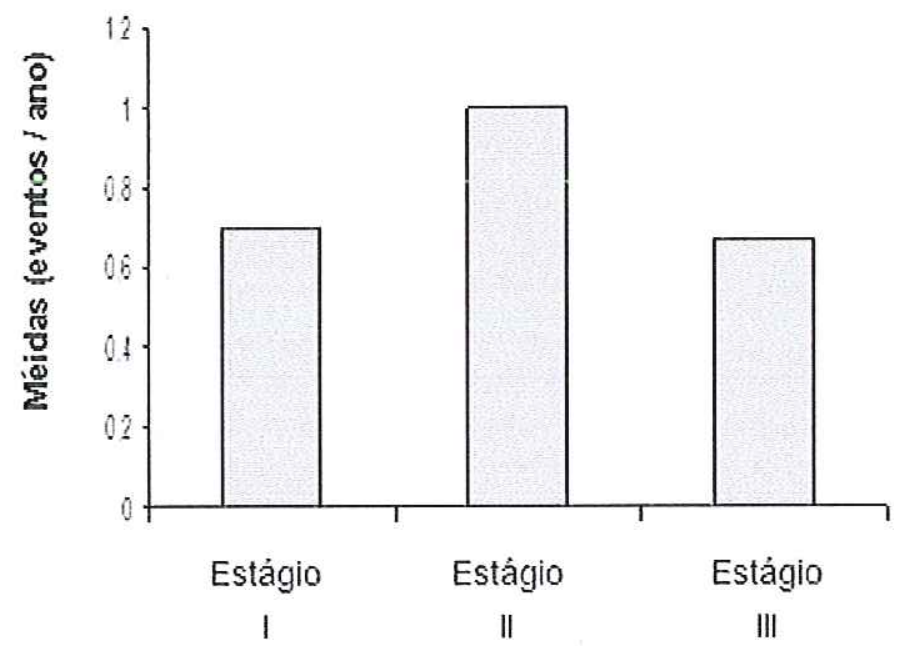

Figura 5.33 - Comparação entre 1) Evolução da Taxa de Urbanização (km2 / ano), 2) Número de Eventos ocorridos classificados por anos, e 3) Média de ocorrência dos períodos (no. de ocorrências / ano) para cada um dos estágios de urbanização da Bacia do Gregório. 


\section{Estágio I:}

No Estágio I verificou-se o maior acréscimo da taxa de urbanização, ou seja, foi nesse período em que ocorreu a ocupação urbana mais representativa da bacia. Como conseqüência, nota-se também um aumento no número acumulado de eventos.

\section{Estágio II:}

Analisando o Gráfico B da Figura 5.32, observa-se um aumento do número acumulado de ocorrência dos eventos no Estágio II. Tal aumento se refletiu na média de eventos por ano, indicada no Gráfico C como a maior entre os três estágios. Porém, o Gráfico A demonstra que taxa de urbanização sofreu decréscimo considerável nesse período, ou seja, o Estágio II foi o que apresentou maior ocorrência de eventos, porém, foi nele em que a urbanização sofreu a maior desaceleração entre 1940 e 2004. Tal fato indica que os impactos de inundações e alagamentos entre 1970 e 1980 foram conseqüência, em grande parte, da urbanização intensa ocorrida no estágio anterior.

As obras de canalização do córrego do Gregório foram realizadas no Estágio II, provavelmente em função dos crescentes impactos de eventos ocorridos na bacia.

\section{Estágio III:}

O Gráfico C demonstra que ocorreu redução da média (eventos/ano) no Estágio III, para valor semelhante ao apresentado no Estágio I, em que a urbanização ainda não era tão consolidada. Tal fato pode ser explicado por dois aspectos do estágio anterior (estágio II, de 1970 a 1980):

a) Implementação de medidas mitigadoras dos impactos de inundações na bacia

Foi na década de 1970 que se deu a retificação mais significativa do Córrego do Gregório, o que aumentou a velocidade de escoamento das águas pluviais, contribuindo para a diminuição da média de ocorrências para o período seguinte. Nesse período, nota-se na bacia a aplicação dos conceitos vinculados ao conceito higienista (Canholi, 2005 e Silveira, 1998).

b) Desaceleração da urbanização

O Estágio II apresentou um decréscimo na taxa de urbanização, o que indica que a impermeabilização da bacia nesse período foi menos determinante na geração de impactos no escoamento do que a ocorrida nos demais períodos.

Embora a Figura 5.32 indique que a média de ocorrência do período III (de 1980 a 2002) foi próxima à do Estágio I, é importante atentar para o fato de que a população atualmente está mais 
sujeita aos impactos das inundações e alagamentos atualmente do que nos primórdios da urbanização dos fundos de vale, pois a ocupação das áreas de várzeas é mais consolidada atualmente. Além disso, a análise das notícias encontradas indica que os níveis máximos atingidos pelos eventos mais recentes são maiores do que os atingidos em eventos ocorridos nos primórdios da urbanização da bacia (Figura 5.28), o que aumenta o risco de danos à população.

\subsection{AVALIAÇÃO HISTÓRICA DOS TIPOS DE MEDIDAS MITIGADORAS APLICADAS NA BACIA DO GREGÓRIO}

Princípios paisagísticos vinculados à criação de espaços de lazer nos fundos de vale tiveram alguma expressão na bacia de estudo somente na década de 1930 (anteriormente aos Estágios I, II e III), com a implantação do eixo das três praças próximo ao curso do Córrego do Gregório (Figura 5.17). Essas intervenções se classificam, portanto, na fase 02 do diagrama apresentado por Canholi (2005) (Figura 5.34). Após esse período, tais intenções foram colocadas em segundo plano, e o objetivo principal passou a ser unicamente a mitigação dos impactos de inundação. Assim, nos Estágios II e II, nos quais foram implementadas as medidas mitigadoras, as intervenções se deram dissociadas de objetivos paisagísticos, sendo, portanto, classificadas na fase 01 do diagrama apresentado na Figura 5.34.

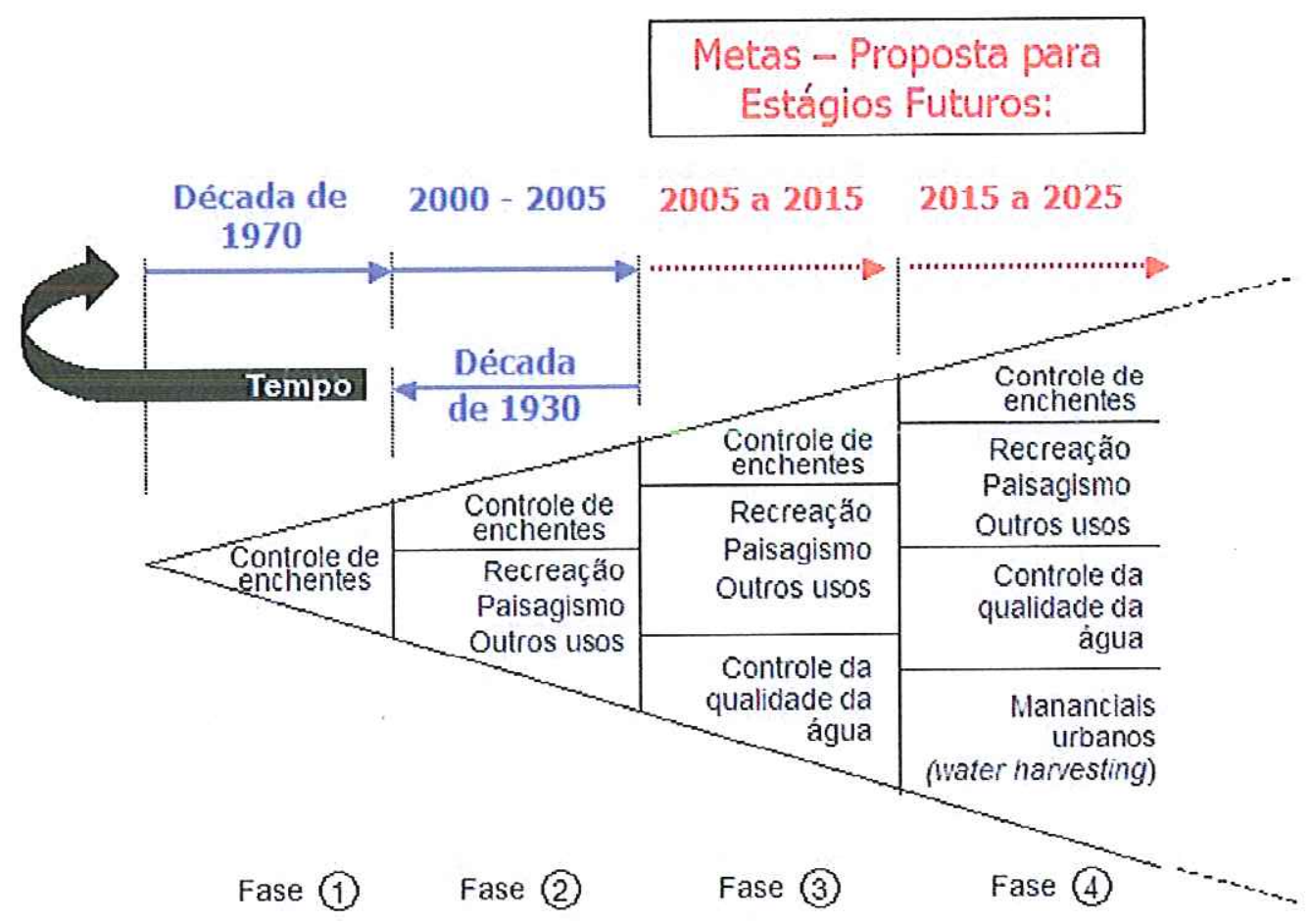

Figura 5.34 - Interpretação para a Bacia do Gregório de diagrama de evolução histórica de objetivos das intervenções relacionadas à drenagem urbana. Fonte: adaptado de Walesh (1989) apud Canholi (2005) 
As medidas empregadas até o ano 2000 na Bacia do Gregório se classificaram, em sua maioria, na fase 01 do diagrama apresentado na Figura 5.34. Mais recentemente, de 2000 a 2005, verifica-se aplicação de medidas vinculadas à fase 2. São indicadas propostas de metas a serem cumpridas em estágios futuros, com a implementação de medidas relacionadas à fase 3, aproximadamente entre 2005 e 2015, e à fase 4, aproximadamente entre 2015 e 2025.

Historicamente, as intervenções relacionadas à drenagem urbana da bacia de estudo foram, em sua maioria, medidas estruturais intensivas, com objetivo único de diminuir os impactos das inundações. A abordagem histórica indica que a aplicação de medidas mitigadoras dos impactos de inundações e alagamentos na Bacia do Gregório foi norteada prioritariamente pelo conceito higienista, principalmente na década de 1970, tendo elevados picos de cheia como conseqüência (Figura 5.35).

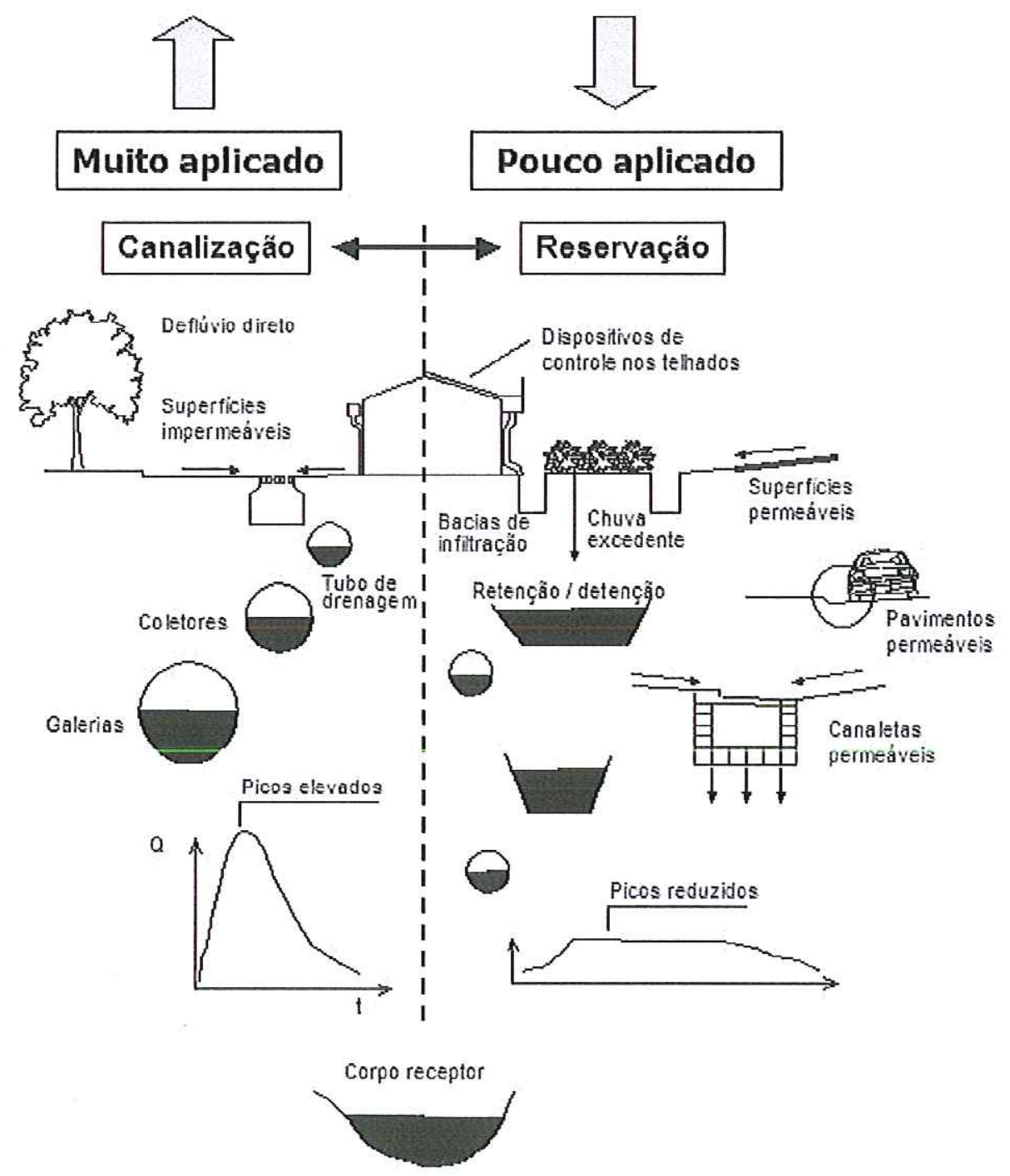

Figura 5.35 - Avaliação da aplicação de conceitos de Canalização e de Reservação na Bacia do Gregório. Fonte: adaptado de Canholi (2005) 
A análise histórica indica também que as medidas mitigadoras aplicadas na bacia foram prioritariamente estruturais. As medidas não estruturais não tiveram aplicação na bacia de estudo ao longo do seu processo de urbanização. Nesse sentido, destaca-se a necessidade de reflexão sobre a possibilidade de aplicação de tais medidas, de modo a complementar as medidas estruturais já adotadas.

Mais recentemente, de 2000 a 2005, nota-se na bacia a aplicação de algumas obras nos fundos de vale que associam as medidas mitigadoras dos impactos de inundações e alagamentos a questões paisagísticas. A visão integrada das questões urbanas que orienta tais intervenções faz com que essas se classifiquem na fase 02 do diagrama apresentado na Figura 5.33.

Um dos exemplos é a intervenção realizada em 2003 próximo ao Mercado Municipal de São Carlos, com o alargamento do vão da ponte da R. Episcopal (Figura 3.13), que dificultava o escoamento das águas pluviais, associado a medidas de relocação de comércio informal, intervenção no sistema viário e extensão de passeio de pedestres (Figura 5.36).

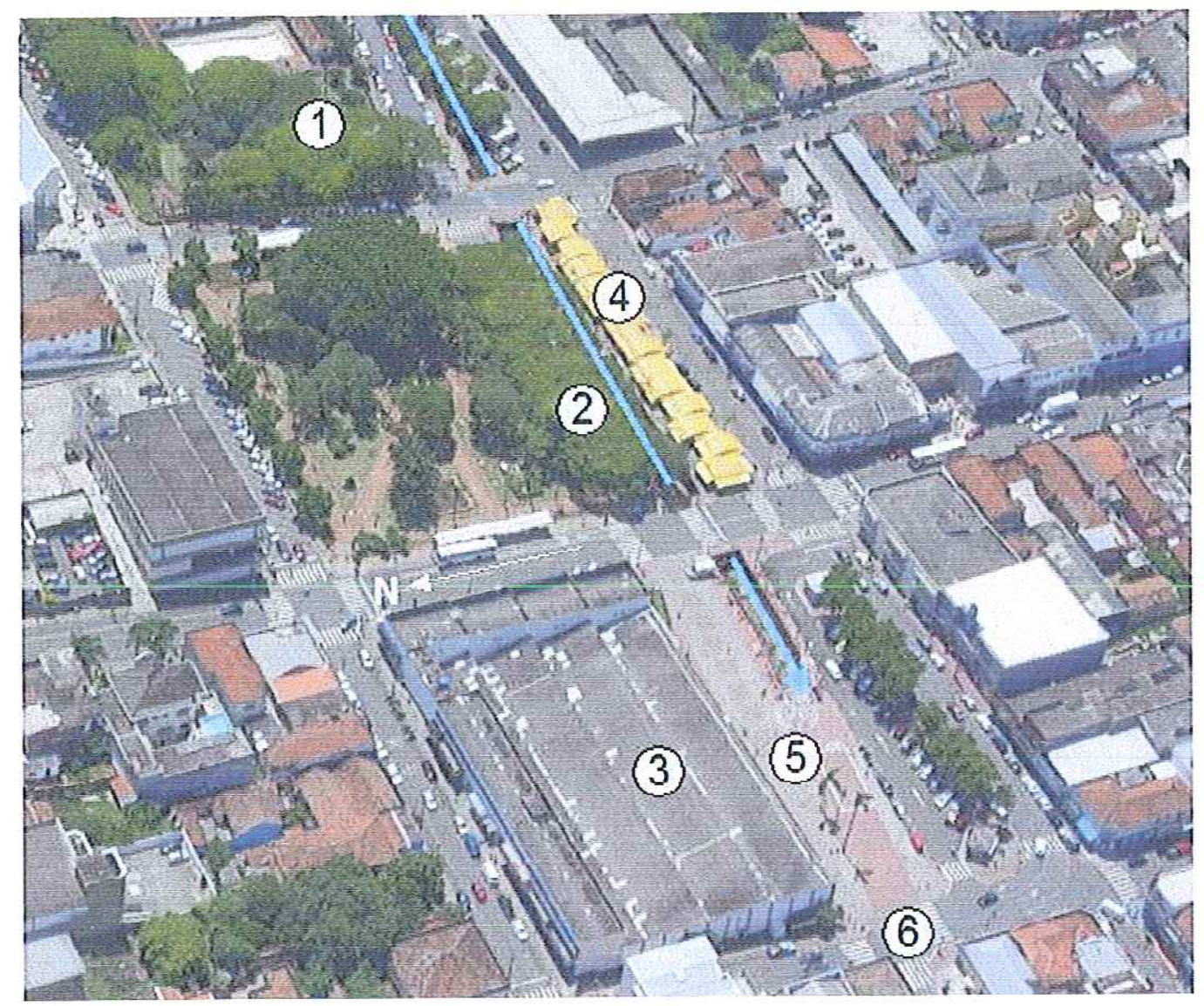

Figura 5.36 - Requalificação de área central próxima ao Mercado Municipal, realizada em 2003. 1) Piscina Municipal, 2) Praça dos Voluntários, 3) Mercado Municipal, 4) Área destinada ao comércio informal, 5) Passeio de pedestres, 6) Ponte da Rua Episcopal. Fonte: adaptado de ANELLI (2005) 
Ainda em São Carlos, porém na Bacia do Tijuco Preto, localizada próximo à Bacia do Gregório, destaca-se o exemplo de projetos de requalificação ambiental e urbana de trecho do córrego próximo à nascente, com a intenção de constituição de espaço de lazer no fundo de vale (Figuras 5.37, 5.38 e 5.39$)$.

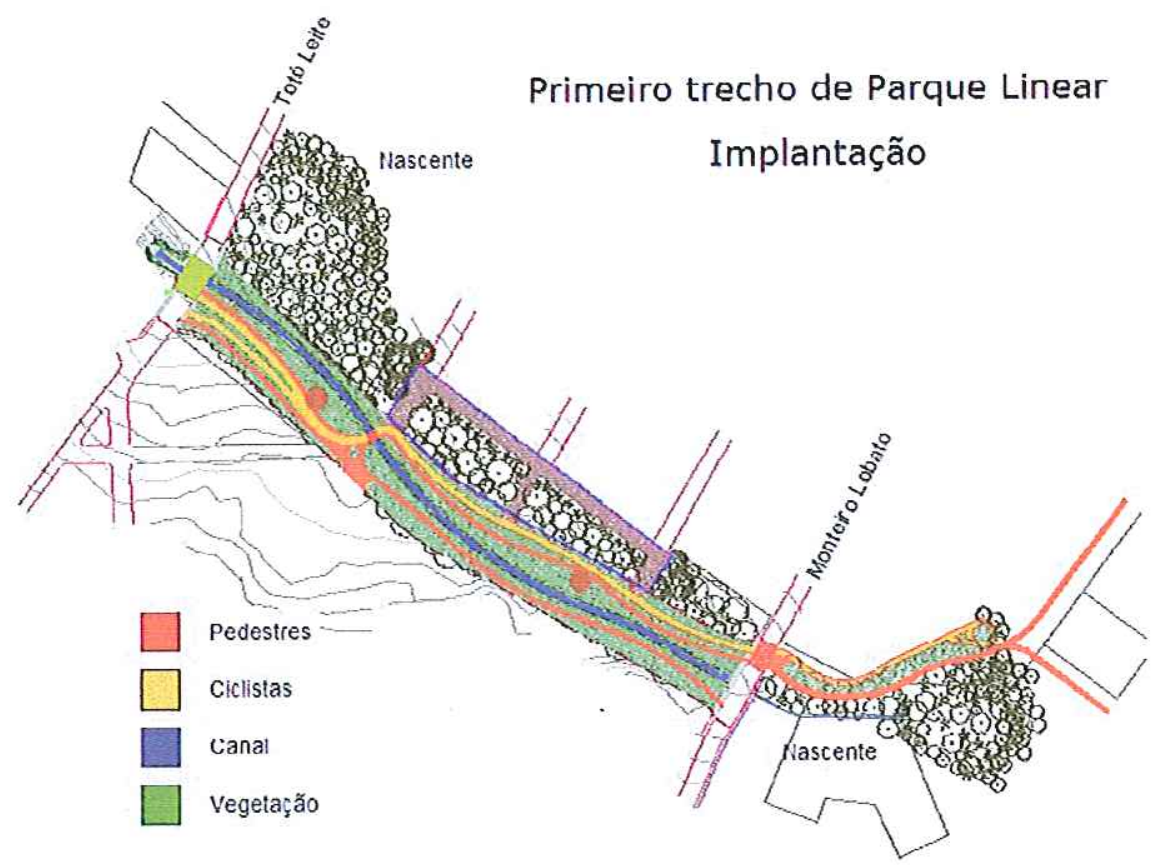

Figura 5.37 - Projeto de recuperação ambiental e urbana para trecho do Córrego Tijuco Preto. Autores: Teia Casa de Criação e Silva Leme Engenharia Ltda. Fonte: ANELLI (2005)

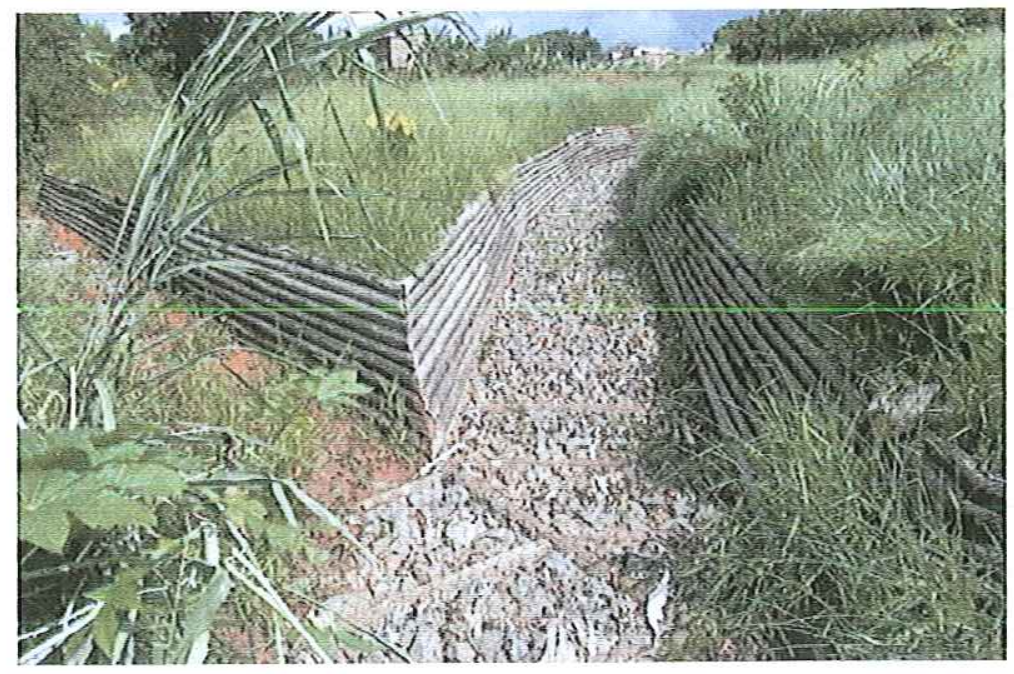

Figura 5.38 - Foto de catálogo representando o aspecto final da requalificação Fonte: ANELLI (2005) 


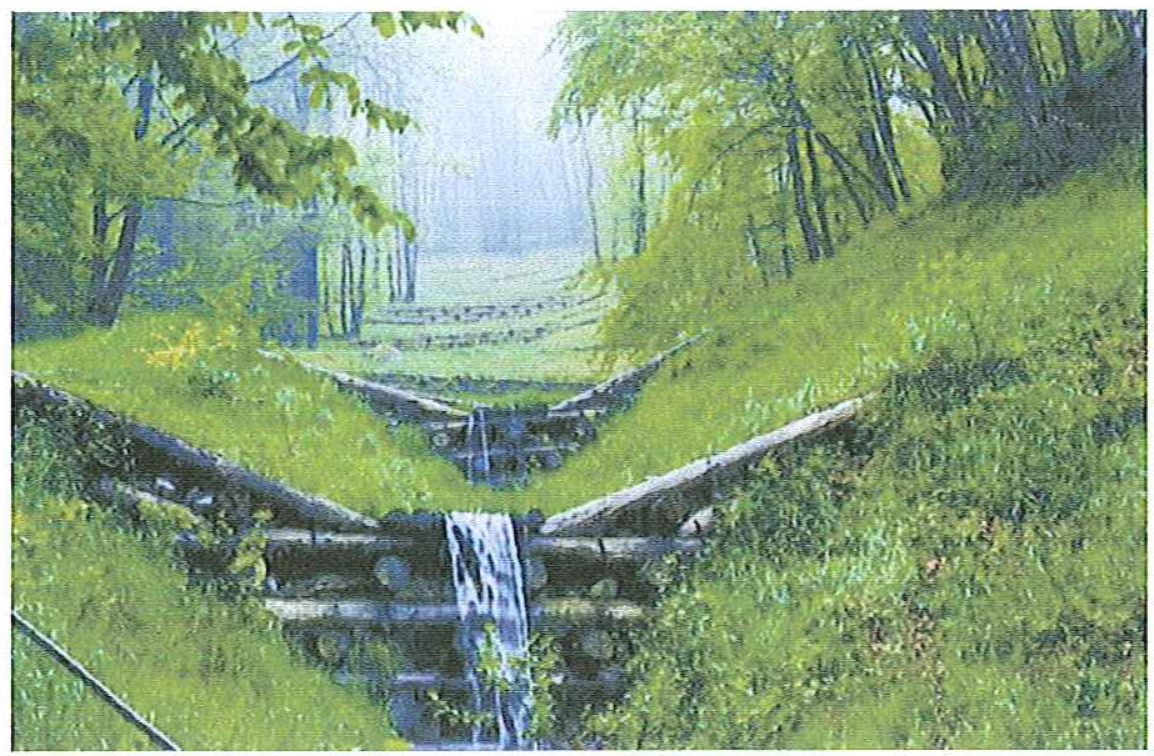

Figura 5.39 - Foto de catálogo representando aspecto final dos degraus de dissipação. Fonte: ANELLI (2005)

Nota-se, portanto, a existência de algumas intervenções mais recentes nos fundos de vale com intenção de promover não só a mitigação dos impactos de inundações e alagamentos, mas também de criar espaços de lazer e de recreação nos fundos de vale. Tais intervenções já indicam o início do surgimento de uma nova abordagem do gerenciamento da drenagem urbana nas intervenções nos córregos, buscando promover a recuperação ambiental das bacias hidrográficas. Com essas intervenções, identifica-se a intenção de propor soluções viáveis de recuperação ambiental para as situações já consolidadas, considerando a urbanização já existente nas áreas de margens e a alteração do traçado dos córregos.

Além disso, o Plano Diretor de São Carlos (PMSC, 2004), aprovado em 2005 pela Câmara Municipal, propõe a implementação de Áreas Especiais de Interesse Ambiental em fundos de vale de córregos urbanos, o que também índica uma primeira intenção de revalorização dessas áreas pela implementação de medidas não estruturais. 


\section{CONCLUSÕES}

A análise das notícias indicou que os dados sobre duração dos eventos e tempo de permanência das inundações ou alagamentos não costumam ser abordados com freqüência nos jornais, ou são abordados de maneira pouco precisa. Os dados sobre níveis máximos atingidos foram abordados com frequiência maior nas notícias. Ainda assim, foi possível obter indicação de níveis máximos atingidos somente em $25 \%$ das notícias analisadas. Esses fatos reforçam a necessidade de manutenção de monitoramento hidrológico da bacia para obtenção de tais dados.

Os impactos ocasionados por inundações na região do Mercado Municipal foram agravados pela ocupação urbana na Bacia do Gregório e pela falta de ordenamento territorial nas áreas ribeirinhas. Os registros históricos indicam que a região já se apresentava como área sujeita ‘à inundações desde os primórdios da expansão urbana de São Carlos, na década de 1930. No entanto, as taxas de ocupação urbana e a ocupação de várzeas mostram um processo de expansão que não considerou tal suscetibilidade da área.

A avaliação da urbanização da bacia entre 1940 e 2004 demonstra que a evolução ocorrida entre 1950 e 1970 foi responsável em grande parte pelos impactos de inundações, já que a partir de 1970 o aumento no número acumulado de ocorrências foi se acentuando, mesmo com a diminuição da taxa de urbanização verificada a partir de 1970.

A regulação insuficiente nos últimos 60 anos possibilitou a ocupação intensa das áreas de várzea, principalmente pela implantação de avenidas marginais e aumento indiscriminado da impermeabilização do solo. Na década de 1970 (Estágio II), os impactos das inundações ganharam maior representatividade, como decorrência da intensa urbanização ocorrida no período anterior, entre 1950 e 1970. Buscando mitigar os impactos ocasionados pelo intenso escoamento superficial gerado pela urbanização da bacia, foram realizadas sucessivas canalizações do Córrego do Gregório, sendo as mais representativas realizadas na década de 1970.

A recuperação do histórico da bacia demonstra que as medidas mitigadoras dos impactos de inundações aplicadas se caracterizaram predominantemente pela aplicação do conceito higienista, por meio da implementação de medidas estruturais intensivas, de caráter pontual e paliativo. Os conceitos de reservação e de prevenção, assim como a aplicação de medidas não estruturais, não tiveram expressão no histórico do gerenciamento das águas urbanas da bacia. As medidas aplicadas foram 
localizadas exclusivamente nos fundos de vale, não considerando a área da bacia como um todo como espaço de atuação para mitigação dos impactos de inundações e alagamentos. As medidas aplicadas na escala do lote, por exemplo, não tiveram nenhuma aplicação no histórico de implementação de medidas mitigadoras na bacia, o que gera uma falta de tradição que pode dificultar as primeiras abordagens sobre o tema. Tal aspecto deve ser considerado no desenvolvimento de propostas futuras.

Algumas intervenções paisagísticas visando à criação de áreas de lazer nos fundos de vale tiveram representação na bacia somente nos primórdios de sua urbanização, na década de 1930, e mais recentemente, a partir de 2000. A maior parte das intervenções nos fundos de vale de São Carlos teve como objetivo exclusivamente mitigar os impactos de inundações e alagamentos, por meio de canalizações, e resolver possíveis problemas de mobilidade urbana, com a construção de avenidas marginais aos córregos.

$\mathrm{O}$ fato de que intervenções recentes tenham sido guiadas por intenções paisagísticas indica o fortalecimento de uma nova abordagem da drenagem que deve ser progressivamente incorporada na gestão urbana. Tal abordagem se caracteriza pela associação da drenagem a demais questões urbanas, tais como criação de espaços públicos de lazer, implementação de infra-estrutura para mobilidade de pedestres e ciclistas, promoção de usos alternativos das infra-estruturas de drenagem em períodos de seca, entre outros. 


\section{RECOMENDAÇÕES}

A perspectiva histórica indica a necessidade de implementação de medidas mitigadoras complementares às já realizadas. É necessário promover a incorporação de uma nova abordagem da drenagem urbana nas tomadas de decisões para o planejamento futuro, baseada nas seguintes diretrizes gerais:

- Adoção de postura preventiva, e não somente paliativa em relação a impactos já existentes;

- Priorização de medidas que promovam a retenção das águas pluviais, e não somente o aumento da velocidade de escoamento de águas pluviais por meio da canalização dos córregos urbanos;

- Consideração do processo histórico no desenvolvimento de futuras obras de drenagem, adotando-se valores de tempo de retorno de inundações baseados em dados históricos para a elaboração dos projetos.

Recomenda-se a adoção de medidas não estruturais associadas a medidas estruturais na bacia. A seguir apresentam-se as recomendações baseadas em medidas não estruturais e em medidas estruturais, e também para o desenvolvimento de futuros estudos:

\section{Medidas não estruturais:}

- Aplicação do Zoneamento Ecológico-Econômico (ZEE), instrumento estabelecido pelo Decreto Federal 4297/2002, para urbanizações futuras;

- Impedimento de ocupação urbana em áreas de várzea para empreendimentos futuros, com base na Lei Federal 4771/65;

- Implantação de Sistema de Alerta Antecipado de Inundações, em especial em bacias experimentais com curtos tempos de concentração;

- Continuação da sistematização de monitoramentos hidrológicos na sub-bacia experimental do Gregório (a partir FINEP-CT-HIDRO, 2002) de modo a fornecer um banco de dados consistido para a CT-Águas Urbanas da ABRH;

- Elaboração de legislação complementar sobre as Áreas de Especial Interesse Ambiental em área urbana, estabelecidas pelo Plano Diretor de São Carlos, de modo a incentivar a utilização das áreas de fundo de vale como parques e espaços de lazer, promovendo um uso que garanta a não ocupação de áreas com risco de inundação e possibilite a manutenção das 
áreas verdes, garantindo a permeabilidade do solo e possibilitando melhor qualidade de vida à população;

- Avaliação das possibilidades de implementação de IPTU ecológico na bacia como um todo, de modo a incentivar a retenção de águas pluviais nos lotes.

\section{Medidas Estruturais}

- Implementação de medidas estruturais extensivas de retenção de águas pluviais na bacia, como trincheiras de infiltração e dispositivos de reuso de água na escala do lote domiciliar como uma das medidas mitigadoras dos impactos de inundações a jusante;

- Implementação de medidas estruturais intensivas de retenção de águas pluviais na bacia, associadas a espaços de lazer, como por exemplo implantação de reservatórios que, com manutenção eficiente, podem ser utilizados para práticas esportivas e de lazer em períodos de ausência de chuvas.

\section{Recomendações para futuros estudos:}

- Aplicação do método de utilização dos dados monitorados pelo SIGRH, disponíveis para todo o estado de São Paulo, para recuperação de histórico de inundações em demais cidades paulistas, já que os produtos desse trabalho podem subsidiar tomadas de decisão para o planejamento futuro;

- Realização de levantamento histórico complementar em futuros estudos, utilizando níveis de referência de Precipitações Diárias inferiores a $70 \mathrm{~mm}$, já que há indicação de eventos de inundação ocorridos na região do Mercado Municipal em datas em que a PDiária foi menor do que esse valor. 


\section{REFERÊNCIAS BIBLIOGRÁFICAS}

ALVES, Elisânia Magalhães. (2005) Medidas não estruturais na prevenção de enchentes em bacias urbanas: cenários para a Bacia do Gregório, São Carlos - SP. Dissertação (Mestrado em Ciências da Engenharia Ambiental) - Escola de Engenharia de São Carlos, Universidade de São Paulo, São Carlos. 2005.

AMADOR, Itamar Moraes. (1990) As Manifestações Sociais e Econômicas conjugadas com as condições físico-ambientais determinam a paisagem urbana: Estudo de Caso São Carlos - SP. Dissertação (Mestrado em Arquitetura e Urbanismo) - Escola de Engenharia de São Carlos, Universidade de São Paulo, São Carlos. 1990.

AINDA repercutem em São Carlos os efeitos da última inundação. (1947). A Folha, São Carlos, 25 fev 1972.

Andrade, Juliana Pontes Machado de; OLIVETE JÚNIOR, Celso; MENDIONDO, Eduardo Mario. Calibração de modelo de previsão hidrometeorológica voltado para sistema de alerta antecipado contra enchentes. In: SIMPÓSIO BRASILEIRO DE RECURSOS HÍDRICOS, 16. , 1993, João Pessoa-PB. Anais. João Pessoa: ABRH.

ANELLI, Renato Luis Sobral. (2005) Projetos desenvolvidos na Prefeitura Municipal de São Carlos na gestão de 2001 a 2004: apresentação no curso de Arquitetura e Urbanismo da EESCUSP. Acervo pessoal do autor.

ANTÔNIO, Maurício de Agostinho. (1993). Enchentes em Bauru - SP: efeito da urbanização. In: SIMPÓSIO BRASILEIRO DE RECURSOS HÍDRICOS, 10. , 1993, Gramado-RS. Anais. Porto Alegre: ABRH, v. 2, p. 99-108.

BALA, Marco. (2005). Águas do nicho urbano de São Carlos: uma inundação nilesca. Primeira Página, São Carlos, 09 set. 2005. Opinião, Caderno A, p. 2.

BAPTISTA, Márcio; NASCIMENTO, Nilo O.; RAMOS, Maria Helena D.; CHAMPS, José Roberto B. (1998) Aspectos de Evolução da Urbanização e dos Problemas de Inundações em Belo Horizonte. In: BRAGA, B.; Tucci, C.; Tozzi, M. (Org.) (1998). Drcnagem urbana: gerenciamento, simulação, controle. Porto Alegre: Ed. UFRGS/ABRH.

BARBASSA, Admir Pacelli. (1991) Simulação do efeito da urbanização sobre a drenagem pluvial na cidade de São Carlos - SP. 327p. Tese (Doutorado em Hidráulica e Saneamento) - Escola de Engenharia de São Carlos, Universidade de São Paulo, São Carlos. 1991.

BARROS, REGINA MAMBELI (2005) Previsão de enchentes para o Plano Diretor de Drenagem Urbana de São Carlos (PDDUSC) na Bacia Escola do Córrego do Gregório. 279 p. Tese (Doutorado em Hidráulica e Saneamento) - Escola de Engenharia de São Carlos, Universidade de São Paulo, São Carlos. 2005.

BENINI, Rubens de Miranda. (2005). Cenários de ocupação urbana e seus impactos no ciclo 
hidrológico na bacia do córrego do Mineirinho. Dissertação (Mestrado em Ciências da Engenharia Ambiental) - Escola de Engenharia de São Carlos - Universidade de São Paulo, 2005.

BERTONI, J. C.: TUCCI, C. E. M. (2002) Precipitação. In: TUCCI, C. E. M. (Org.) (2002). Hidrologia: ciência e aplicação. Porto Alegre: Ed. UFRGS/ABRH.

BERZ, Gerhard. (2000). Flood Disasters: Lessons from the Past - Worries for the Future. In: SYMPOSIUM ON RIVER FLOOD DEFENCE, 2000, Kassel. Anais. Kassel: Herkules Verlag, v. 2, p. F1-F10

BISINOTTO, Dagmar Abadia (1988). Evolução urbana de São Carlos. Relatório (Iniciação Cientifica) - Escola de Engenharia de São Carlos - Universidade de São Paulo, São Carlos. 1988. Departamento de Arquitetura e Urbanismo.

BOLDRIN, Rodrigo Süzes. (2005). Avaliação de Cenários de Inundações Urbanas a partir de medidas não estruturais de controle: Trecho da Bacia do Córrego do Gregório, São Carlos - SP. Dissertação (Mestrado em Hidráulica e Saneamento) - Escola de Engenharia de São Carlos, Universidade de São Paulo, São Carlos. 2005.

BRASIL. Estatuto da Cidade (2001). Estatuto da Cidade: guia para implementação pelos municípios e cidadãos. Brasília: Câmara dos Deputados, Coordenação de Publicações.

BRUAND, Yves. (1997). São Paulo ou a negação do urbanismo. In: Arquitetura Contemporânea no Brasil. São Paulo: Editora Perspectiva. 3ed. 1997.

CANHOLI, Aluisio Prado. (2005). Medidas não Convencionais. In: Drenagem urbana e controle de enchentes. São Paulo: Editora Oficina de Textos. 2005.

CHUVA diluviana. (1932). Correio de São Carlos, São Carlos, 26 fev 1932.

DEVESCOVI, Regina. C. Balieiro. (1987) Urbanização e Acumulação: um estudo sobre a cidade de São Carlos. 261p. Monografia - Universidade Federal de São Carlos, São Carlos. 1987.

DOZENA, Alessandro. (2001) São Carlos e seu "desenvolvimento": contradições urbanas de um pólo tecnológico. 140p. Dissertação (Mestrado) - Faculdade de Filosofia, Ciências e Letras Universidade de São Paulo, São Paulo. 2001.

DRENAGEM do Gregório: projeto já está nas mãos do interventor. (1972). A Folha, São Carlos, 23 abr. 1972, p 1.

EMBRAPA Pecuária Sudeste. (2004). Dados sobre chuvas em São Carlos. São Carlos. Arquivos da EMBRAPA.

ESTEVES, R. L.; MENDIONDO, E. M. (2003) Análise comparativa entre equações e observações do tempo de concentração em uma bacia urbana de São Carlos, SP. In. SIMPÓSIO BRASILEIRO DE RECURSOS HÍDRICOS, 15., 2003, Curitiba-PR. Anais - Desafio à Gestão da Água no Limiar do Século XXI, Porto Alegre: ABRH. 1 CD-ROM. 
ESTEVES, Rafael Lucio. (2003). Inventário de Bacias Urbanas: Córrego do Gregório. Disponível em http://www.baciaescola.hpg.com.br . Acesso em: 05 de abril de 2003.

ESTRAGOS causados pelas chuvas. (1947). Correio de São Carlos, São Carlos, 03 mar 1947.

FGTS atende só $6 \%$ das vítimas das cheias. (2004). Folha de São Paulo, São Paulo, 10 mai. 2004. Ribeirão, Caderno C, p. 3.

FIPAI/PMSC (2003) - Fundação para o Incremento da Pesquisa e Aperfeiçoamento Industrial / Prefeitura Municipal de São Carlos. Protijuco - Projeto de Recuperação Ambiental das Várzeas do Alto Tijuco Preto visando o Plano Diretor na sua Bacia Hidrográfica. Contr. Adm. Nº19/2003. Rel. Técn.. NIBH-SHS/EESC/USP

GOERL, Roberto Fabris; KOBIYAMA, Masato. (2005). Considerações sobre inundações no Brasil. In: SIMPÓSIO BRASILEIRO DE RECURSOS HÍDRICOS, 16, 2005, João Pessoa-PB. Anais. João Pessoa: ABRH.

GRACIOSA, Melissa Cristina Pereira. (2005). Trincheiras de infiltração como tecnologia alternativa em drenagem urbana: modelagem experimental e numérica. Dissertação (Mestrado em Hidráulica e Saneamento) - Escola de Engenharia de São Carlos - Universidade de São Paulo, 2005.

IBGE - Instituto Brasileiro de Geografia e Estatística (2000), Cidades: Resultados do Universo Censo 2000. Disponível em http://www.ibge.gov.br . Acesso em: 10 de outubro de 2003.

IBGE - Instituto Brasileiro de Geografia e Estatística. Censos Demográficos 1940, 1980 e 2000. Brasília: DF

INTERNATIONAL FLOOD NETWORK. (s/d) Effective Flood Management for Precious Water and Life. Tokyo: International Flood Network. Folder.

INTERNATIONAL STRATEGY FOR DISASTER REDUCTION; UNITED NATIONS. (2003) Living with Risk: Turning the tide on disasters towards sustainable development - World Disaster Reduction Campaign. Geneva. Folder.

INUNDAÇÃO derruba propaganda de Alckmin. (2005). Folha de São Paulo, São Paulo, 26 mai. 2005. Cotidiano, p. C3.

LEME, Maria Cristina da Silva (Org.) (1999). Urbanismo no Brasil: 1895 - 1965. São Paulo: Studio Nobel / FAU-USP / FUPAM.

MACEDO, R. F. de; SOUZA, S. A.; ANDRADE, J. P. M.; MARCO, G. de; MENDIONDO, E. M. (2004). Cenários de política de controle de impactos devido a inundações. In: Seminário Latino Americano de Políticas Públicas em Recursos Hídricos, 1. 2004, Brasília - DF. Anais.

MCT/CGE - Ministério de Ciência e Tecnologia / Centro de Estudos e Gestão Estratégica. (2002) Diretrizes estratégicas para o Fundo de Recursos Hídricos de Desenvolvimento Científico e Tecnológico. Brasília. Disponível em http://www.ana.gov.br . Acesso em: 11 de agosto de 2004. 
MENDES, H. C.; VERÇOSA, M. M. D.; MATSUNAGA, S. P.; MENDIONDO, E. M. (2004). 'Hidro-solidariedade' como mecanismo de gestão em políticas públicas para a prevenção de riscos hidrológicos. In: Seminário Latino Americano de Políticas Públicas em Recursos Hídricos, 1. 2004, Brasília - DF. Anais.

MENDES, Heloisa Ceccato; MENDIONDO, Eduardo Mario. (2004). Histórico da Expansão Urbana e Incidência de Inundações: O Caso da Sub-Bacia do Gregório, São Carlos - SP - Brasil. Artigo submetido à RBRH - Revista Brasileira de Recursos Hídricos, em 26 de agosto de 2004.

MENDIONDO, E.M.; OHNUMA JUNIOR. A. A.; BENINI, R. M.; PERES, R. B. (2004) Metodologia Simplificada de Cenários de Planejamento para a Recuperação Ambiental de Bacias Urbanas. In: Congresso Latino Americano de Hidráulica, 21. 2004, São Pedro - SP. Anais.

MENDIONDO, E.M. (2005 a). Scenarios of South American Floods - From Mitigation Disasters to Early - Warning Strategies. International Conference on Monitoring, Prediction and Mitigation of Water-Related Disaster. Kyoto. Japan. p.12-15. January, 2005.

MENDIONDO, E. M. (2005 b). Flood risk management of urban waters in humid tropics: earlywarning, protection and rehabilitation. Invited Paper In: C. Tucci \& J.Goldenfum (orgs.) Workshop on Integrated Urban Water Managmt. in Humid Tropics, UNESCO IHP-VI (Int.Hydrol.Program), 2-3 April 2005, Foz de Iguaçu, Brazil.

MENDIONDO (2005 c). Esclarecimentos sobre impacto ambiental na discussão da PGV- São Carlos. Disponível em http://www.shs.eesc.usp.br/hidraulica . Acesso em: 28 de outubro de 2005.

MONTAÑO, Marcelo. (2002). Os recursos hídricos e o zoneamento ambiental: o caso do município de São Carlos. 100p. Dissertação (Mestrado) - Escola de Engenharia de São Carlos Universidade de São Paulo, São Carlos. 2002.

NEWTON: "Próximo passo é a ponte da Alexandrina". (2003). Primeira Página, São Carlos, 09 jan. 2003.

OHNUMA JÚNIOR, Alfiedo A. (2005). Cenários de Reuso de Água Pluvial e Controle da Drenagem Visando a Recuperação Ambiental da Micro-Bacia do Alto Tijuco Preto, São Carlos/SP. Dissertação (Mestrado em Ciências da Engenharia Ambiental) - Escola de Engenharia de São Carlos - Universidade de São Paulo, 2005.

ONG AMIGOS DO GREGÓRIO (2005). É hora de salvar o Gregório. Primeira Página, São Carlos, 09 set. 2005. Caderno A, p. 2.

PMSC - Prefeitura Municipal de São Carlos (2004). Plano Diretor de São Carlos I: Projeto de Lei, CD-Rom.

PMSC/SMHDU - Prefeitura Municipal de São Carlos / Secretaria Municipal de Habitação e Desenvolvimento Urbano. (2002) Conferência da Cidade. CD-ROM. 
PMSC/SMHDU - Prefeitura Municipal de São Carlos / Secretaria Municipal de Habitação e Desenvolvimento Urbano . (2001) Fichas de aprovação de loteamentos em São Carlos. São Carlos. Arquivos da SMHDU.

Projeto FINEP/CT-HIDRO/EESC/USP-DAEE/SP - CNPq - 01.02.0086.00. Experimento piloto de gerenciamento integrado de bacias urbanas para o plano diretor de São Carlos, SP. 2002 (www.busplanodiretor.hpg.ig.com.br)

QUEIROZ, E.A. (1996). A Utilização do Sistema de Informações Geográficas no Estudo da Dinâmica do Escoamento Superficial em Áreas Urbanas: Aplicação na Bacia do Córrego do Gregório. 1996. Dissertação (Mestrado em Hidráulica e Saneamento) - Escola de Engenharia de São Carlos - Universidade de São Paulo, São Carlos, 1991.

REBELATTO, Daisy Aparecida do Nascimento. (1991) A influência do processo de ocupação do solo na Bacia do Rio Gregório em São Carlos (SP) sobre a incidência de enchentes nas áreas próximas ao Mercado Municipal. 149 p. Dissertação (Mestrado em Hidráulica e Saneamento) Escola de Engenharia de São Carlos - Universidade de São Paulo, São Carlos, 1991.

RIGHETTO, J. M., BARROS, R. M., MENDIONDO, E. M. (2003). Avaliação da seguridade e percepção pública sobre riscos de enchentes em várzeas urbanizadas: $\mathrm{O}$ caso do micro-centro da cidade de São Carlos - SP. In: SIMPÓSIO BRASILEIRO DE RECURSOS HÍDRICOS, 15. , Curitiba-PR. Anais - Desafio à Gestão da Água no Limiar do Século XXI. Porto Alegre: ABRH. 1 CD-ROM.

RIGHETTO, Julian Margarido. (2005). Modelo de seguro para riscos hidrológicos no contexto de manejo integrado de bacias hidrográficas. Dissertação (Mestrado em Ciências da Engenharia Ambiental) - Escola de Engenharia de São Carlos - Universidade de São Paulo, 2005.

ROLNIK, Raquel. (1995). Planejamento Urbano nos anos 90: novas perspectivas para velhos temas. In: SILVA, Kleber Pinto. A cidade contemporânea: tendências e conceitos. Bauru: UNESP: Faculdade de Arquitetura, Artes e Comunicação: Departamento de Arquitetura, Urbanismo e Paisagismo.

SANTOS, Magda Carmo dos (2002). Águas Revoltas: história das enchentes em Santo André. Santo André: Semasa / PMSA, 106 p.

SÃO Paulo submersa. (2005). Folha de São Paulo, São Paulo, 26 mai. 2005. Cotidiano, Caderno C, p. 1.

SEADE- Fundação Sistema Estadual de Análise de Dados. (2004). Informações dos municípios paulistas. Disponível em http://www.seade.sp.gov.br . Acesso em: 16 de junho de 2004.

SECRETÁRIO de obras e representantes do comércio visitam o canal do córrego do Gregório na baixada do Mercado Municipal. (2003). Primeira Página, São Carlos, 09 jan 2003.

SIGRH - Sistema Integrado de Gerenciamento de Recursos Hídricos de São Paulo. (2004). Banco de Dados Pluviométricos do Estado de São Paulo. Disponível em http://www.sigrh.sp.gov.br . Acesso em: 11 de novembro de 2004. 
SIGRH - Sistema Integrado de Gerenciamento de Recursos Hídricos de São Paulo. (2003). Plano Estadual de Recursos Hídricos 2000 - 2003. CD - Rom

SILVEIRA, André Luiz Lopes da. (1998). Hidrologia Urbana no Brasil. In: BRAGA, B.; Tucci, C.; Tozzi, M. (org.) Drenagem urbana: gerenciamento, simulação, controle. Porto Alegre: Ed. Universidade/UFRGS/ABRH.

SIVAPALAN, M.; TAKEUCHI, K.; FRANKS, S.; GUPTA, V.; KARAMBIRI, H.; LAKHSMI, V.; LIANG, X.; MCDONNELL, J.; MENDIONDO, E. M.; O'CONNELL, P. E.; OKI, T.; POMEROY, J.; SCHERTZER, D.; UHLENBROOK, S.; ZEHE, E. (2003). IAHS Decade on Predictions in Ungauged Basins (PUB), 2003-2012: Shaping an exciting future for the hydrological sciences. Hydrological Sciences Journal, Wallingford-UK, v. 48, n. 6, p. 857-880.

SOUZA, Saide Kahtouni Proost de. (2002) Cidade das Águas. Tese (Doutorado em Arquitetura e Urbanismo) - Faculdade de Arquitetura e Urbanismo - Universidade de São Paulo, São Paulo. 2002.

STEINKE, Rosana. (2002) Ruas curvas versus Ruas retas na história das cidades do Eng. Jorge de Macedo Vieira. 291p. Dissertação (Mestrado em Arquitetura e Urbanismo) - Escola de Engenharia de São Carlos - Universidade de São Paulo, São Carlos, 2002.

TEMPORAL atinge São Carlos e deixa um rastro de destruição. (1998). A Folha, São Carlos. 26 fev 1998.

TOENSMANN, Frank. (2000). About the History of Flood Defence: The Northern Hesse Example. In: SYMPOSIUM ON RIVER FLOOD DEFENCE, 2000, Kassel. Anais. Kassel: Herkules Verlag, v1., p.B63 - B85

TUCCI, C. E. M.; BERTONI, J. C. (Org). (2003). Inundações urbanas na América do Sul. Porto Alegre: ABRH, $471 \mathrm{p}$.

TUCCI, C. E. M. (2002). Controle de Enchentes. In: TUCCI, C. E. M. (2002). Hidrologia: ciência e aplicação. 3 ed.. Porto Alegre: UFRGS /ABRH, 471 p.

WORKSHOP RIOS URBANOS, 2003, São Paulo (2003). Anais - Intervenção Urbanística na região do Rio Pinheiros em São Paulo. São Paulo: FAU-SP, 96 p. 


\section{ANEXO 01}

Fotos das Notícias:

Evento específico de Inundação ou Alagamento na Bacia do Gregório 


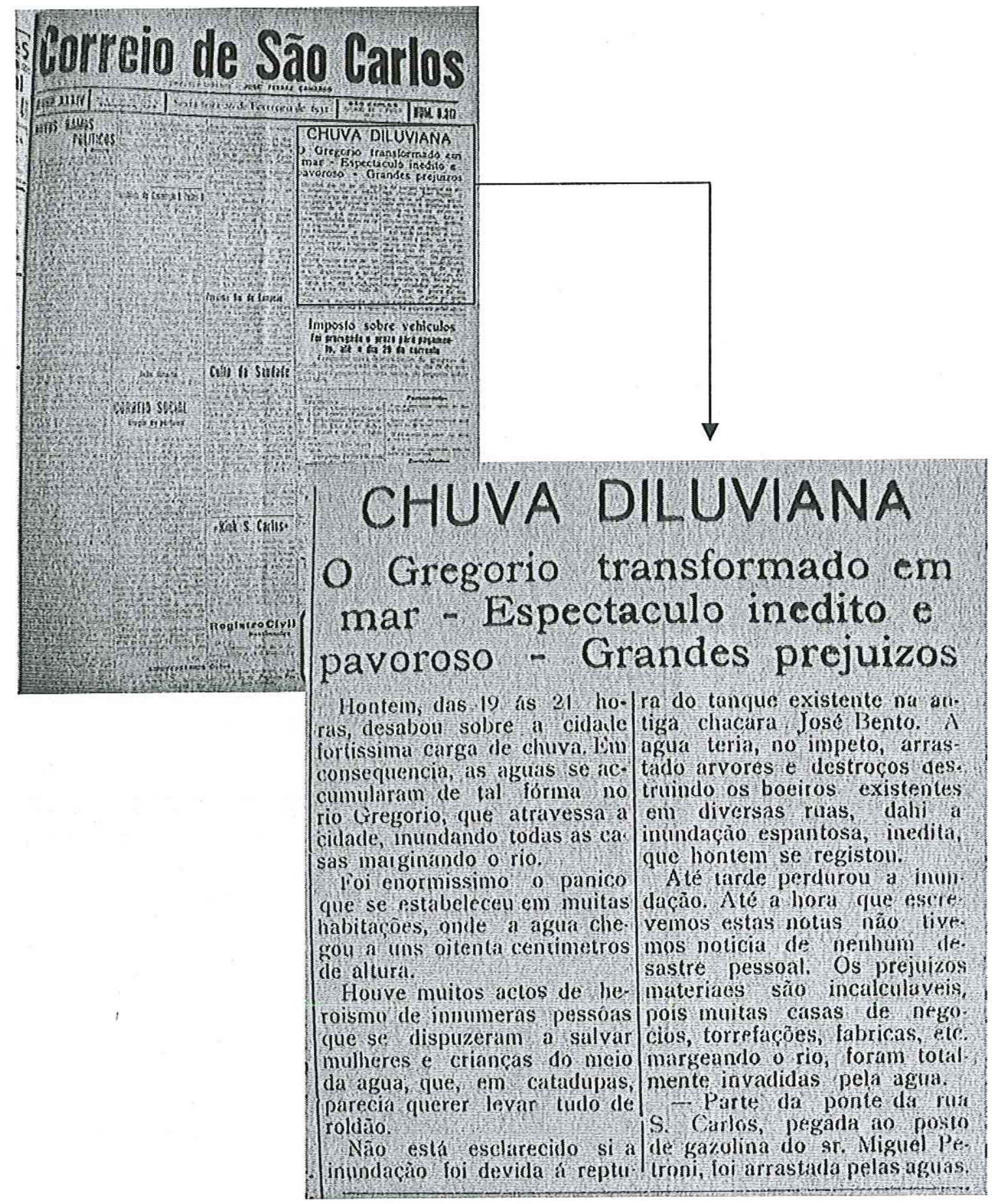

26-02-1932 - Chuva diluviana - Correio de São Carlos 


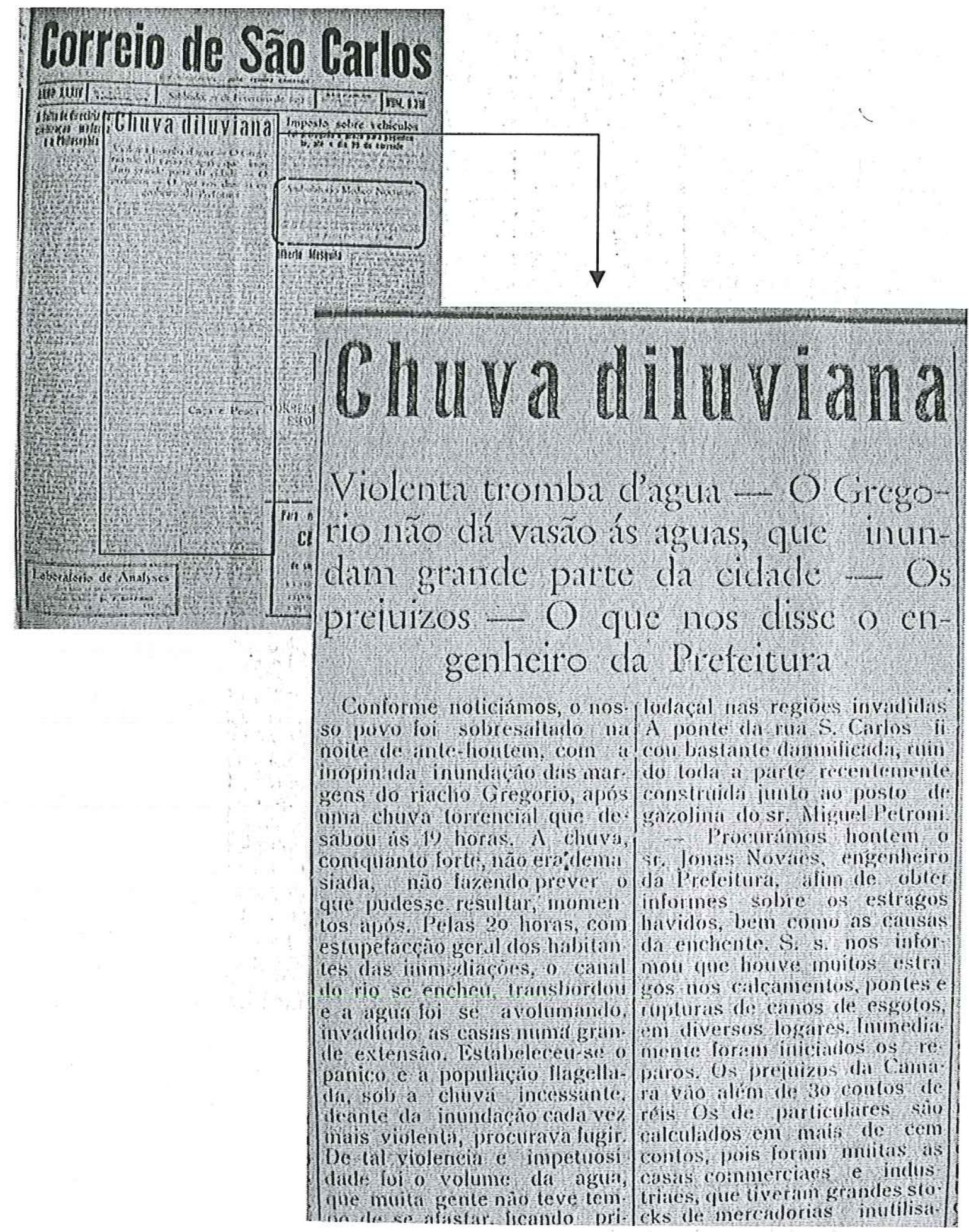

27-02-1932 - Chuva diluviana - Correio de São Carlos - Parte 1 


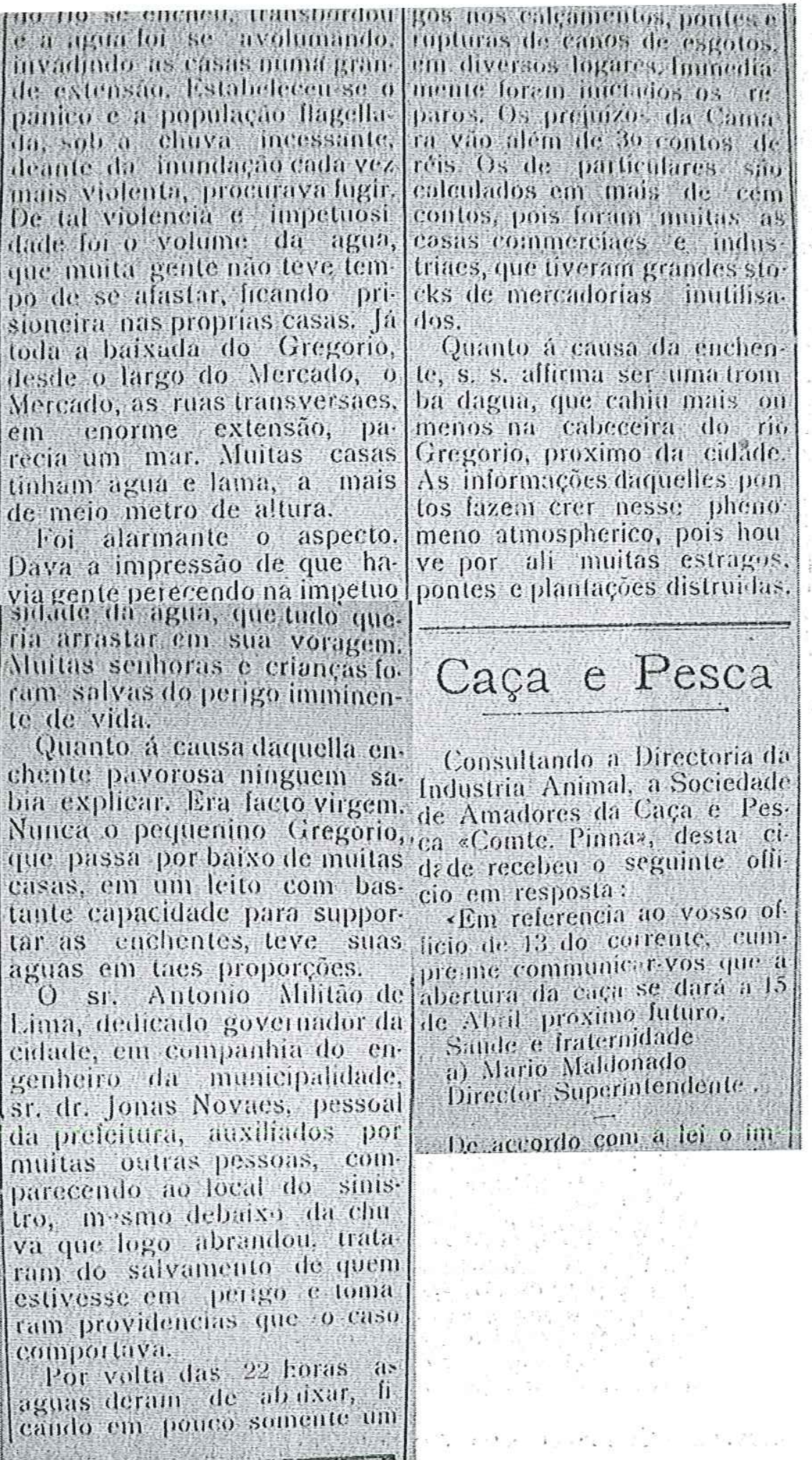

27-02-1932 - Chuva diluviana - Correio de São Carlos - Parte 2 


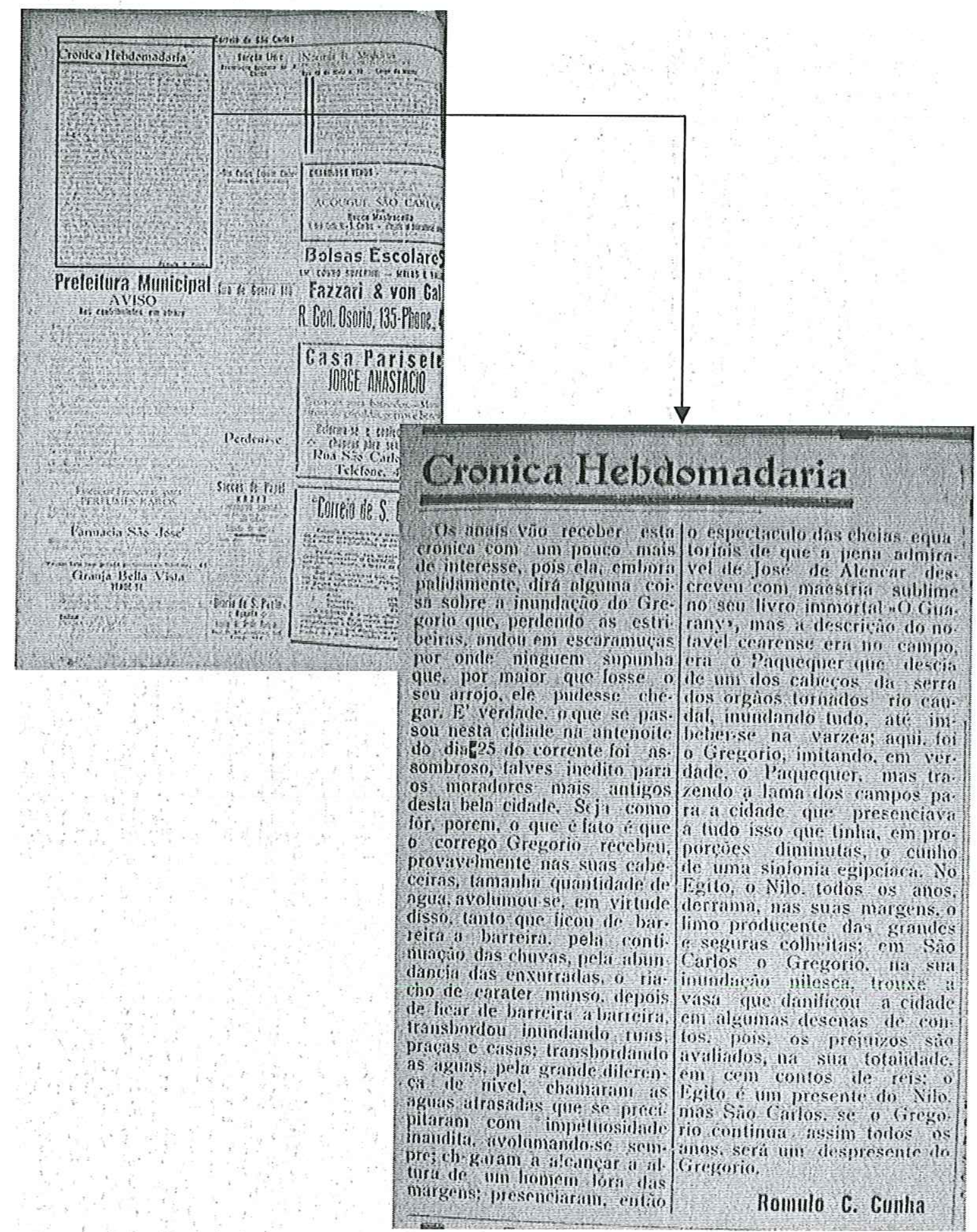

03-03-1932 - Crônica Hebdomadária - Correio de São Carlos 


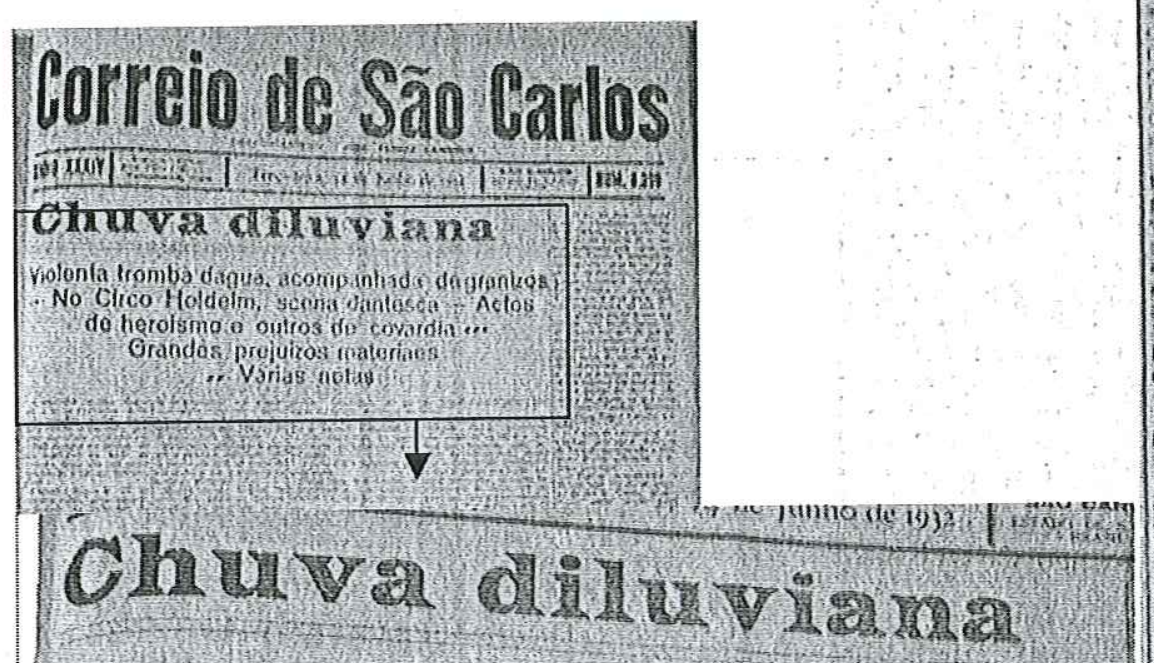

Violenta tromba dagua, acompanhada degranizos .. No Circo Holdelm, scena dantesca ... Actos de heroismo e outros de covardia Grandes prejuizos materiaes 7. Varias notas

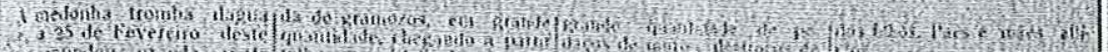

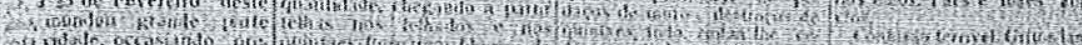

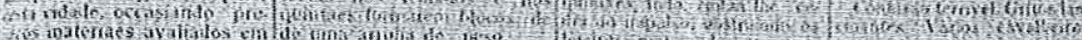

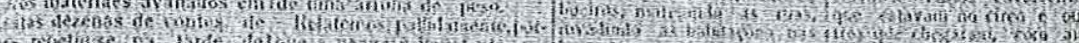

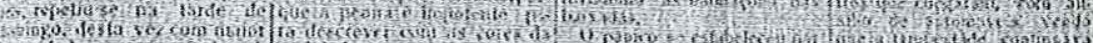

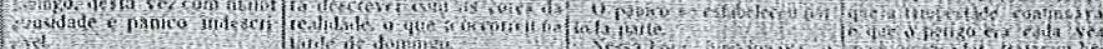

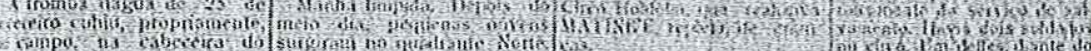

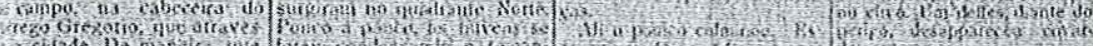

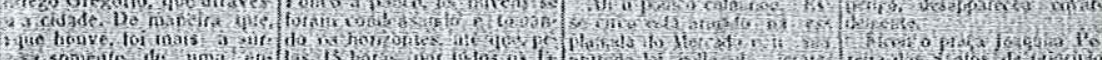

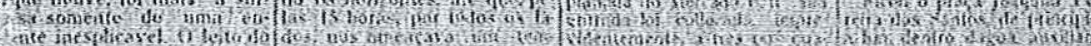

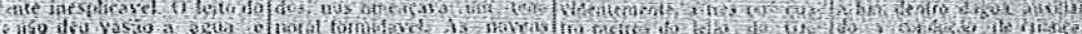

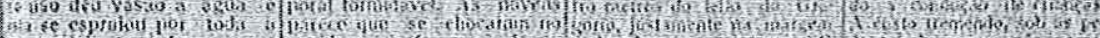

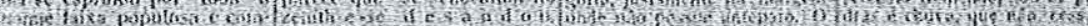

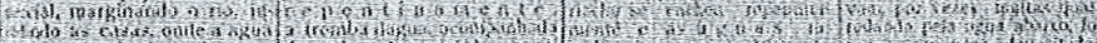

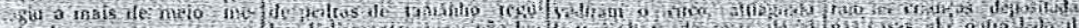
- s sisura

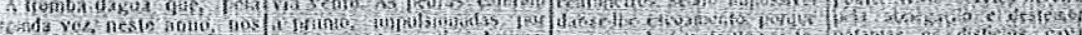

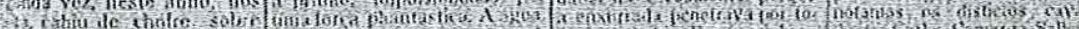

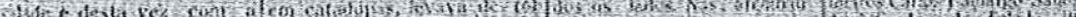

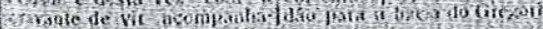

\section{CONVIIT}

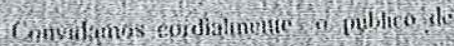

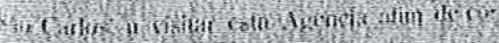

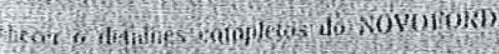

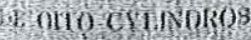

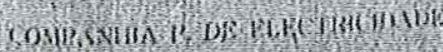

A)

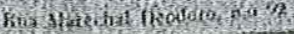

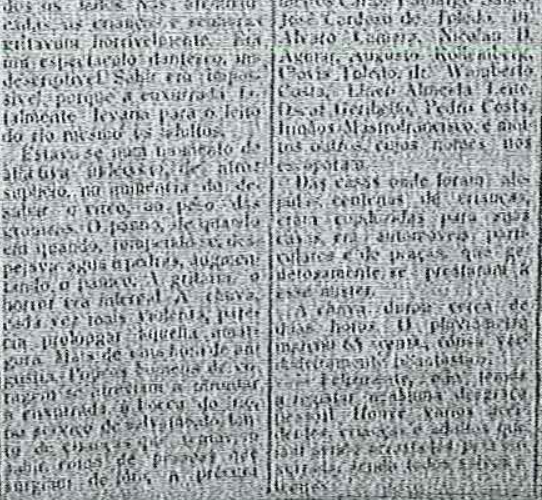

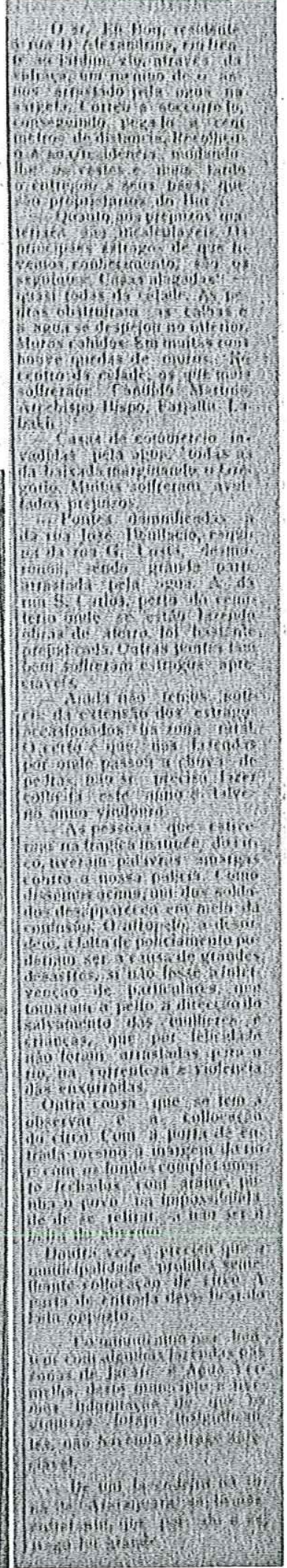

14-06-1932 - Chuva diluviana - Correio de São Carlos 


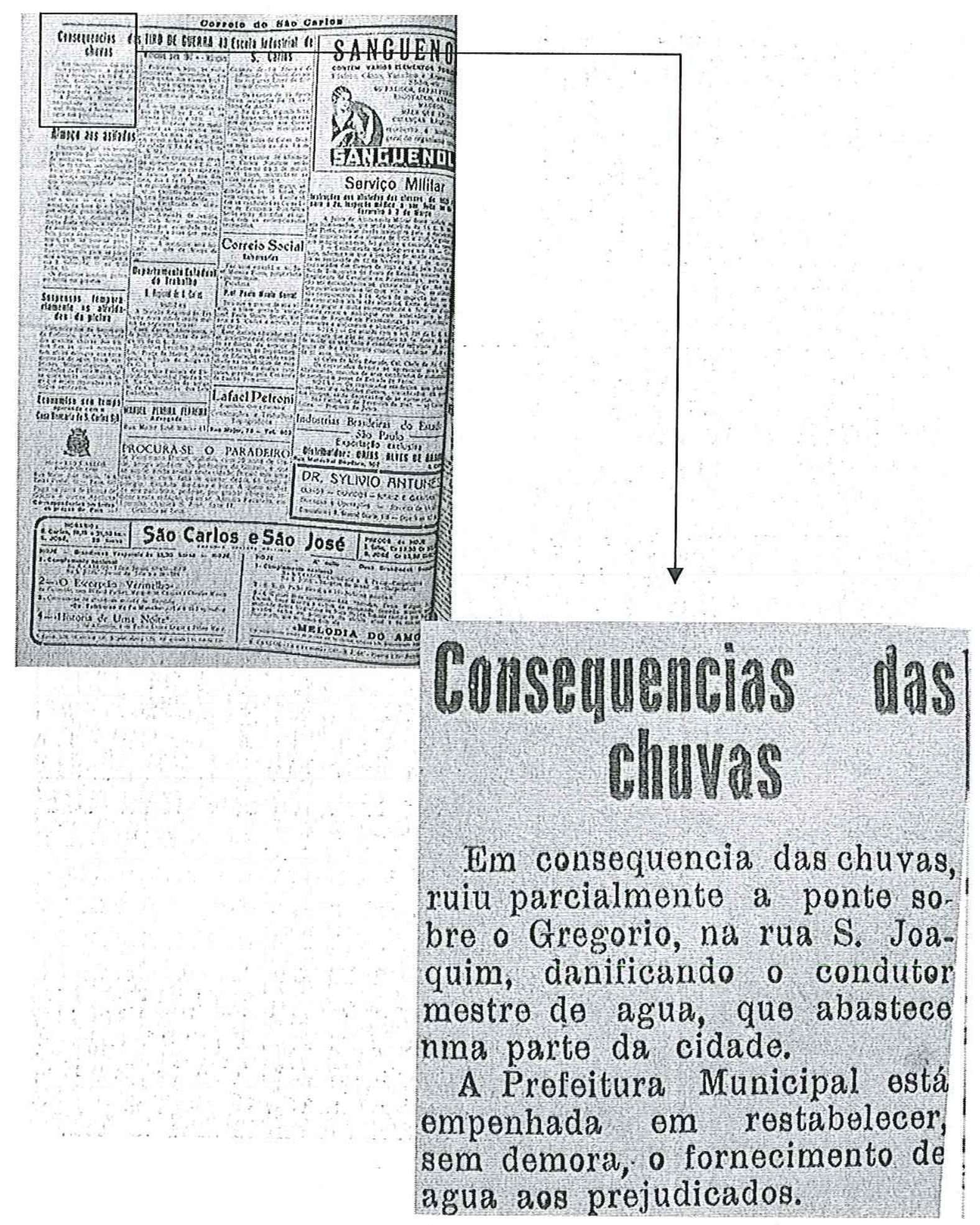

23-02-1947 - Conseqüências das chuvas - Correio de São Carlos 


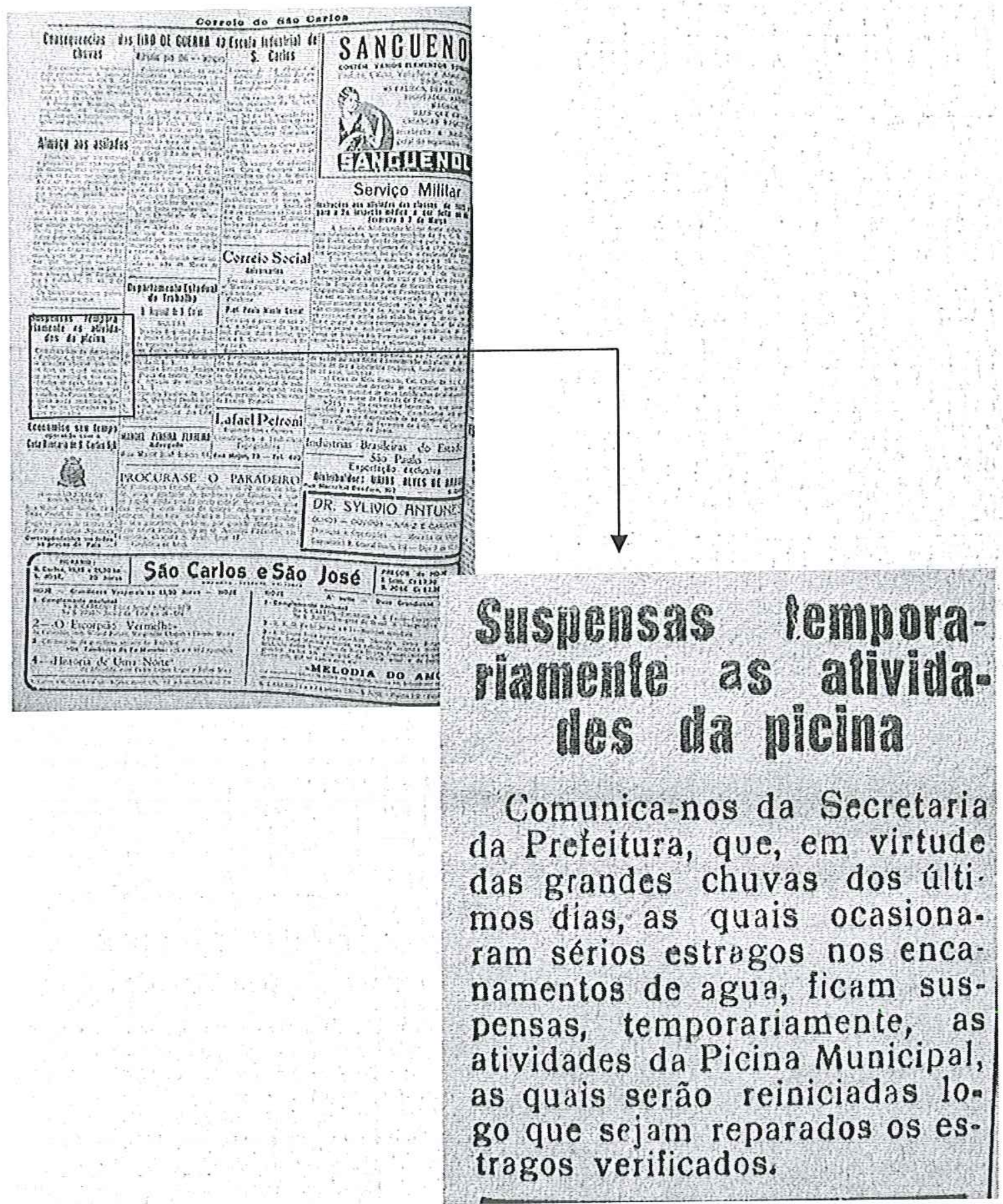

23-02-1947 - Suspensas temporariamente as atividades da picina - Correio de São Carlos 


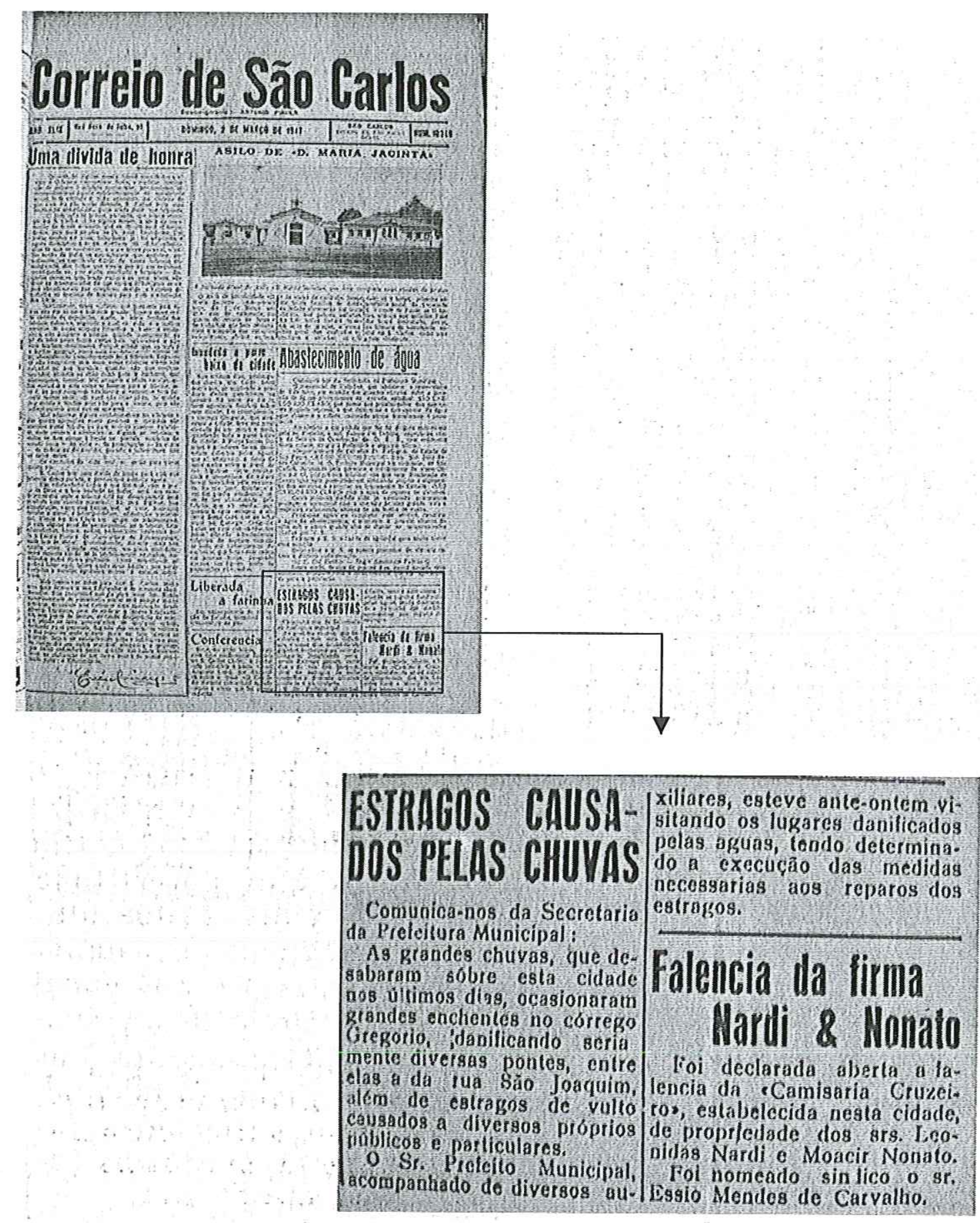

03-03-1947 - Estragos causados pelas chuvas - Correio de São Carlos 

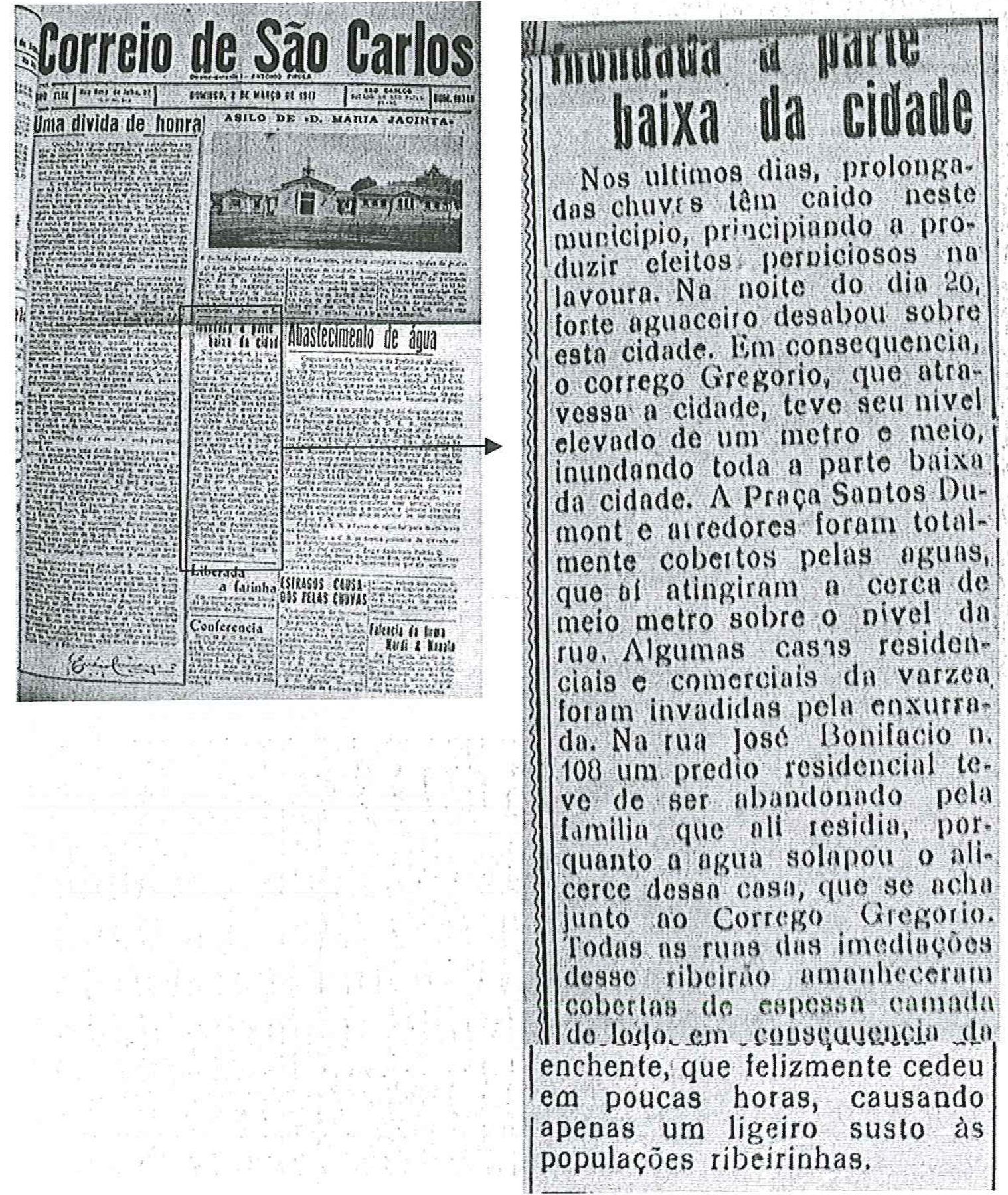

02-03-1947 - Inundada a parte baixa da cidade - Correio de São Carlos 


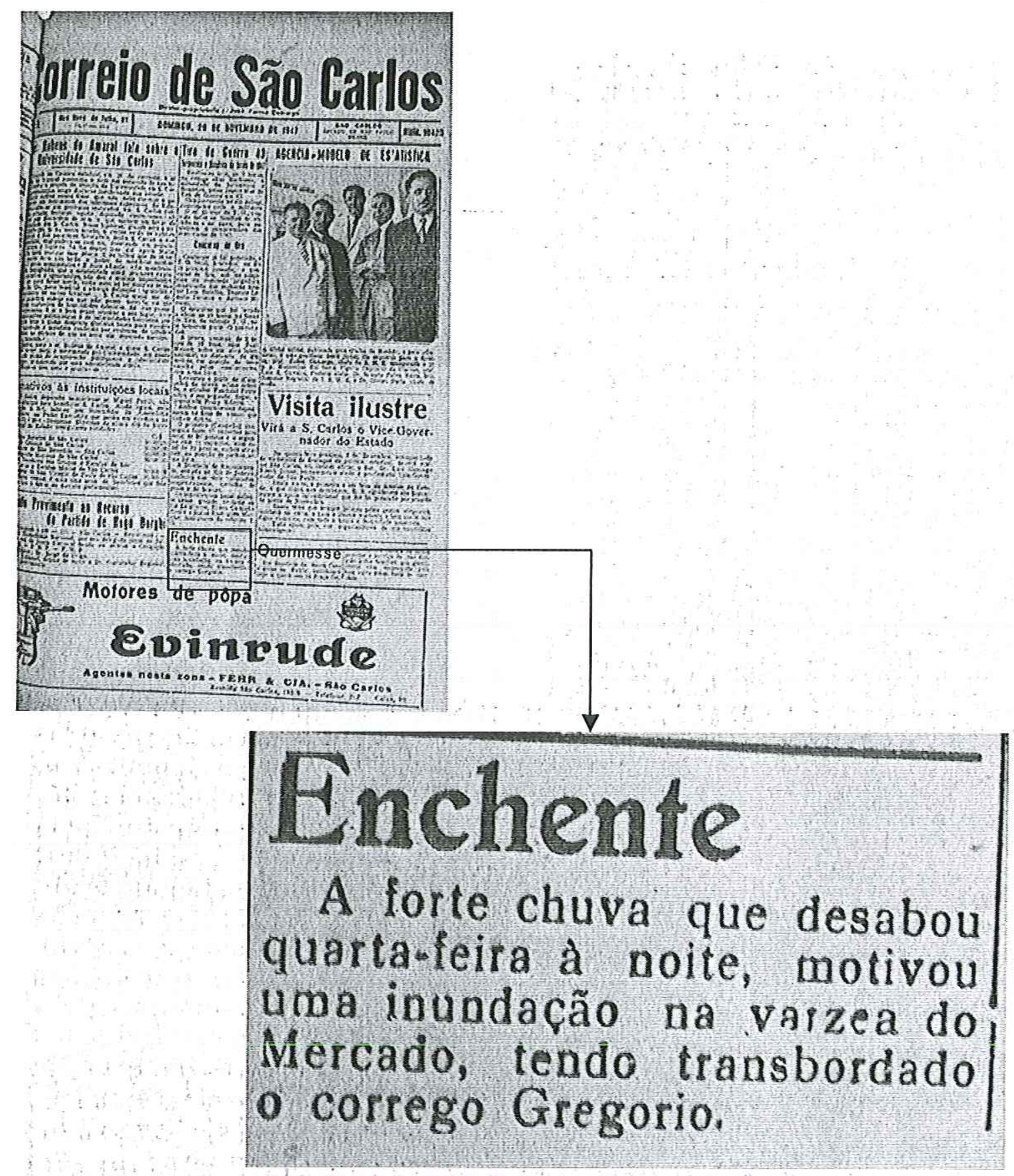

20-11-1947 - Enchente - Correio de São Carlos 


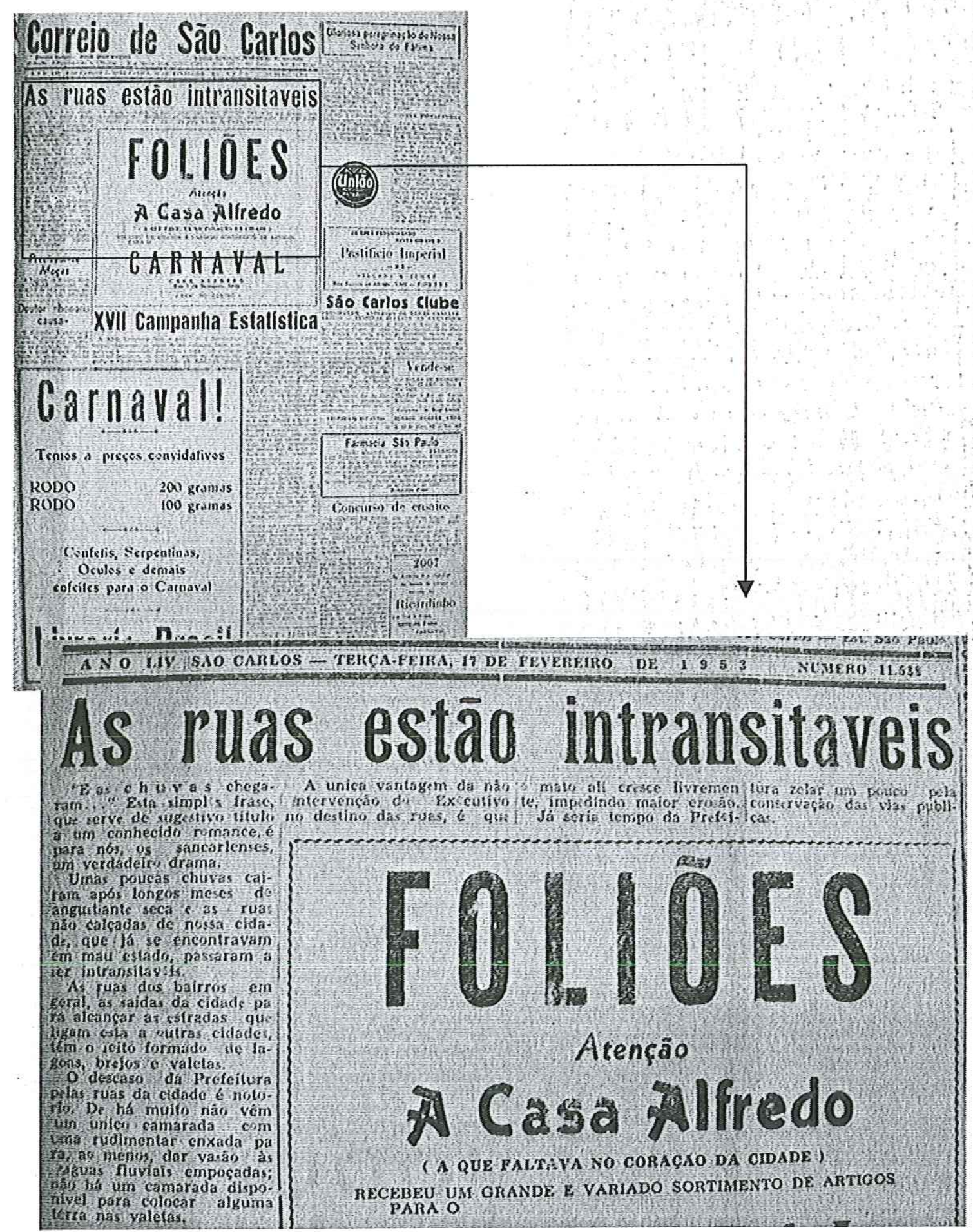

17-02-1953 - As ruas estão intransitáveis - Correio de São Carlos 


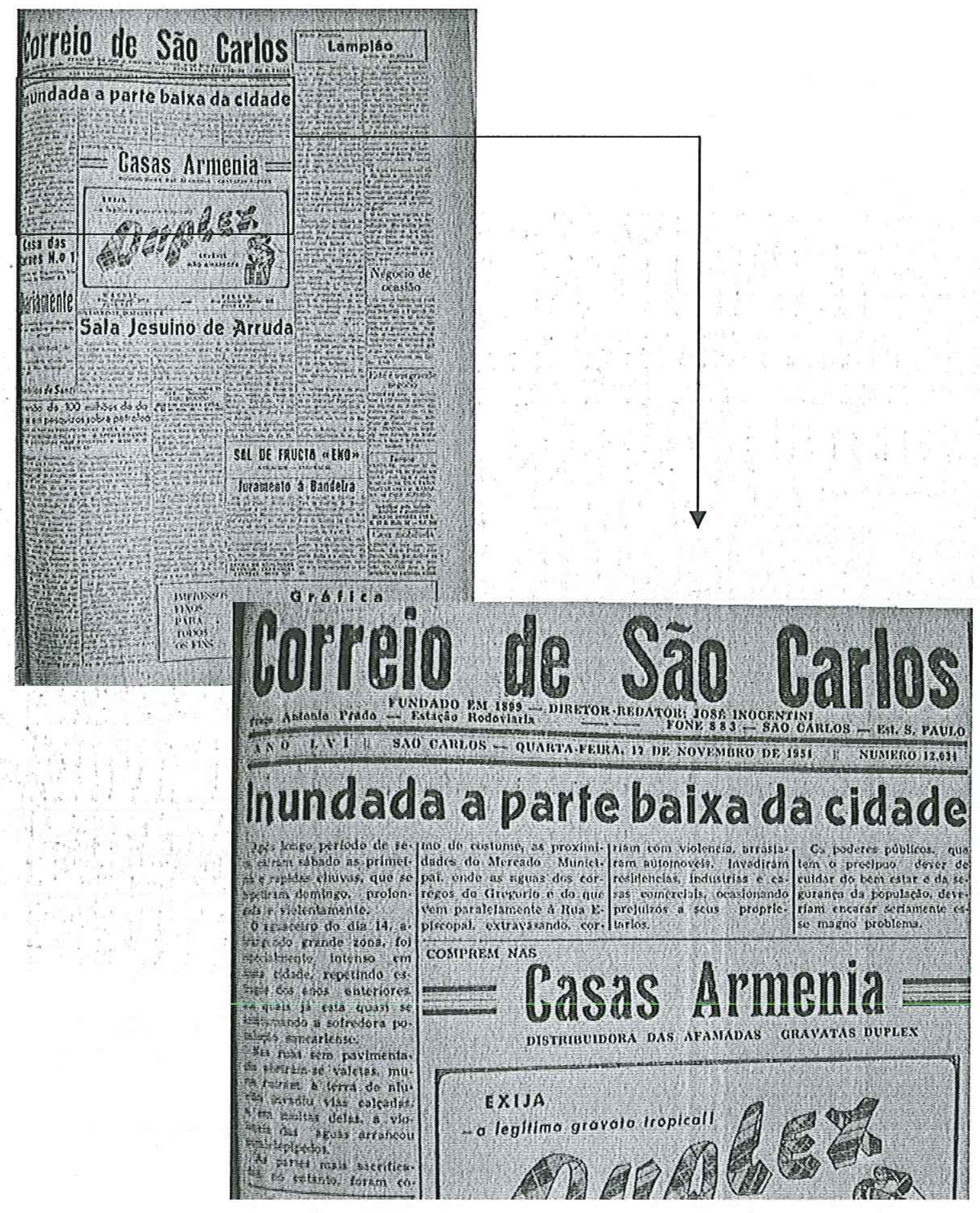

17-11-1954 - Inundada a parte baixa da cidade - Correio de São Carlos 


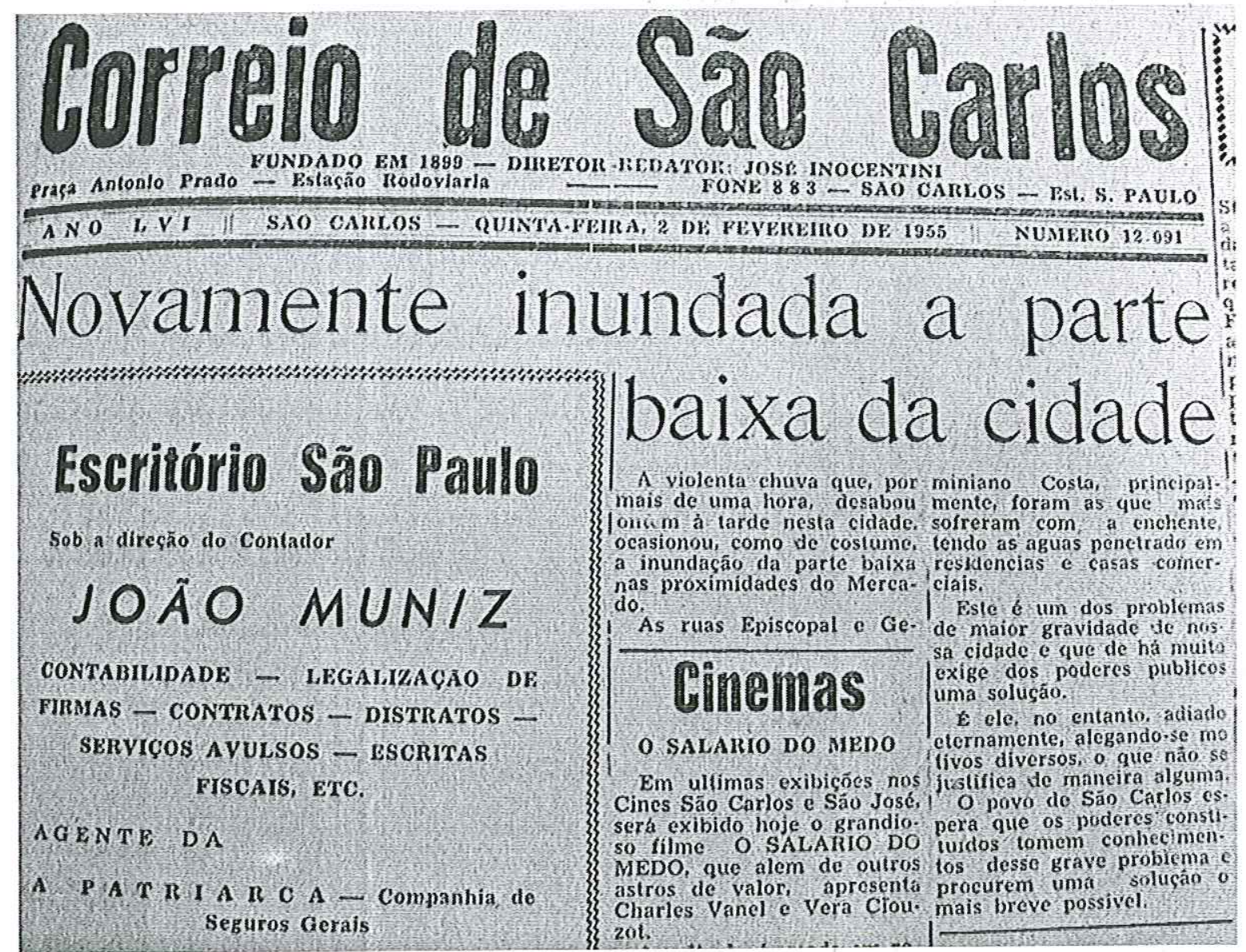

02-02-1955 - Novamente inundada a parte baixa da cidade - Correio de São Carlos 


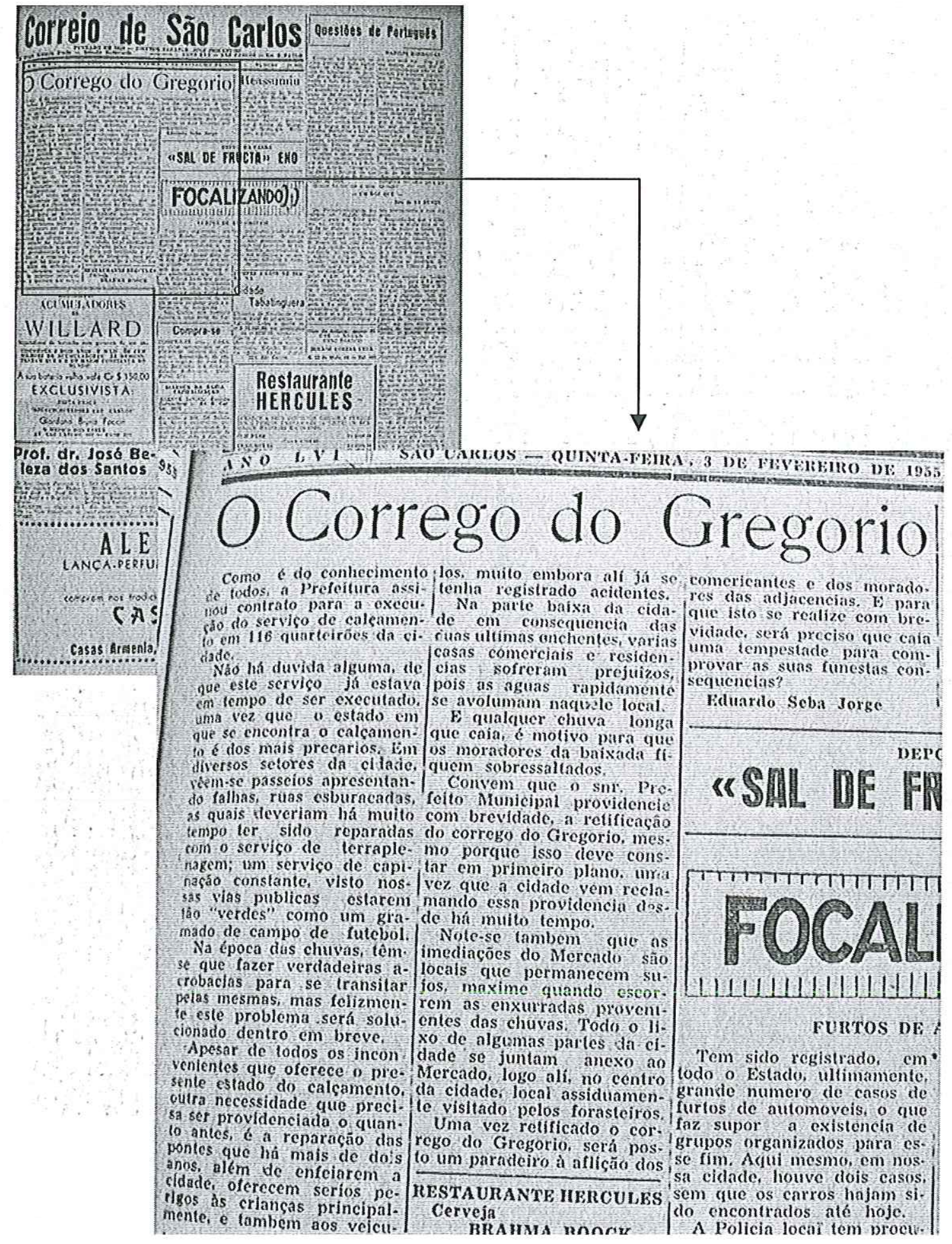

03-02-1955 - O Córrego do Gregório - Correio de São Carlos 


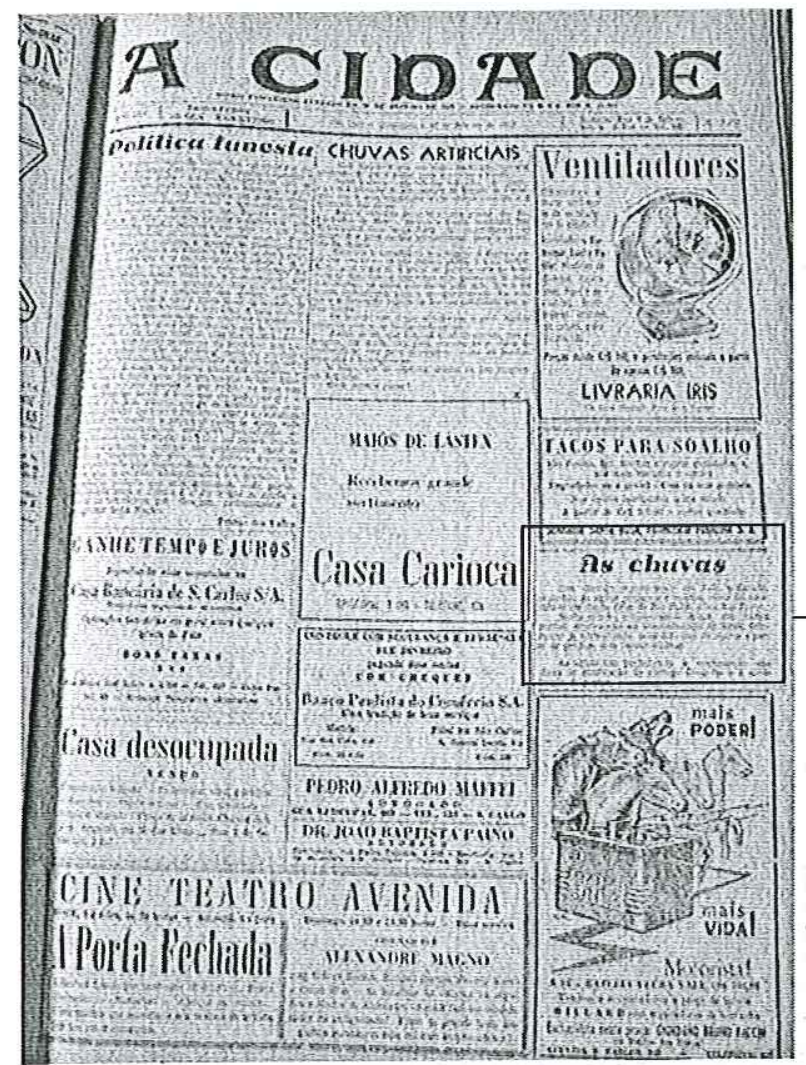

\section{8 charvas}

Tem chovido copiosamente em todo o Estado, causando as aguas prejuizos e mortes, como foi cons? tatado em Santa Cruz do Rio Pardo o em Rio Preto,

Nesta cidade, verificaram-se danos em vários pontos, interrupsão no abastecimento de agua, felizmente já normalizado, desabamentos de muros e parte de prédios, sem causar vítimas.

As aguas têm prejudicado a continuacão das obras de retificação do córrego Gregorio e a cons* trução de pontes. 


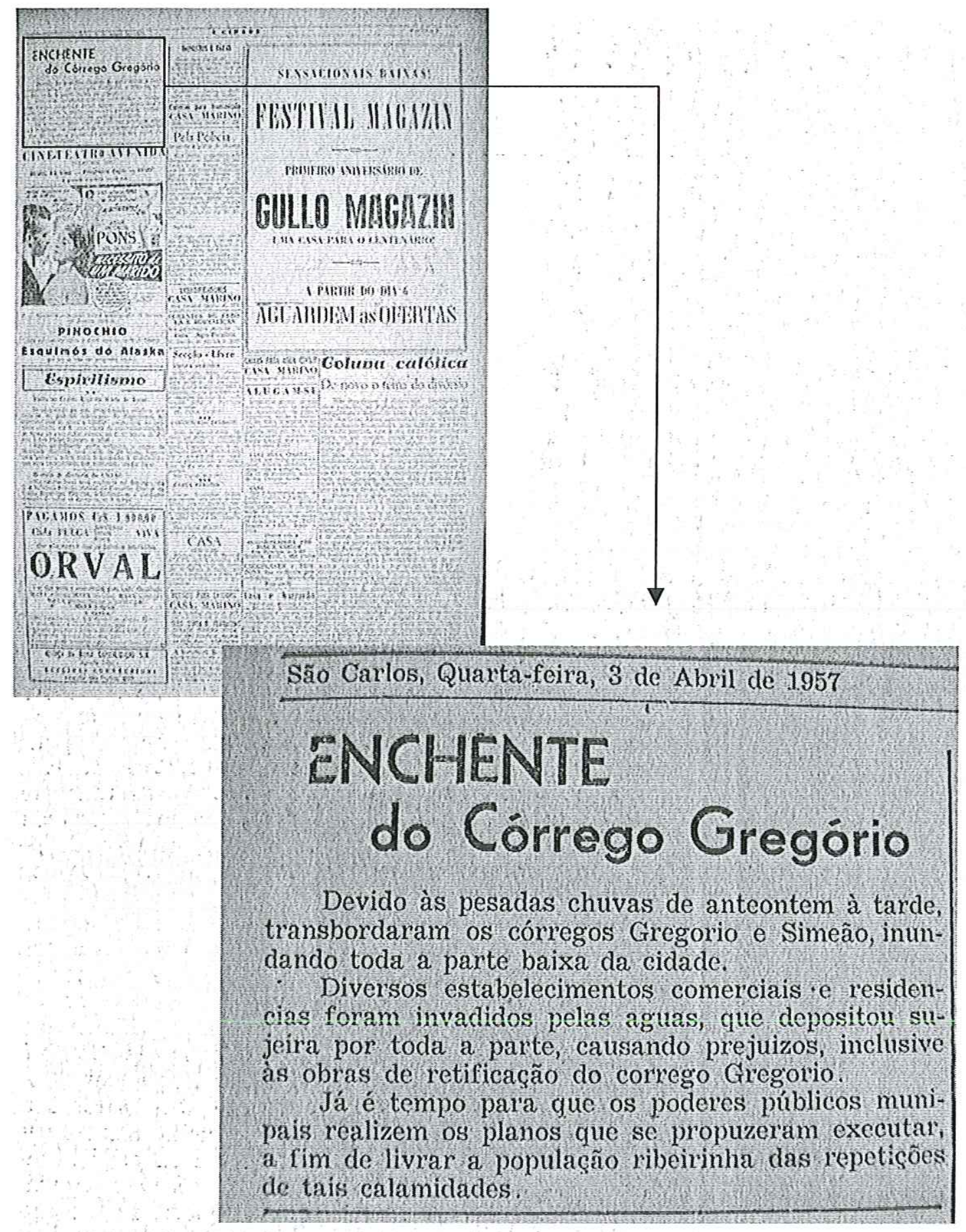

03-04-1957 - Enchente do Córrego Gregório - A Cidade 


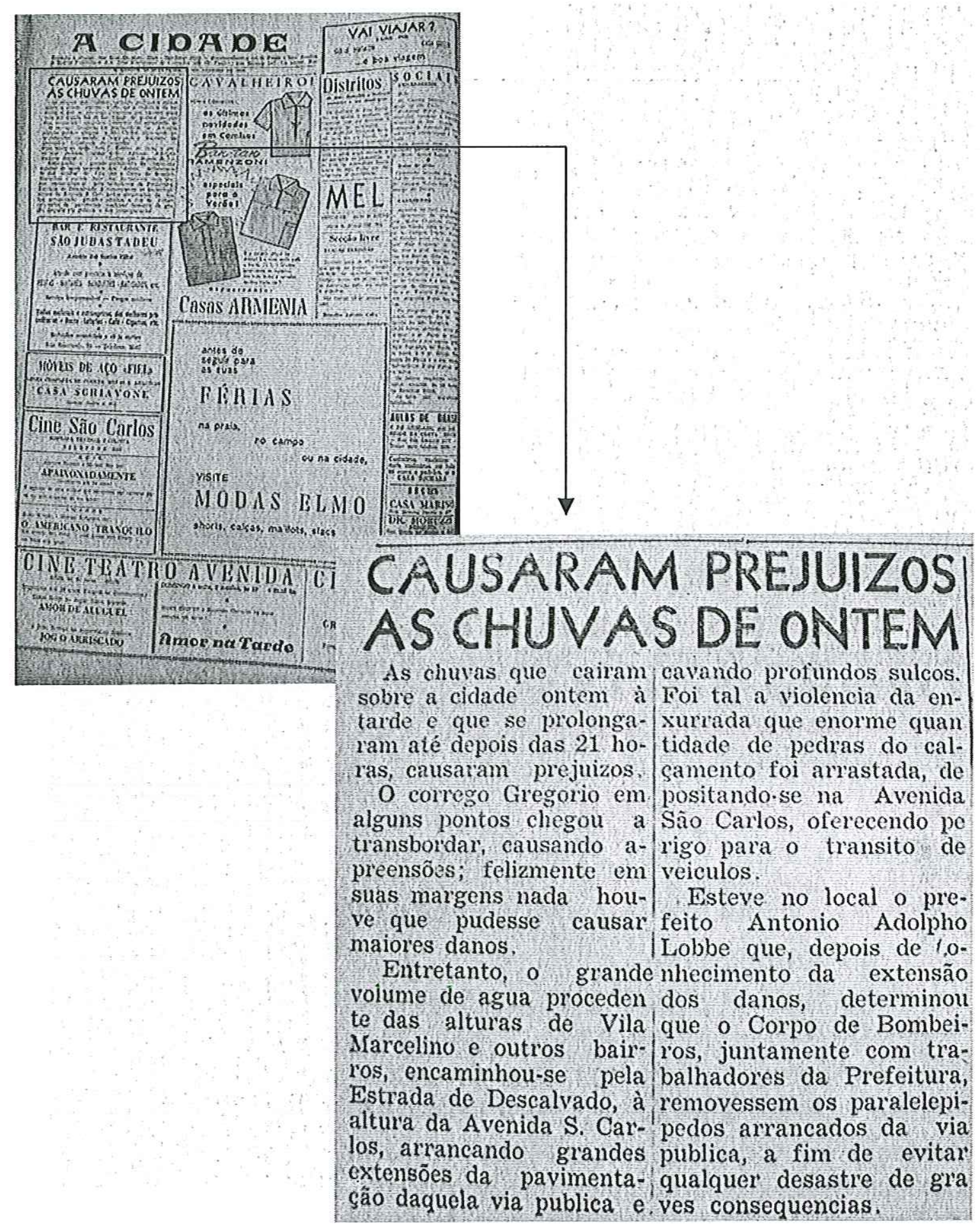

13-01-1960 - Causaram prejuízos as chuvas de ontem - A Cidade 


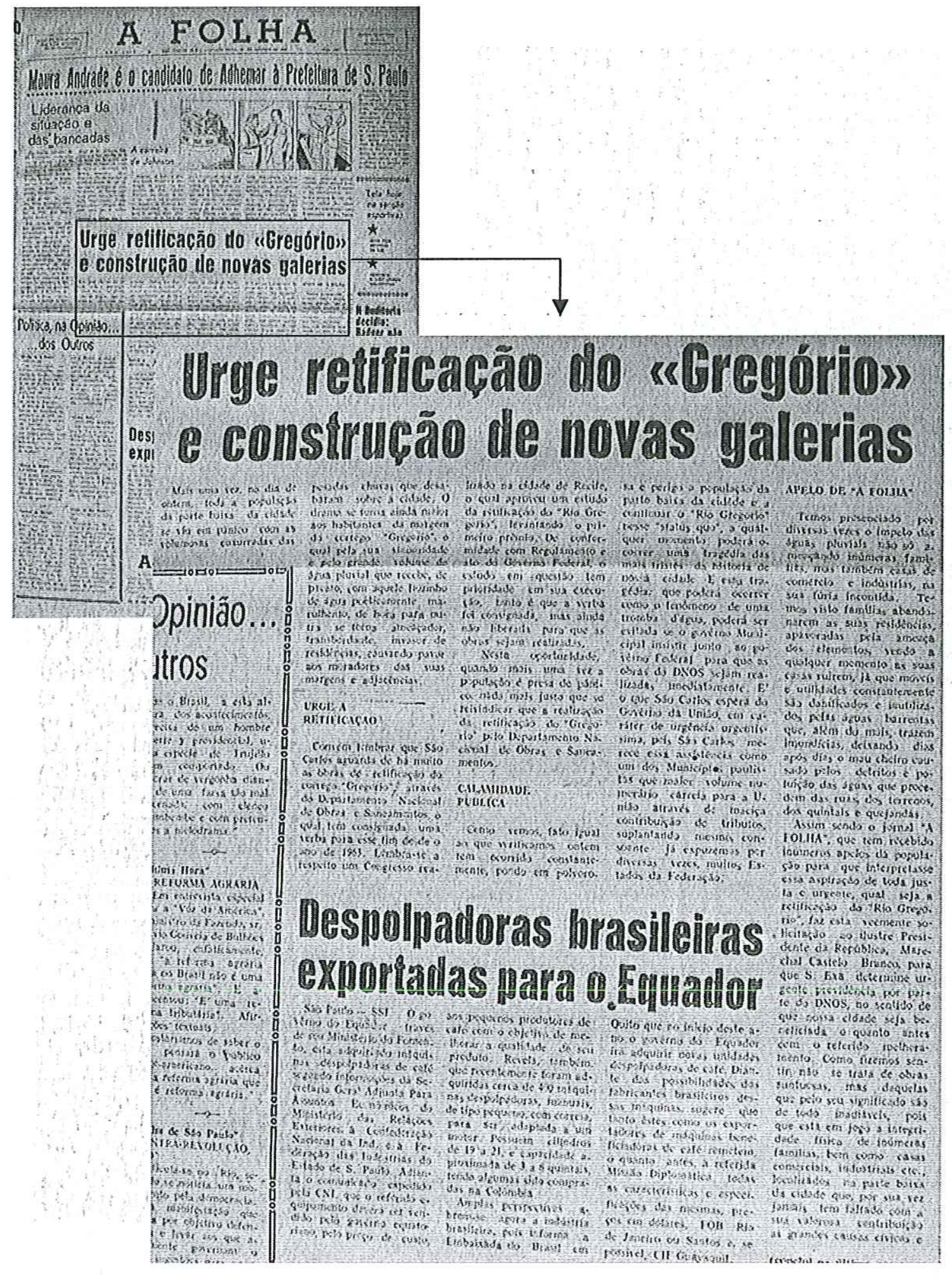

20-01-1965 - Urge retificação do Gregório e construção de novas galerias - A Folha 


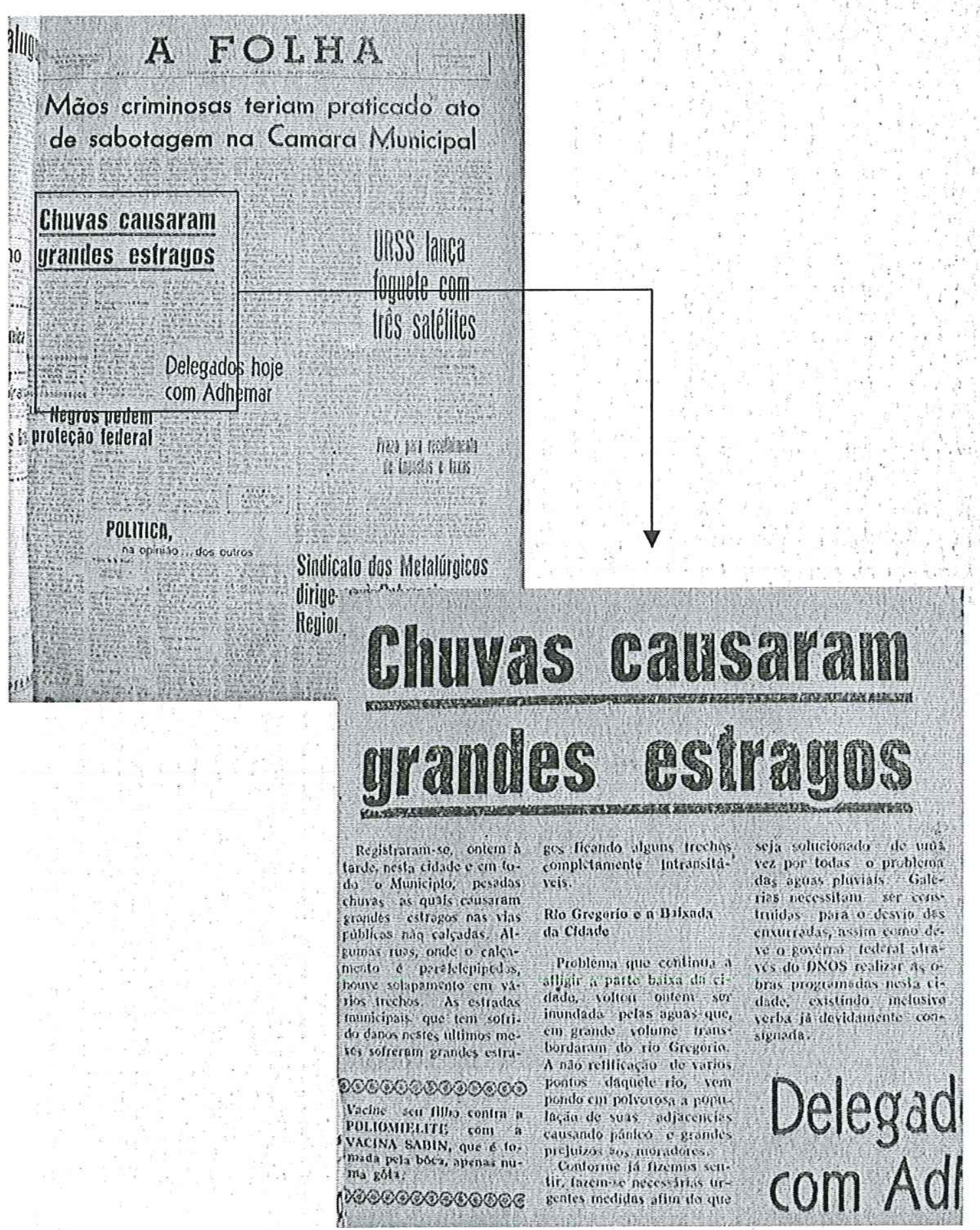

23-02-1965 - Chuvas causaram grandes estragos - A Folha 


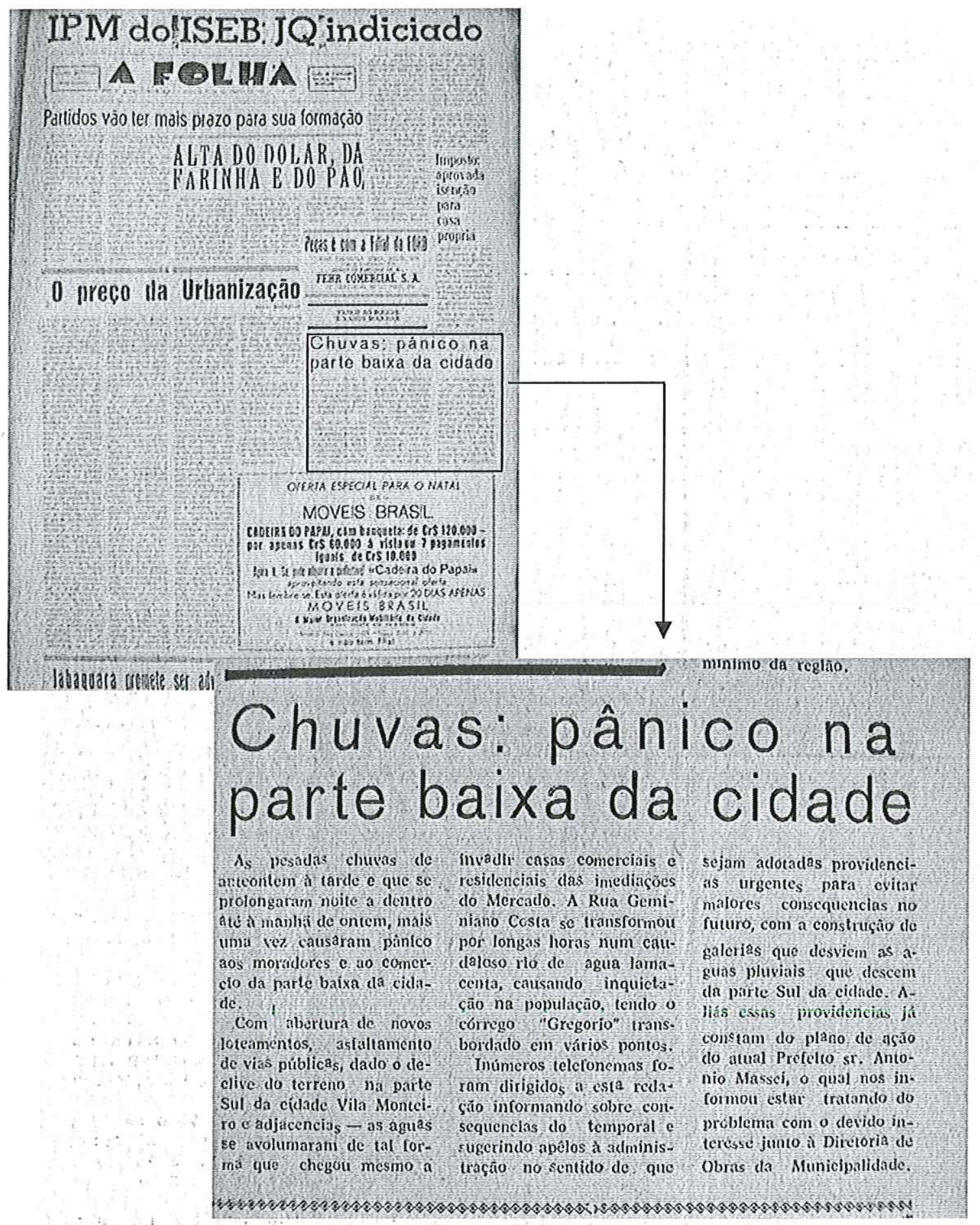

11-12-1965 - Chuvas: pânico na parte baixa da cidade - A Folha 


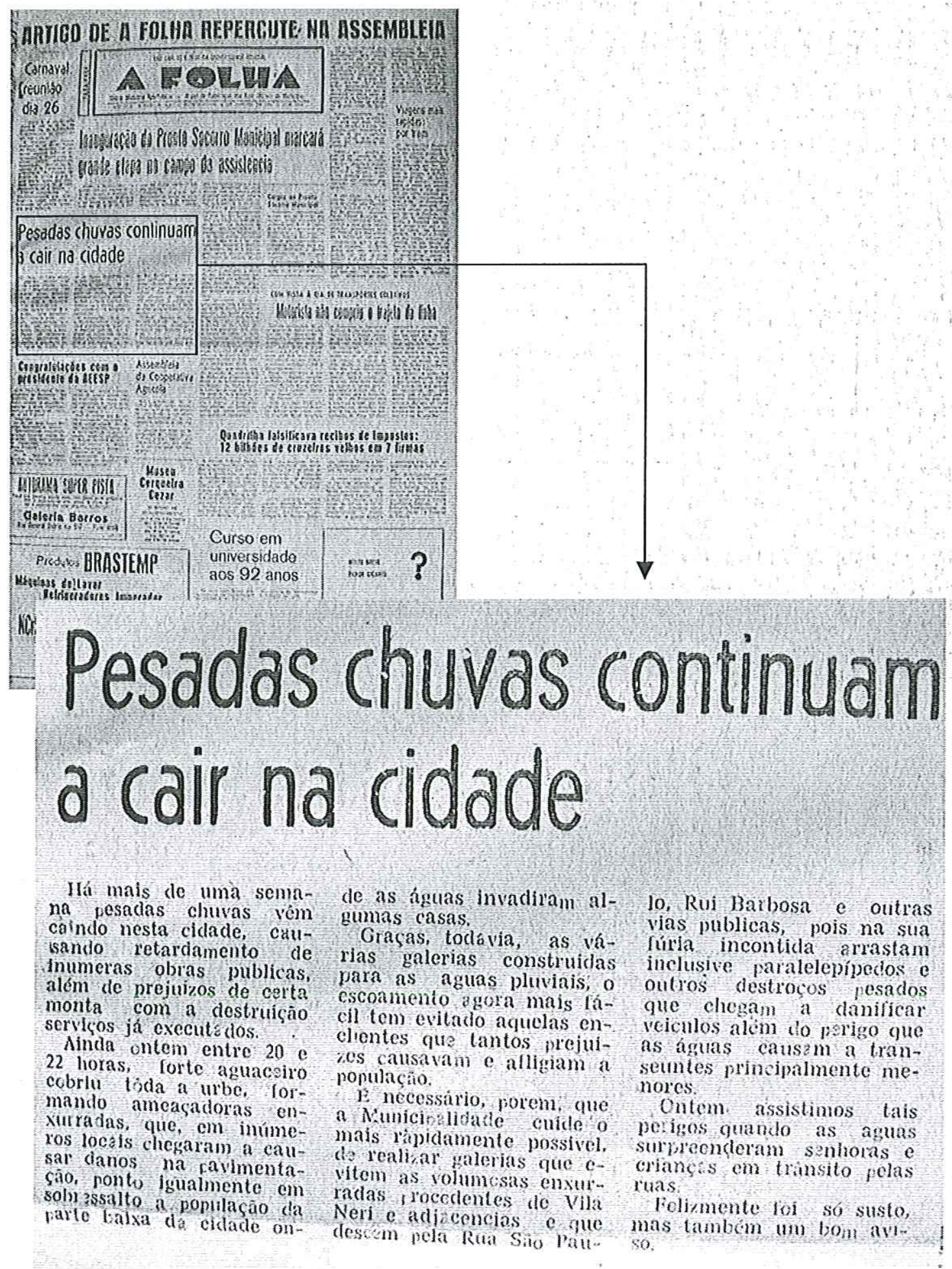

18-01-1968 - Pesadas chuvas continuam a cair na cidade - A Folha 

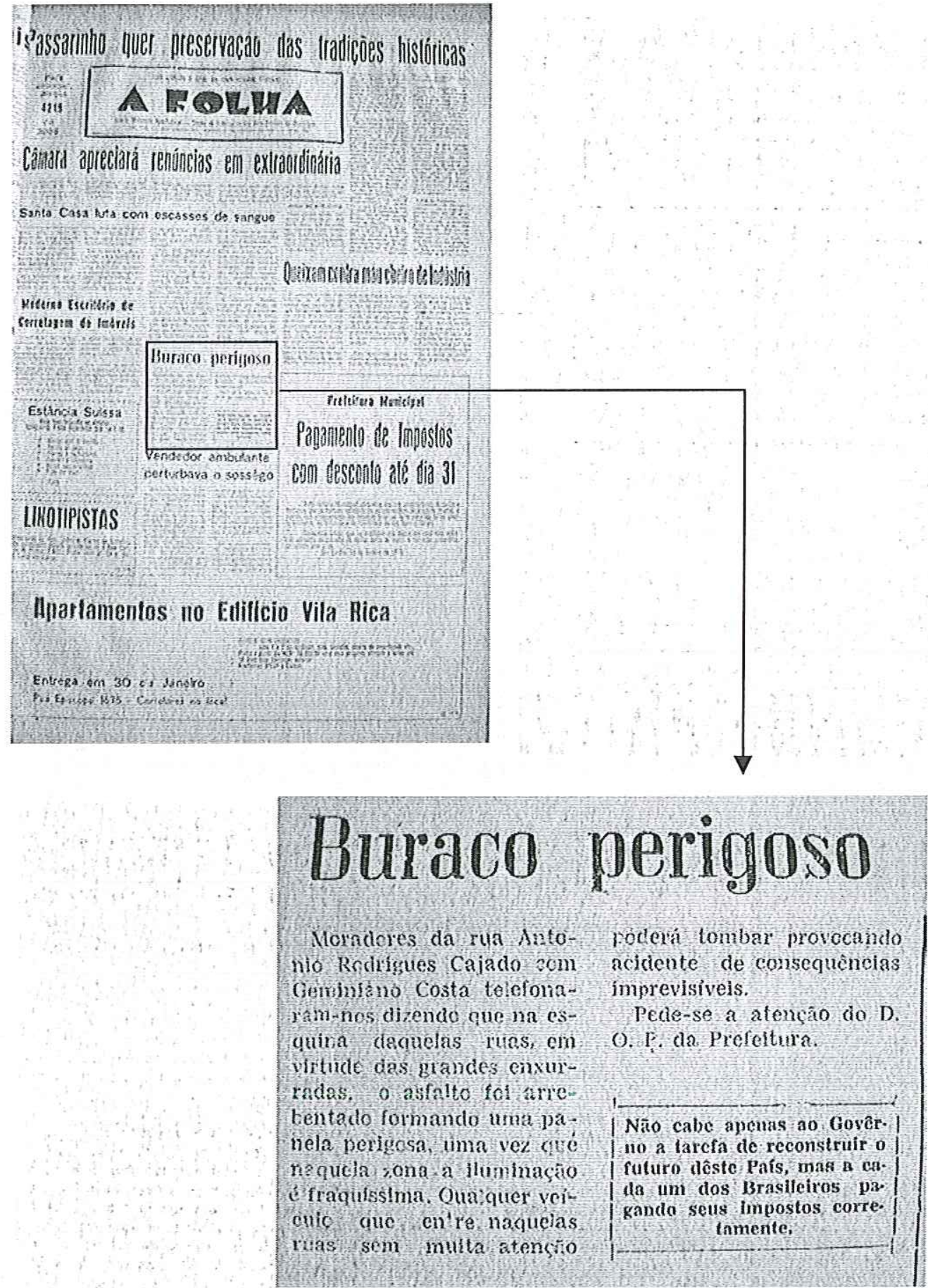

17-01-1970 - Buraco Perigoso - A Folha 

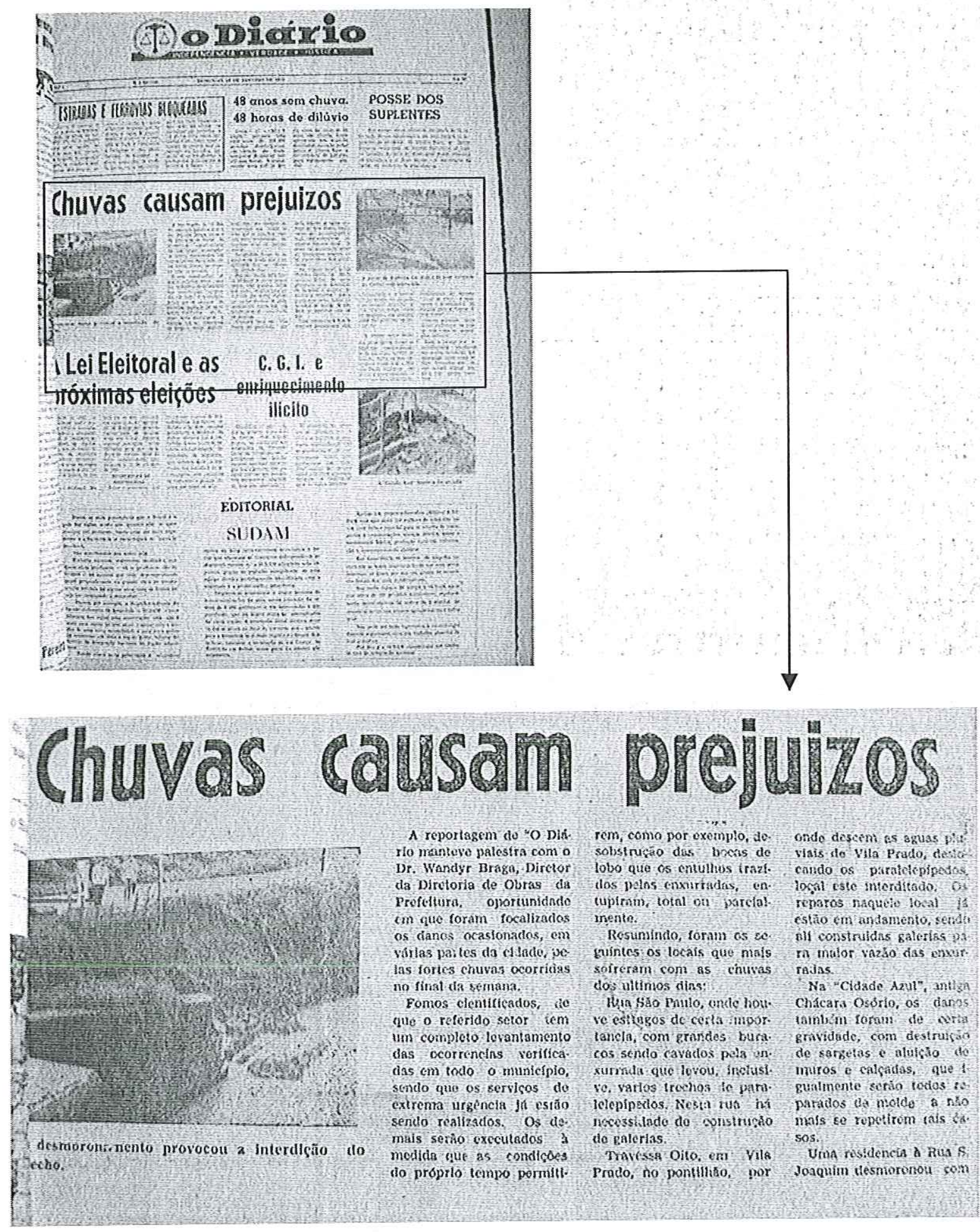

18-01-1970 - Chuvas causam prejuízos - O Diário - Parte 1 


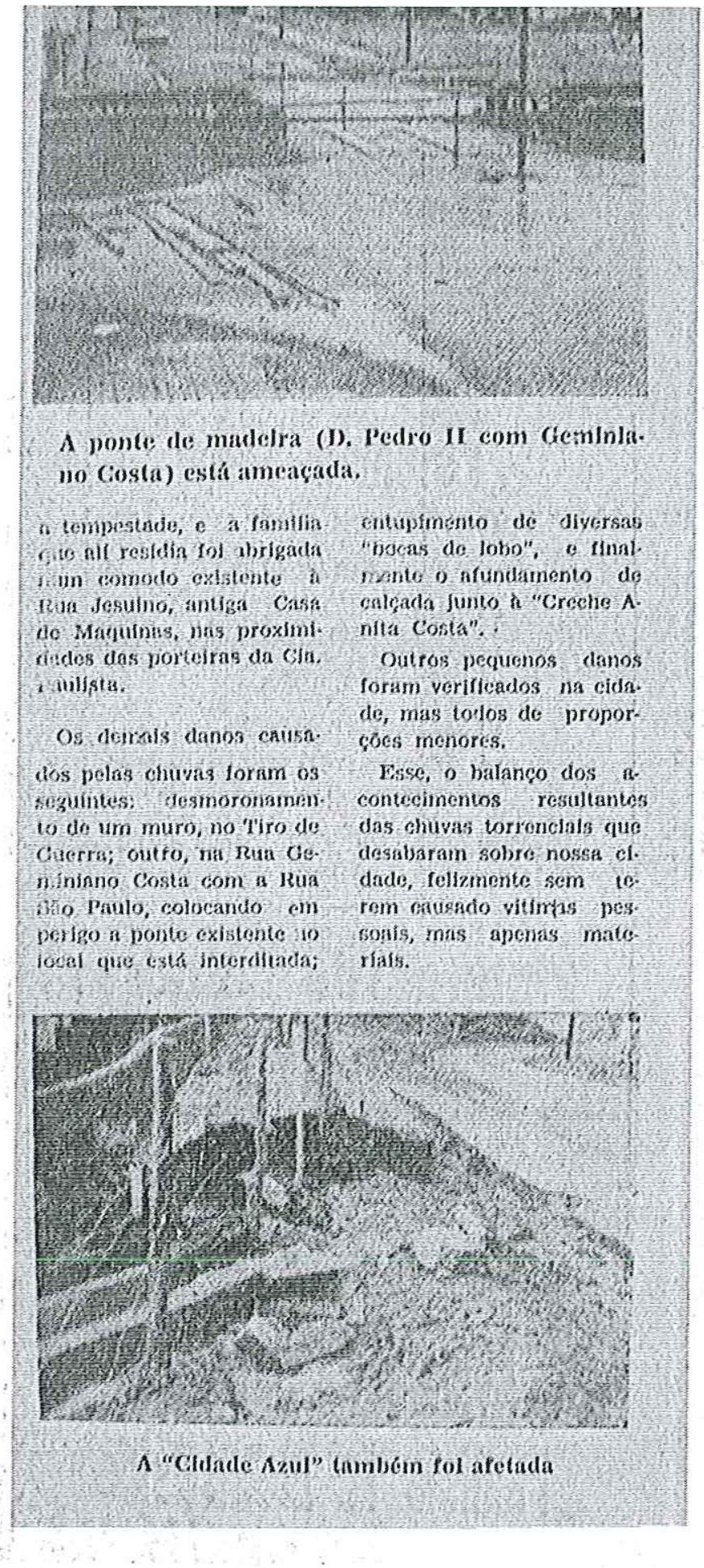

18-01-1970 - Chuvas causam prejuízos - O Diário - Parte 2. 

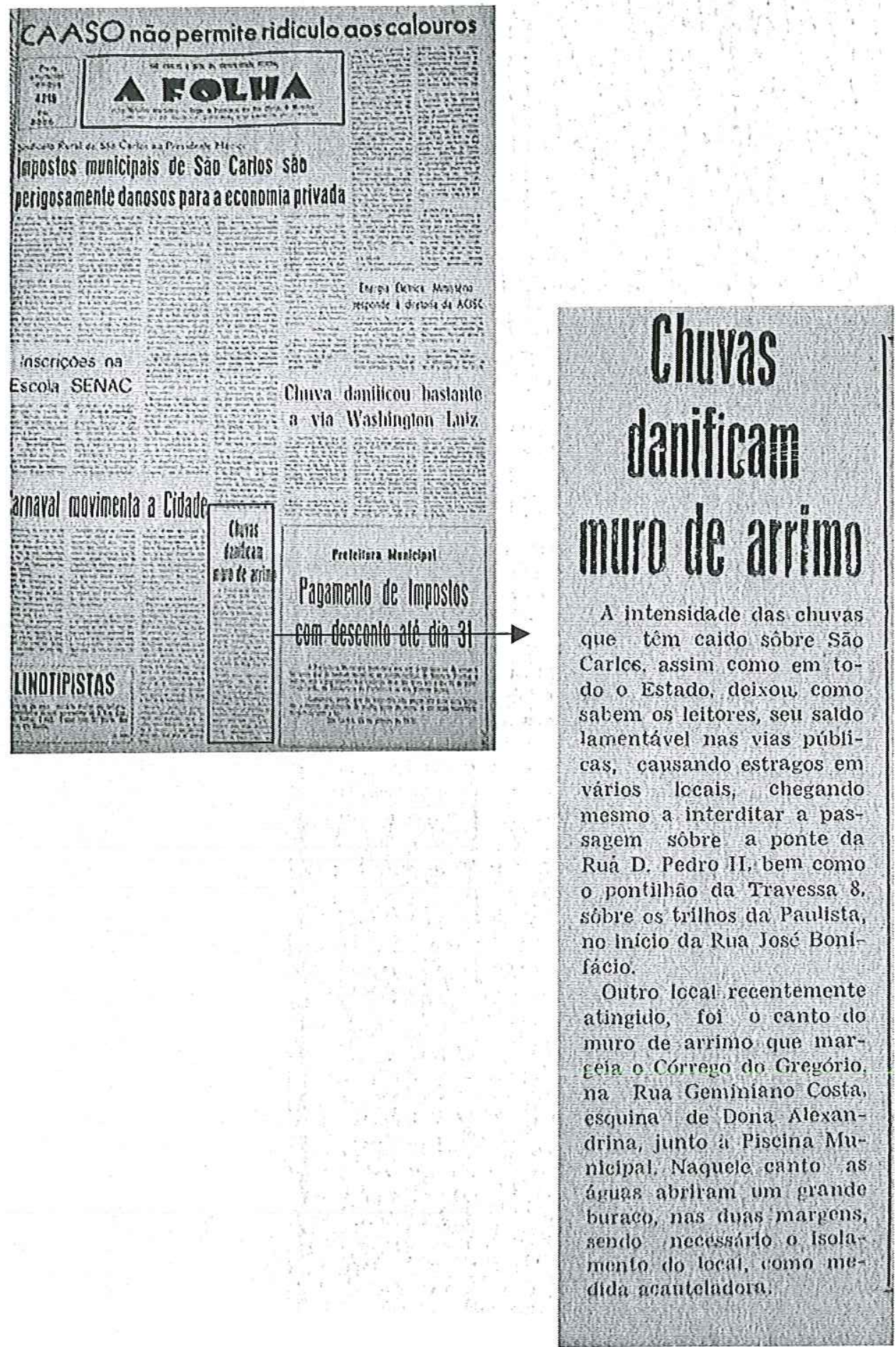

22-01-1970 - Chuvas danificam muro de arrimo - A Folha 

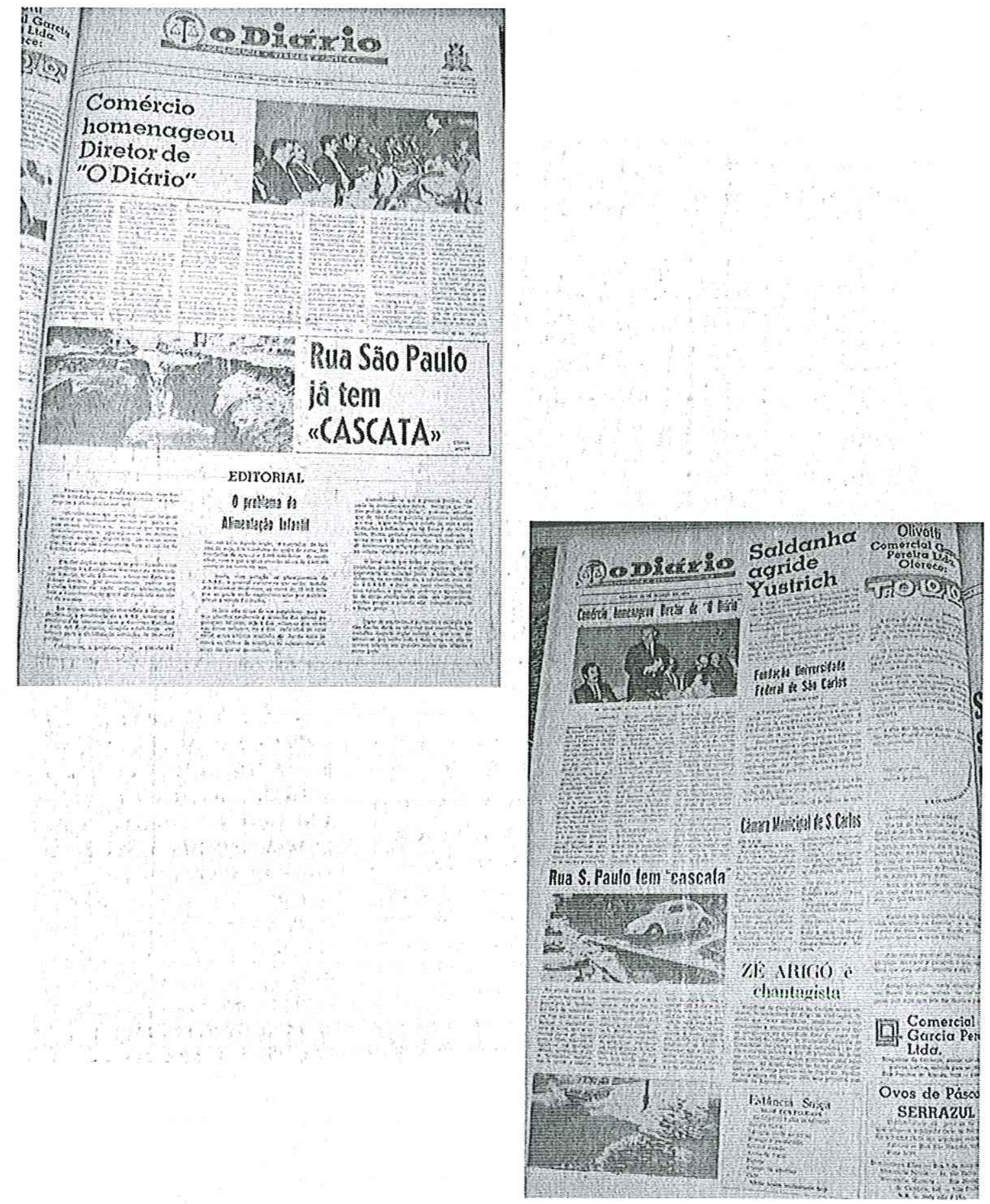

14-03-1970 - Rua São Paulo já tem cascata - O Diário - Parte 1 


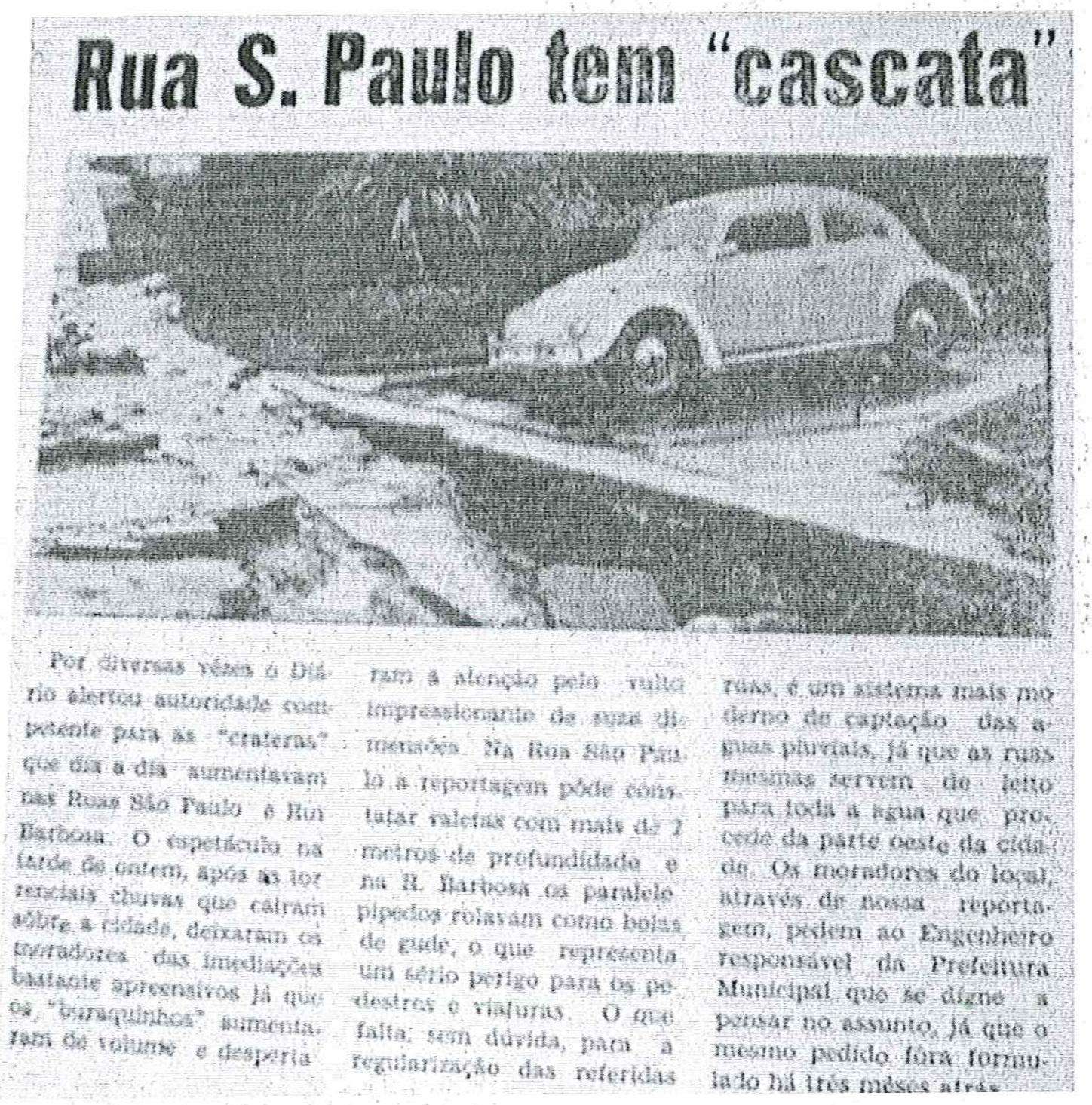

14-03-1970 - Rua São Paulo já tem cascata - O Diário - Parte 2 


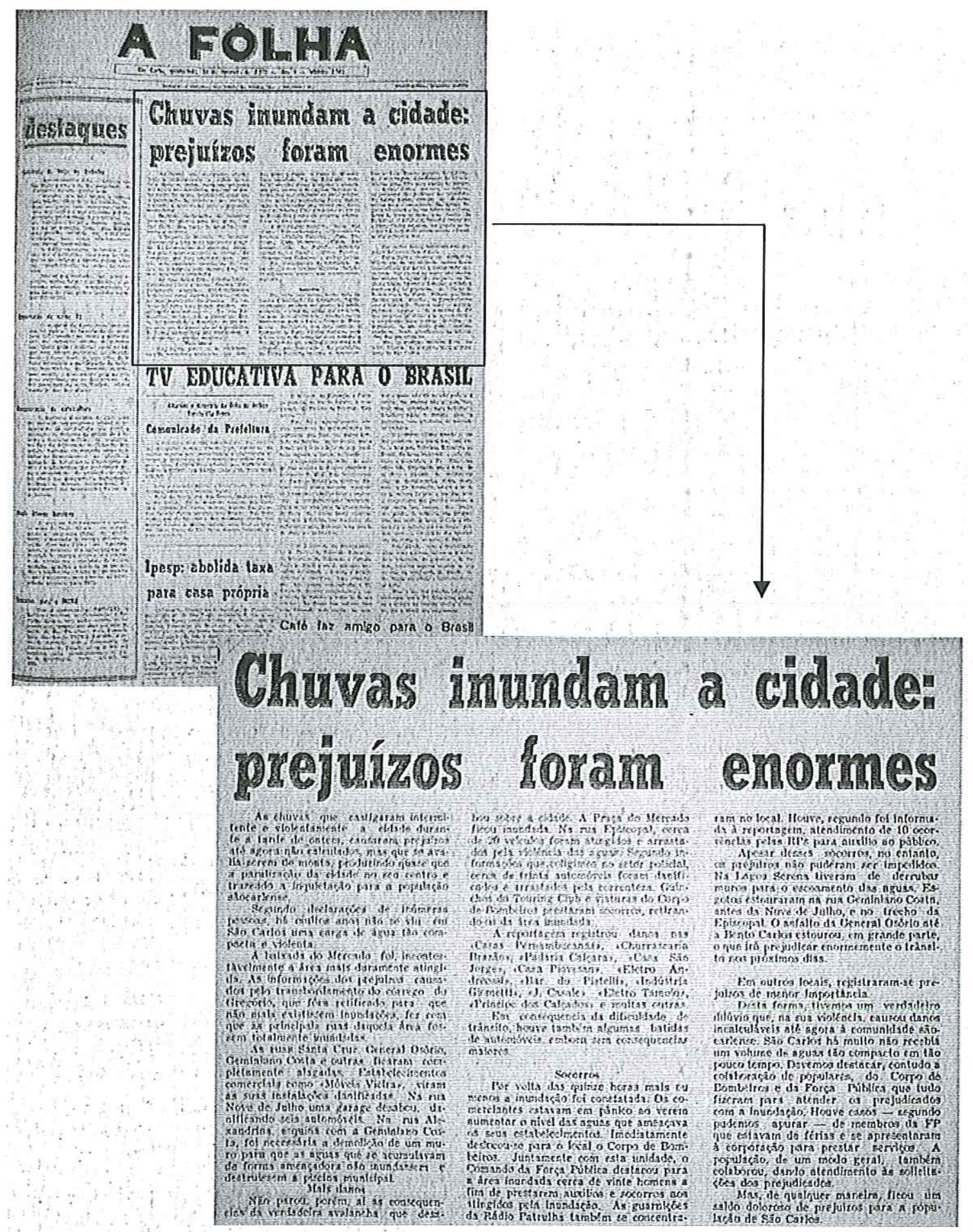

24-02-1972'- Chuvas inundam a cidade: Prejuízos foram enormes - A Folha 

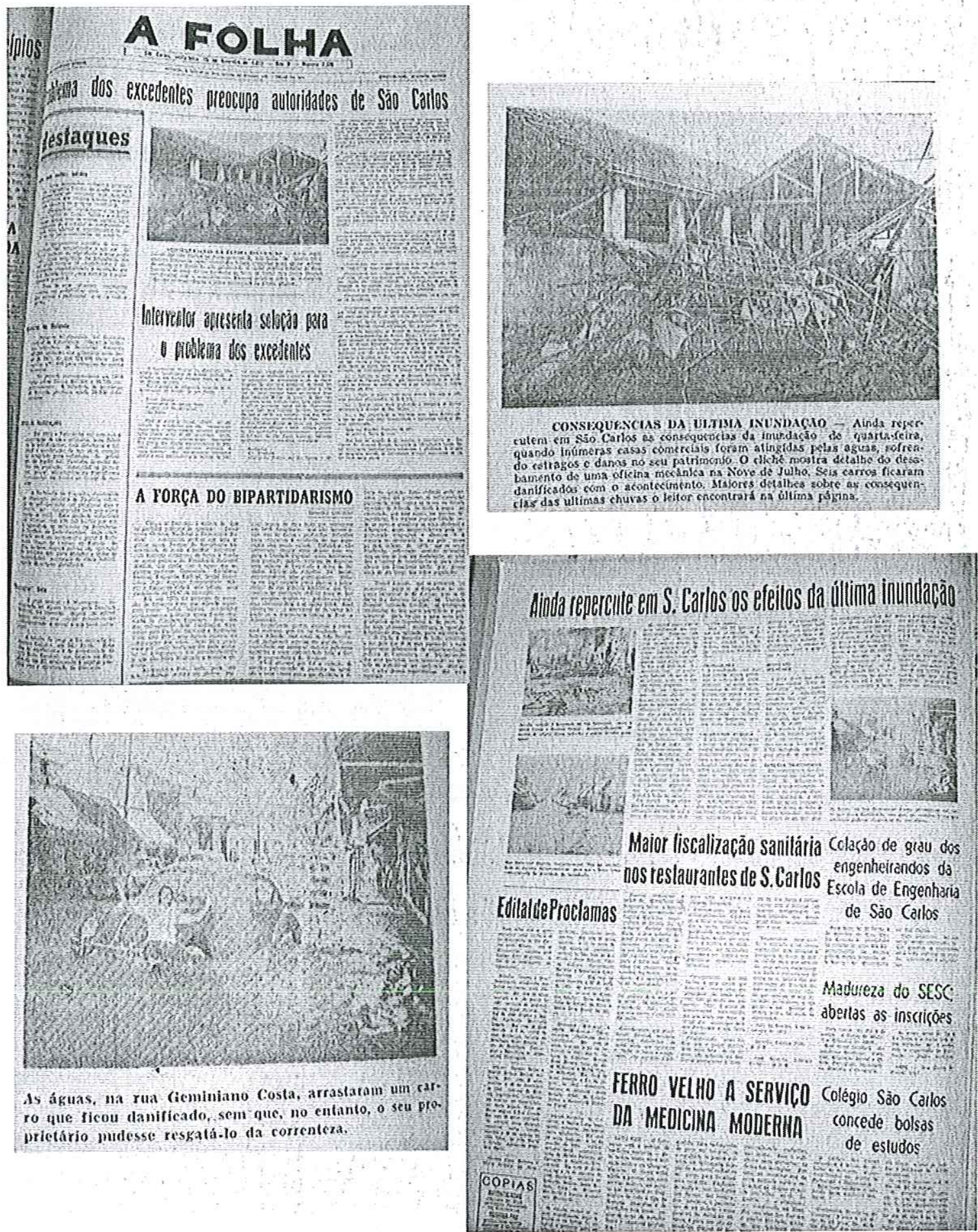

25-02-1972 - Ainda repercute em São Carlos os efeitos da última inundação - A Folha Parte 1 


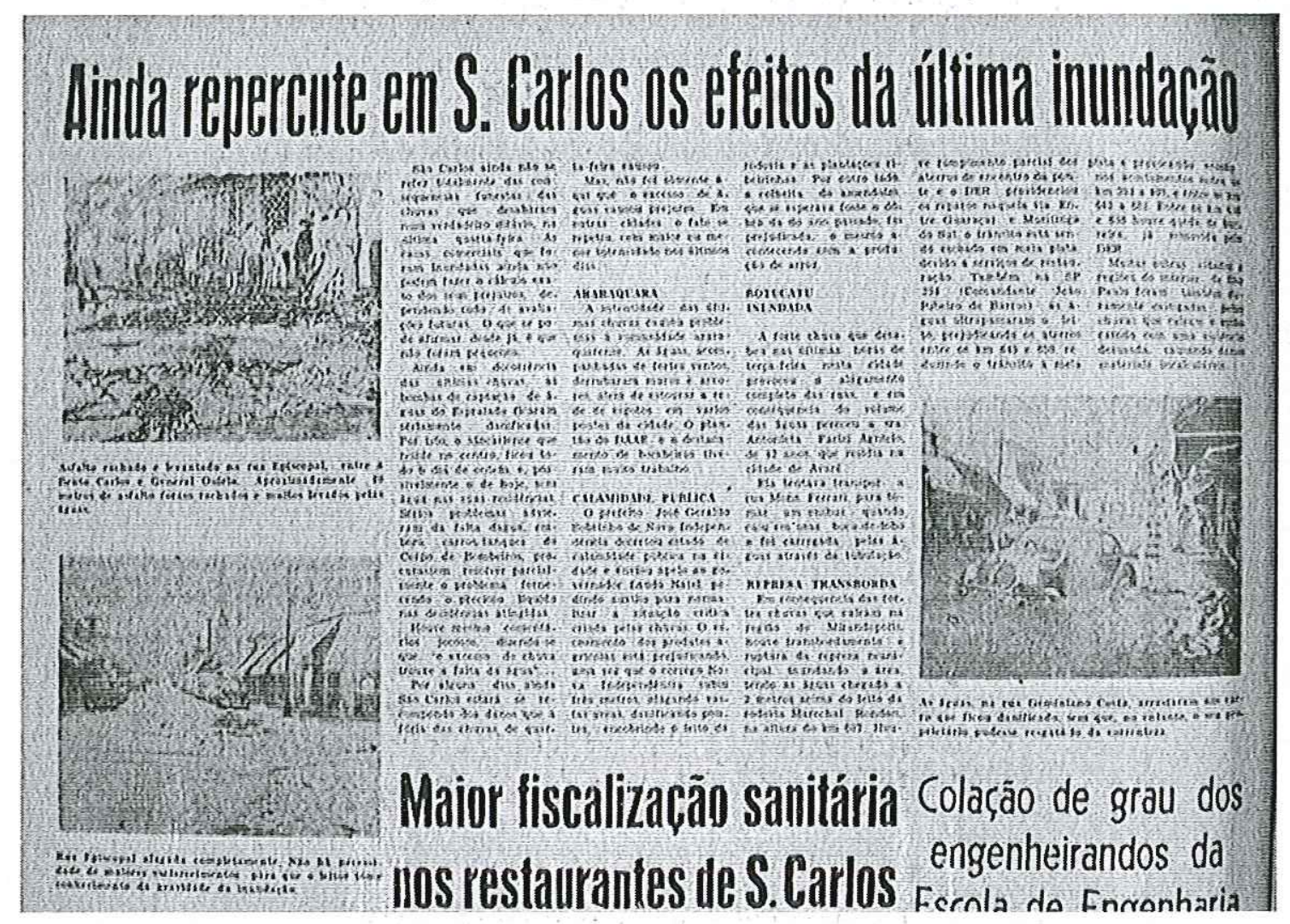

25-02-1972 - Ainda repercute em São Carlos os efeitos da última inundação - A Folha Parte 2 


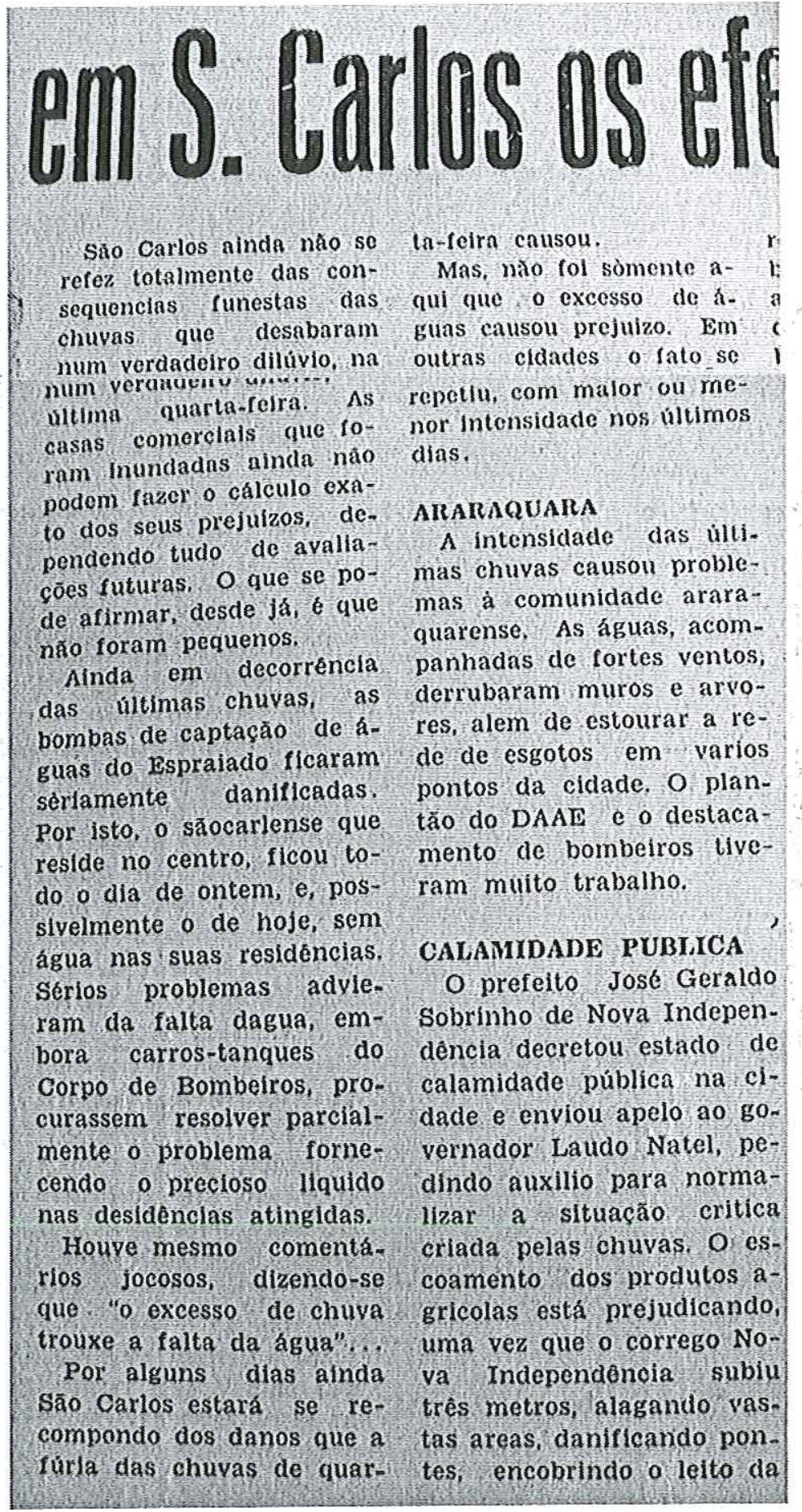

25-02-1972 - Ainda repercute em São Carlos os efeitos da última inundação - A Folha Parte 3 


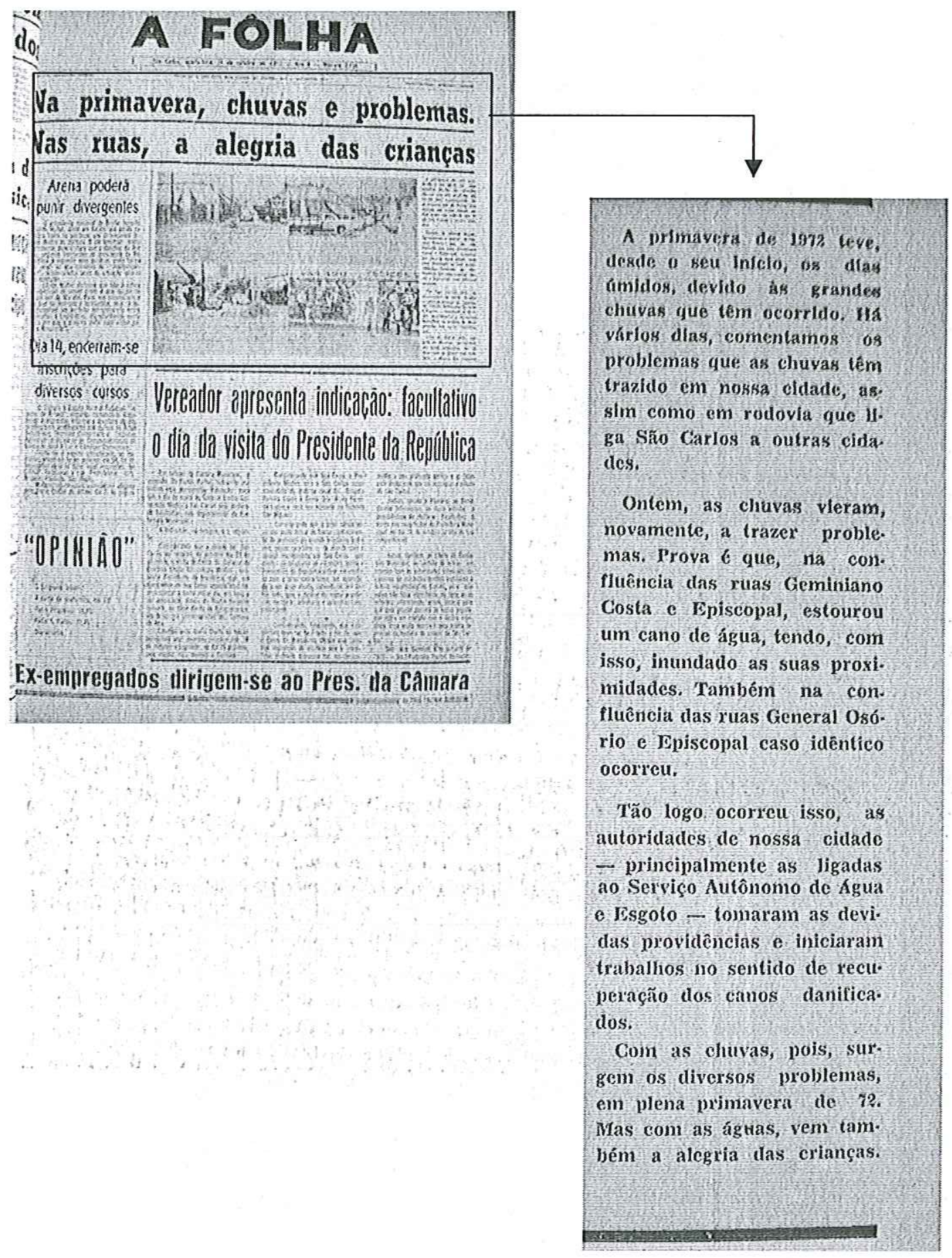

11-10-1972 - Na primavera chụvas e problemas. Nas ruas a alegria das crianças - A Folha - Parte 1 


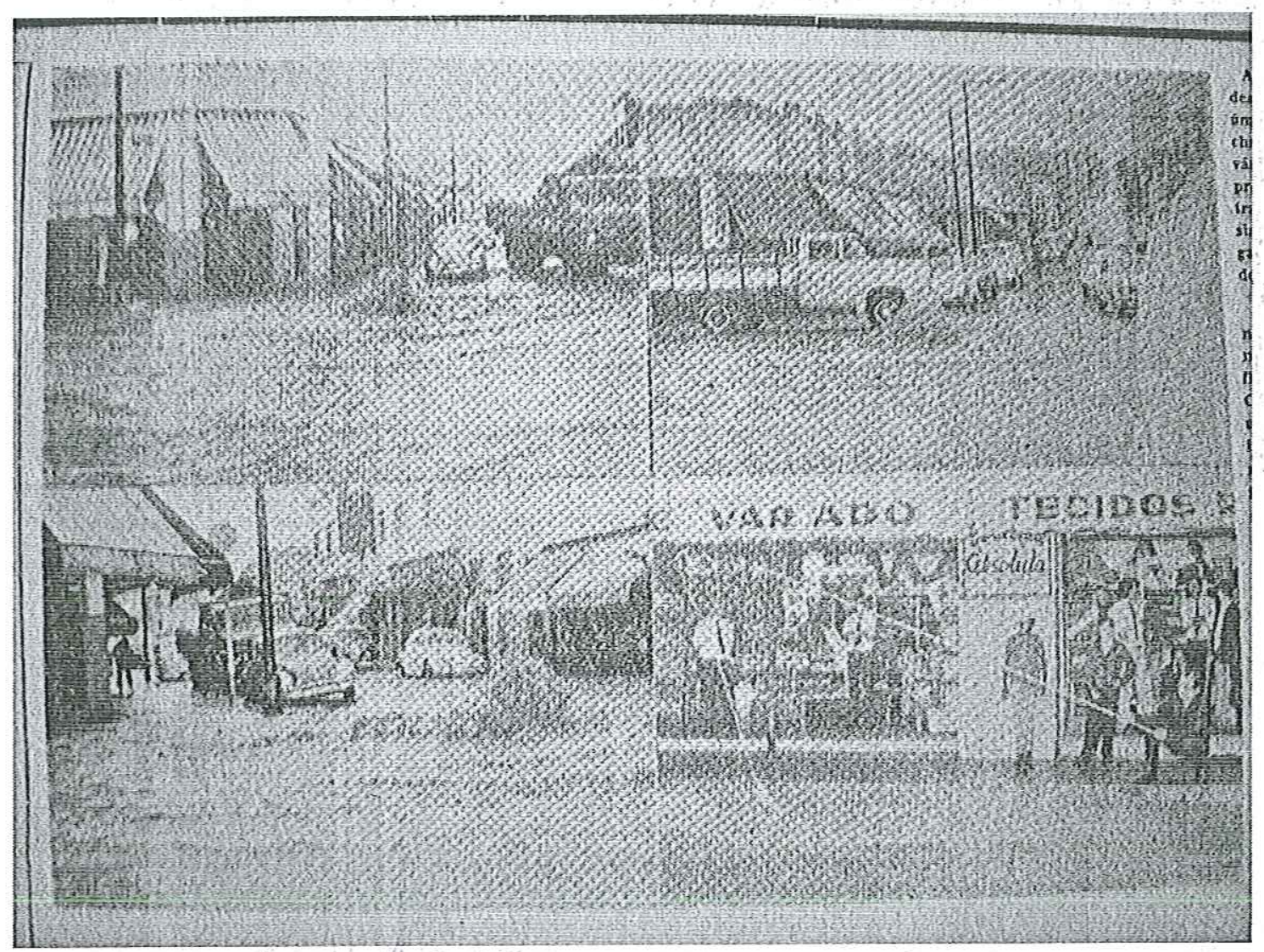

11-10-1972 - Na primavera chuvas e problemas. Nas ruas a alegria das crianças - A Folha : - Parte 2 


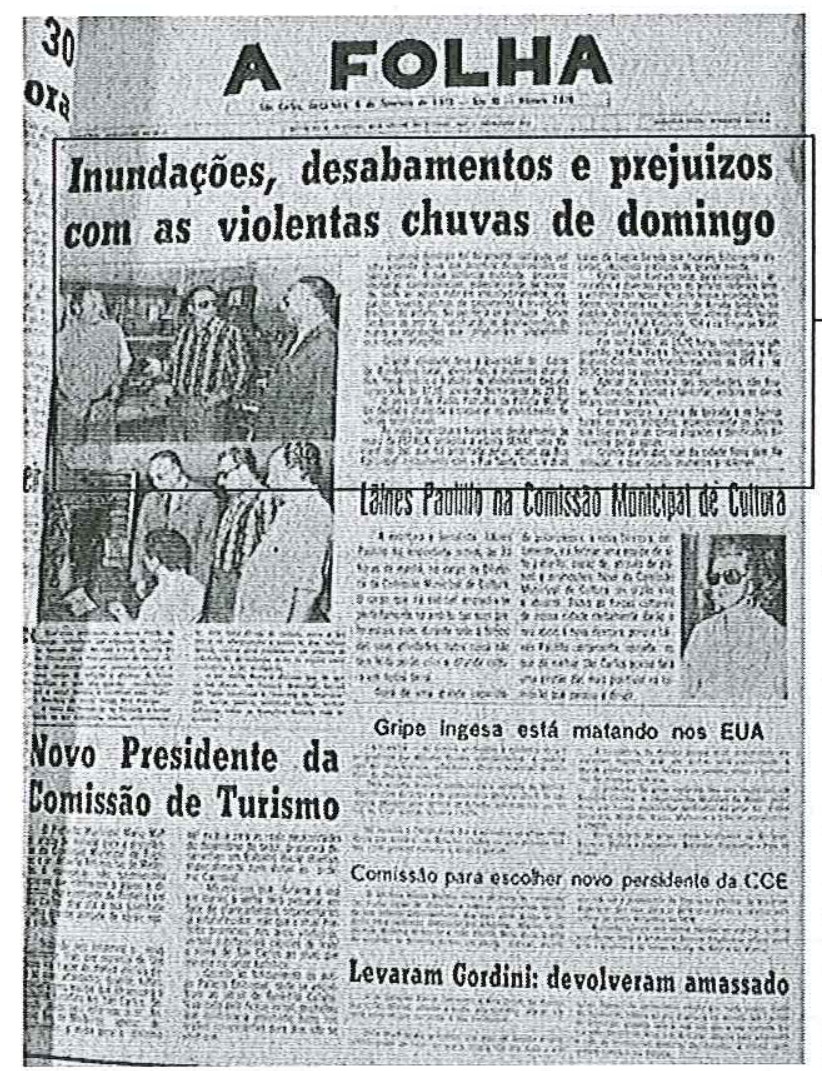

0 ultimo domingo foi duramente castigado por uma violenta cliuva que apanliou despreveniidos os sãocarlenses. A sua violência inusitada provocou inumeras consequencias, especialmente na baixa. da, onde as aguas subiram assustadoramente, ala. gando, levando pedras de calcamento e levantando trechos do asfalto. Na periferia os estragos foram lambém de monta, registrando-se desabamentos de muros e inundacóes que produziram alagamento nas casas atingidas.

Grande atividade teve a guarnicăo do Corpo de Bombeiros local, atendendo a inumeros chama dos, tendo início o trabalho de atendimento daquela corporacảo às 17,55 , somente terminando às 23,30.

0 servico de Radio Patrulha da Policia Militar foi também cliamada a cooperar no atendimento de várias ocorrências.

As mais lamentaveis foram um desabamento de muro da FEPASA, próximo à escola SENAI, Uma Va. riant de Jaú que foi arrastada pelas aguas na Rula Episcopal, cruzamento com a Rua Santa Cruz, e duas casas da Lagoa Serena que ficaram totalmente ala. gadas, causando preiuizizos de grande monta.

Várias ruas tiveram seus paralelepipedos ar. rancados e diversas partes do asfalto cederam ante a violência das aguas. No asilo houve inundacâo sem danos. Unia casa na Jesuino de Arruda também fo alagada. Outras inundações sem vítimas ainda foram verificadlas na Rua Visconde, 926 e na Treze de Maio. esquina com a Rui Barbosa.

Por outro lado, as 15,20 horas registroul-se um incendio na Rua Padre Teixeira, esquina com a Ro. drigues Cajado nos transformadores da CPE $e$ às 20,30 horas na agencia Discasa.

Apesar da violéncia das inundacões, não hiou. ve, felizmente, vitimas a lamentar, embora os danos selam consideraveis.

Como sempre, a zona da baixada e os bairros foram os mais atingidos, especialmente os ultimos que tiveram varias casas alagadas e danificadas du. ramente pelas agulas.

Grande parte das ruas da cidade ficou sem ilu. minação, o que causou inumeros problemas.

06-02-1973 - Inundações, desabamentos e prejuízos com as violentas chuvas de domingo A Folha 


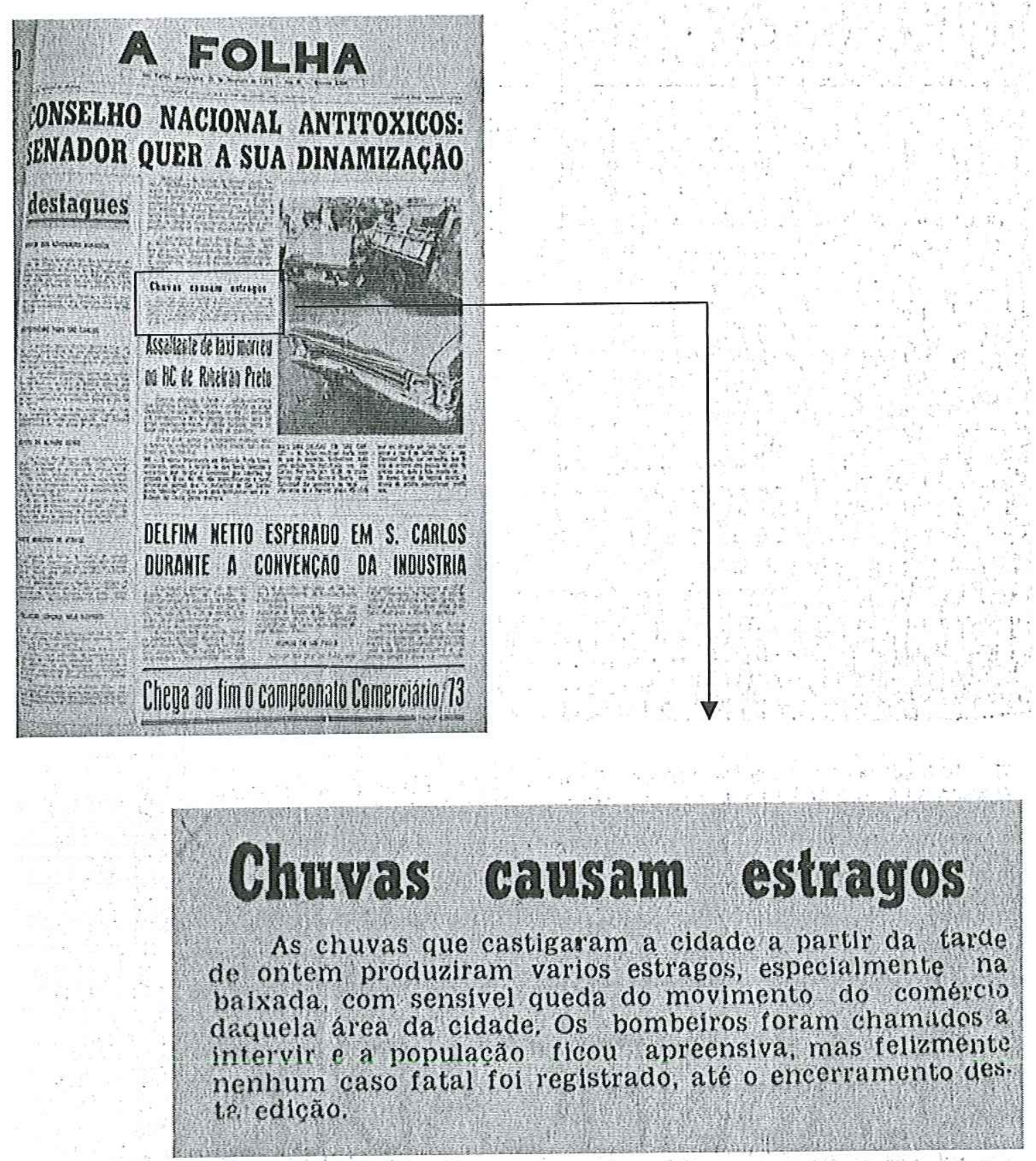

21-02-1973 - As chuvas - A Folha 

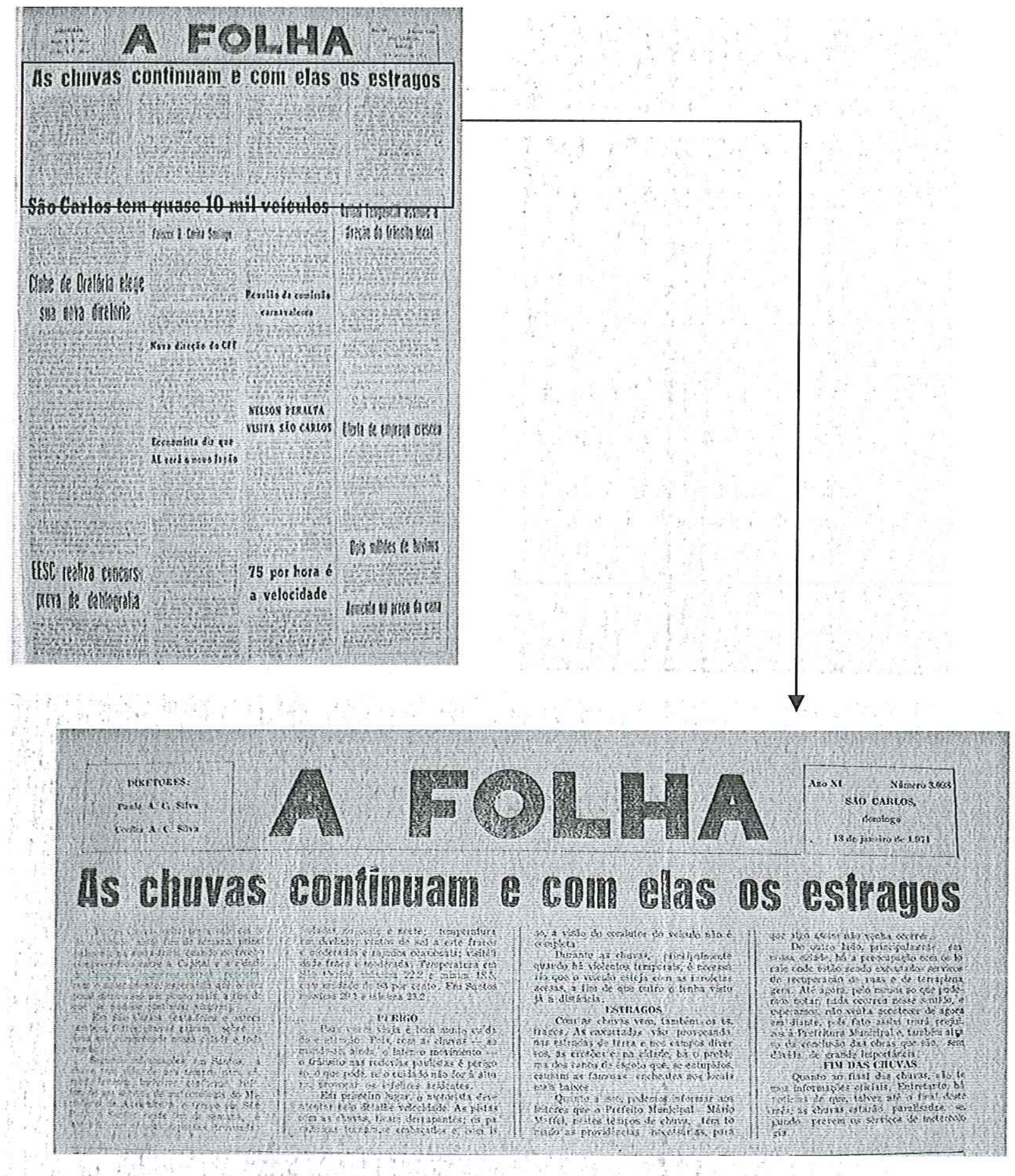

13-01-1974 - As chuvas continuam e com elas seus estragos - A Folha 

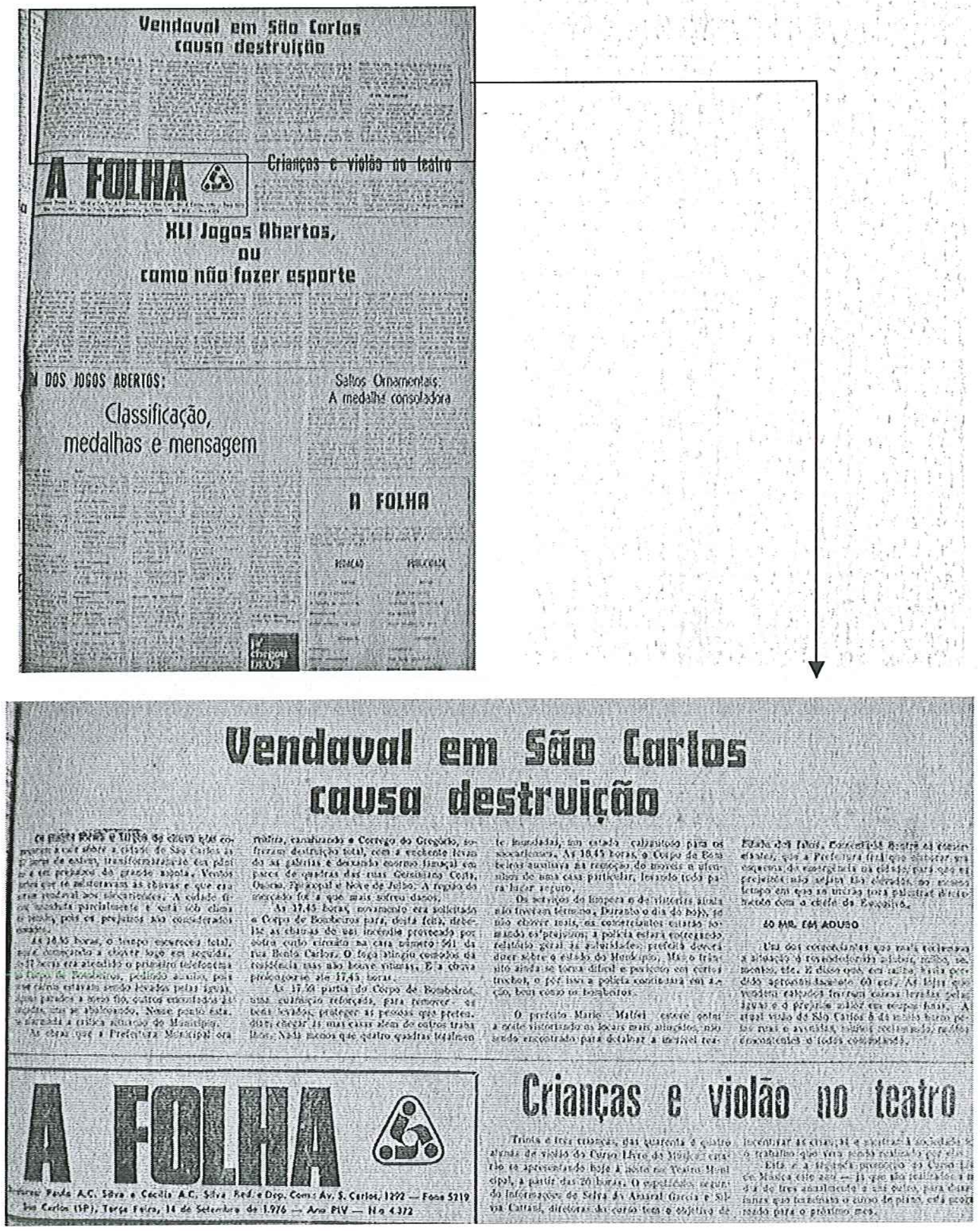

14-09-1976 - Vendaval em São Carlos causa destruição - A Folha 


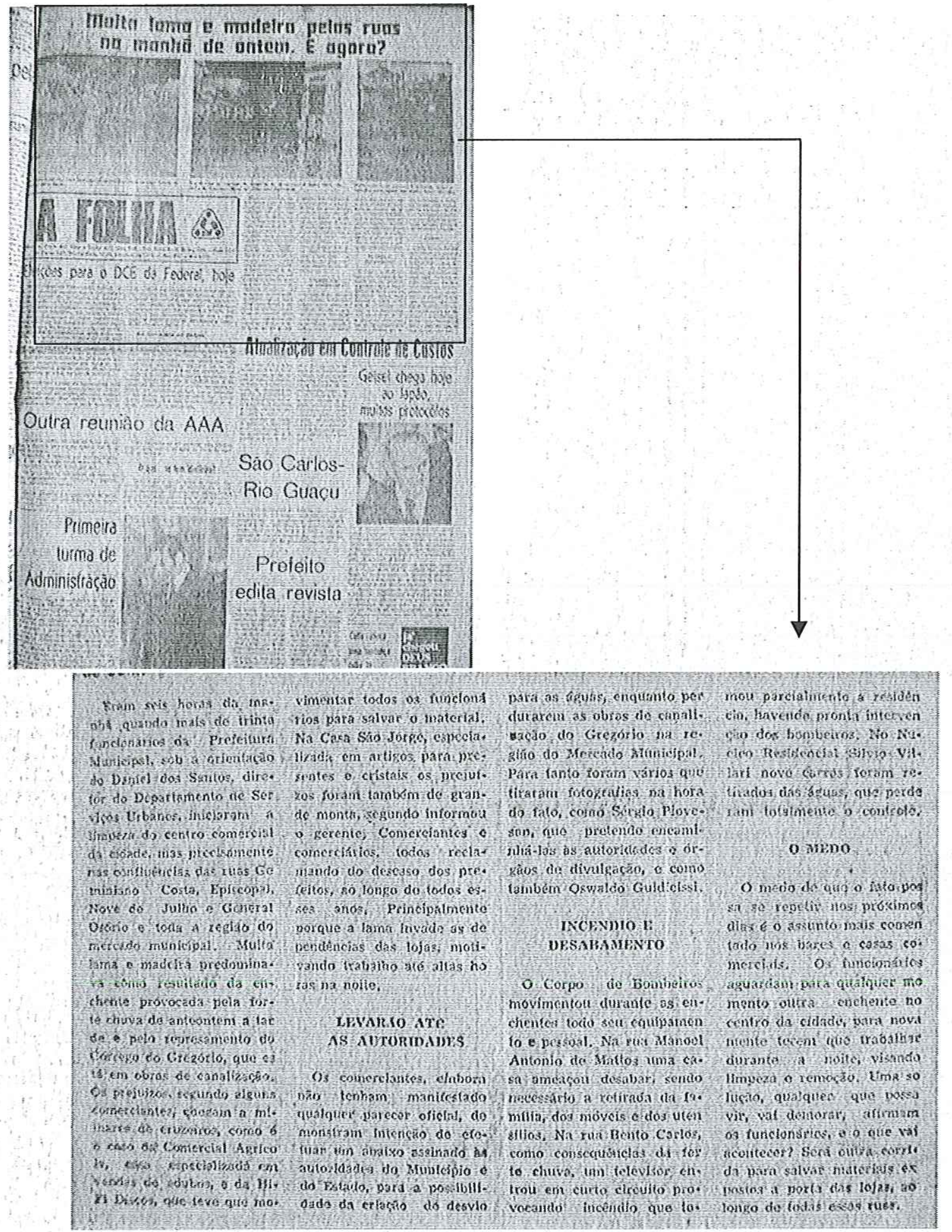

15-09-1976 - Muita lama e madeira nas ruas na manhã de ontem. E Agora? - A Folha 


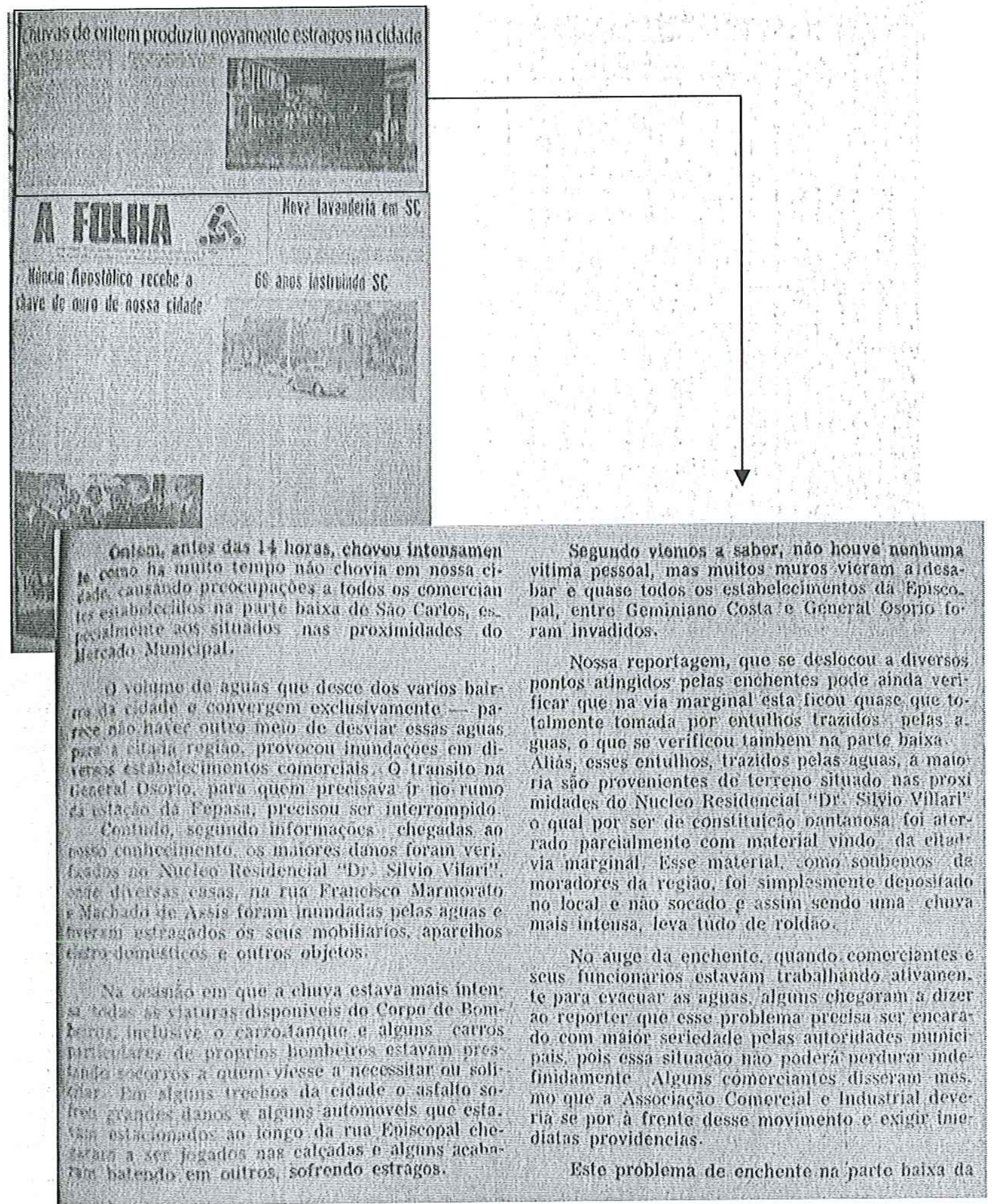

\section{2-03-1977 - Chuvas de ontem produziu ( sic) novamente estragos na cidade - A Folha}




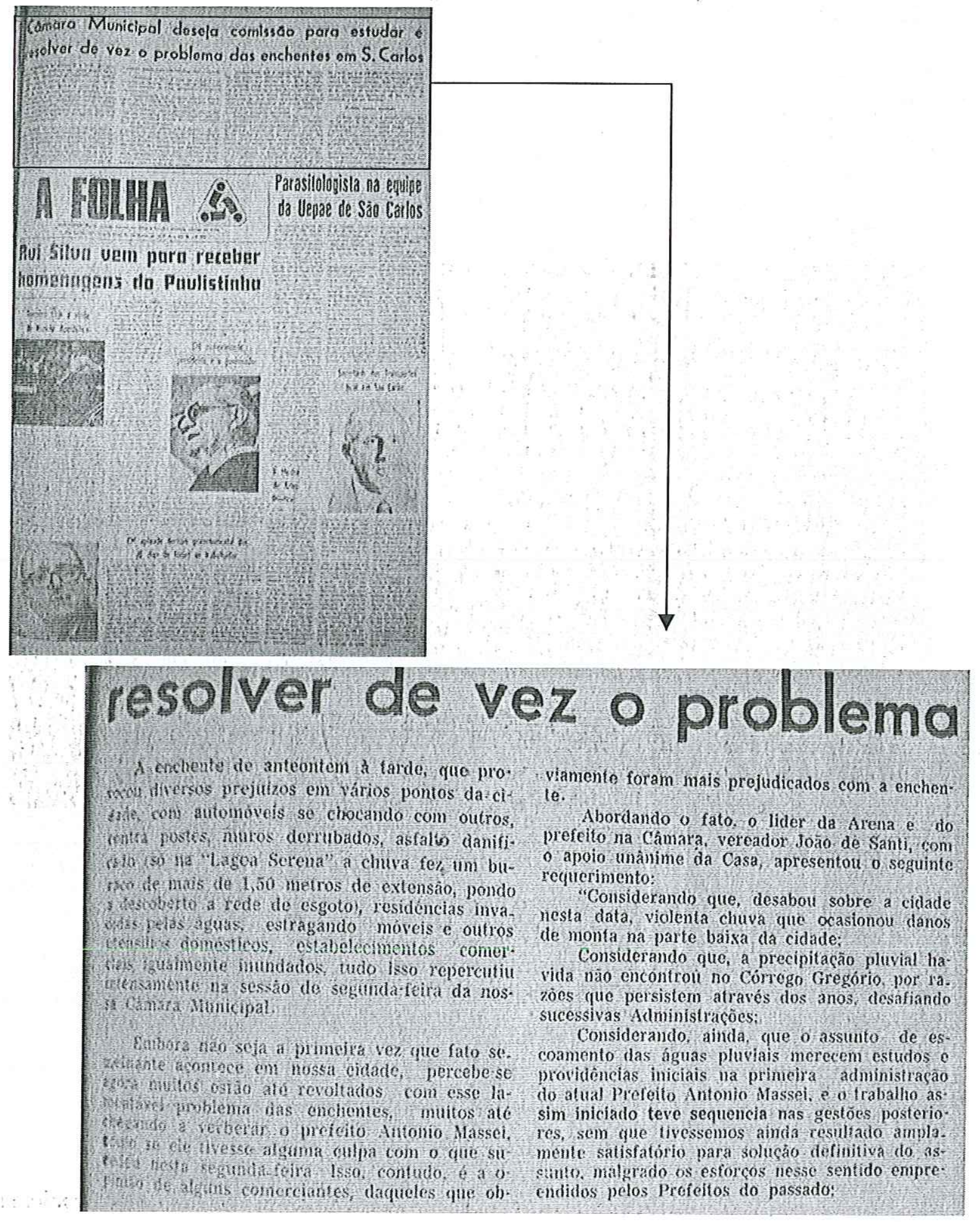

23-03-1977 - Câmara municipal deseja comissão para estudar e resolver de vez o problema das enchentes em S. Carlos - A Folha - Parte 1 


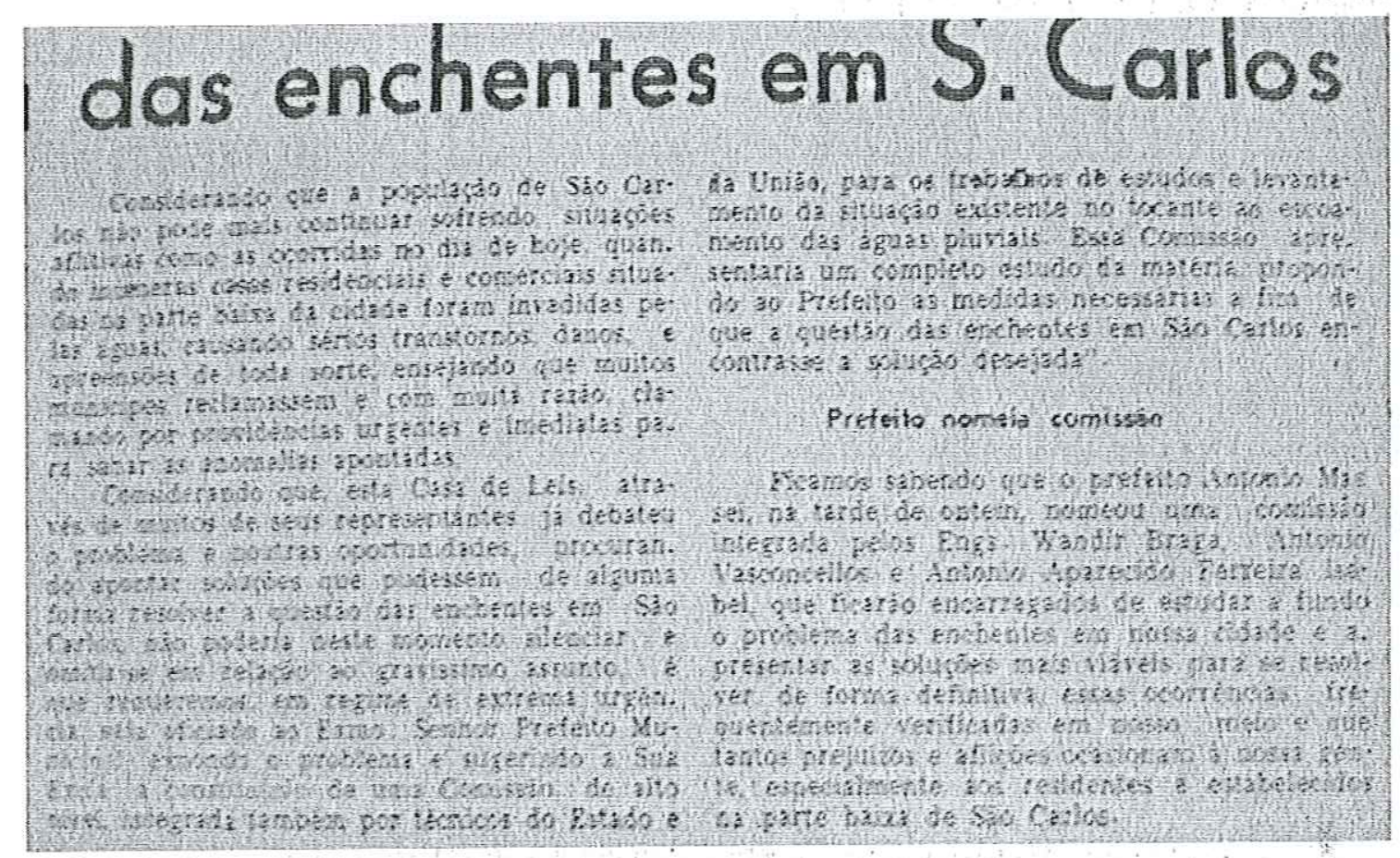

23-03-1977 - Câmara municipal deseja comissão para estudar e resolver de vez o problema das enchentes em S. Carlos - A Folha-Parte 2 


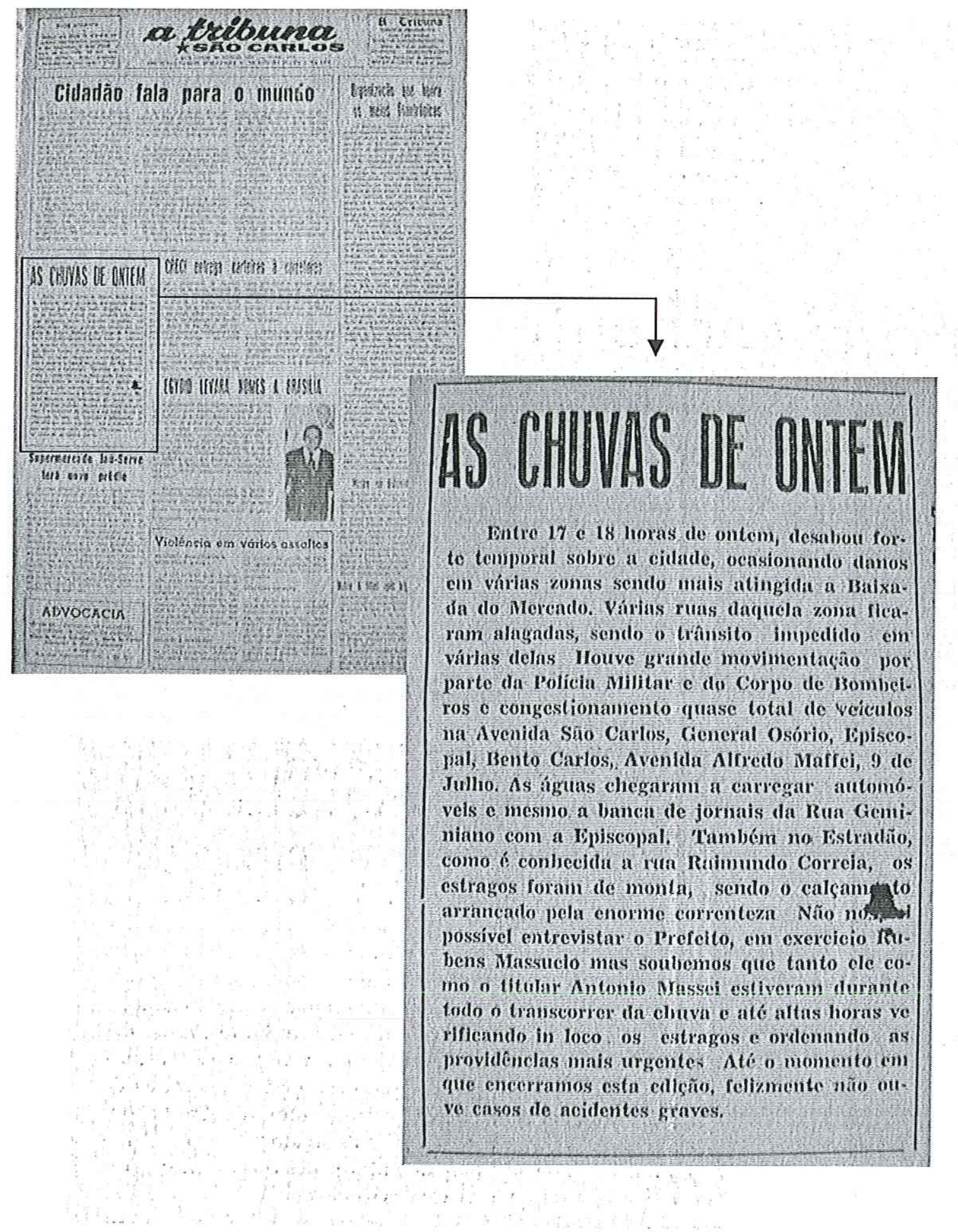

10-01-1978 - As chuvas de ontem - A Tribuna 

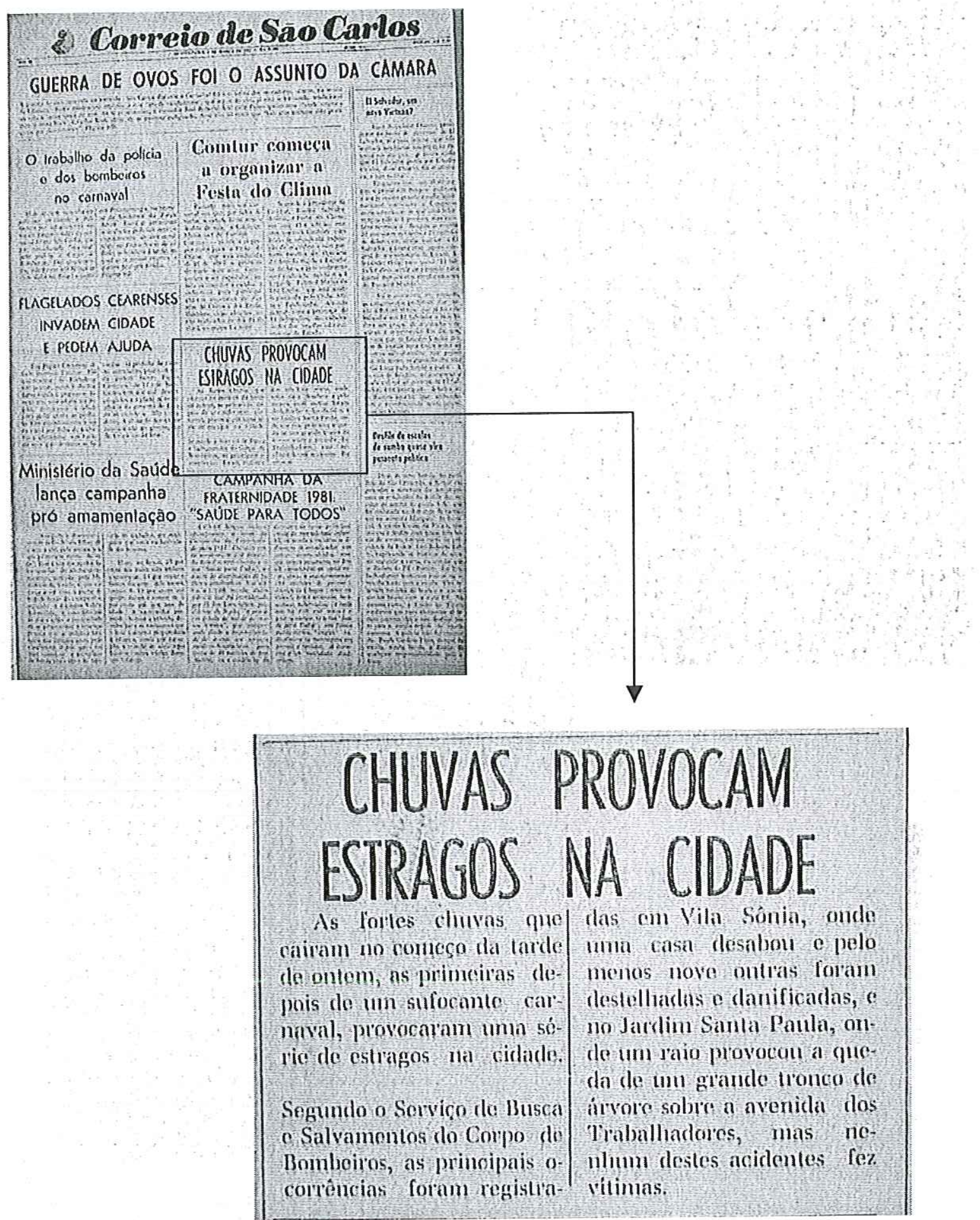

05-03-1981 - Chuvas provocam estragos na cidade - Correio de São Carlos 

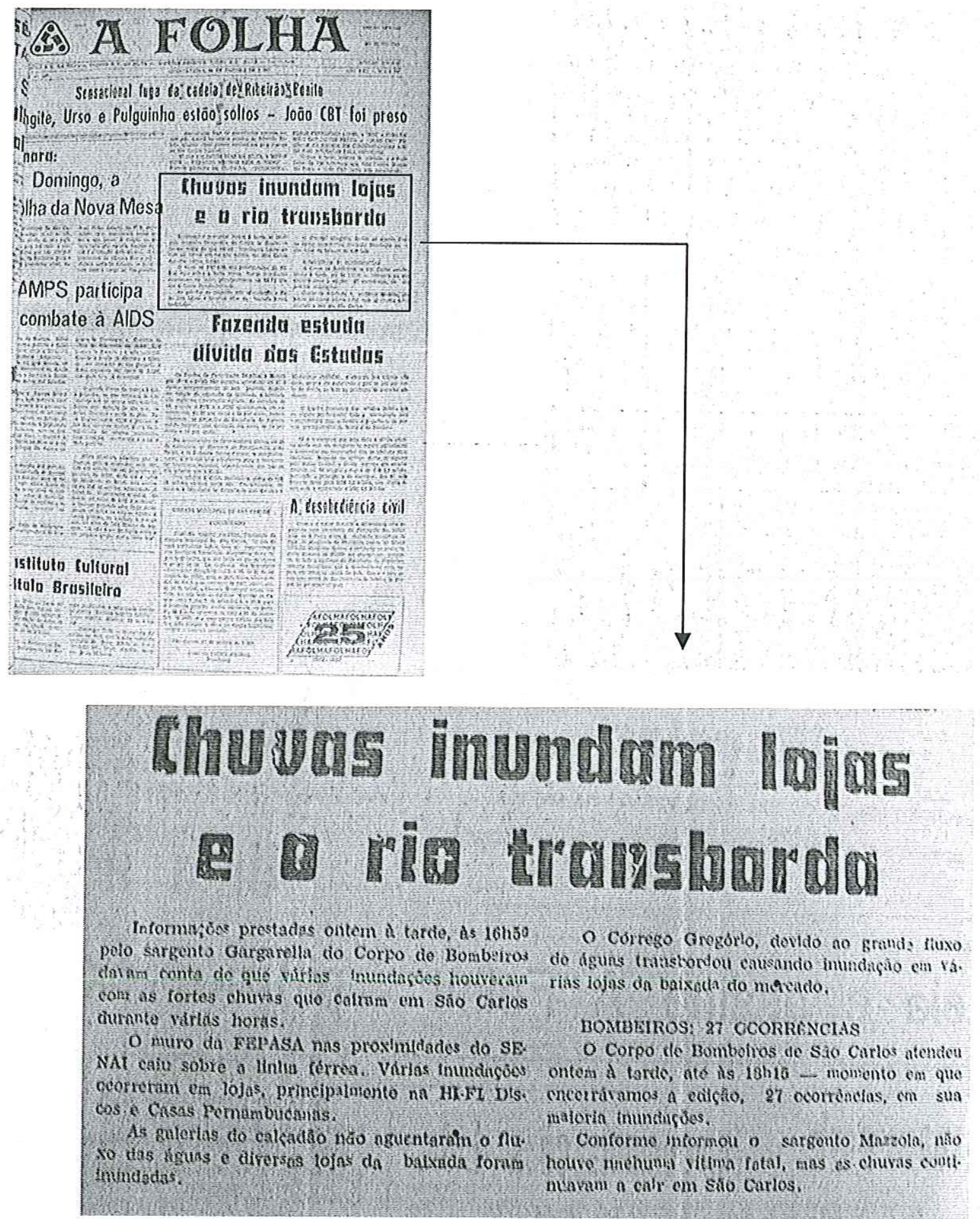

28-01-1987 - Chuvas inundam lojas e o rio transborda - A Folha 

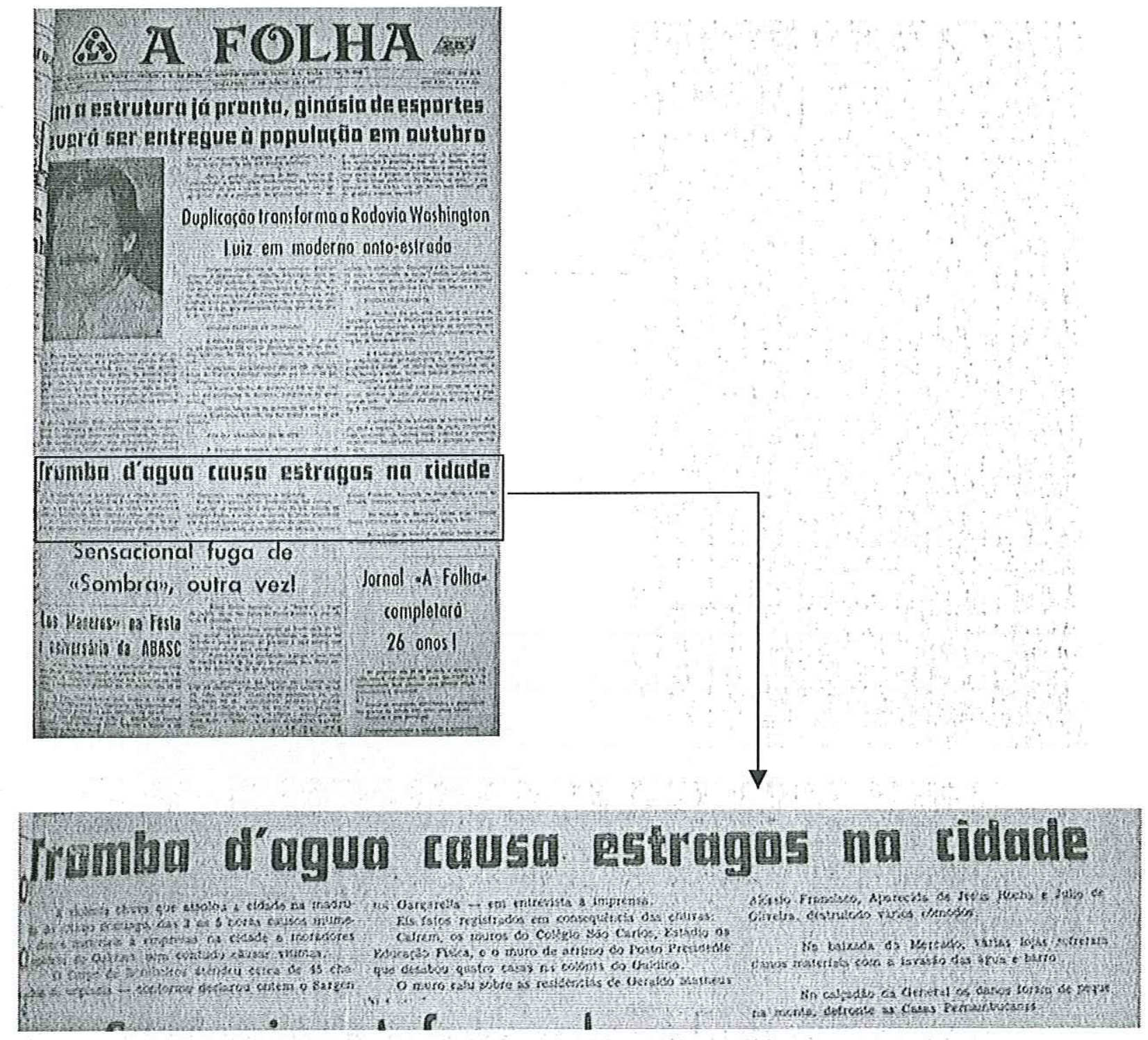

12-01-1988 - Tomba d'água causa estragos na cidade - A Folha 


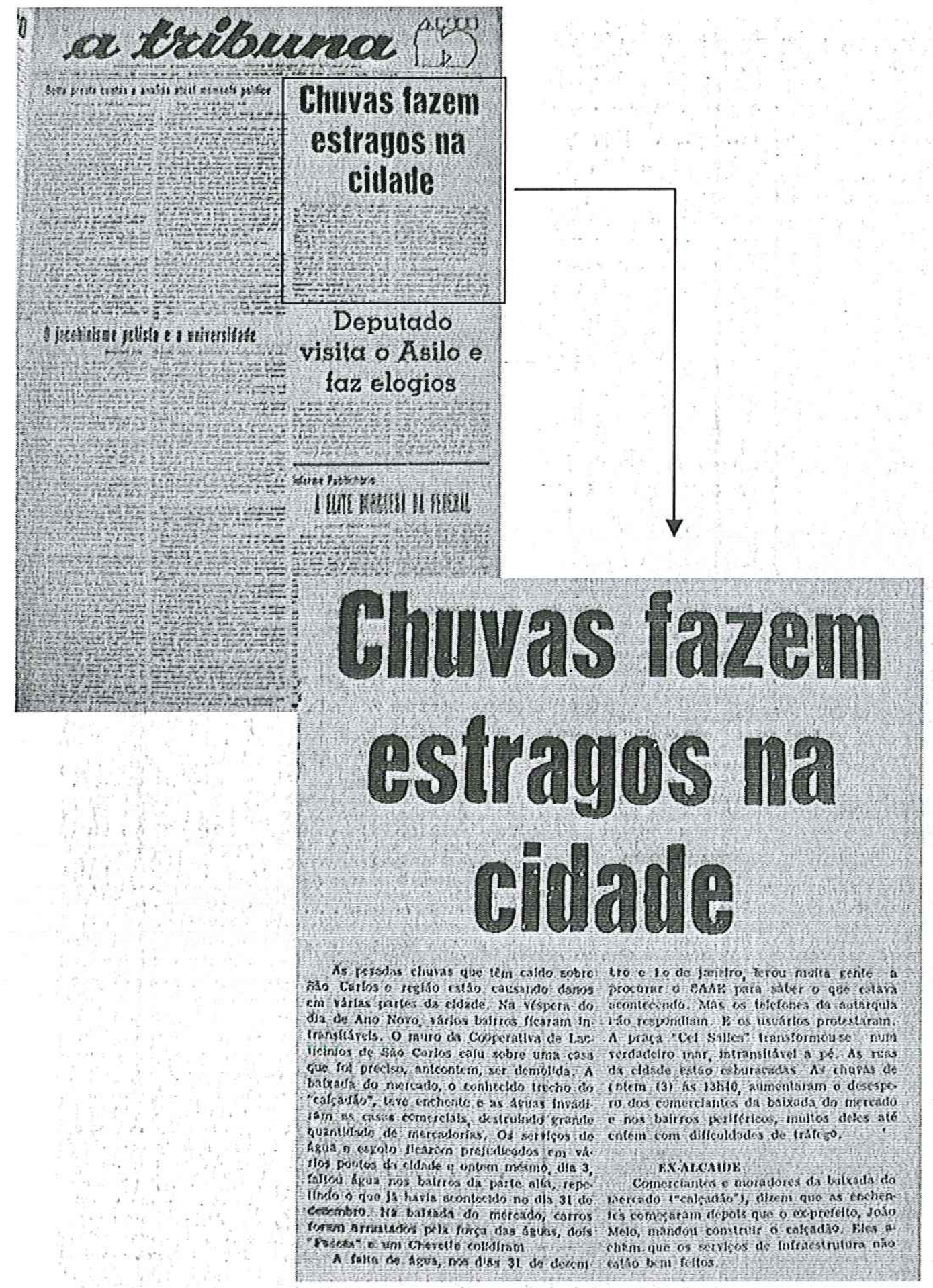

03-01-1990 - Chuvas fazem estragos na cidade - A Tribuna 


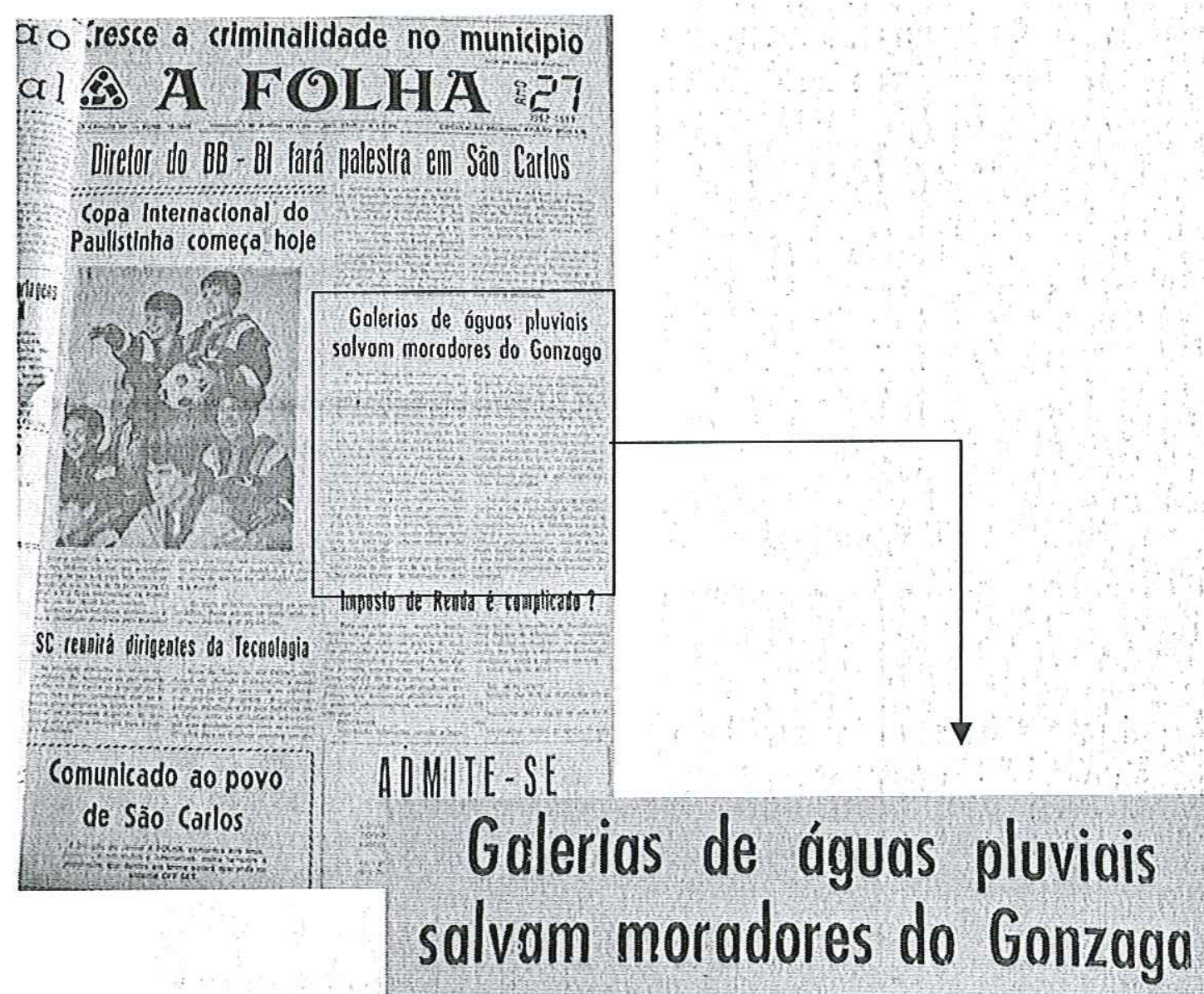

As forlos chuvas quo cairam na noito Comunitára da Presídencia da Ropublica, do 31 do dezembro o causaram sérios di Soricriado Comunitaria do llabilactón pop nos con toda a cidacle, principalmente na Jar a a PROHAB - Sảo Canlos, Aposat de

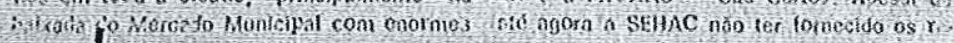

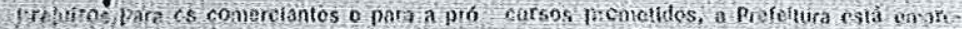

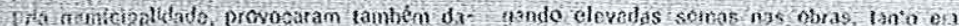

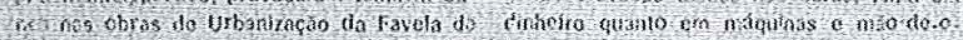

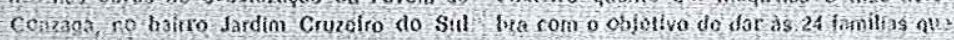

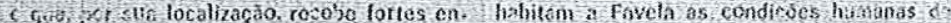

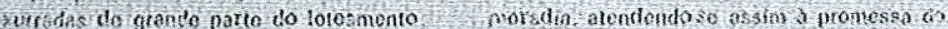
Fotrotano. cracas às várias linhas de inetśto Vadinho do Guzzl de integtar agage

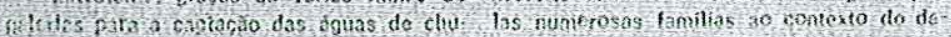

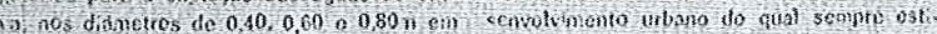
va maior parte iniplentalas na área ear ur- Scram marginalizadas.

berizecio ovitou-se uma catóstrole poki con a ntcrilia do zas na favola eir. decli. Duronte as fories chirvas que intrangh

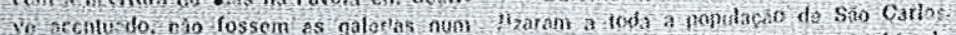

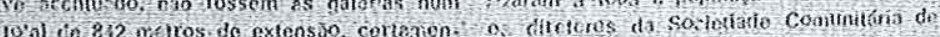

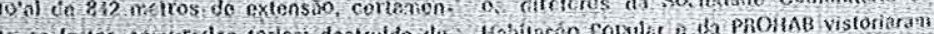

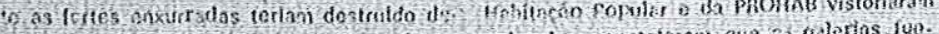

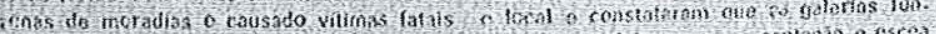

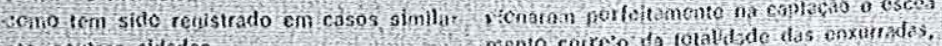

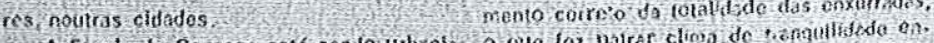

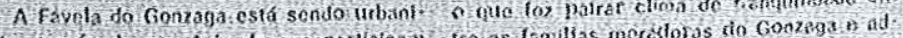

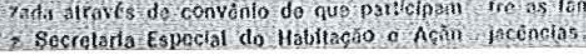

07-01-1990 - Galeria de águas pluviais salva moradores do Gonzaga - A Folha 


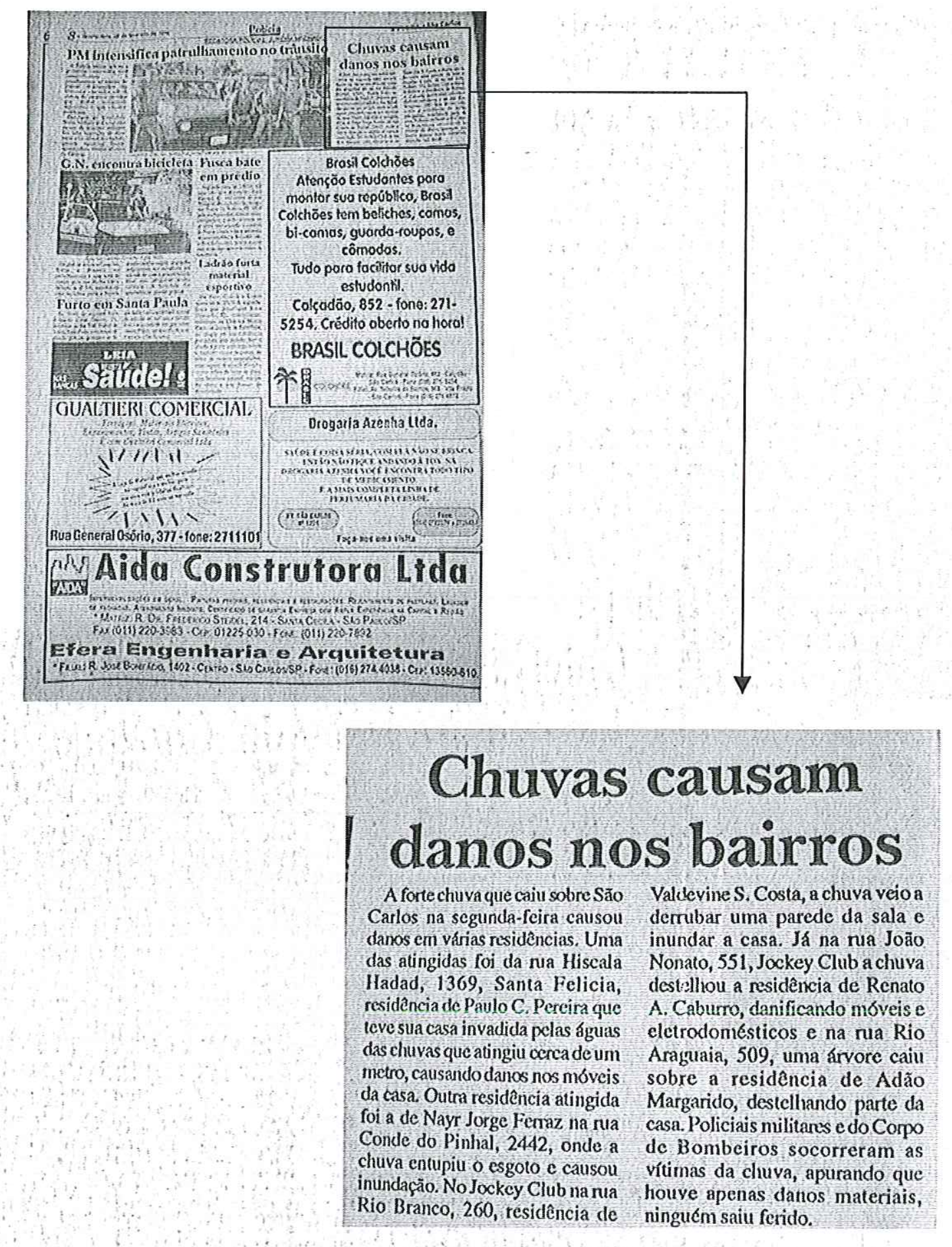

28-02-1996 - Chuvas causam danos no bairros - A Folha 


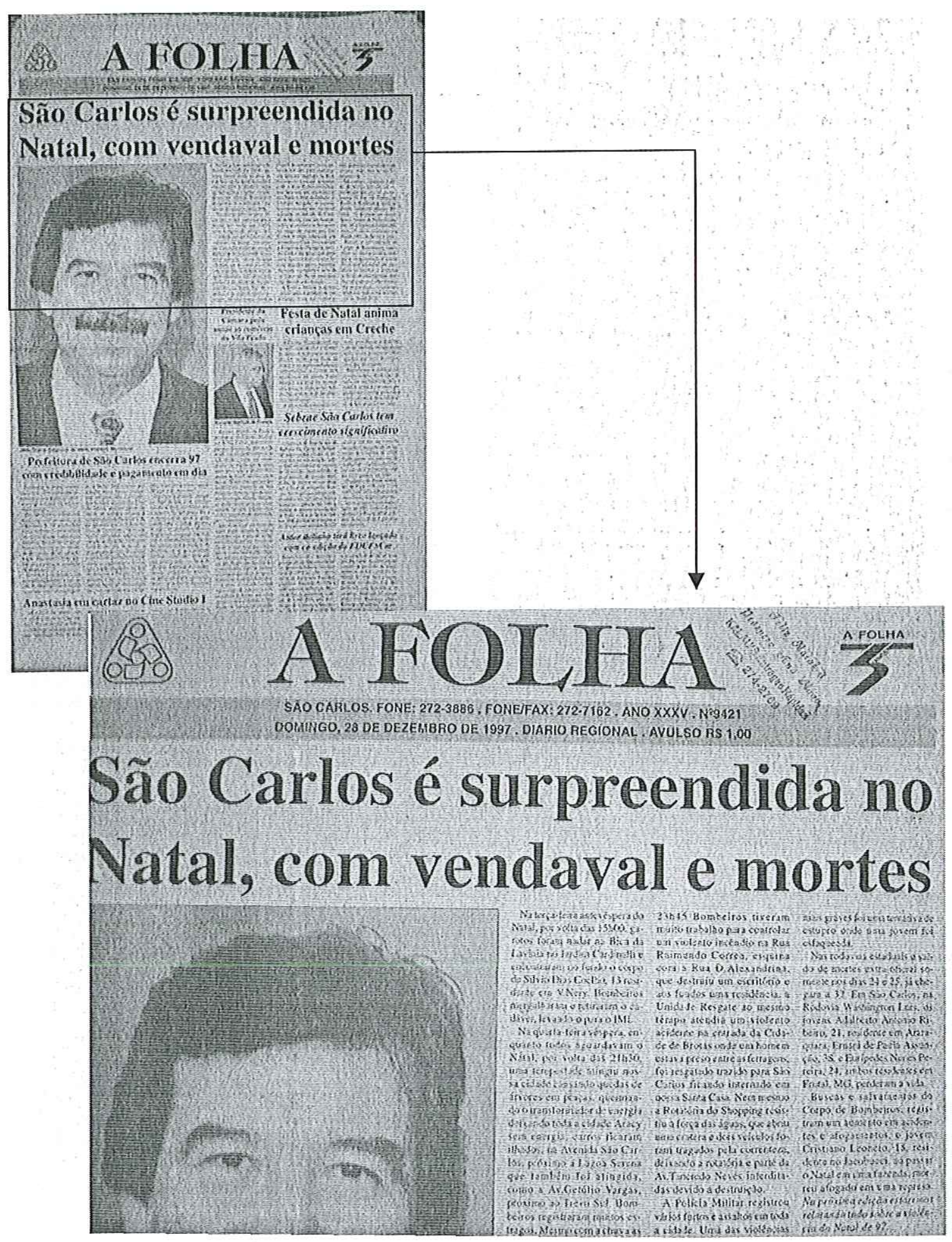

28-12-1997 - São Carlos é surpreendida no Natal com vendaval e mortes - A Folha 


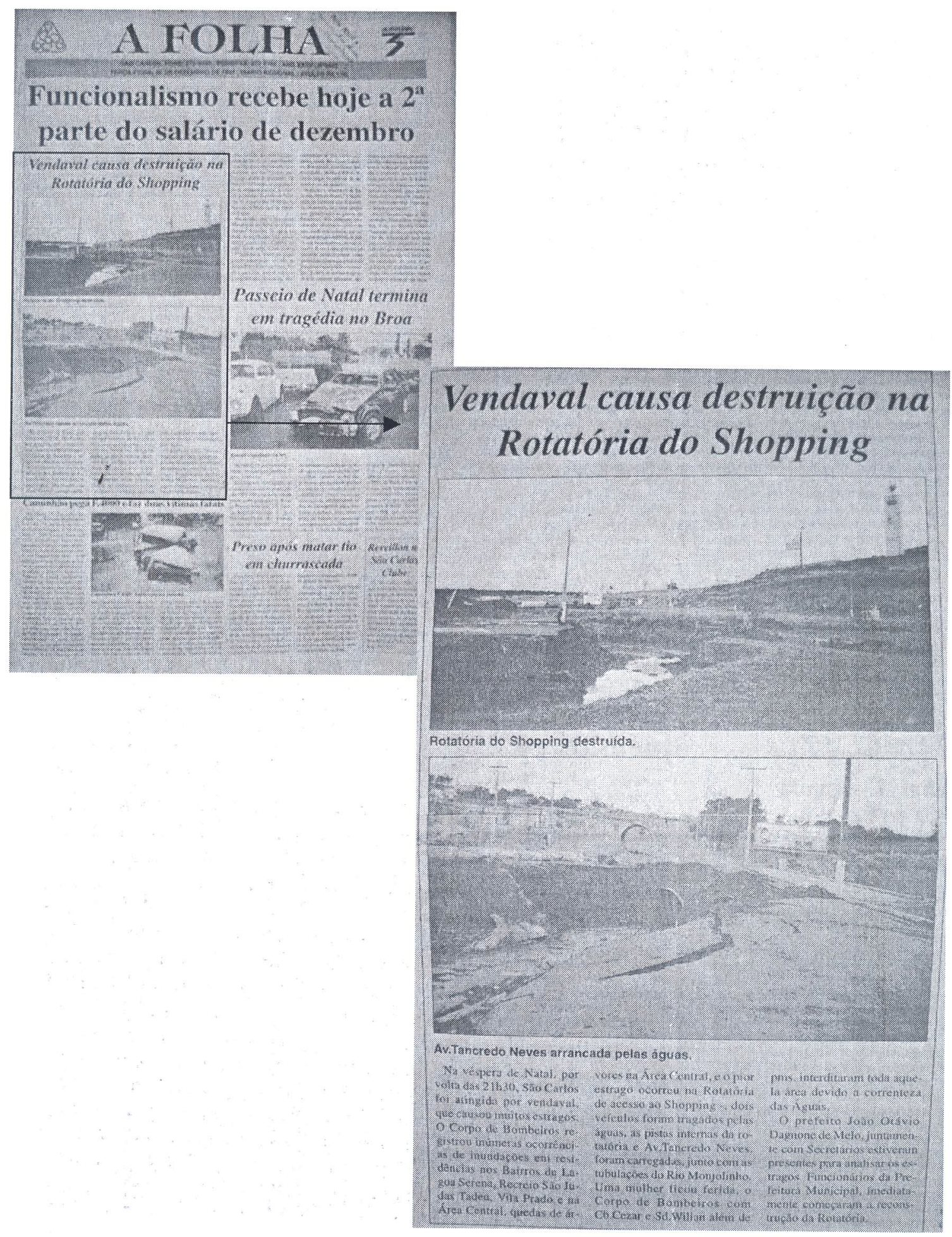

30-12-1997 - Vendaval causa destruição na rotatória do Shopping - A Folha 


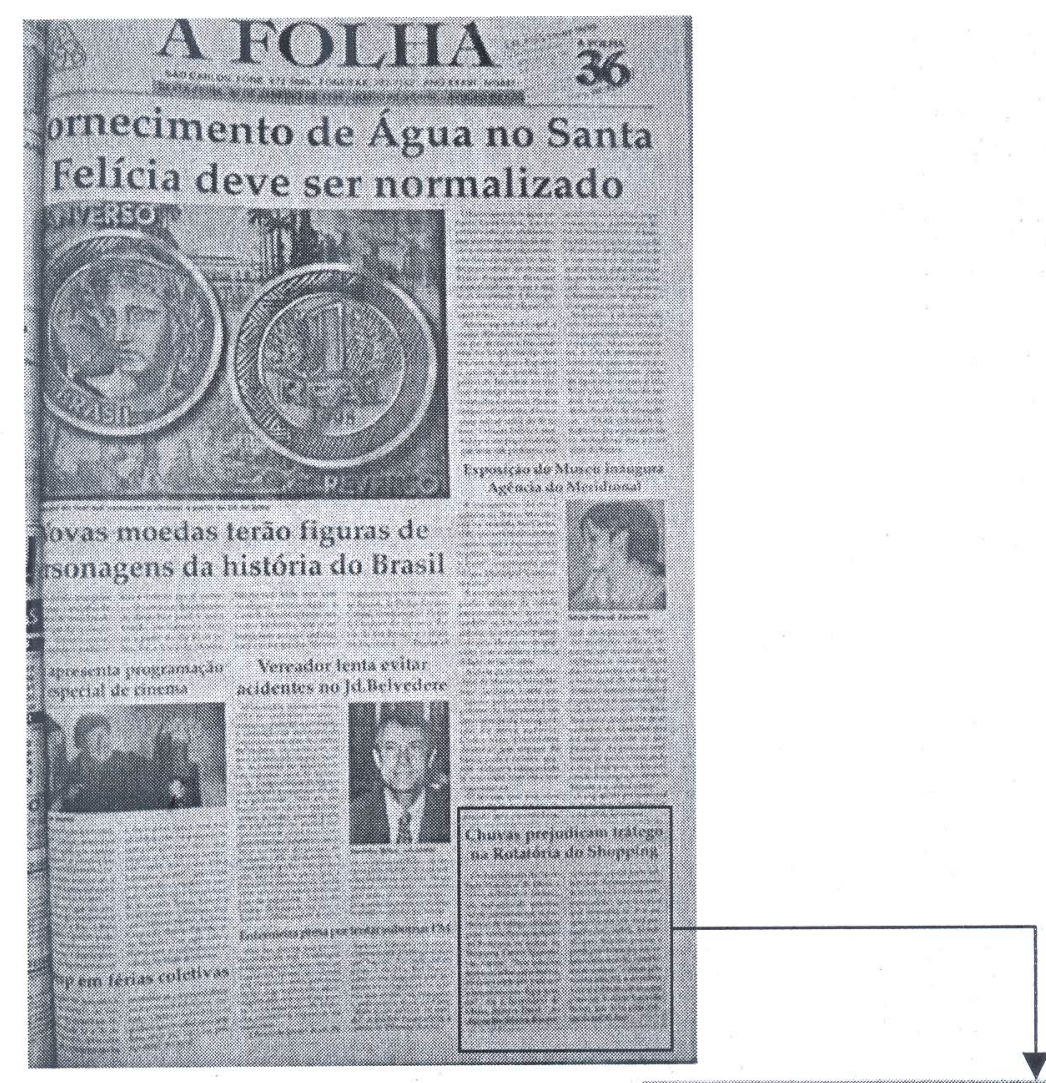

Chuvas prejudicam tráfego na Rotatória do Shopping

Os runciomarios da Secre judicaramaquela ponte sent lana Municipal de Obras e lidoSesc-Rotatoria (defromServicos Publicos continuam traballando intensamente para amenizar os problemas de tráfego causados pelas fortes chuvas na regiäo da Rotatória de acesso ao Shopping Center lguatemi Sáo Carios. "Nos estamos tenlardo achar wma alternadva para o trâncito para que o tranctomo néo fique mat or". dia o Secretirio de Dbras, Marcos Plemi. " As

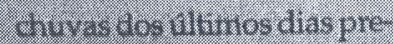
re ao ( risto) c ela está com promelida: Nos leremos que interdilarla. Por en: quanto o tránsito esta past sando com cautela Acredi: to que, ficando pronta a ponte provisor in que nos es. tamos teminando o wroble ma se amerive?". Ontempala manha (dia 29), a scoretana invioul a construgión de uma ponte na Averida Tincrodo Neves, que deve estiri con. duita em 15 dirs

30-01-1998 - Chuvas prejudicam tráfego na rotatória do Shopping - Folha 


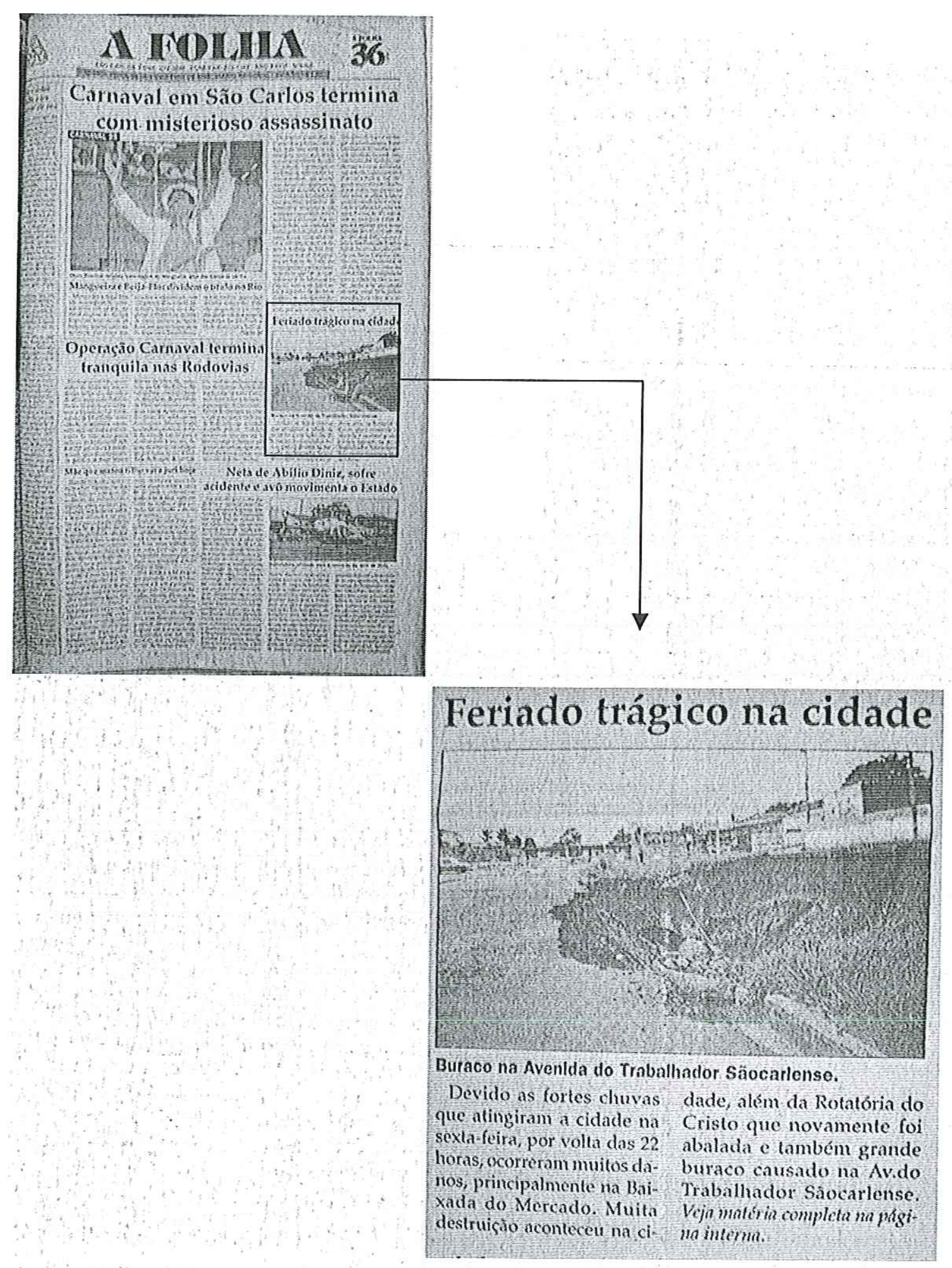

26-02-1998 - Feriado trágico na cidade - A Folha 


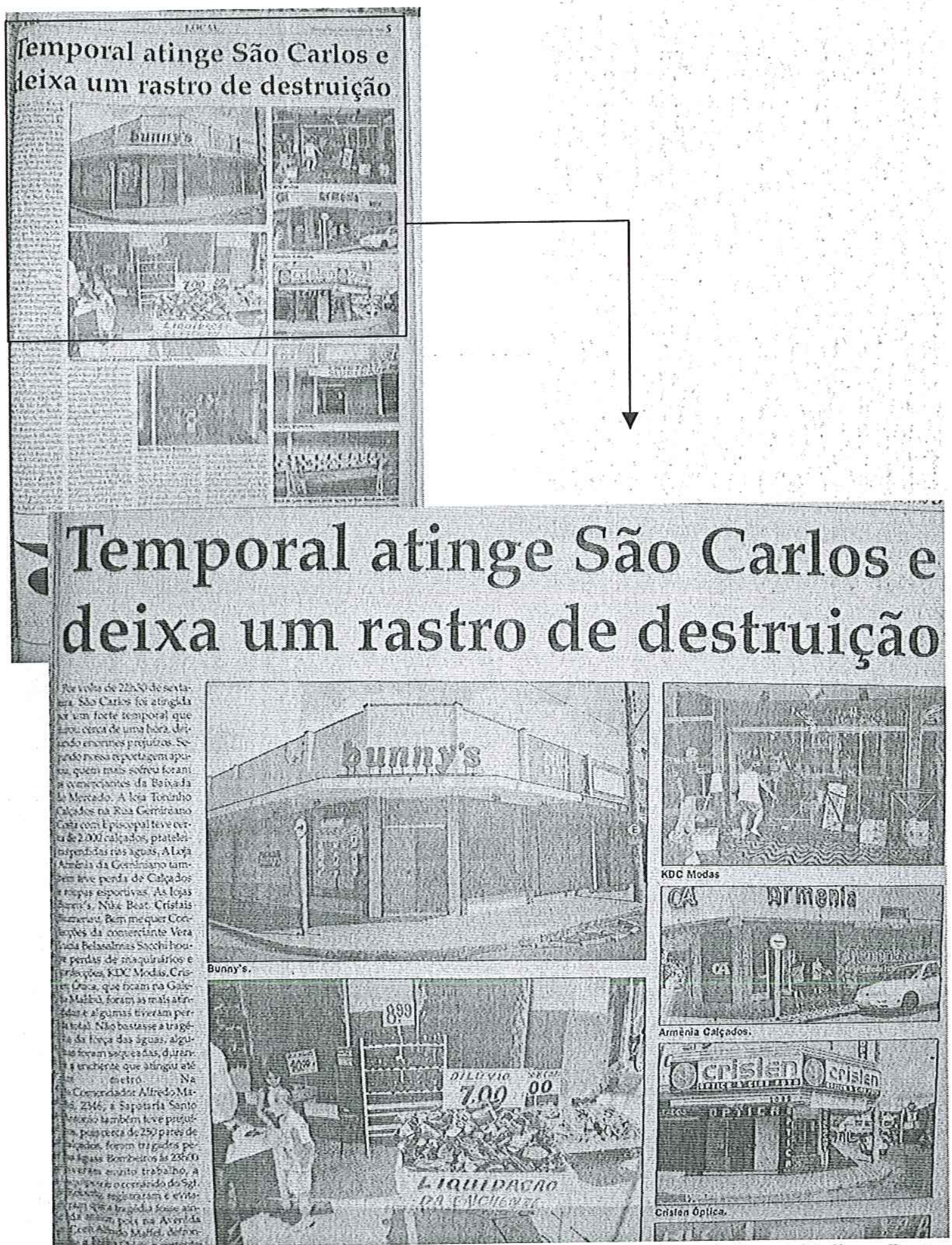

26-02-1998 - Temporal atinge São Carlos e deixa um rastro de destruição - A Folha - Parte 1 


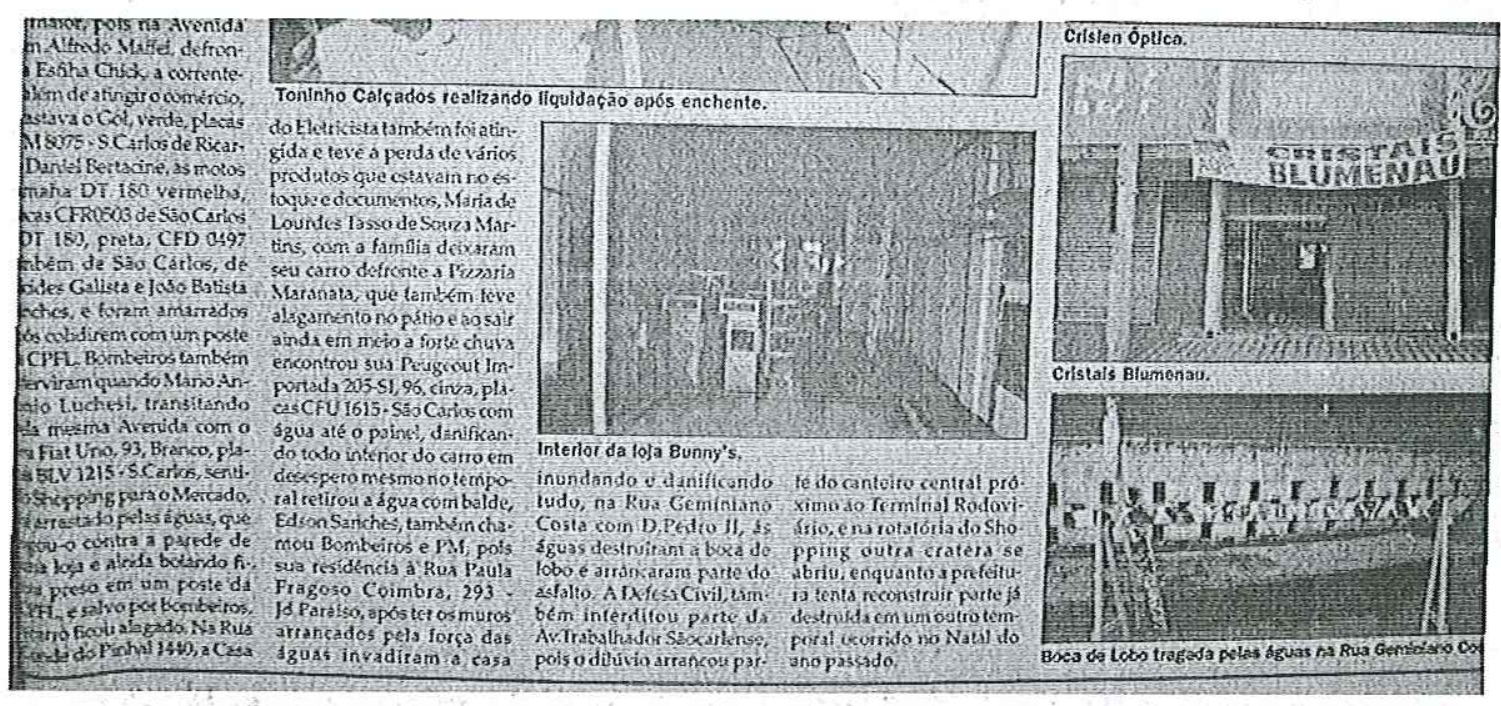

26-02-1998 - Temporal atinge São Carlos e deixa um rastro de destruição - A Folha - Parte 2 


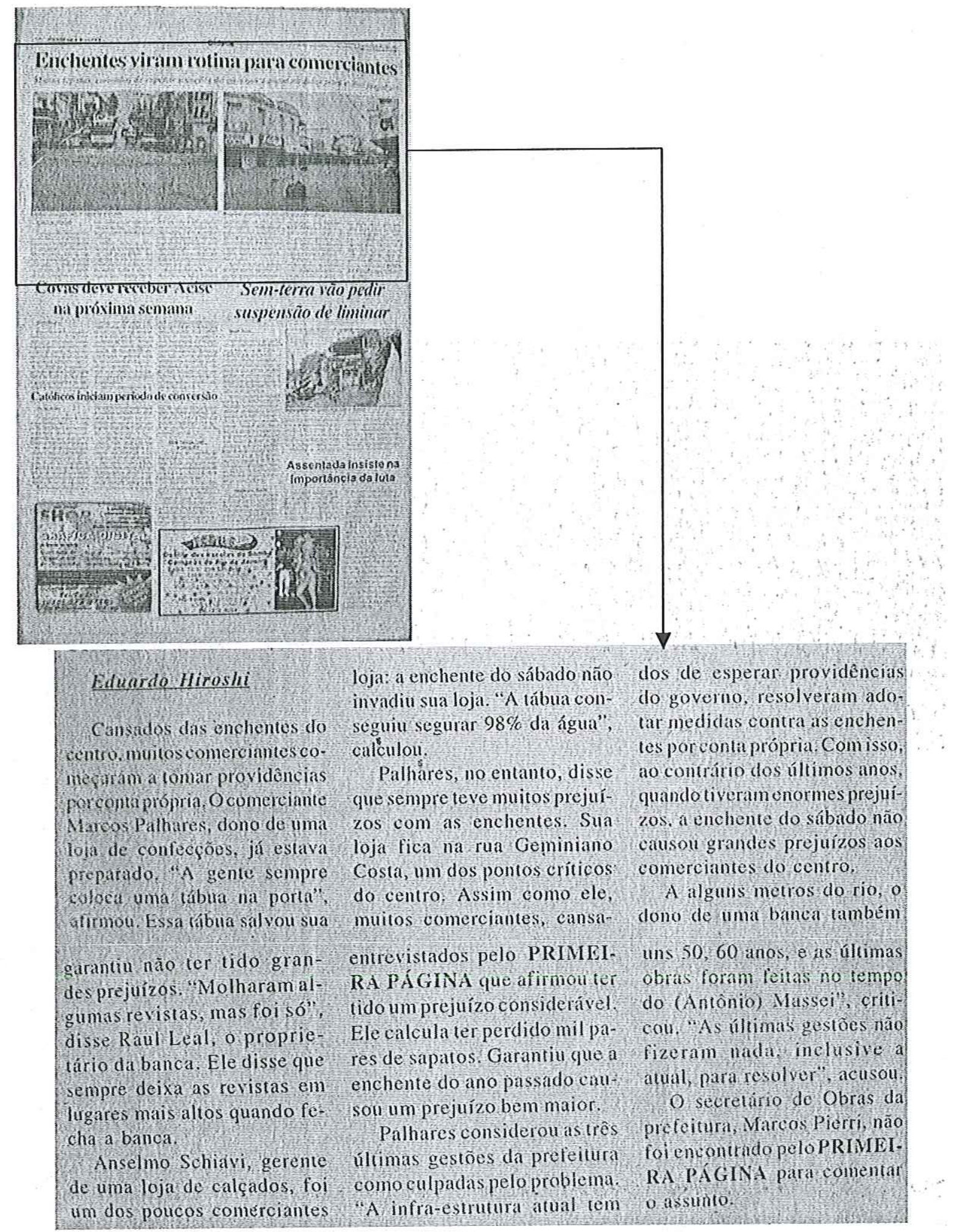

18-01-1999 - Enchentes viram rotina para comerciantes - Primeira Página - Parte 1 


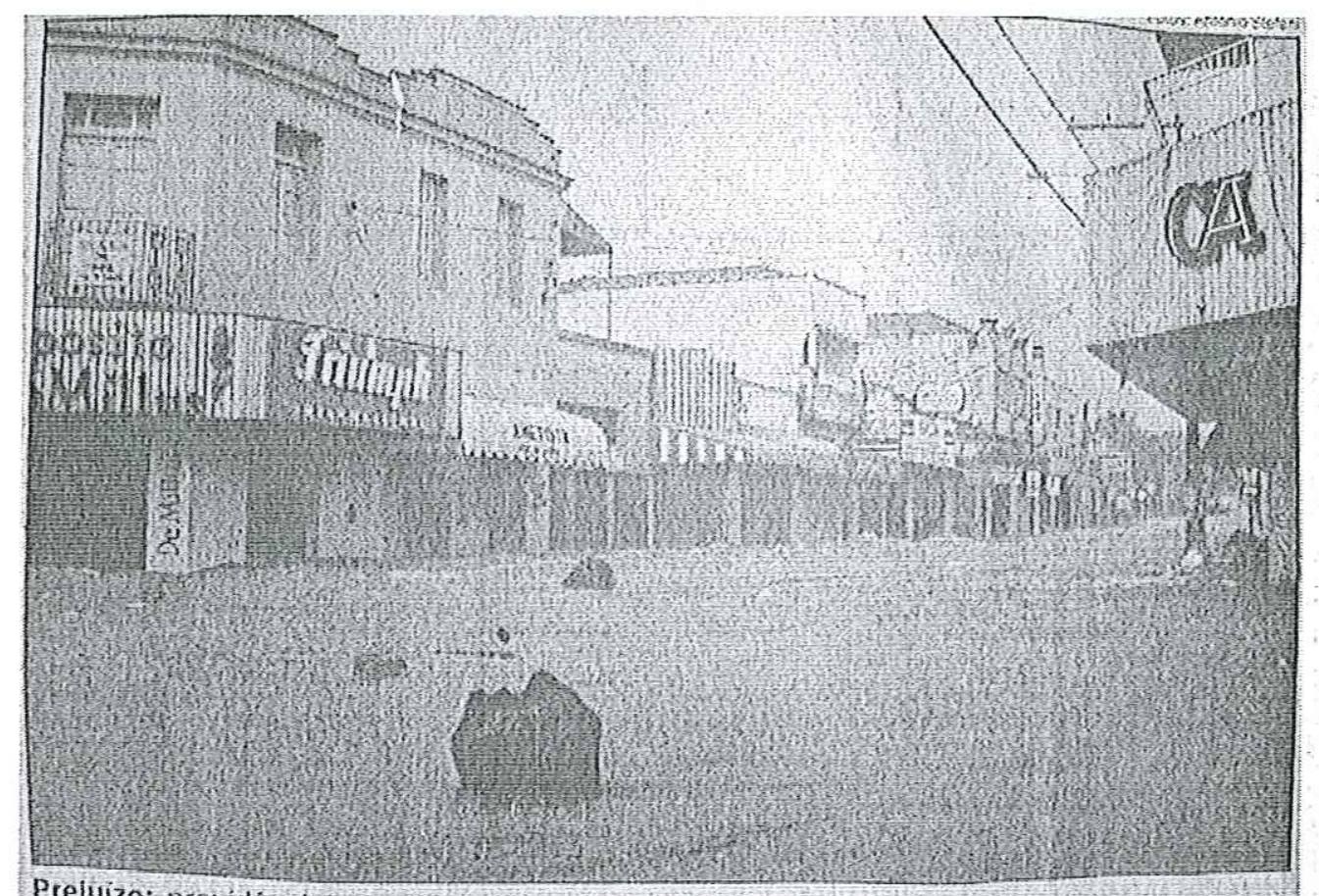

Prejuizo: providéncias oor conta dos comerciantes

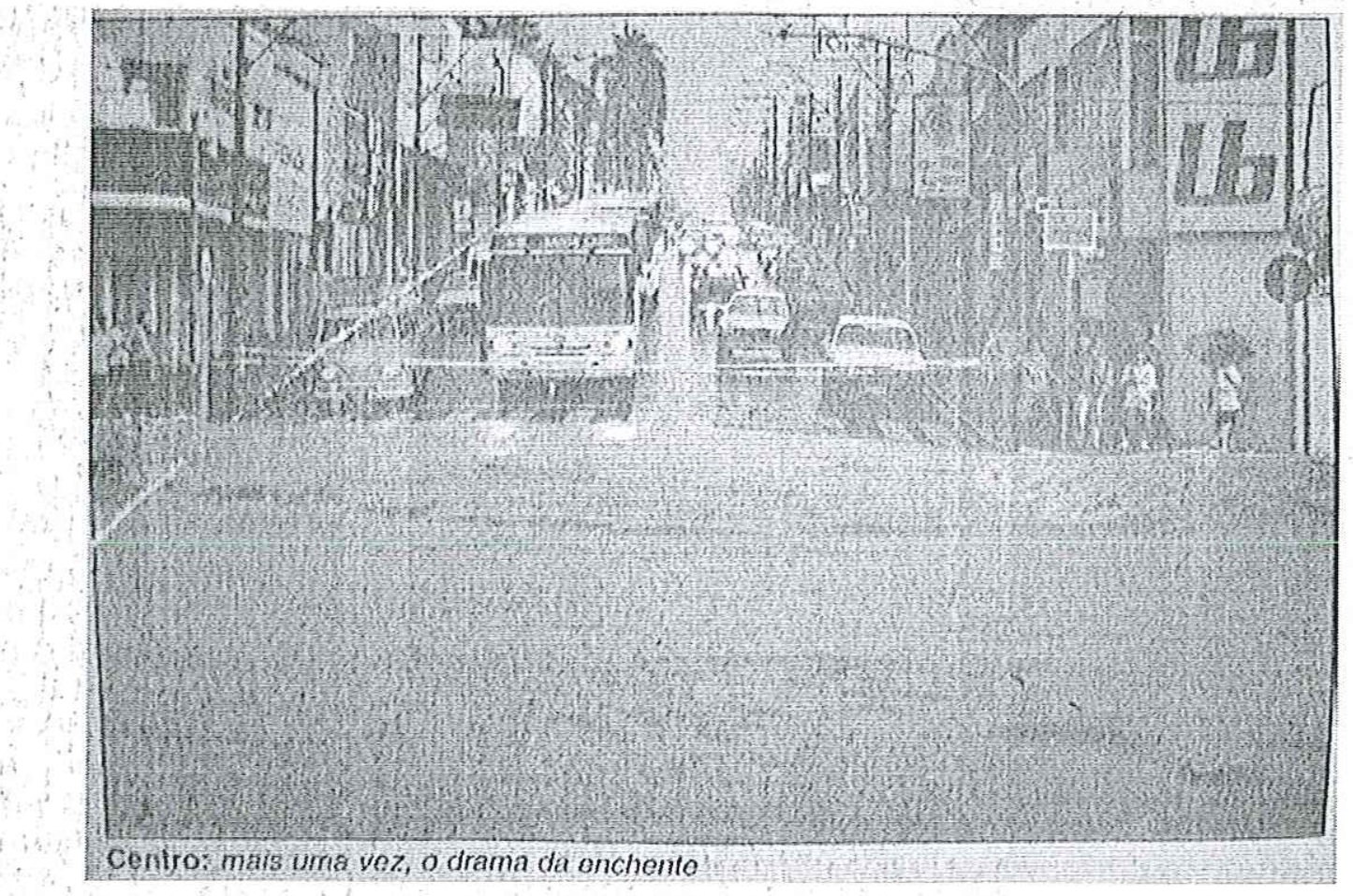

18-01-1999 - Enchentes viram rotina para comerciantes -Primeira Página -Parte 2 


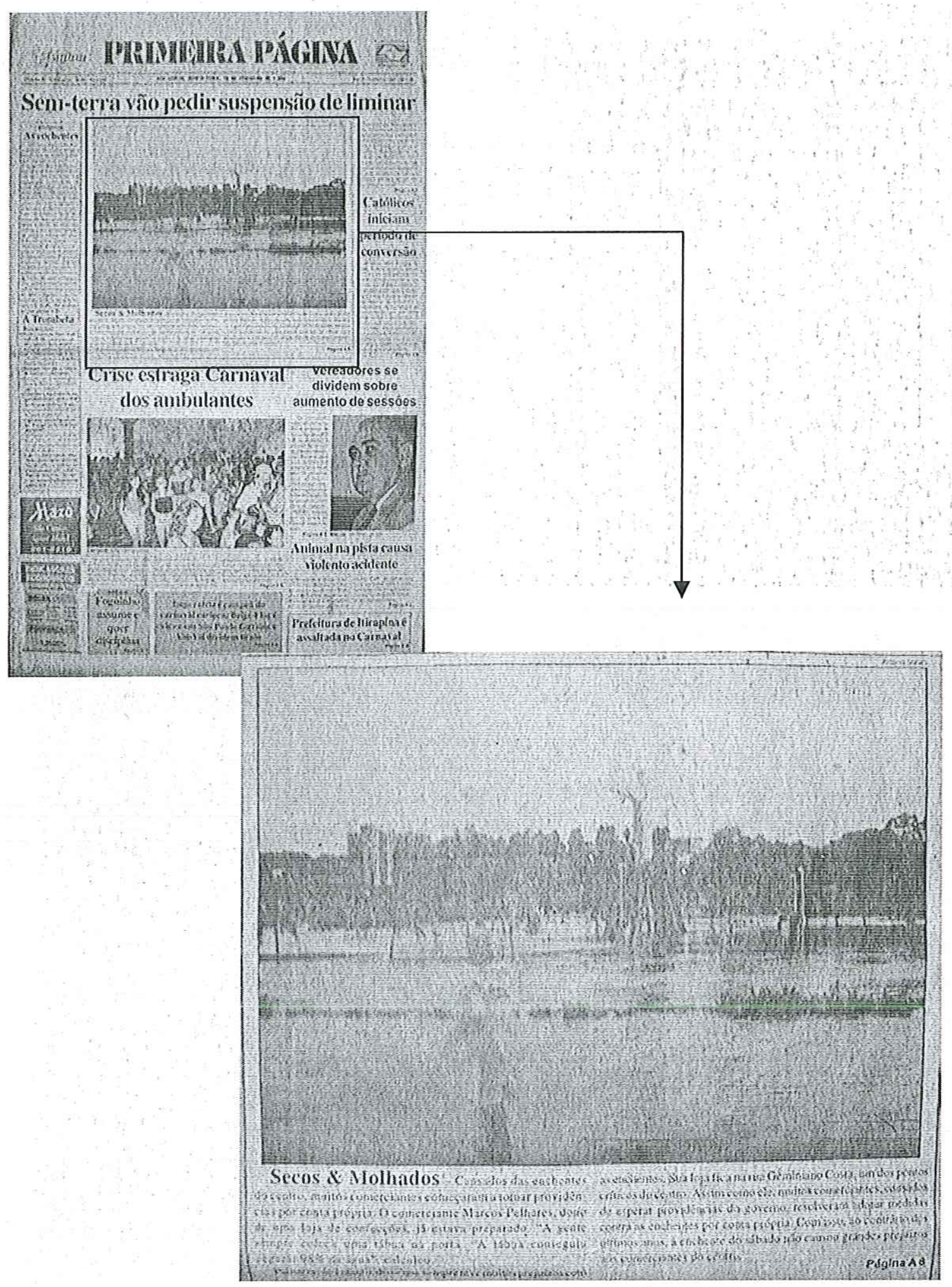

18-01-1999 - Secos e molhados - Primeira Página 


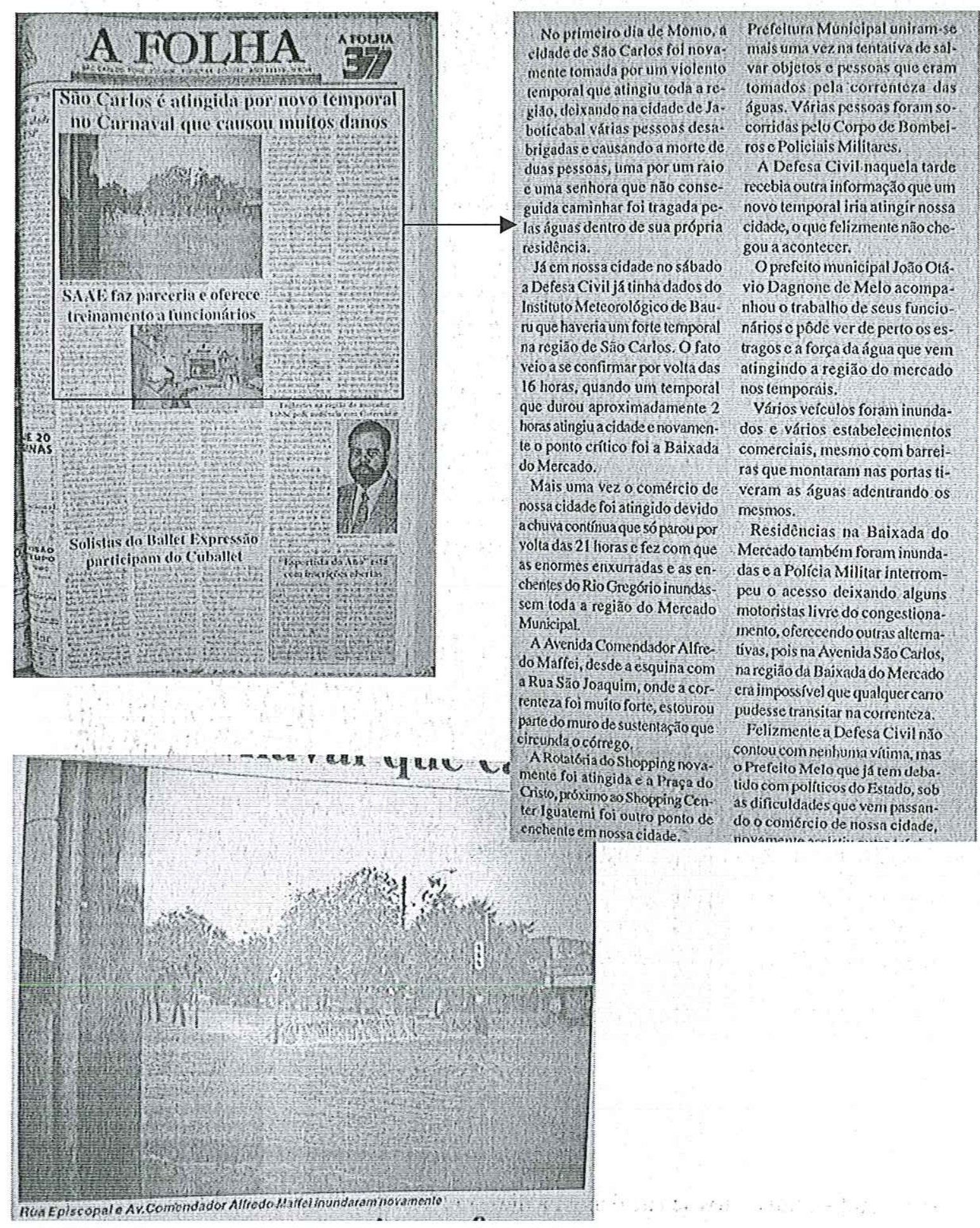

19-02-1999 - São Carlos é atingida por temporal no Carnaval que causou muitos danos - A Folha 


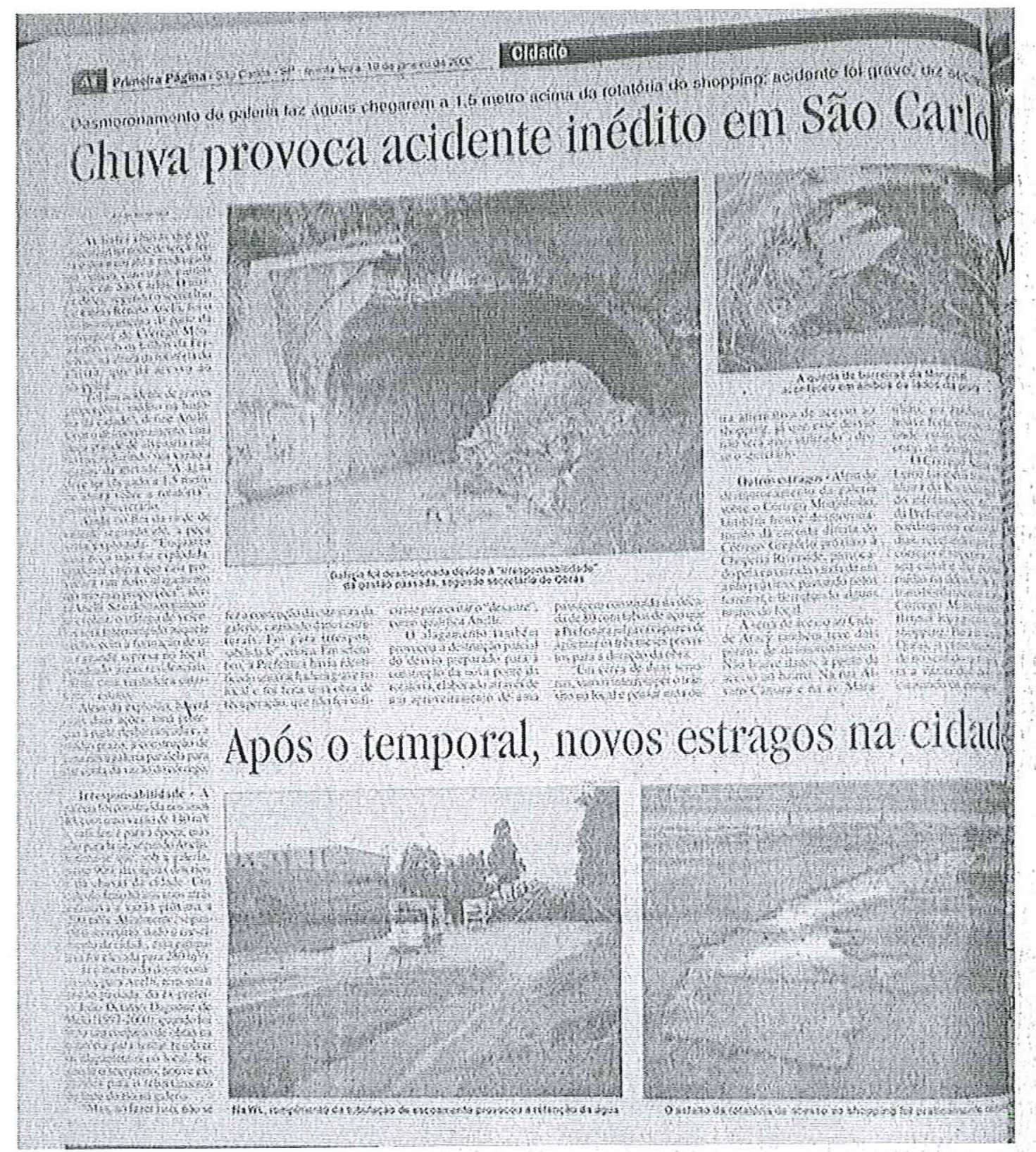

10-01-2002 - Chuva provoca acidente inédito em São Carlos - Primeira Página 

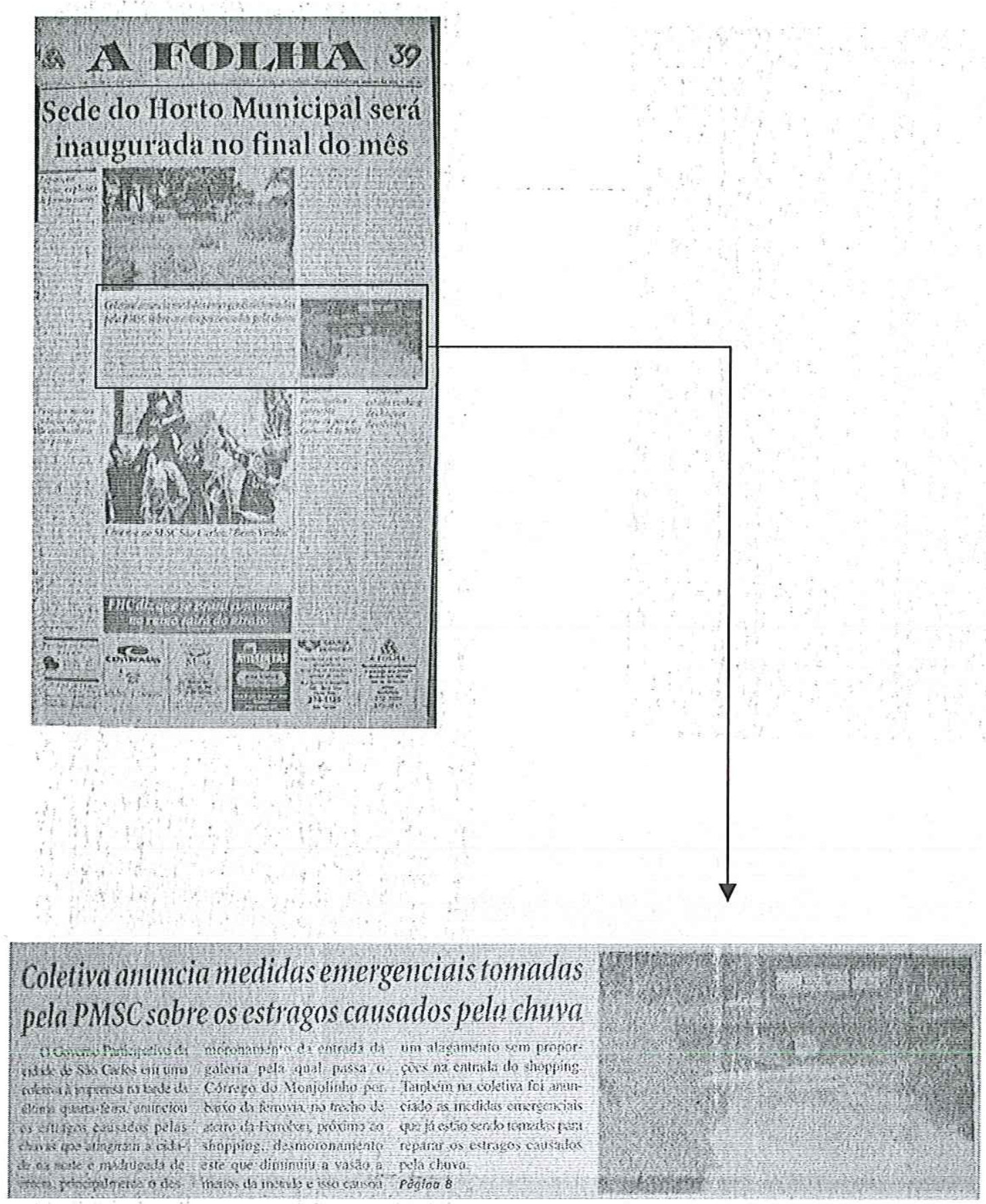

10-01-2002 - Coletiva anuncia medidas emergenciais tomadas pela PMSC sobre os estragos causados pela chuva - A Folha - Parte 1 


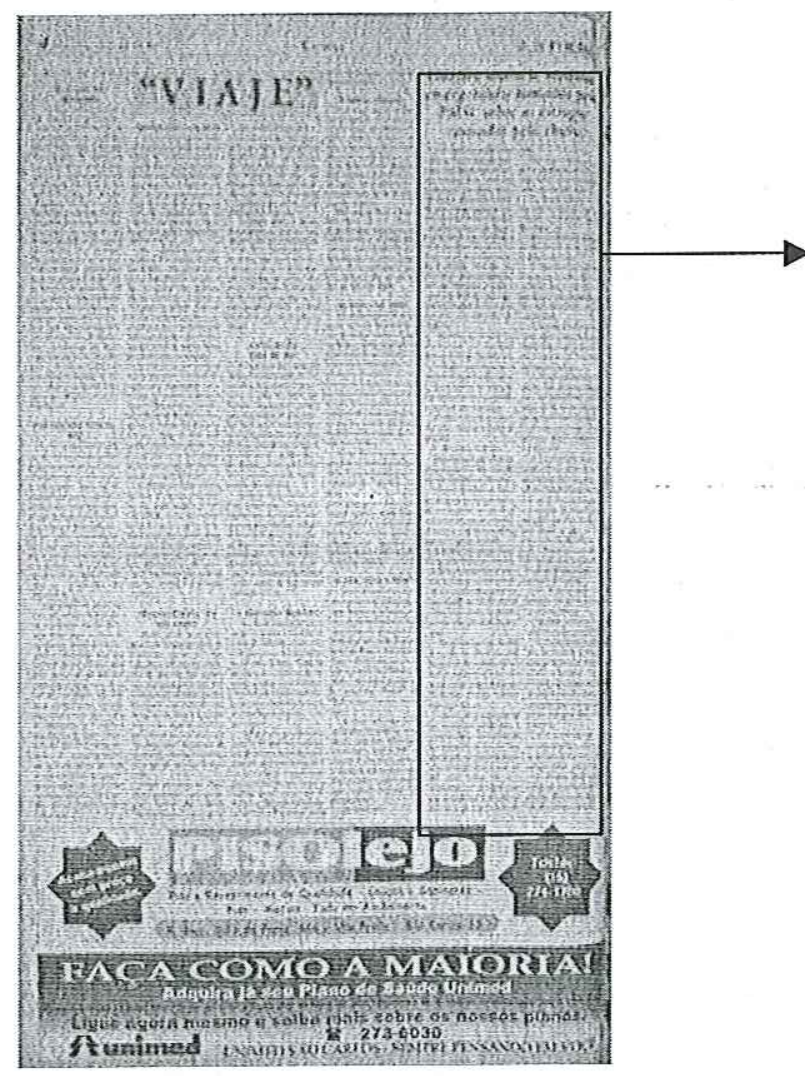

\section{Coletiva anuncia medidas emergenciais tomadas pel PMSC sobre os estragos causados pela chuva}

OGovenoparticipativola obri.

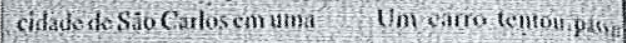
Coletiva aimprensithatardo da plo alaganento, inis for

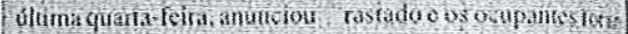
os estragos causados pelas soconidosplonisgate. Clinvis gue atingirama cidade $\quad 2$ - Desmoronankno a tha noile e madngada de on: encosia direits do corteg

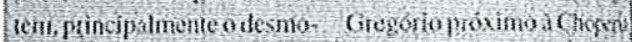
ronamone da entrida daga, Rivesside.

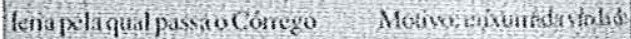

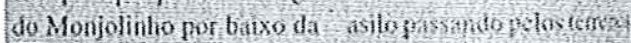
ferrovia no trocho de aterro edembantomuros:

da terroban, proximo ao 3- Dompontos dedem?

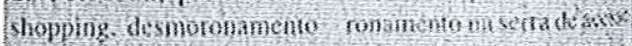

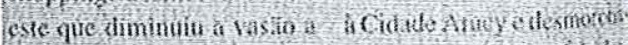

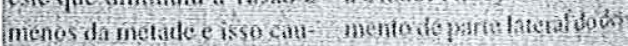

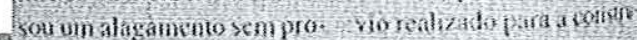
potcoes na critrada do grodsponte.

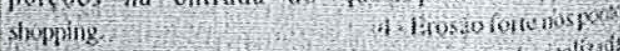

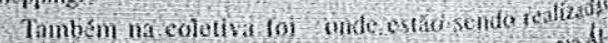
anumciado is medrdas obrio de drengerimanan

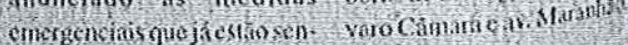
do iom as pain reparat os 5 to Jarditim Gombaga:

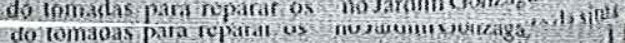

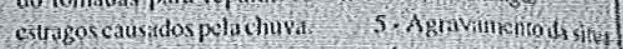

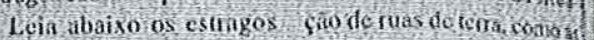
causados pela chiva, segundo ruas do Presidestia Collo

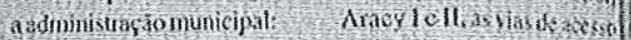

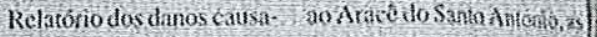

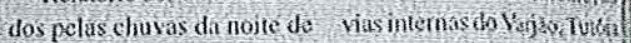

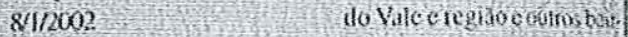
1-Rotitória do Cristo rosdacidade.

Desmoronamentodipalic 6. Transbordmeno Vla passagem do Monjolinho córego Santa Mariado leng por sob os wilhos da Ferroban. ma allura do kartedromo bo

Motivo:aumento to voli: lectiotransbodamentocst medesguas do riodeconente ritoem 30 dias, reselando of do crescimento da cidade o a demanta do vízảo dos

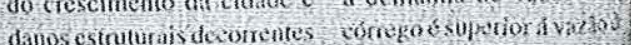
dombaixamentodakitodono seil canal o das fonk

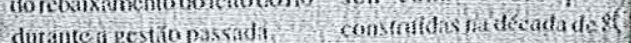
A PMSC identificounts if Transtrordamento on

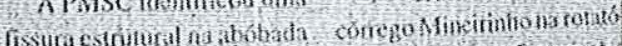

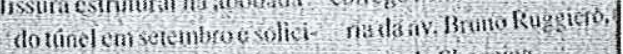

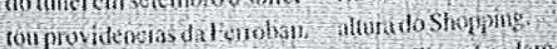
As obrastealizadaspolacon $\quad$. Transhordamanto S.

10-01-2002 - Coletiva anuncia medidas emergenciais tomadas pela PMSC sobre os estragos causados pela chuva - A Folha - Parte 2 


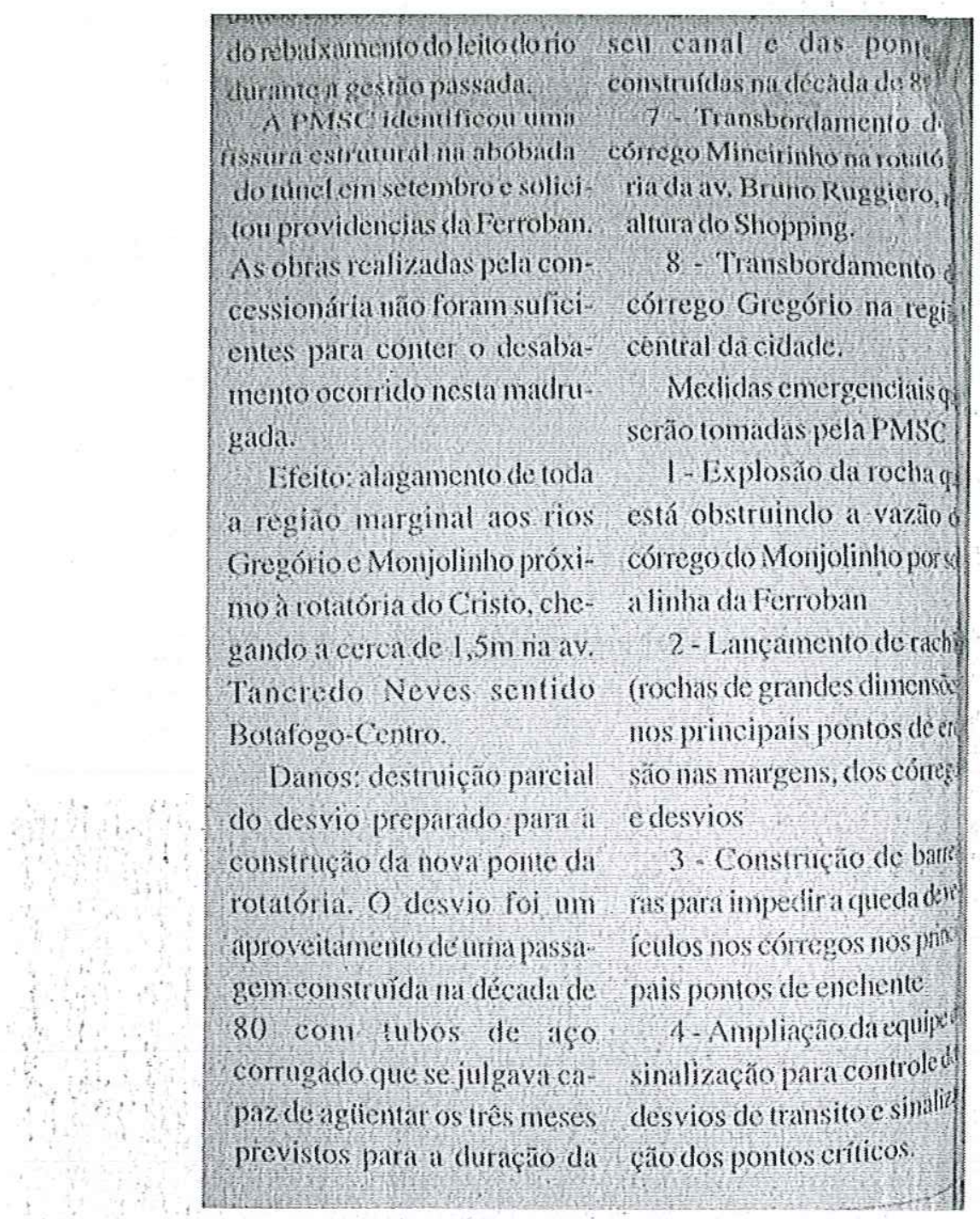

10-01-2002 - Coletiva anuncia medidas emergenciais tomadas pela PMSC sobre os estragos causados pela chuva-A Folha-Parte $3 \ldots, \ldots, \ldots$ 


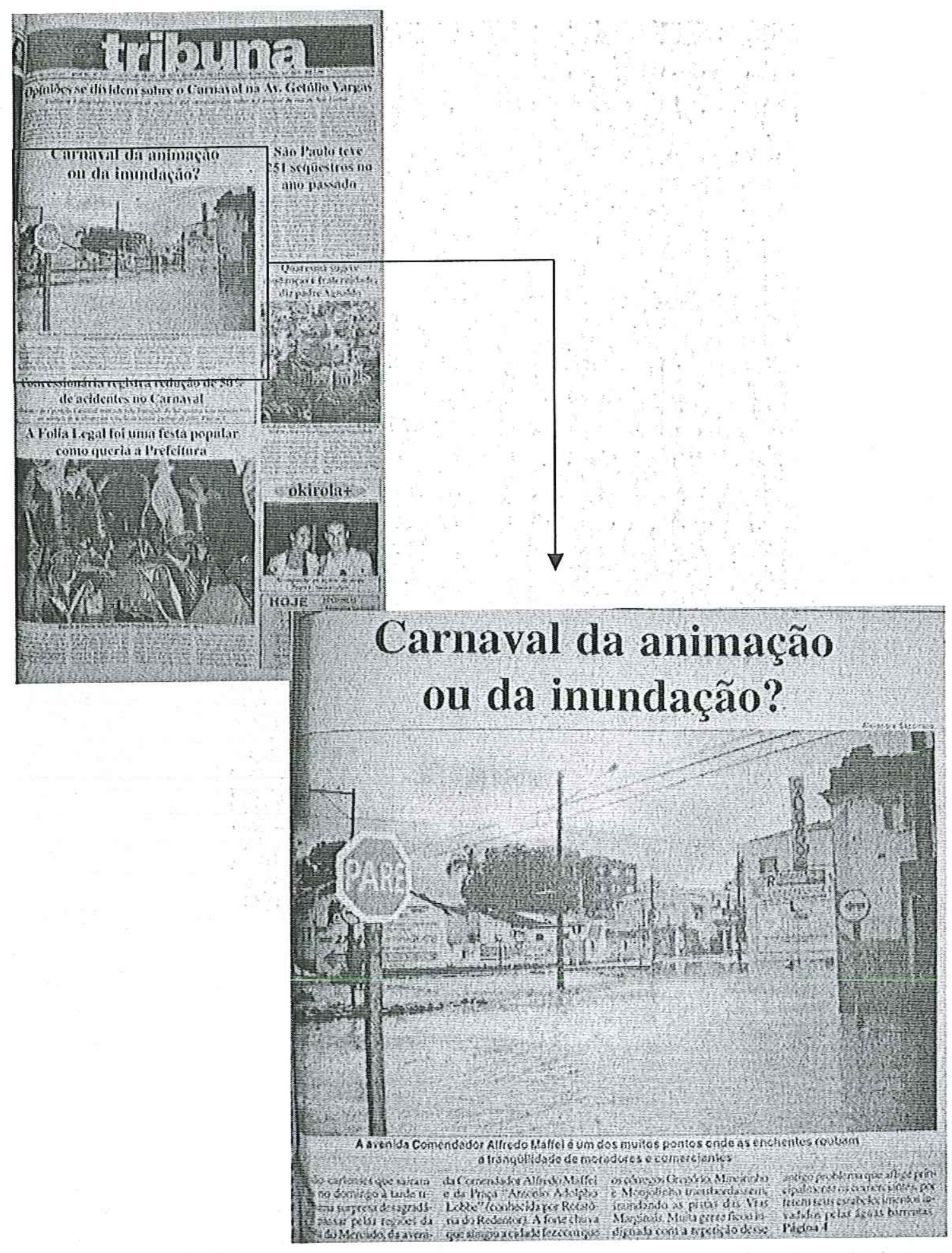

14-02-2002 - Carnaval da animação ou da inundação - A Tribuna - Parte 1 


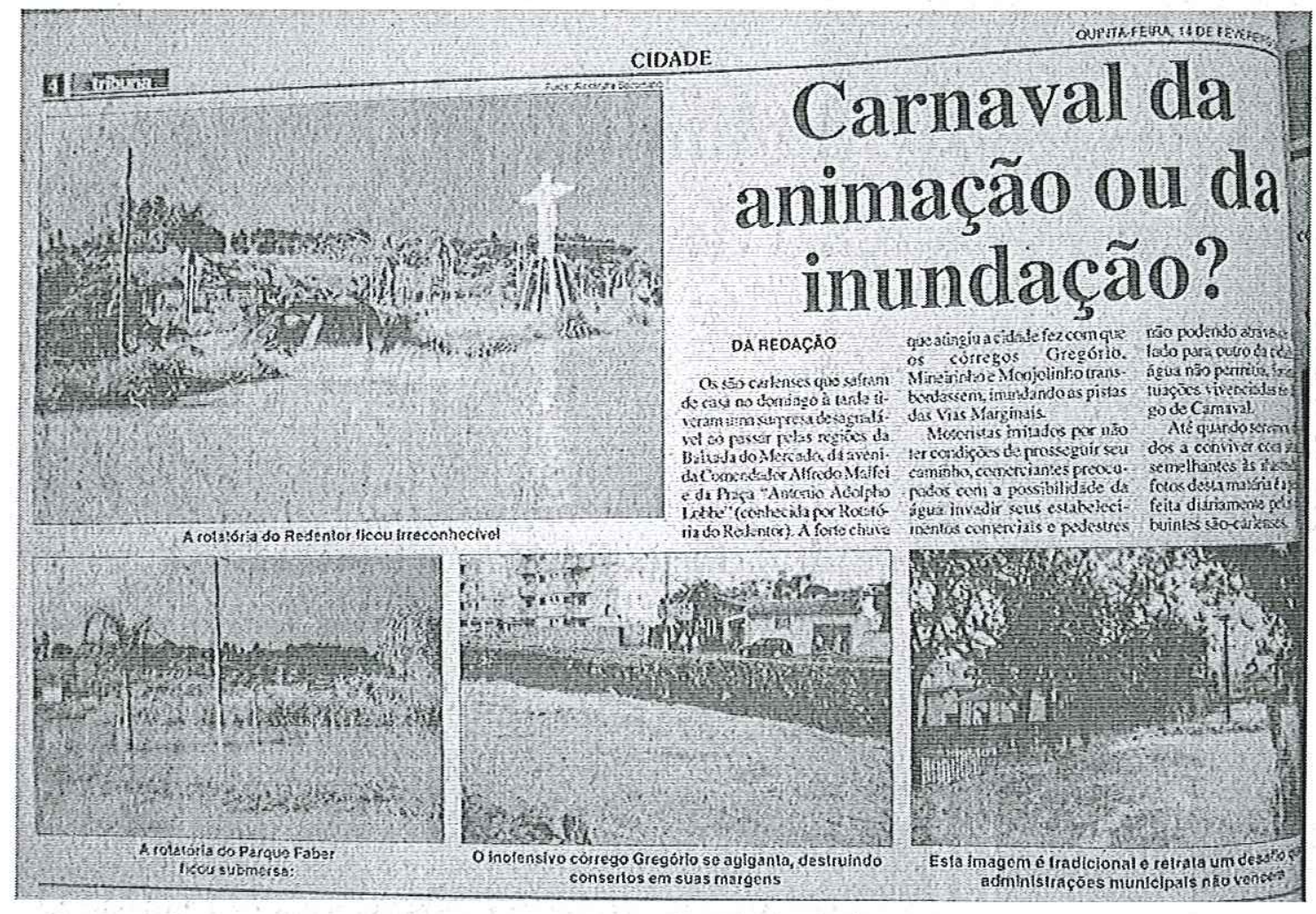

14-02-2002 - Carnaval da animação ou da inundação - A Tribuna - Parte 2 


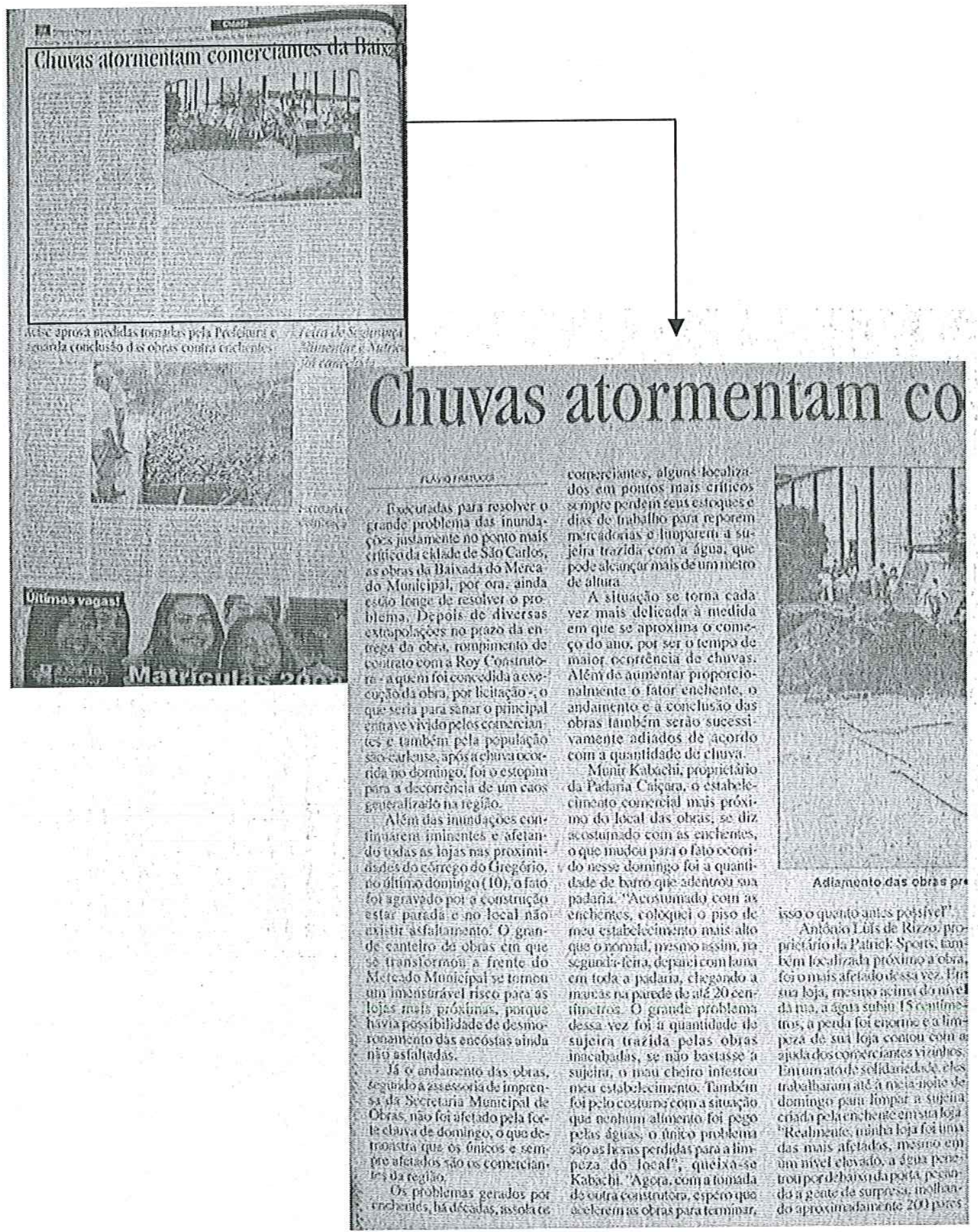

12-11-2002 - Chuvas atormentam comerciantes da baixada - Primeira Página - Parte 1 


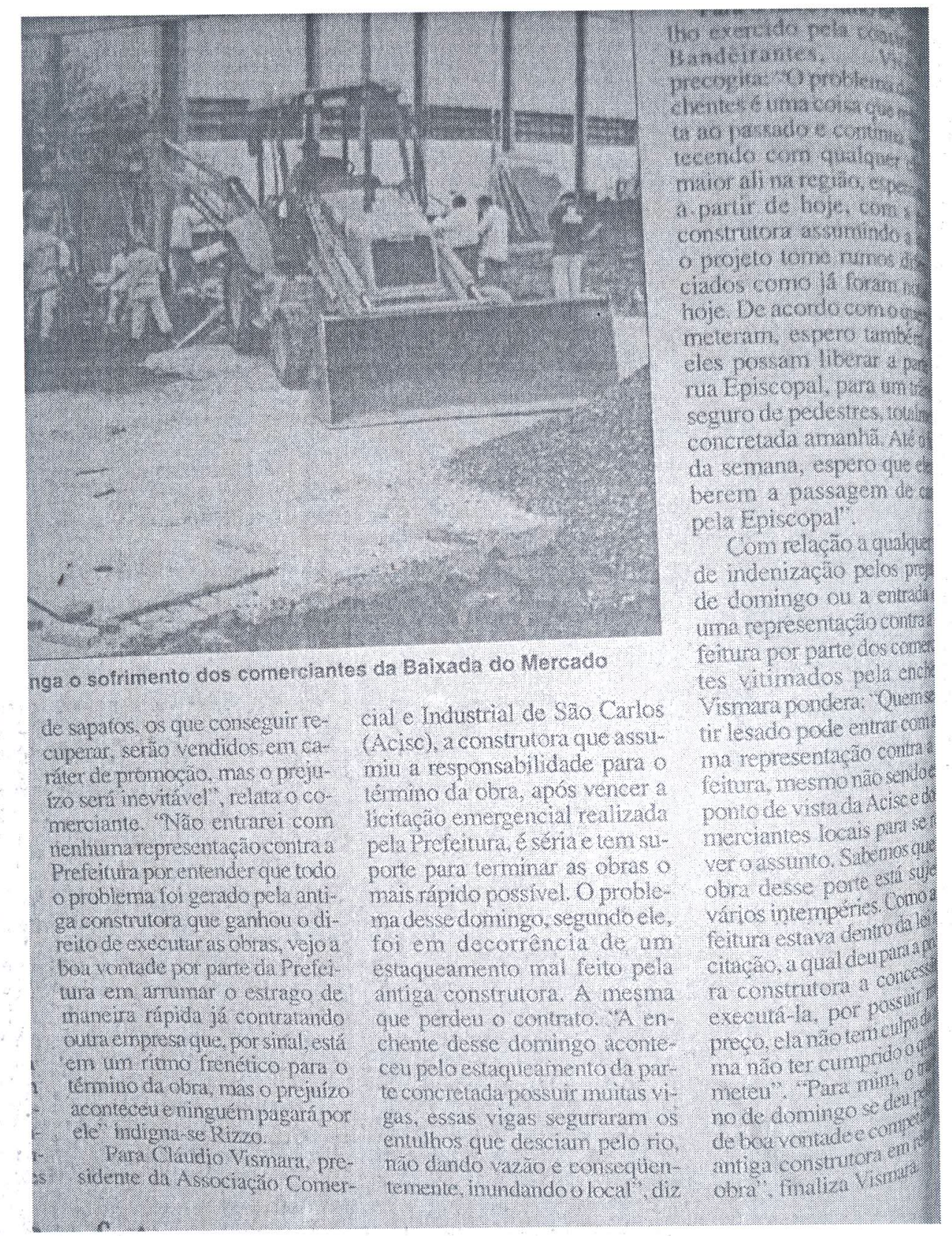

12-11-2002 - Chuvas atormentam comerciantes da baixada - Primeira Página - Parte 2 


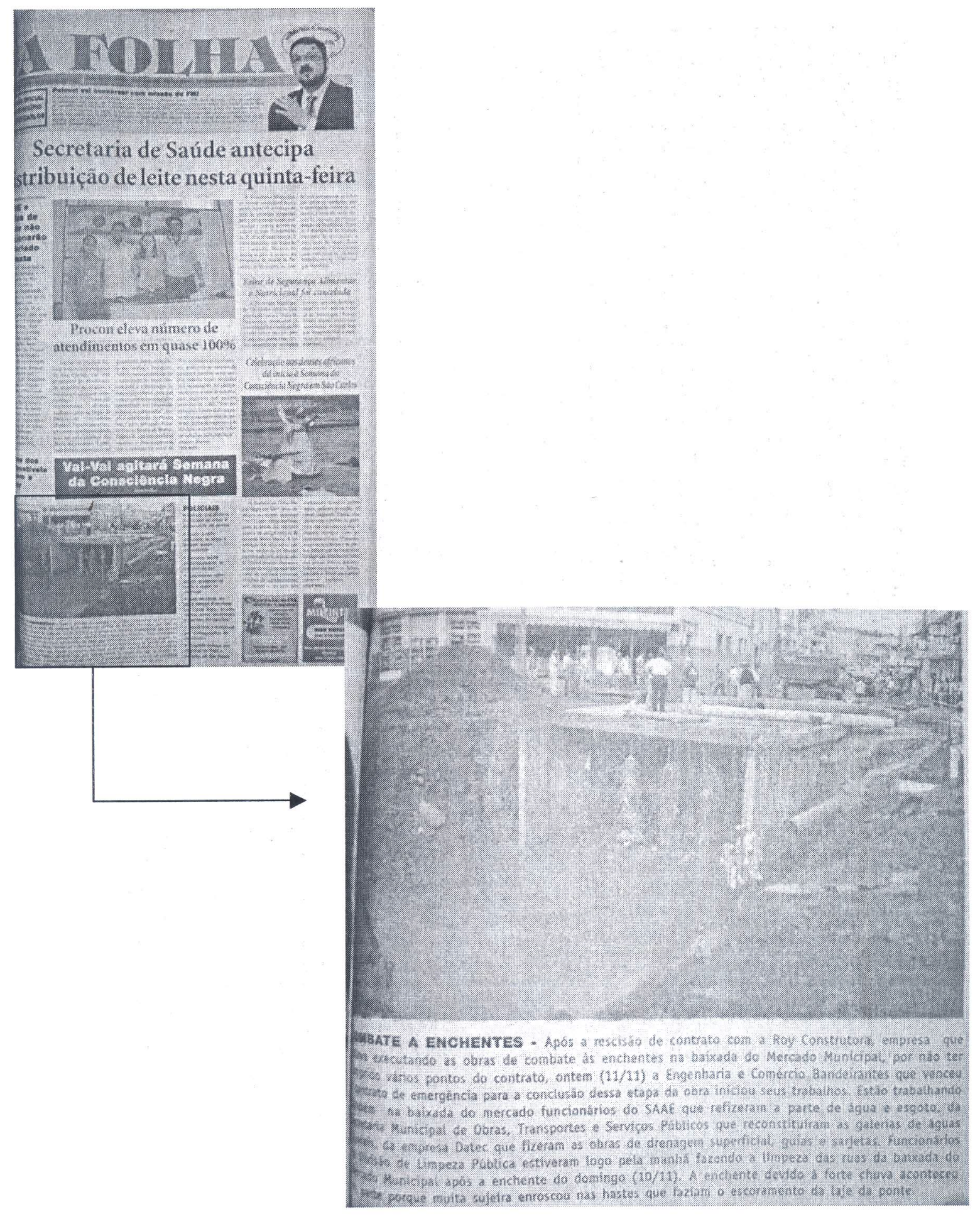

12-11-2002 - Combate a enchentes - A Folha 

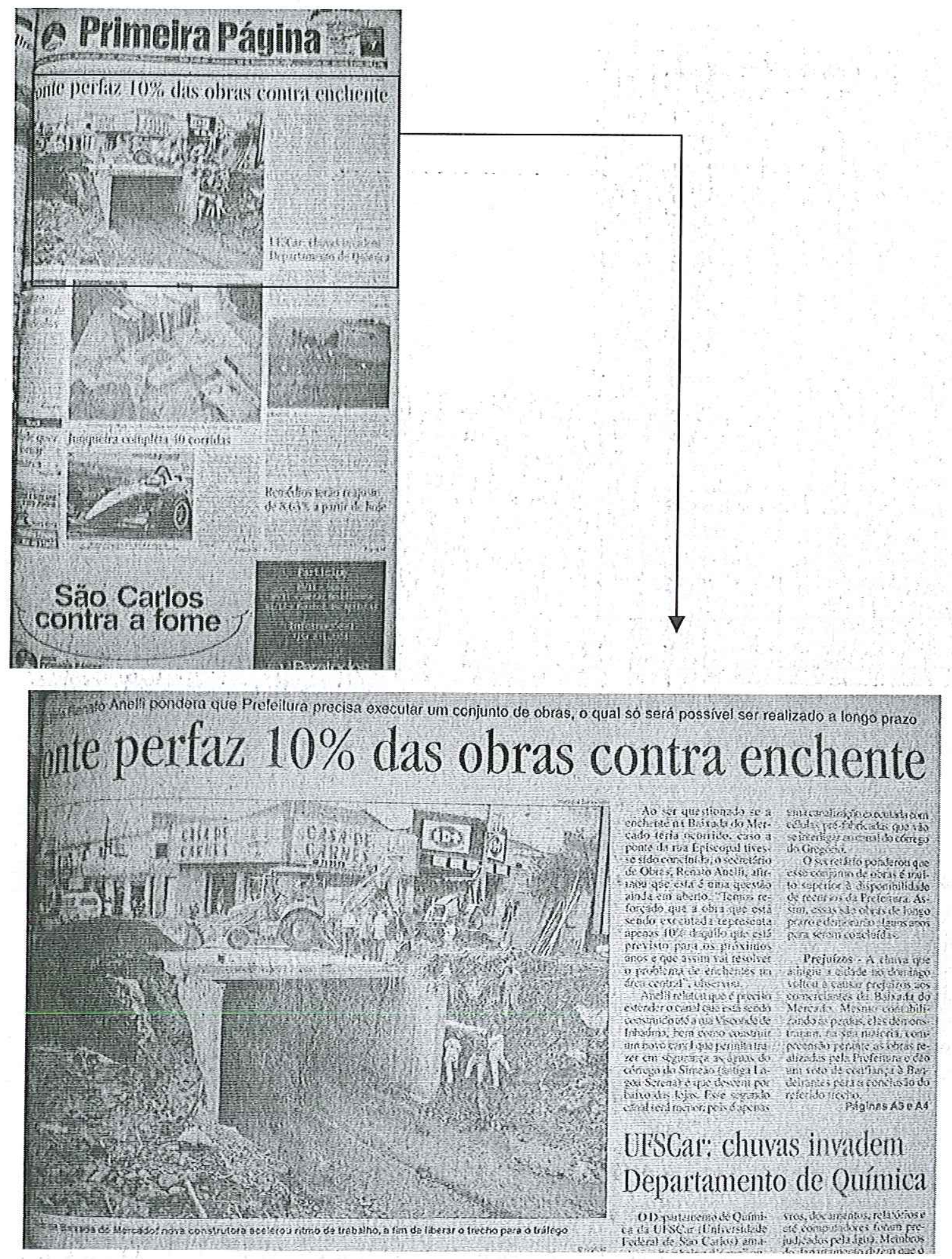

12-11-2002 - Ponte perfaz 10\% de obra contra enchente - Primeira Página - Parte 1 


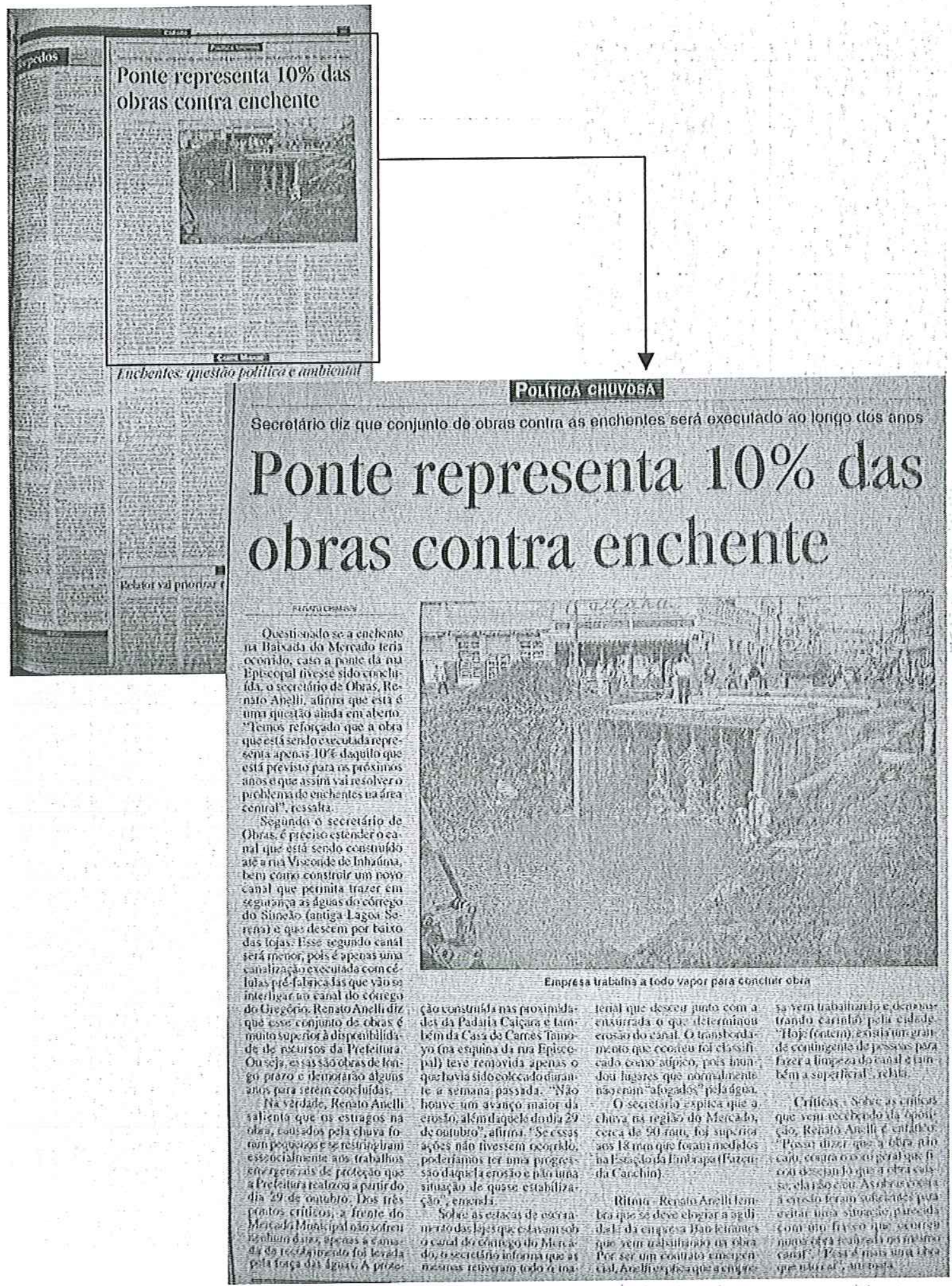

12-11-2002 - Ponte perfaz 10\% de obra contra enchente - Primeira Página - Parte 2 


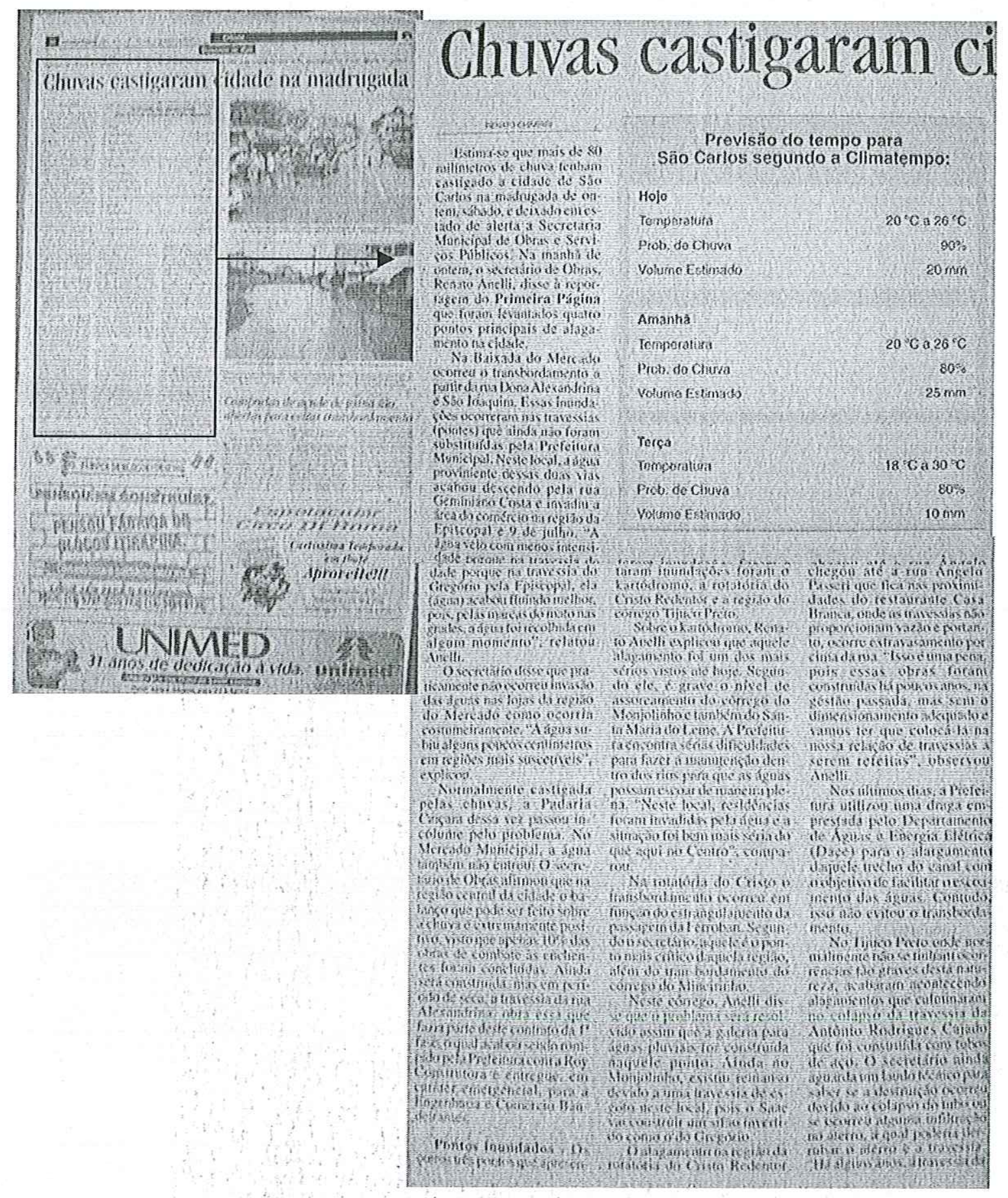

05-01-2003 - Chuvas castigaram cidade de madrugada - Primeira Página - Parte 1 

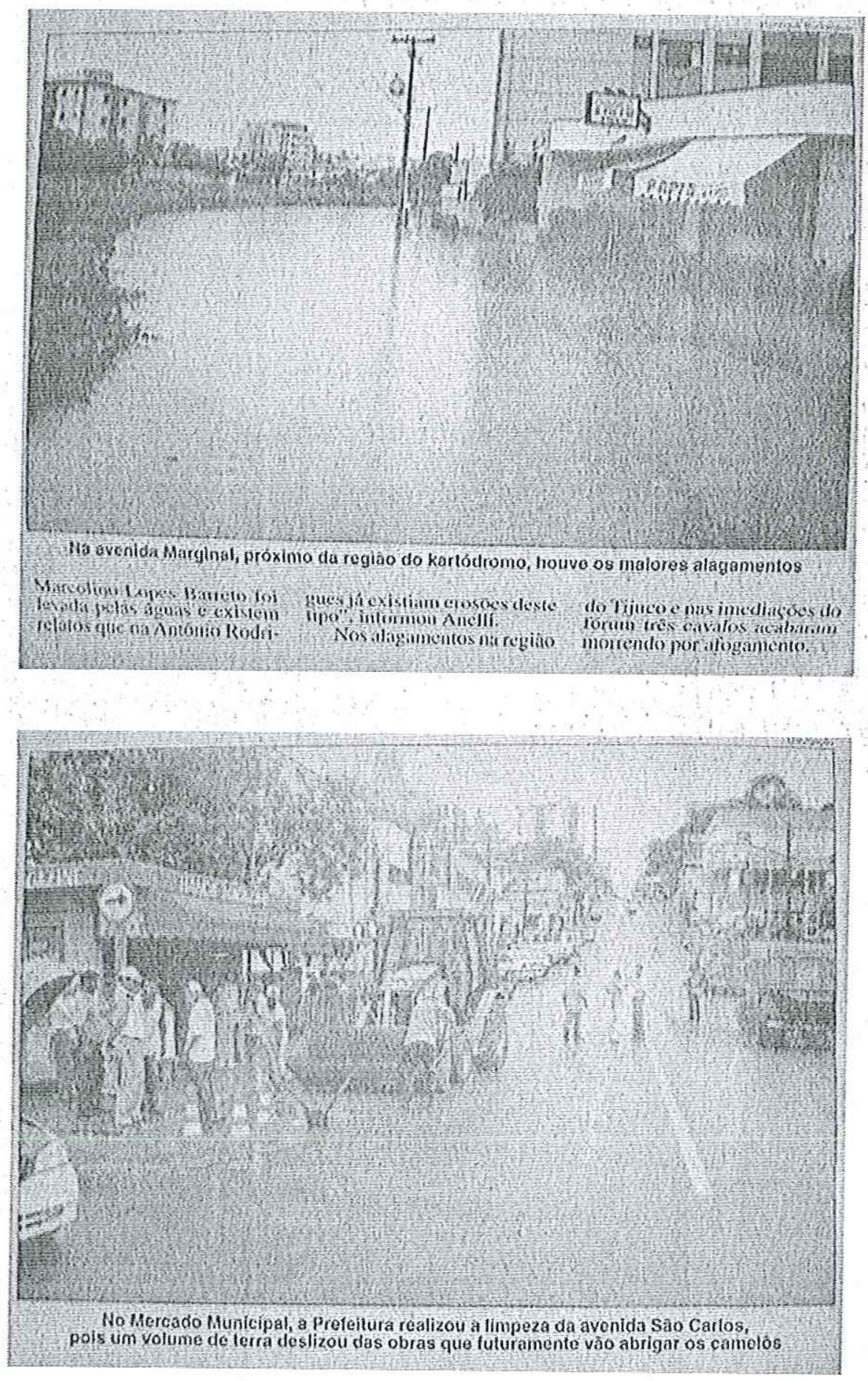

05-01-2003 - Chuvas castigaram cidade de madrugada - Primeira Página - Parte 2 

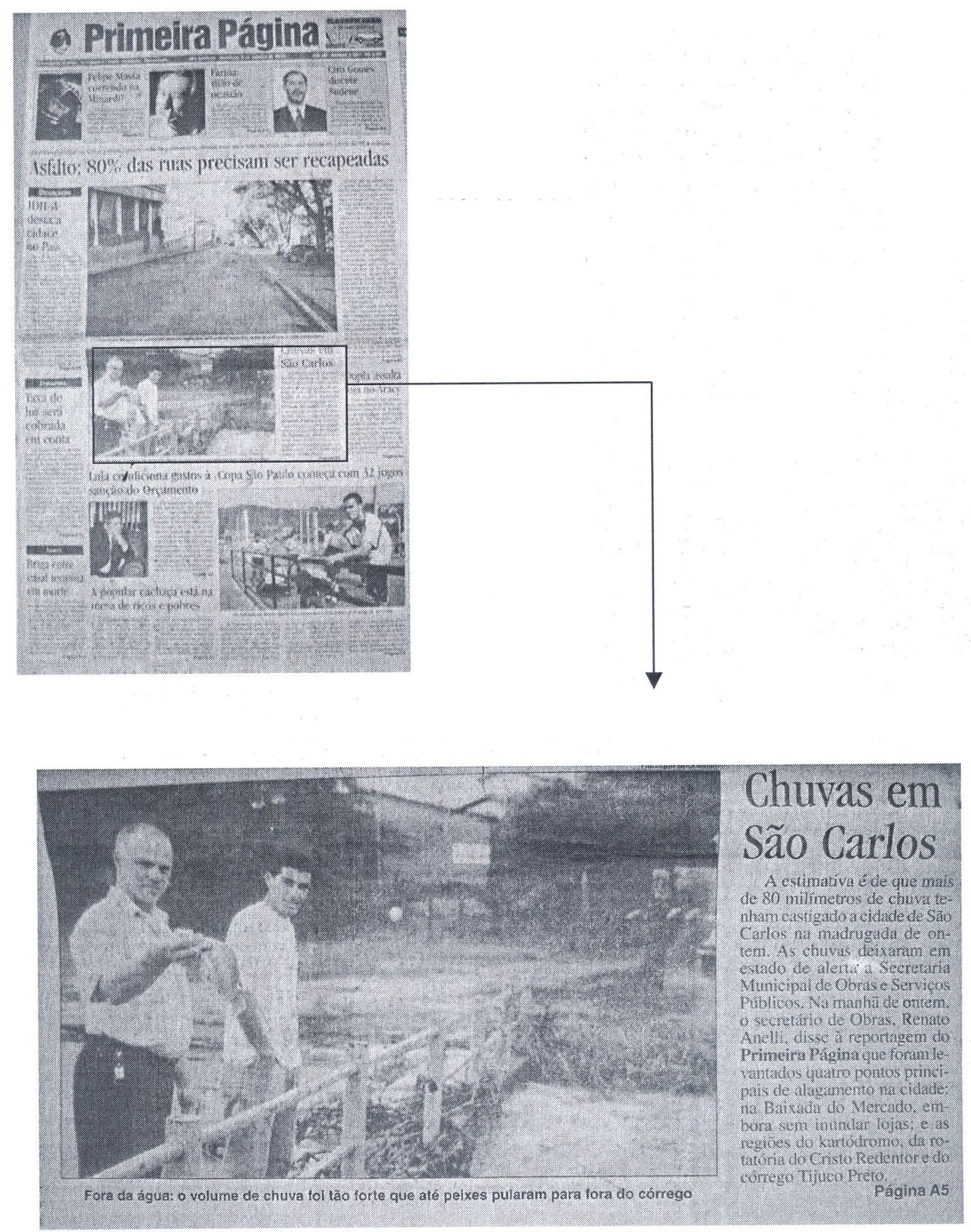

05-01-2003 - Chuvas em São Carlos - Primeira Página 


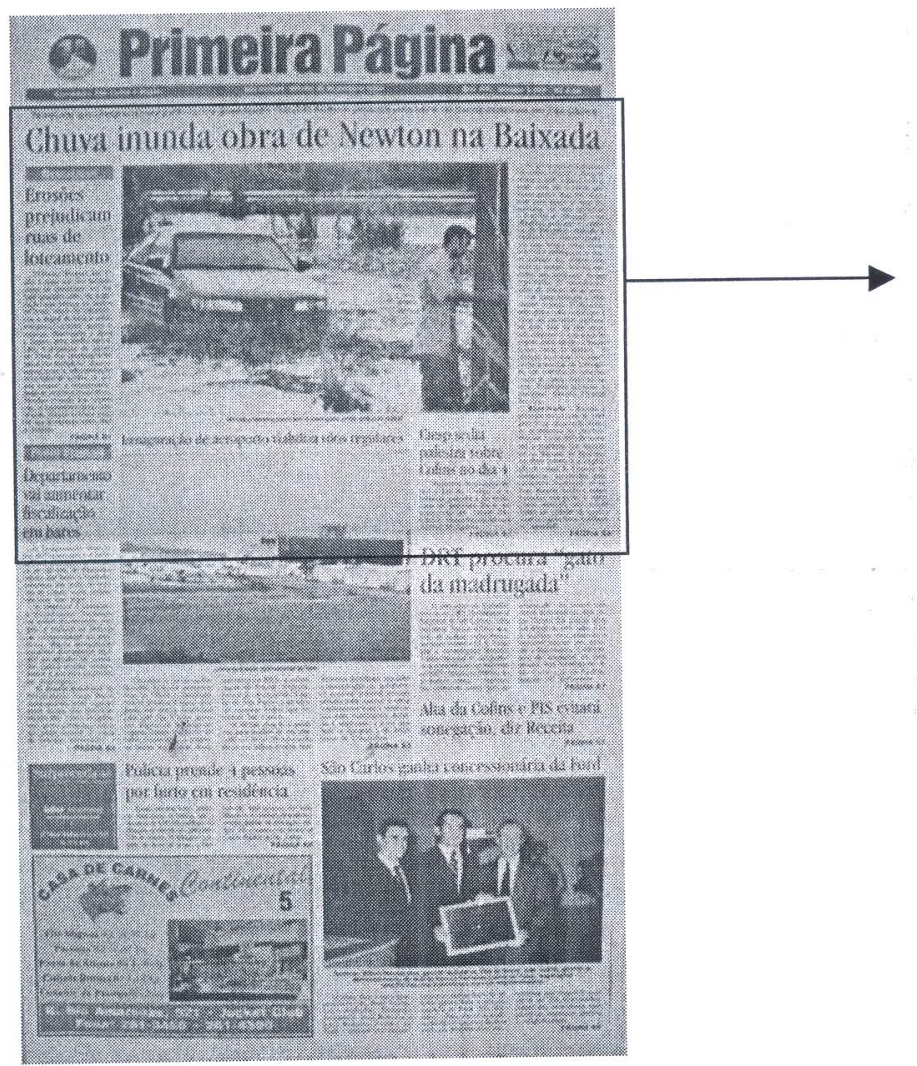

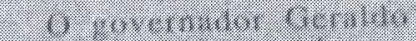

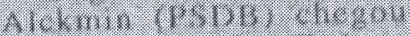

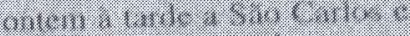

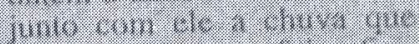

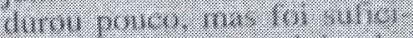

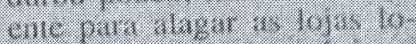

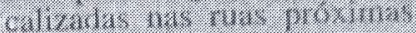

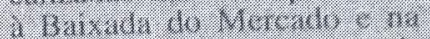

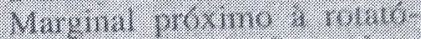

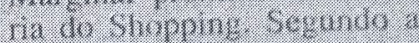

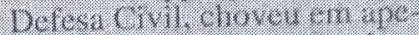
nas uma hora e minto minu. tos 153.3 míninetro: on ma. or deumulo dos ultimos setc anos na cidale. $\$ 0$ com vel: culos nas enchentes foram regisiradas 37 ocurrencias. wern de quedas de arvores.

A árua comecou a subr rapido demais. Colocamo: uma olaca para evilar gue a água da enchente entrasse na loja. mas mesmo as:im não adiantou e esta agun de esgoto cheia de lixo e barair tomou conta da fammacia. A solucrio toi o rodo e. 0 pino". conta a auxiliar de loborratonio que rrabaha emi uma lat: macia de mampulación da rua José Bonifácio próxima a Marginal, Daniela Cristina Viccim:

Reprovado - Basion a

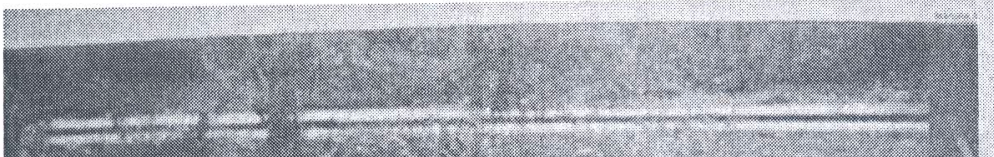
prmeira chuvi lorte de 2004 para levar cuxumrade abaixo an promessas do proteito Newron Lima (PT) de resolver o problemi dis. enchenles na Baixada do Mori.nio. A. luas pontes a ambira ctio do cimal do Contego do Creyormo. projotali.. polo scorretário mumicipal ate 0.

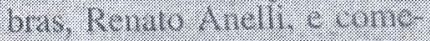

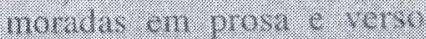

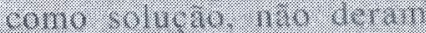

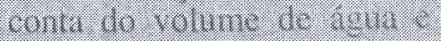

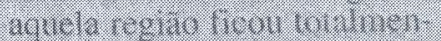

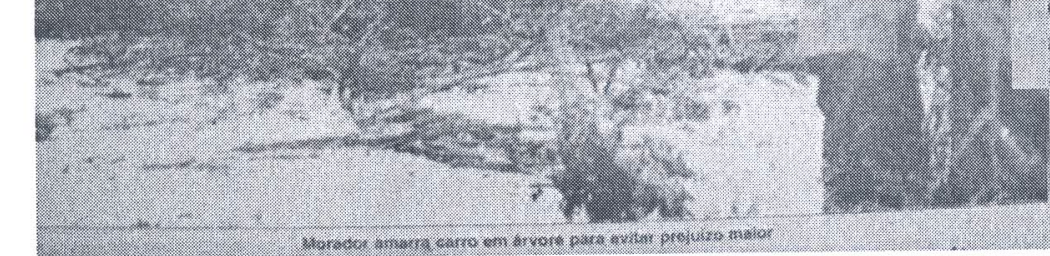

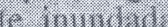

\section{1-01-2004 - Chuva inunda obra de Newton na baixada - Primeira página}




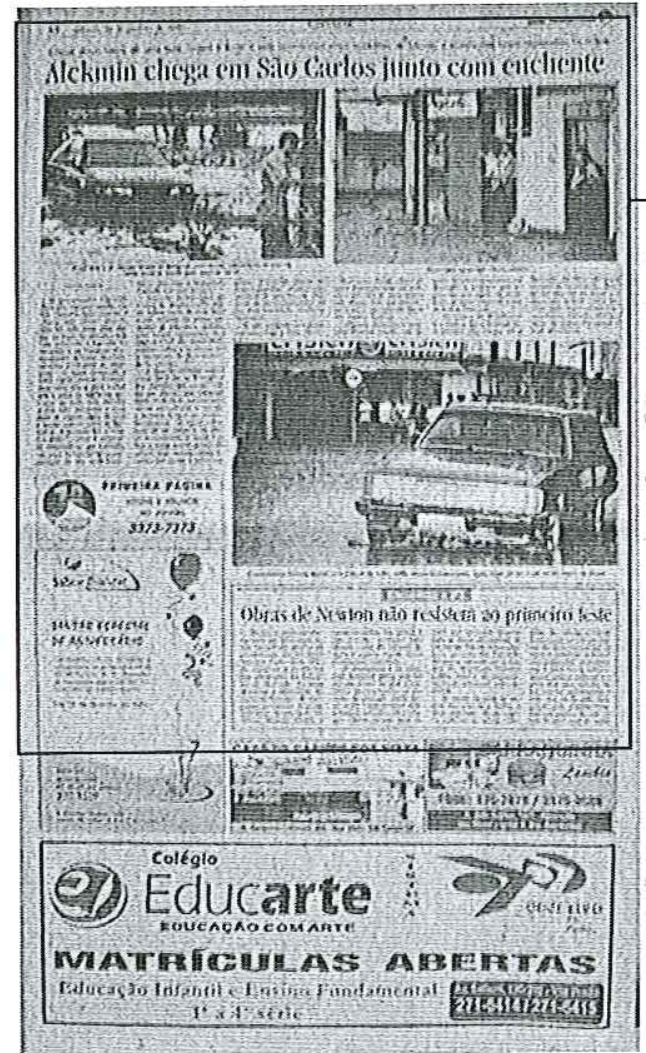

panos, plásticos, placas de tero e papelà", relata o pro prietário de uma loja de con serto de eletrodoméstice na nua José Bonifício, Norberlo Veronese.

B não somente os lojistas sofreram com a forte chuva
"Mell carro ficou cheio de água. Conscgui tirar um pouco e até ligá-lo para tentar sair daqui, mas foi difícil", reclama a aposentada Geni dos Santos Garcia.

Alguns munícipes também ficaram ilhados em al-
MARLALIGUATIOS

O governador Geraldo Alckmin chegou ontem em Săo Carlos e junto com ele a chinva que durou pouco, mas foi suficiente para alagar as lojas localizadas nas ruas proximas a Baixada do Mercado e na Marginal (Comendador Alfredo Maffei), próximo a rotatória do shopping. "A água começou a subir rápido demais. Colocamos uma placa para evitar que a água da enchente entrasse na loja, mas mesmo assim não adiantou e esta água de esgoto cheia de lixo e barata tomou conta da farmácia. A solução foi o rodo e o pano" conta d auxiliar de laboratório que traballia em uma farmácia de mani pulação da rúa José Boni- fácio próxima a Marginal, Daniela Cristina Viccini.

Scgundo informações do Corpo de Bombeiros, a chuva durou cerca de una hora c sete ocorrências dentre acidentes de trânsito e inundaçöes foram registradas. Já a Defesa Civil não tinha informações sobre a encliente até o momento do fechamento desta edição.

A água da enchente tomou conta das lojas da Baixada e deu trabalho aos comercialltes que tiveram que trabalhar além do horário normal para salvar mercadorias e móveis e também limpar os estabelecimentos. "A água subiu mais de um metro e foi difi. cil de controlar. A nossa loja fica a meio metro acima do asfáto, mas mesmo assim tivemos que conter a água con

ficuldades para chegar até a José Bonificio.

31-01-2004 - Alkimin chega em São Carlos junto com enchente - Primeira página - Parte 1

guns estabelecimentos na da e liveram que a ardar por mais de meia hora a igua abaixar para poderem iransitar a Defesa Civil tiveran di
Baixada do Mercado para atenter às ocorréncias, devido ao trânsito no local e a agua que tomou conta das? principais ruas como $\mathrm{Co}$ mendador Alfredo Maffei. ove de Julho Episcopal e

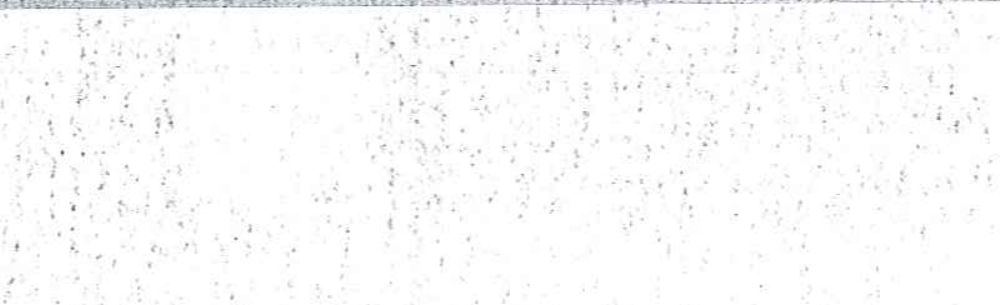

- 


\section{Whorlanise th th? \\ Obras de Newton não resistem ao primeiro teste}

Bastau a princira chilla ferte de 20014 para leyó conurrada abaixo as promessas do prefeito Nawion lima Neto (PT) de resblver o problema Uas enchentes na Baixa do da Mercado. As duas pontés a a ampliaçâo do Eanal do Córreyo do Gregrio. projetadis pelo secrétario municipal do Qbras. Renato Anelli, comemoradas em prosa e verso como solução, nầo deram conta do volume de agua e aquela regiảo ficou cotalmente inundada.

A demagogia e os sofis. mas lançados pelos petistas davam conta de que a tragédia das enchentes já era coisa do passado. Além dis so, o PT fazia, durante todo o tempo, cortesía com o chapéu alheio, já que mais de
$70 \%$ dos recursos usados para as obras de combate as enchentes foram repassados pelo governador Geraldo Alckmin, devido ao Irabatho do deputado federal Lobbe Neto o do empresá rio Paulo Altomani, todos do PSDB.

As cenas da tarde de ontem mostraram a todos a dura realidade. No desespero, cada um se salvou cuino póde. As chuvas yoltaran a apavorar os comercian tes da área central da ci dade e também motoris. tas, pedestres, motoquei ros e civistas e infeliz mente podein retornar no: próximos dias Contra fa. tos múo há argumentos: 0 fim das enchentes pro. palado pelo prefúito New ton náo passoul do um so. nho de uma noite de verão.
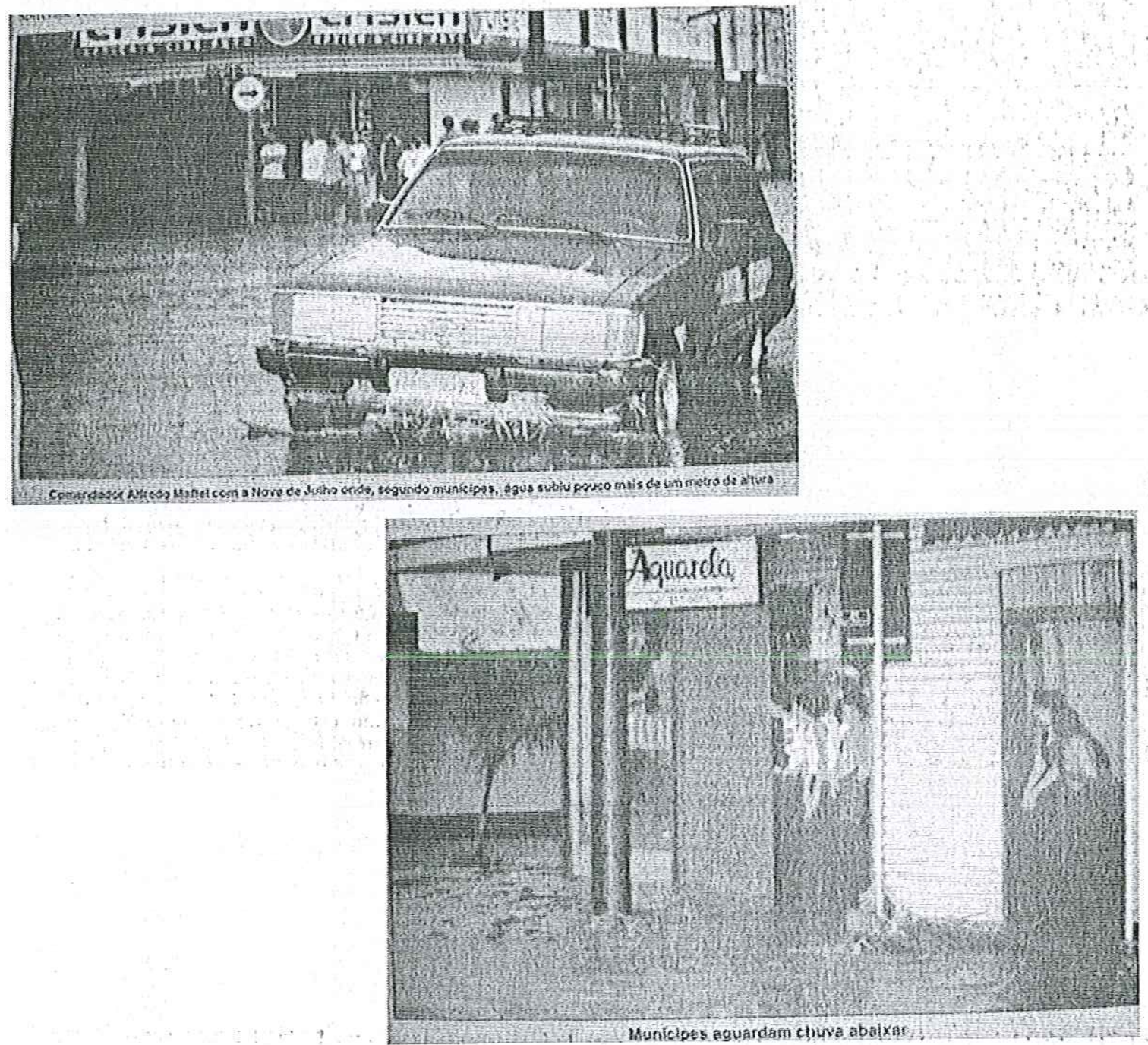

31-01-2004 - Alkimin chega em São Carlos junto com enchente - Primeira página - Parte 2 

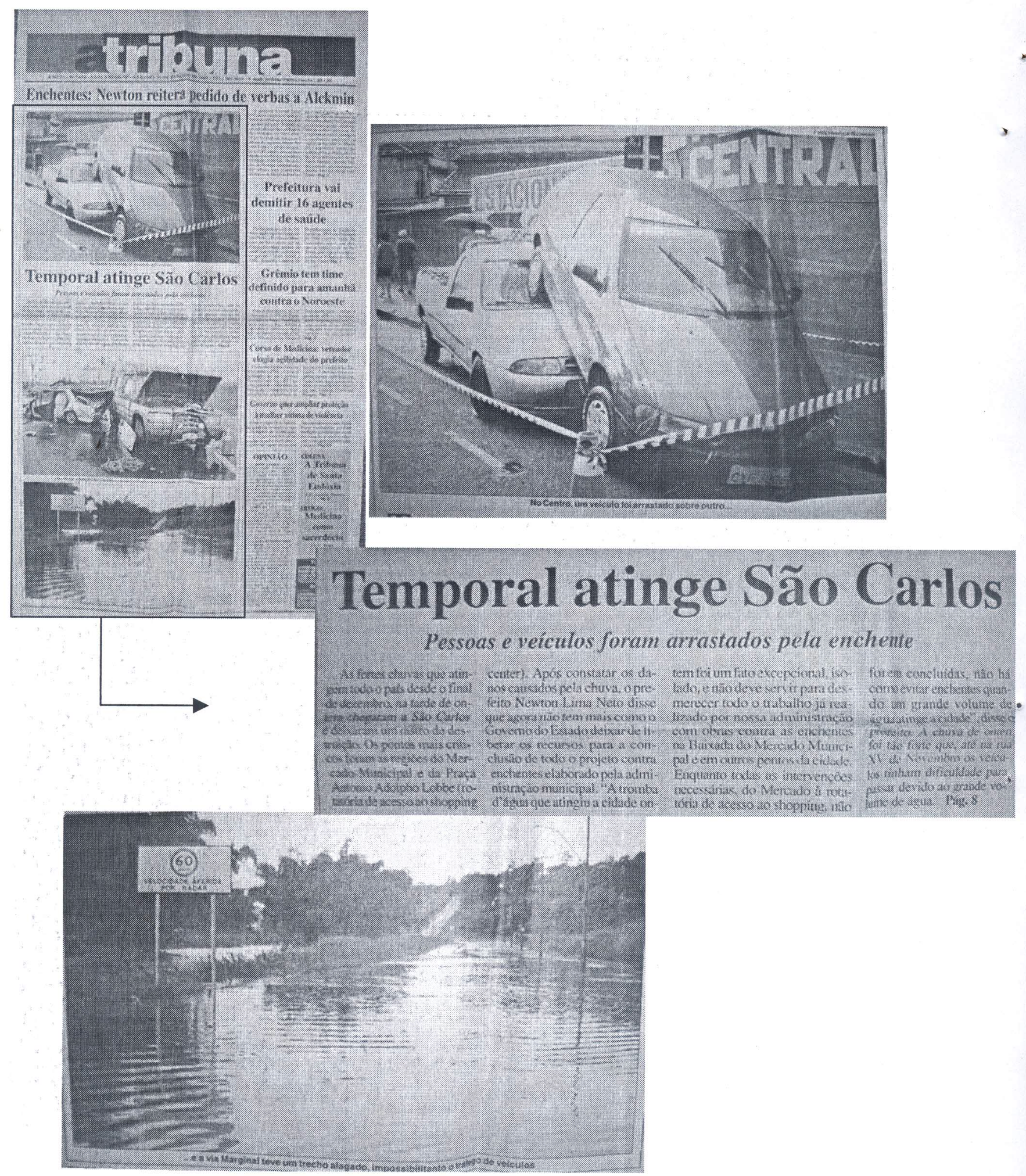

31-01-2004 - Temporal atinge São Carlos - A Tribuna 


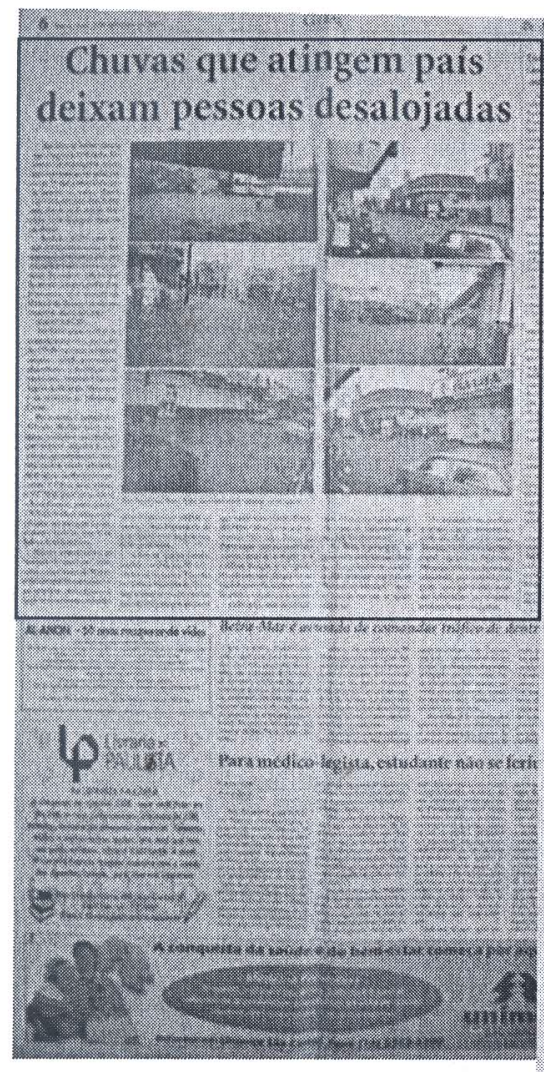

A. chims tortes chusis que atingiram is Etadio lint slleiros ja matum 66 pessoas er deixumand desalojudus cercrac ac 55 mill somerie no mos de janciro em todo o Mrasil. cujos extados que nxis sofreran fornun os dis regiño Nor deste. en os da regria Sudeste du Brasil:

Ao rodo, 20.751 casas fo. ram danificulase cutar 2.498 destruida: crivdo o pals por caira das fortes chuvas de ja: neiro, Derenas de cidudes que icam nas margens do Rio Sin Francisco, nos criadios da Bahia e de Servipu, estio em estado de alerta mixíno.

SÃOCARLOS

En Sio Carlos, no final da urde de sexta-ferri, por wolta de 17 hoo um forne temporal atingiu a cidade prowocsudb alagamentos e destrucicit, as partes mais :ainglidas formo as reziles do Mercado Municinal e da rohatoria do Shopping Cener.

Na avenida Comendider Alredo Matroi, alem dis

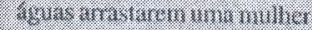
que teriuva abundonas seu

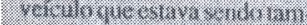
bern crtava schido arrastallo

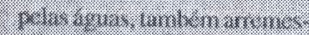

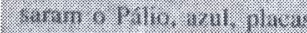

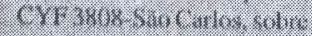

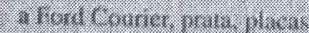

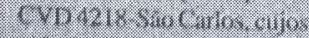
o.

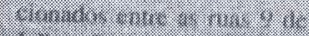

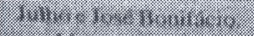

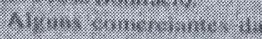

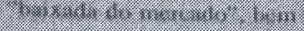

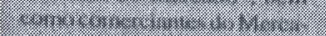

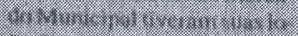

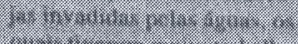

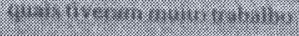
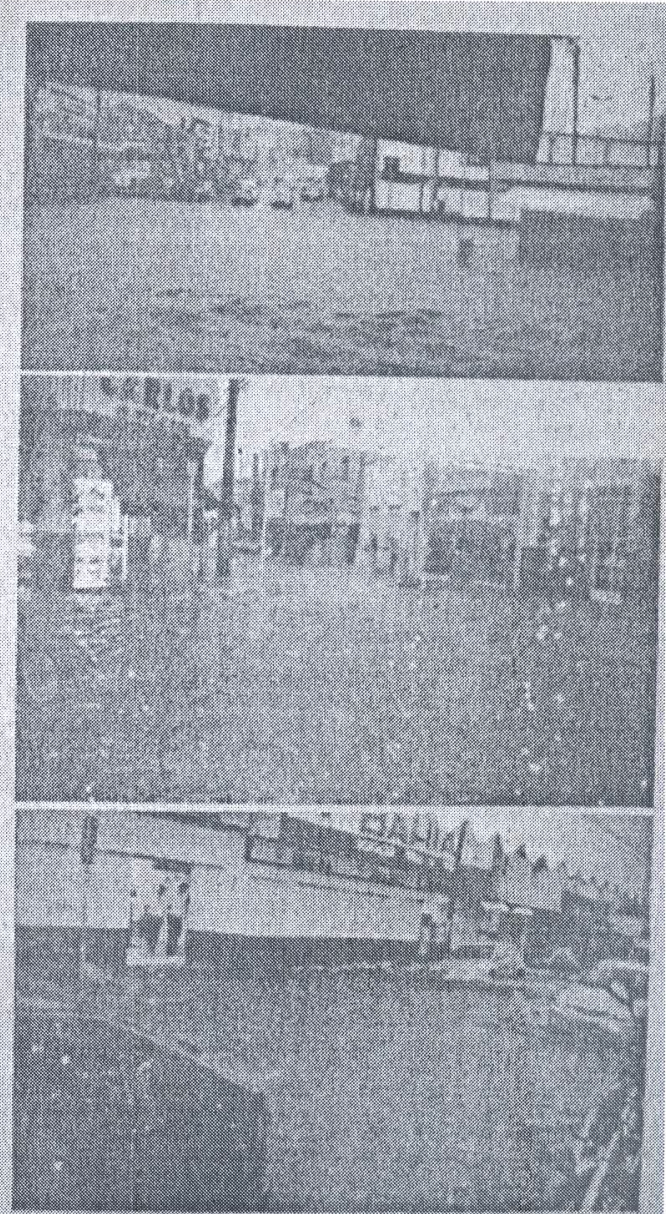

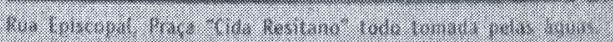

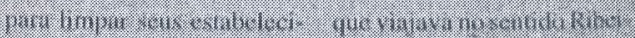

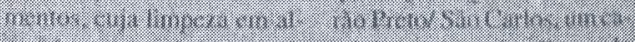

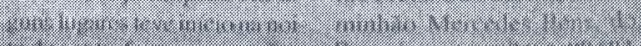

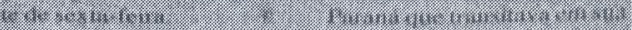

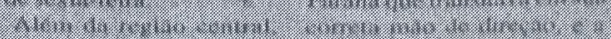

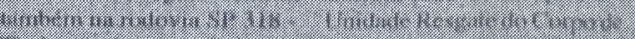

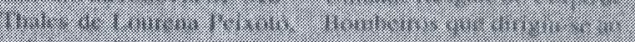

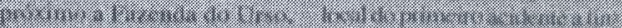

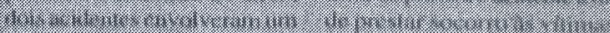

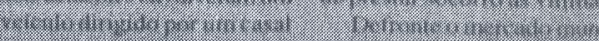

\section{3-02-2004 - Chuvas que atingem pais deixam pessoas desalojadas - A Folha - Parte 1}




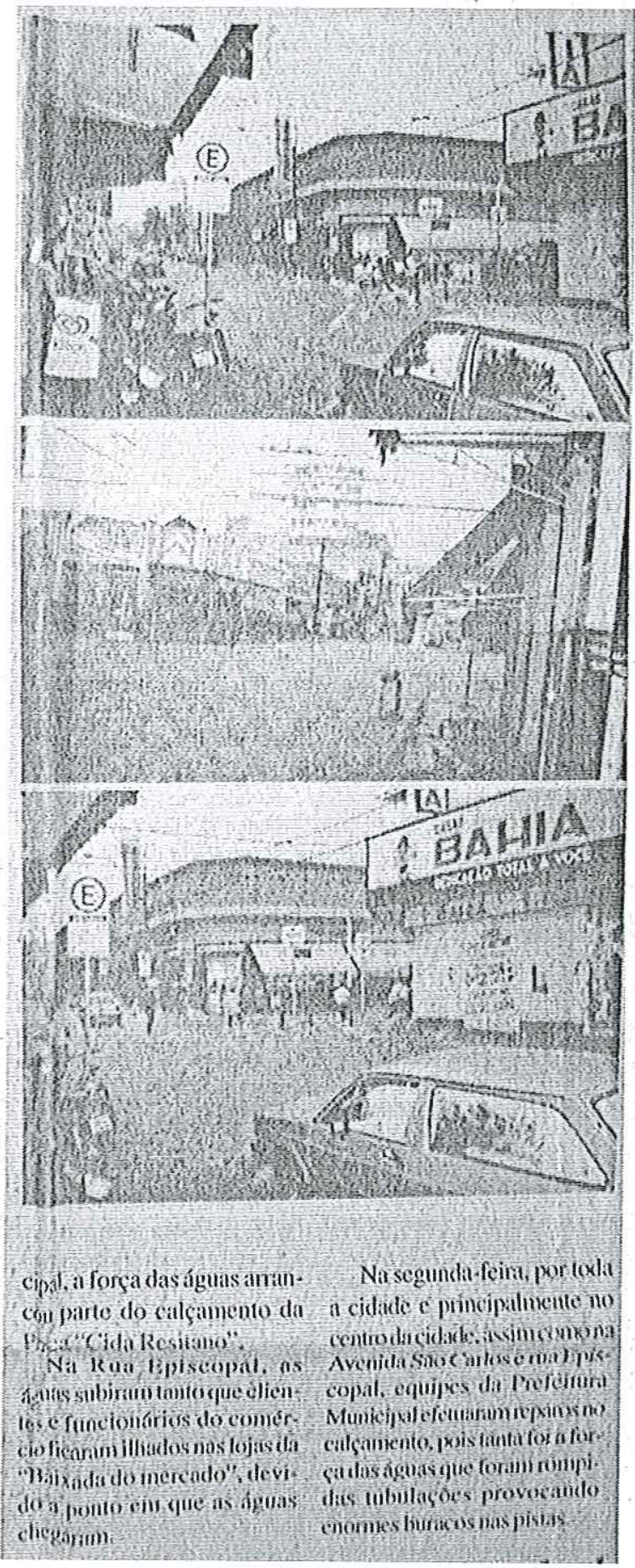

03-02-2004 - Chuvas que atingem pais deixam pessoas desalojadas - A Folha - Parte 2 


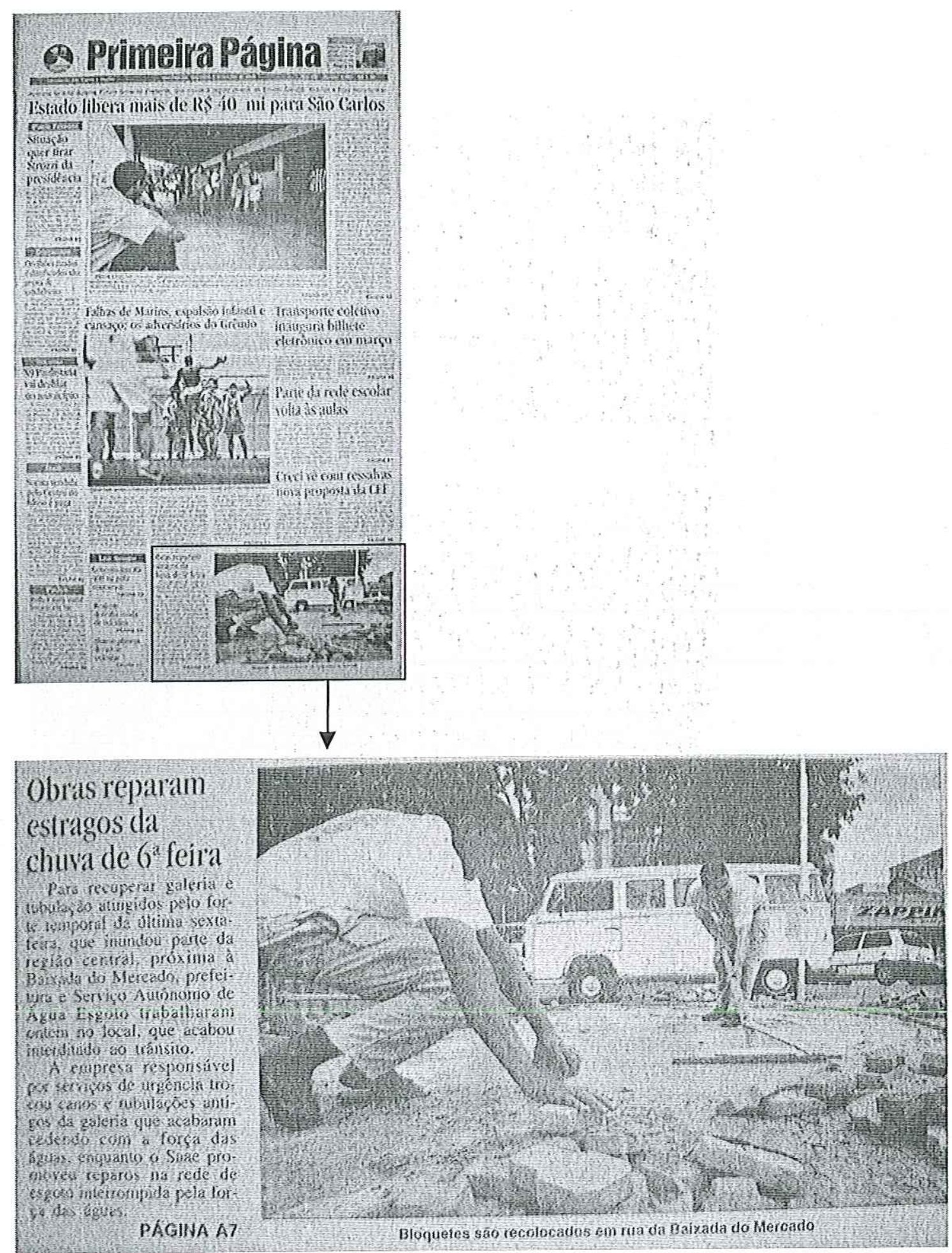

03-02-2004 - Obras reparam estragos da chuva de $6^{\mathrm{a}}$ feira - Primeira Página 


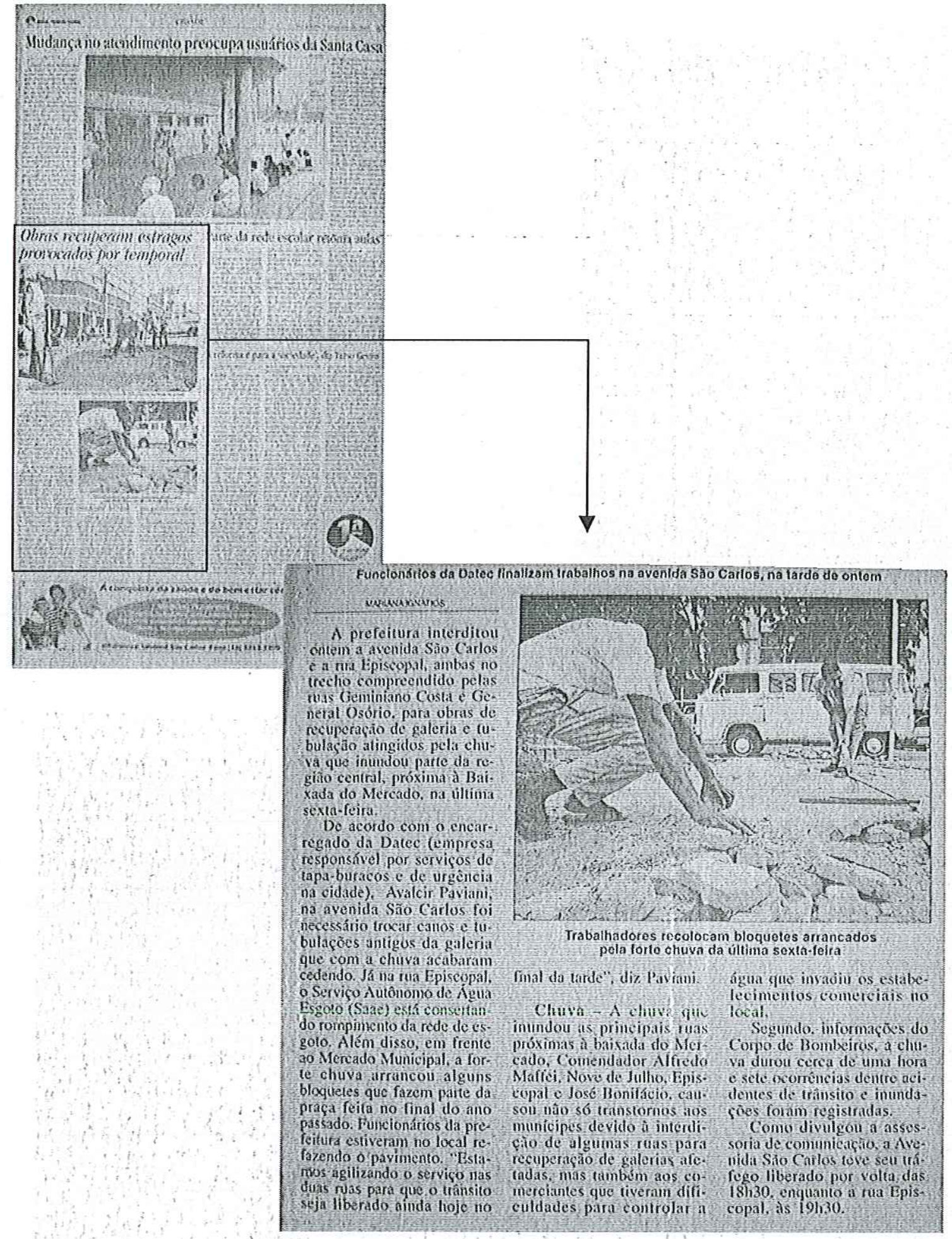

03-02-2004 - Obras recuperam estragos provocados por temporal - Primeira Página 

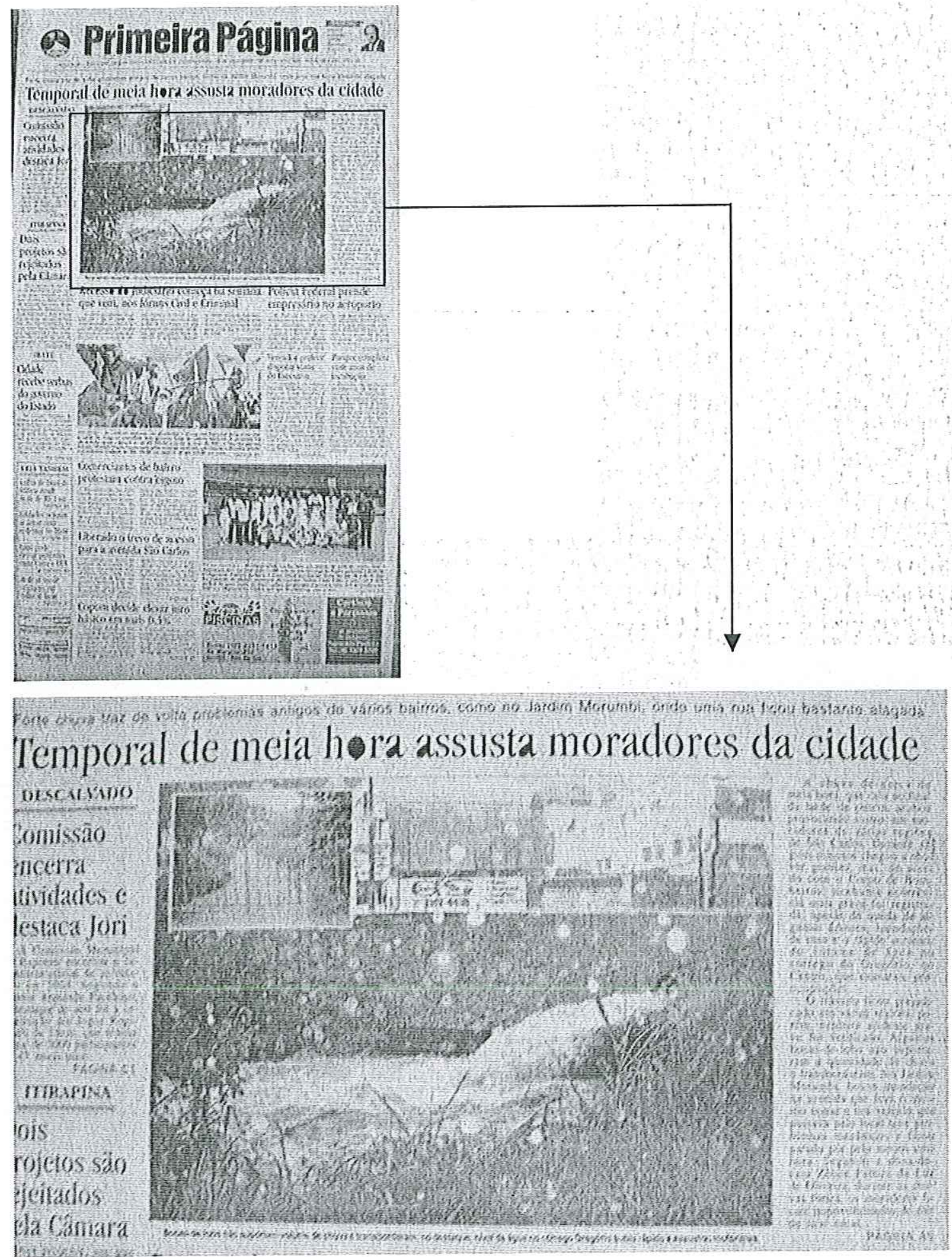

16-12-2004 - Temporal de meia hora assusta moradores da cidade - Primeira Página 


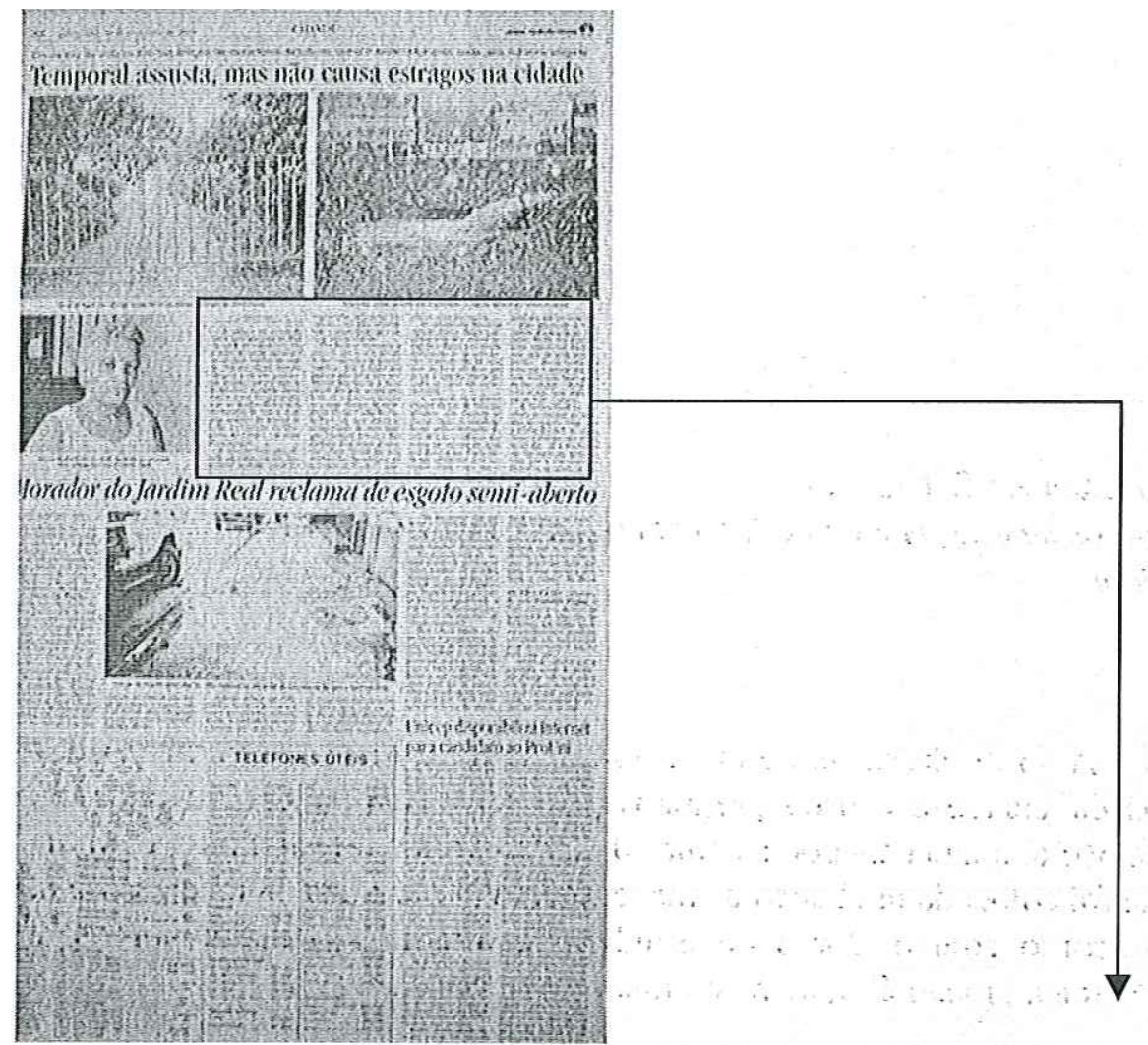

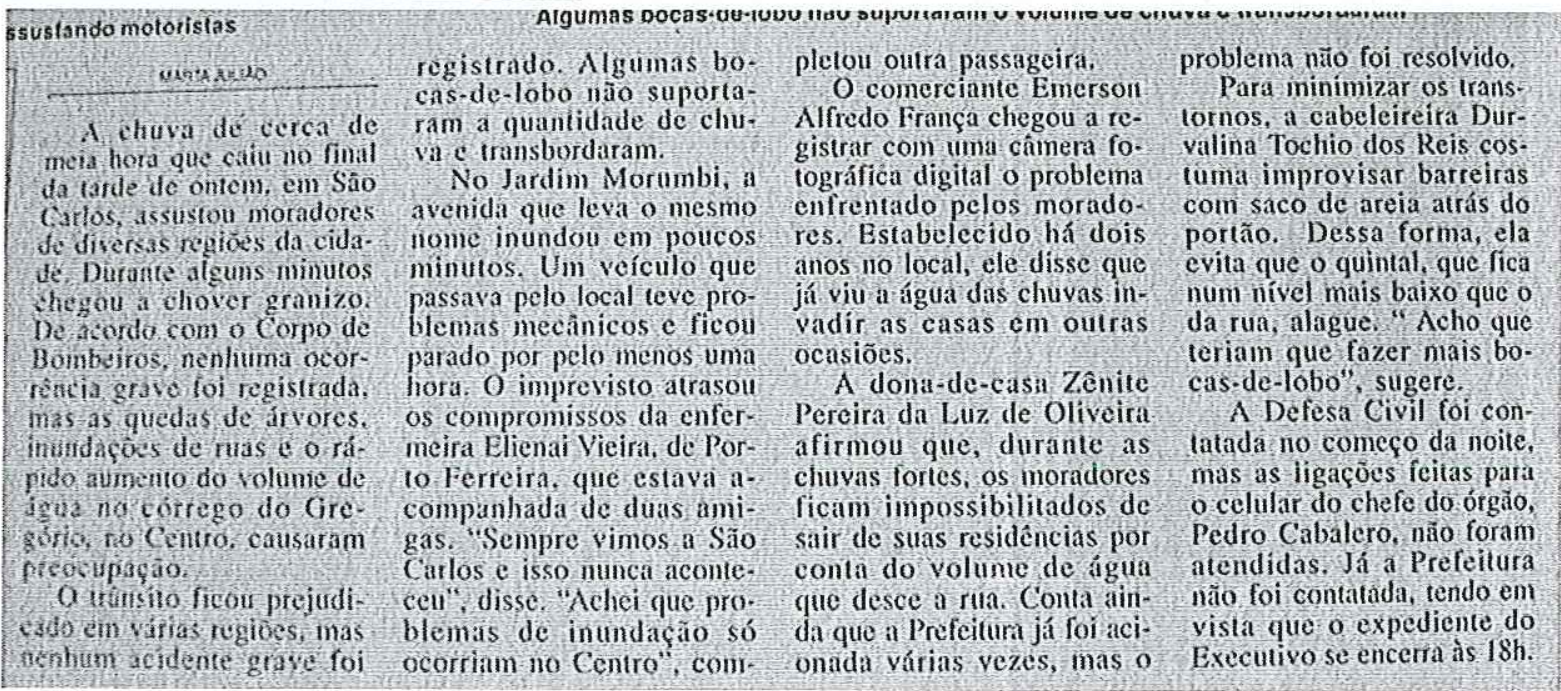

\section{6-12-2004 - Temporal assusta, mas não causa estragos na cidade - Primeira Página}


Chuva causa alagamentos em São Carlos

Foram registrados pontos de alagamento na lagoa Serena, praça Itália, mercado municipal e na marginal

\section{EPTV Central}

20/12/2004 14:35:00 - A forte chuva que atingiu São Carlos na noite de domingo (19) alagou alguns pontos da cidade e causou prejuízos para os comerciantes. Segundo a vendedora, Silvana de Melo, a água chegou a subir 30 centímetros em frente à loja em que trabalha. Ela disse que foi colocado um banco de madeira para evitar que a água entrasse no estabelecimento. De acordo com o Corpo de Bombeiros, foram registrados pontos de alagamento na lagoa Serena, praça Itália, mercado municipal e na marginal.

20-12-2004 - Chuva causa alagamento em São Carlos - http://eptv.globo.com/noticias 


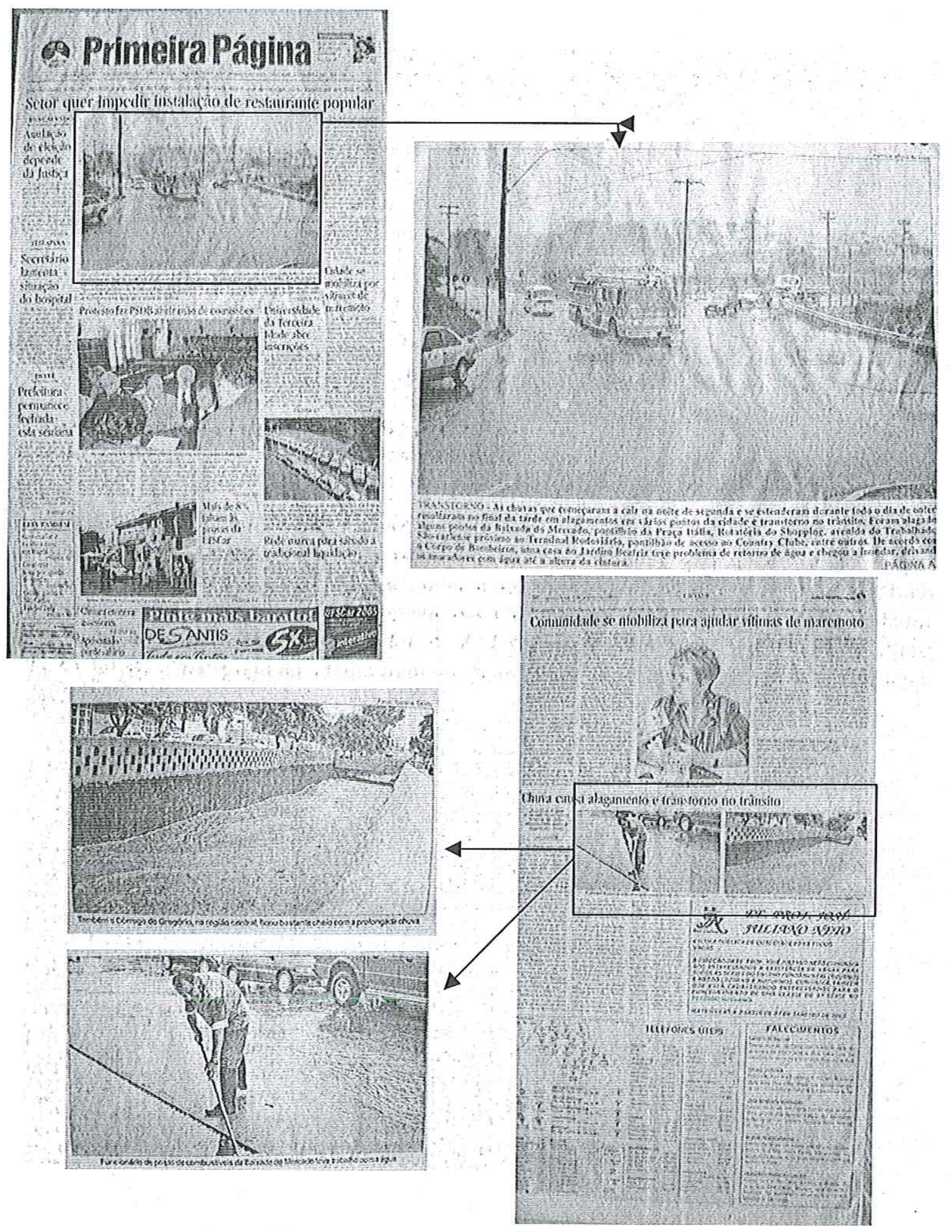

05-01-2005 - Chuvas causam alagamento e transtorno no trânsito - Primeira Página Parte1 


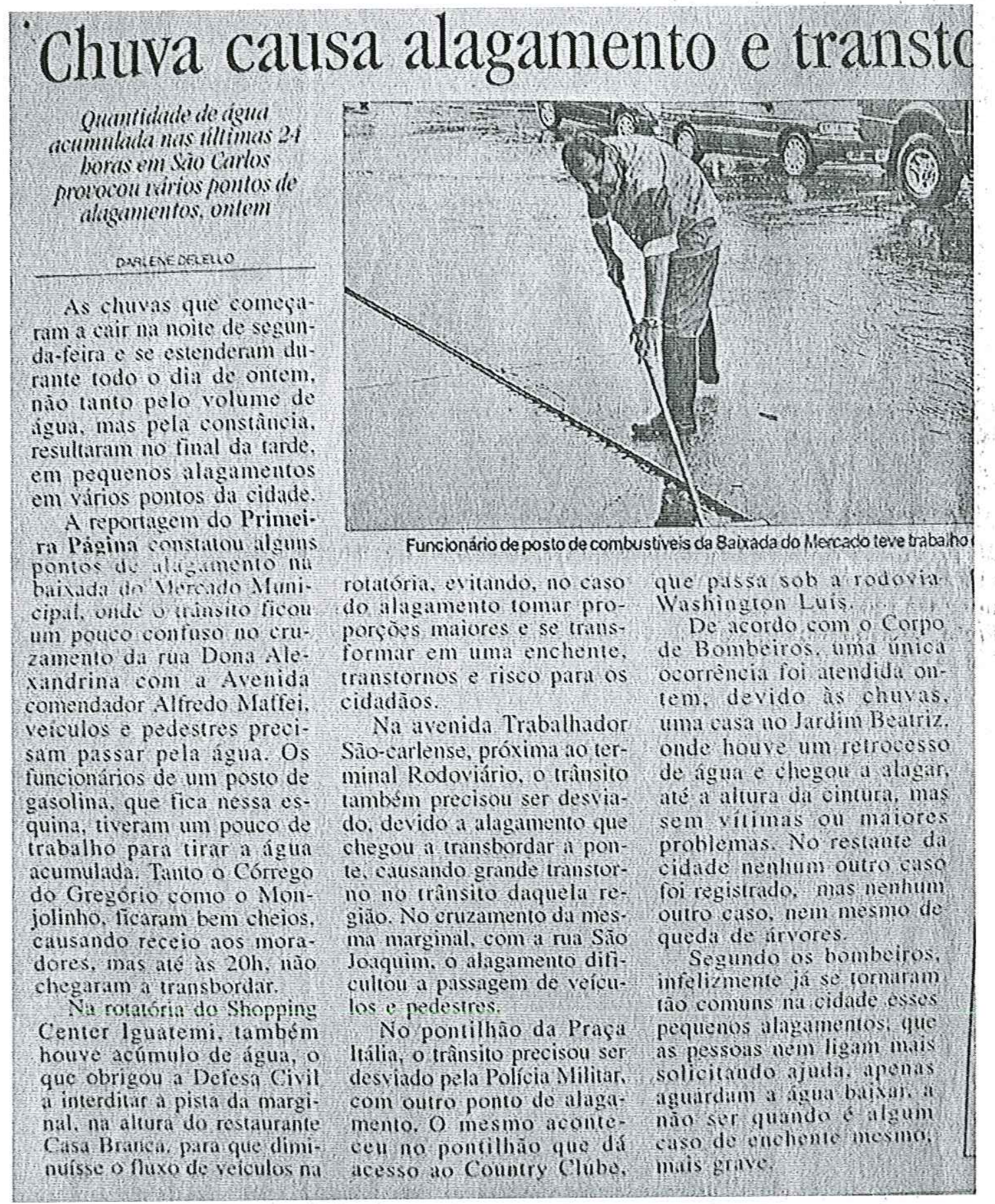

05-01-2005 - Chuvas causam alagamento e transtorno no trânsito - Primeira Página Parte2 


\section{Chuva causa estragos em São Carlos}

Parte de um barranco desabou na avenida Marginal

EPTV Central

16/03/2005 15:07 - A chuva forte que atingiu São Carlos nesta quarta-feira causou estragos. Parte de um barranco desabou na avenida Marginal. A prefeitura informou que fará reparos no local nesta tarde. Na estrada que liga o município a Ribeirão Preto, funcionários da empresa que administra o local farão o reforço da sinalização para evitar acidentes.

16-03-2005 - Chuva causa estragos em São Carlos - http://eptv.globo.com/noticias/ 


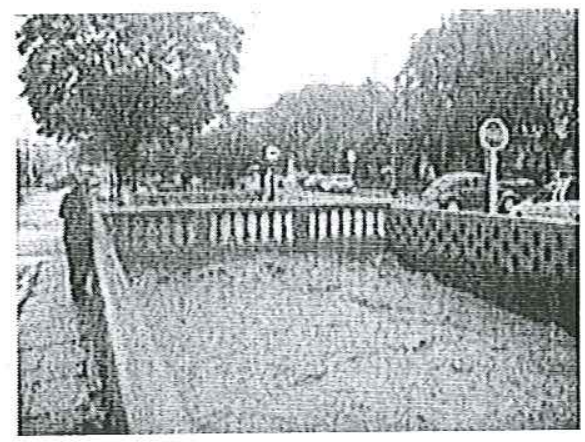

17/03/05: CHUVAS PROVOCAM PONTOS DE

ALAGAMENTO

Uma equipe da Secretaria Municipal de Transporte, Trânsito e Vias Públicas acompanhou atentamente a forte chuva que caiu durante toda manhã de quarta, dia 16, em São Carlos. Segundo informações do Departamento de Trânsito, aconteceram alguns pontos de alagamentos, mas não houve inundações na região urbana. Os pontos mais críticos foram no cruzamento da rua São Joaquim com Geminiano Costa e, nas primeiras horas da manhã, um pequeno congestionamento sob o viaduto na Praça Itália, por conta de alagamento no local, rapidamente solucionado.

17-03-2005 - Chuvas provocam pontos de alagamento - http://www.saocarlos.sp.gov.br/ 


\section{ANEXO 02}

Fotos das Notícias:

Intervenções e Obras relacionadas à drenagem na Bacia do Gregório 


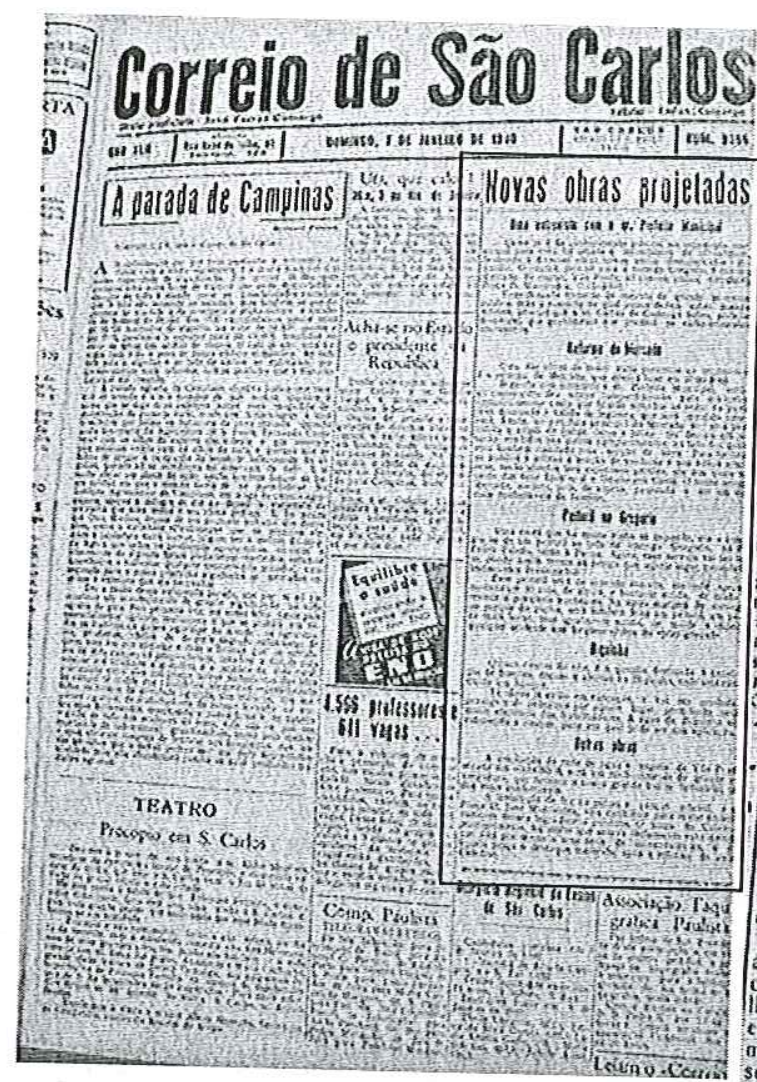

ithlovas diras projetallas Uana ealrevisla com o sr. Preleilo Municipal

como la ts do conbecimento pubico, no otcamento usu.

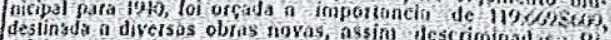

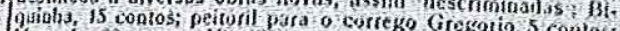

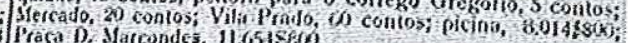
raca 1). Marcondes, 11.6518500 .

publico, mas a respeito do qual pouco de grande ioteresso

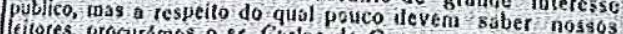
municipal, gue necessarios gue gentiphla nos prestou os esclarecimentos

\section{Retorma do Mercado}

Una das obras de major vulto previslas no orcanento Sezuado nos icado, que deverá ficar eln 20,0004000 li construidos de noyos o sr. Preleito Municipal seta compratumentos esses Thão destinado a ves que licaráo siluados ao redor do phryi csia, Assim, no pavilla de legumes, Trie sera inantido coro mitida a venda ila frúa principal do Mercodo só será serao vendidos nos uuv, como e peixe. Os deruals an será tambero fostar compartimentos, ao lado dos gua

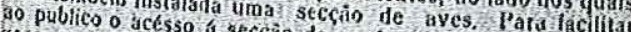
zens, seta 0 abritos ties efa de verdiltas e aos novos ailita canto das ruas o discos Mercado, foudato tosis coplartavaio, pois, te asjélo, passando. onosso untigo

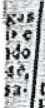
Uasa coisa que ha muito vinha se impondo, cia coisto

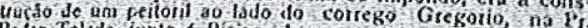

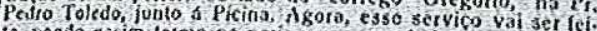

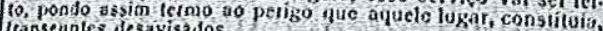

madamente 30 cins do cimeiro armado, medindo aptoxi.

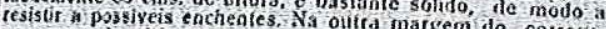
120 parque da picioa, setá ramberin feito um peitoril corrego. co mass baxo, mas igualmento solido, de molde a impedir Biquinha

Qinze contos de réis, é a quantia destina a consti co de bsciros, drenos e alerros na Binjugho ond a consleu. is um borque.

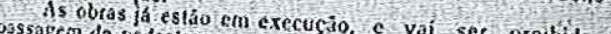

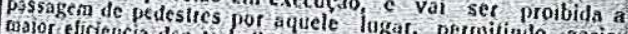

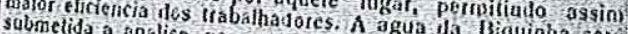
Oulias obras

A ampliacảo da redo do ob orgada em lockosoco, sera uin inelhorgoto da Vila Prado

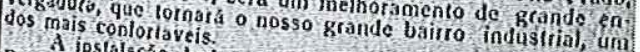
A iostalesía do

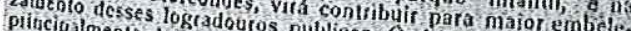

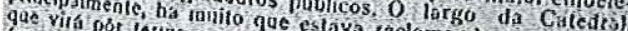
gavela pras lerilo a uma seric do Caledral. Hesm. 

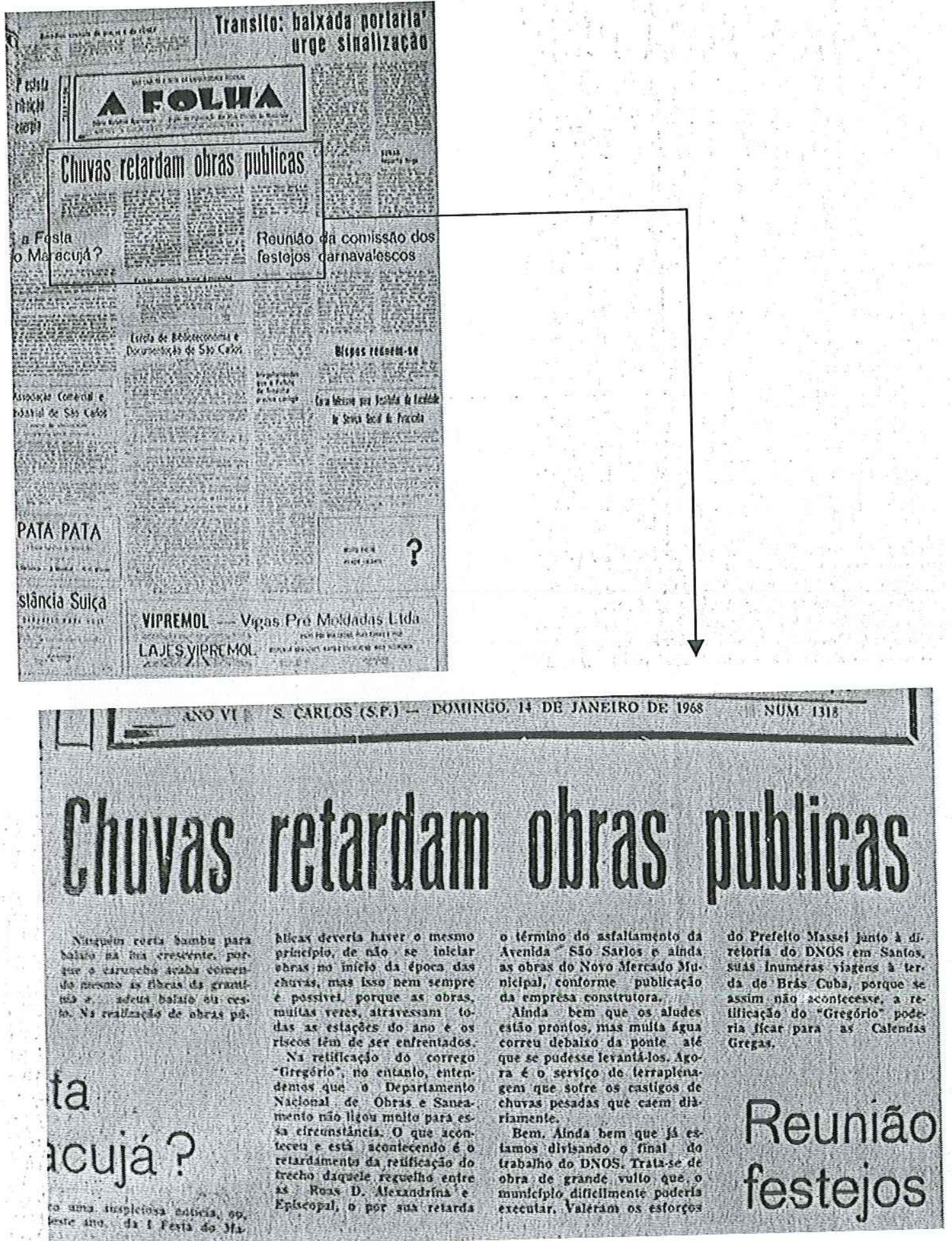

14-01-1968 -Chuvas retardam obras publicas - A Folha 


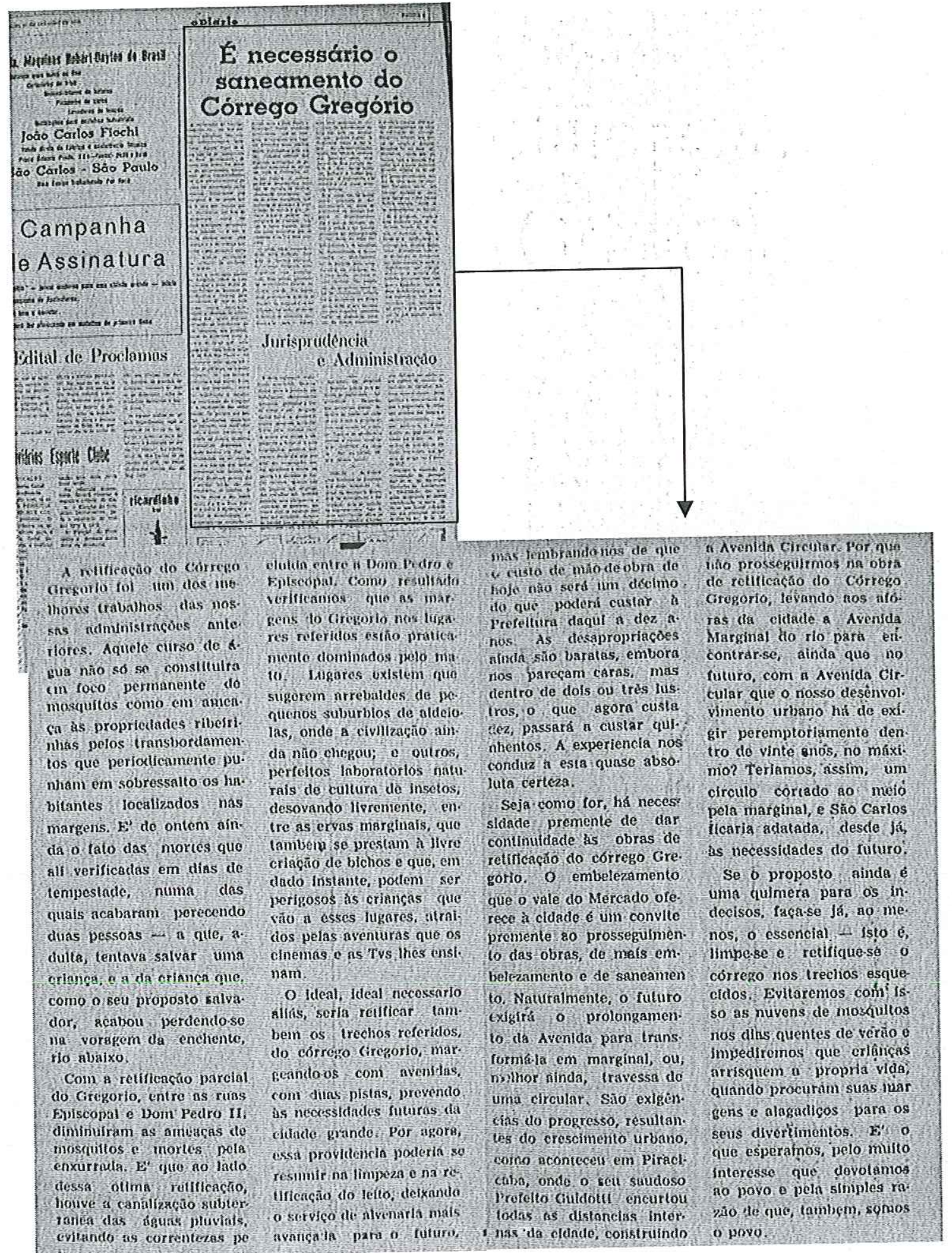

17-01-1970 - É necessário o saneamento do Córrego Gregório - O Diário - Parte 1 
is sarkeths, $60 \mathrm{~m}$ possibill. clado do noletontes como a: gubie do mogo quo, anos jassndos, etilu numa sargo la da lua sảo paulo o to iurastaclo pelas aguas até $\rho$ leito do eorrego, na ocasiño violento, 40 qua tamirem resultou a sua morte, Vêse, pelo que expomos, como fol importante o traballio dis retifleacăo do Gregorio e a canalizaçũo las enxur radas. Os perígos que tan tas apreonsoes causaram no passado, nüo mala exis: tem, e como resultacio cldade 56 tornou moderna, oferecendo seguranç $\theta$ sauda mesmo nos dlas da fempestade ou no resulta. do dos insetos que tantos tormentos têm causado ao pavo. Aconteco, porem, que - servico alnda ná esté conclutdon os treohos do rlacho entro o seu nasce: douro a a Rua Dom Pedro II $\theta$ entre a Eplscopal o 0 Asllo de Mendloidado, por: manecem nus condlsoes an tarlores a canalizacino con.

17-01-1970 - É necessário o saneamento do Córrego Gregório - O Diário - Parte 2 


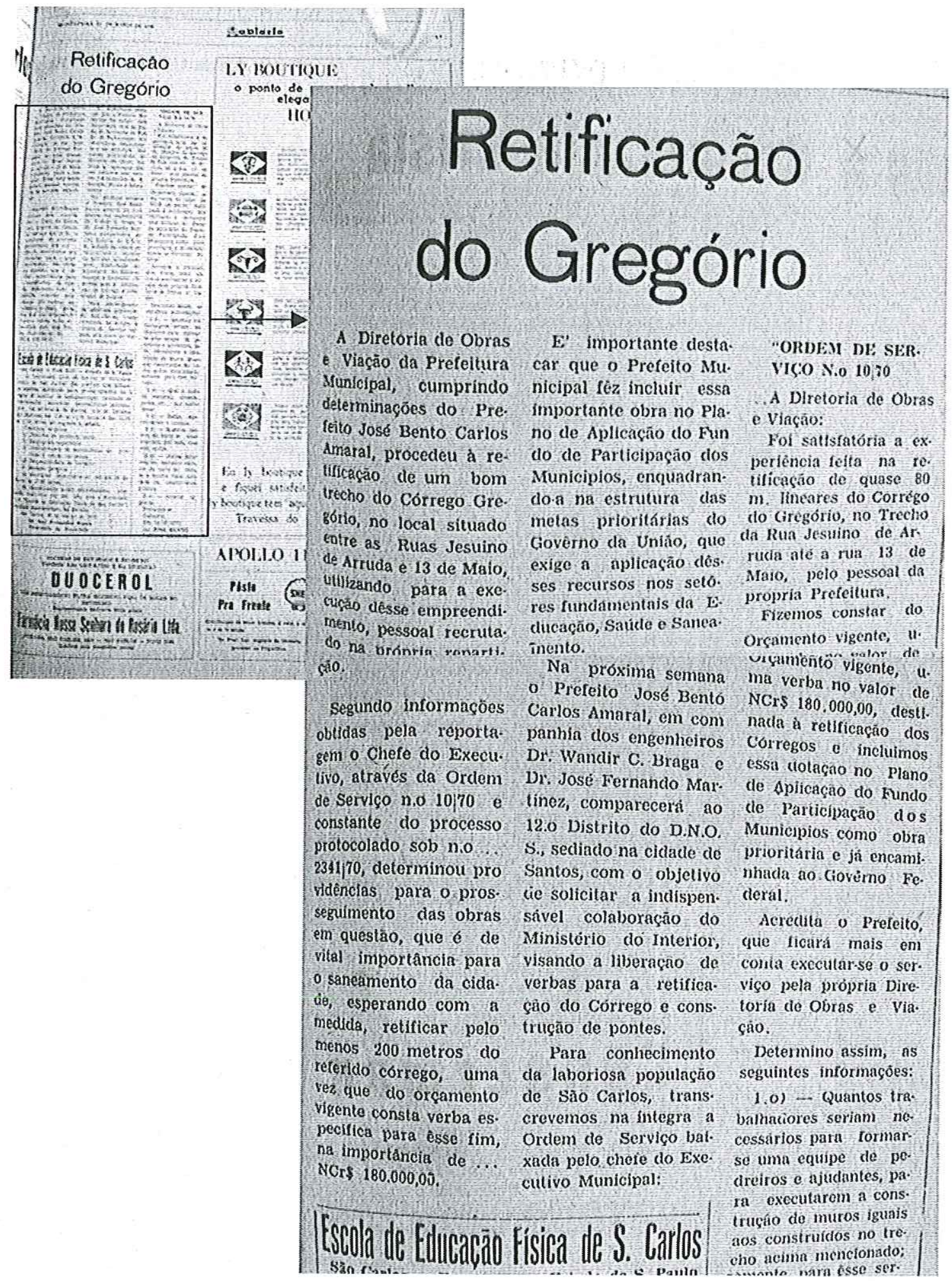

12-03-1970 -Retificação do Gregório O Diário - Parte 1 


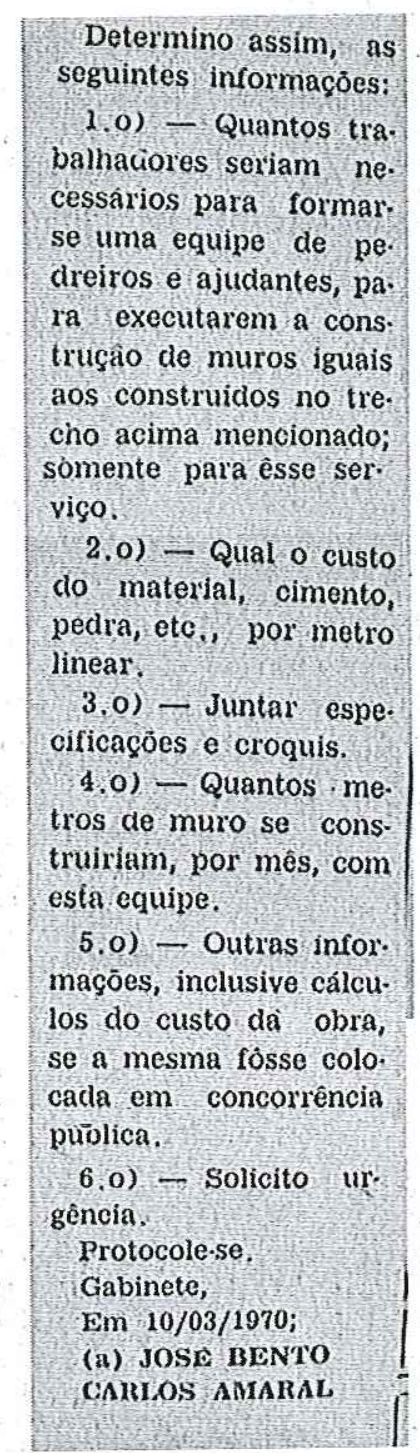

12-03-1970 -Retificação do Gregório O Diário - Parte 2 

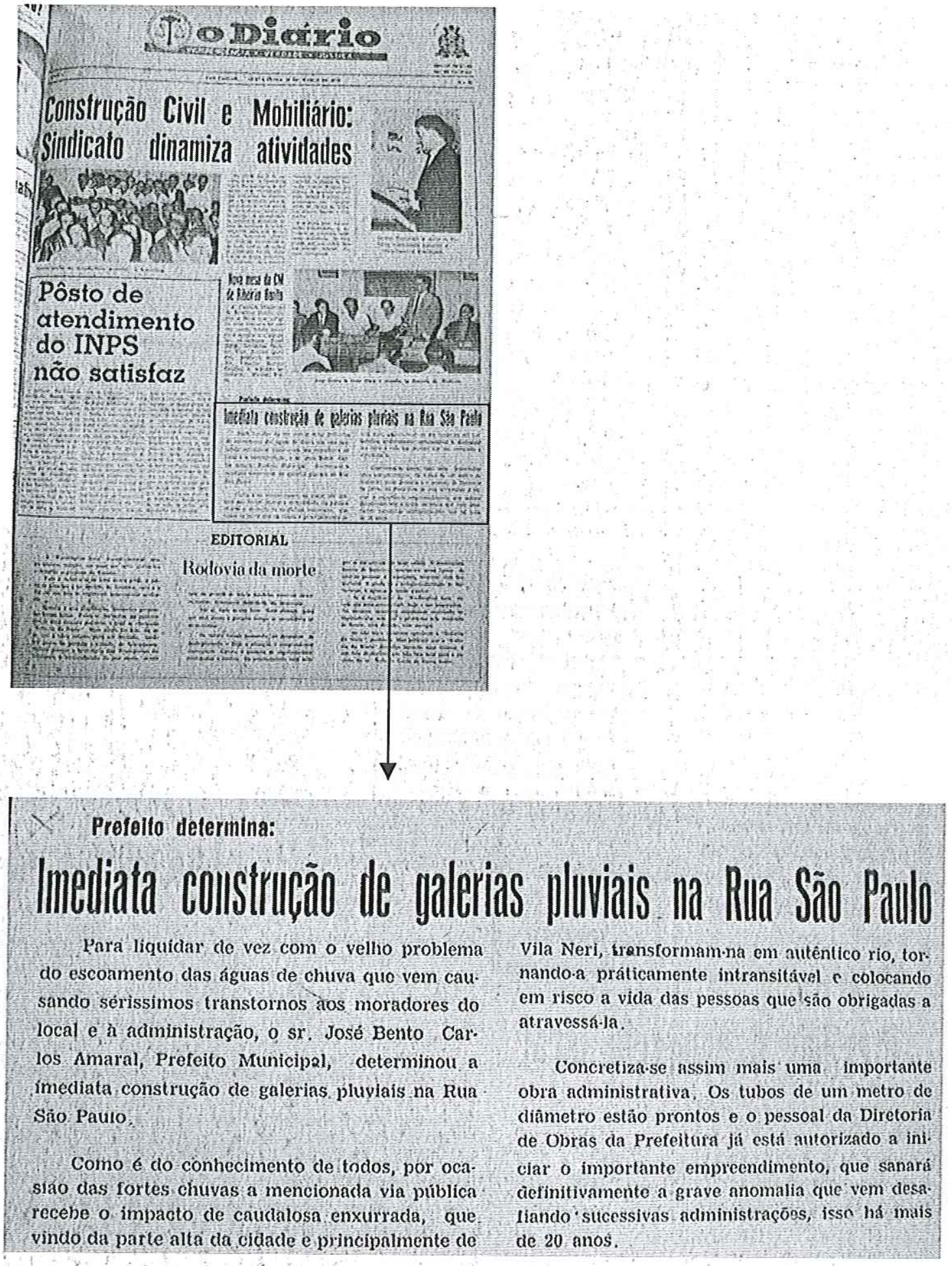

20-03-1970 - Prefeito determina imediata construção de galerias pluviais na rua São Paulo O Diário 


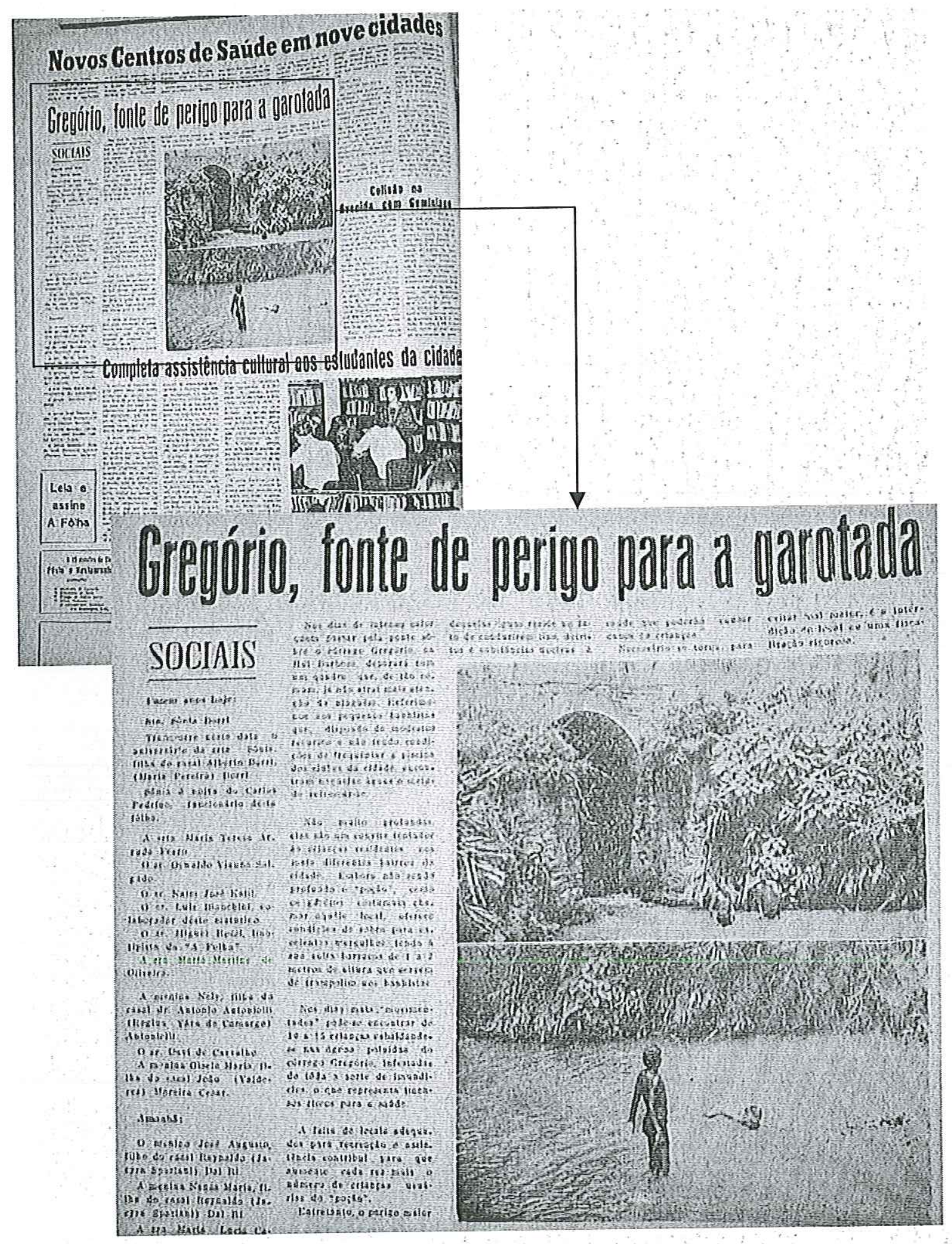

28-02-1971 - Gregório fonte de perigo para a garotada - A Folha

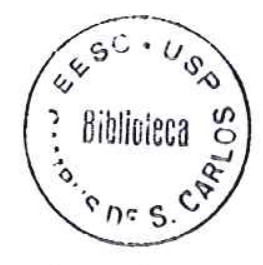




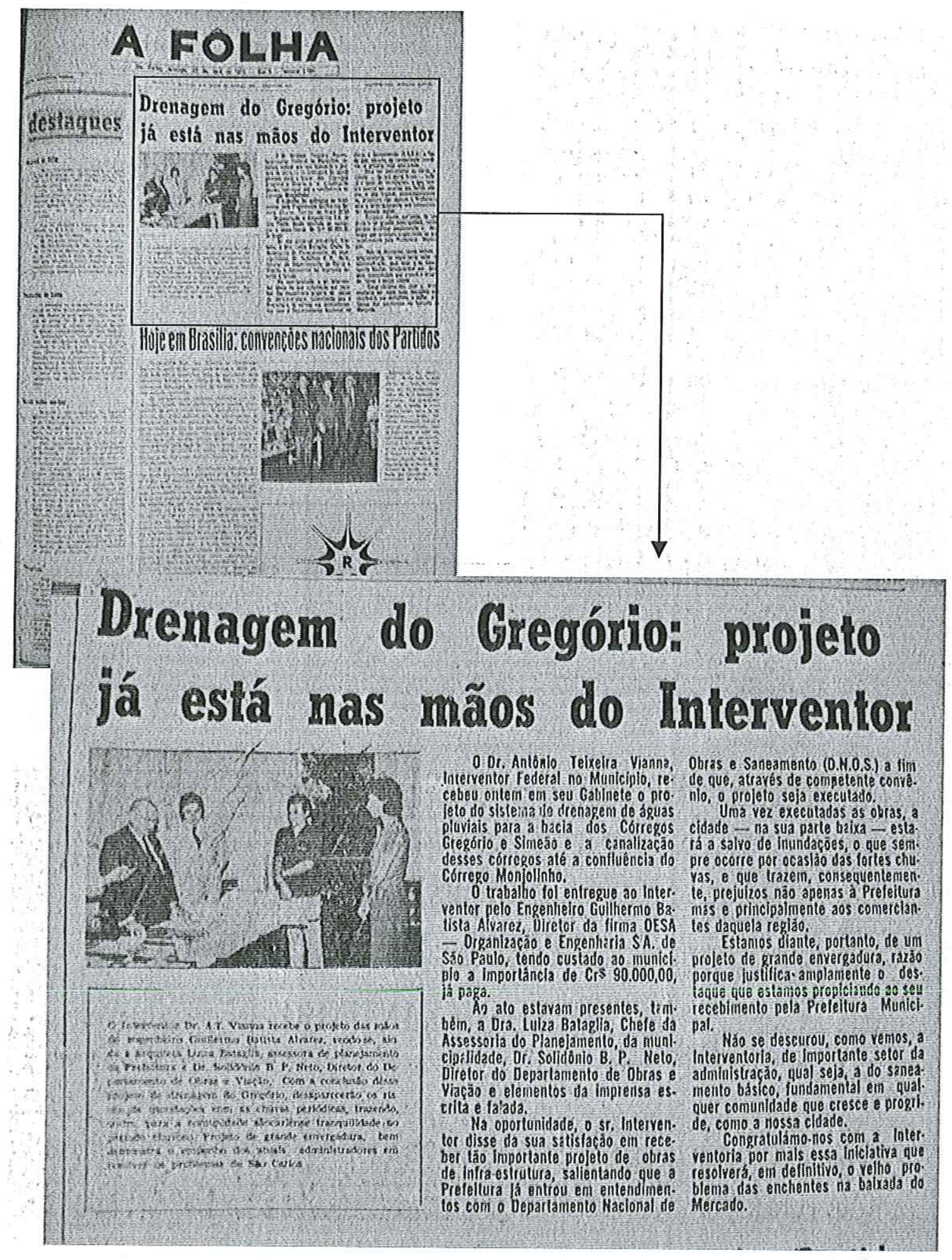

23-04-1972 - Drenagem de Gregório projeto já esta nas mãos do interventor - A Folha 


\section{A FOLHA}

Wii dois sorvicos inoditos no Brasil,
corroio dobxará suas tarilas on 73 Liso ilo Mosirailo ina Uiilversilbalo (itoral: Marcos ilo Mlouso Marlins

Moul do Juil teuilu-se

(tia) Ien 101 contenado

C.

n.

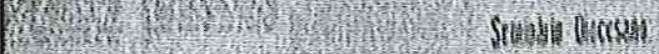

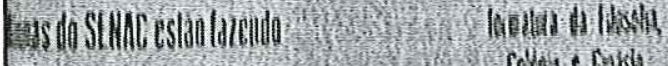

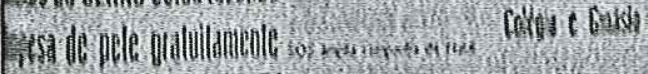

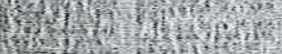

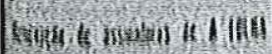

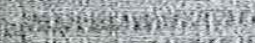

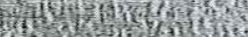

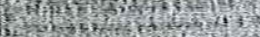

1.0.

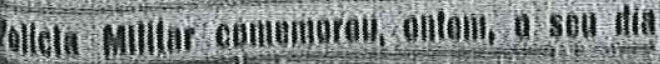

Novo troclio lio bronorlo

ostí soimlo rolilloallo

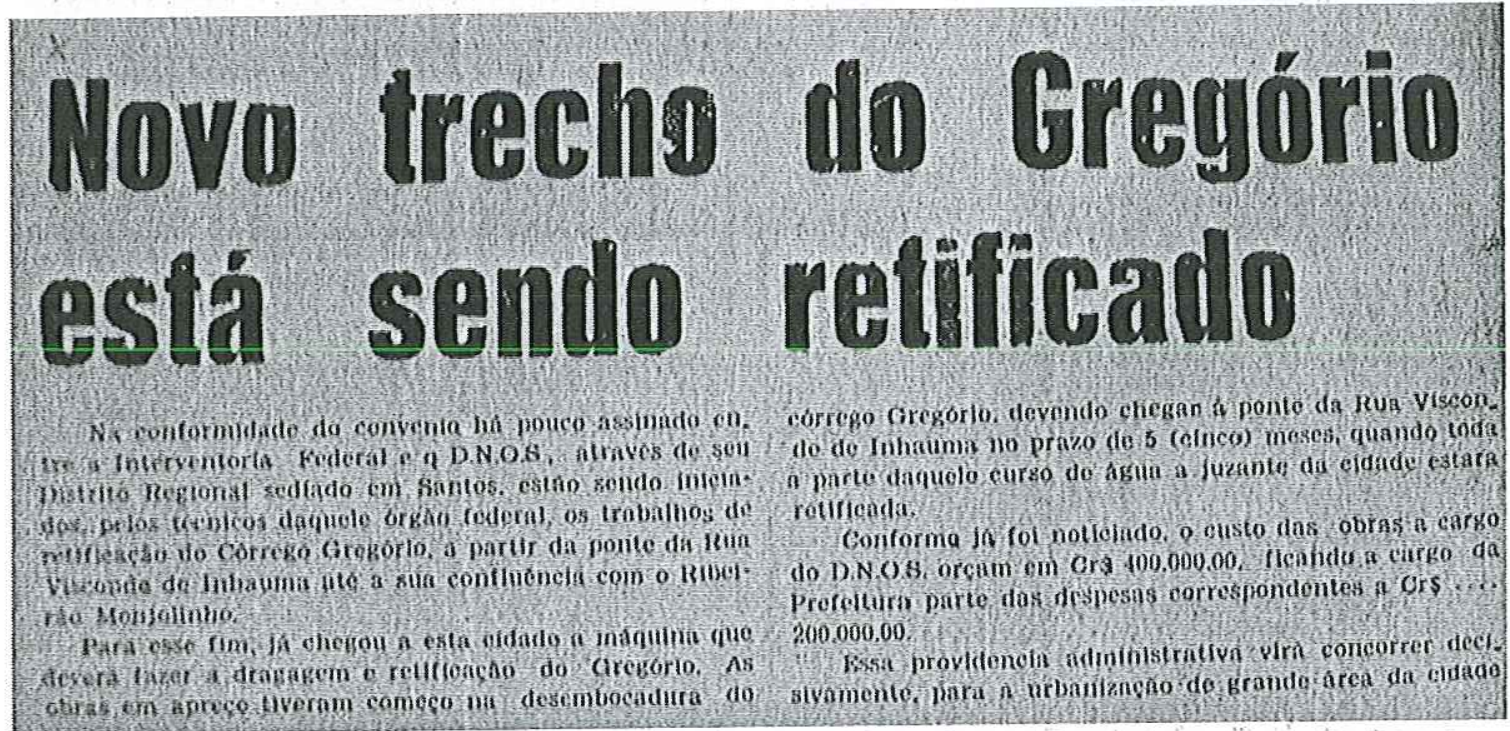

$\therefore$ is i i

16-12-1972 - Novo trecho do Gregório esta sendo retificado - A Folha 

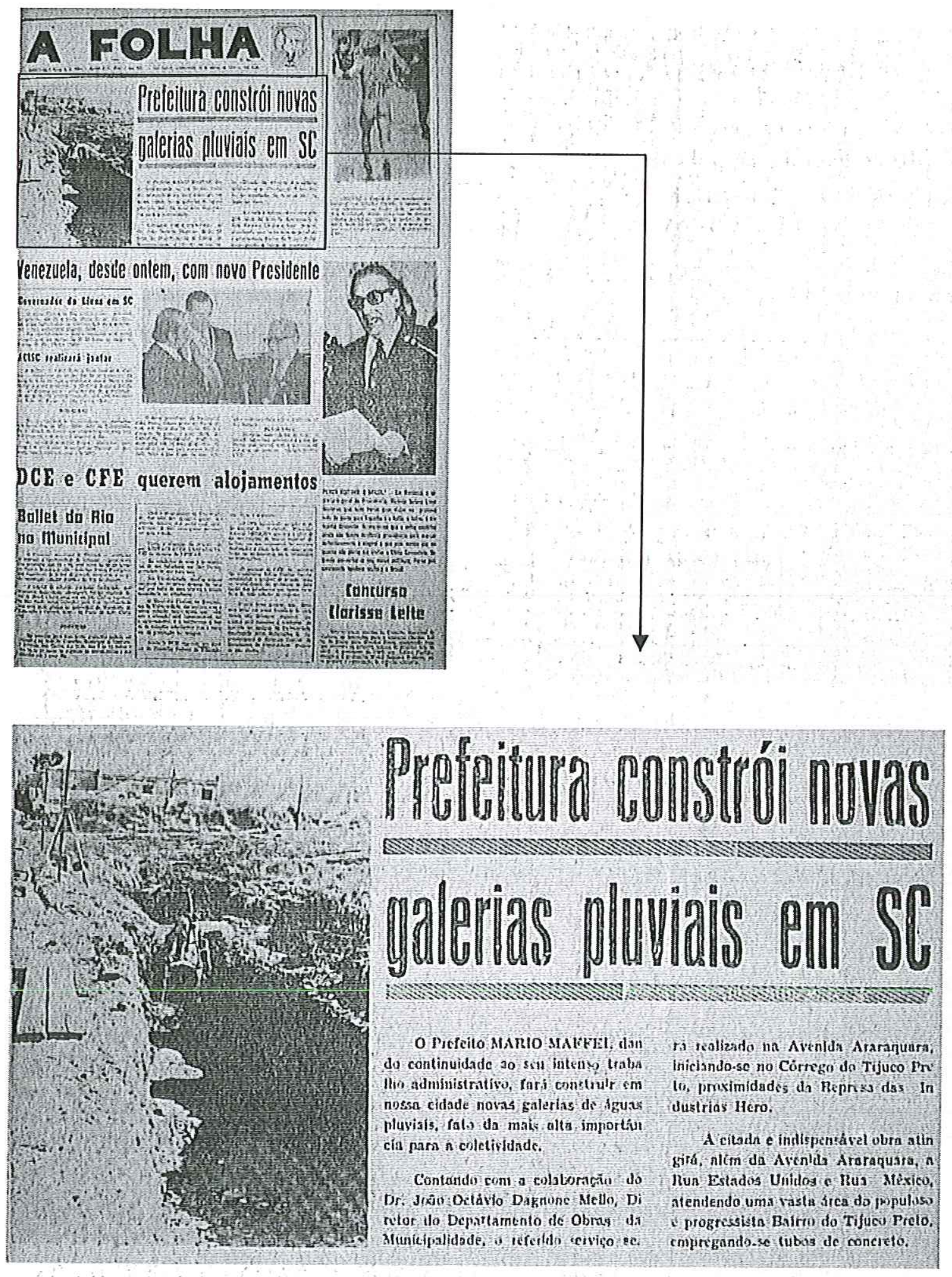

14-03-1974 - Prefeitura constrói novas galerias pluviais em SC - A Folha 


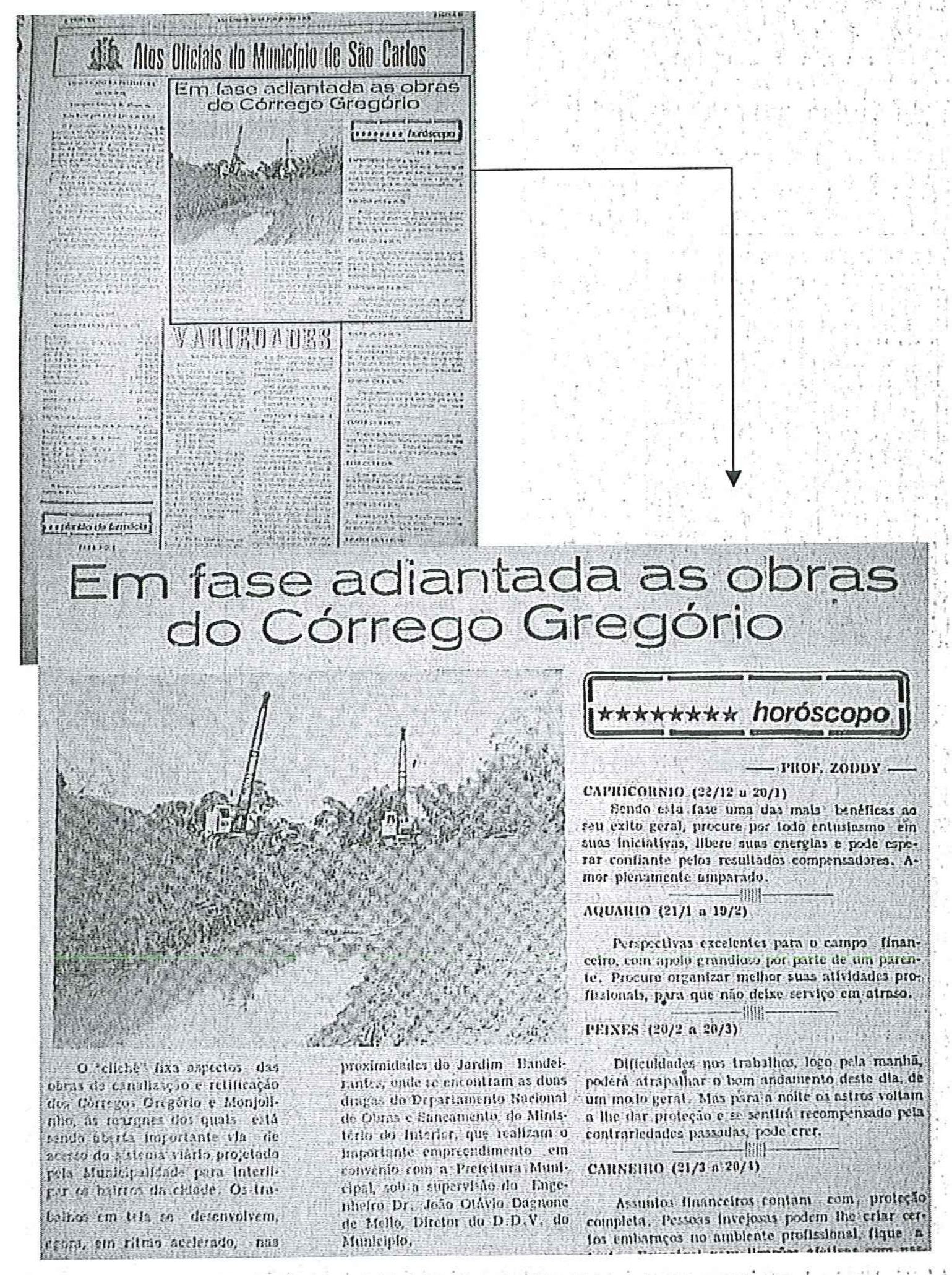

12-01-1975 - Em fase adiantada as obras do córrego Gregório - A Tribuna 


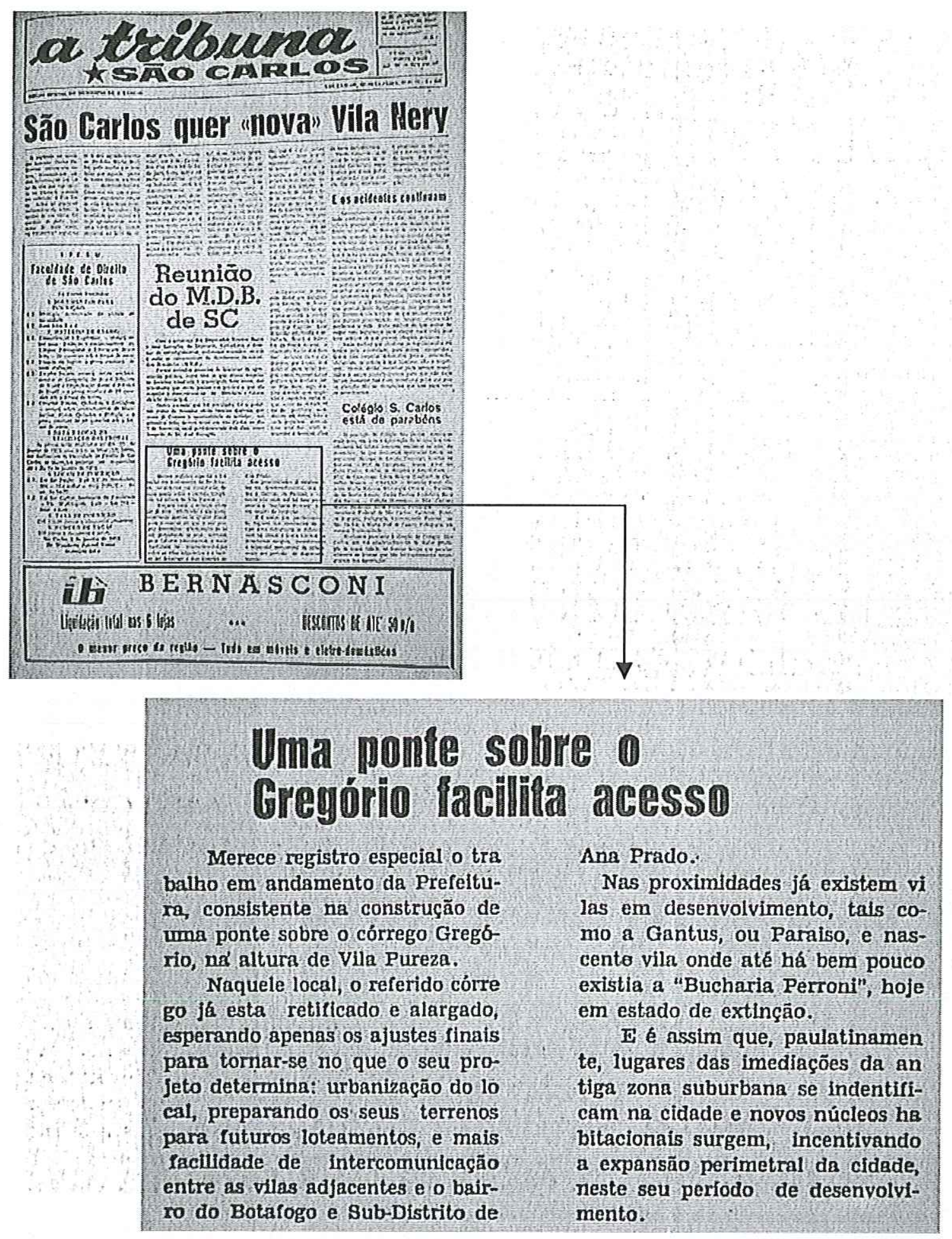

22-01-1975 - Uma ponte sobre o Gregório facilita acesso - A Tribuna 

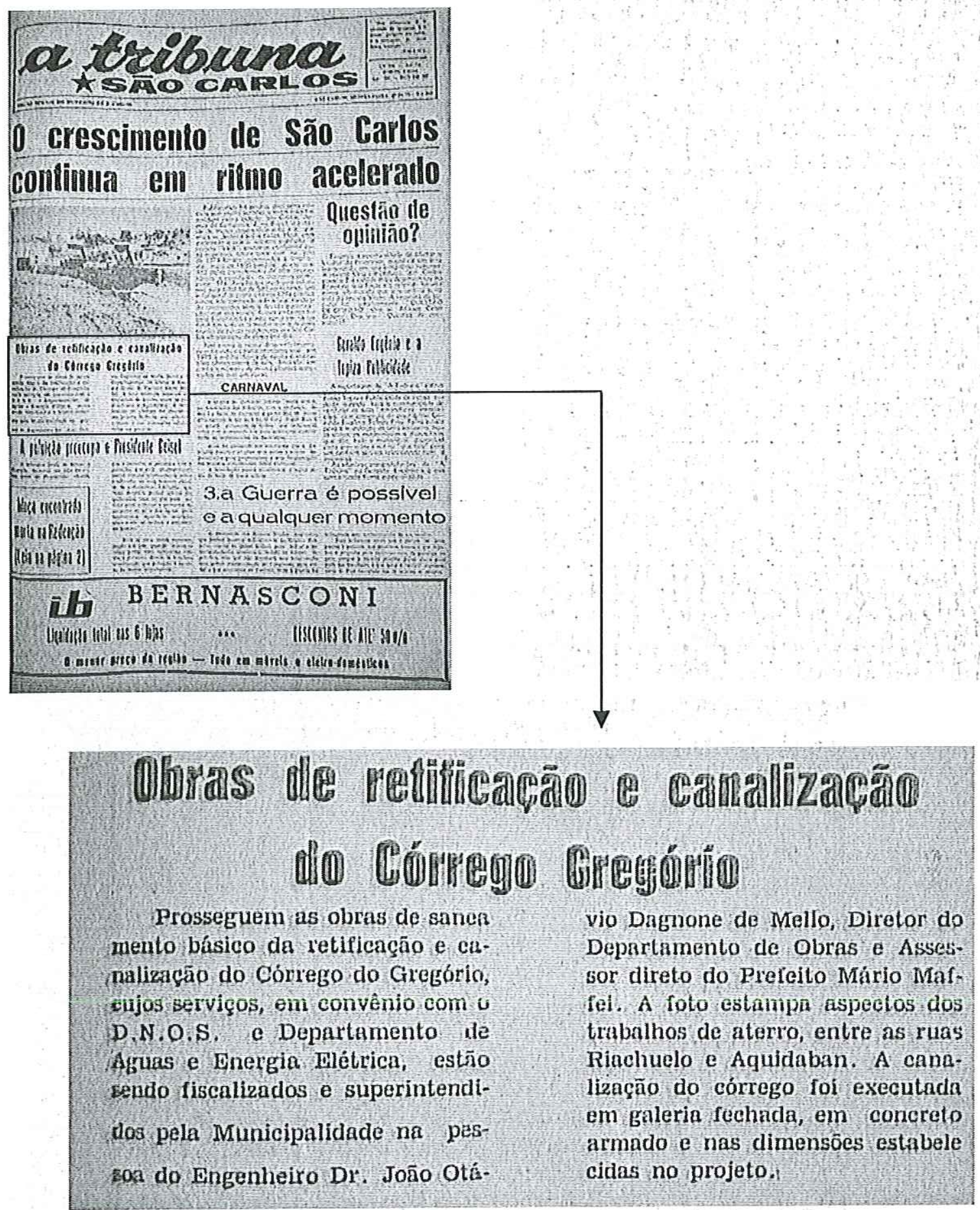

23-01-1975 - Obras de retificação e canalização do córrego Gregório - A Tribuna 


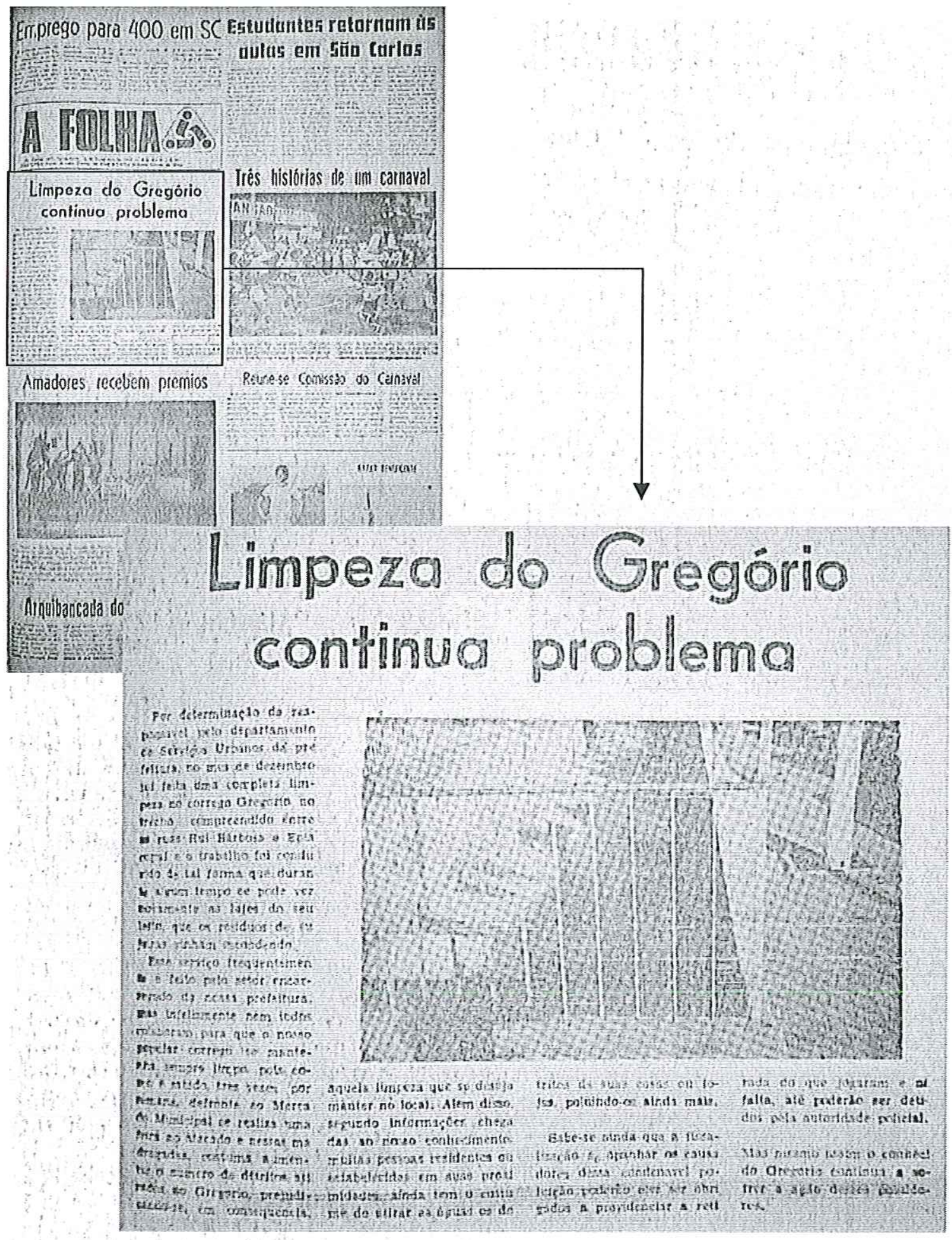

12-02-1977 - Limpeza do Gregório continua com problema - A.Folha 


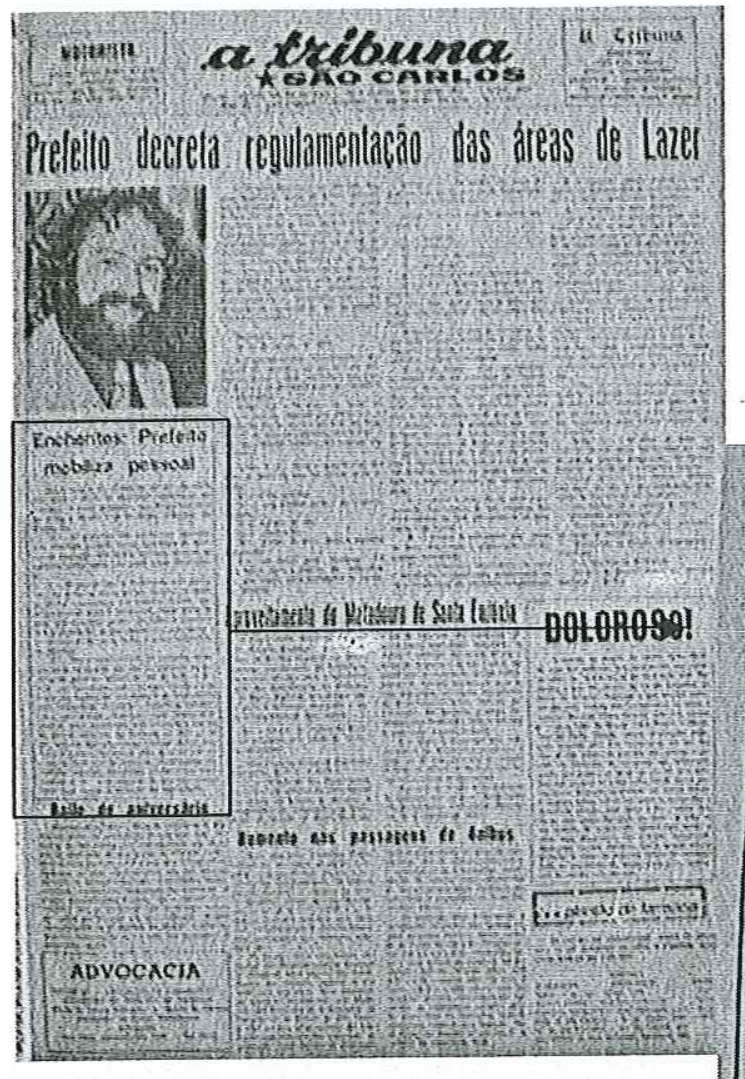
to

\section{Enchentes: Prefeito} mabiliza pessoal

Its a integra da Ordem de Sorviço expedida pelo Senhor Chefe do Executivo Municipal, em exerciclo, Rubens Massúclo, aos Depaitamentos de Obras e Viaçáo e de Serviços Urbanos da Prefeitura:

1 - O problema das enchentes somente será resolvido quando forem realizados os servicos de captaçáo das águas fluviais, através de galerias, obras essas que teráo iniclo brevemene.

2 - Enquanto isso a Prefeitura deve prosurar, por todos os meios ao seu alcance, minorar: os efeitos calamitosos das pesadas chuvas que se precipitam sobre o Municipio, nessa época do ano, pois elas têm gerado prejuizos e transtornos a populaçáo, notadamente aos moradores e comerciantas da parte baixa e áreas adjacentes. ao Mercado.

3 - Objetivando reduzir os estragos causados pelas enchentes até que se realizem os servicos de galerias, determino ao D,O.V. e D.S. U. que mobilizem todas as suas Divisóes e Se tores, em regíme de prontidão e de emergéncia para oferecerem imediata e completa assistêncla à comunidade flagelada pela intempérie. quando estas ocourerem, seja durante o dia ou 110 poriodo noturno. As Divisóes do DOV e $D$. SU, através das respectivas Chefias deveni conrocar o pessoal necessáilo para auxiliar nas tarefas de prestacão de socorios. molbilizando, outrossim. vefculos, máquinas, ferramentas, equipamentos, etc., e os recuisos de que dispuzerem para fazen frente à situacão de colamidade."

14-01-1978 - Enchentes prefeito mobiliza pessoal - A Tribuna 


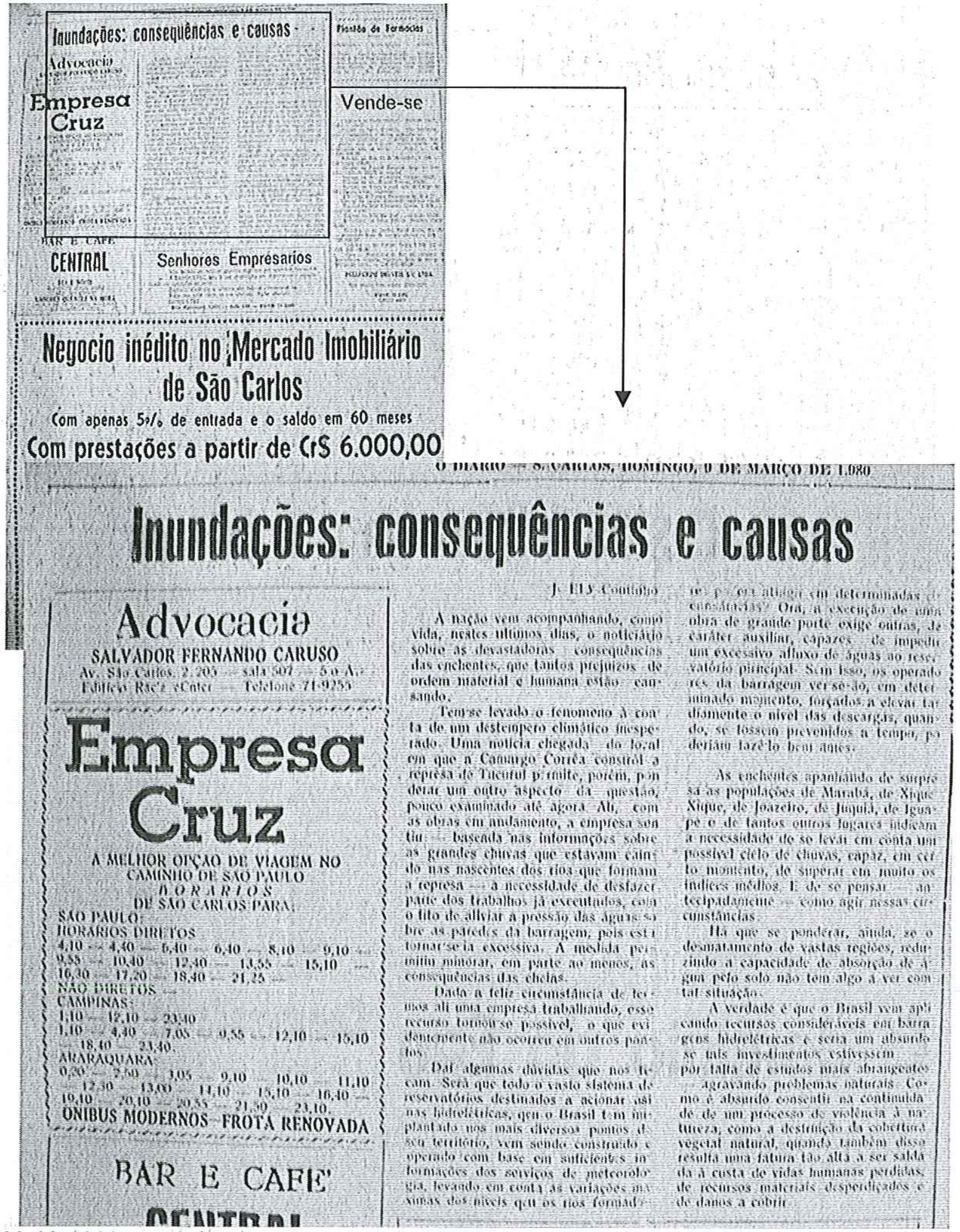

09-03-1980 - Inundações: Consequiências e causas - O Diario 


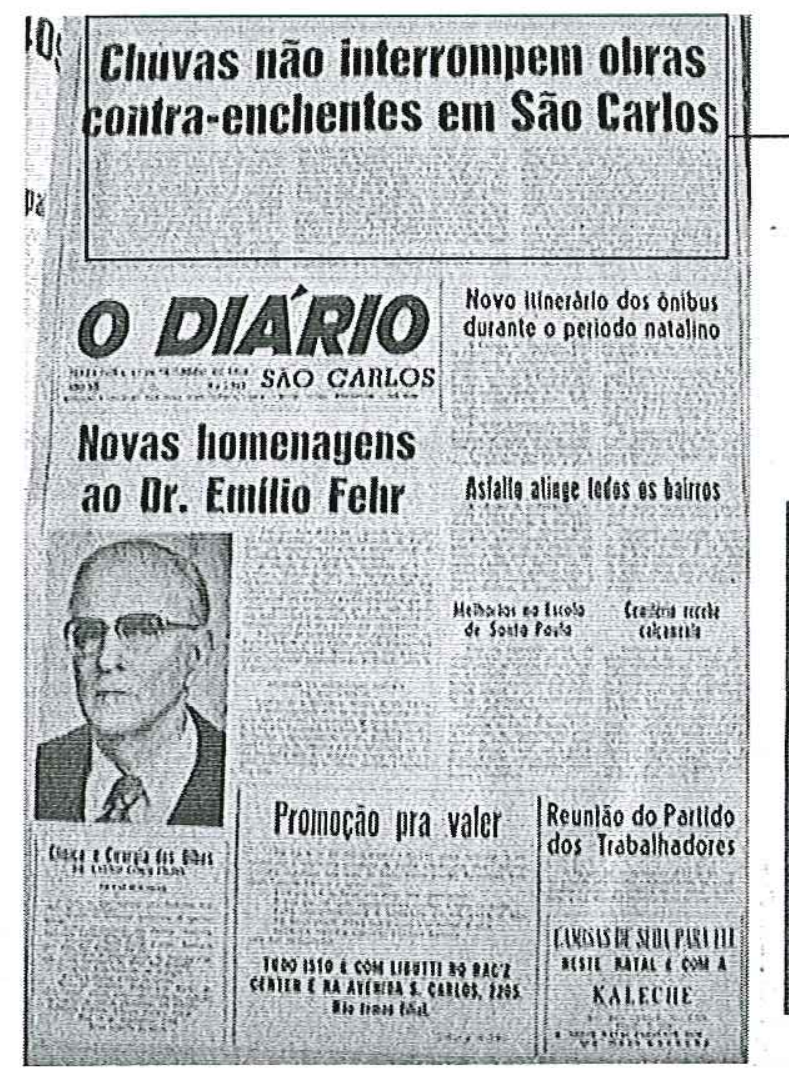

São Carlos desde a Psaça ltălia até o Mercado, foram imiplan tados sistemas de captação e escoamento no Núcleo Silsio Villari e na Rua Raimundo Corrèa. Agora as obras estäo cor. centradlas em Vila Isabel através da Rua Santa Gertrudes, estendendo-se até a Prạ̧a ltália e também na Rua Cel. Julio dugusto Salles de Oliveira, desdo o Conjunfo Educatíco e Esportivo do SESI, alén de extenso trecho margeando as lintias ferreas da FEPASi, nos fundos das indístrias SICOM. Apesar de liá muito nảo terem sido observadas as eniclientes que a tudo danificava na baixacla da cidade, as obras prosseguem atraves de rigoroso planejamentó técnico que tem por base o crescante lluxo da água pluvial priunda de extent: sos setores urbanos que nos viltinos anos vêm recobendo as inelitorias que culminam com o asfaltamento das vias pibli. cas:

Segundo observaçoes do Prefeito Antonio Mlassel usse programa năo podera ser interrompido e será objeto de ontras

12-12-1980 - Chuvas não interrompem obras contra enchentes em São Carlos - O Diário opsoes quanto ao ponto de despejo liuje convergente para córego Gregório, variaçấo essa qule gcorrerá segumilo o si cimento urbano que em pouco ganhará sutras bacias hídrog ficas Observou ele; "A cidade cresce como nunca. 0 s! ficas Observou ele, "A cidide cresce como nunca. O sa
gimento do nowos bairros e cónsequente exiensáa do asfat exigen da adininistragào municinal redobrados cuidatos dotála com obras duradouras que a protcjan contra as chentes. Foi um desafio que assmimios. IE contimia sendu i desalio se analisarnos náo apenas as exigências lcrnicas ni tambént os clevados custos le lais obras".

A não ser devido a pequenos periodos a interrum provocada pelas pesadlas cliivas dos viltimos tempos em s Carlos o regiăo, as ubras contra cinclientes na Zona Sul pro seguem normalmente, para total solictio dos angustiant problemas sentidos pelos noradores e empresas nis ádjacé cias de Vila Isabel, SESI, Rua Col. Julio a. Salles de olive ra e outros fontos urbanos. 


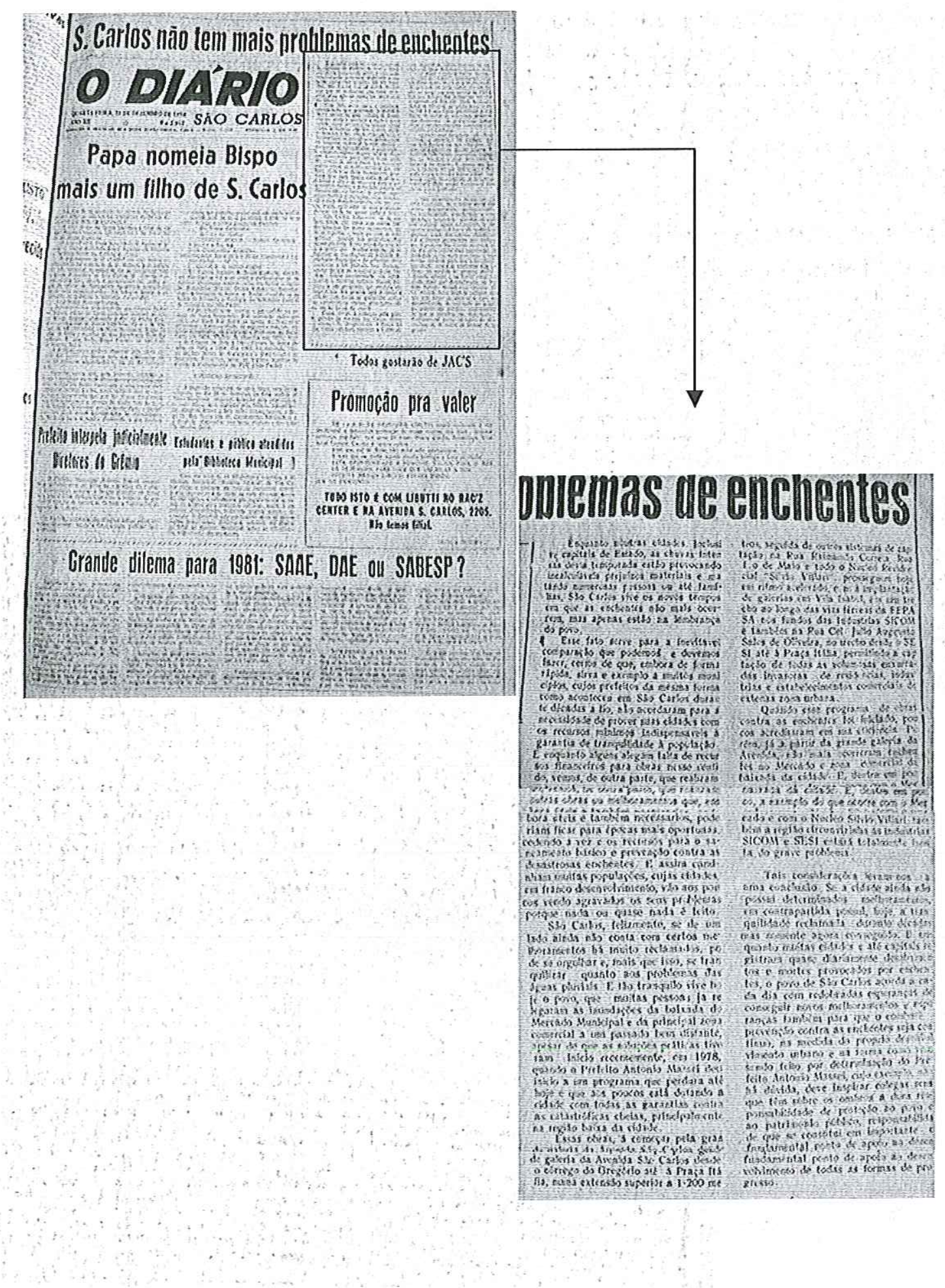

32-12-1980 - São Carlos não tem mais problemas de enchentes - O Diário 


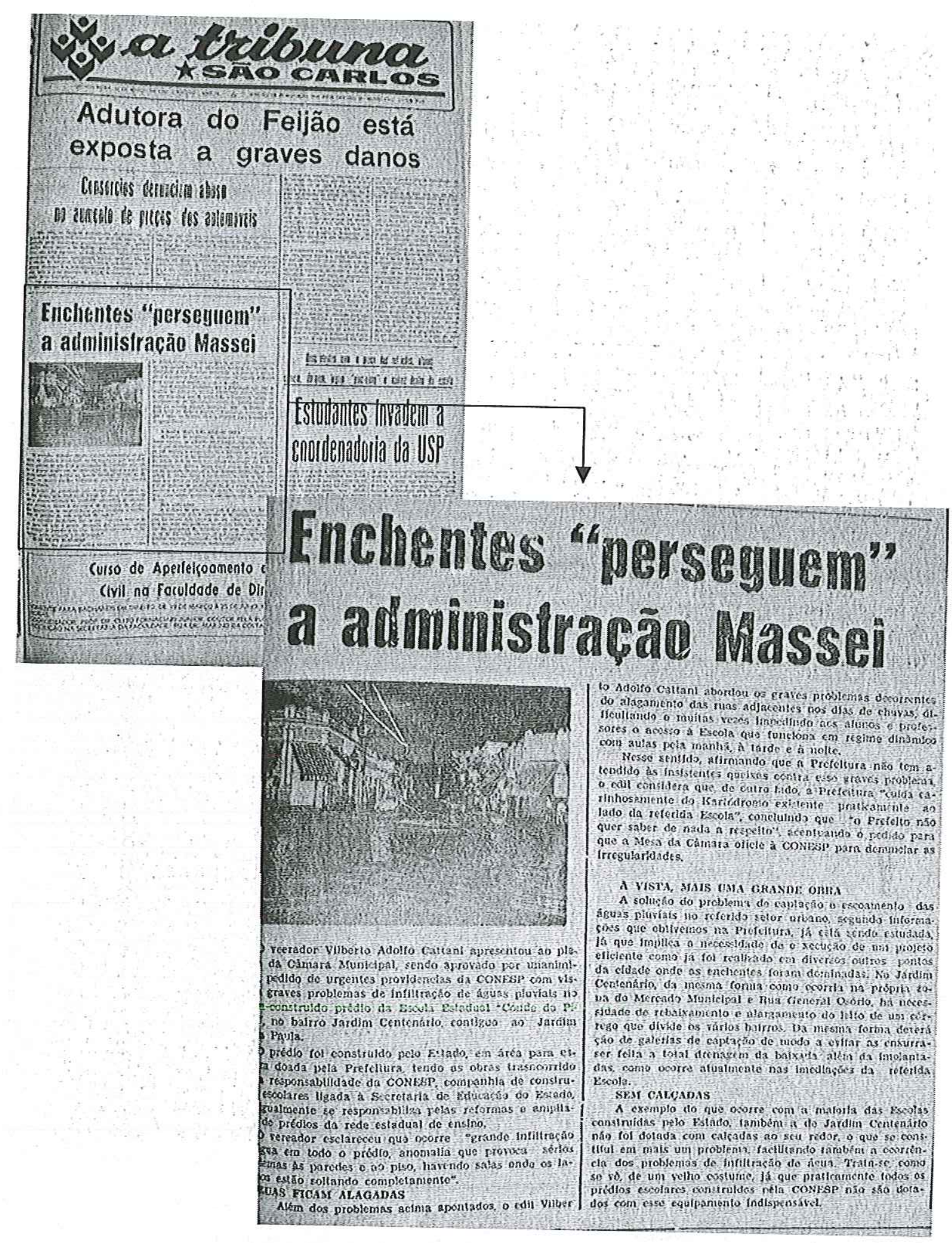

12-03-1982 - Enchentes "perseguem" a administração Massei - A Tribuna 

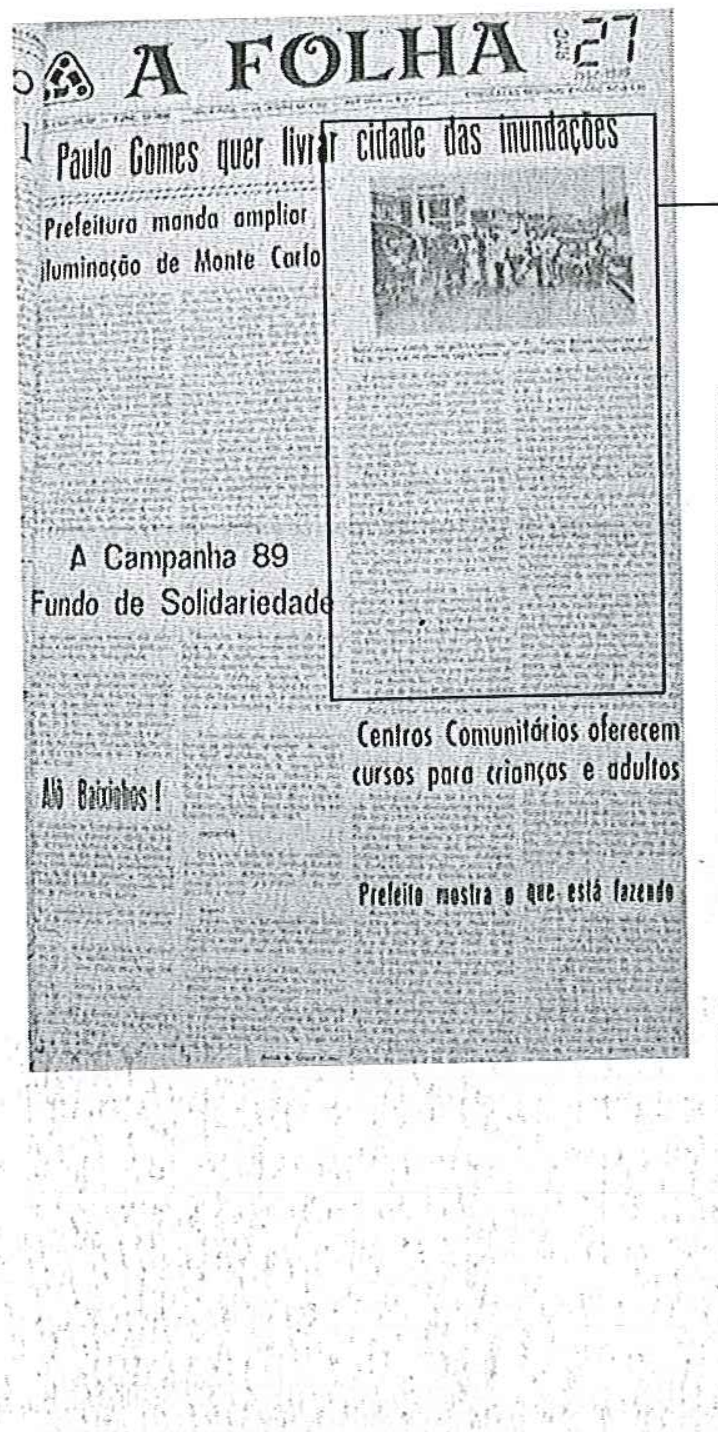

23-01-1990 - Paulo Gomes quer livrar a cidade das inundações - A Folha

का 15 


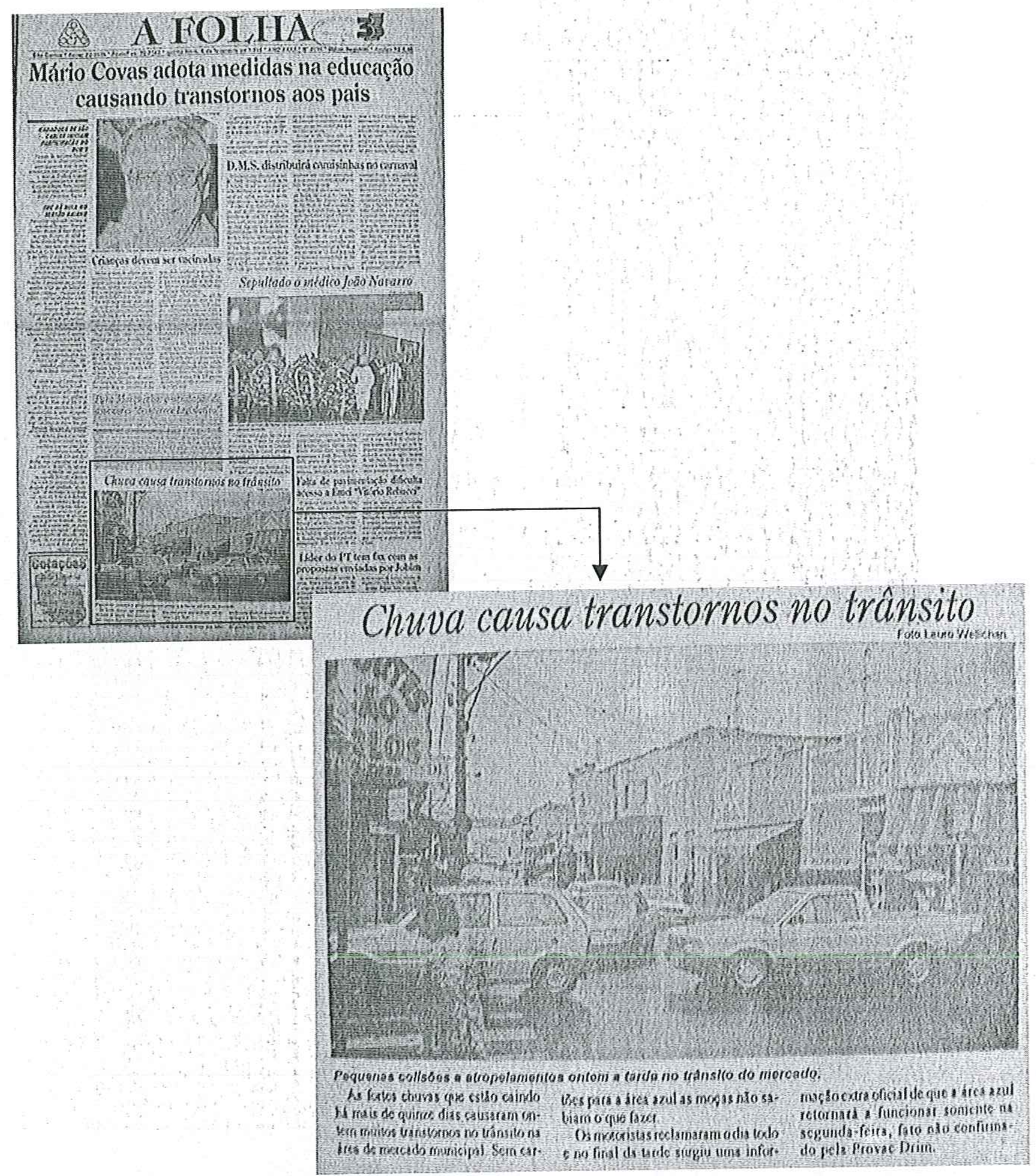

09-02-1995 - Chuva causa transtorno no trânsito - A Folha 


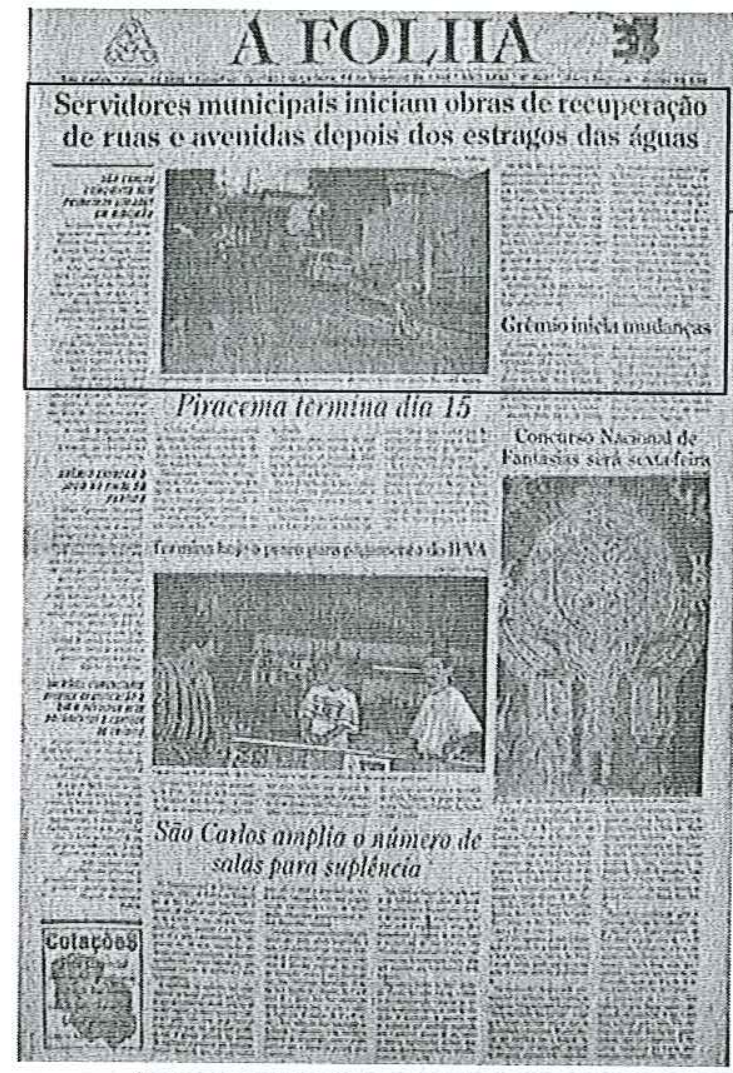

As fortes chitivas quo atingiram o cstado nestas ullimas semanas, provocaram abertiura de muitos buracos por toda a oddade, bein como nas estradas. Mas este é uim quadro homogéneo em lodo o estado. Em Săo Carlos, o De partamento de Obras Viárias está aguardando que o tempo se fíme para dar início a operaça tapa buracos, pois com o solo ainda úmido ou com água, fica impossivel ofetuar o servi. co, uma vez que o inaterial não se agre8s adecuadamente o ainda há amea. cas de mais chuva.

Entrelarito, assim que o tempo so límar, os buracos serăo cobertos o tudo voltará ao nomal.
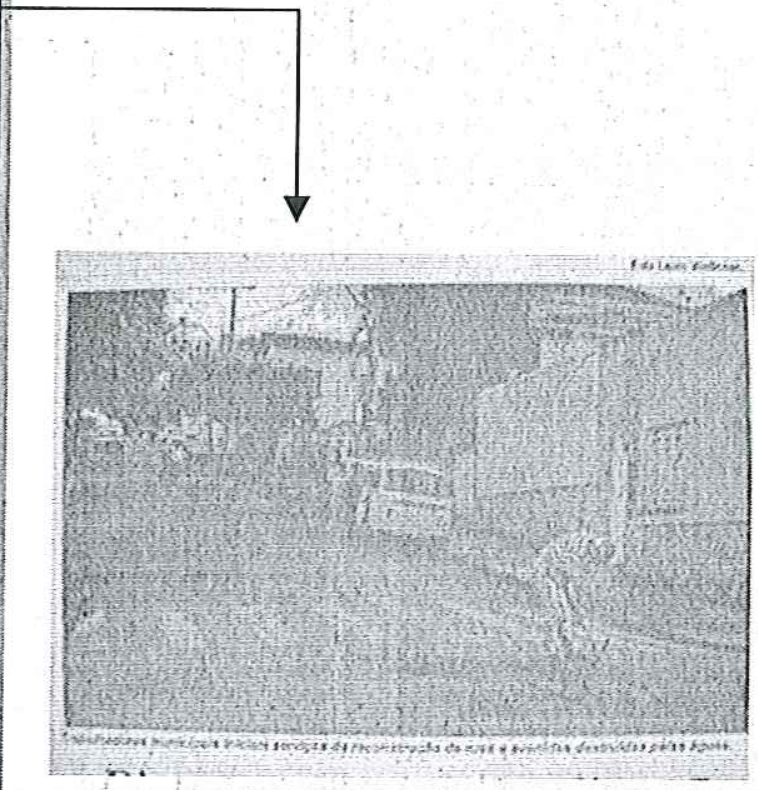

Por enquanto a recomendaça o 8 que os motoristas sejam pridentes o tonham bastanto cliidado. Mas mesmo assim, ontem a prefótura municipale o SAAE - Sorviço Autôniomo de Agua c Esgoto íniciaram os servicos de recuperacáo das avenídas e ruas face a trégua das chuvas. Na Rua Säo Joa quim, esquina da Jesuino do Arnuda, proximidades da abasc os traballhado. res iniciaram os servicos logo pela manliá, seguindo as oricitaçóes do prefoito Rubens Massucio o do diretor do SAAE Eduardo Antonio Cotrim. Para o prefeito Ruberis Massucio, a cidado estará limpa o soin buiracos dentro de alguns dias.

14-02-1995 - Servidores municipais iniciam obras de recuperação de ruas e avenidas depois dos estragos das águas - A Folha 

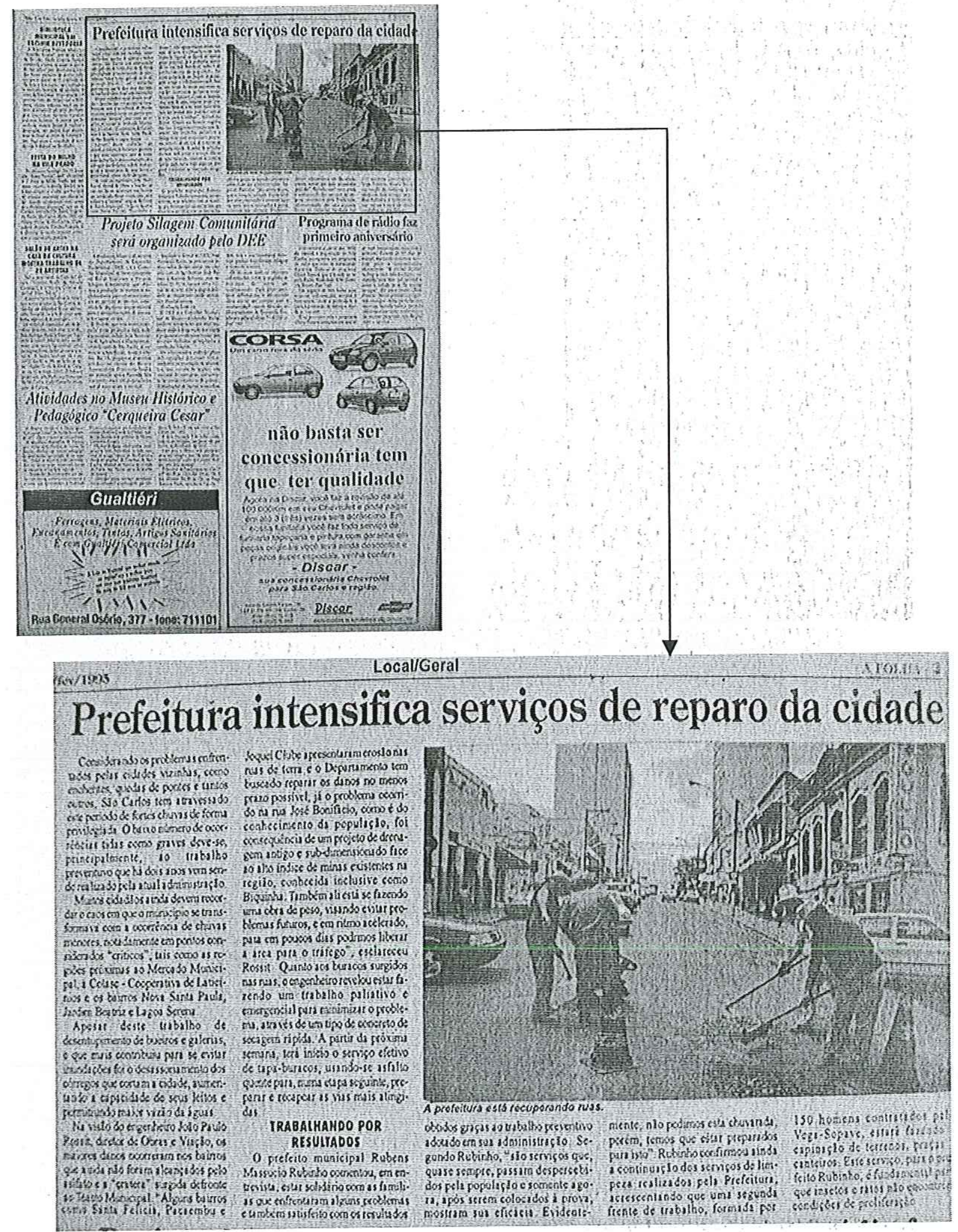

17-02-1995 - Prefeitura intensifica serviços de reparo na cidade - A Folha 


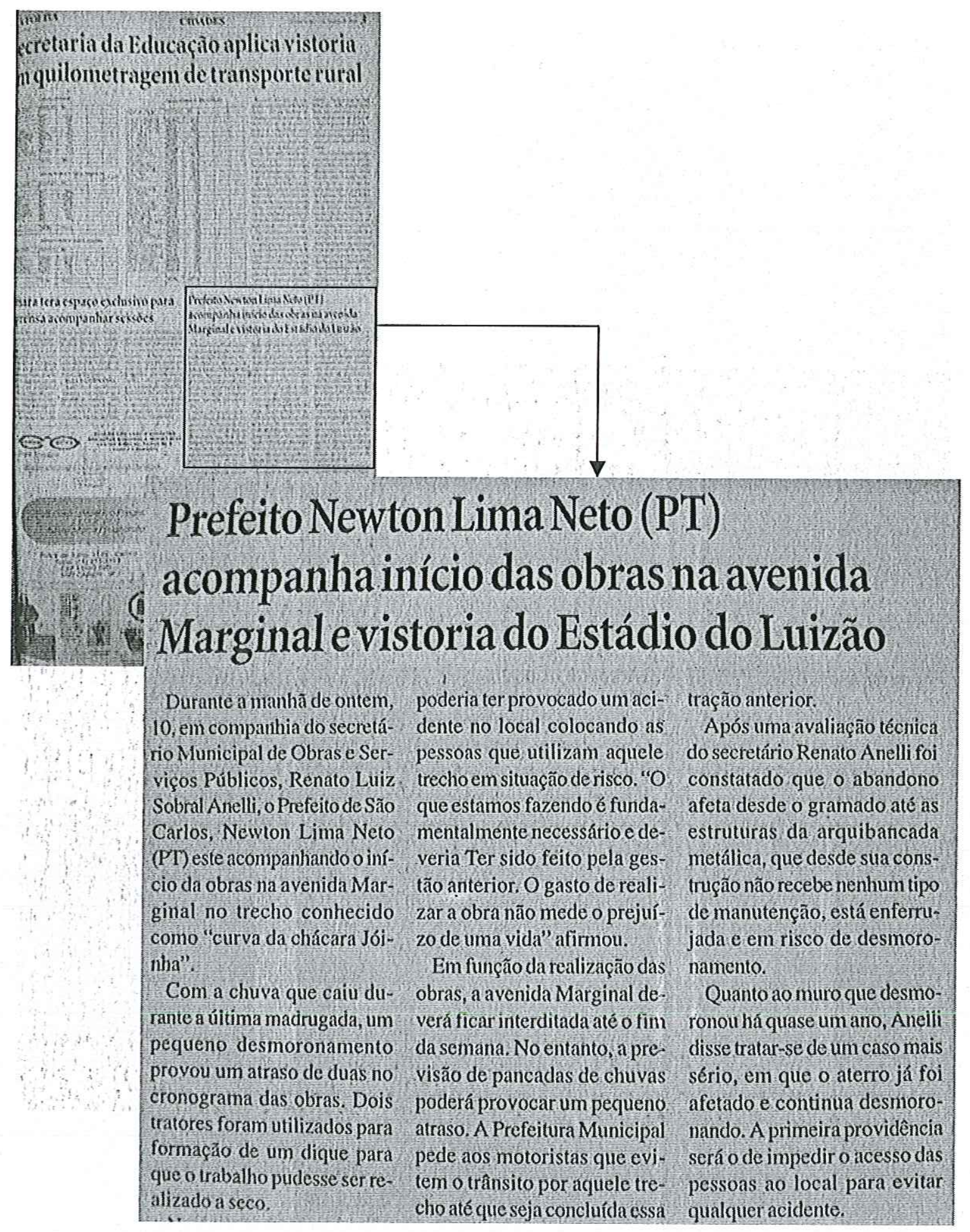

11-01-2001 - Prefeito Newton Lima (PT) acompanha início das obras na avenida marginal e vistoria no estádio Luizão - A Folha - Parte 1 


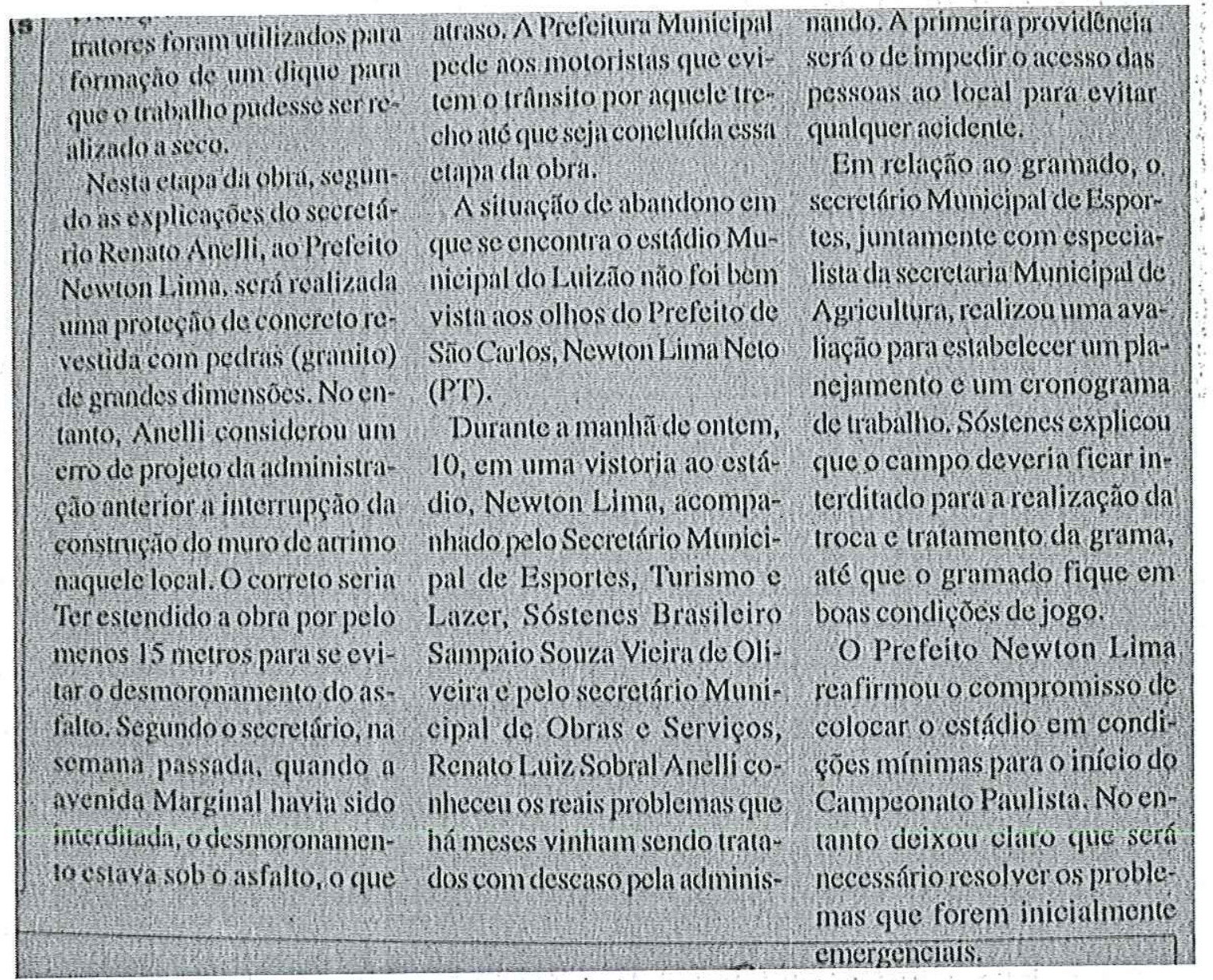

11-01-2001 - Prefeito Newton Lima (PT) acompanha início das obras na avenida marginal : e vistoria no estádio Luizão - A Folha - Parte 2 


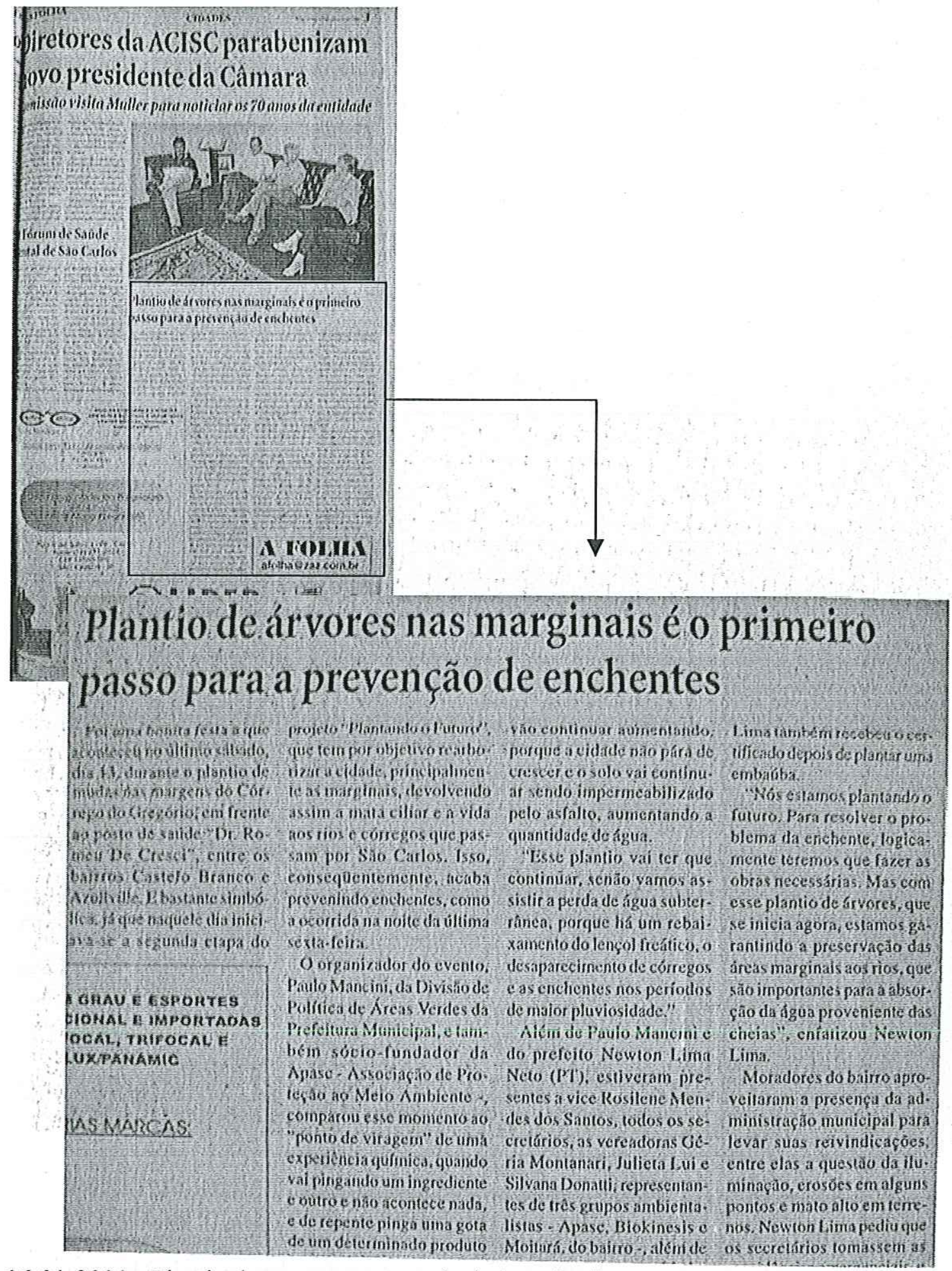

16-01-2001 - Plantio de arvores nas marginais é o primeiro passo para a prevenção de enchentes - Folha - Parte 2 
Apase-Assnciacío de Pro-
testo ao Meio Ambiente -
comparoul esse momento ao
"ponto de viragem" de una
experiencia químicil, quando
sai pingando un ingrediente
e outro e näo acontece nada,
e de repente pinga uma gota
de um determinado produto e muda de cor.

"Faz anos que a gente vem lutando pela preservação dos rios, sem que ninguém nos escutasse. E naquele moinento conseguimos reunir a sociedade civil, representada por três. gruposecológicos, e a municipalidade, na figura do prefeito, reconhecendo a importância do que vínhamos pregando há mais de 20 anos", explicou.

Segundo ele, se não se fizer essa urbanização das marginais, miciada no sábado. certamente as enchentes
Neto (PT), estiveram presentes a vice Rosilene Mendes dos Santos, todos os secretários, as vereadoras $G c e-$ ria Montanari, Julieta Lui e Silvana Donatti, representantes de três grupos ambientalistas - Apasc, Biokinesis e Moitará, do bairro -, além de muita gente da comunidade, entre elas as professoras Claudete Rosales e Kátia Schuizer. Muitas criancas participaram do plantio das 250 mudas, recebendo um diploma com seu nome e o da árvore plantada. Newton
Moradores do bairro apro. veitaram a presença da administraç̃o municipal para levar suas reivindicações, entre elas a questấo da iluminação, erosões em alguns pontos e mato alto em terrenos. Newton Lima pediu que os secretários tomassem as providências emergenciais, $e$ os outros assuntos deverão estar sendo apresentados durante as reuniões do Orçamento Participativo, quando a população serí convidada a disculir os problemas e prioridades de cada bairro.

\section{A F(d) IHIA afolha@zaz.com.br}

16-01-2001 - Plantio de arvores nas marginais é o primeiro passo para a prevenção de enchentes - Folha - Parte 2 

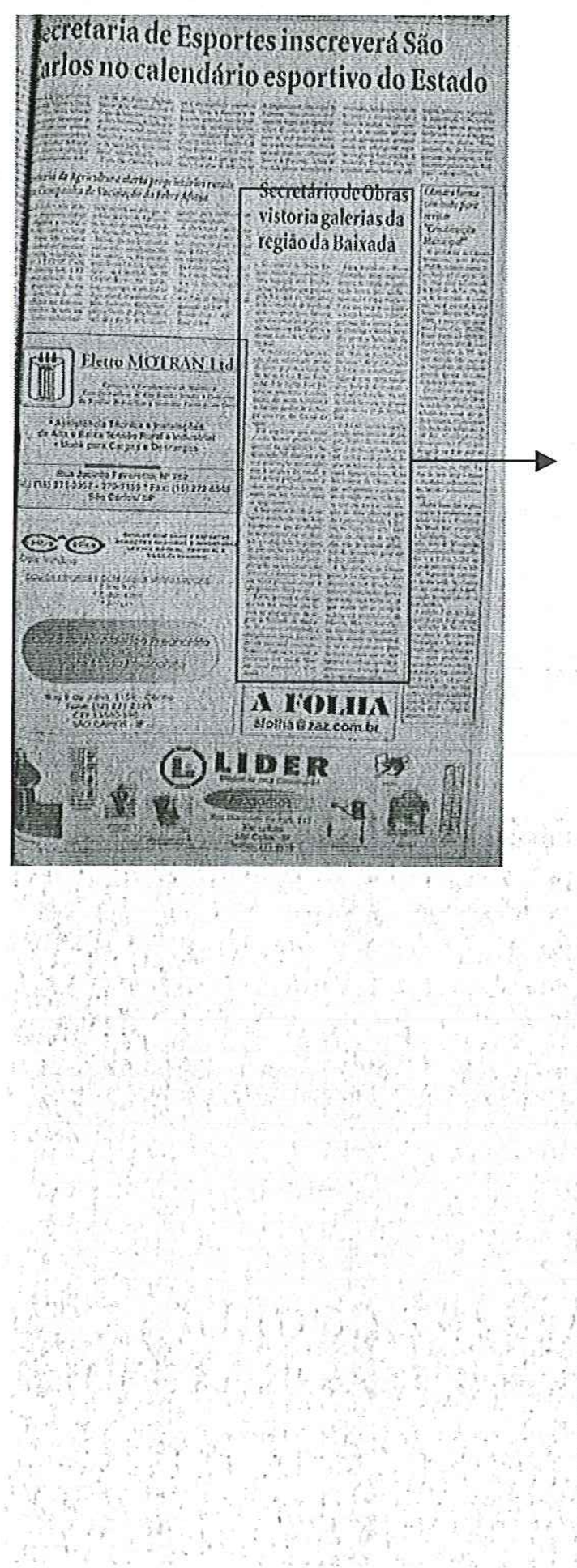

24-01-2001 - Secretário de obras vistoria galerias da região da baixada - A Folha vistoria galerias da região da Baixada
Secretário de Obras Re- Tapa-buracos Foram nato Anelli fezontem (23) chamadas duas empresas; uma inspeçảo mais detalha - dentro do limite de contra. da nas galerias que passam taçó dircta, para ajudar in pela Báxada do Mereado, operaçăo tapa-buracos. com o objetivo de verificar Una das empresas contra quais os principais fatores tadas já finalizov o trabalho que tem contribufdo para as nas ruas Maranhio e Geral enchentes em Sáo Carlos:a do Domingos Adabo, no tre. última ocorrida há corca de cho entre a Tancredo Ne. 20 dias

"Coilstátamos o que já titha sido informado pelos tecricos: as pontes felias ha 50, 60 anos nas Ruas Epis. conal, 9 de Julho, Jose Bo nif́cico, anteriores a canalização, são muito estreitas e se tomam pontos de estran. ulaniento do fluxo d igua".

Ele explicou qué essas pontes foram preservadas quando da canalizaçáo, na década de 70 , mas que elas tem uma seçăo muito infeHor a largura do canal e isso acaba prejudicando a yazáo em períodos de chela, sendo um dos fatores para os allagámentos.

A Secrelaria de Obras es ará trabalhando com duas hipóteses no gue diz respei. to ao problema das enchen. es: a viabilidade do projeto de prevençäo em vigencia. que tove ińcio e foi inter rompido na administraçăo anterior, calternativas par um novo projeto, como o alargamento das pontes.

"Bssas pontes estrcitas sh̆o uin dos fatores que le Vam ao alagamento da re gito da Baixida do Merca. do. Ja cstamos estudando o alargamento delas, para po der ter um canal constante Vamos olimizar o canal já cxisterite. eri vez de fazer um canal paralclo". ifisso Anelil

es e o conjunto habitacio nal "Romeu Santini" e na travessa 7. Hoje (24) e quin. ta-feira, os trabalhos pros. seguent com outra equipe que estará descendo a Av.Carlos Botelho. $\mathrm{Na}$ sex. ia-feira os reparos prosse guem na rua 15 de Novem-

O SAAE também está fazendo uma cotaça de pre cos, dentro da verba-limite que dispensa licitaçăo, para em caráter emergencial, fe. char os buracos abertos du rante reparos na rede. $\mathrm{E}$, na Secretaria de Obras, está em andamento o processo de licitaçăo, arravés de car ta-convite, para a contrata ça de uma empresa que dará prosseguimento à ope. raçáo tapa-buraco, nāo mais em regime de urgen cla, mas de grande neces. sidade, de mancira geral em toda a cidade.

A Secretaria de Obras pede a compreensão dos motoristas com relaçío aos treclios interditados para. operaça tapa-buracos, já que essas obras sempre acarrotam transtornos de transito. Mas vai tentares tar informando com antece déncia, através da imprensa os locals interditidos parí os reparos para fue os mo toristas escolham caminhos altorinitivos ovitando assim us congestionabientos.

sectetaniv ue voias 


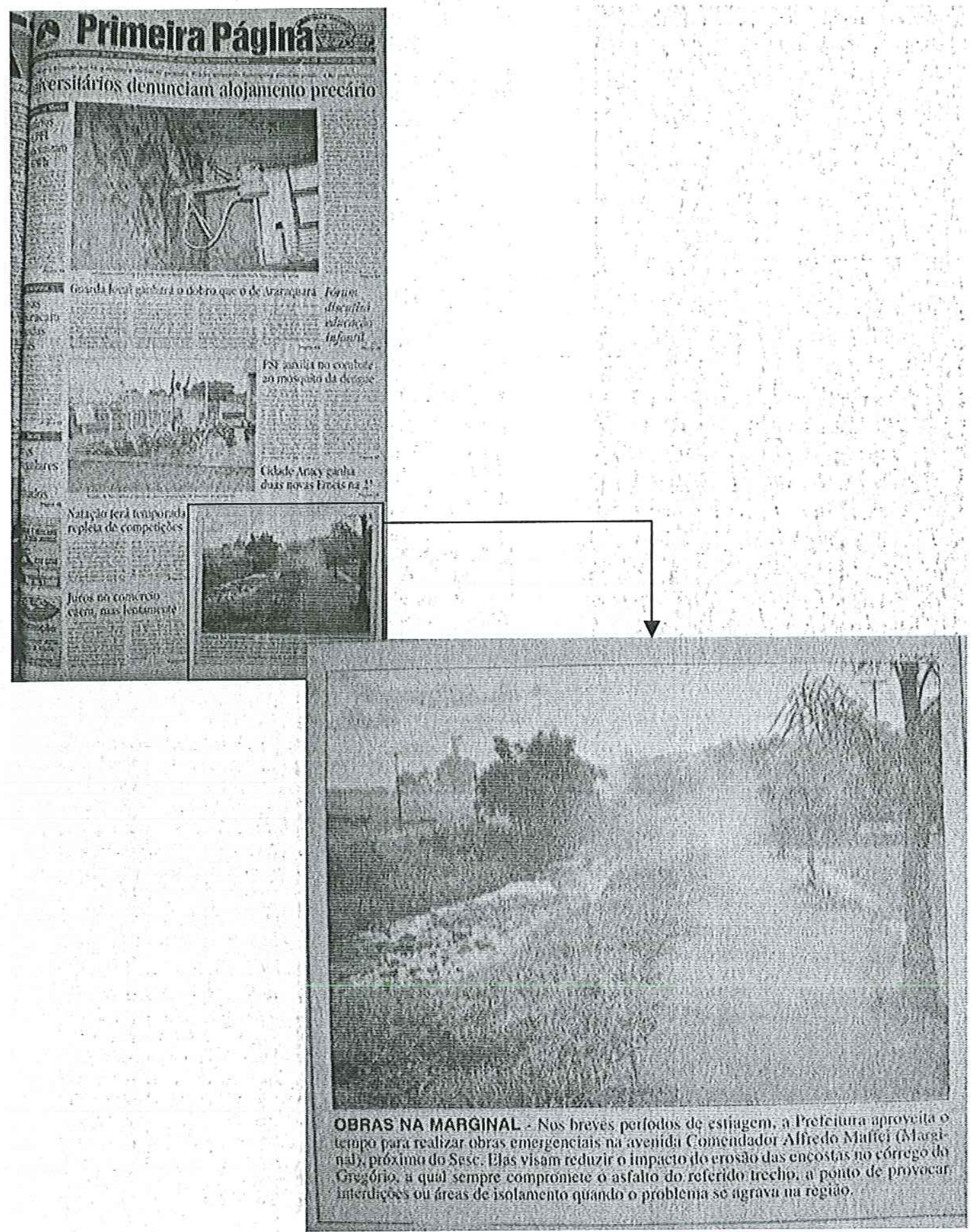

26-02-2002 - Obras na marginal - Primeira página 


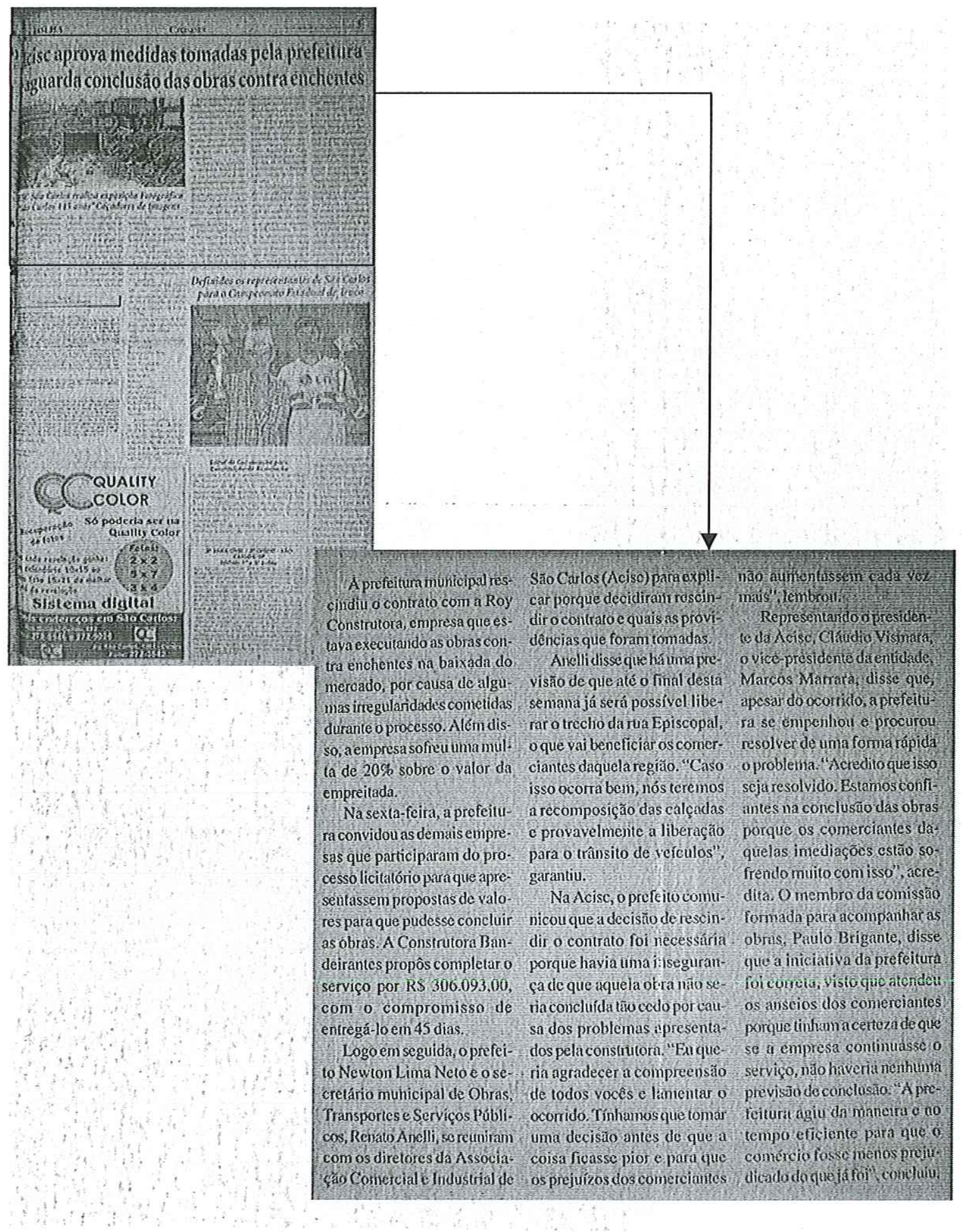

12-11-2002 - Acisc aprova medidas tomadas pela prefeitura e aguarda a conclusão de obras contra enchente - A Folha 


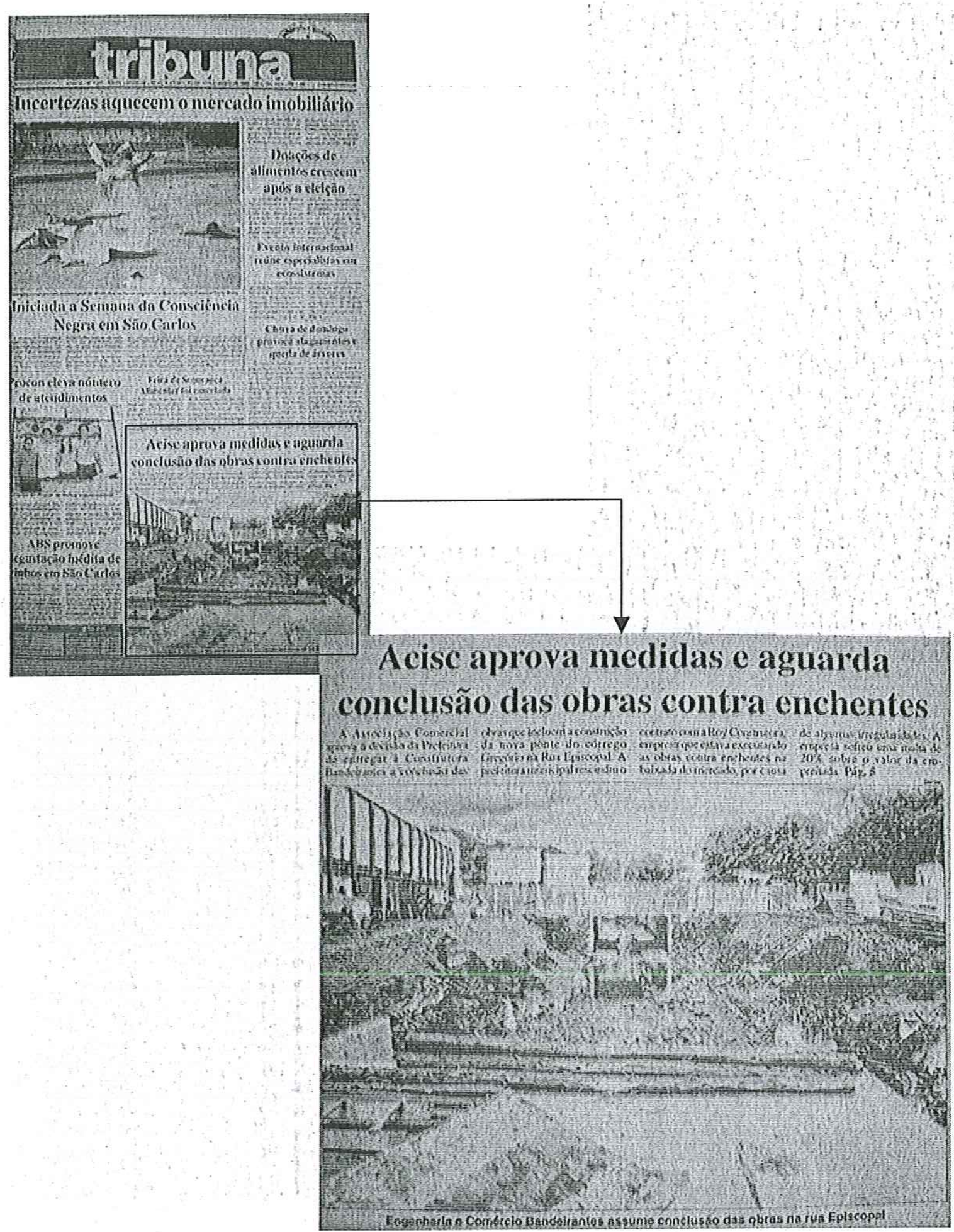

12-11-2002 - Acisc aprova medidas e aguarda conclusão das obras contra enchentes - $\mathrm{A}$ Tribuna - Parte 1 


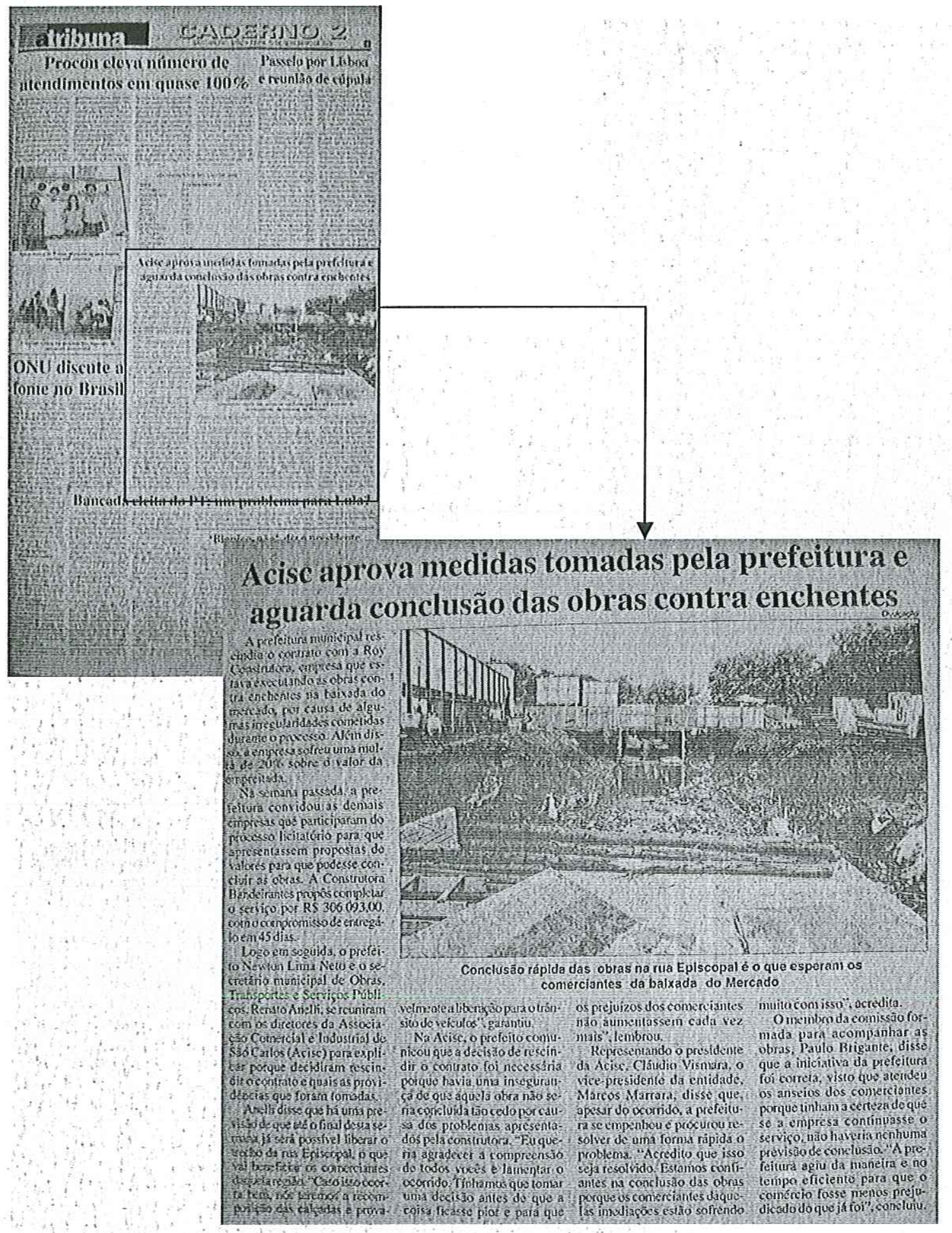

12-11-2002 - Acisc aprova medidas e aguarda conclusão das obras contra enchentes - A Tribuna-Parte 2 


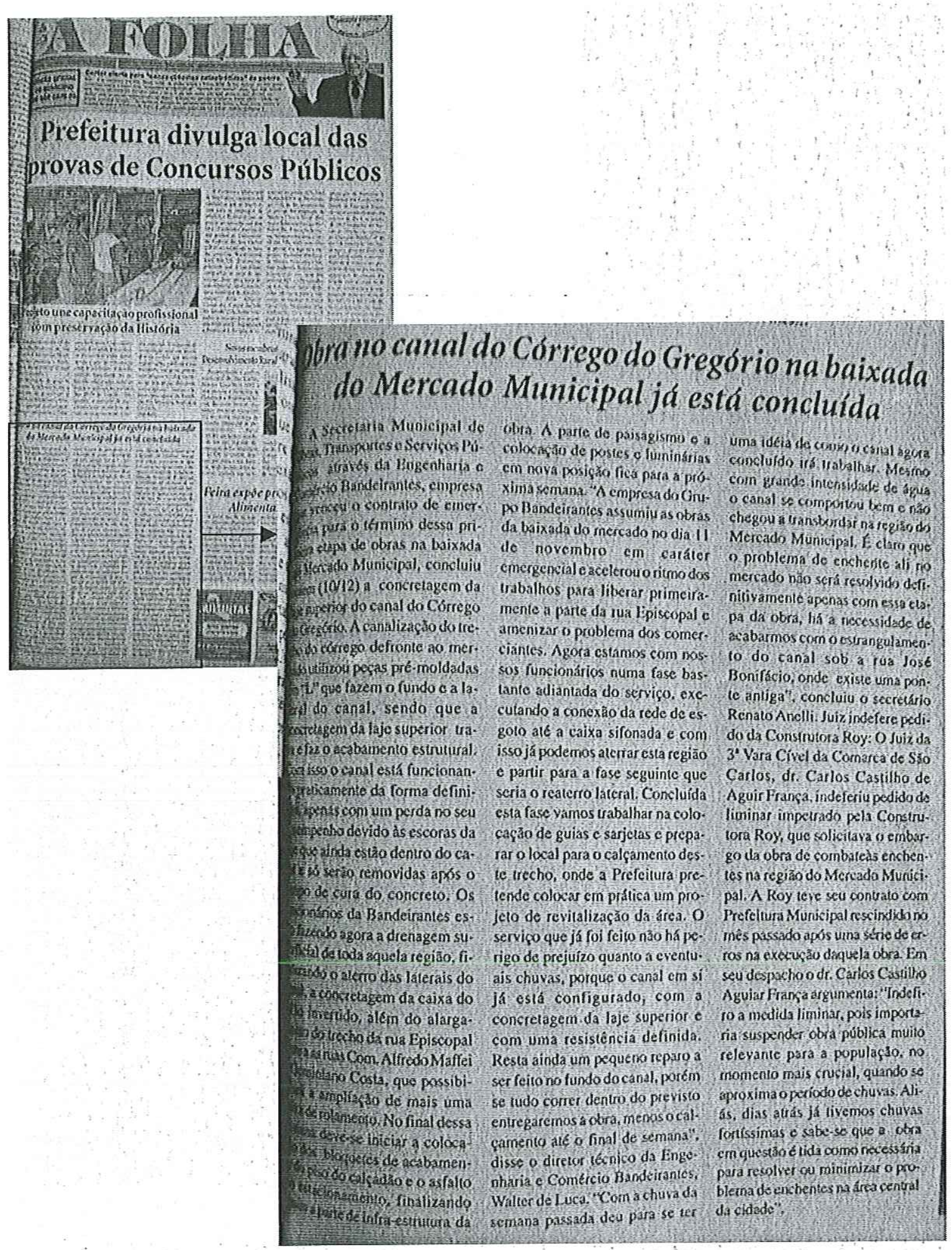

11-12-2002 - Obra no canal do córrego do Gregório na baixada do mercado municipal já esta concluída - A Folha 


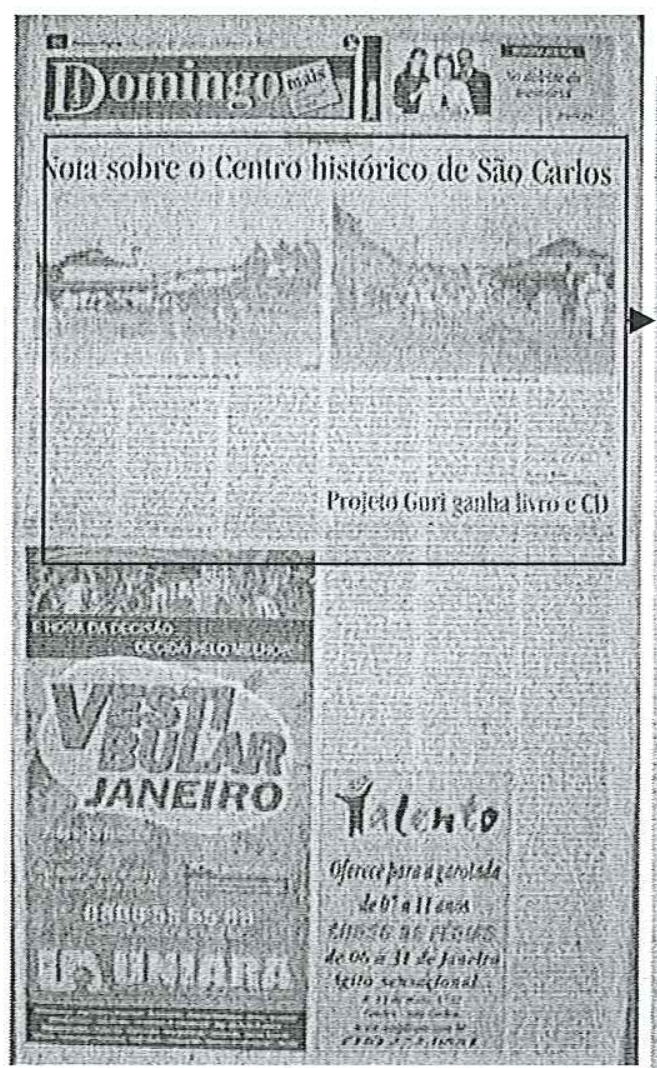

.

\section{Nota sobre o Centro hi}

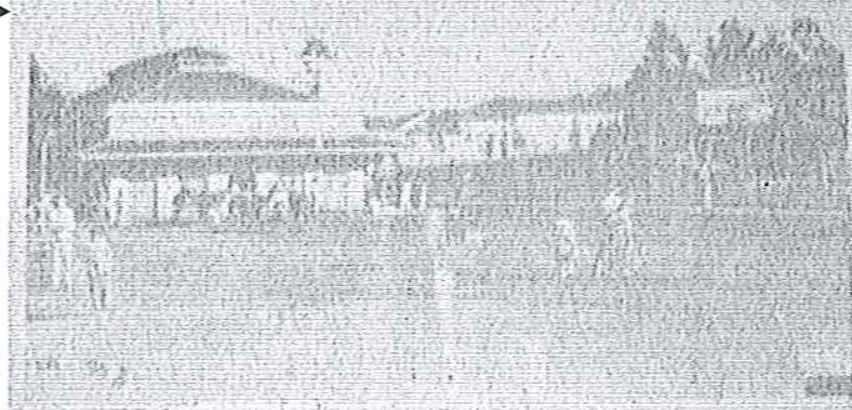

Area do metcsio mugictpal na dectada 10

1..... Curntion

Yintiks un levio gete for

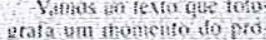

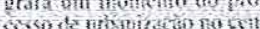

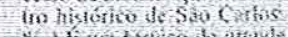

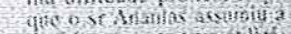

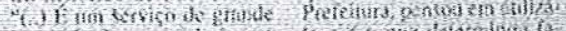

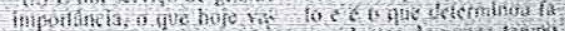

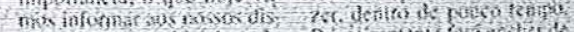

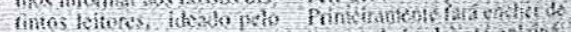

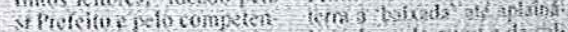

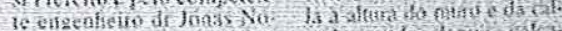

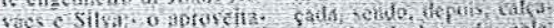

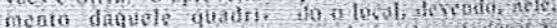

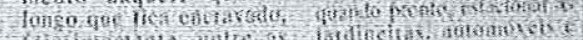

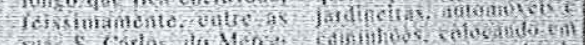

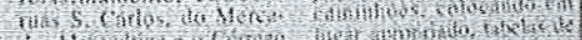

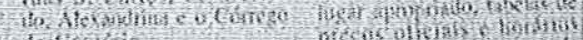

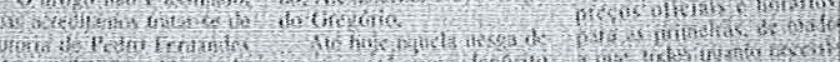

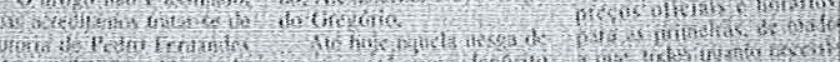

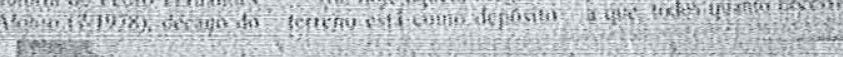

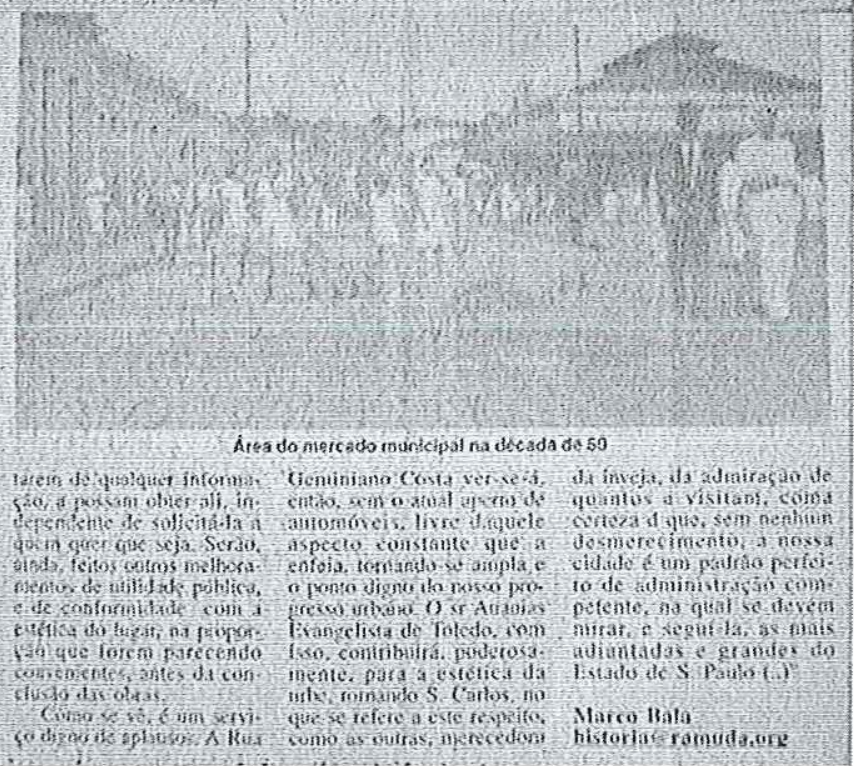




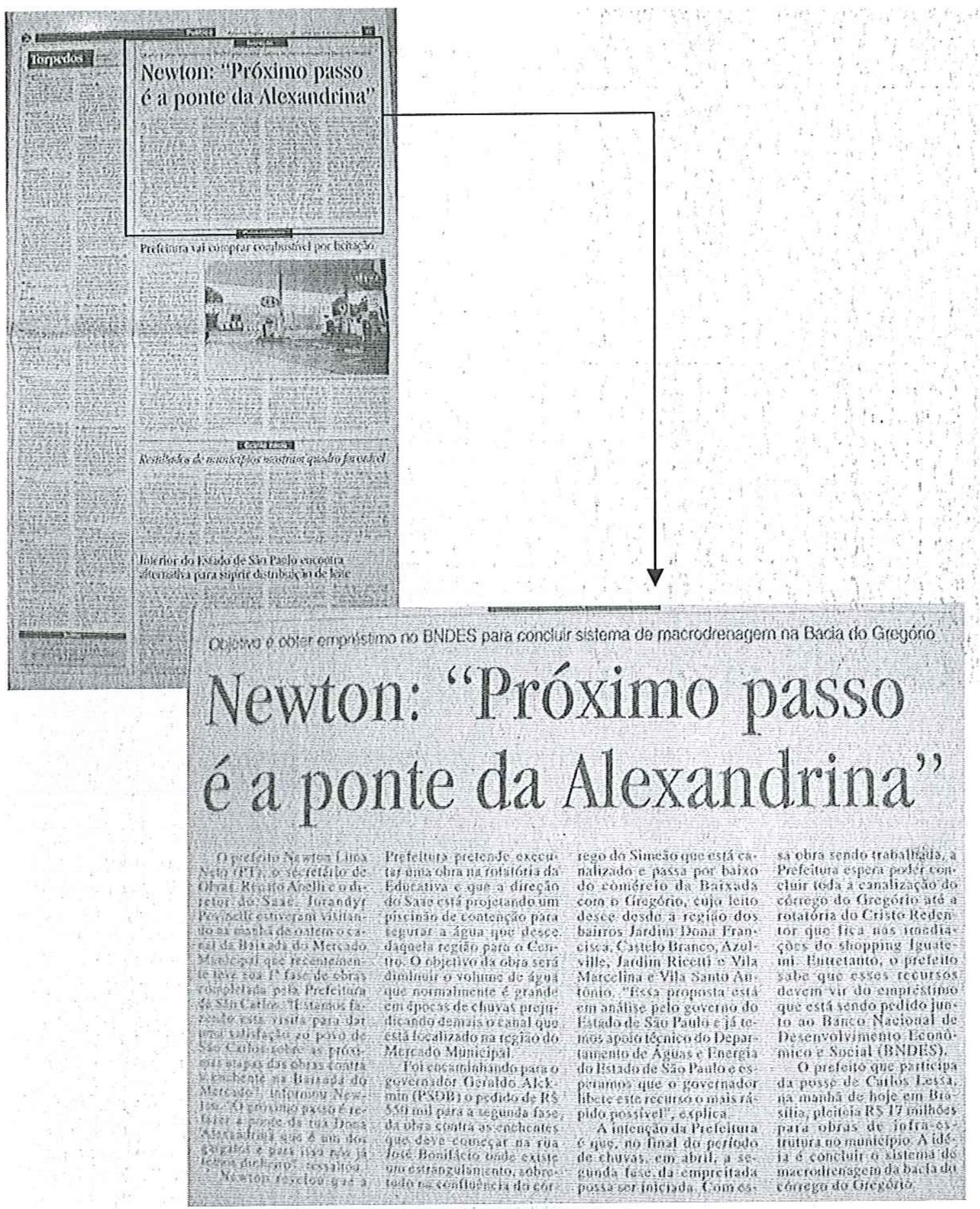

09-01-2003 - Newton: "Próximo passo é a ponte da Alexandrina" - Primeira Página 


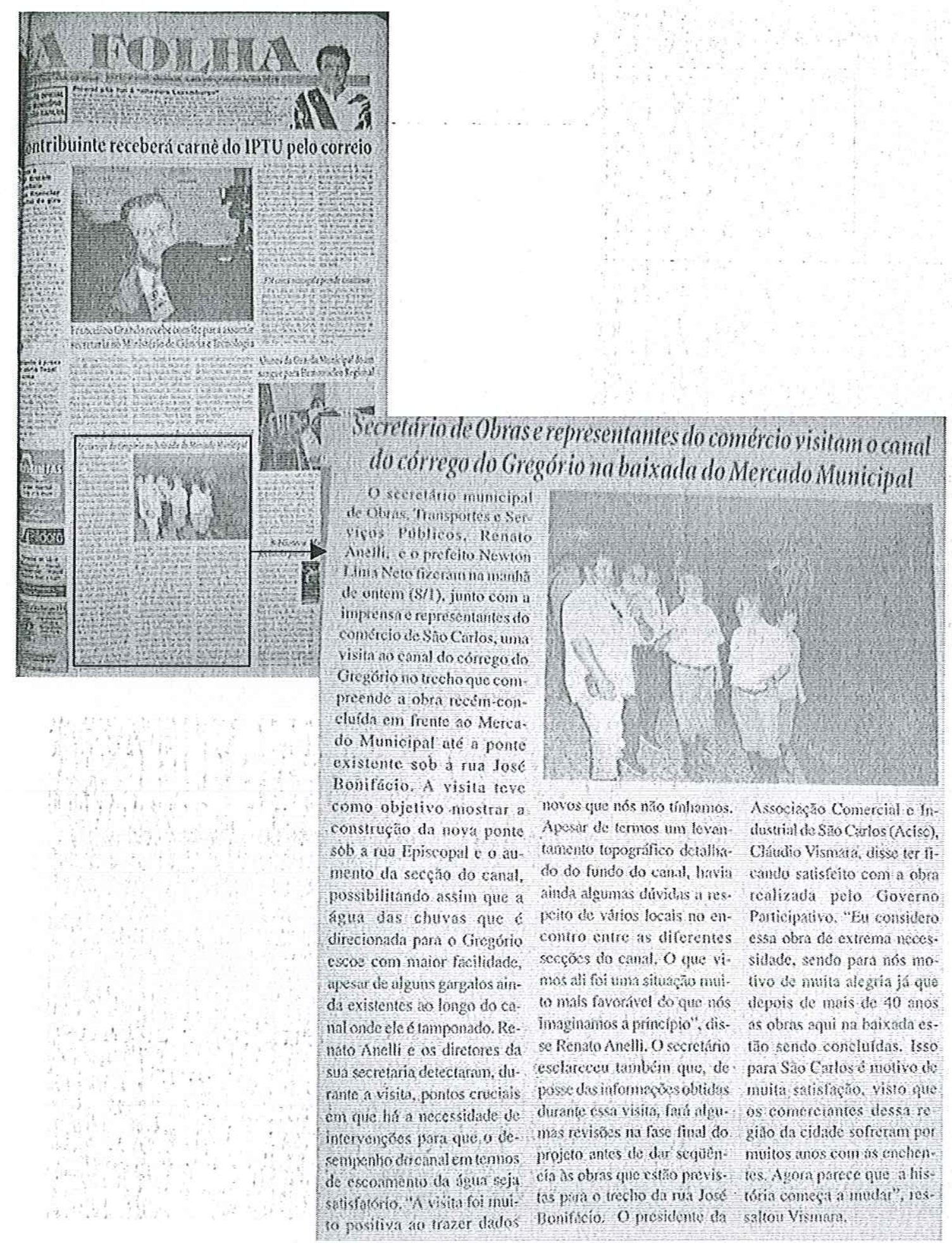

09-01-2003 - Secretario de Obras e representantes do comércio visitam o canal do córrego Gregório na baixada do mercado municipal - A Folha 

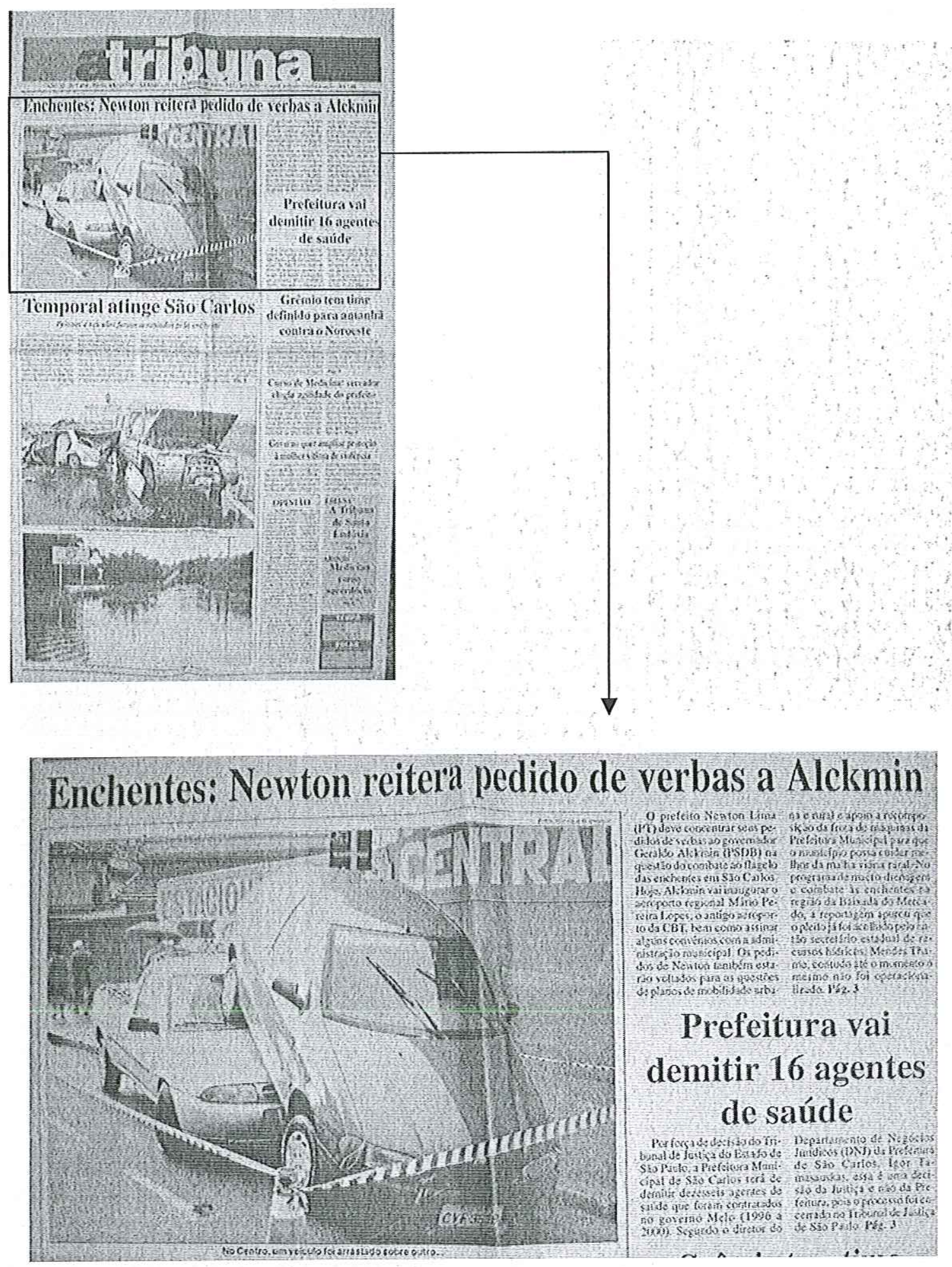

31-01-2004 - Enchentes: Newton reitera pedido de verbas a Alckmin - A Tribuna - Parte 1 


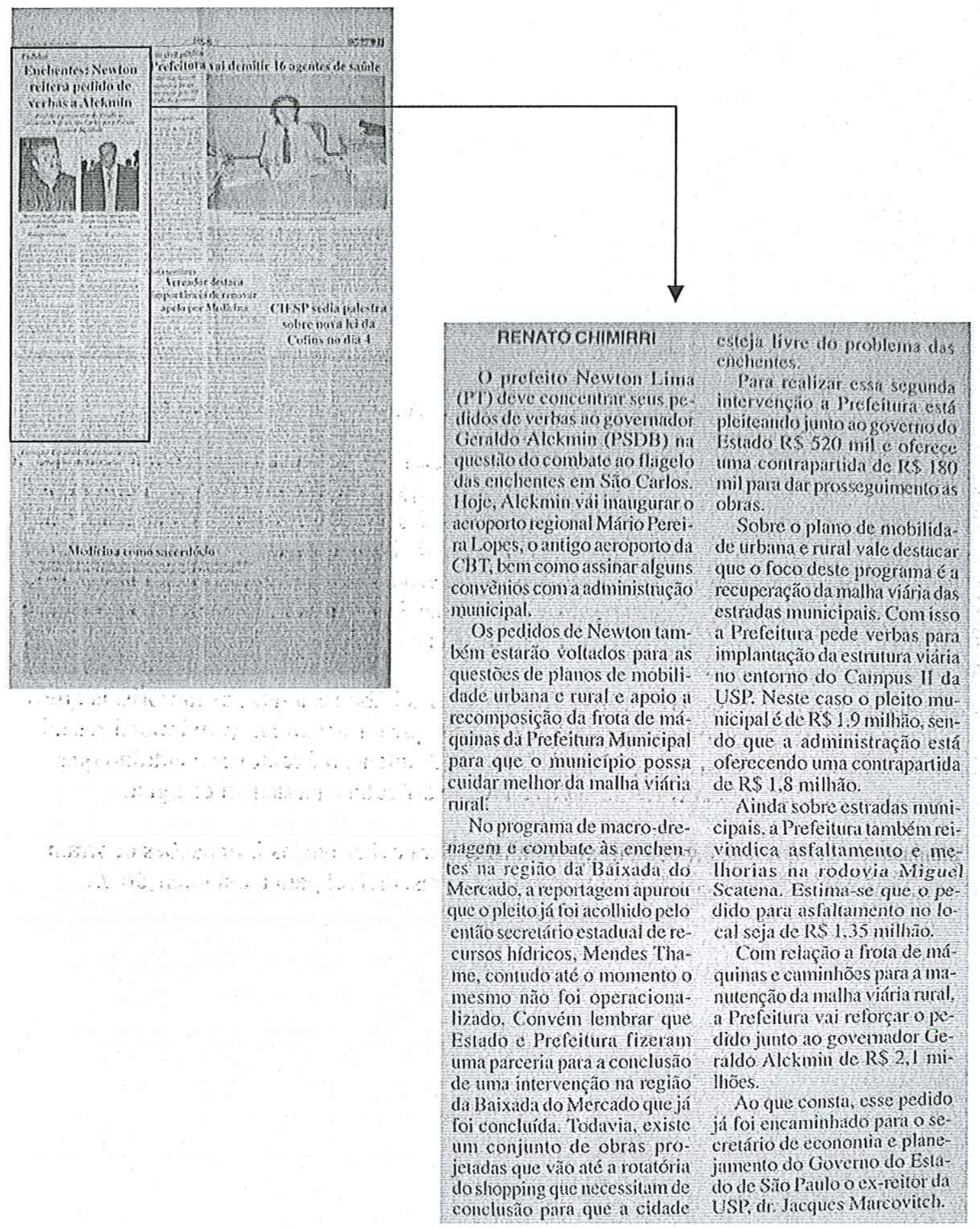

31-01-2004 - Enchentes: Newton reitera pedido de verbas a Alckmin - A Tribuna - Parte 2 


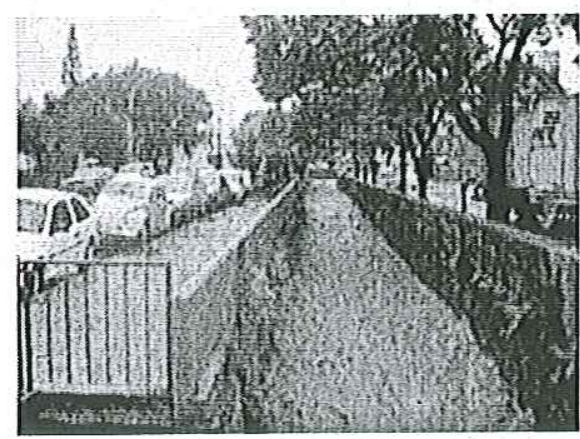

》 PREFEITURA REALIZA LIMPEZA DO CÓRREGO

Amanhã, dia 22, a Prefeitura estará realizando a limpeza do córrego do Gregório com o objetivo de melhorar a vazão das águas das chuvas nos trechos localizados na região central. Para isso, a partir das oito da manhã, o trânsito será interrompido na avenida Geminiano Costa, esquina com a rua São Joaquim. A interdição poderá se estender até o final do dia.

A Secretaria Municipal de Transporte, Trânsito e Vias Públicas avisa aos motoristas que a obra será executada por toda extensão do Córrego e que o trânsito nas proximidades será interditado de acordo com o progresso da limpeza. A intenção é remover o entulho que acaba sendo arrastado pela correnteza das chuvas e dificulta a passagem da água.

Trata-se de uma medida preventiva que contribui para evitar que as inundações ocorram com freqüência durante as chuvas, além de ser imprescindível para a manutenção da limpeza da cidade.

22-03-2005 - Prefeitura realiza limpeza do córrego Gregório http://www.saocarlos.sp.gov.br/ 


\section{$\underline{\text { ANEXO } 03}$}

Fotos das Notícias:

Inundações e alagamentos em demais pontos da cidade de São Carlos 


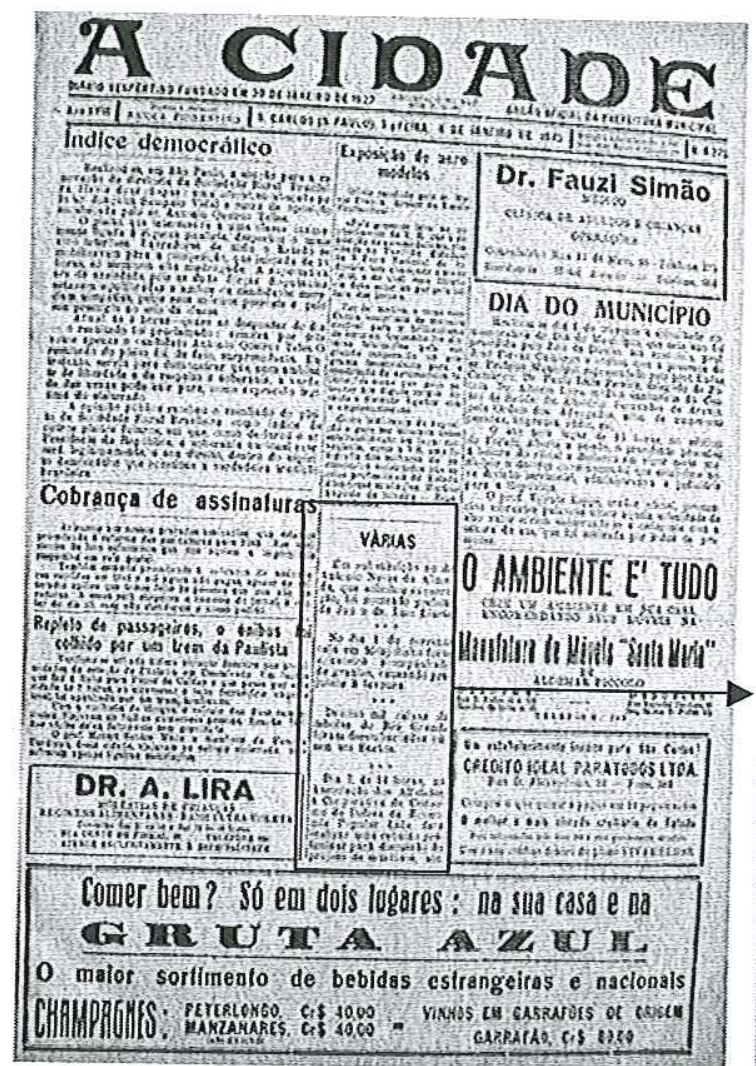

\section{VÁRIAS}

Em substituição ao $\mathrm{dr}$. Antonio Noves do Almoi. da, que solicitou exonera. cão, foi nomeado prefoito do Jaú o dr. Luiz Liarte.

$$
4 \%
$$

No dia 1 do corrente caiu em Monjolinho forte aguacoiró acompanhado de granizo, causando pro. juizos à lavoura.

Dezoito mil caixas de cebolas do Río Grando foram desembareadas on. tem om Santos.

*: $\Rightarrow$

Dia 7, ás 14 horas, na Assnciação dos Alfuiates, a Cooperativa do Consu. mo de Defesa da Econo. mia Popular Ltda. fara cealizar uma reuniáo pre. liminar para discussão do projeto do estatutos, eto.

04-01-1945 - Varias - A Cidade 


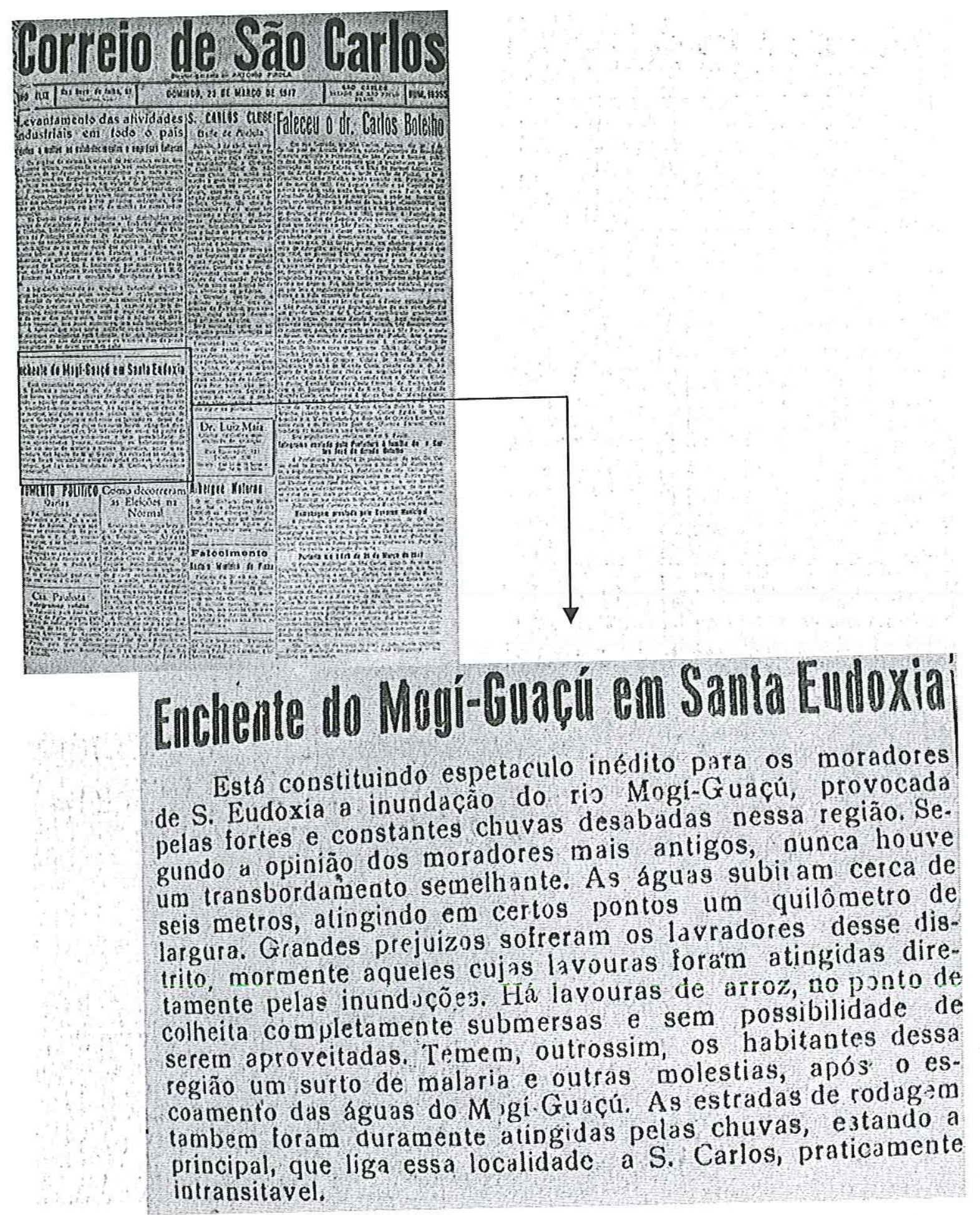

23-03-1947 - Enchente do Mọi-Guaçu em Santa Eudóxia - Correio de São Carlos 


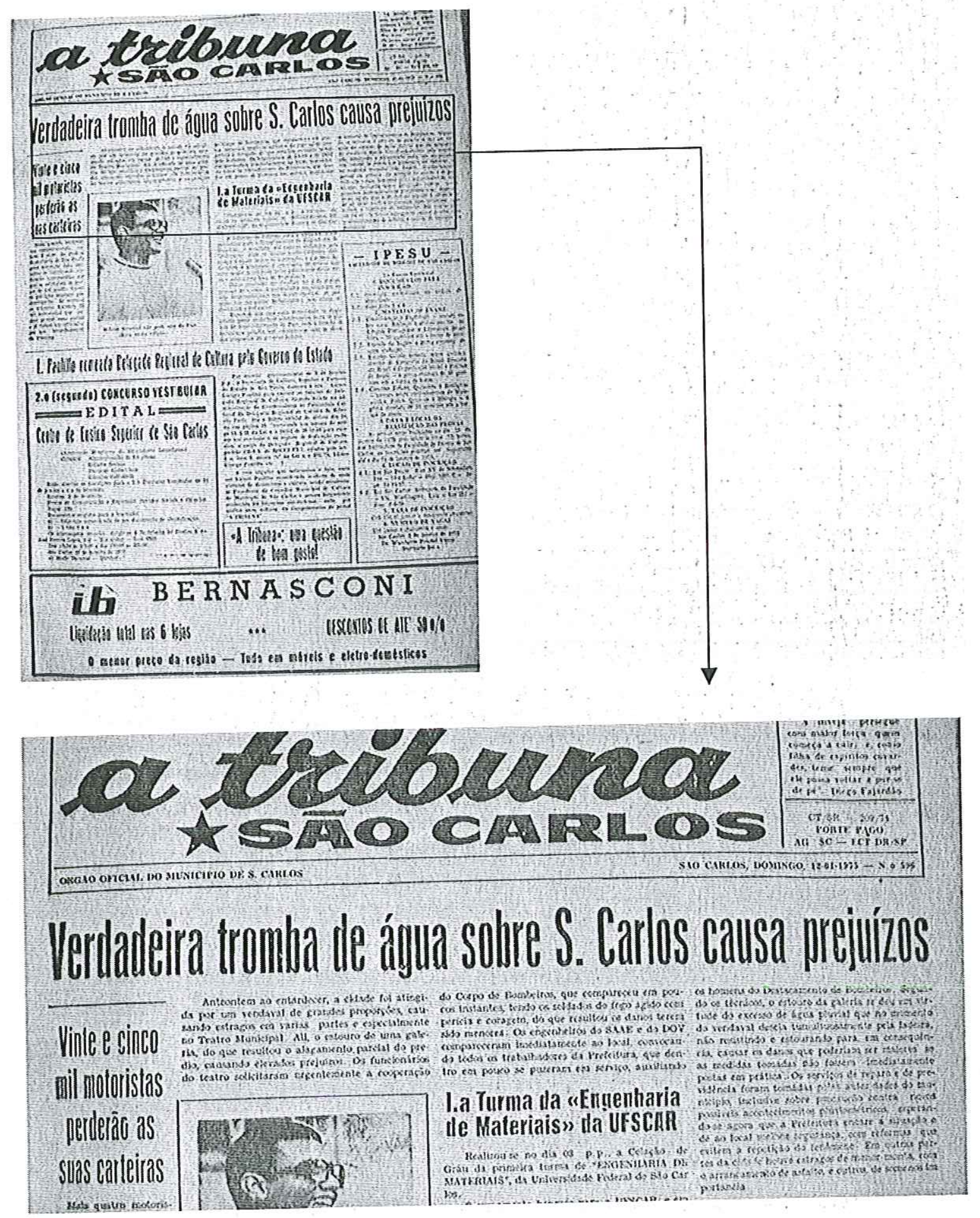

12-01-1975 - Verdadeira tromba d'água sobre S. Carlos cauza prejuízos - A Tribuna 


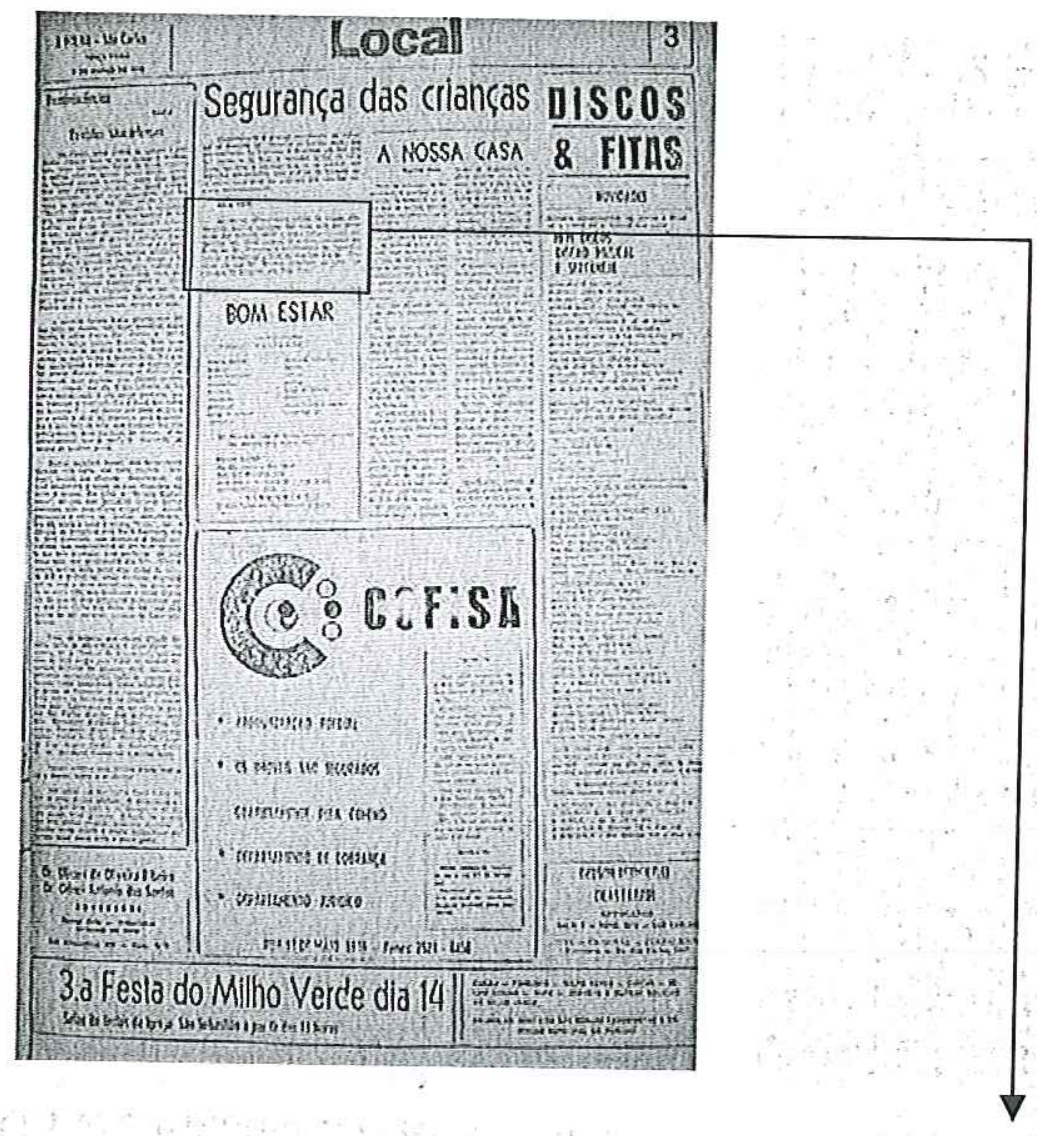

\section{VILA NERI}

As chuvals ultimamente caidas na cidade pro. vocaram muitos estragos nas ruas sem pavimen. tacáo dos bairros, onde o mato naturalmente all. mentou. em vonsequencia. 0 mosno vereador in. dicoli $30 \mathrm{Sr}$. Prefeito a neecessidade de "mandar limpar e consertar o leito da rua que é a $2 a$. Travessa da rtua Dr. Wailter Schintzer, ao lado da Chacara do Bragito, em Vila Neti.

09-03-1976 - Vila Nery - A Folha 

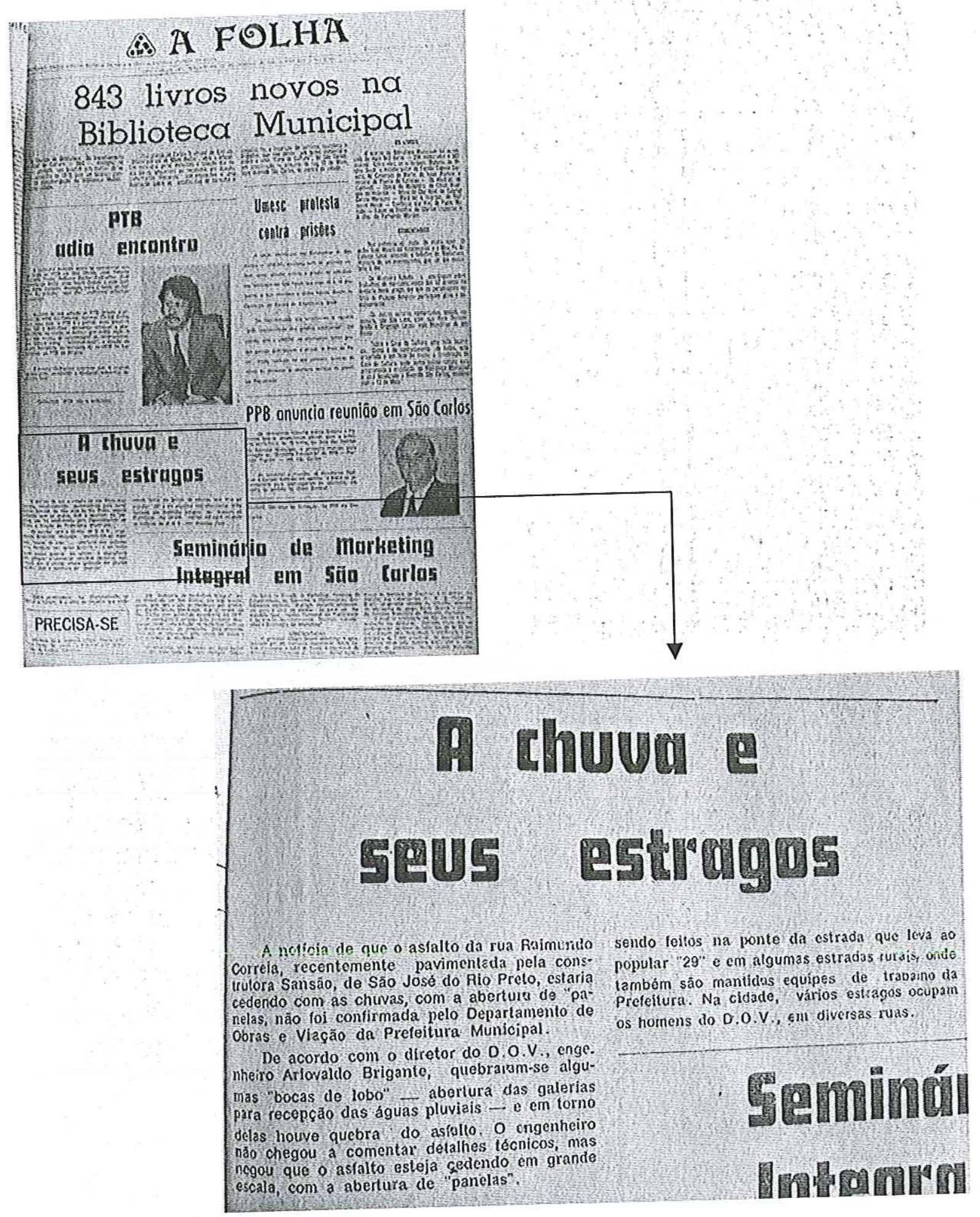

22-01-1980 - A chuva e seus estragos - A Folha 


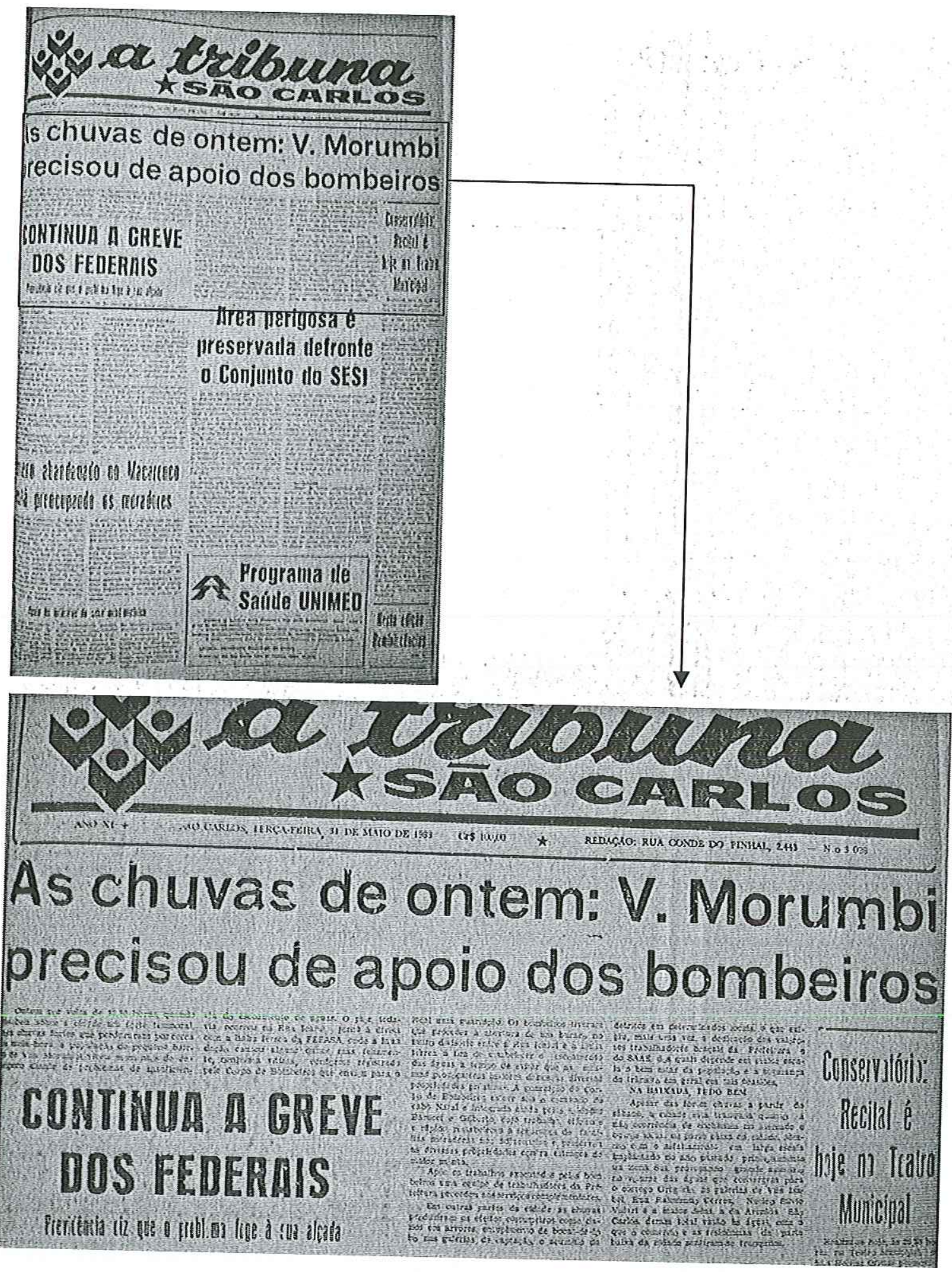
31-05-1983 - As chuvas de ontem: V. Morumbi precisou de apoio dos bombeiros - A
Tribuna 


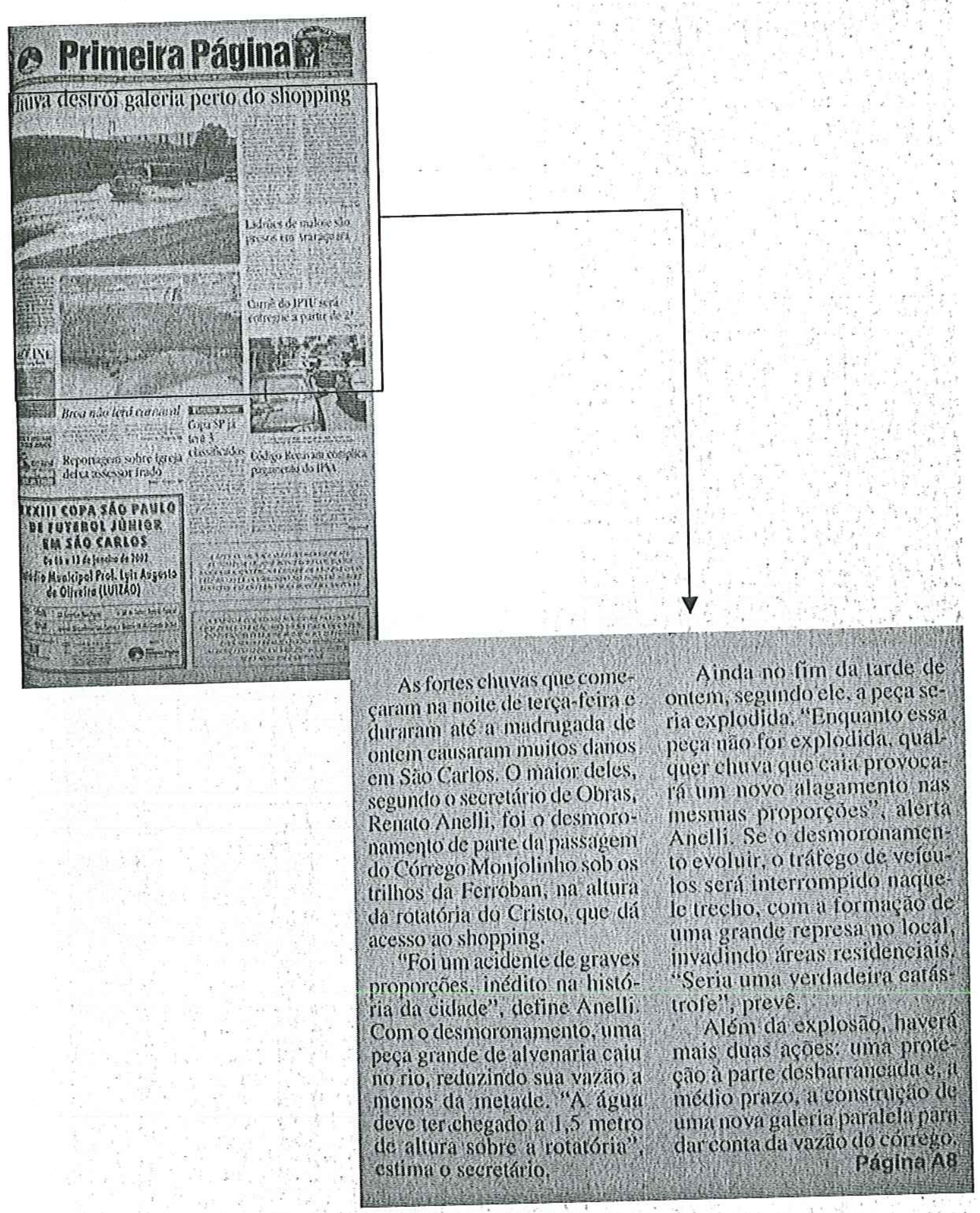

10-01-2002 - Chuva destrói galeria perto do Shopping - Primeira Página 


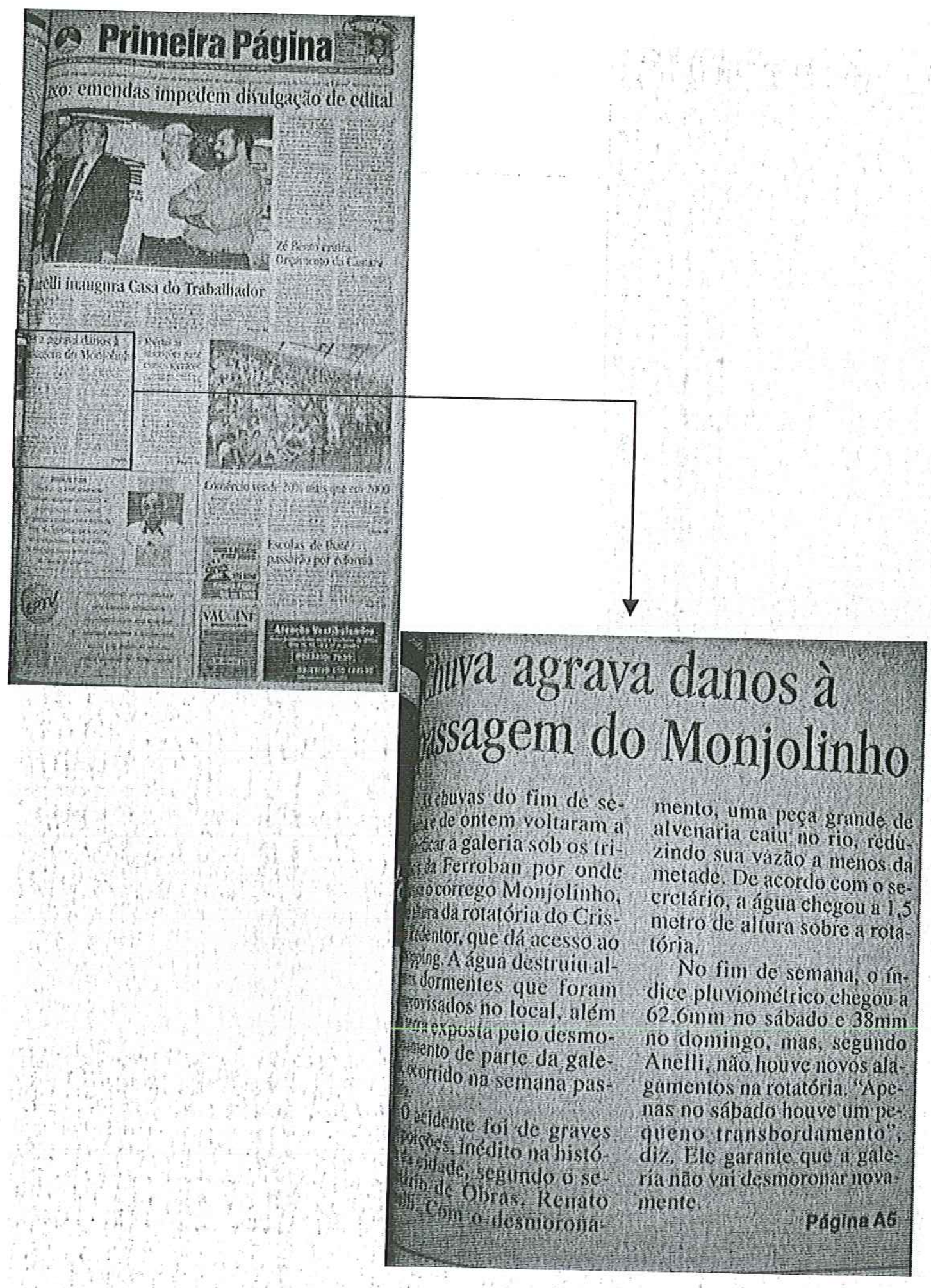

15-01-2002 - Chuva agrava danos à passagem do Monjolinho - Primeira Página 


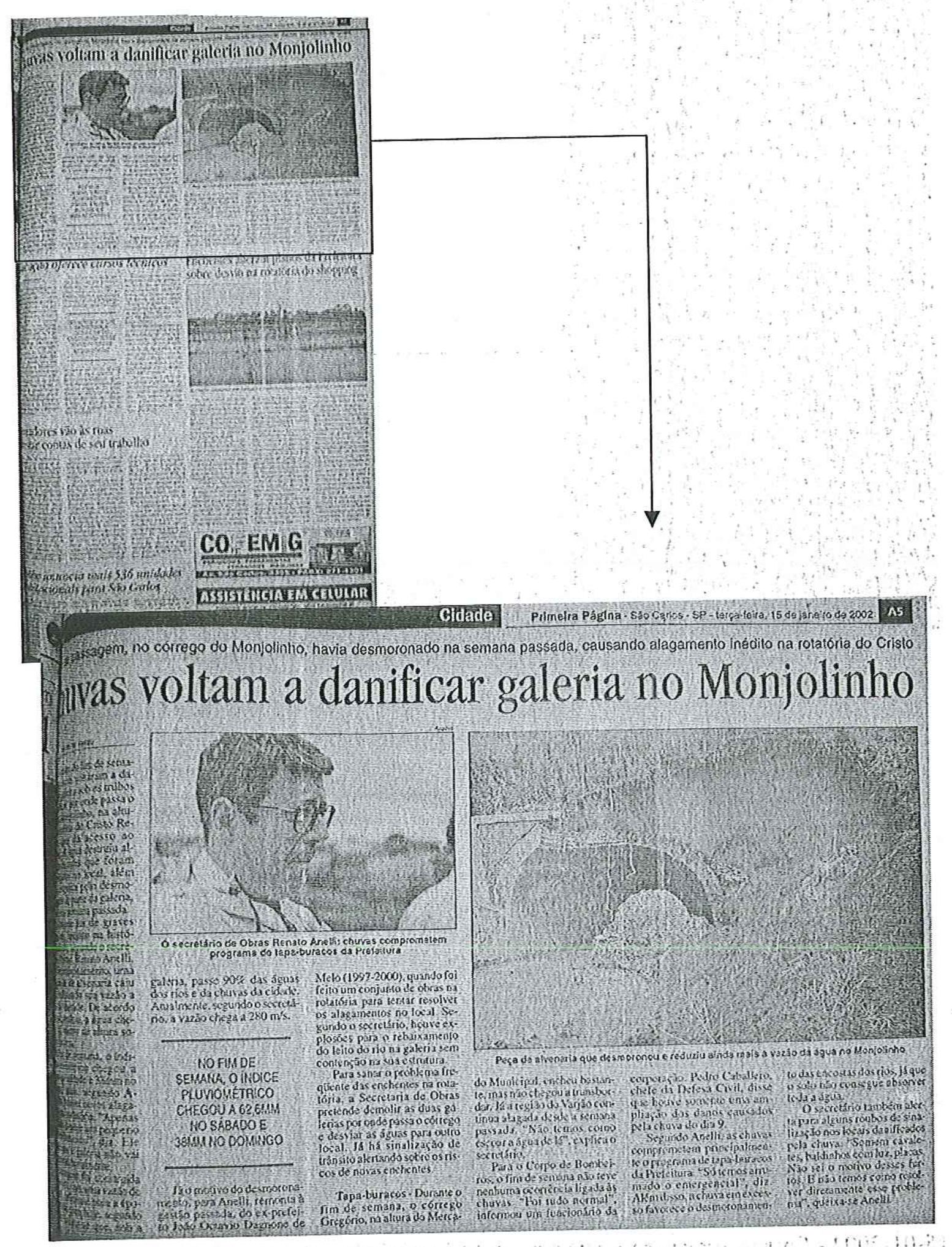

15-01-2002 - Chuvas voltam a danificar galeria no Monjolinho - Primeira Página 


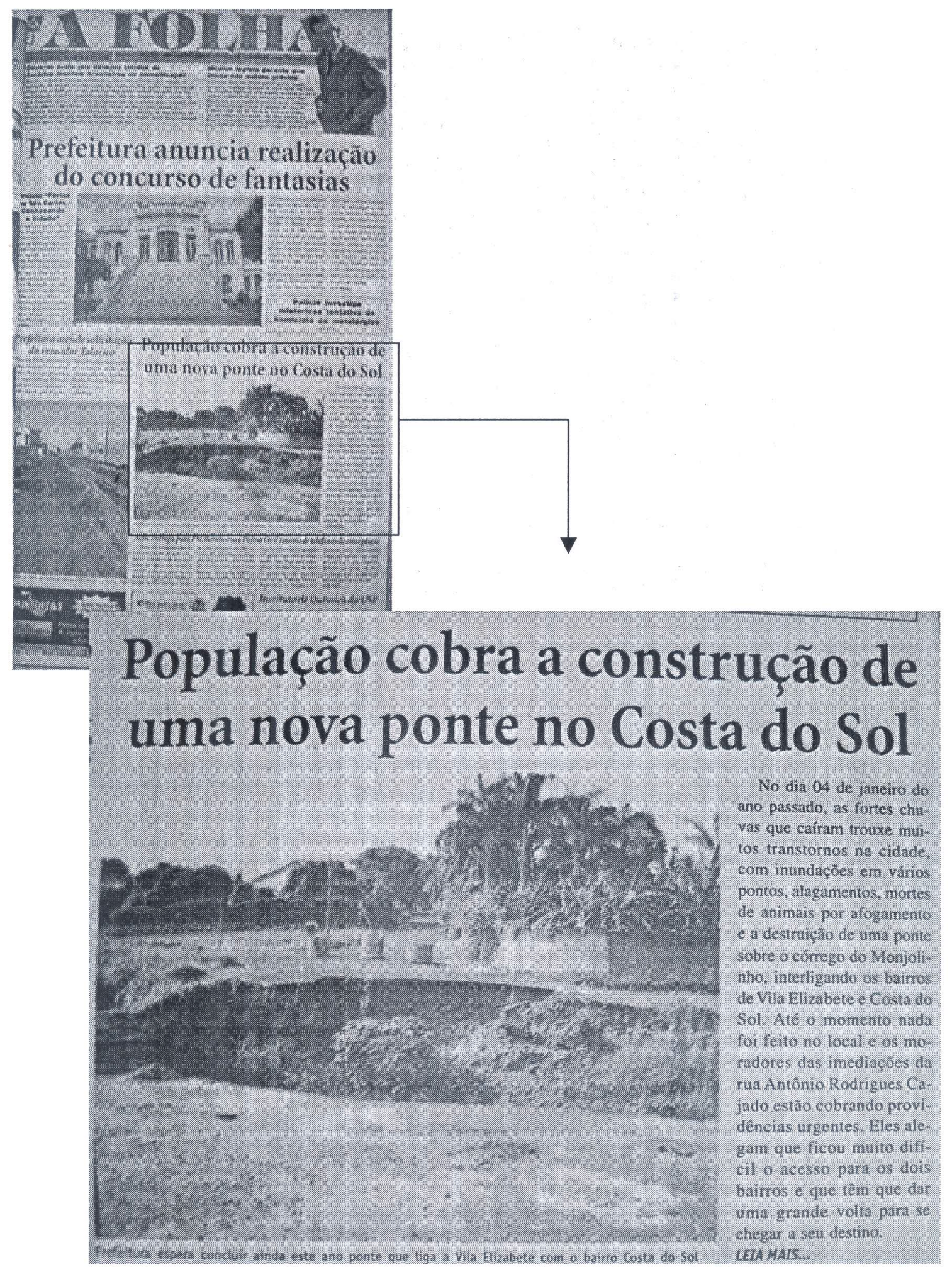

08-01-2004 - População cobra a construção de uma nova ponte no Costa Sol - A Folha Parte 1 
4.10 .0101010 .911100

No dia 04 de janeiro do ano passado, as fortes chuvas que carram trouxe muitos transiornos na cidade, com inundaçes em vários pontos, alagamentos, mortes de animais por afogamento e a destruição de uma ponte sobre o córrego do Monjolinho, interligando os bairros de Vila Elizabete e Costa do Sol.

Até o momento nada foi feito no local e os moradores das imediaçôes da rua Antônio Rodrigues Cajado estão cobrando providencias urgentes. Eles alegam que fi.cou muito difícil o acesso para os dois bairros e que têm que dar uma grande volta para se chegar a seu destino. Os comerciantes estabelecidos na rua Antônio Blanco também já estão sentindo a queda nas vendas.

O secretário municipal de Obras, Transportes e Serviços Públicos, Renato Anelli, foi procurado para saber quando está prevista a construção de uma nova ponte naquele local. Segundo ele, isso deve ocorrer ao longo deste ano, já que a obru for aprowada pelororcamento Participartivo para 2004. "O projctoja se ericon: Ira em rase final de realiza. çấ c acrediumos que nos próximos meses já poderemos abrir a licitaç̃o para a cons: truçüo da ponte" informa.

Anelli explica que o que houve naquele trecho foi a rupura do aterro onde era utilizado um tubo ármico, que foi levado com a força da água. De acordo com o secretário, não havia dotação orçamentária no ano passado para a construçióo de uma nova passagem. "Como a rua Antônio Rodrigues Cajado não se estende por muitos quarteirōes dos dois lados, consideramos que era possível aguardar o ano de 2004 para a construcão de uma nova ponte", lembra.

O secretário esclareceu também que há uma pendência da parte ambiental, em função daquela ponte está localizada na bacia do Tijuco Preto, onde se encontra com todas as abras embargadas por decisão do Tribunal de Justiça do estado de São Paulo, por causa das denúncias apresentadas pelo Ministério Público.

08-01-2004 - População cobra a construção de uma nova ponte no Costa Sol - A Folha Parte 2 

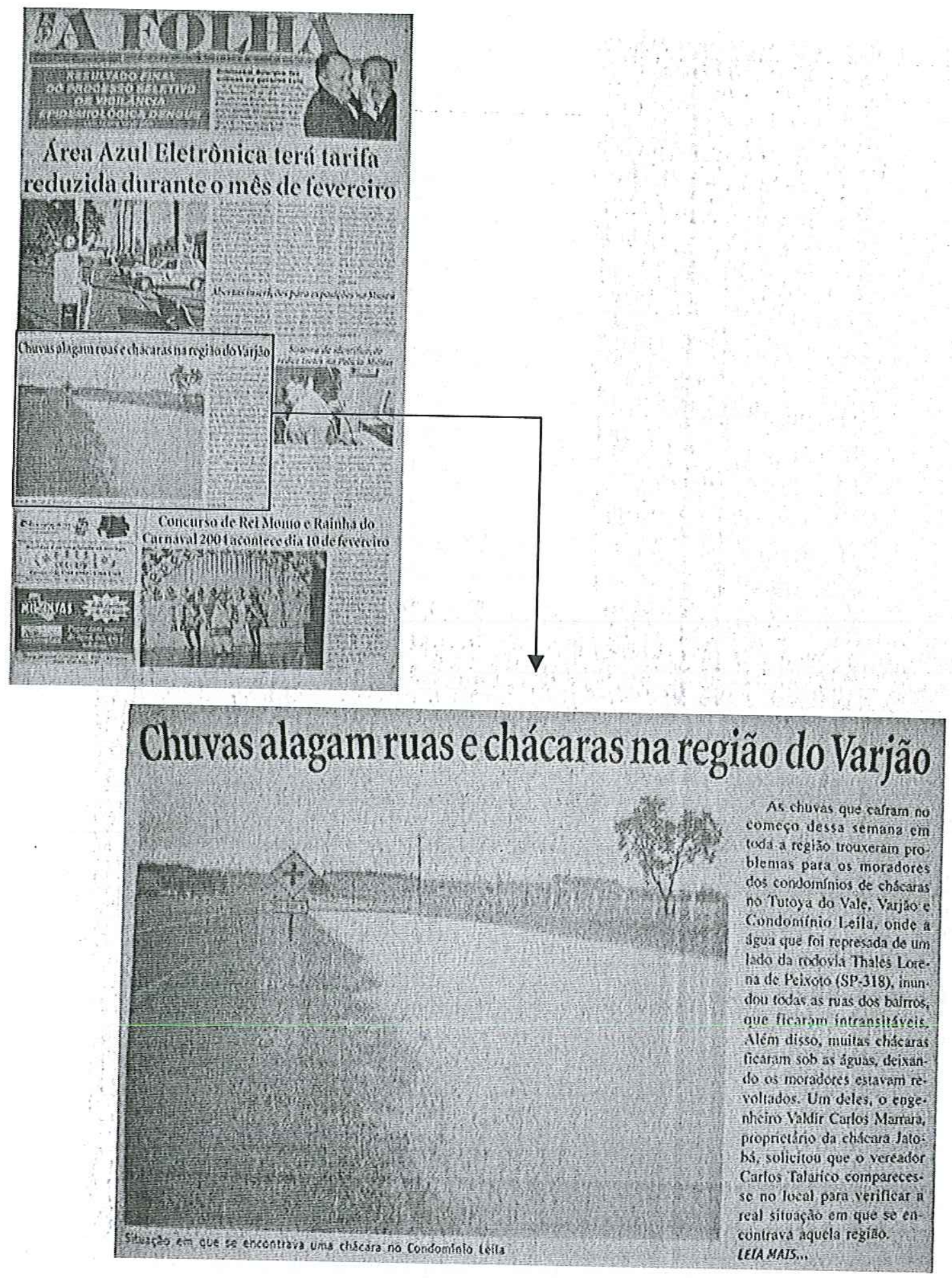

27-01-2004 - Chuvas alagam ruas e chácaras na região do Varjão - A Folha - Parte 1 


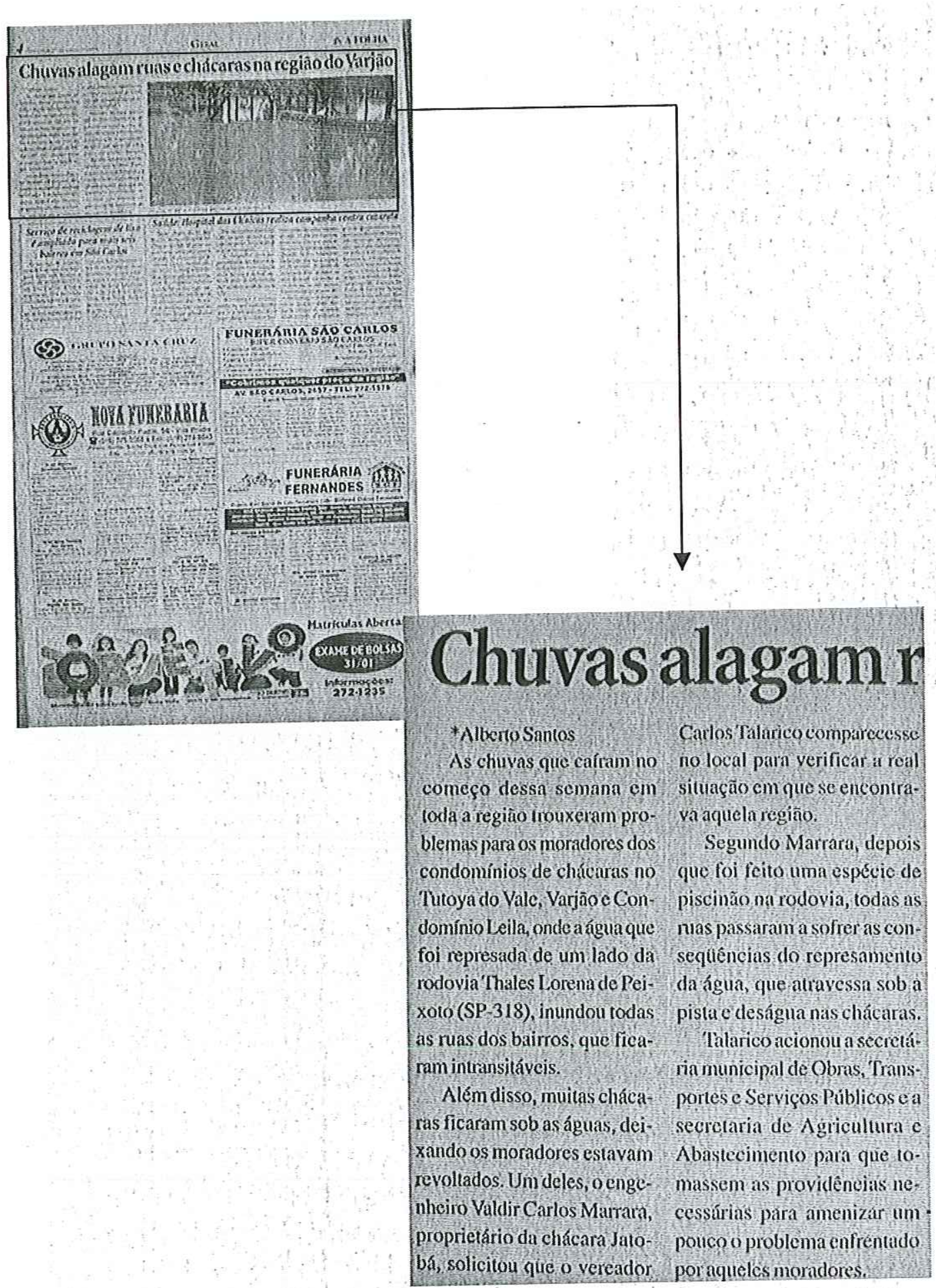

27-01-2004 - Chuvas alagam ruas e chácaras na região do Varjão - A Folha - Parte 2 


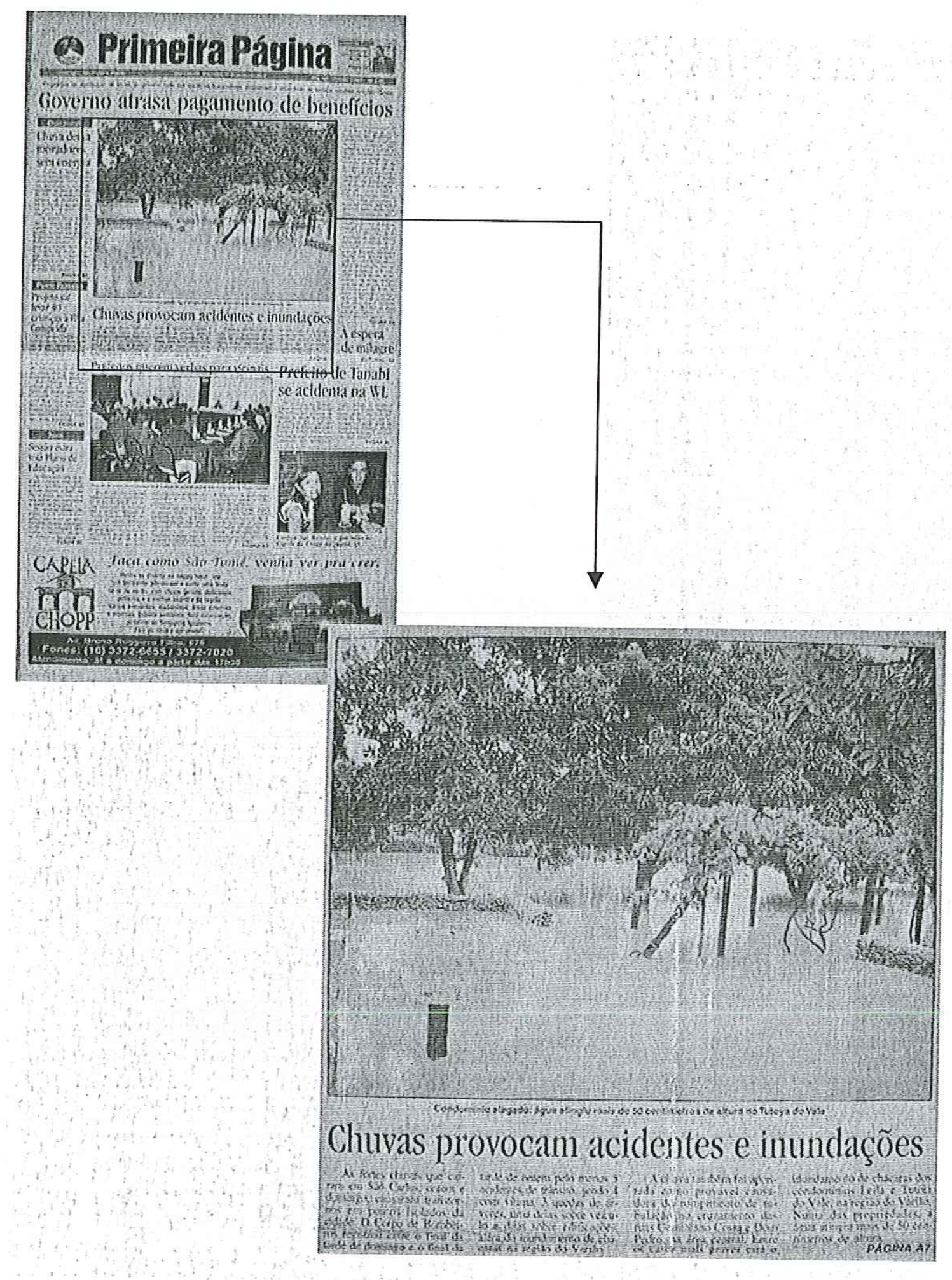

27-01-2004 - Chuvas provocam acidentes e inundações - Primeira página - Parte 1 


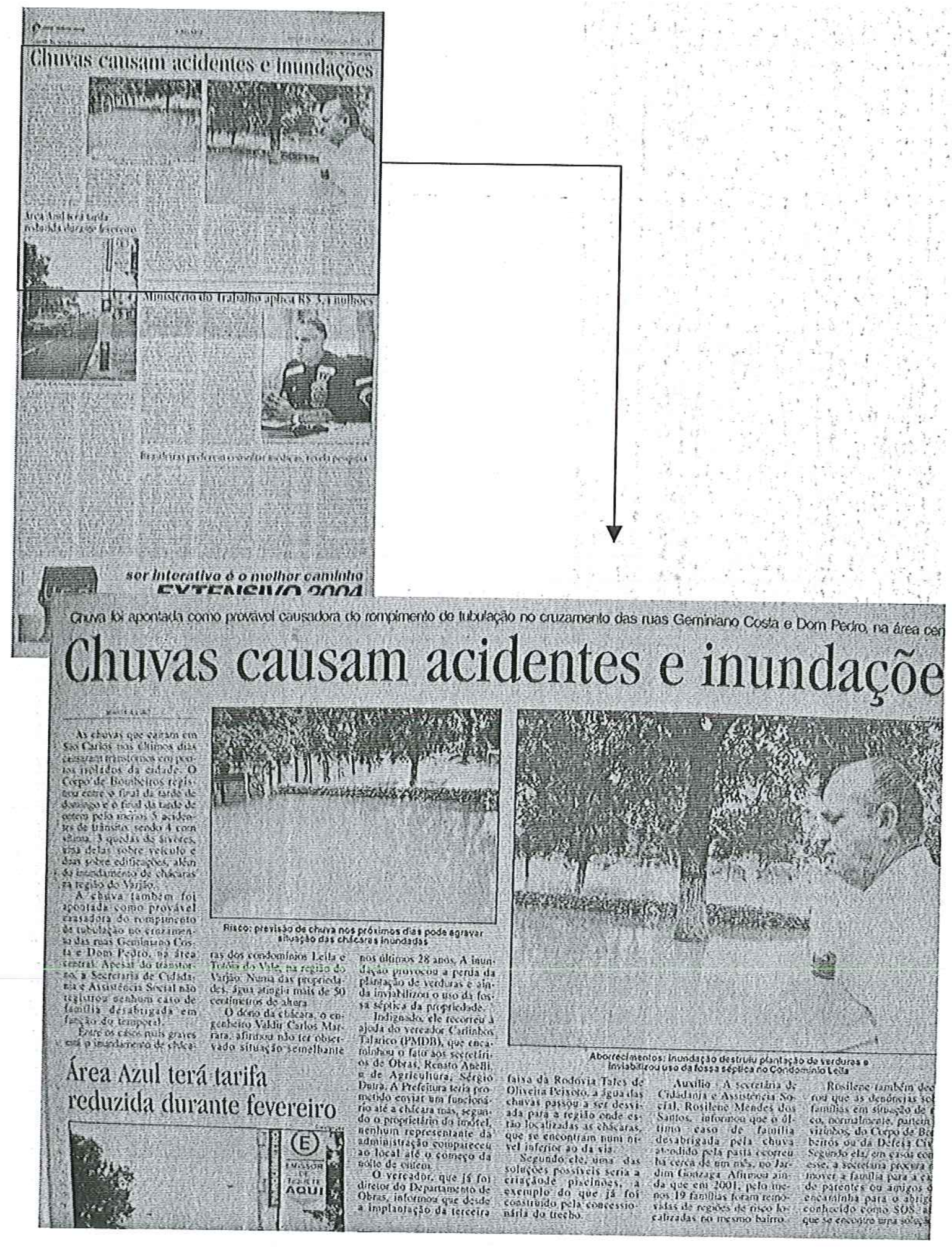

27-01-2004 - Chuvas provocam acidentes e inundações - Primeirà página-Parte 2 


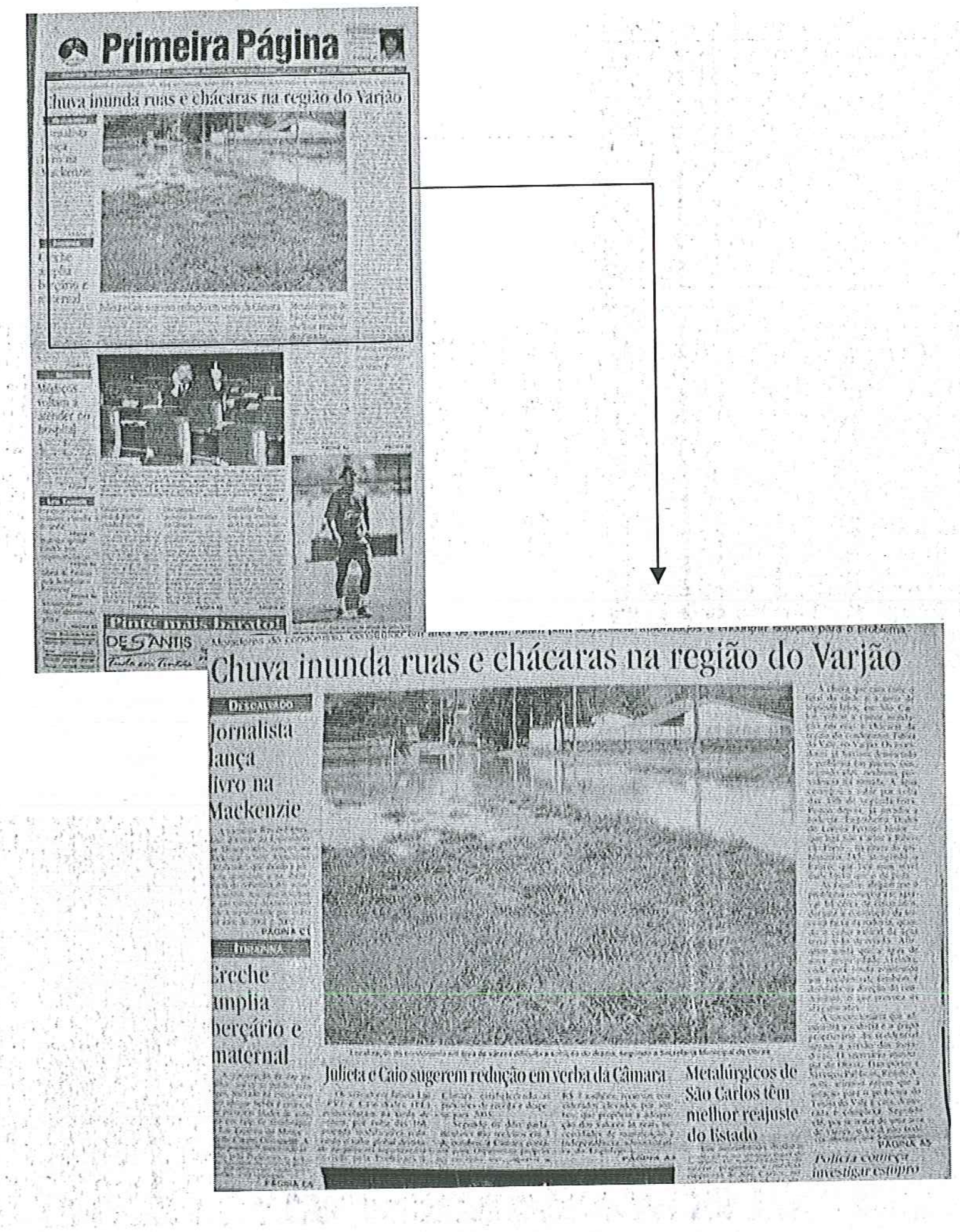

17-11-2004 - Chuva inunda ruas e chácaras na região do Varjão - Primeira Pagina 


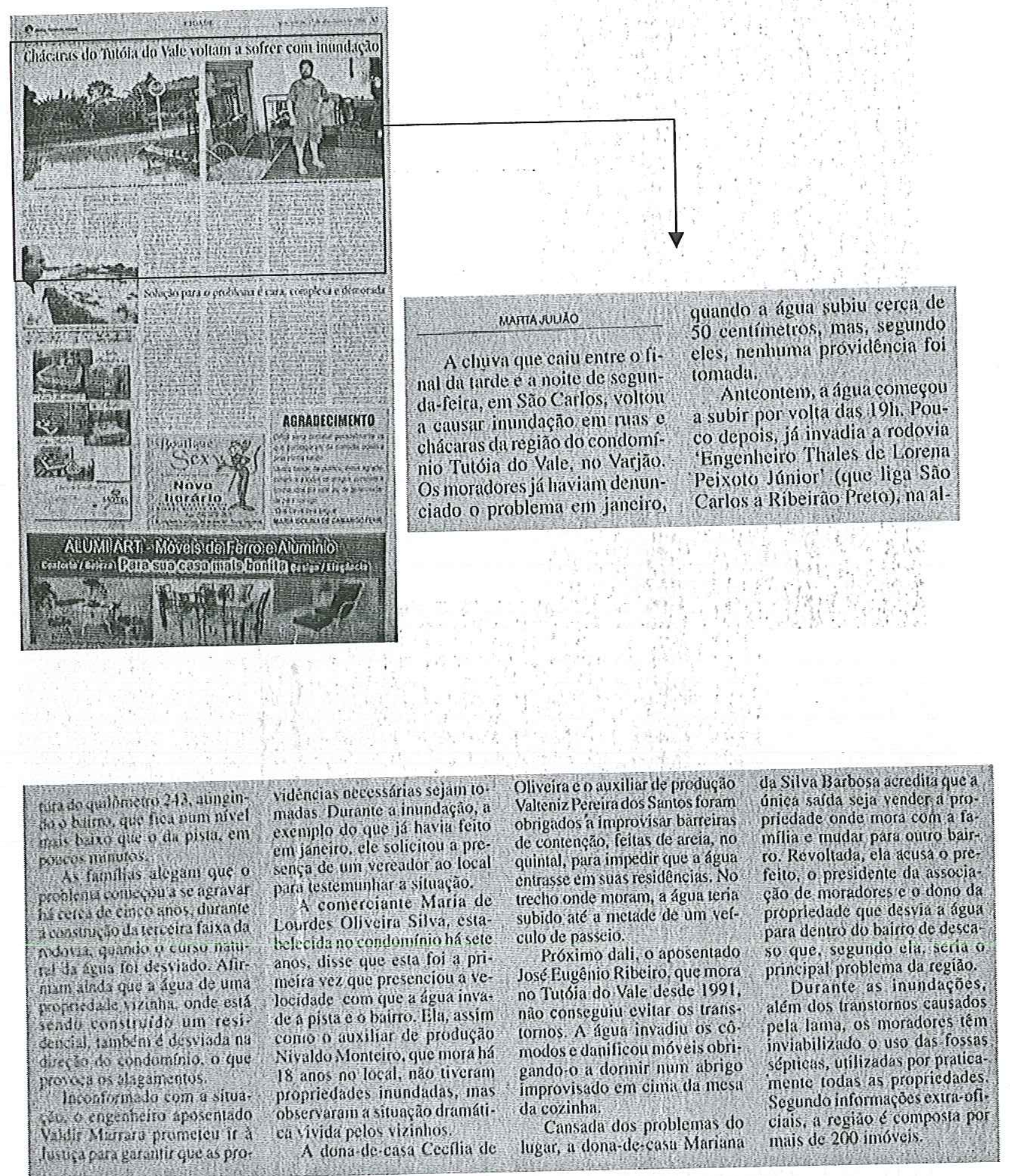

17-11-2004 - Chácaras do Tutóia do Vale voltam a sofrer com inundação - Primeira Pagina - Parte 1 


\section{Solução para o problema é cara, complexa e demorada}

Oxecrefatio mimedpal de Qbus. Thinsiontes e Servigos Aublicos, Renato duelli, afirmoa onicm yac a solicto para

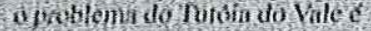
cala. demorada e complexit.

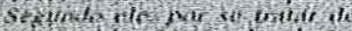

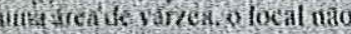
colkgis abrigar um lotetínchlo.

- Anelliesplicou que a Prefei. vitur verio construindo orliagnós. tho dis situaça jo junto vom a pto. inotor de Neio Ambiente, lid Mard lectein wilho c oultas par. kesenolvidas. Oestidoja cons. 20u, fur exemplo, que os con donínios Leila e Tutóla do Valc forati construidos sobre o leito va uin affuevte interilitente do comego lararaca que desapirece no reriedo seco, mas yolla a Howe furante as chuvas

Máa solucionsr o problema, a sectetślib acredita que sola

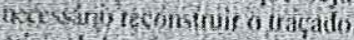
ofimal Georrego e construir

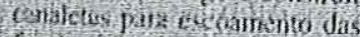
Gguts, alem us criat una nowa

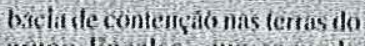
gropin tínealso. que segundo moradores évesjonsável pelo agravimento do problemi. Aivili nato sabe precisar yua montante de recurros se in ne

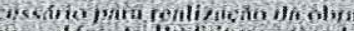

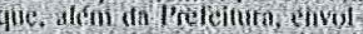
veria a participaçio da lziealso e da concessioníria Autoyjas que adminisistra a rulovia.

O nduvogado do grupo len: calso. Antonio llélío de Paula J.eltic Jr, alimiol gile o cliente que adiministra os condomí. nios Damilia e Dámba 2 nảo contribui de nentiuma manuira para o agraváíento do proble. ma do túlóia do Vale Ele in. formul quo na áreir das pro. priedades do grujo já foràn constiofdas tres bacias de comtencáo que foram sulicientes para conter as águas dumite a chityi de segunda feira.

Eeite If atimiou aifida ouc af Encalso ja se comprometeo. extrafofictalinente, com o $\mathrm{Mi}$ nisierio Páblico e es gen minto rizaçio do DJapleN (I eparta mento Istadual de Proteçits atos Recursos Naturais) parri cons Iruir uma quarta bicifi com en pacidade poin reter 59 vis

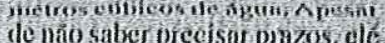
garanitiu que, una ves autori. Iidia, a obra pode ser construida em policos díns.

$\Lambda$ assessoria de limprensa da concessionária Aulovias negou que o problema de inumilaçăo tenlia surgílo apos a construcatio ila terccira hixa mi foxlovia Len genlieiro linles de Lorena Pei. xolo Júnior e nifirmou ler da dos yue comprovam que o pro blema já existia. Declatom ần da gue, guando convidada para particjpar de um grupo rle esti. dos que biusca soluçoes para o

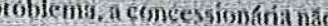
medlu esforçes para ientai $r$ solver os transtorios centrenta dos pria comunidade Jocal.

O qerendor Jase Pinfiein.

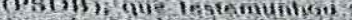

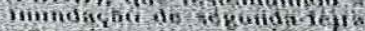
sifirinoti tue ter entrailocon se presentacio no Ministerio Pu blico em janciro jedindo, alên de provilenefas lesnicas a pu: niçálo de futoridades gud ele considera responsaveis pela

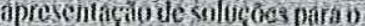
caso, Alirmol ainda yue a po: puliçio nîno prode ser responsa. bilizadí por um conilomintio construídosum a minalise provia necessína para sua vinbilizacuo.

Pinlieiro nako srabe informar o estagio aftua da neăo. Afiman. no contanto, que reiterarin on pedj: do caso fosse necessánio (M/J)

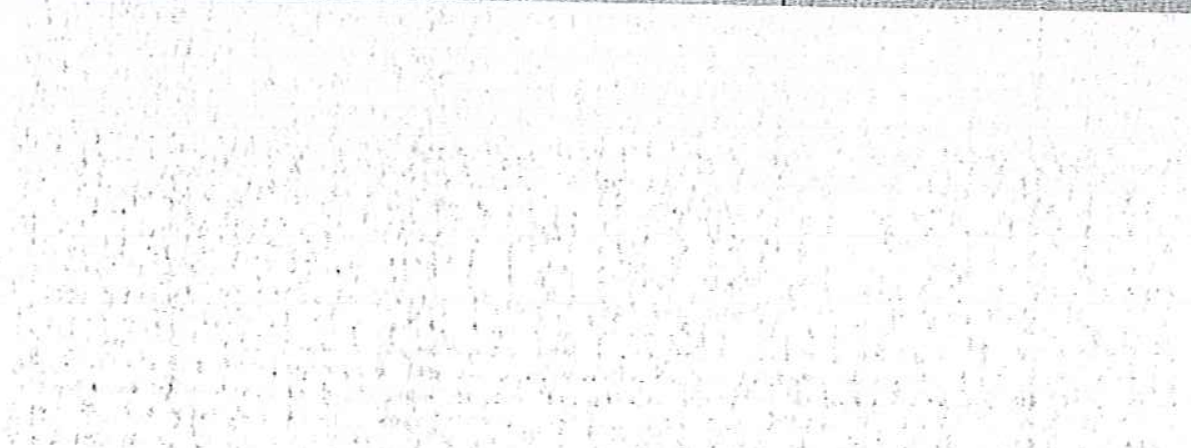

17-11-2004 - Chácaras do Tutóia do Vale voltam a sofrer com inundação - Primeira Pagina
- Parte 2

\section{AGRRADECIMENTO}




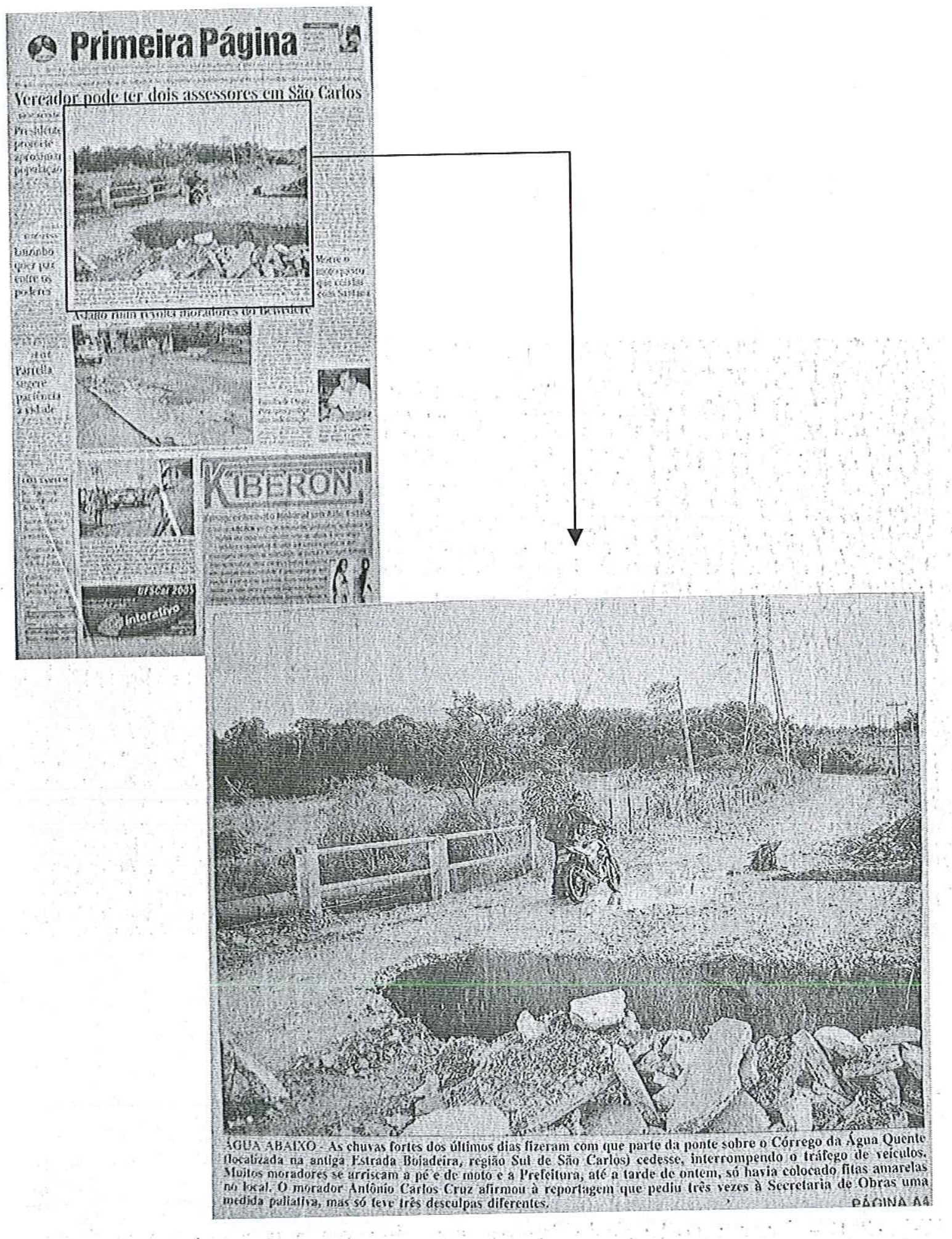

05-01-2005 - Chuvas derrubam ponte e atrapalham moradores - Primeira Página - Parte 1 


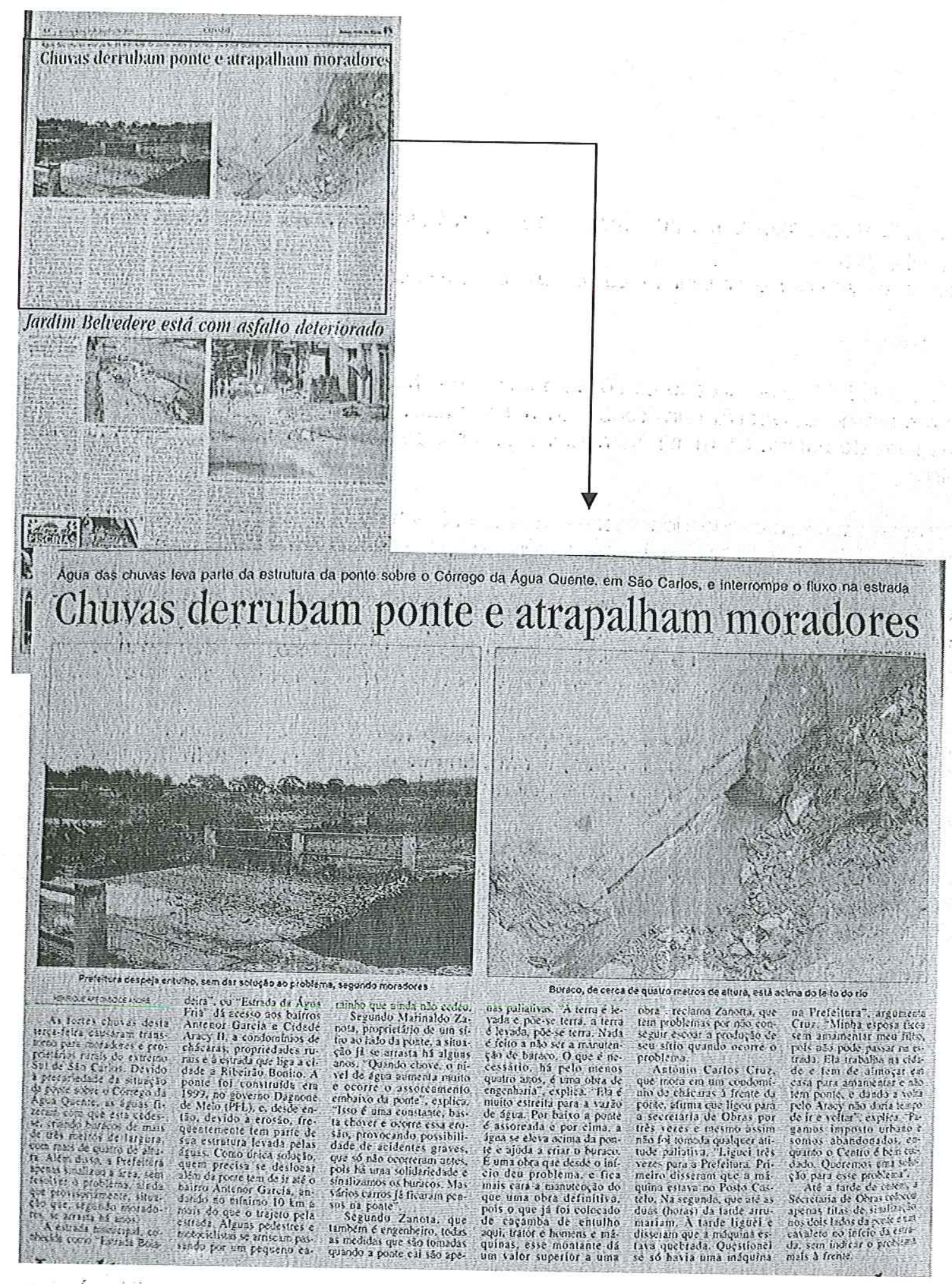

05-01-2005 - Chuvas derrubam ponte e atrapalham moradores - Primeira Página - Parte 2 


\section{Moradores invadem rodovia para protestar contra enchentes em São Carlos \\ Protesto causou congestionamento de um quilômetro na pista}

\section{EPTV Central}

19/01/2005 20:16 - Moradores do condomínio de chácaras Varjão, em São Carlos, protestam nesta Quarta-feira contra enchente causada pela chuva, que invade as casas e as ruas do bairro. Os manifestantes invadiram a pista da rodovia que fica ao lado do bairro.

O protesto causou congestionamento de um quilômetro na pista dos dois sentidos da rodovia. A Polícia Rodoviária liberou o trânsito após 45 minutos.

Segundo o secretário municipal de governo, João Müller, a intenção é achar os responsáveis pela enchente. De acordo com o promotor de Meio Ambiente, Edward Ferreira Filho, foram realizados laudos técnicos e os alagamentos estariam sendo provocados por causa de obras da empresa Encalso para canalizar o córrego do local.

Ele disse ainda que há má vontade da prefeitura para resolver as enchentes. 0 advogado da Encalso, Hélio de Paula, confirmou que o córrego foi canalizado e disse que a obra foi autorizada por órgão ambientais por meio de um termo de ajuste de conduta.

A assessoria de imprensa da prefeitura afirmou que não há má vontade em resolver o problema. A assessoria disse ainda que as medidas determinadas pelo Ministério Público já estão em andamento.

19-01-2005 - Moradores invadem rodovia para protestar contra enchentes em São Carlos http://eptv.globo.com/noticias/ 
d) Sgua Fria, e os granjéros e horticultores, tem de des. viar pelo Cidado Aracy para chegaren ìs suas residênci. as e cscoarem a prodiçẩo. respectivamente. Desvio que aumenta eni cerea de dez aumenta on cerca
yuilónecros o trajeto.

Neste allo, os primeiros buracos deste allo foram formados na madrugada do dia 4 de janeiro. No dia 6. a Pre. teitura completou as crate. ras com entulho e terra. "obra" que durou menos de 36 horas As chuvas da noite do dia 7 de janeiro irromperan novamente as crate. peram novamente as crate.
ras, novamente impossibilit. tando o trânsito. Desta yez. a Prefeitura fez uma montanha de entulho sobre o bu. raco da margem direita, mais suscetível, o que vem mantendo a massa. Porém, já está se criando um novo buraco. que a qualquer mo. mento pode se tornar, nova. mente uma cratera.

nente. uma cratera,
Uima moradora da regiảo Rosîngela Silva Alves. Ira balhadora rural, diz que

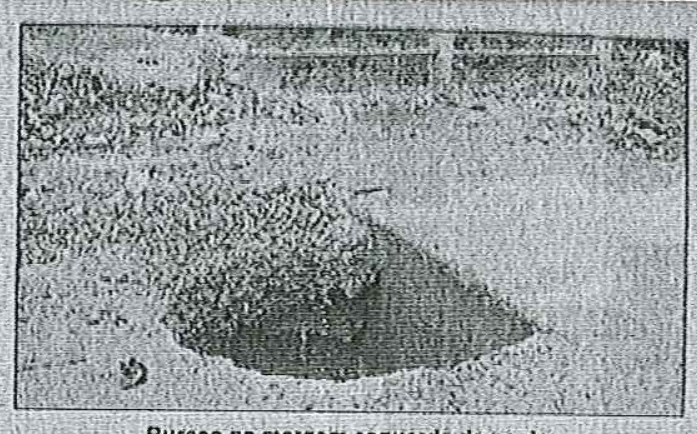

Buraco na margem esquerda da ponte: Prefelitura diz que pode consertar hoj

formar ontem. "Começou com a chuva de ontem, e de hoje continuou", relatn. Segundo Rosângela, alguns carros pela manha ainda con seguiam passar, o que, no início da tarde; já era impos. sível". E reclama sobre a prodiçấo rural que tem do desviar pelo Cidade Aracy. "De manhä o caminliảo pas. sou, mas agora năo tem unais condiçấo. Vai ter desviar ate - Aracy. O pessoal as vezes corre o risco c passa mas do jeito que aumentou na hora do almoço nảo vai mais ter como" afirma.

Assín como outros mo. radores, que nas oulras oca sióes reclamaram que a Pre. feilura toma apenas medi. das paliativas, en vez de dar uma soluçấo definitiva. Rosângela far o mesmo re clame "A mánina (da Pre. feitura) vem e volta, rem e volta. É chover e fazer bu. raco". Por ler de passar sob a ponte, devido ao gado que riu muitas vezes de parto a atravessa o rio, ela confe-

\section{8-01-2005 - Ponte sobre Água Quente cede a chuva de novo - Primeira Pagina - Parte 1}




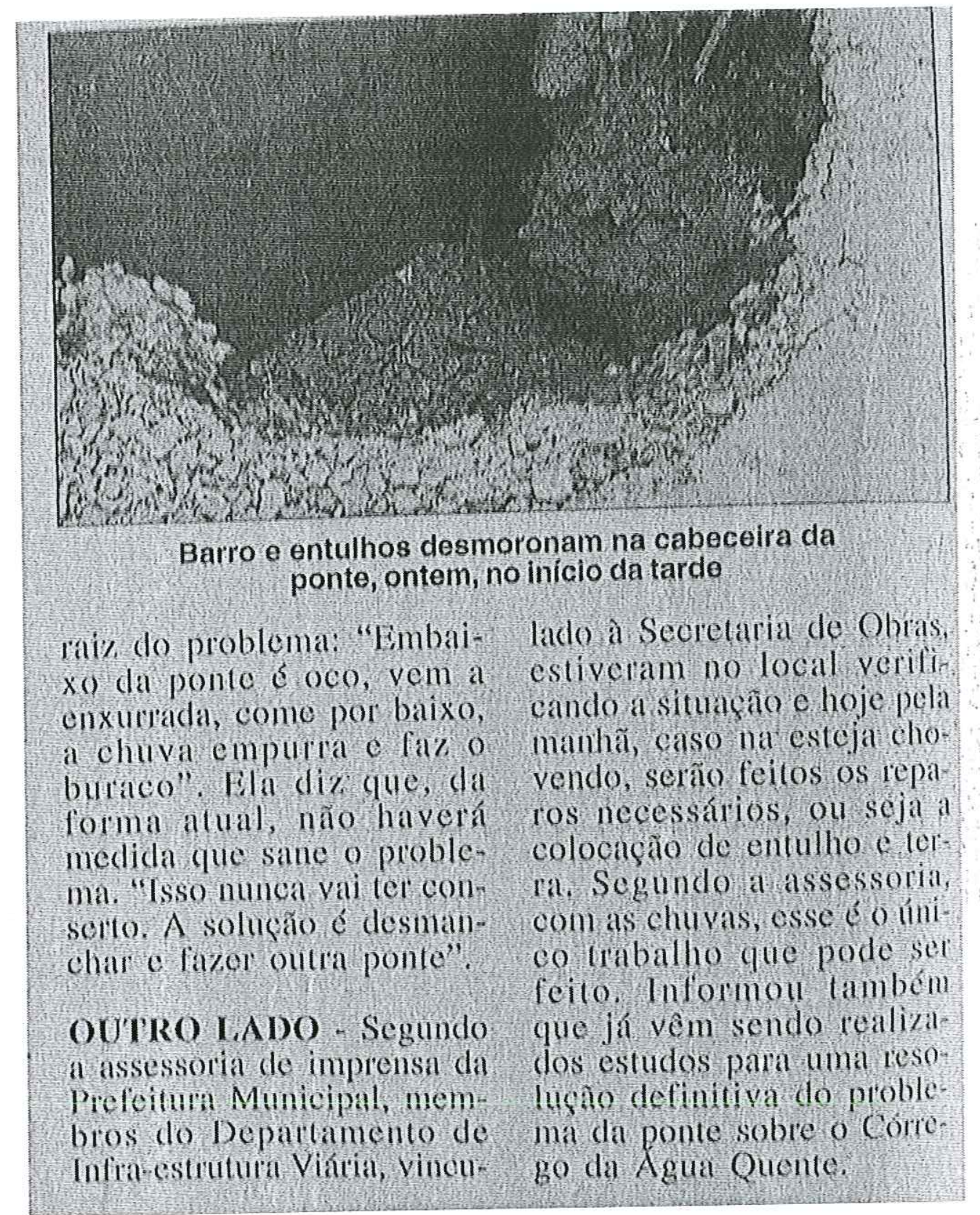

28-01-2005 - Ponte sobre Água Quente cede a chuva de novo - Primeira Pagina - Parte 2 


\section{ANEXO 04}

Fotos das Notícias:

Notícias gerais sobre o tema 


\section{Varias noticias}

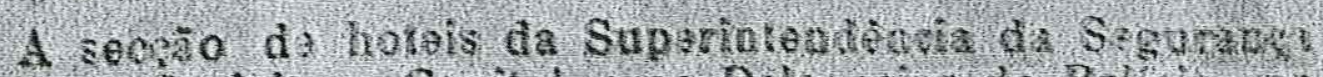
Políica e Social, na Capital, e as Delegavira de Políeis. no

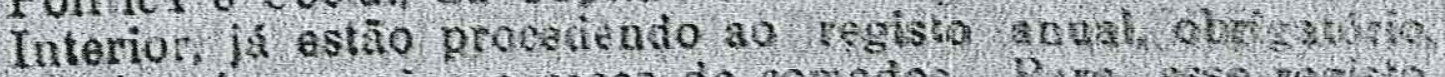
dos hoteis, penscius o casas de cowodos. larer esse resisto, cujo prazo termina em 31 de marso rindouto os mieressa. dos poderão procurar instrugias nas raspectiras uelegachise

\section{(3)}

O presidente da Republica assioen decrate lai dispondo sobro a matanga de racas a bazacros nos estubelprimentos

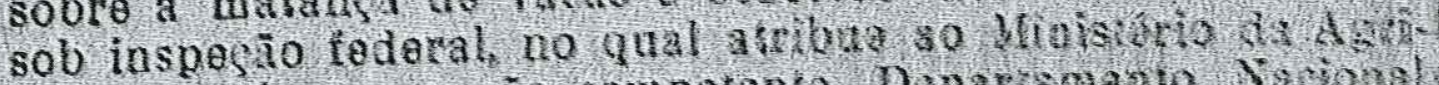
cultura, palo seu orgño comparente. Dapariamento Nisioual, de Produejo Animal, o eneargo de thxir om instencoss eso pociais a serem expodidas ate o dia 16 de janeiro de caria ano, a porcentagen de vacas a bazerros caja makny's possa ser pormilida nos estabolecimentos sol inspęão federal.

$$
\text { int }
$$

Nesto mòs pagam-80 as seguintos impostos:

Nunicipal - Terrirorial urbano.

Estadual - Voioulos do-cargs.

Foderal - Imposto de consumo.

Devido ás grandes ohuvas, yerificourse um desmoranamonto na zona Mairink-Santos, Seis eq. sas de turma ruiram, mortondo quatro oriangas o ficando feridas mais pessoas. 


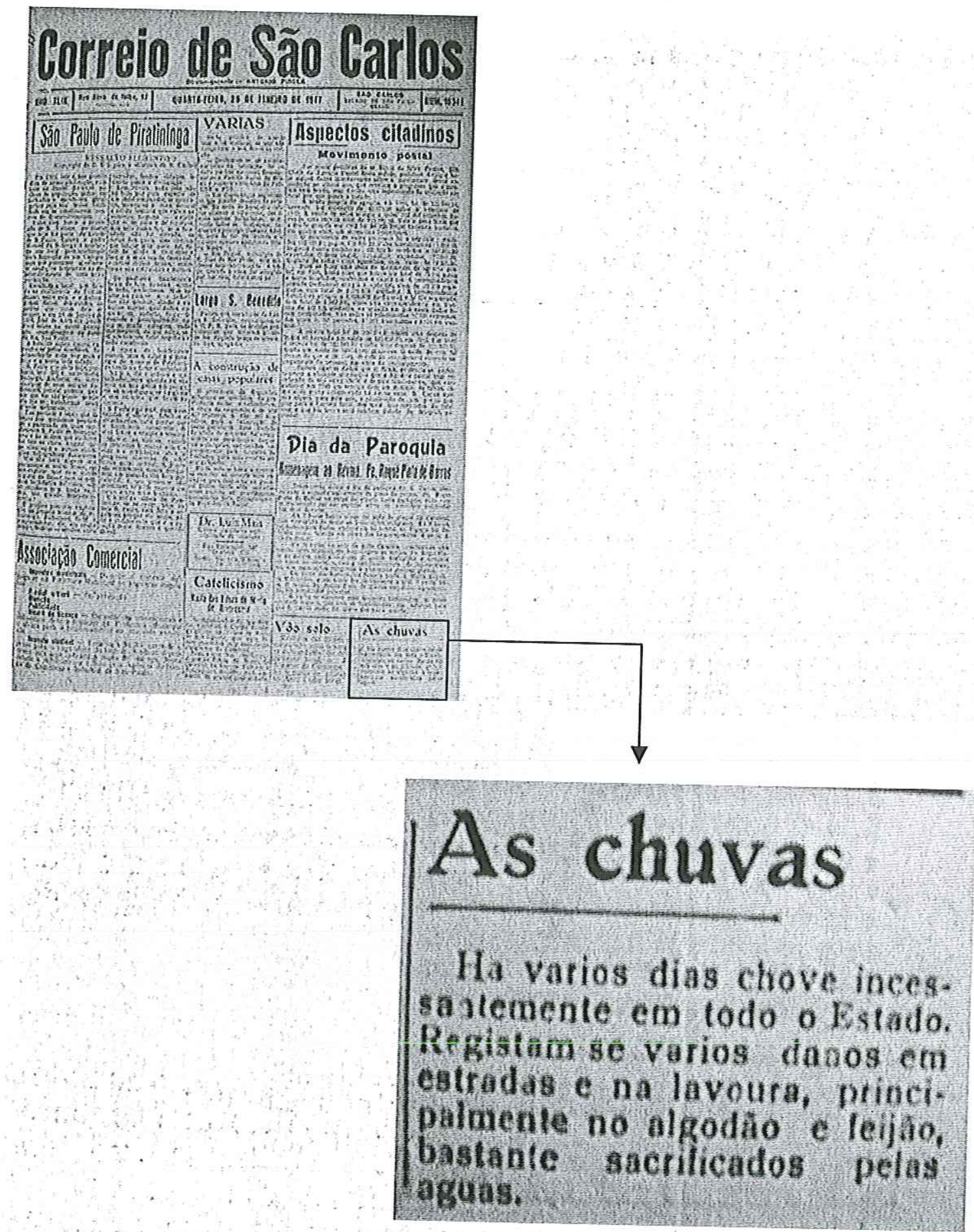

29-01-1947 - As chuvas - Correio de São Carlos 


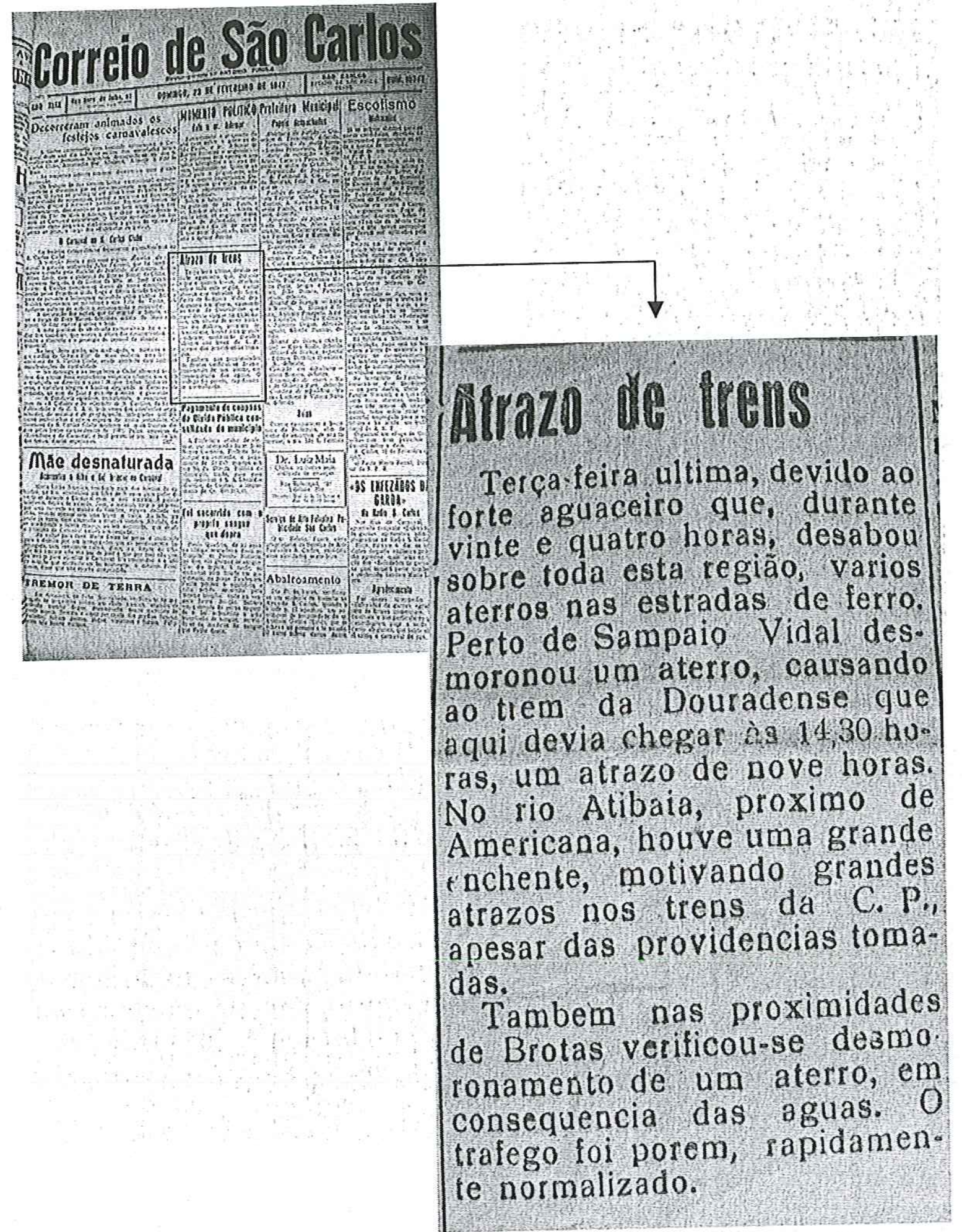

23-02-1947 - Atrazo de trens - Correio de São Carlos 


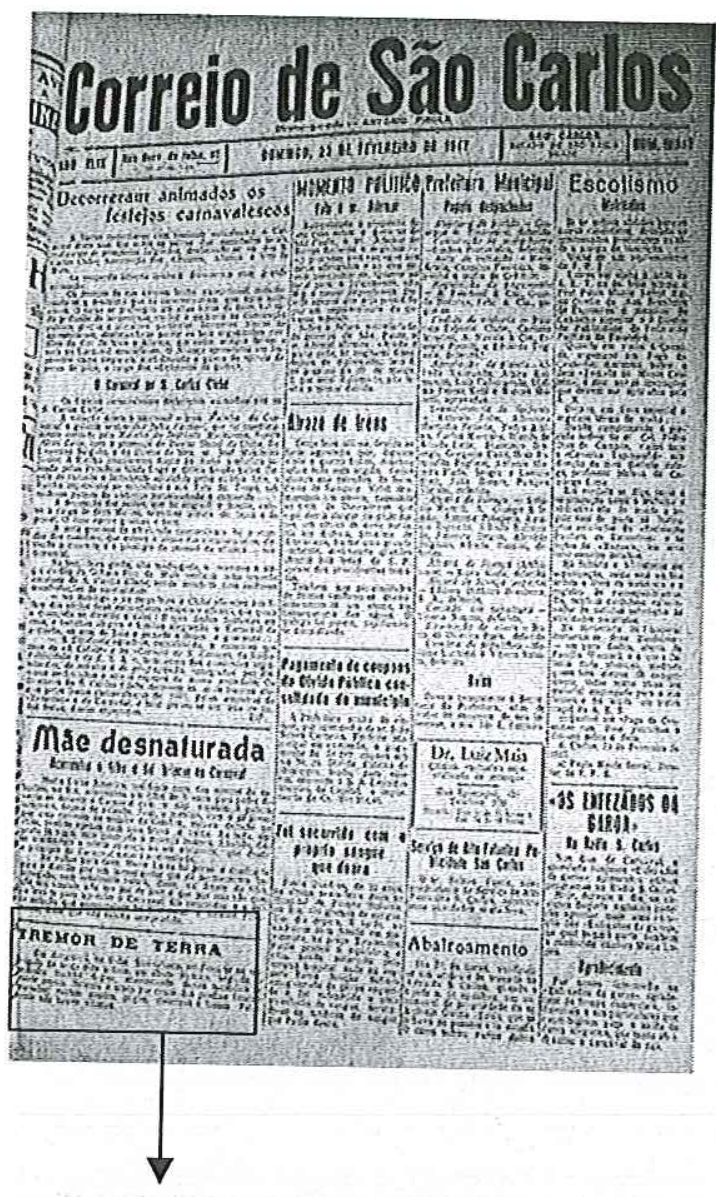

\section{TREMOTR DE TIERT:}

Em Aroguacú, na linha Sorocabana, verificou-se na ma drugada de teica-leira ultima, um abalo sismico, seguido de grande monta. Setenta e cinco por cento dos predios ficaram avariados; ruiram pontes, pocos, cistermab ofossas Reliz mente nảo houve vitima pocos, cisternas e fossas. Feliz.

23-02-1947 - Tremor de terra - Correio de São Carlos 

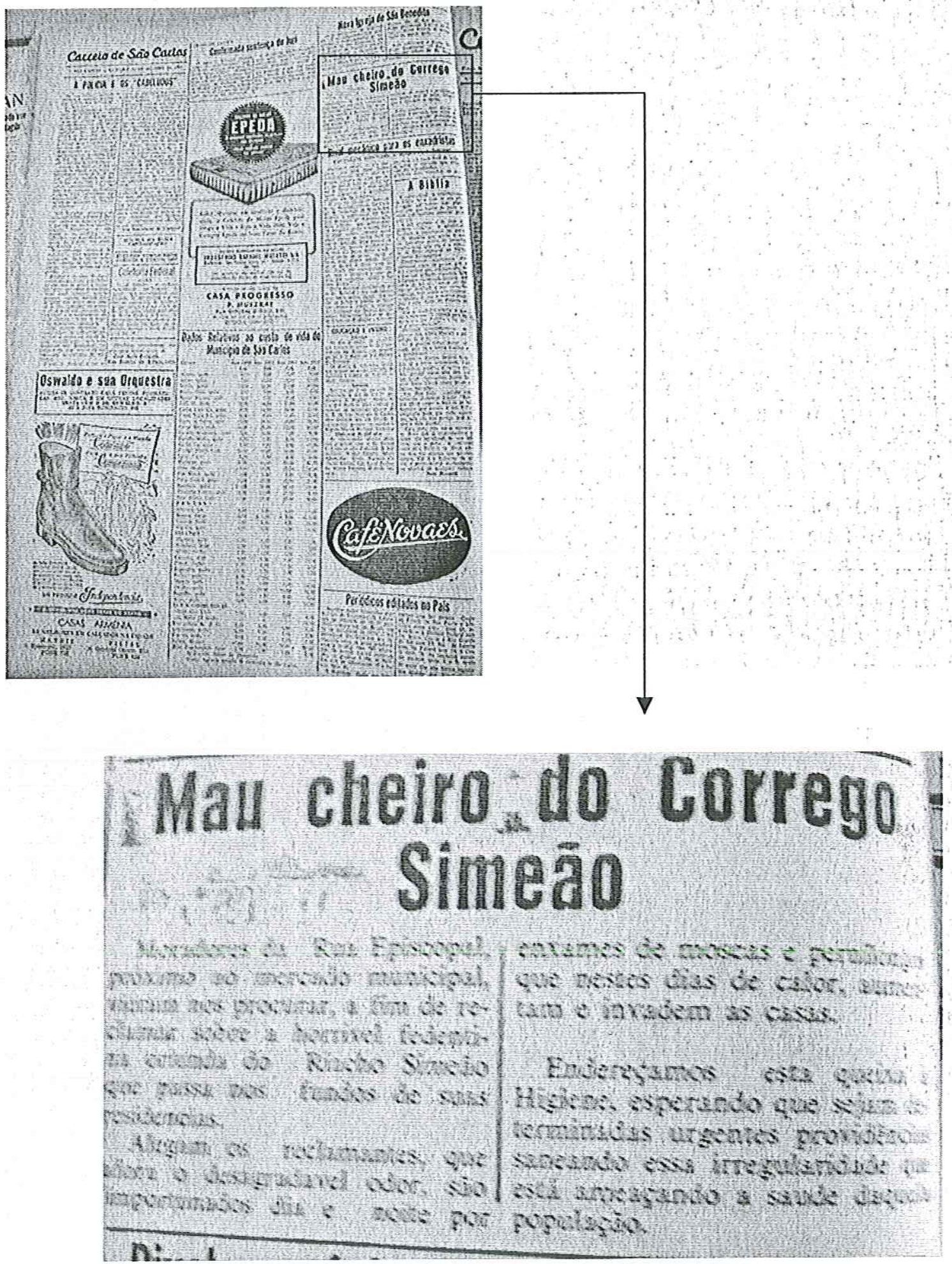

13-01-1956 - Mau cheiro do Córrego Simeão - Correio de São Carlos 


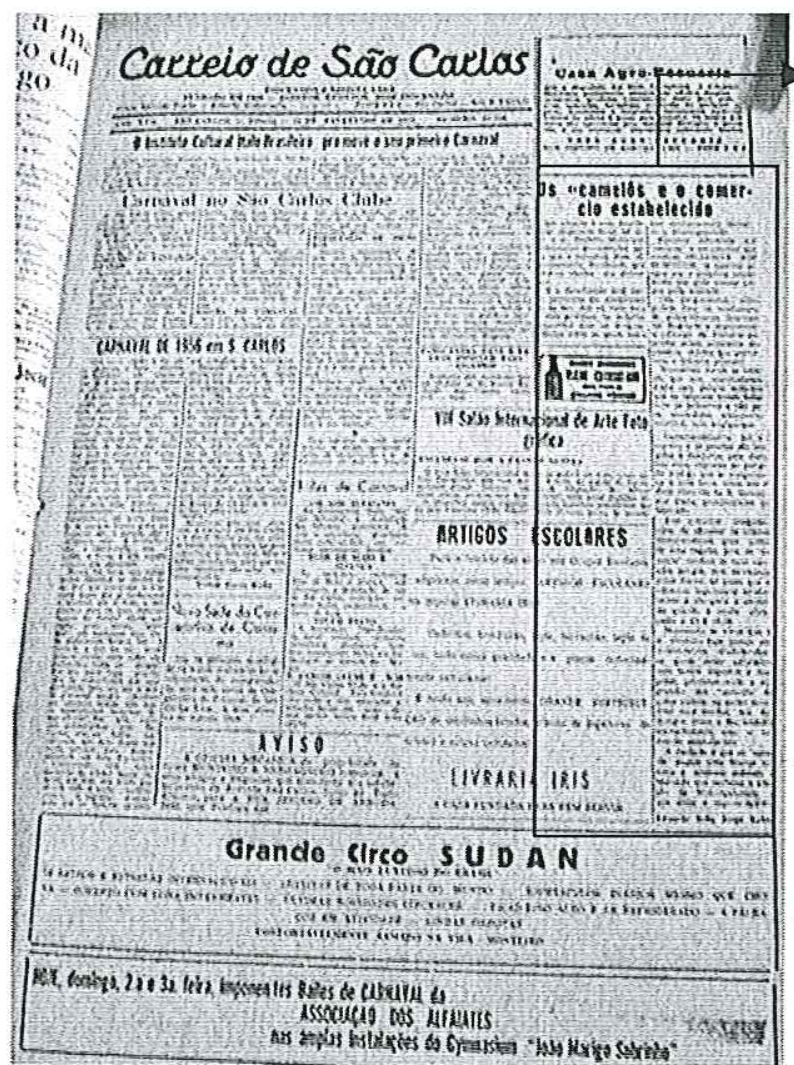

\section{Os ccamelós e 0 comer. cio estalielecidio}

Ein atcncio a nota inserta tem conhecimento, inclus? num vespertino local, hí di- vo a Munlcipalislado. as, o sr. Prefelto Munleipal Fazemos retercincia nas

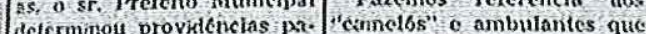
determinot provich atic

ra que o comerclo losse n- venda JNelusive AOS gorosamente fiscalizado por DOMINGOS, os mesmos at efetuar vendas aos domin. ugos que o comercio estabe lecido náo poile verider por

b a liscalizaçáo está sẹi, que sería multado.

do procedida em cunprimen Orn, perguntamos, como to às leis. Até al, tudo bem podein cles, os yendertores

Năo podemos, no entanto, de quiliquiliarias, desrespel concordar com as irregula., tar flagrante e impunemell. ridades sobre as quals todos te o Código de Posturas que

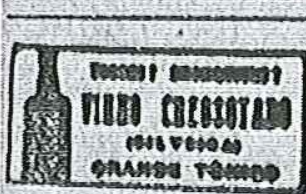
proibe sejam colocaxios nos passcios, objetos que perturbcm o transito páblico? Numerosas foram as vezes eri que nos manifestamos sobro isso, porque achamos que as calçadas foram feitas que as calcadas foram leitas
pera os pedestres a najo pa.

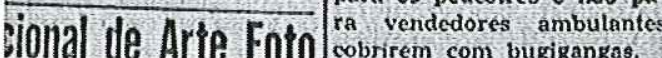

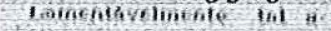

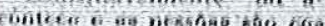

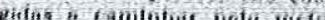
(a) 10 b Wii lia te

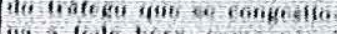

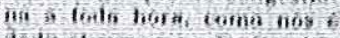

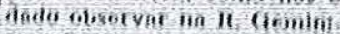
ane cosio, mosimidedea alo. Merciado.

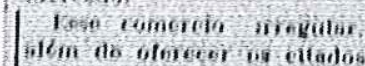

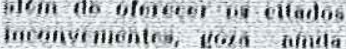
cla vino revalla, pola, wa yea

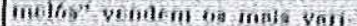

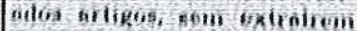

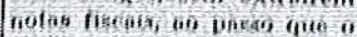

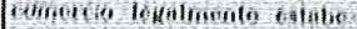

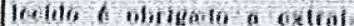
lag julando o venda villin Iinesa o Cr.s 10,00\%

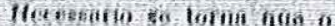

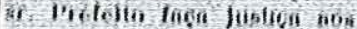

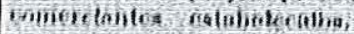
04 viliale calob refintactog

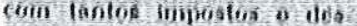

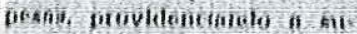
vreacón dor "remolos" do noran fliliter ori ontlia intos

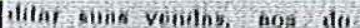

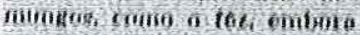

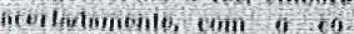
intorelo estalivieclito.

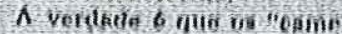

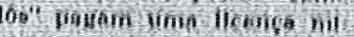

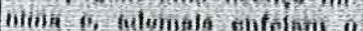
Mercalo vilie redlamia a alen. con te stiminiontatos a cilio Giviando aeba Jorge Keblie.

11-02-1956 - Os camelos e o comercio estabelecido - Correio de São Carlos 

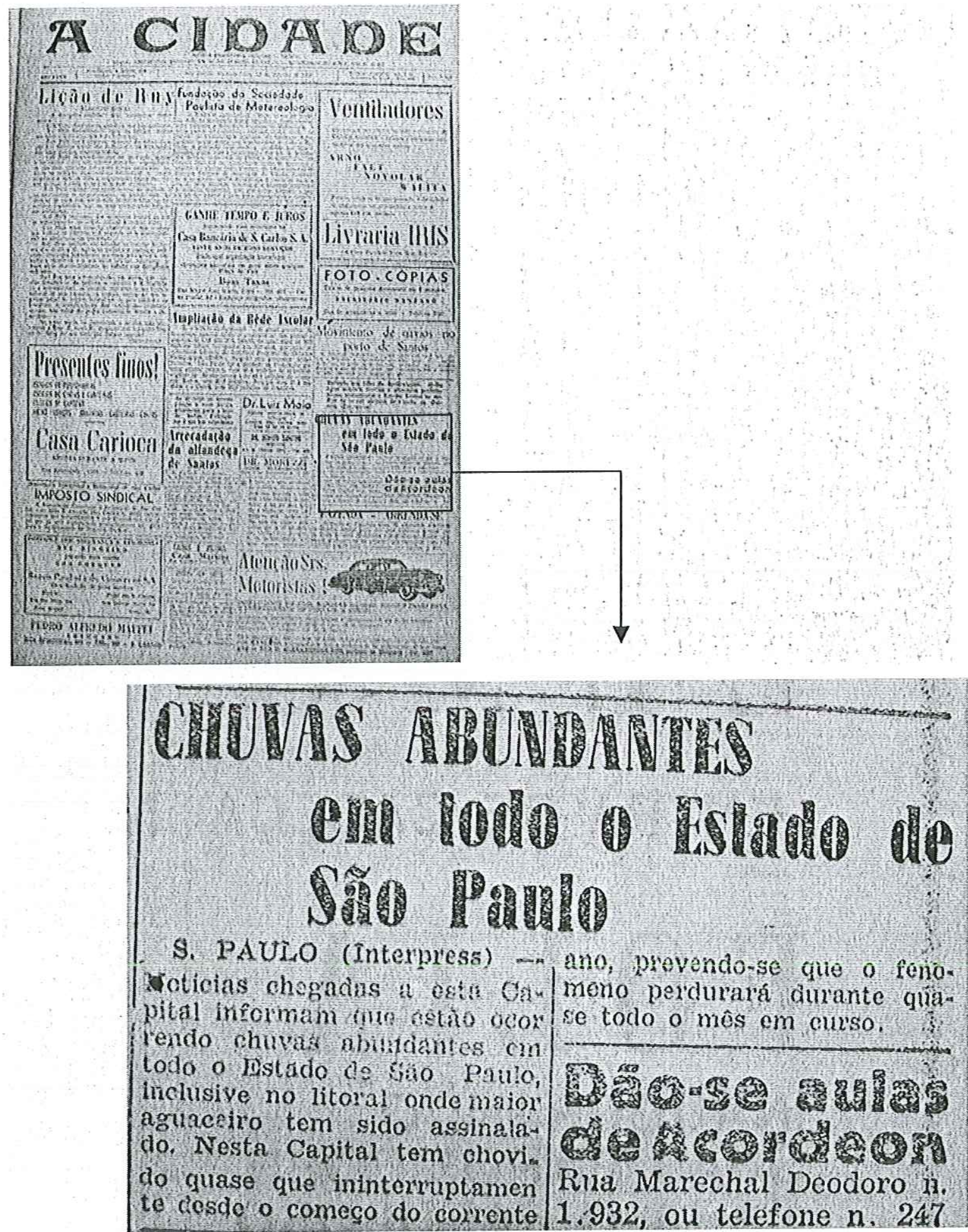

12-01-1959 - Chuvas abundantes em todo o Estado de São Paulo - A Cidade 


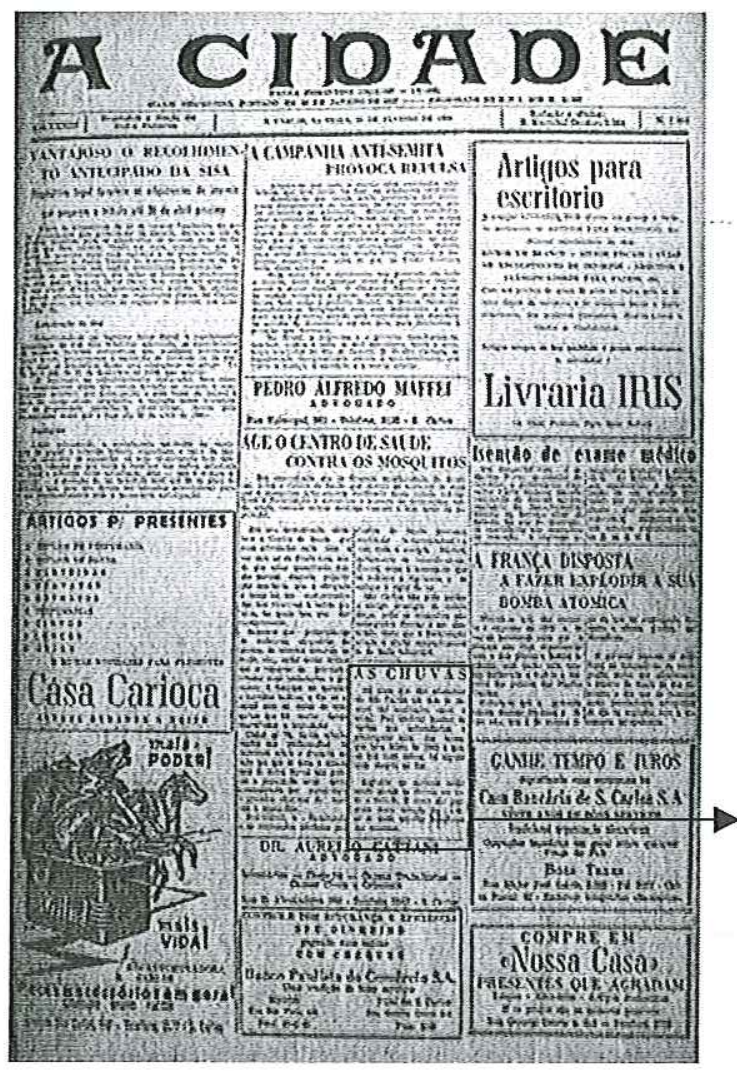

\begin{tabular}{|c|}
\hline 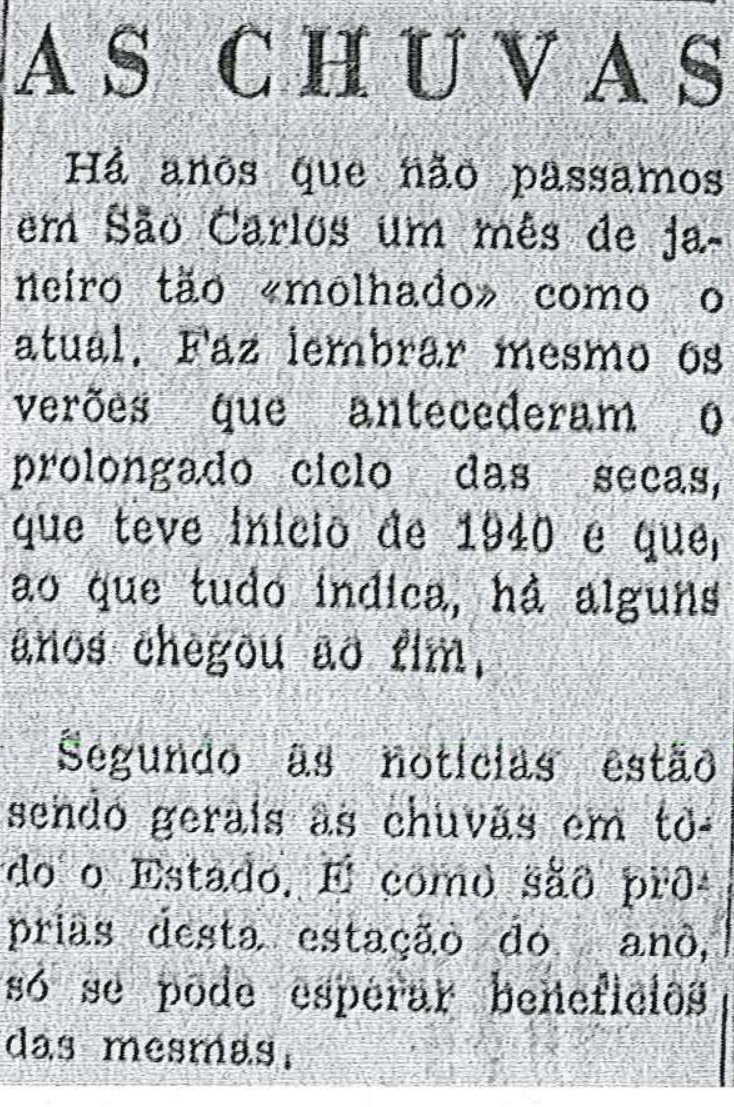 \\
\hline
\end{tabular}

11-01-1960 - As chuvas - A Cidade 

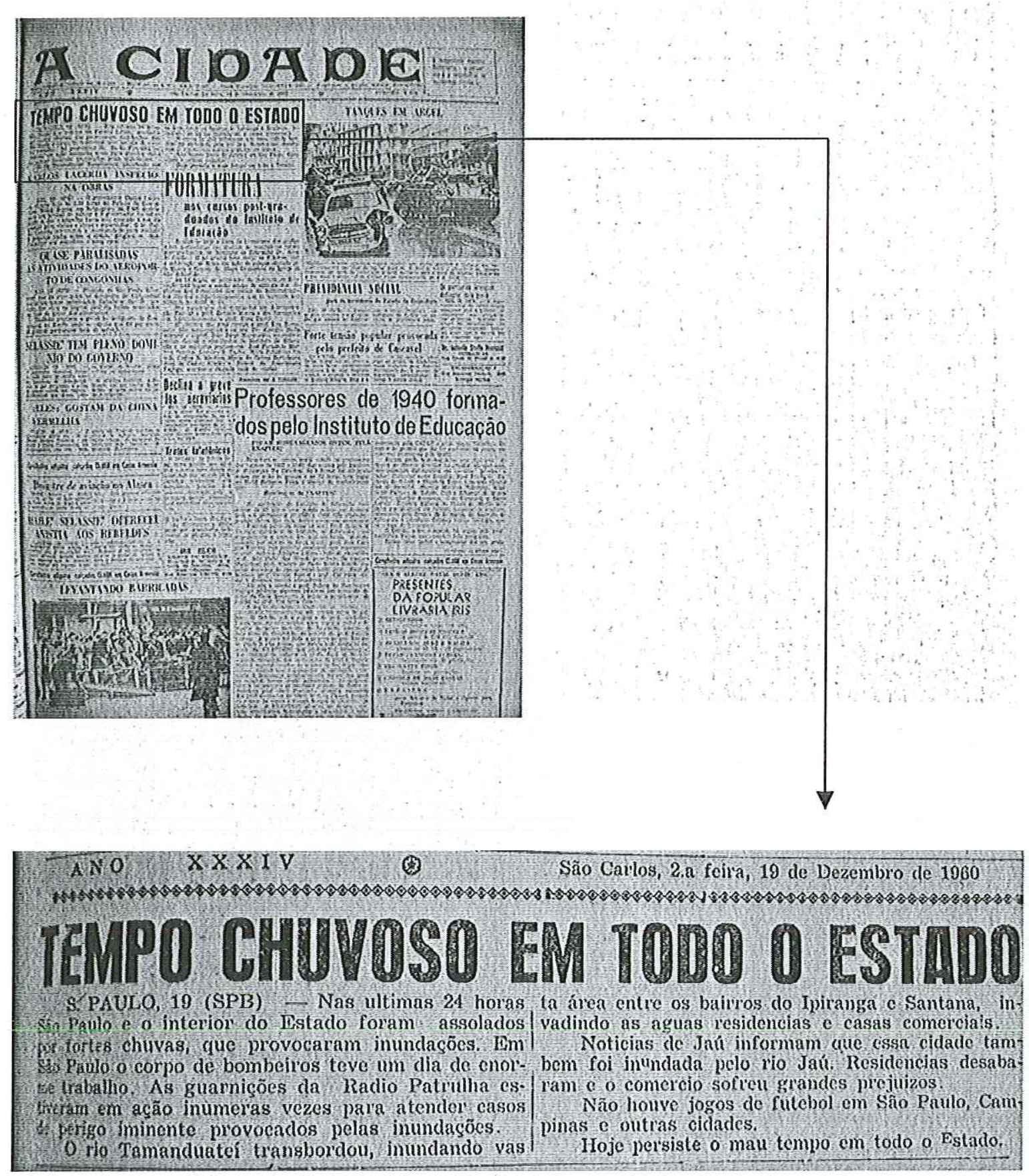

19-12-1960 - Tempo chuvoso em todo estado - A Cidade 


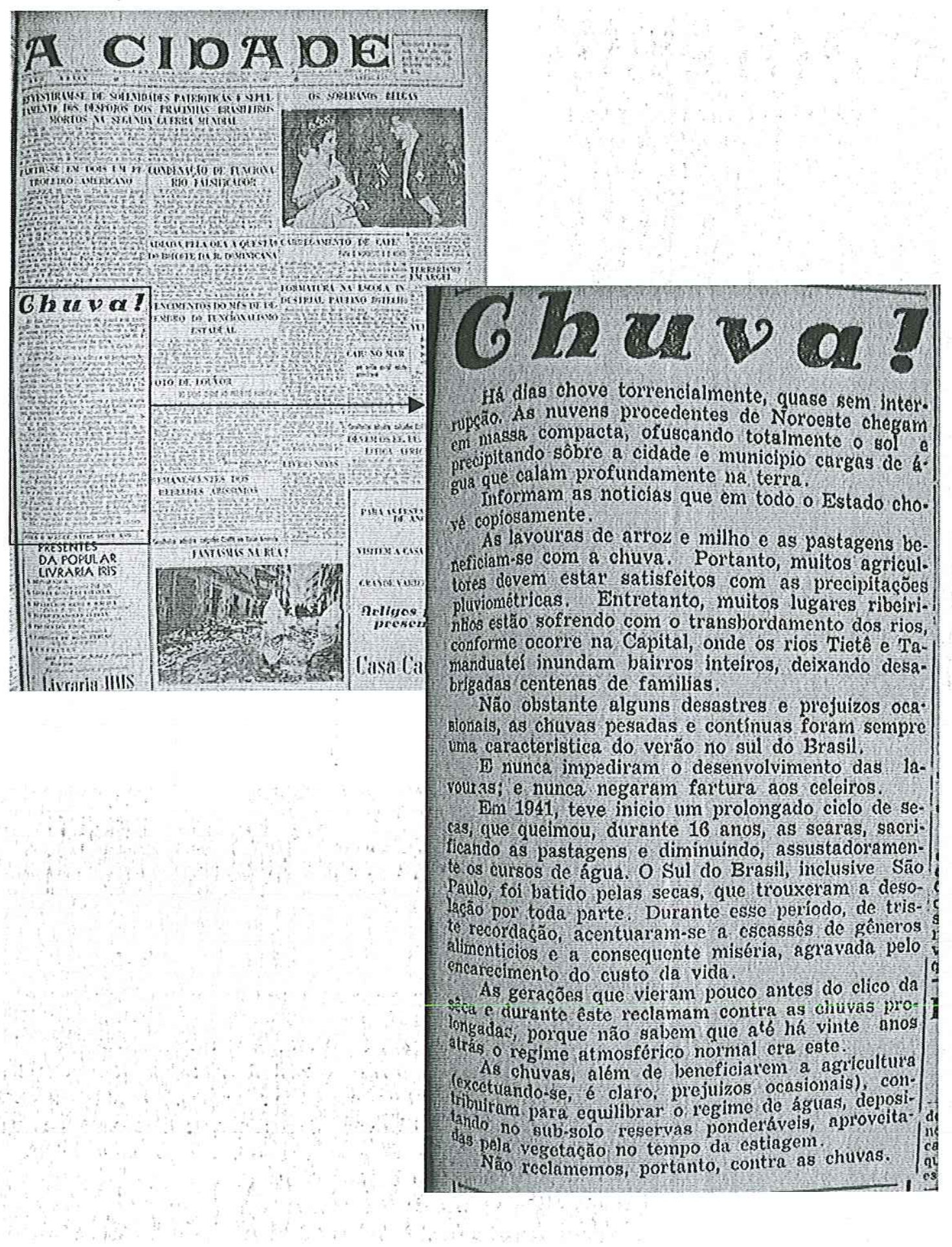

22-12-1960 - Chuva - A Cidade 

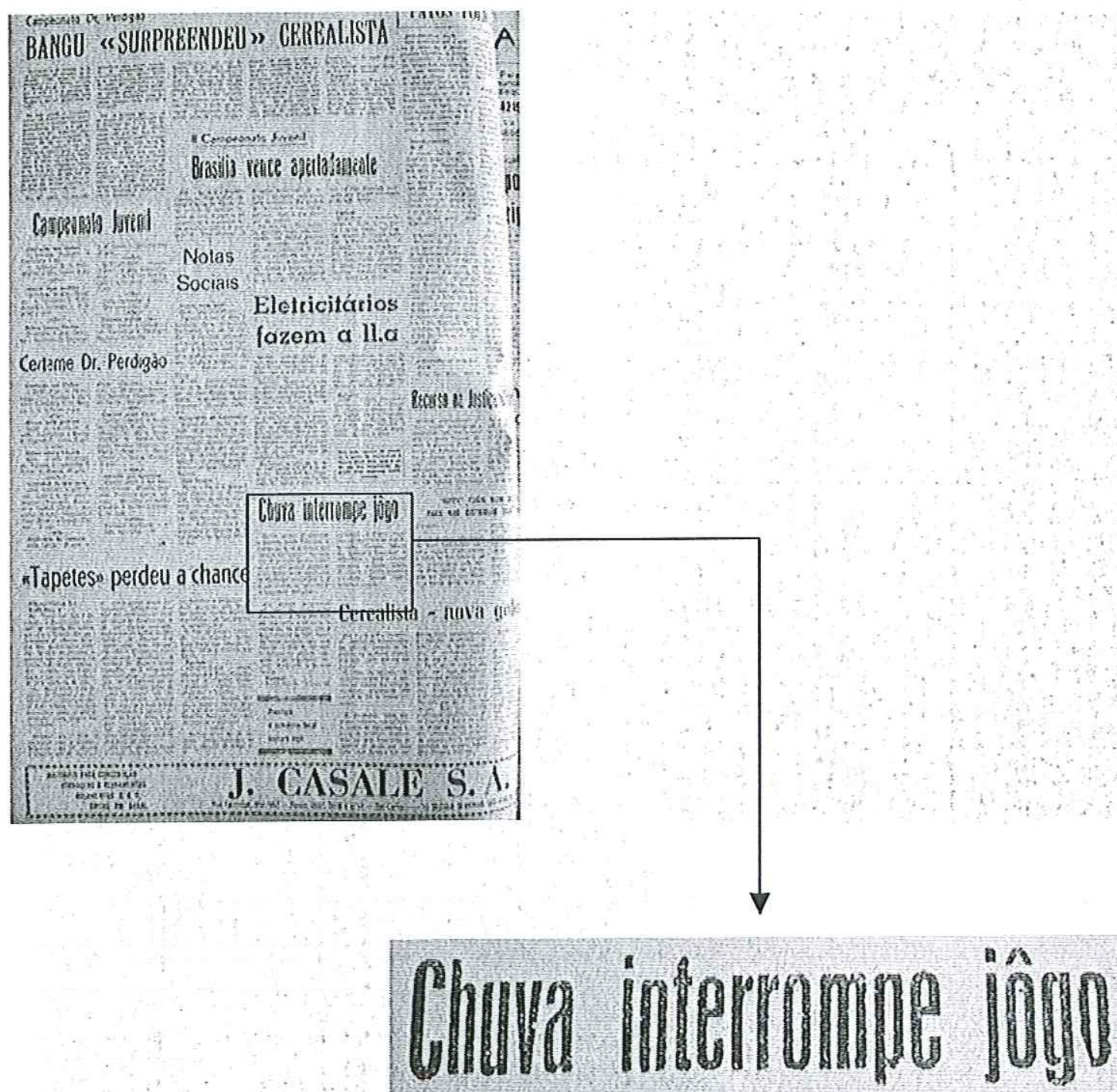

Durou apenas 20 minutos a partida entre Paulistão e Ipiranga; a forte cliuva que calu lả no "Luizảo" fez com que 0 árbitro interrompesse o cotejo, pois o gramado nâo tinha maís condicóes. - Paulistão vencla por 1 a 0, gol contra do agueiro 1 piranguista Salvatorl:
Sebastiano e Pedio; Jorge, Gerson Marcos e Zé Carlos; Roberto, Vicente, Mauricio, Ademir e francisco, IPIRANGA: João Caylos, Salvatori o Osmil; Odair, Irumberto e Carlos Alberto; Claudecir, Dimas, Paulo, wilson e Levada. 


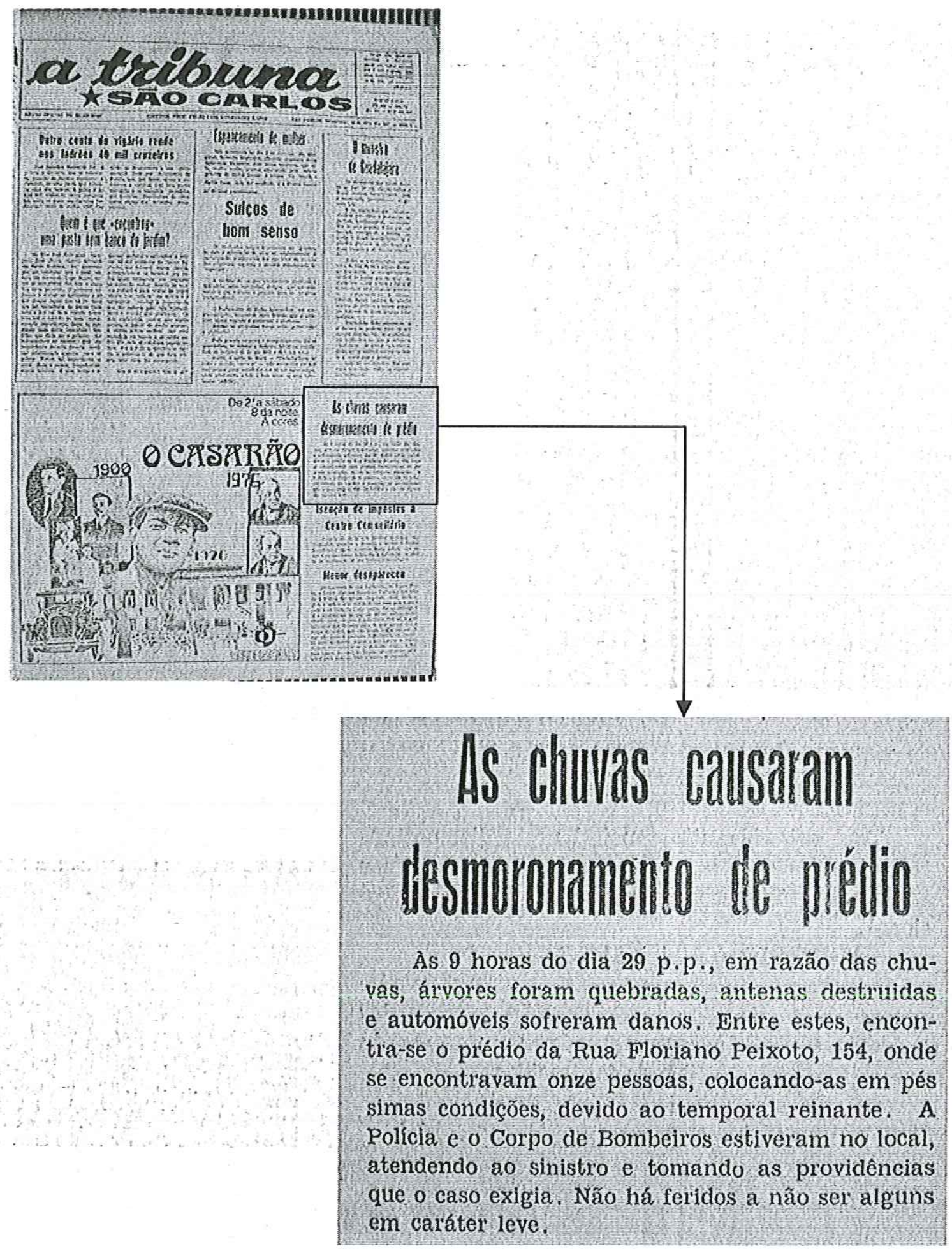

06-06-1976 - As chuvas causaram desmoronamento de prédio - A Tribuna 

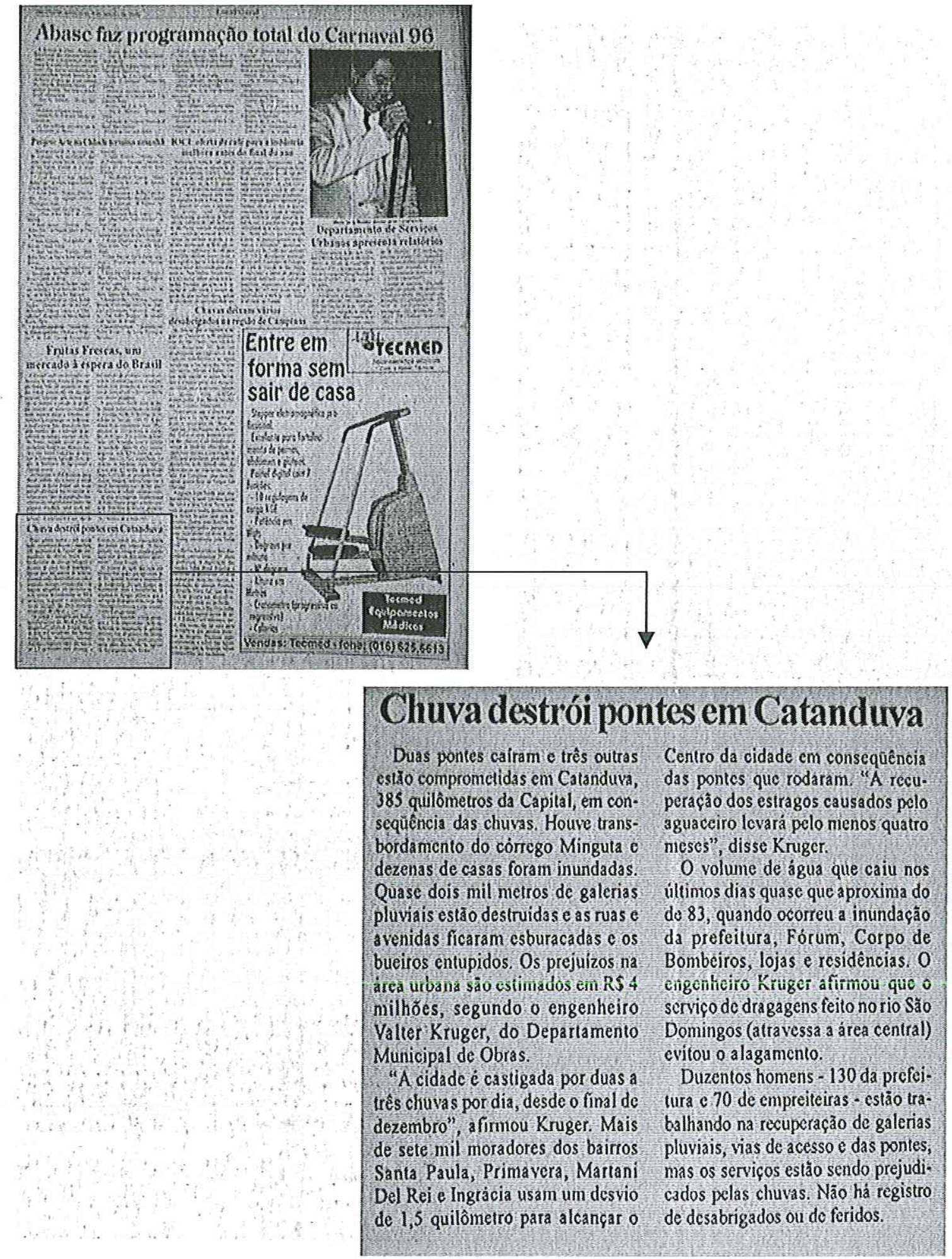

05-01-1996 - Chuva destrói pontes em Catanduva - A Folha 


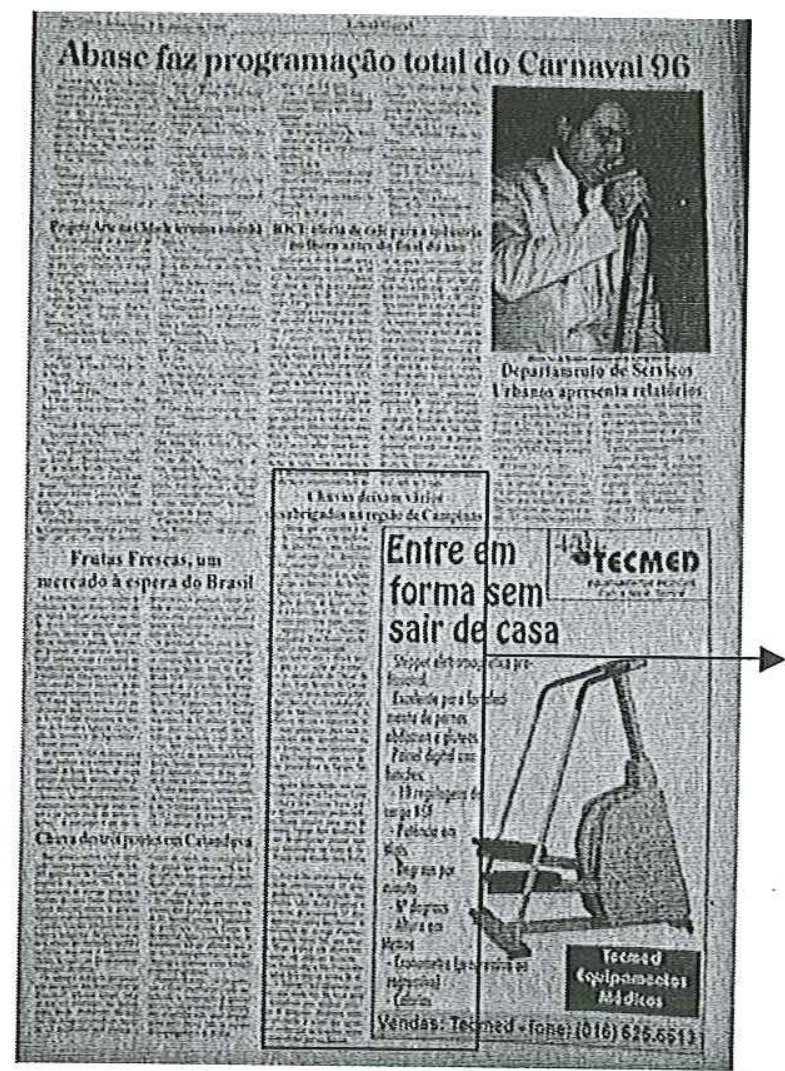

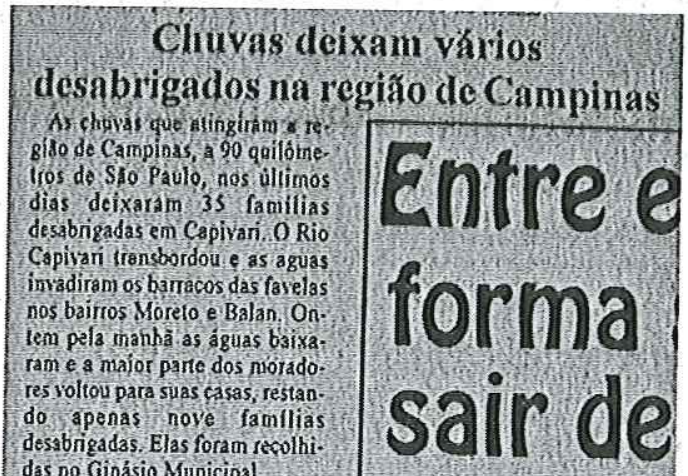

das no Ginásio Municipal.

"Esperamios que a chuva pare pars que o rio volle ao nermal? disse o secretario de obras de Capivari, Iran Rosallo de Carva tho. Todos os anos durante a épo. ca das churas, o rio transborda e atinge as familias nibeinnhis, A prefétura iniciou a consinuçảo dé 103 casas populares, para onde os moradores serdo iransfendos. As obras davem ser concluidas enj ju. nho. Em Campinas una casa de. sabou quarta-feira no Parque Sáo Quirino.

Ninguém ficou ferido, mas seus moradores, o casal Luciano Leite da Silva e Vera Lúcia Terra, grá. vida de quatro neses, pardeu tudo. Eles foram levados para casa de parentes. Outras duas familias fi. caram desabrigadas porgue suas casas, localizadas em áreas de ris. co, foram inlerdiladas pela Defsa Civil

As chuyas dos úlínios dois dias também inlerromperam 35 obras da préfeitura A duplicaszo das avenidas $10 \mathrm{hm}$ Boyd Dunlop Amoreiras if achmulam is dia de straso por causa das chuyas. A canalizac 30 do corrego Proenca. ine avenida Norte-Sul, que deveria ficar pronita em dezenbro. tanbsin noo pjde ser cosluida

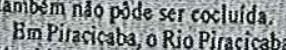
If sublu dois nelros acima do i Yel A Dafesa Civil informou; po. rép que anda náo há rísco para os moradores quo residem proxi nos às roarsens. Técricos esta. monitorasdo o nivel das 8 o para kilar ques as fonilies suas surpiendidss por enchentes.
Stepper eletromagl fissional.

Excelente para fort mento de pernas, abdómen e glúteos. Painel digital com? funcões:

-10 regulagens de carga KGF - Potência em Wats - Degraus por minuto - Ne degraus - Altura em Metros - Cronometro (prog regressivo) - Calorías

Vendas: Tea

05-01-1996 - Chuvas deixam vários desabrigados na região de Campinas - A Folha 


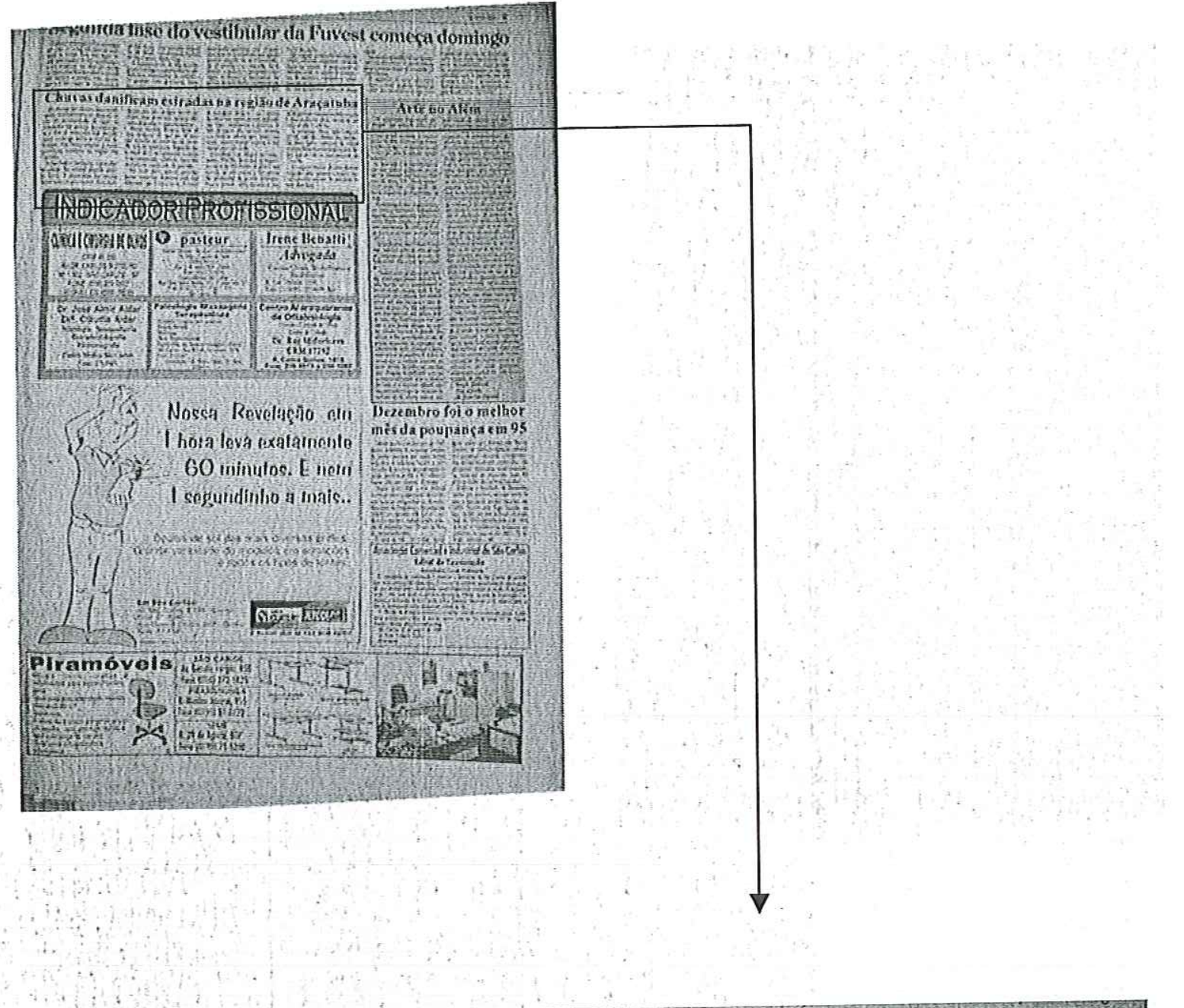

\section{Chuvas danificam estradas na região de Araçatuba}

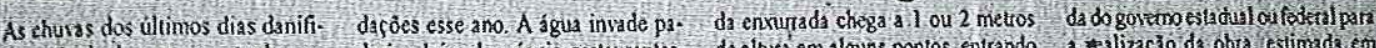
carra moncinsimente as esiradas nunis nio pavimenladas da regiào de fratula Na maioria dos niunicipici filu de uransporte está prejudi. candos entrega diäria de leite nos is. ticioios Nas areas urbanas o naior problena acontece na regiào em probitaibo darias, lojas de móveis, restaurantes Neide Rosales Borges, dona de (n) fam cia diz que dos que tratustha no comćcicio, há 10 so fre conl as inundaçōes. Segundo ela 3 cidade de 15 milhabitantes ampliou a payimentação asfältica, mas nà A nu Osino Junqueira, a principal iniestiu na construção de galerias. ar cidade fica sempre alagada quan. Por causa disso, grande partc das a intensidade das chuvas a guas escorrem somente pela rua do chole. $A$ intensidade das desse vetzo jz provocaram duas inun.

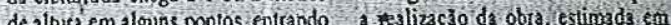
nas lojas, residencias e quinasis. A mais de RS 3 milhotes. de de esgoto náo suporta a demana. A vereadora Mana Juhia Loina es detrilos renluem para dentro das (PTB), uma dis vitimas dis encher casas esnaramando sujeira a mal les disse ove o scomércio da cinade - sempre fochs éintertomne as ativis cheiro para lodo laco.

0 prefeito José Miguel do Nasci. mento (PSDB), disse que ja implan. Cucera de 300 meros da gateris oue a procisa de pelo menos I, des qundo chove intenumente ent Castitho.

Enalguns baimos, as casss ficatam 3130 d is ars semsn 6 militos nis. grincipal, que é mais baixa. 0 nivel

Para oprefeito seria necessiria aju cos e alemos calram. Os prejuzios io ram maleriais

05-01-1996 - Chuvas danificam estradas na região de Araçatuba - A Folha 


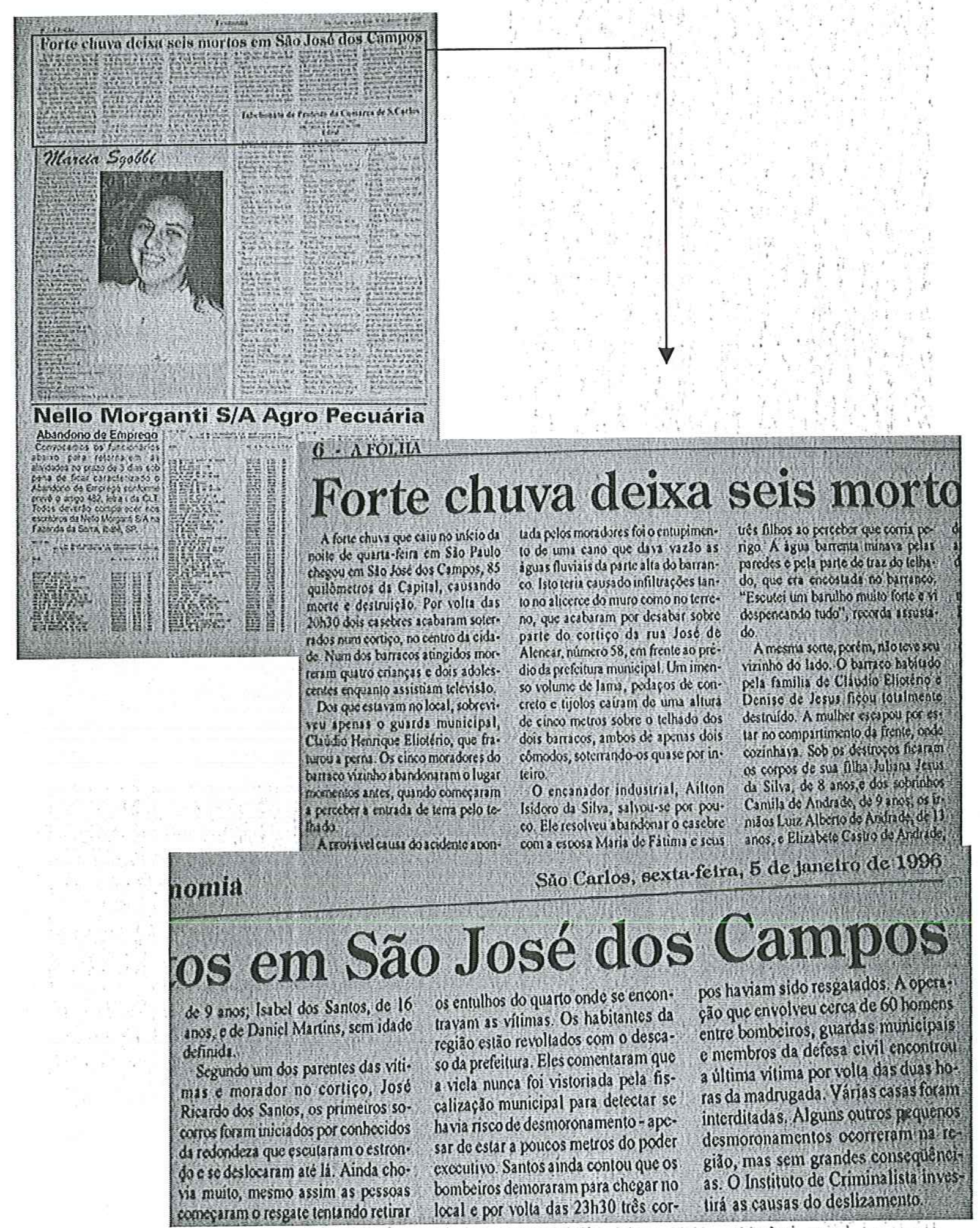

05-01-1996 - Forte chuva deixa seis mortos em São José do Campos - A'Fölha 


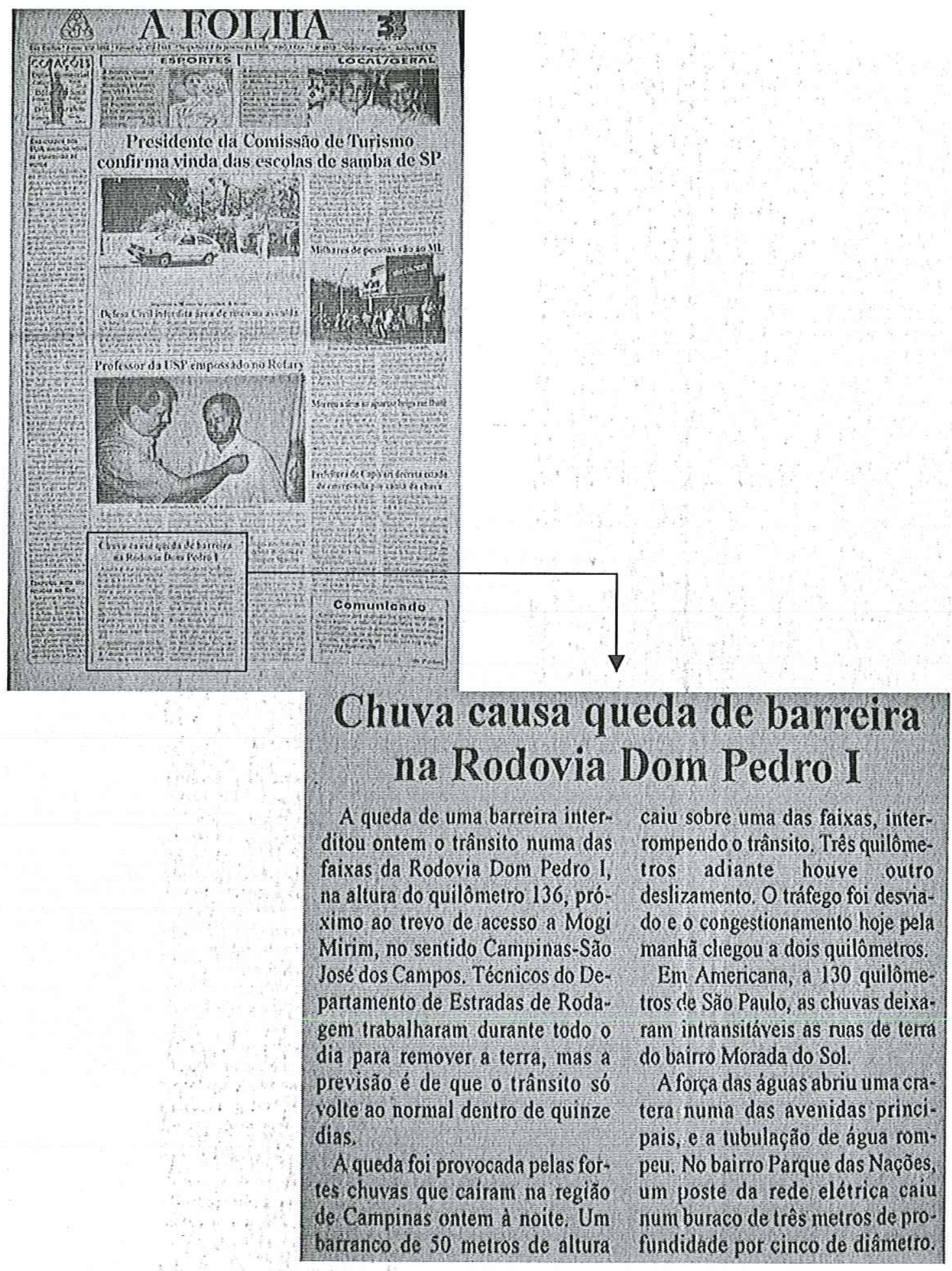

09-01-1996 - Chuva causa queda de barreira na Rodovia Dom Pedro I - A folha 


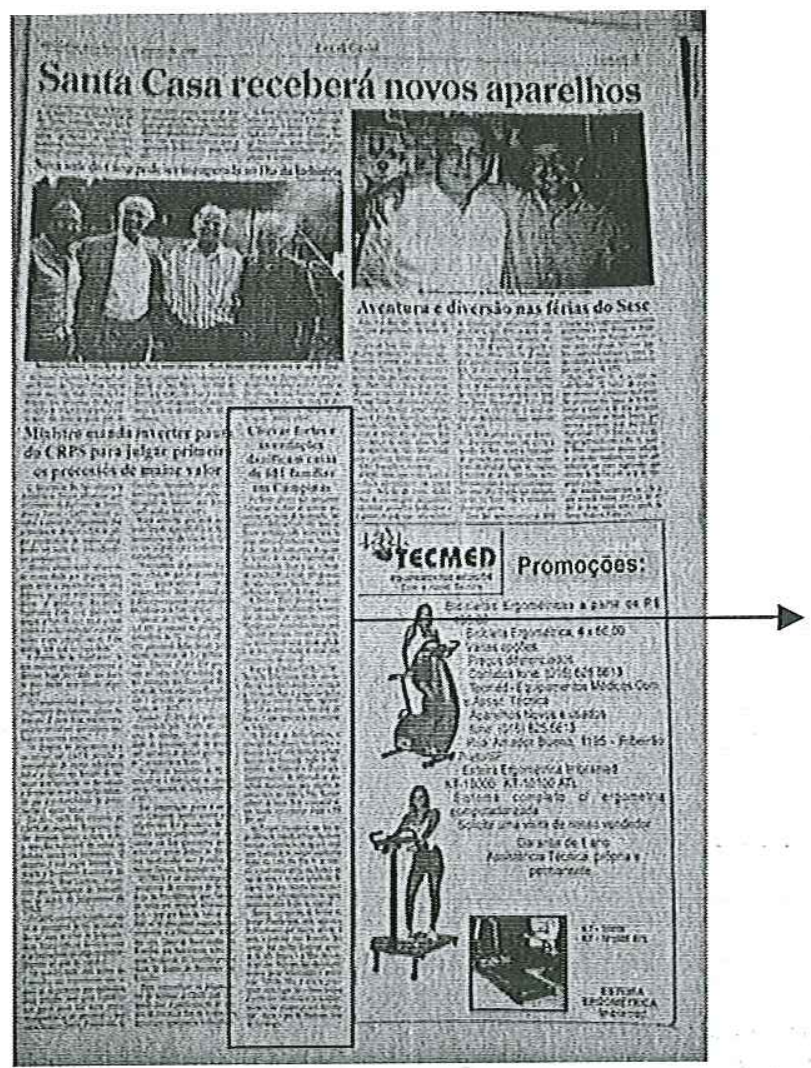

Chuvas fortes e
inundacoues
danificam casas
de 681 familias
em Cainpinas

As rolios chinas que castiganan Campinas no final de scmuna di xaran um rastro de destruiça. Se sundo a Diess Givil, 681 fa milis foram aferadas pela cocréncia de alagamentos e inundacers: Na zons leste dez deslizamenlos atingúan is fliceles da Jardin Flamboyant c Vila Brandins Num deles, cosrido no sabado $((6))$ i noile, icés pessoss de uma mesmis fanifía morrctam sokitradis quando dormiam

A Défes Citil desslojou ontera 211 possoss gue habilasam bariacos sm sítuaslo de risco no Jardin Flamborant As familias forom para calas de pirtiles Outros is bama. cos estao interditados desdos sibido c os moradoces form levados para un csols municipal.

Scgundo a Díśs Civilialo bar. iros da zoni leste foram inandi. despor transbardanknto de sortictor C 33 cisas form alsgadas polas Isuis dis shaves. Forin registra?

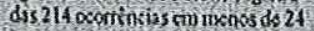
hors, o que foptessats lam rowerds in cideds:

No distrito de Barióo Oenaldo, colicko Ria Brdnco transbordoa e inundol cass onde funcioni a Rete Nacionisl de Pesquisa órgáo do Ministéria da Ciéneia e Tecnologis. Eguipancontos de informálica que scriam distribuidos para centros de pesquisass en lodo o Pais ficaram coberto de lama Todo o material vi. rou sucsta e o prejuizo chega a RS 800 mil.

No Parque Iniprador, que fica ns periteris da cidade, 3 força da chura romper a tubulação de água e abriu umi cratcra de 80 metros quadrados num das nuas. N3 Vila 31 de Matfo, acrenteas abriu um buraco na nia de tcrra elevou a tubula $\xi_{3}$ do esgoto $O$ s dois bairnos passaram a munha semo fomainiento de águs, enquanto cram fellos os reparos.

Oriem, o clima era de revolta no Jrdim Flamboyant, onde ocorreu o deslizamento que mutou sibado à noile o porteiro lose Bcnedito dos suntos, sus mulher Gislaine, grávi: di de trés meses, e a fillis Stefany, deum ano, Parentes das vitinas perelendem palir indenizaça 30 ó preicitura "Minha fillu is stave proct. rando outro lugar pana morar porque a pefeitura no tomava providencias pars dar seguranca zos morado. res", disse o pai de Gislaine José do Camang

09-01-1996 - Chuvas fortes e inundações danificam casas de 681 famílias em Campinas - A Folha 

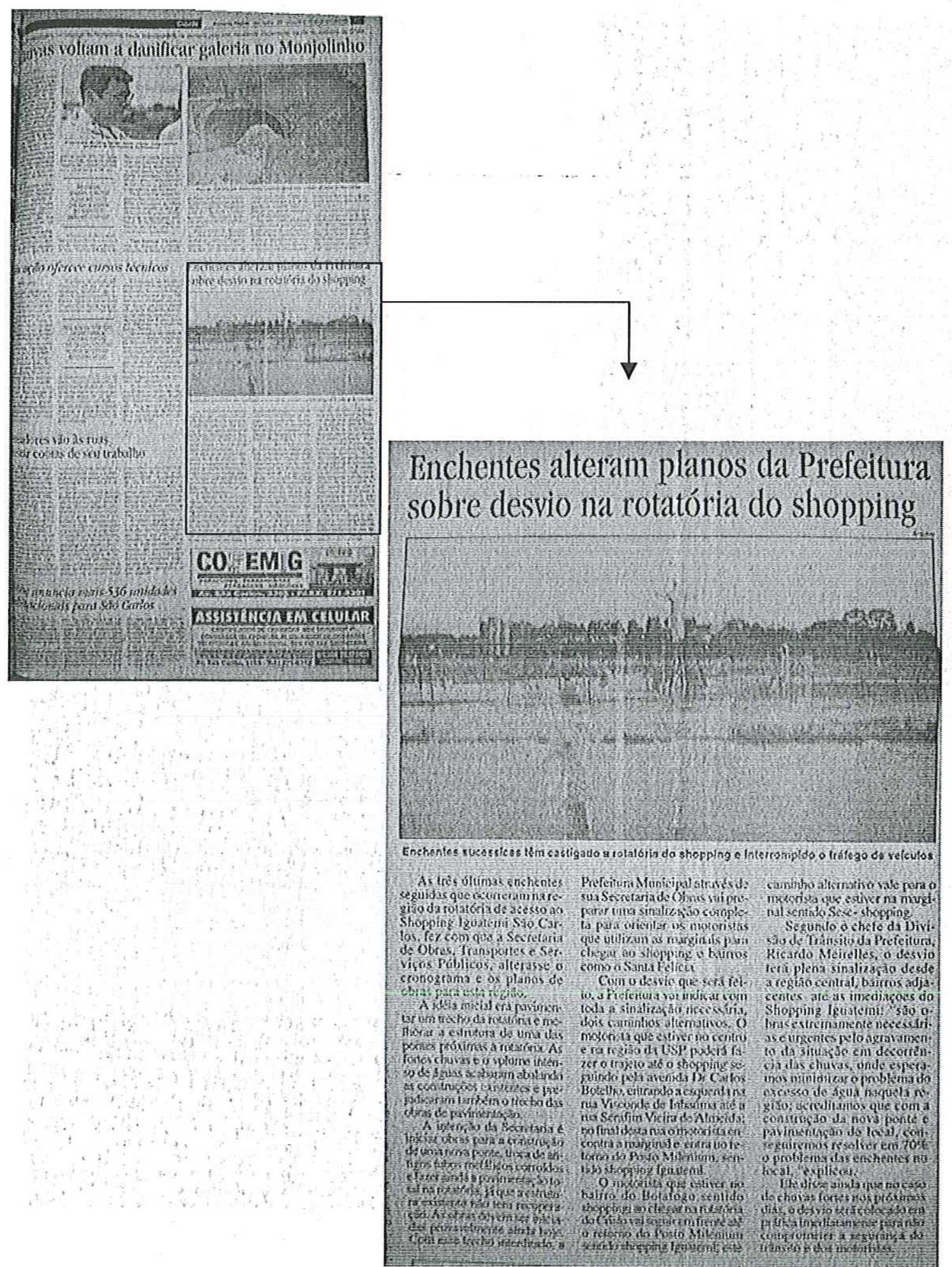

15-01-2002 -Enchentes alteram planos da prefeitura sobre desvios na rotatória do shopping

- Primeira Página .. 


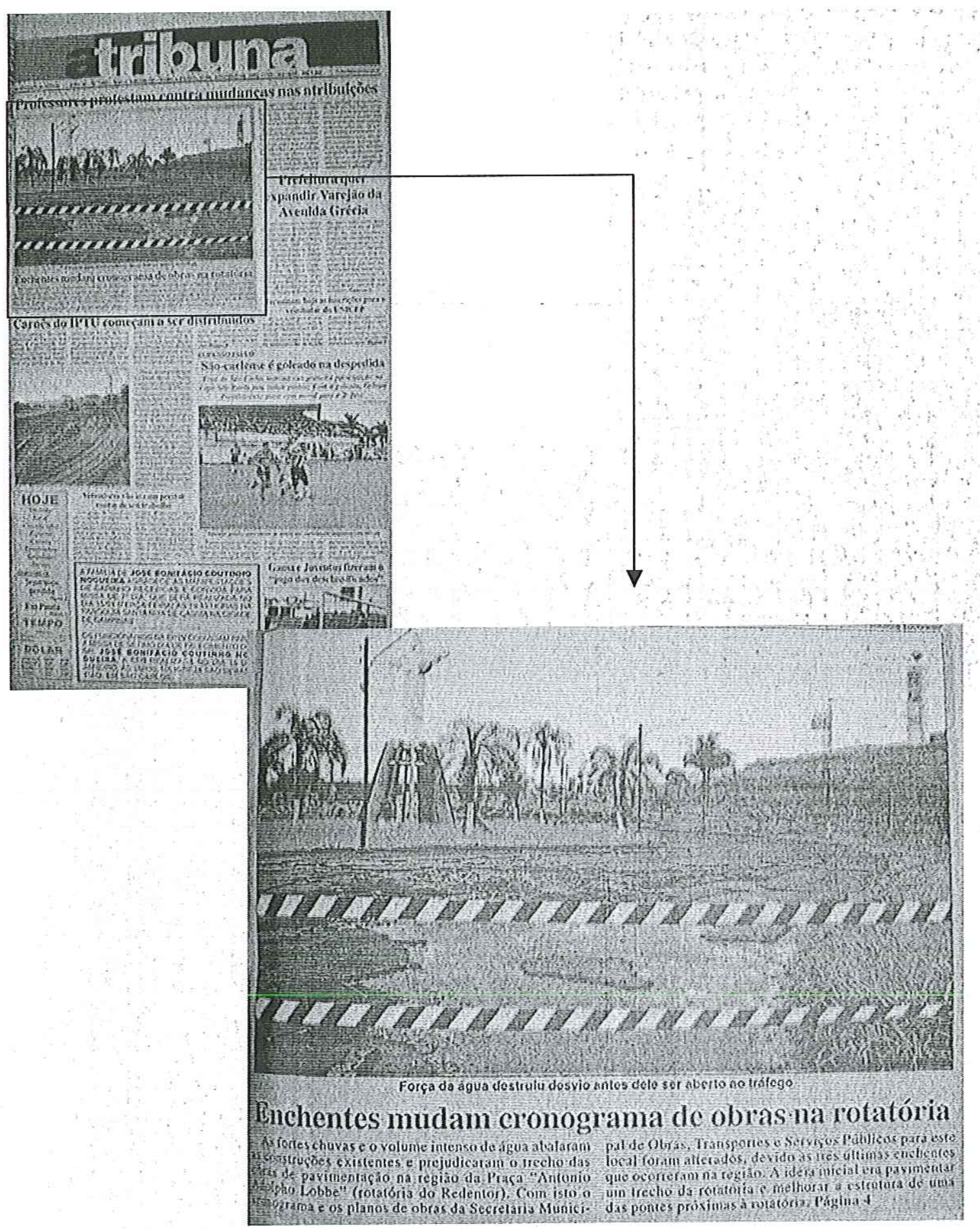

15-01-2002 - Enchentes mudam cronograma de obras na rotatória - A Tribuna 


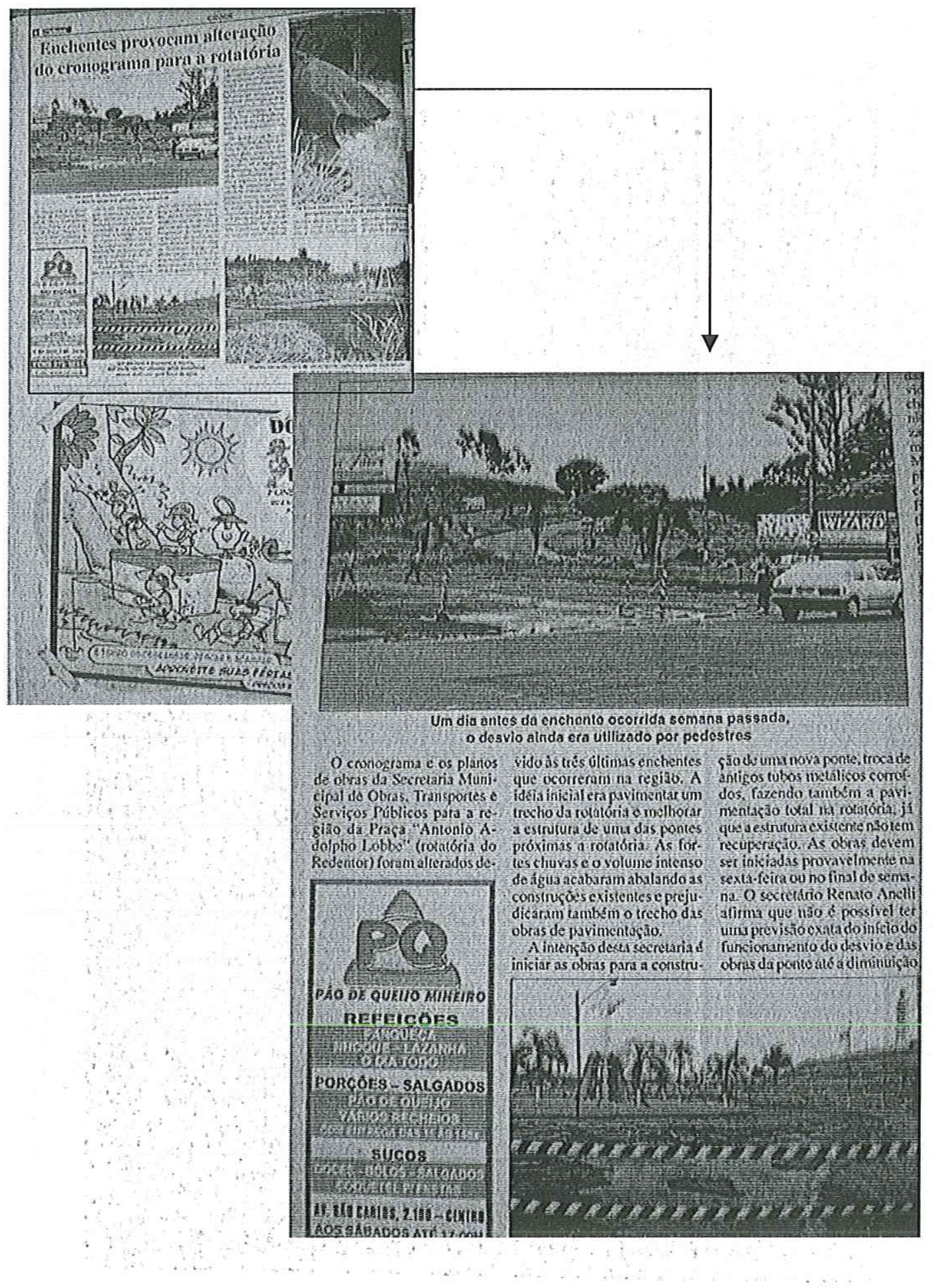

15-01-2002 - Enchentes provocam alteração no cronograma para a rotatória - A Tribuna Parte 1

i $\therefore$ 


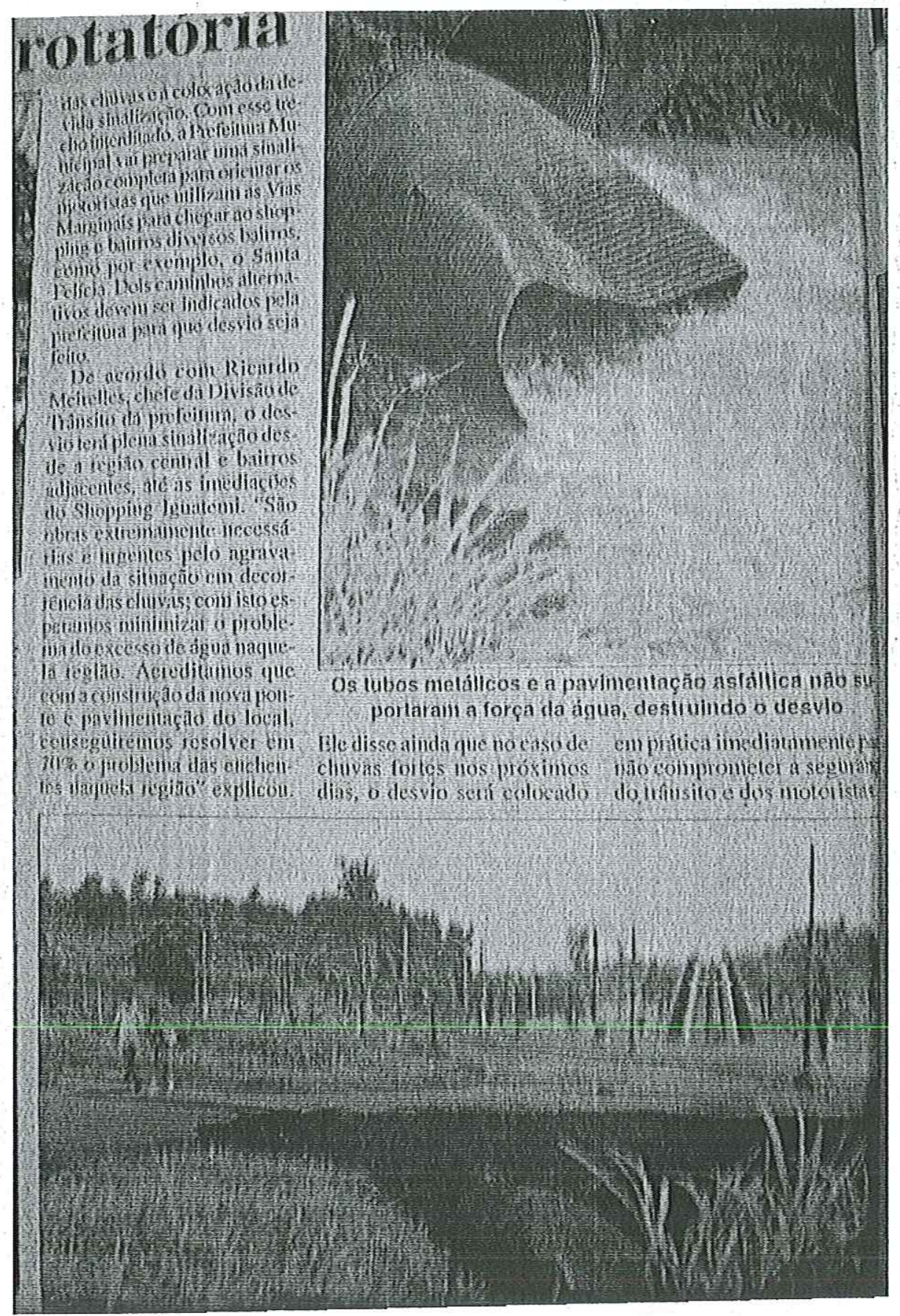

15-01-2002 - Enchentes provocam alteração no cronograma para a rotatória - A Tribuna Parte 2 

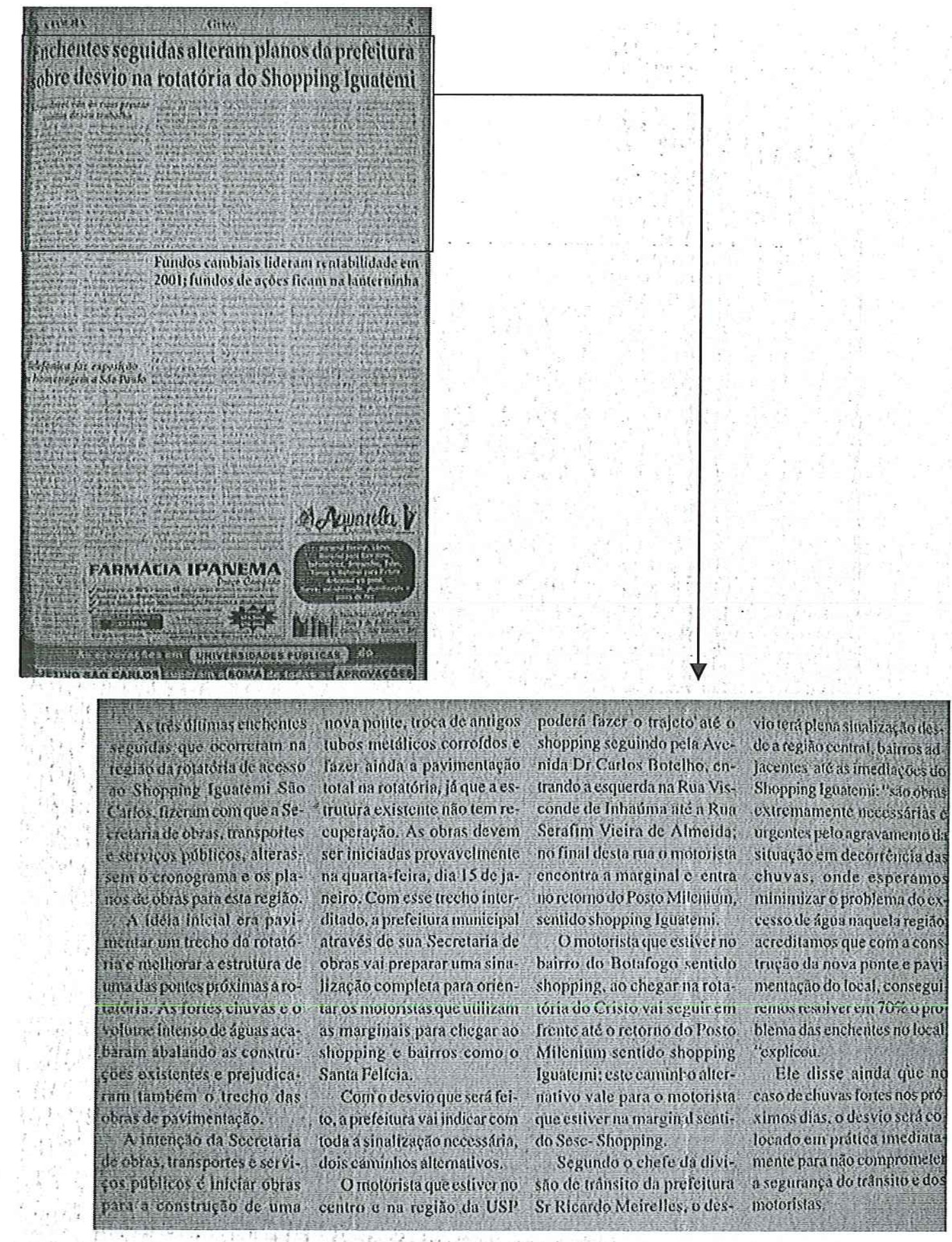

\section{5-01-2002 - Enchentes seguidas alteram planos da prefeitura sobre desvios na rotatória do} Shopping Iguatemi - A Folha 


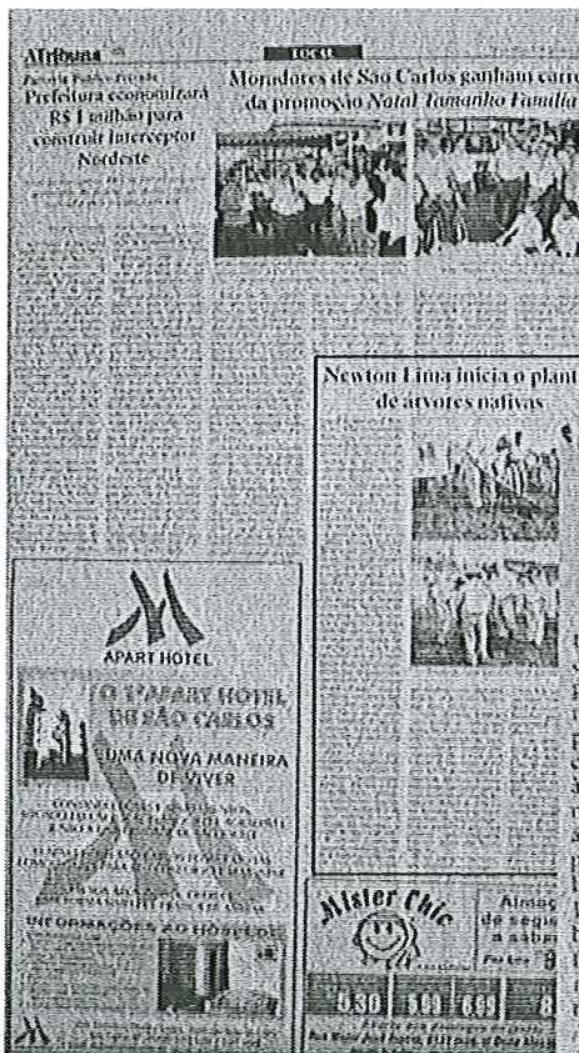

\section{Newton Lima inicia o plantio} de árvores nativas

Opereiro moakipes sei

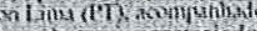
e nor o geu secrosarias. amingato pritam ato at. dimisifationda nosit gectio plamando as margens de eresco Mandintho, proving insams de cristo a yn merra das 1,061 midas de arores nativas que sersio

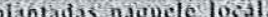
2010 (9) (10)

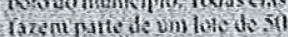

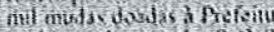
ra Mancipil rela Sos Allotion. Mintis dessuper

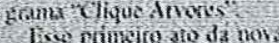
gestato foi, na werdader uno anipliacato do prinzeiro ato quando da posse de Varton Eimasom pino plan Resiten Risichestiendesuinatoput brasil no pilikise Jardin Po. blsode siac arlosicni frente 20 Palac te Conde do Pinhal Gotounituto toliz por repe. Iis un ato yte ha yours ano der maito ceto 0 programa cres lo Sho arrouss. Nosss mela, nesse Goundo mandato es supesar

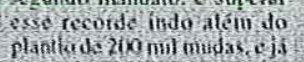
coms onor hoje:

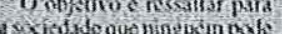

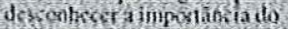
meki stribsente ns adiministra. cru poblica Por lor a Pres

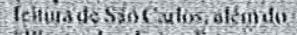

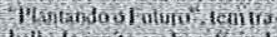
tullibo mutocinterofinada quelide bis ambicital, cons a proservingan das nareserss: muales o da fatrich of alle.

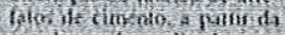
issiclisemikgralles deconst I)

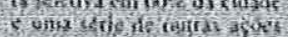

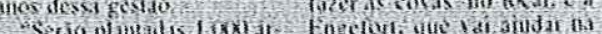

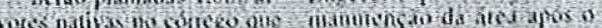
banlis Sto Carlos, danto ini plario.

(2) d ums

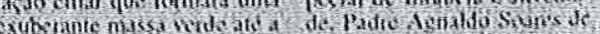

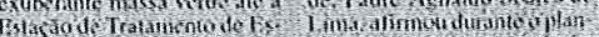

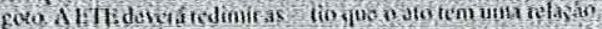

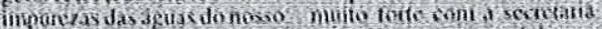

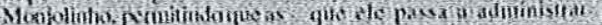

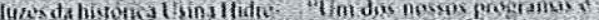

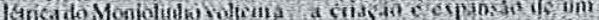

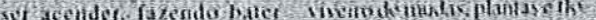

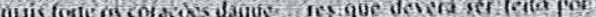

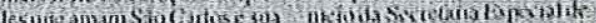
(3)

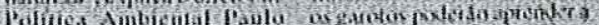

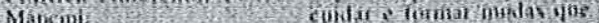

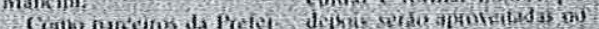

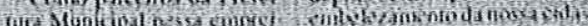

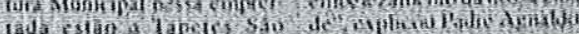

04-01-2005 - Newton Lima inicia o plantio de árvores nativas - A Tribuna 

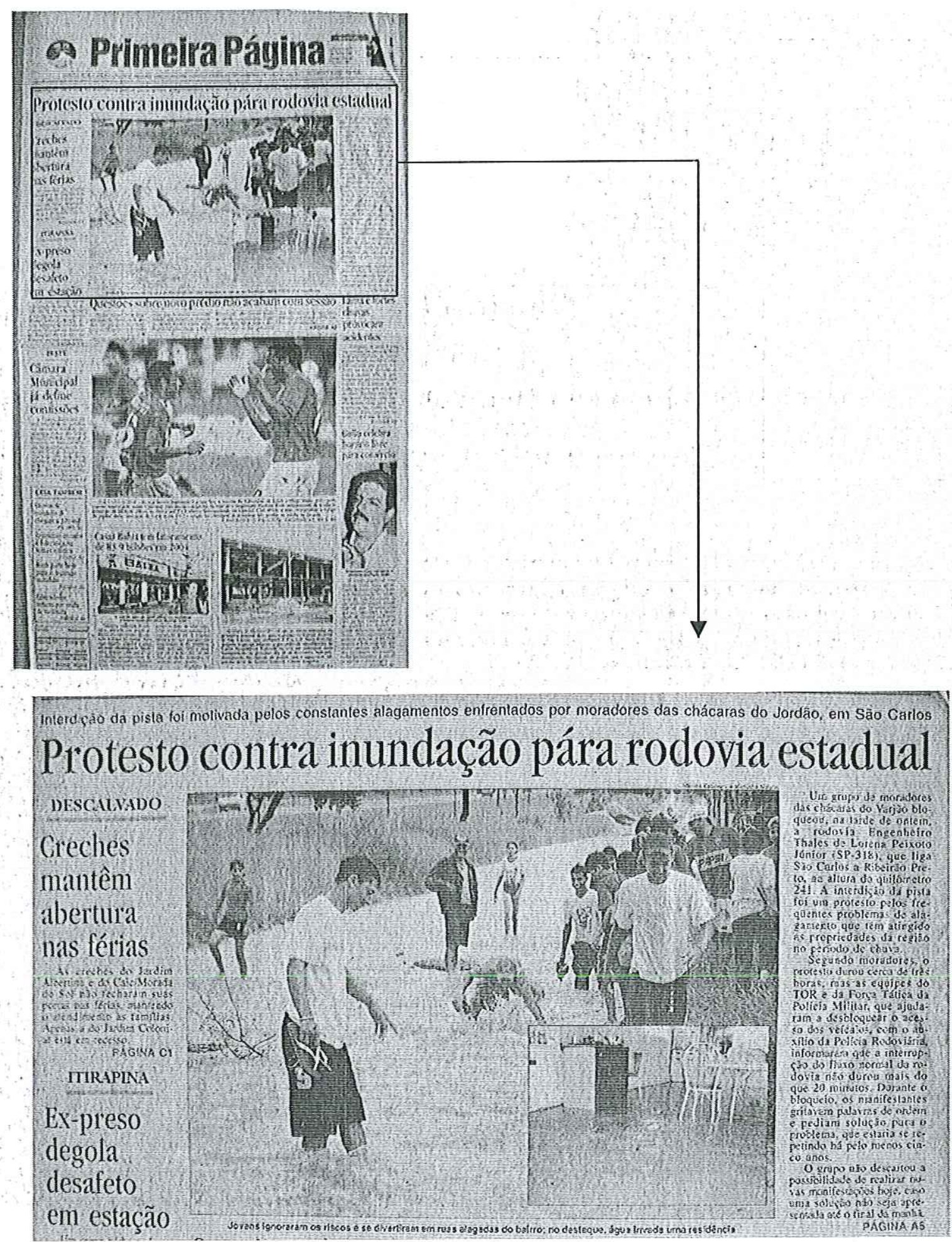

20-01-2005 - Protesto contra inundação para rodovia estadual - Primeira Página 


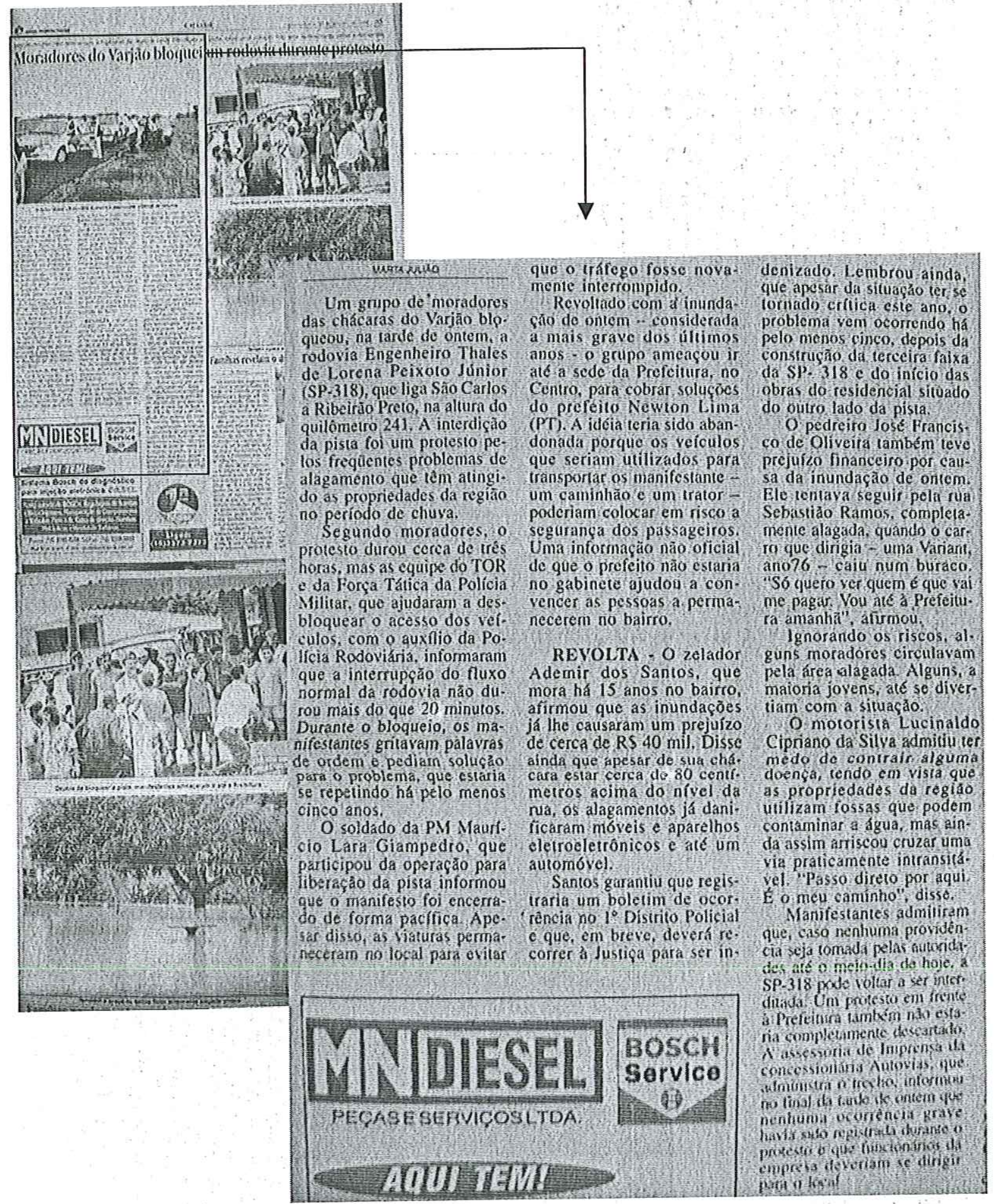

20-01-2005 - Moradores do Varjão bloqueiam rodovia durante protesto - Primeira Pagina 


\section{Quantidade de chuva já é o dobro do que em janeiro passado}

em São Carlos

Foram registrados 234 milímetros nos primeiros 20 dias de janeiro

EPTV Central

20/01/2005 20:13 - A Embrapa Pecuária Sudeste divulgou nesta Quinta-feira que nos primeiros 20 dias de janeiro deste ano a quantidade de chuva na região de São Carlos foi mais do que o dobro da registrada no mesmo mês no ano passado. Foram 234 milímetros esse ano contra 102 em 2004.

20-01-2005 - Quantidade de chuva já é o dobro do que em janeiro passado em São Carlos http://eptv.globo.com/noticias/ 


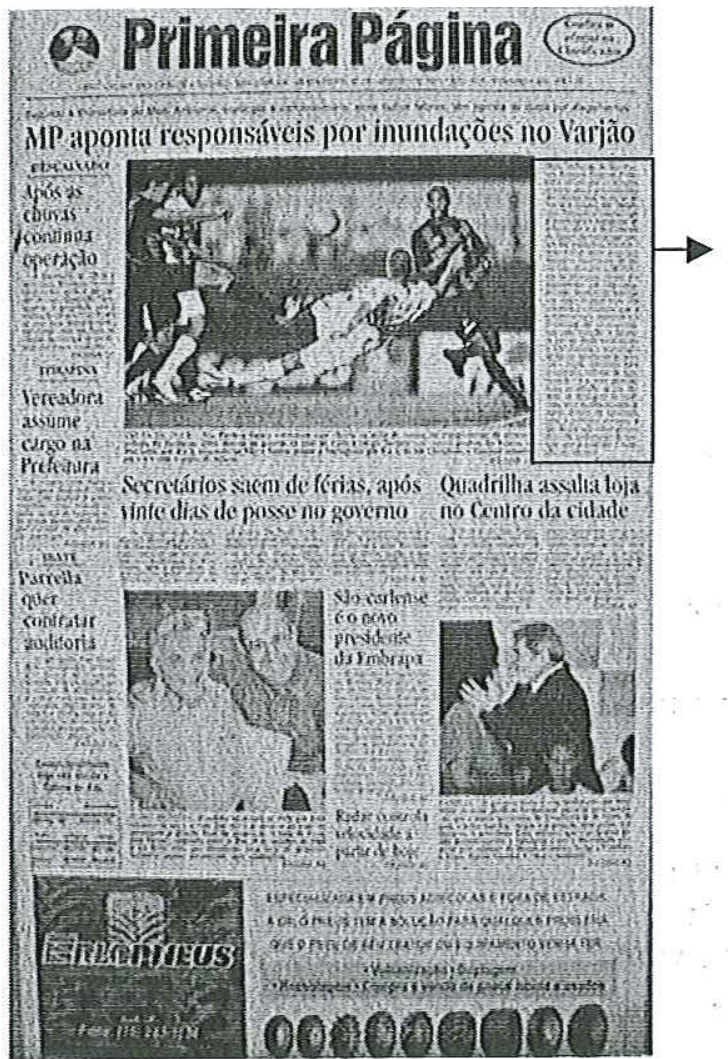

O promotor público do Meio Ambiente de São Carlos, Edward Ferreira Filho, disse ontem que os estudos jia realizados e as inundaçoes dos últimos dias na regiáo do Varjâo levaram o MP (Ministério Público) a concluir que a localização e lopografia do loteamiento e a escoamento de águas das terras que pertencem à enpresa Encalso . responsável pelos empreen dimentos localizados do outro lado da rodovia $\mathrm{SP}-318$. são as principais causas dos alagamentos que vêm prejudicando dezenas de fanilias nos cínco últimos anos. Ele também considerou que a concessionária Autovias e a Prefeitura săo co-responsáveis pela siluação. A primeira por ler impermeabilizado o solo durante a construçăo de faixas adicionais a rodovia - o que contribuiu para aumentar a volume de água escoada - e a outra pela demora lla adoção de um sistema de drenagem na local. Una nova audiência entre as partes deverá ser agendada para a próxima semana, a fim de que seja elaborado um termo de ajustamento de conduta que possibilite a solufáo do impasse.

PÁGINA AG

21-01-2005 - MP aponta responsáveis por inundação no varjão - Primeira Pagina - Parte 1 


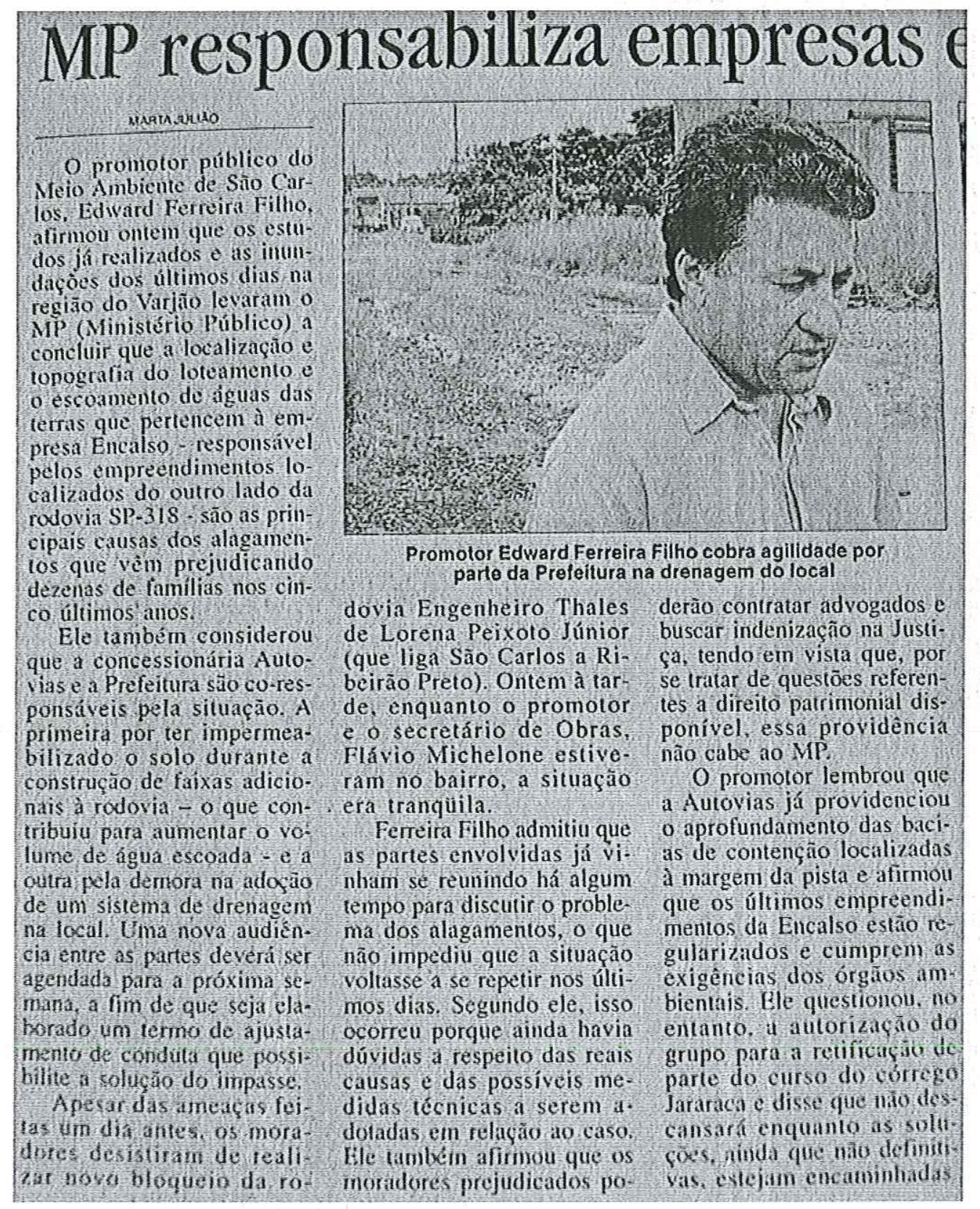

21-01-2005 - MP aponta responsáveis por inundação no varjão - Primeira Pagina - Parte 2 


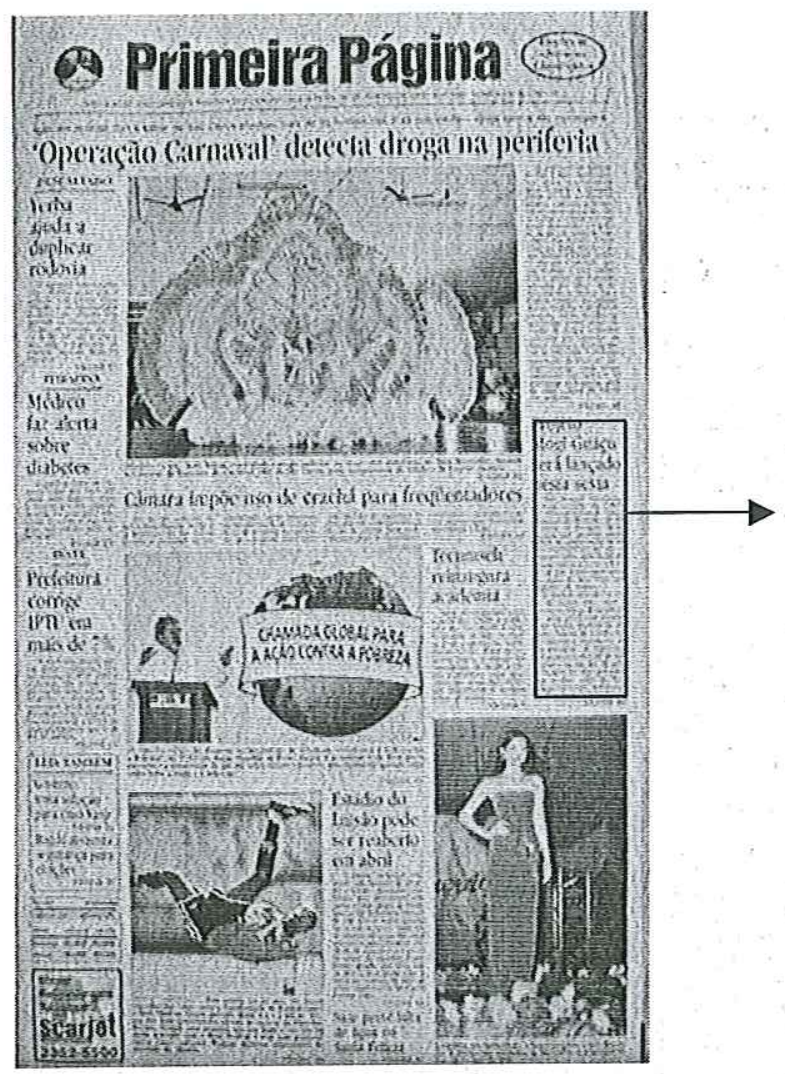

Projeto

Mogi-Guaçu será lançado nesta sexta

Será lanfado oficialmen. to hoje, a partir das $13 \mathrm{~h} 30$ na Oficina Gultural sérgio Buarque de Holanda: de São Carlos, o Projeto MogiGuaçu, que pretende nortear açóes de preservação na bacia hidrográfica do rio de mesmo nome, que nasce em Minas Gerais e corta o Estado de São Paulo, bem como na região do Alto Mogi, que engloba 18 cidades.

O projeto, iniciado há cerca de quatro anos, com 0 estudo do Mogi, é coordenado pelo professor Evaldo Luiz Gaeta Espíndola, do Neea (Núcleo de Estudos em Ecossistemas Aquáticos) do Departamento de Hidráulica e Saneamento da USP de Sấo Carlos e foi um dos 30 sele. cionados no ano passado, para receber verba do Programa Patrocinio Ambiental! da Petrobras.

PÁGINA A4

28-01-2005 - Projeto Mogi-Guaçu será lançado nesta sexta - Primeira Pagina 


\section{$\underline{\text { ANEXO 05 }}$}

Análise das Notícias:

Evento específico de Inundação ou Alagamento na Bacia do Gregório 


\begin{tabular}{|c|c|c|c|c|c|c|c|c|c|}
\hline $\begin{array}{l}\text { Data da } \\
\text { Notícia }\end{array}$ & Jornal & $\begin{array}{c}\text { Data da } \\
\text { Chuva }\end{array}$ & $\begin{array}{l}\text { Título da } \\
\text { notícia }\end{array}$ & \begin{tabular}{|c|} 
Nivel Máximo \\
(mencionado \\
no texto ou \\
aferido por \\
observação de \\
foto)
\end{tabular} & Danos causados & $\begin{array}{l}\text { Duração da } \\
\text { Chuva }\end{array}$ & $\begin{array}{l}\text { Tempo de } \\
\text { Permanência }\end{array}$ & Área inundada & $\begin{array}{l}\text { Resumo da } \\
\text { noticia }\end{array}$ \\
\hline $26 / 2 / 1932$ & $\begin{array}{l}\text { Correio de } \\
\text { São Carlos }\end{array}$ & $25 / 2 / 1932$ & $\begin{array}{l}\text { Chuva } \\
\text { diluvianal }\end{array}$ & $\begin{array}{c}80 \mathrm{~cm} \text { em } \\
\text { algumas casas } \\
\text { (citado na } \\
\text { notícia) }\end{array}$ & \begin{tabular}{|c|} 
"Inundação de todas \\
as casas que \\
margeiam o rio \\
Gregório. Os \\
prejuizos materiais \\
são incalculáveis \\
pois muitas casas de \\
negócios, \\
torrefaçōes, fábricas \\
margeando o rio \\
foram totalmente \\
invadidas pela água. \\
Parte da ponte da \\
rua São Carlos \\
pegada ao posto de \\
Gasolina do Sr. \\
Miguel Petroni foi \\
arrastada pelas \\
águas."
\end{tabular} & 19 as $21 \mathrm{~h}$ & $\begin{array}{c}\text { Das } 20 \text { as } 22 \text { horas } \\
\text { (citado na notícia } \\
\text { posterior) }\end{array}$ & \begin{tabular}{|c|} 
Margens do Rio \\
Gregório
\end{tabular} & \begin{tabular}{|c|} 
Forte chuva fez \\
com que o Gregório \\
transbordasse \\
causando pånico \\
na população. As \\
águas chegaram a \\
$80 \mathrm{~cm}$ de altura em \\
algumas casas. Os \\
prejuizos materiais \\
são incalculáveis \\
pois muitas casas \\
de negócios, \\
torrefaçōes, \\
fábricas margeando \\
o rio foram \\
totalmente \\
invadidas pela \\
água.
\end{tabular} \\
\hline
\end{tabular}




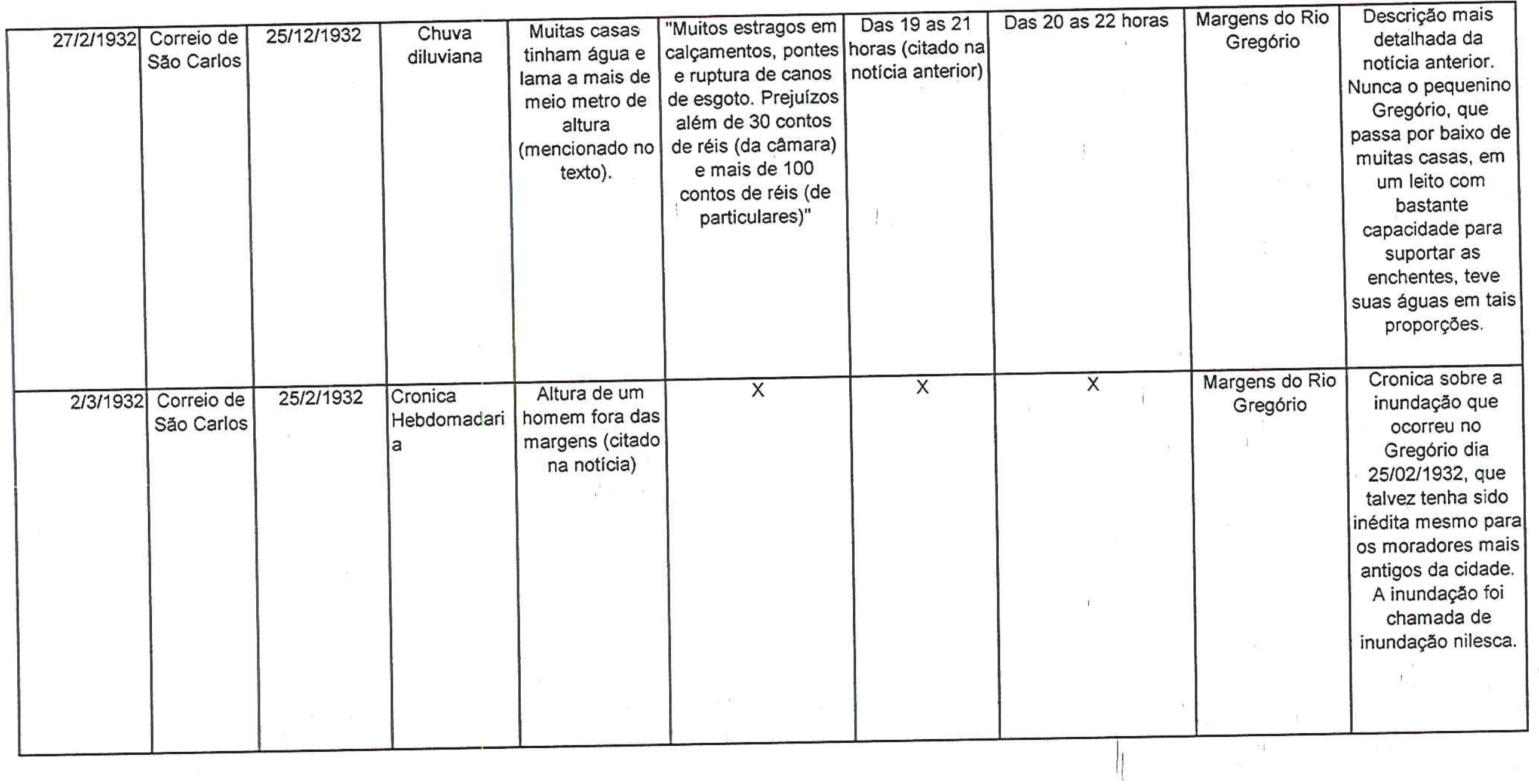




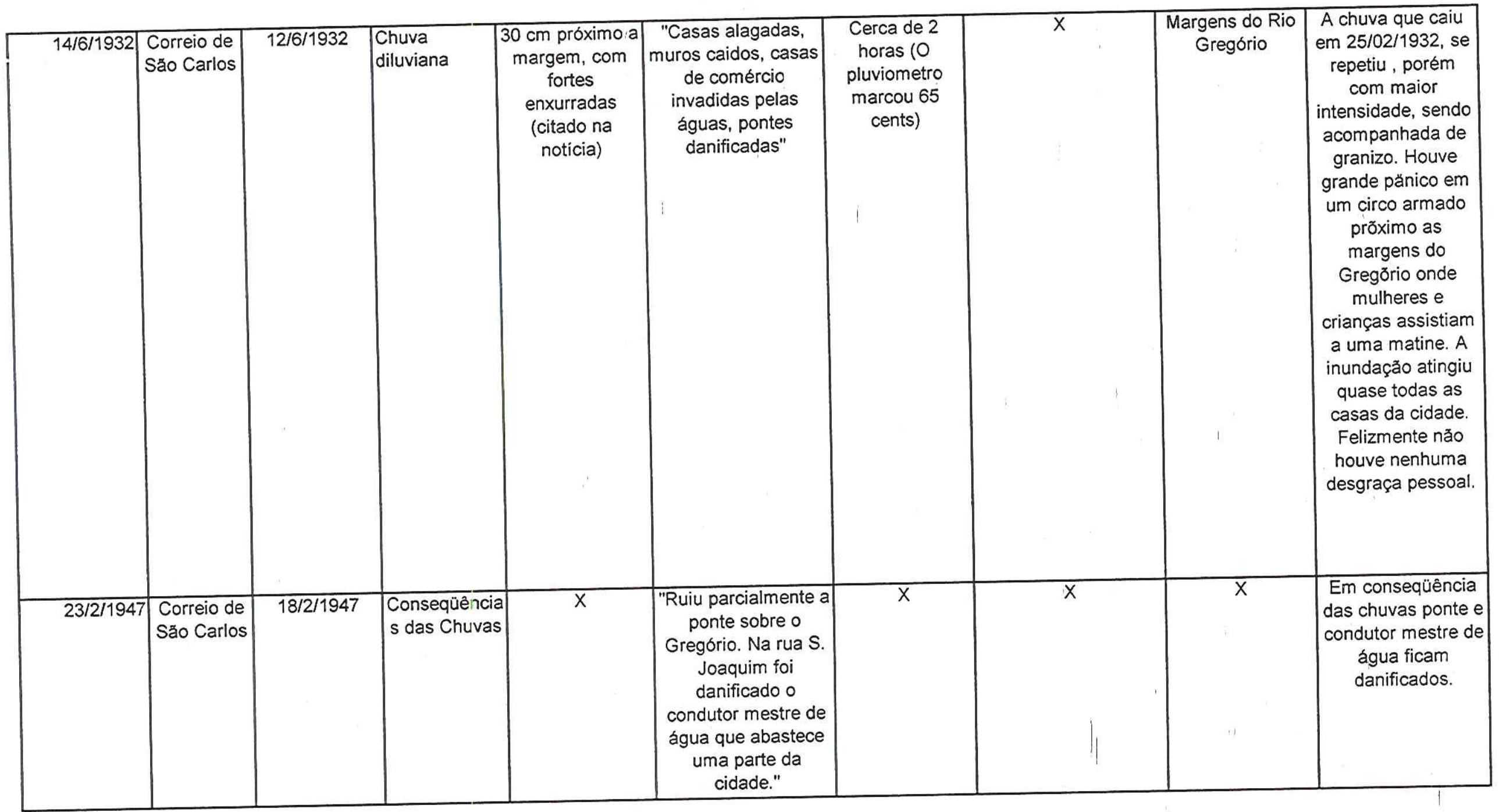




\begin{tabular}{|c|c|c|c|c|c|c|c|c|c|}
\hline $23 / 2 / 1947$ & \begin{tabular}{|l|} 
Correio de \\
São Carlos
\end{tabular} & $18 / 2 / 1947$ & \begin{tabular}{|c|} 
Suspensas \\
temporariame \\
nte as \\
atividades das \\
piscinas
\end{tabular} & $\bar{x}$ & $\begin{array}{c}\text { "As chuvas } \\
\text { ocasionaram sérios } \\
\text { estragos nos } \\
\text { encanamentos de } \\
\text { água." }\end{array}$ & $\bar{x}$ & $x$ & $\bar{x}$ & \begin{tabular}{|c|} 
Em virtude das \\
grandes chuvas \\
foram suspensas \\
temporariamente as \\
atividades da \\
piscina pois os \\
encanamentos de \\
água ficaram com \\
sérios problemas.
\end{tabular} \\
\hline $2 / 3 / 1947$ & $\begin{array}{l}\text { Correio de } \\
\text { São Carlos }\end{array}$ & $26 / 2 / 1947$ & \begin{tabular}{|c|} 
Inundada a \\
parte baixa da \\
cidade
\end{tabular} & $\begin{array}{c}\text { Nivel do } \\
\text { Gregório subiu } \\
1,5 \text { metros } \\
\text { (mencionado no } \\
\text { texto), } 0,5 \text { metro } \\
\text { na praça Santos } \\
\text { Dumond }\end{array}$ & $x$ & $x$ & Poucas horas & $\begin{array}{c}\text { Baixada da } \\
\text { Cidade e Praça } \\
\text { Santos Dumond }\end{array}$ & \begin{tabular}{|c|} 
Forte aguaceiro que \\
caiu sobre a cidade \\
fez o Gregório \\
transbordar. A \\
inundação durou \\
poucas horas mas \\
causou susto na \\
população \\
ribeirinha.
\end{tabular} \\
\hline $20 / 11 / 1947$ & \begin{tabular}{|l|} 
Correio de \\
Săo Carlos
\end{tabular} & $16 / 11 / 1947$ & Enchente & $\bar{x}$ & $\bar{x}$ & $x$ & $\bar{x}$ & $\bar{x}$ & \begin{tabular}{|c|} 
Inundação na \\
várzea do mercado, \\
tendo transbordado \\
o córrego.
\end{tabular} \\
\hline
\end{tabular}




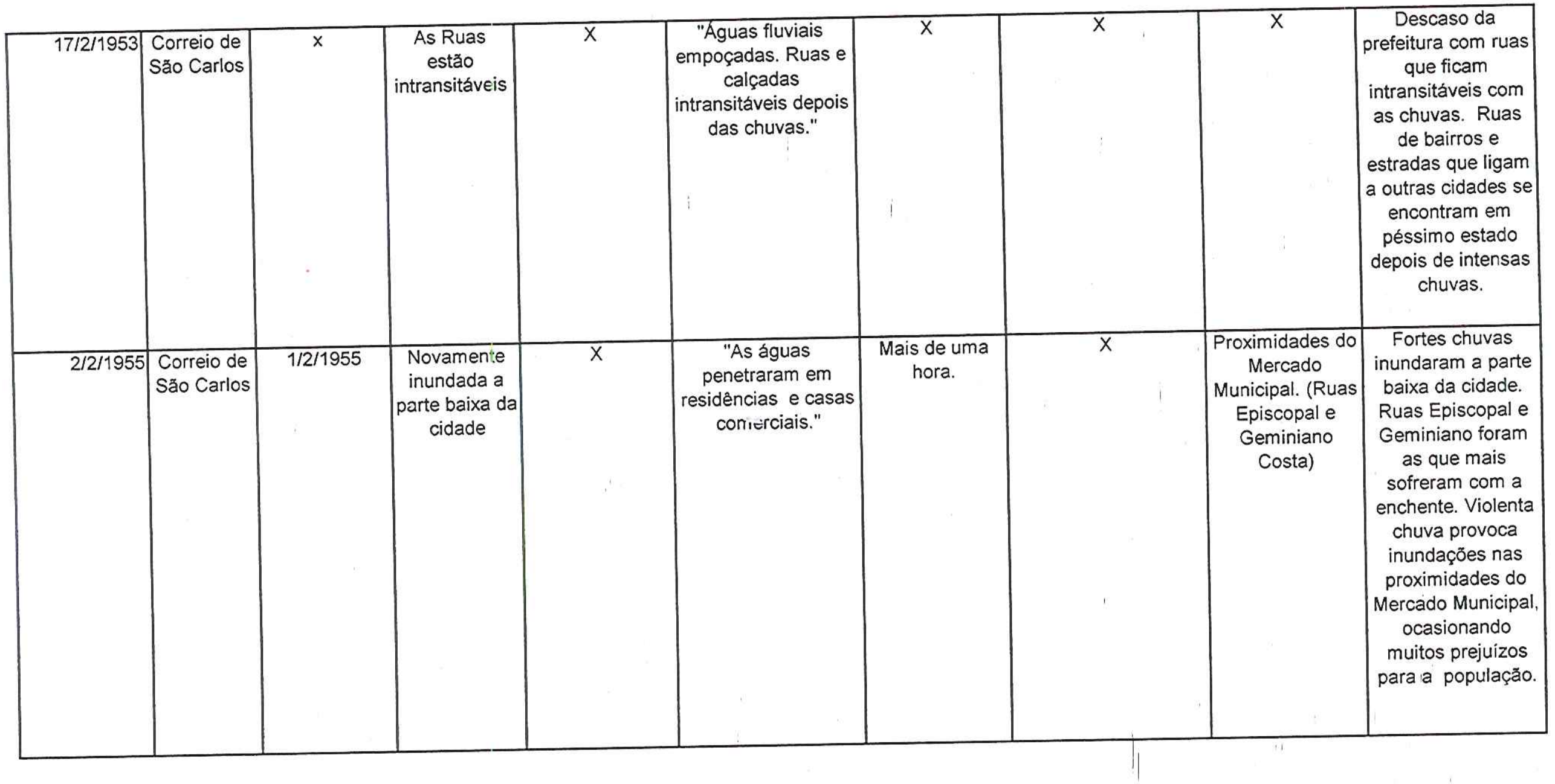




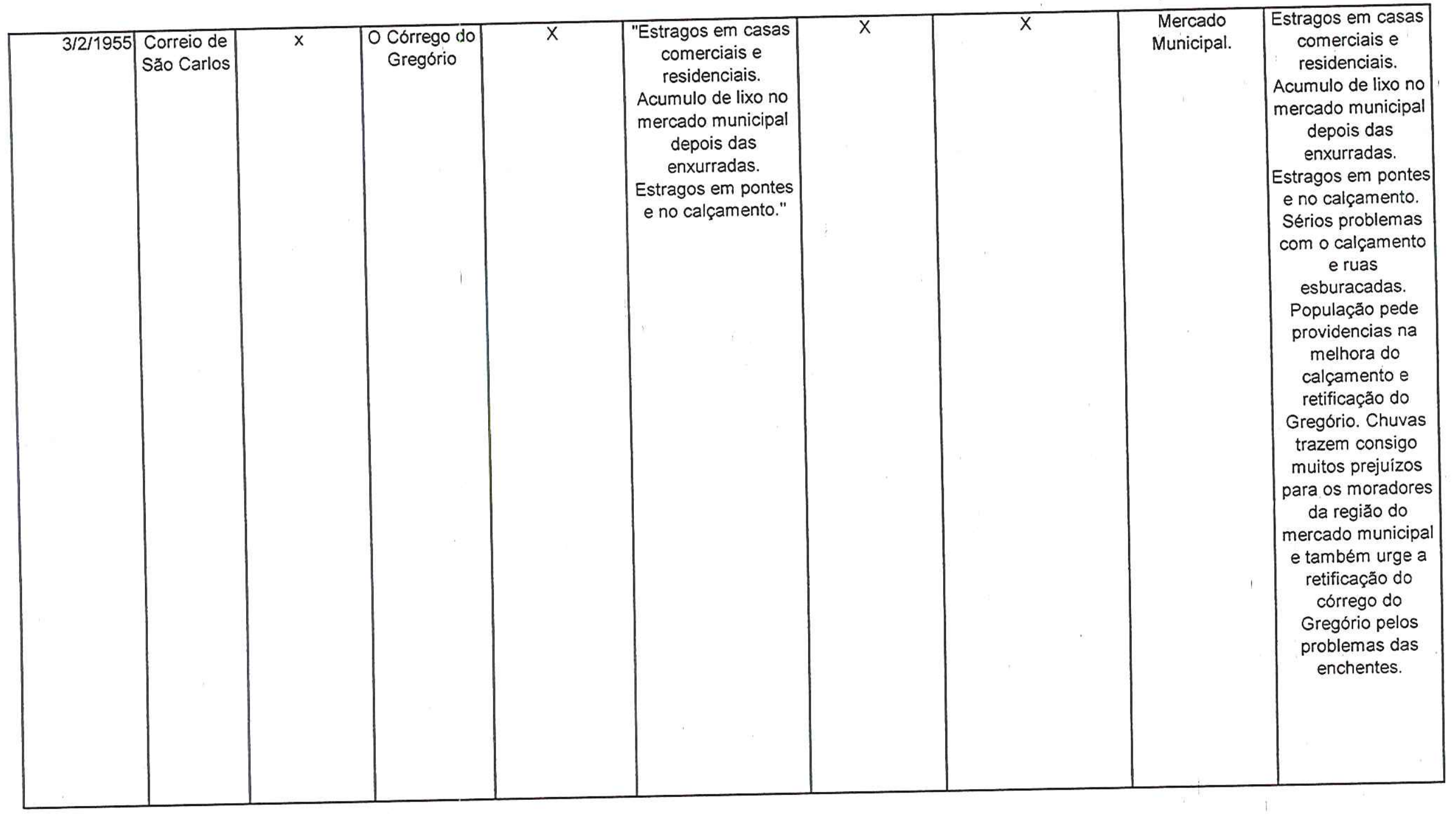




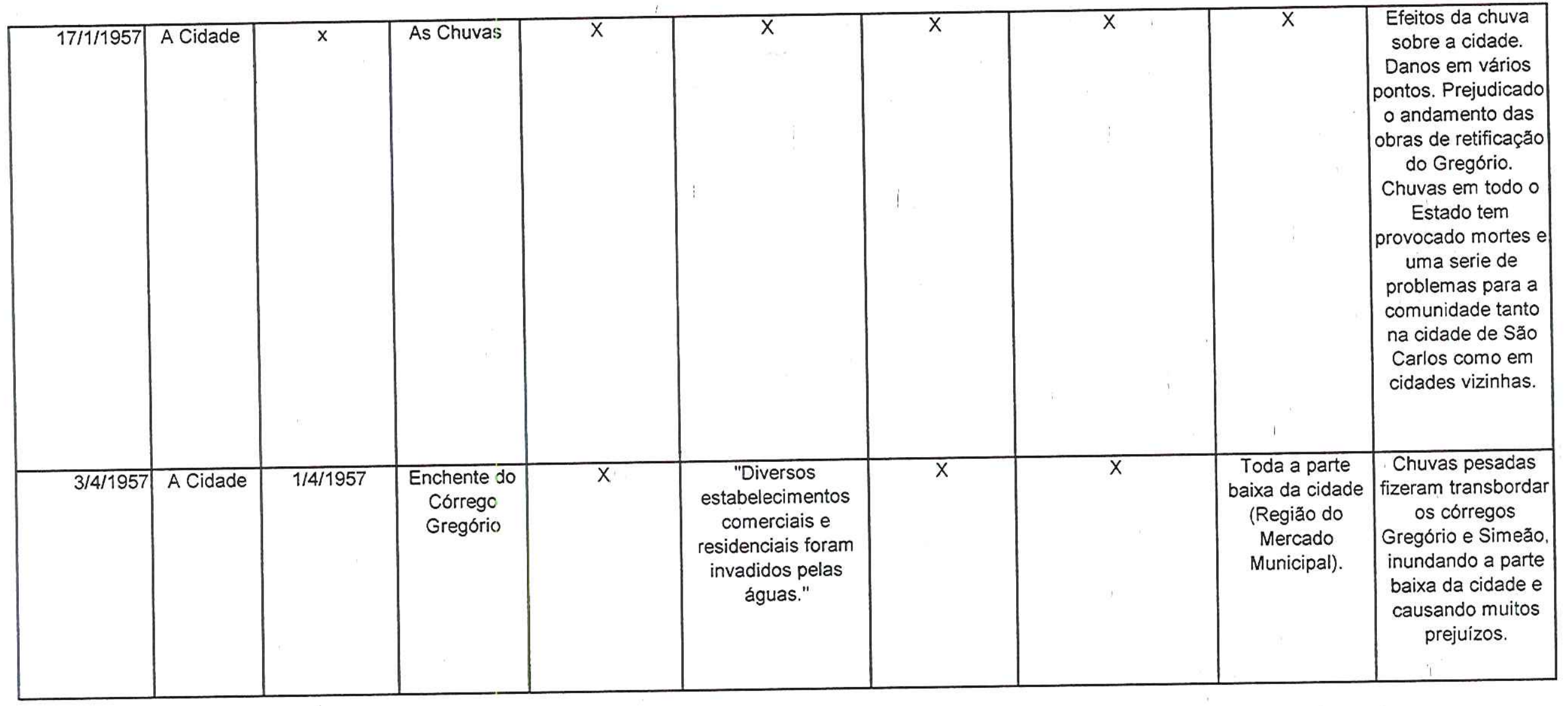




\begin{tabular}{|c|c|c|c|c|c|c|c|c|c|}
\hline $13 / 1 / 1960$ & A Cidade & $12 / 1 / 1960$ & $\begin{array}{c}\text { Causaram } \\
\text { prejuizos as } \\
\text { chuvas de } \\
\text { ontem }\end{array}$ & $x$ & \begin{tabular}{|c|} 
"O córrego do \\
Gregório transbordo \\
em vários pontos. A \\
agua arranco \\
grandes extensठ̃es \\
de pavimento da Av. \\
São Carlos. Grande \\
quantidade de \\
pedras do \\
calçamento foi \\
arrastada, \\
depositando-se na \\
Av. Săo Carlos."
\end{tabular} & $\begin{array}{c}\text { Da tarde até um } \\
\text { pouco mais das } \\
9 \text { da noite. }\end{array}$ & 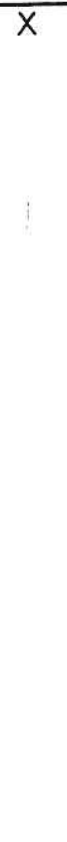 & $\begin{array}{l}\text { Centro de São } \\
\text { Carlos. }\end{array}$ & $\begin{array}{c}\text { O córrego do } \\
\text { Gregório } \\
\text { transbordou em } \\
\text { vários pontos. A } \\
\text { água arrancou } \\
\text { grandes extensões } \\
\text { de pavimento da } \\
\text { Av. São Carlos. } \\
\text { Grande quantidade } \\
\text { de pedras do } \\
\text { calçamento foi } \\
\text { arrastada, } \\
\text { depositando-se na } \\
\text { Av. São Carlos. } \\
\text { Bombeiros e } \\
\text { trabalhadores da } \\
\text { prefeitura fizeram a } \\
\text { limpeza da via } \\
\text { publica a fim de } \\
\text { evitar outros } \\
\text { acidentes. }\end{array}$ \\
\hline
\end{tabular}




\begin{tabular}{|c|c|c|c|c|c|c|c|c|c|}
\hline $20 / 1 / 1965$ & A Folha & $19 / 1 / 1965$ & \begin{tabular}{|c|} 
Urge \\
retificaçăo do \\
Gregório e \\
construção de \\
novas \\
galerias
\end{tabular} & $\bar{x}$ & $\begin{array}{l}\text { "O córrego } \\
\text { transbordou e } \\
\text { invadiu as } \\
\text { residéncias" }\end{array}$ & $x$ & $x$ & $\begin{array}{c}\text { Parte Baixa da } \\
\text { cidade }\end{array}$ & \begin{tabular}{|c|} 
O córrego do \\
Gregório \\
Transbordou. Pede- \\
se as obras de \\
retificaçăo do \\
Córrego alegando- \\
se calamidade \\
pública. A \\
população de São \\
Carlos ainda \\
aguarda a obra de \\
retificaçăo do \\
córrego Gregório, \\
tentando minimizar \\
assim o perigo \\
constante da \\
população da parte \\
baixa da cidade \\
quando chove.
\end{tabular} \\
\hline $23 / 2 / 1965$ & A Folha & $\bar{x}$ & $\begin{array}{c}\text { Chuvas } \\
\text { causararn } \\
\text { grandes } \\
\text { estragos. }\end{array}$ & $x$ & $\begin{array}{c}\text { "Estragos nas vias } \\
\text { publicas, ruas e } \\
\text { estradas." }\end{array}$ & $\bar{x}$ & $\bar{x}$ & $\begin{array}{c}\text { Parte baixa da } \\
\text { cidade (Região } \\
\text { do Mercado } \\
\text { Municipal). Rio } \\
\text { Gregório. } \\
\end{array}$ & \begin{tabular}{|c|} 
Pesadas chuvas \\
causaram grandes \\
estragos nas vias \\
publicas. A nåo \\
retificaçăo do rio \\
Gregório produz o \\
trasbordamento do \\
mesmo causando \\
pânico e prejuizos \\
aos moradores. \\
\end{tabular} \\
\hline
\end{tabular}




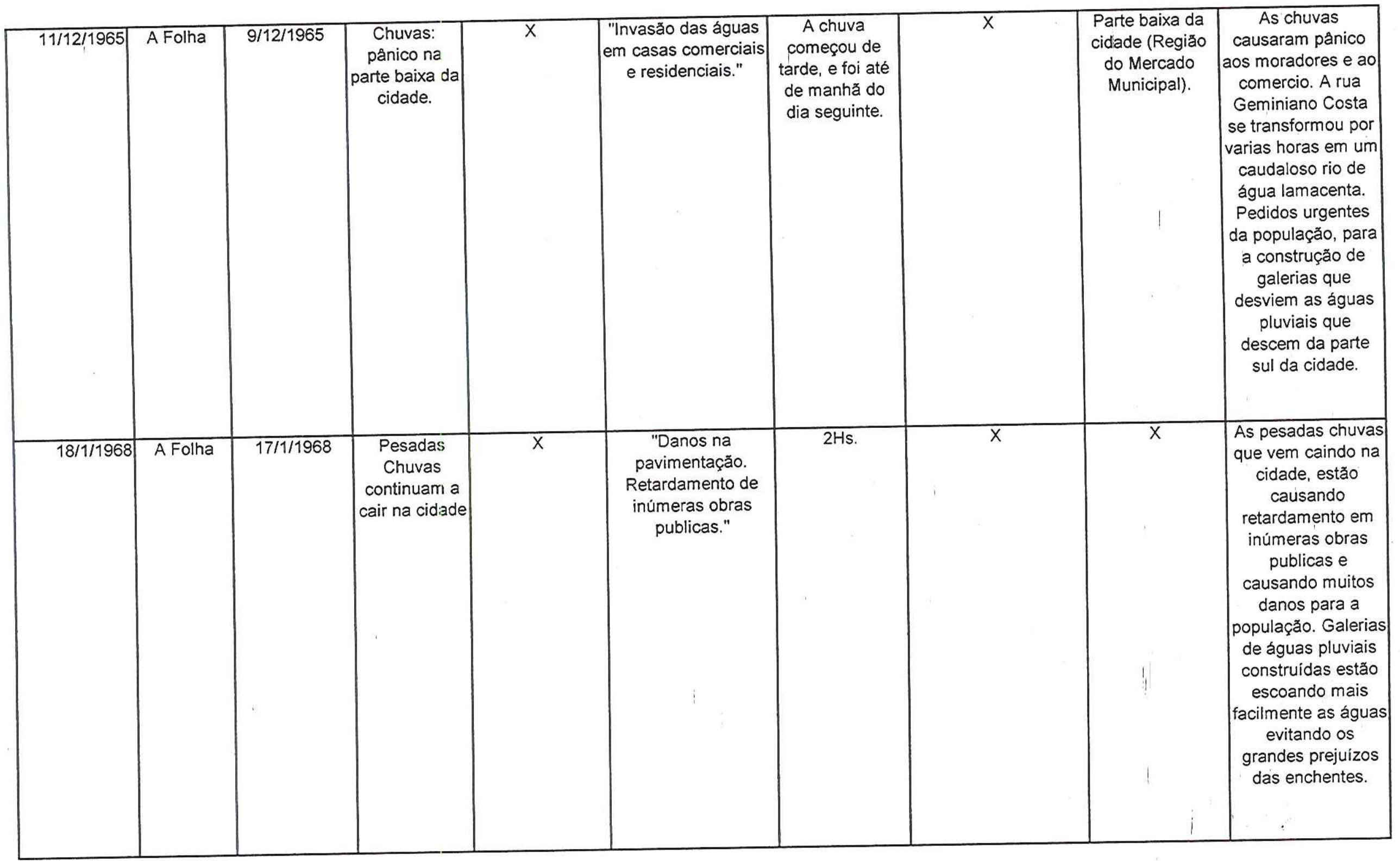




\begin{tabular}{|c|c|c|c|c|c|c|c|c|c|}
\hline $17 / 1 / 1970$ & A Folha & $\bar{x}$ & $\begin{array}{c}\text { Buraco } \\
\text { Perigoso }\end{array}$ & $\bar{x}$ & $\begin{array}{l}\text { "Cruzamento das } \\
\text { ruas Antonio } \\
\text { Rodrigues Cajado } \\
\text { com Geminiano } \\
\text { Costa teve o asfalto } \\
\text { arrebentado." }\end{array}$ & 1 & $\bar{x}$ & $\begin{array}{c}\text { Ruas Geminiano } \\
\text { Costa e Antonio } \\
\text { Rodrigues } \\
\text { Cajado. } \\
\end{array}$ & \begin{tabular}{|c|} 
Entre as Ruas \\
Geminiano Costa e \\
Antonio Rodrigues \\
Cajado se formou \\
um grande buraco \\
devido a forte \\
enxurrada que \\
arrebentou o \\
asfalto.
\end{tabular} \\
\hline $18 / 1 / 1970$ & O Diário & $17 / 1 / 1970$ & $\begin{array}{c}\text { Chuvas } \\
\text { causam } \\
\text { prejuizos. }\end{array}$ & $x$ & \begin{tabular}{|c|} 
"Grandes buracos \\
sendo cavados pela \\
enxurrada. Em vários \\
trechos foram \\
levados os \\
paralelepipedos. Dest \\
ruição de sarjetas e \\
aluirão de muros e \\
calçadas.Desmorona \\
mento de uma \\
residência. Entupime \\
nto de diversas \\
bocas de lobo."
\end{tabular} & $\bar{x}$ & 1 & \begin{tabular}{|c|} 
Rua São Paulo, \\
bairro Vila Prado, \\
Cidade Azul.
\end{tabular} & $\begin{array}{c}\text { Foram localizados } \\
\text { vários danos em } \\
\text { várias partes da } \\
\text { cidade, pelas fortes } \\
\text { chuvas ocorridas } \\
\text { no final de semana. } \\
\text { As chuvas afetaram } \\
\text { ruas e bairros em } \\
\text { pontos diversos da } \\
\text { cidade. }\end{array}$ \\
\hline $22 / 1 / 1970$ & A Folha & $\bar{x}$ & $\begin{array}{l}\text { Chuvas } \\
\text { danificarn } \\
\text { muro de } \\
\text { arrimo. }\end{array}$ & $\begin{array}{l}\text { Canto do muro } \\
\text { de arrimo. }\end{array}$ & \begin{tabular}{|c|} 
"Estragos em vários \\
locais.Abertura de \\
um grande buraco \\
nas duas margens \\
do córrego do \\
Gregório. Foi \\
interditado a ponte \\
sobre a rua D. Pedro \\
II, bem como o \\
pontilhão da \\
Travessa $8 . "$
\end{tabular} & $\bar{x}$ & $\bar{x}$ & $\begin{array}{c}\text { Centro. Rua } \\
\text { Geminiano Costa } \\
\text { esquina Dona } \\
\text { Alexandrina }\end{array}$ & \begin{tabular}{|c|} 
Chuvas intensas \\
sobre a cidade de \\
São Carlos \\
proporcionaram \\
muitos estragos na \\
parte central da \\
cidade, nas \\
proximidades do \\
Córrego Gregório.
\end{tabular} \\
\hline
\end{tabular}




\begin{tabular}{|c|c|c|c|c|c|c|c|c|c|}
\hline $14 / 3 / 1970$ & O Diário & $13 / 3 / 1970$ & $\begin{array}{l}\text { Rua São } \\
\text { Paulo tem } \\
\text { "cascata" }\end{array}$ & $x$ & \begin{tabular}{|c|} 
"Na Rua Såo Paulo, \\
valetas com mais de \\
2 metros de \\
profundidade; na \\
Rua Rui Barbosa \\
paralelepipedos \\
rolavam como bolas \\
de gude."
\end{tabular} & $x$ & $x$ & \begin{tabular}{|l|} 
Rua Săo Paulo e \\
Rua Rui Barbosa
\end{tabular} & $\begin{array}{c}\text { Reclamação que é } \\
\text { necessário um } \\
\text { sistema mais } \\
\text { moderno de } \\
\text { captação das } \\
\text { águas das chuvas, } \\
\text { já que as Ruas Săo } \\
\text { Paulo e Rui } \\
\text { Barbosa servem de } \\
\text { leito para toda água } \\
\text { que procede da } \\
\text { parte oeste da } \\
\text { cidade. }\end{array}$ \\
\hline $24 / 2 / 1972$ & A Folha & $23 / 2 / 1972$ & $\begin{array}{l}\text { Chuvas } \\
\text { inundam a } \\
\text { cidade: } \\
\text { prejuizos } \\
\text { foram } \\
\text { enormes. }\end{array}$ & $x$ & \begin{tabular}{|c|} 
"Estabelecimentos \\
comerciais \\
alagados. Carros \\
arrastados. O asfalta \\
das ruas General \\
Osório ate a Bento \\
Carlos foram \\
estouradas."
\end{tabular} & $x$ & $x$ & $\begin{array}{c}\text { Centro. Mercado } \\
\text { municipal. } \\
\text { Córrego do } \\
\text { Gregório. }\end{array}$ & \begin{tabular}{|c|} 
As chuvas \\
castigaram \\
violentamente a \\
cidade de São \\
Carlos, mas \\
precisamente na \\
regiåo do mercado \\
municipal. \\
Produzindo assim \\
inquietação e \\
muitos prejuizos \\
para a população \\
săo-carlense.
\end{tabular} \\
\hline
\end{tabular}




\begin{tabular}{|c|c|c|c|c|c|c|c|c|c|}
\hline $25 / 2 / 1972$ & A Folha & $23 / 2 / 1972$ & \begin{tabular}{c|} 
Ainda \\
repercute em \\
São Carlos os \\
efeitos dal \\
última \\
inundação
\end{tabular} & \begin{tabular}{|} 
Aproximadament \\
e $50 \mathrm{~cm}$ \\
(observação da \\
foto)
\end{tabular} & $\begin{array}{c}\text { "Daños no } \\
\text { património de } \\
\text { inúmeras casas } \\
\text { comerciais. Em uma } \\
\text { oficina na Rua } 9 \text { de } \\
\text { Julho seis carros } \\
\text { foram danificados. } \\
\text { Bombas de captação } \\
\text { de água no } \\
\text { Espraiado ficaram } \\
\text { seriamente } \\
\text { danificadas e o são- } \\
\text { carlense que reside } \\
\text { no centro ficou sem } \\
\text { água." }\end{array}$ & $\bar{x}$ & $\bar{x}$ & \begin{tabular}{|c|} 
Rua Nove de \\
Julho, Episcopal, \\
Bento Carlos, \\
General Osório e \\
Geminiano \\
Costa.
\end{tabular} & $\begin{array}{c}\text { Chuva que desabou } \\
\text { num verdadeiro } \\
\text { dilúvio causou } \\
\text { prejuizos que não } \\
\text { foram pequenos. }\end{array}$ \\
\hline $11 / 10 / 1972$ & A Folha & $10 / 10 / 1972$ & $\begin{array}{c}\text { Na primavera, } \\
\text { chuvas e } \\
\text { problemas. } \\
\text { Nas ruas, a } \\
\text { alegria das } \\
\text { crianças }\end{array}$ & $\bar{x}$ & $\begin{array}{c}\text { "Estouro de canos } \\
\text { de água" }\end{array}$ & $x$ & $x$ & $\begin{array}{c}\text { Ruas Episcopal, } \\
\text { Geminiano Costa } \\
\text { e General } \\
\text { Osório. }\end{array}$ & \begin{tabular}{|c|} 
Na confluência das \\
ruas Geminiano \\
Costa e Episcopal, \\
e General Osório e \\
Episcopal, \\
estouraram canos \\
d'água que \\
inundaram as \\
proximidades
\end{tabular} \\
\hline
\end{tabular}




\begin{tabular}{|c|c|c|c|c|c|c|c|c|c|}
\hline $6 / 2 / 1973$ & A Folha & $4 / 2 / 1973$ & \begin{tabular}{|c|} 
Inundaçס̄es, \\
Desabamento \\
s e Prejuizos \\
com as \\
violentas \\
chuvas de \\
domingo
\end{tabular} & $\bar{x}$ & $\begin{array}{l}\text { "Aguas levaram } \\
\text { pedras de } \\
\text { calçamento, } \\
\text { levantamento de } \\
\text { trechos de asfalto, } \\
\text { desabamento de } \\
\text { muros, carro } \\
\text { arrastado na Rua } \\
\text { Episcopal no } \\
\text { cruzamento com a } \\
\text { Rua Santa Cruz. } \\
\text { Desabamento de } \\
\text { Muro da Fepasa. } \\
\text { Duas casas da } \\
\text { Lagoa Serena } \\
\text { ficaram totalmente } \\
\text { alagadas." }\end{array}$ & $x$ & $\begin{array}{c}17: 55 \text { até } 23: 30 \text { (inicio } \\
\text { e término das } \\
\text { chamadas no corpo } \\
\text { de bombeiros da } \\
\text { cidade). }\end{array}$ & \begin{tabular}{|c|} 
Baixada da \\
cidade e \\
periferia. Rua \\
Episcopal, Lagoa \\
Serena, Asilo, \\
FEPASA, Rua \\
Jesuino de \\
Arruda, Rua \\
Visconde e Treze \\
de Maio, esquina \\
com Rui \\
Barbosa. \\
\end{tabular} & \begin{tabular}{|c|}
$\mathrm{Na}$ baixada as \\
águas subiram \\
assustadoramente \\
alagando, levando \\
pedras de \\
calçamento e \\
levantando trechos \\
de asfalto. $\mathrm{Na}$ \\
periferia houve \\
desabamento de \\
muros e \\
inundaçठ̄es.
\end{tabular} \\
\hline $21 / 2 / 1973$ & A Folha & $20 / 2 / 1973$ & $\begin{array}{l}\text { Chuvas } \\
\text { causam } \\
\text { estragos }\end{array}$ & $\bar{x}$ & $\begin{array}{c}\text { "Vários estragos na } \\
\text { baixada" }\end{array}$ & $x$ & $x$ & $\begin{array}{l}\text { Baixada do } \\
\text { Mercado }\end{array}$ & $\begin{array}{c}\text { Chuvas causaram } \\
\text { vários estragos na } \\
\text { baixada do } \\
\text { mercado com } \\
\text { sensivel queda no } \\
\text { comercio }\end{array}$ \\
\hline $13 / 1 / 1974$ & A Folha & $11 / 1 / 1974$ & $\begin{array}{c}\text { As chuvas } \\
\text { continuam e } \\
\text { com elas os } \\
\text { estragos. }\end{array}$ & $\bar{X}$ & \begin{tabular}{|c|} 
"Estragos nas \\
estradas de terra. No \\
campo o problema \\
são as erosð̋es. Na \\
cidade os canos de \\
esgotos entupidos \\
que causam \\
enchentes nos \\
lugares baixos."
\end{tabular} & $\bar{x}$ & $\bar{x}$ & \begin{tabular}{|c|} 
Centro. Mercado \\
municipal. \\
Córrego do \\
Gregório. Săo \\
Carlos. \\
\end{tabular} & \begin{tabular}{|c|} 
As chuvas que \\
cairam sobre a \\
cidade de São \\
Carlos e região no \\
final de semana \\
trouxeram muitos \\
problemas no \\
campo, assim \\
como na cidade.
\end{tabular} \\
\hline
\end{tabular}




\begin{tabular}{|c|c|c|c|c|c|c|c|c|c|}
\hline $14 / 9 / 1976$ & A Folha & $13 / 9 / 1976$ & $\begin{array}{c}\text { Vendaval em } \\
\text { Săo Carlos } \\
\text { causa } \\
\text { destruiçãao. }\end{array}$ & $x$ & \begin{tabular}{|c|} 
"Carros foram \\
levados pelas águas. \\
As obras de \\
canalização do \\
Córrego do Gregório \\
sofreram destruição \\
total. Incêndio em \\
uma residência."
\end{tabular} & $50 \mathrm{~min}$. & $x$ & $\begin{array}{l}\text { Regiåo do } \\
\text { Mercado } \\
\text { Municipal. } \\
\qquad\end{array}$ & \begin{tabular}{|c|} 
A cidade ficou \\
inundada \\
parcialmente, e os \\
prejuizos são \\
considerados \\
elevados. Os \\
ventos fortes que \\
se misturavam às \\
chuvas causaram \\
vendaval. O Corpo \\
de bombeiros teve \\
que auxiliar a varias \\
que se \\
encontravam em \\
situação de perigo \\
durante e depois do \\
temporal.
\end{tabular} \\
\hline $15 / 9 / 1976$ & A Folha & $13 / 9 / 1976$ & \begin{tabular}{|c|} 
Muita lama e \\
madeira pelas \\
ruas na \\
manhã cle \\
ontem. E \\
agora?
\end{tabular} & $\begin{array}{l}\text { Cerca de } 25 \mathrm{~cm} \\
\text { (aferido por } \\
\text { observação de } \\
\text { foto) }\end{array}$ & $\begin{array}{l}\text { "Incêndio em uma } \\
\text { residência. A lama } \\
\text { invade as } \\
\text { dependências das } \\
\text { lojas. Prejuizos de } \\
\text { milhares de } \\
\text { Cruzeiros." }\end{array}$ & $\bar{x}$ & $x$ & $\begin{array}{l}\text { Região do } \\
\text { Mercado } \\
\text { Municipal. }\end{array}$ & $\begin{array}{c}\text { Prefeitura municipal } \\
\text { iniciou a limpeza do } \\
\text { centro comercial da } \\
\text { cidade. Muita lama } \\
\text { e madeira } \\
\text { predominantemente } \\
\text { como resultado da } \\
\text { enchente } \\
\text { provocada pela } \\
\text { forte chuva. Os } \\
\text { prejuizos segundo } \\
\text { comerciantes } \\
\text { chegam a milhares } \\
\text { de cruzeiros. }\end{array}$ \\
\hline
\end{tabular}




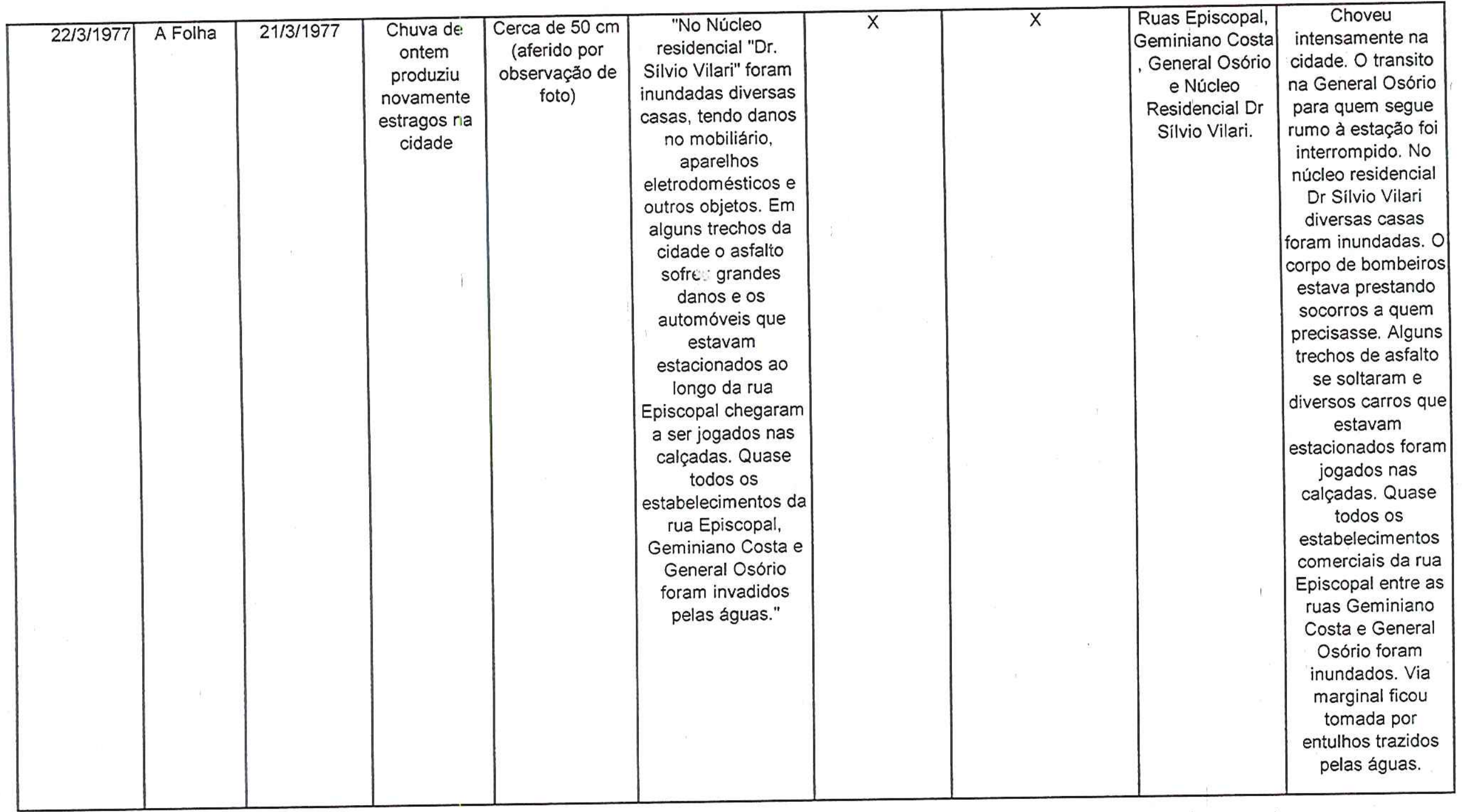




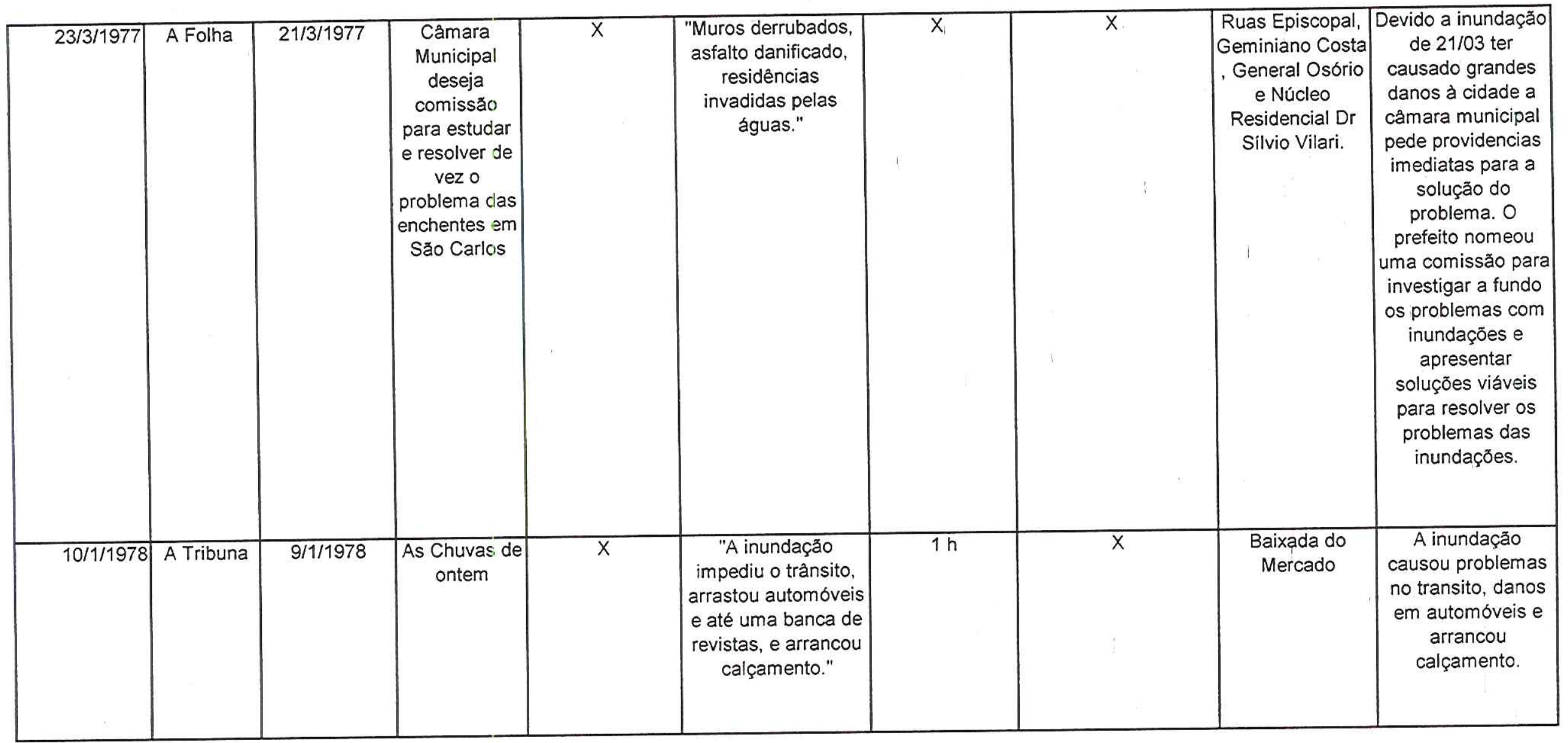




\begin{tabular}{|c|c|c|c|c|c|c|c|c|c|}
\hline $5 / 3 / 1981$ & $\begin{array}{l}\text { O Correio } \\
\text { de São } \\
\text { Carlos. }\end{array}$ & $4 / 3 / 1981$ & $\begin{array}{c}\text { Chuvas } \\
\text { provocam } \\
\text { estragos na } \\
\text { cidade. }\end{array}$ & $x$ & $\begin{array}{c}\text { Uma casa desabou e } \\
\text { pelo menos nove } \\
\text { outras foram } \\
\text { destelhadas e } \\
\text { danificadas. Um raio } \\
\text { provocou a queda de } \\
\text { um grande tronco de } \\
\text { arvore sobre a } \\
\text { avenida dos } \\
\text { Trabalhadores. }\end{array}$ & $x$ & $\bar{x}$ & $x^{x}$ & $\begin{array}{c}\text { As fortes chuvas } \\
\text { que cairam a tarde } \\
\text { provocaram uma } \\
\text { serie de estragos } \\
\text { na cidade, mas } \\
\text { nenhum dos } \\
\text { acidentes fez } \\
\text { vitimas. }\end{array}$ \\
\hline $28 / 1 / 1987$ & A Folha & $27 / 1 / 1987$ & $\begin{array}{c}\text { Chuvas } \\
\text { inundam lojas } \\
\text { e o rio } \\
\text { transborda }\end{array}$ & $x$ & \begin{tabular}{|c|} 
"O muro da FEPASA \\
caiu sobre a linha \\
férrea. O córrego do \\
Gregório devido ao \\
grande fluxo de \\
águas transbordou \\
causando inundação \\
em varias lojas da \\
baixada do \\
mercado."
\end{tabular} & $x$ & $x$ & $\begin{array}{l}\text { Centro de São } \\
\text { Carlos. }\end{array}$ & $\begin{array}{c}\text { O muro da } \\
\text { FEPASA caiu sobre } \\
\text { a linha férrea. O } \\
\text { córrego do } \\
\text { Gregório devido ao } \\
\text { grande fluxo de } \\
\text { aguas transbordou } \\
\text { causando } \\
\text { inundação em } \\
\text { varias lojas da } \\
\text { baixada do } \\
\text { mercado. O Corpo } \\
\text { de Bombeiros de } \\
\text { São Carlos atendeu } \\
\text { por volta de } 27 \\
\text { ocorrências. }\end{array}$ \\
\hline
\end{tabular}




\begin{tabular}{|c|c|c|c|c|c|c|c|c|c|}
\hline $12 / 1 / 1988$ & A Folha & $10 / 1 / 1988$ & $\begin{array}{c}\text { Tromba } \\
\text { d'água causa } \\
\text { estragos ria } \\
\text { cidade }\end{array}$ & $x$ & $\begin{array}{c}\text { "Queda do Muro do } \\
\text { Colégio São Carlos, } \\
\text { do Estádio da } \\
\text { Educação Fisica e } \\
\text { muro de arrimo do } \\
\text { posto Presidente que } \\
\text { desabou quatro } \\
\text { casas na colônia do } \\
\text { Galdino. Na baixada } \\
\text { do mercado várias } \\
\text { lojas sofreram danos } \\
\text { materiais com a } \\
\text { invasão das águas e } \\
\text { barro." }\end{array}$ & $2 \mathrm{~h}$ & $x$ & \begin{tabular}{|c|} 
Colônia do \\
Galdino, Baixada \\
do Mercado e \\
calçadåo da \\
general.
\end{tabular} & \begin{tabular}{|} 
Danos caudados na \\
cidade após chuva \\
de $10 / 01 / 1988$. \\
Corpo de \\
Bombeiros atendeu \\
45 chamadas de \\
urgência.
\end{tabular} \\
\hline $3 / 1 / 1990$ & A Tribuna & $\bar{x}$ & $\begin{array}{c}\text { Chuvas fazem } \\
\text { estragos na } \\
\text { cidade. }\end{array}$ & $x$ & \begin{tabular}{|c|} 
"Bairıs ficaram \\
intransitáveis. Muro \\
cai sobre uma casa. \\
As águas invadiram \\
as casas comerciais, \\
destruindo grande \\
quantidade de \\
mercadorias. Carros \\
foram arrastados \\
pela força das \\
águas."
\end{tabular} & $\bar{x}$ & $x$ & $\begin{array}{l}\text { Região do } \\
\text { Mercado } \\
\text { Municipal. }\end{array}$ & \begin{tabular}{|c|} 
As pesadas chuvas \\
que tem caído \\
sobre São Carlos e \\
região estão \\
causando danos \\
em varias partes da \\
cidade. O calçadão \\
e varias ruas \\
ficaram alagadas.
\end{tabular} \\
\hline
\end{tabular}




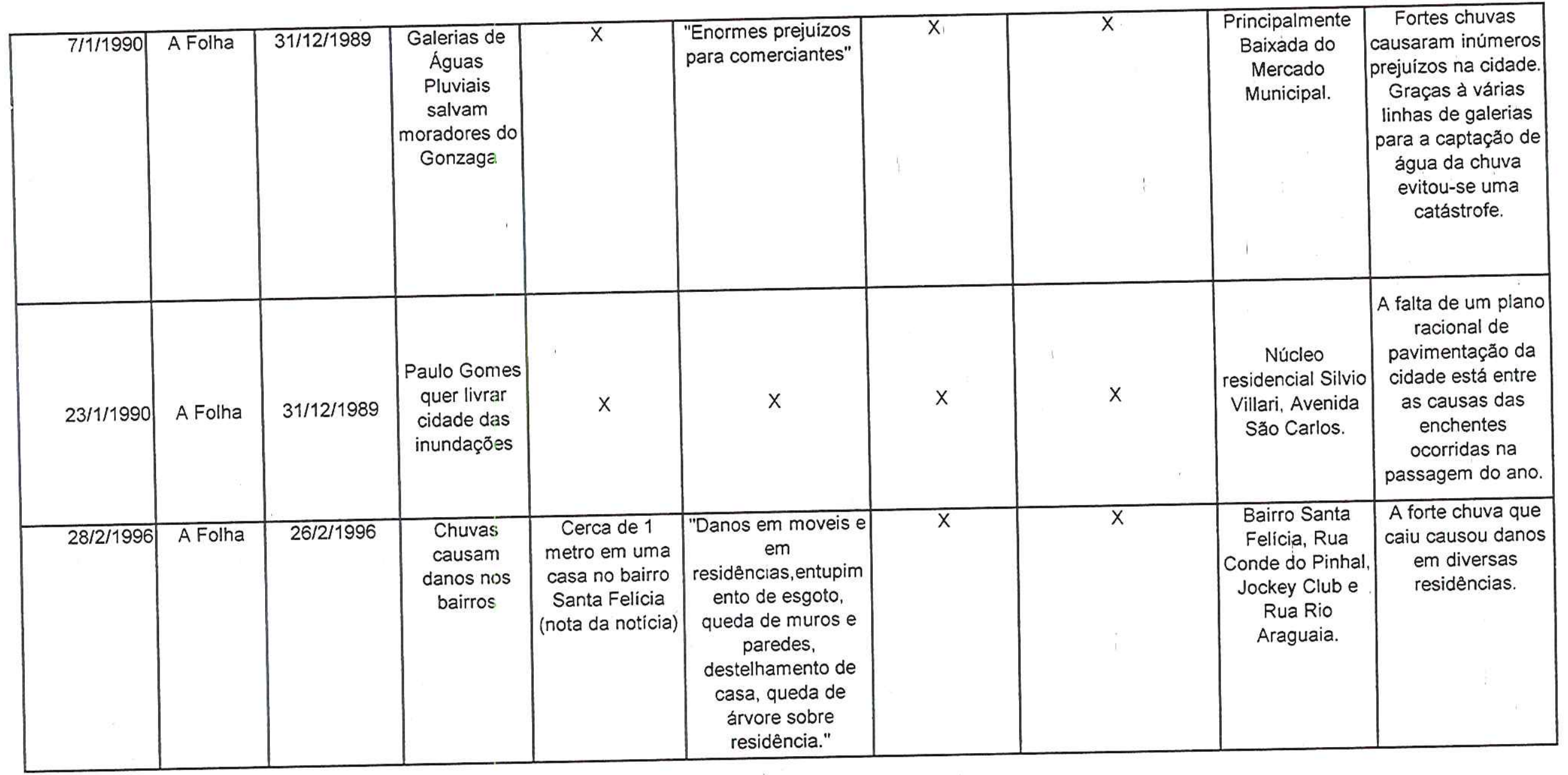




\begin{tabular}{|c|c|c|c|c|c|c|c|c|c|}
\hline $28 / 12 / 1997$ & A Folha & $24 / 12 / 1997$ & \begin{tabular}{|l|} 
São Carlos \\
surpreendida \\
no Natal com \\
vendaval \\
mortes
\end{tabular} & $x$ & $\begin{array}{c}\text { "Queda de árvores } \\
\text { em praças, } \\
\text { transformadores de } \\
\text { energia queimados." }\end{array}$ & $\bar{x}$ & $\bar{x}$ & $\begin{array}{l}\text { Baixada do } \\
\text { Mercado }\end{array}$ & $\begin{array}{c}\text { Forte chuva que } \\
\text { caiu sobre a } \\
\text { cidadepor volta das } \\
21 \mathrm{~h} 30 \text { causou } \\
\text { queda de árvores } \\
\text { em praças, } \\
\text { queimando } \\
\text { transformadores de } \\
\text { energia. Carros } \\
\text { ficaram ilhados na } \\
\text { avenida São } \\
\text { Carlos. }\end{array}$ \\
\hline
\end{tabular}




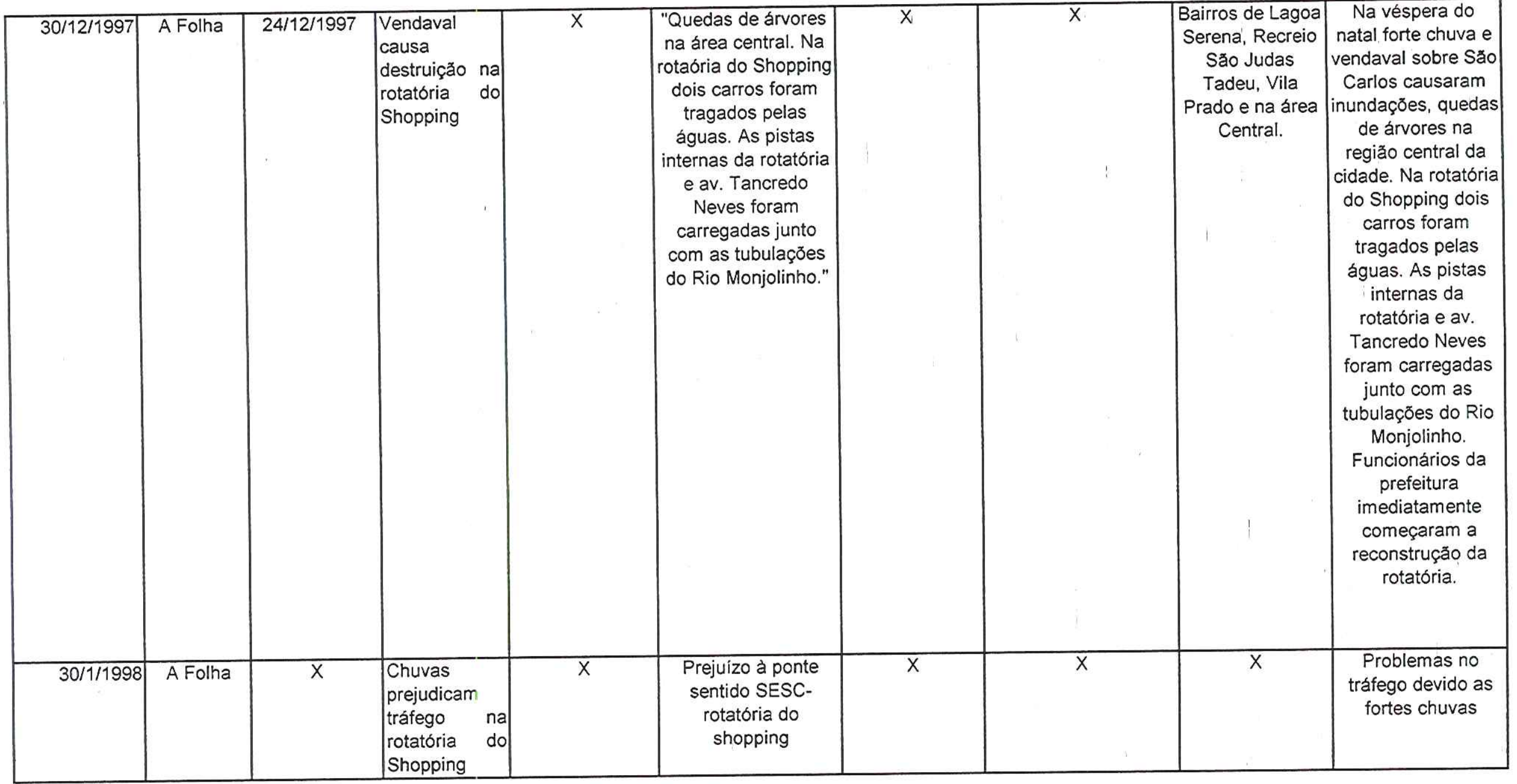




\begin{tabular}{|c|c|c|c|c|c|c|c|c|c|}
\hline $26 / 2 / 1998$ & A Folha & $20 / 2 / 1998$ & $\begin{array}{|ll|}\text { Feriado } & \\
\text { trágico } & \text { na } \\
\text { cidade } & \\
\end{array}$ & $x$ & $\begin{array}{l}\text { Grande buraco na } \\
\text { Av. Trabalhador } \\
\text { Sancarlense, } \\
\text { rotatória do Cristo } \\
\text { Abalada. }\end{array}$ & $x$ & $x$ & $\bar{x}$ & $\begin{array}{l}\text { Devido as fortes } \\
\text { chuvas ocorreram } \\
\text { muitos danos na } \\
\text { cidade } \\
\text { (principalmente na } \\
\text { baixada do } \\
\text { mercado } \\
\text { municipal). A } \\
\text { rotatória do Cristo } \\
\text { novamente foi } \\
\text { abalada. }\end{array}$ \\
\hline $26 / 2 / 1998$ & A Folha & $20 / 2 / 1998$ & $\begin{array}{|lr|}\text { Temporal } & \\
\text { Atinge } & \text { São } \\
\text { Carlos e deixa } \\
\text { um rastro de } \\
\text { destruição }\end{array}$ & $\begin{array}{c}1 \text { metro (citado } \\
\text { na noticia) }\end{array}$ & $\begin{array}{c}\text { "Prejuizos em lojas } \\
\text { nas prc "midades do } \\
\text { mercado municipal } \\
\text { (principalmente lojas } \\
\text { de calçados e } \\
\text { roupas), carros e } \\
\text { motos arrastados } \\
\text { pela forte enxurrada; } \\
\text { muros arrancados } \\
\text { pela força da água; } \\
\text { parte do asfalto no } \\
\text { cruzamento da rua } \\
\text { Geminiano Costa } \\
\text { com Dom Pedro II } \\
\text { foi arrancado." }\end{array}$ & Cerca de 1 hora & 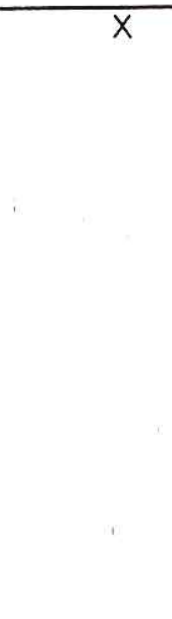 & \begin{tabular}{|c|} 
Baixada do \\
mercado; Av. \\
Comendador \\
Alfredo Mafei; Jd. \\
Paraiso; Av. \\
Trabalhador \\
Sancarlense
\end{tabular} & \begin{tabular}{|c|} 
Fortes chuvas \\
inundaram grande \\
parte da baixada. \\
Muitas lojas tiveram \\
grandes prejuizos \\
sendo que em \\
algumas houve \\
perda total. Carros \\
e motos foram \\
arrastados pela \\
força das águas. \\
Várias ruas foram \\
interditadas. \\
\end{tabular} \\
\hline
\end{tabular}




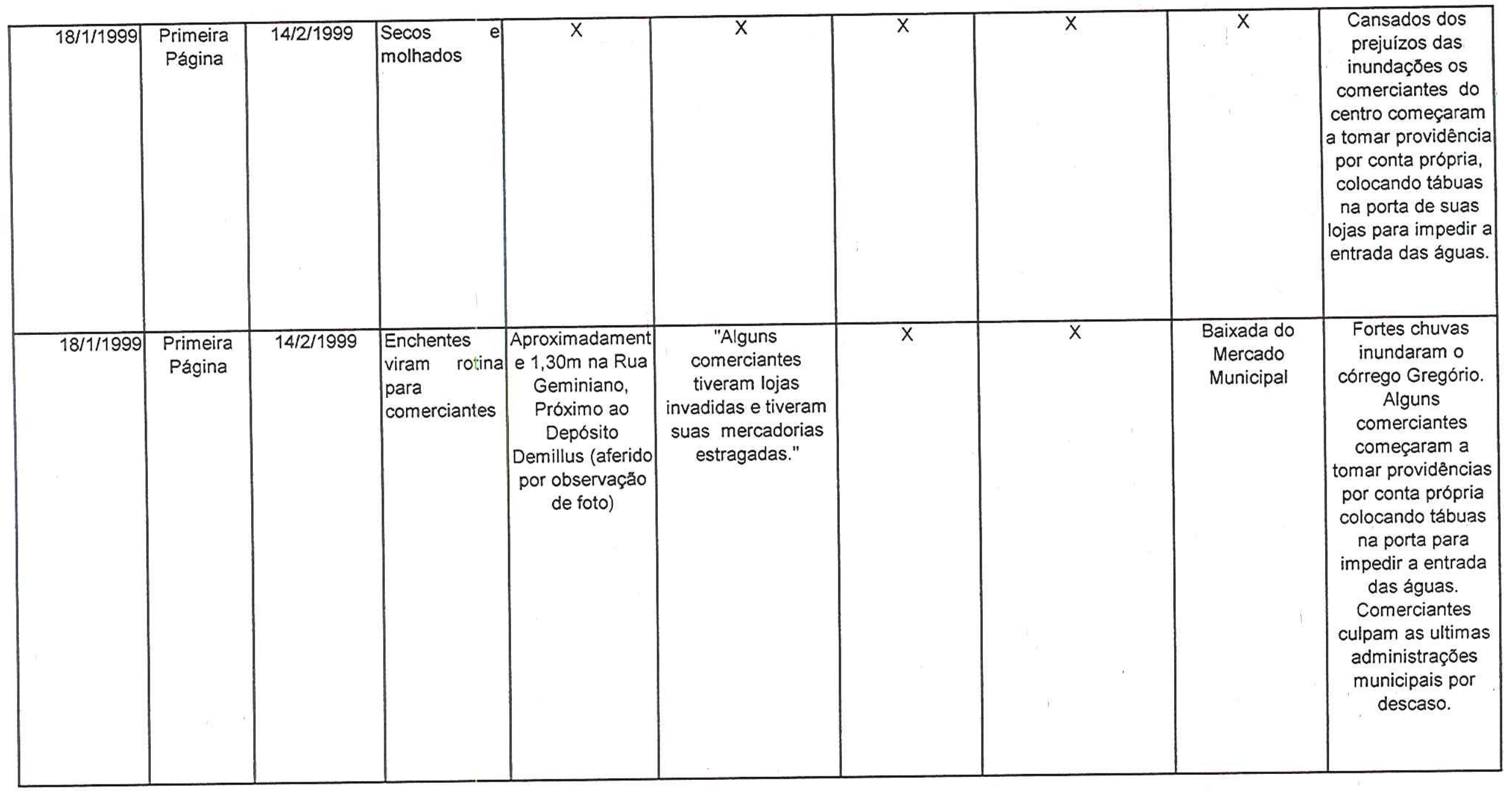




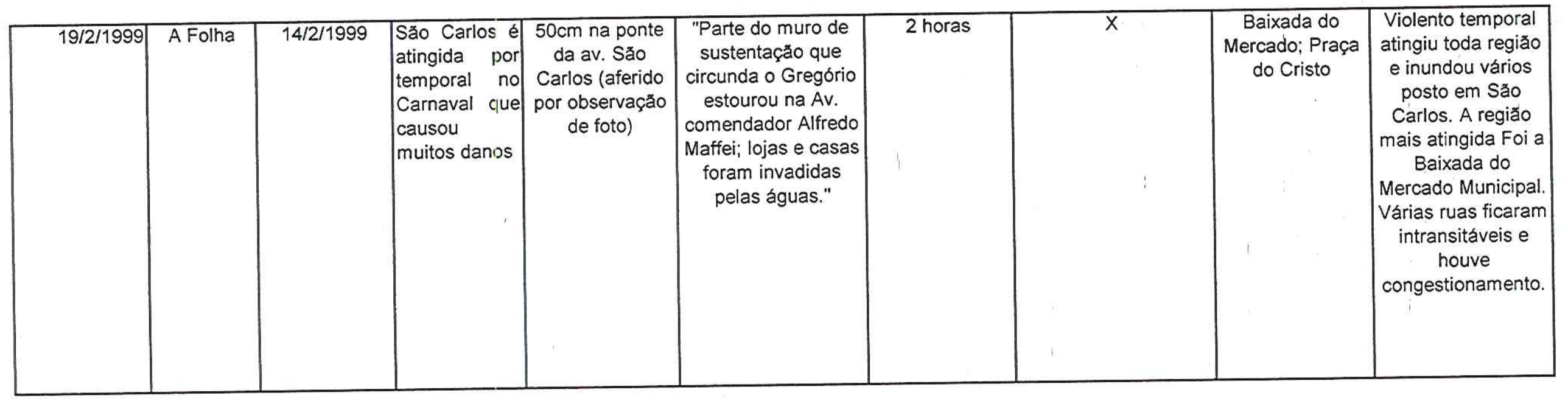




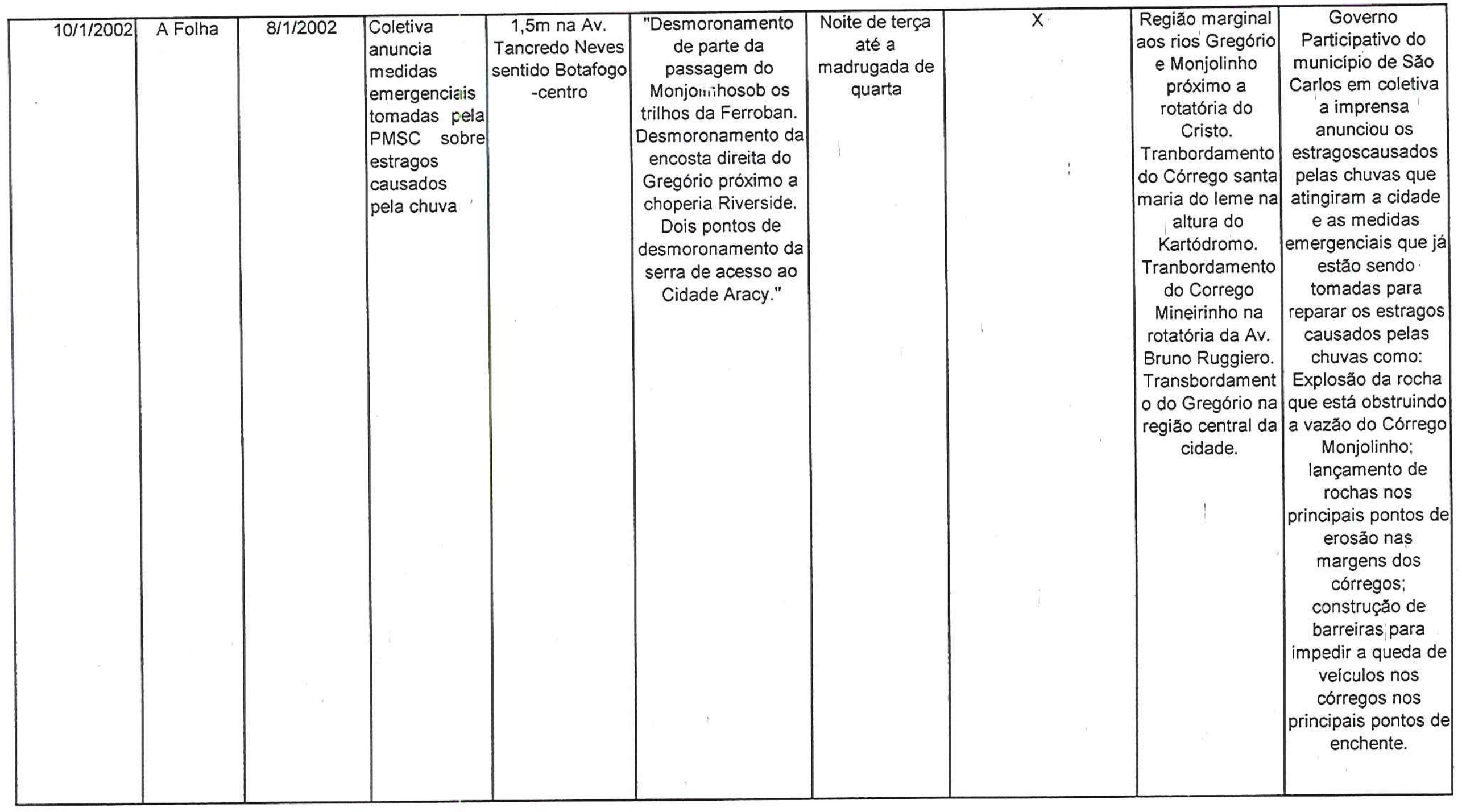




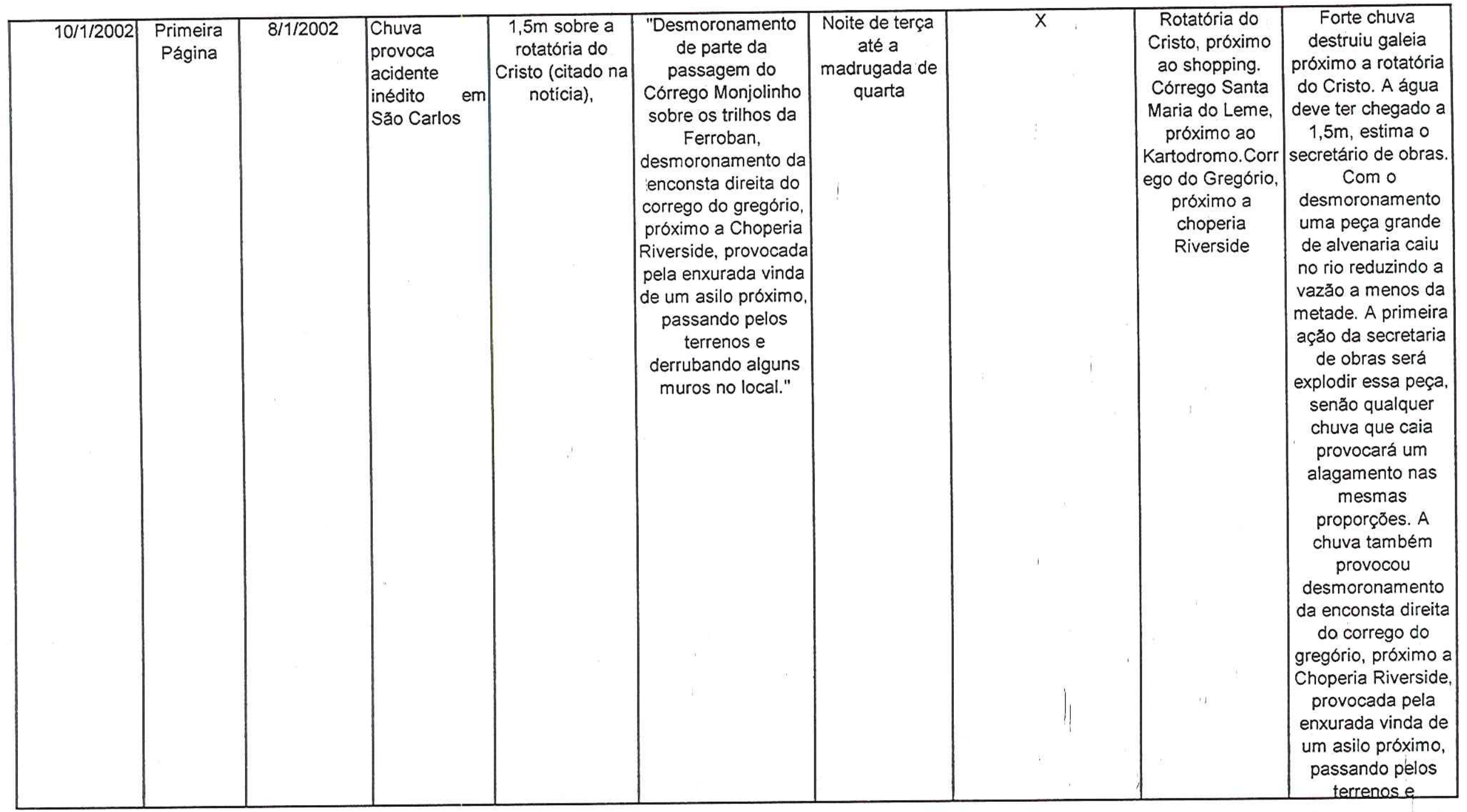




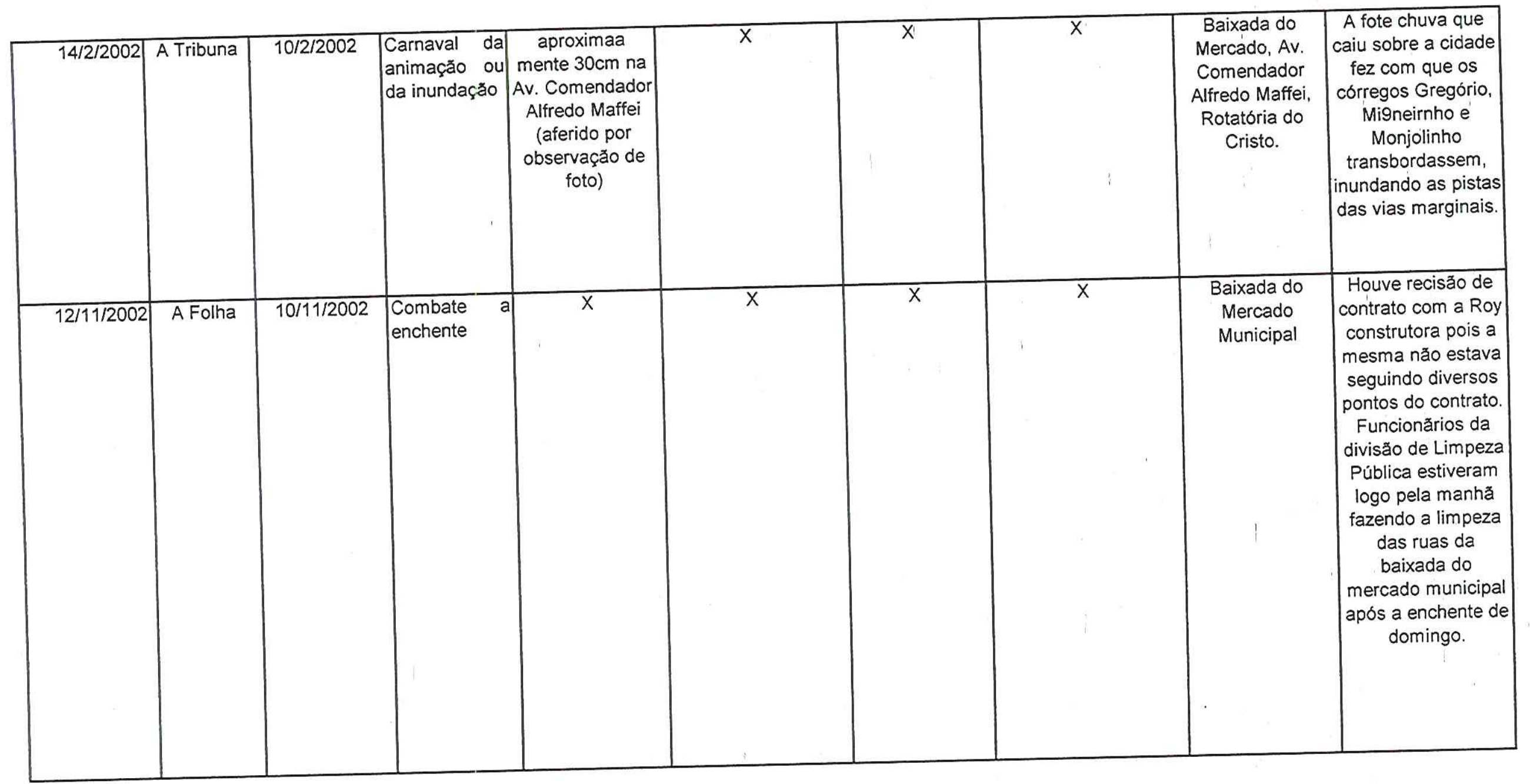




\begin{tabular}{|c|c|c|c|c|c|c|c|c|c|}
\hline $12 / 11 / 2002$ & $\begin{array}{c}\text { Primeira } \\
\text { Página }\end{array}$ & $10 / 11 / 2002$ & \begin{tabular}{|l|} 
Chuvas \\
atormentam \\
comerciantes \\
da baixada \\
\end{tabular} & \begin{tabular}{|c|} 
marcas na \\
parede de $20 \mathrm{~cm}$ \\
na padaria \\
Caiçara.
\end{tabular} & $\begin{array}{c}\text { "Prejuízo dos } \\
\text { comerciantes } \\
\text { próximos à obra." }\end{array}$ & $x$ & & $\begin{array}{l}\text { Baixada do } \\
\text { Mercado } \\
\text { Municipal }\end{array}$ & \begin{tabular}{|c|} 
As fotes chuvas \\
inundaram a regiăo \\
do mercado \\
municipal. O fato \\
foi agravado porque \\
a obra de \\
contenção de \\
enchentes está \\
parada. Há \\
possibilidade de \\
desmoronamento \\
das encostas ainda \\
não asfaltadas
\end{tabular} \\
\hline
\end{tabular}




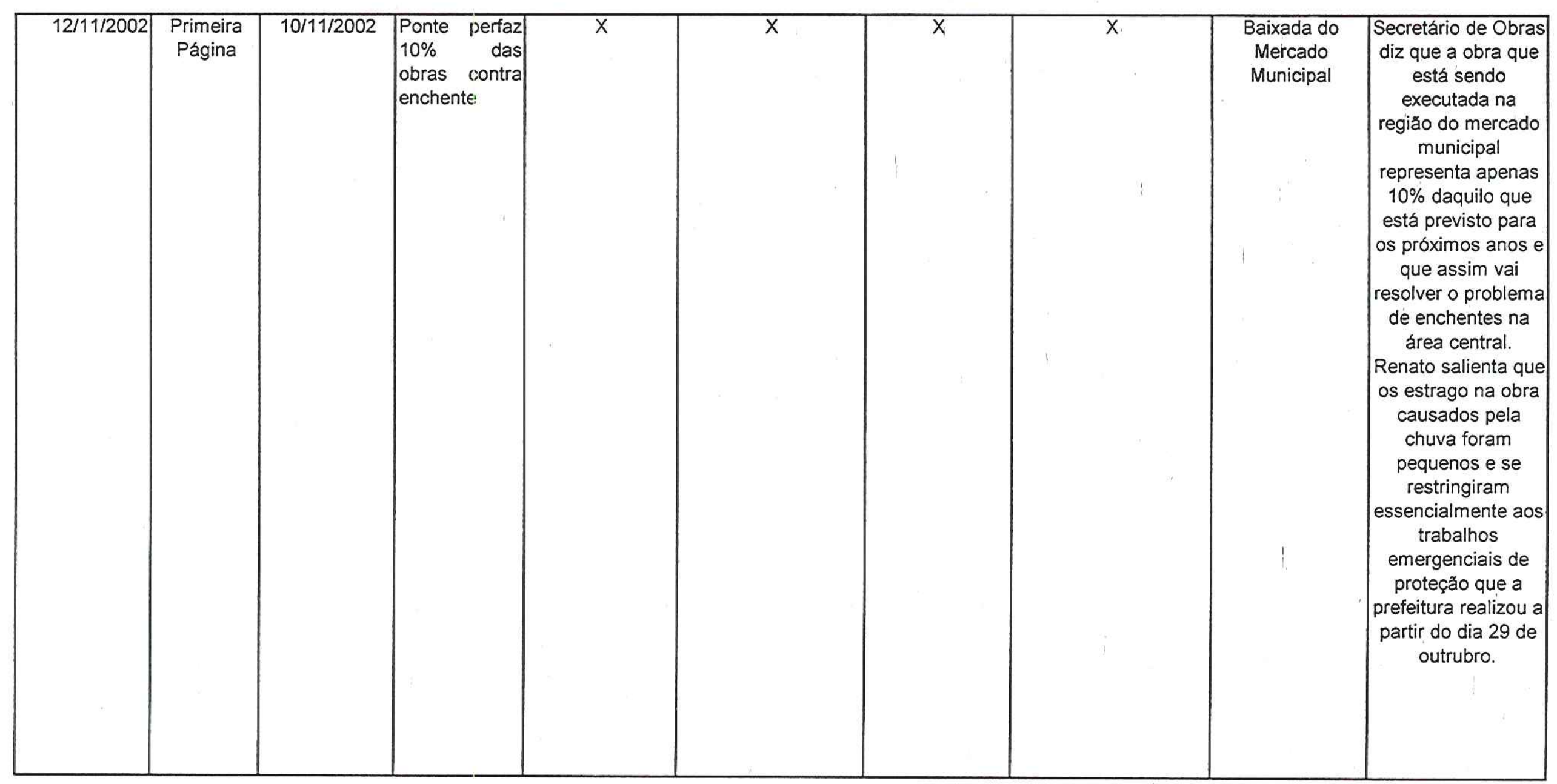




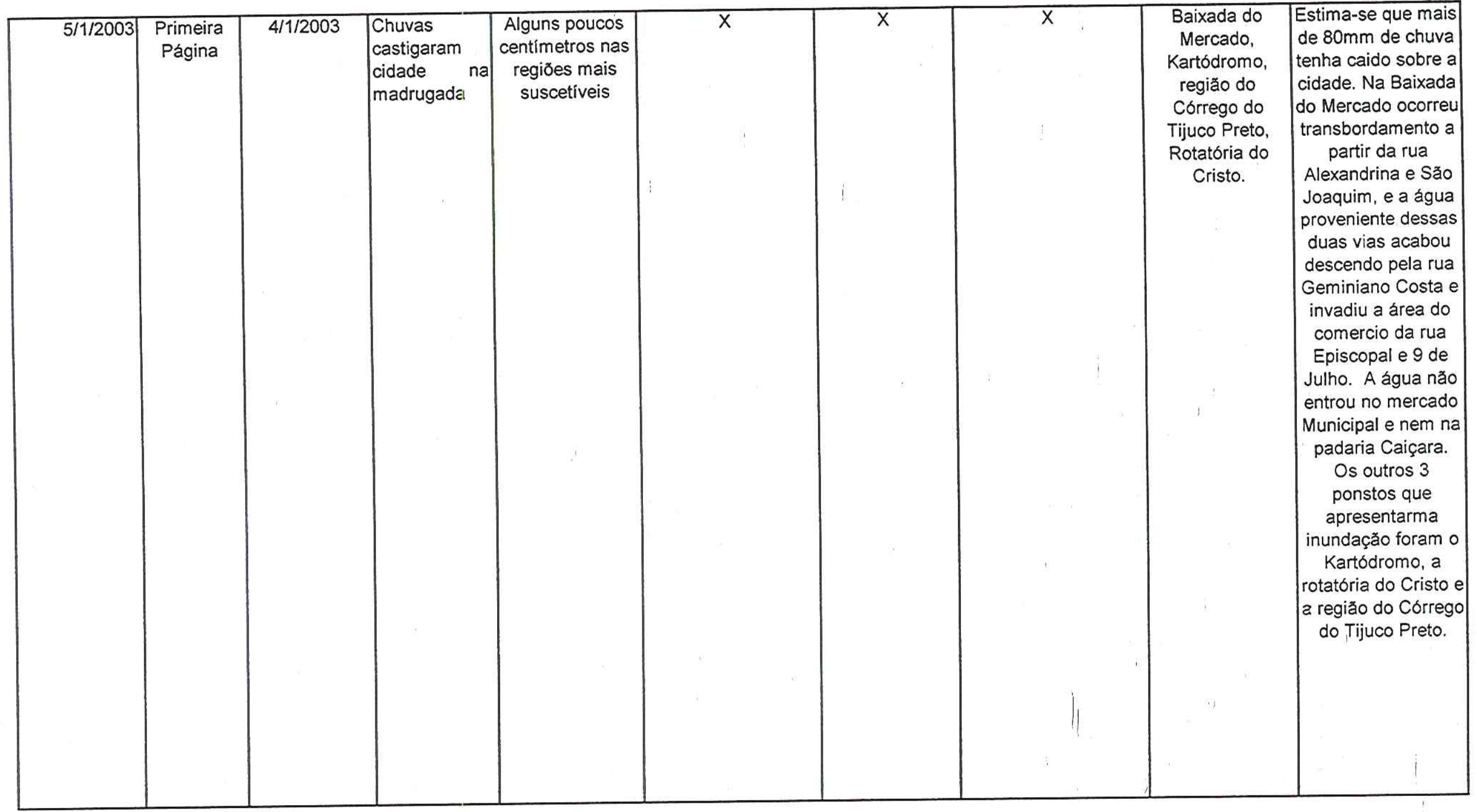




\begin{tabular}{|c|c|c|c|c|c|c|c|c|c|}
\hline $5 / 1 / 2003$ & $\begin{array}{l}\text { Primeira } \\
\text { Página }\end{array}$ & $4 / 1 / 2003$ & 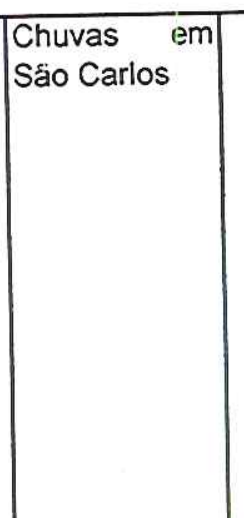 & $\bar{x}$ & $x$ & $x$ & $\bar{x}$ & $\begin{array}{l}\text { Baixada do } \\
\text { Mercado, } \\
\text { Kartódromo, } \\
\text { regiåo do } \\
\text { Córrego do } \\
\text { Tijuco Preto, } \\
\text { Rotatória do } \\
\text { Cristo. } \\
\end{array}$ & \begin{tabular}{|c|} 
A estimativa é que \\
mais de $80 \mathrm{~mm}$ de \\
chuiva tenha caido \\
sobre a cidade na \\
madrugada. Houve \\
alagamento na \\
baixada do \\
Mercado, porém \\
sem inundar as \\
lojas, nas regiões \\
do kartódromo, \\
rotatória do Cristo e \\
Tijuco Preto.
\end{tabular} \\
\hline $31 / 1 / 2004$ & $\begin{array}{l}\text { Primeira } \\
\text { página }\end{array}$ & $30 / 1 / 2004$ & $\begin{array}{|lr|}\text { Chuva inunda } \\
\text { obra } & \text { de } \\
\text { Newton } & \text { na } \\
\text { baixada } & \end{array}$ & $\begin{array}{c}50 \mathrm{~cm} \text { (aferido } \\
\text { por observação } \\
\text { de foto) }\end{array}$ & $x$ & 1 hora e meia & $x$ & $\begin{array}{l}\text { Baixada do } \\
\text { Mercado }\end{array}$ & \begin{tabular}{|c|} 
Chuvas inundaram \\
a região do \\
Mercado Municipal \\
e a Rotatória \\
próxima ao \\
Shopping. Bastou a \\
primeira Chuva \\
forte para levar por \\
água abaixo a \\
promessa do \\
prefeito Newton \\
Lima de resolver o \\
problema da \\
enchente no \\
mercado municipal.
\end{tabular} \\
\hline
\end{tabular}




\begin{tabular}{|c|c|c|c|c|c|c|c|c|c|}
\hline $31 / 1 / 2004$ & $\begin{array}{l}\text { Primeira } \\
\text { página }\end{array}$ & $30 / 1 / 2004$ & $\mid \begin{array}{lr}\text { Alckmin } & \\
\text { chega } & \text { em } \\
\text { São } & \text { Carlos } \\
\text { junto } & \text { com } \\
\text { enchente } & \end{array}$ & $\begin{array}{c}\text { mais de } 1 \text { metro } \\
\text { (mencionado na } \\
\text { noticia) }\end{array}$ & $\begin{array}{c}\text { "Prejuizos em lojas, } \\
\text { Carros arrastados } \\
\text { pela correnteza" }\end{array}$ & $\begin{array}{c}\text { por volta de } 1 \\
\text { hora }\end{array}$ & mais de $30 \mathrm{~min}$ & $\begin{array}{l}\text { Baixada do } \\
\text { Mercado } \\
\text { Municipal }\end{array}$ & $\begin{array}{c}\text { Governador } \\
\text { Geraldo Alkimin } \\
\text { Chegou em São } \\
\text { Carlos Junto com } \\
\text { as Chuvas que } \\
\text { inundaram a } \\
\text { baixada do } \\
\text { mercado municipal. } \\
\text { A água começou a } \\
\text { subir rapidamente e } \\
\text { nem as placas } \\
\text { colocadas nas } \\
\text { portas das lojas } \\
\text { conseguiram conte- } \\
\text { la. }\end{array}$ \\
\hline $31 / 1 / 2004$ & A Tribuna & $30 / 1 / 2004$ & $\begin{array}{l}\text { Temporal } \\
\text { Atinge São } \\
\text { Carlos }\end{array}$ & $x$ & $x$ & $x$ & $x$ & $\begin{array}{l}\text { Baixada do } \\
\text { Mercado, } \\
\text { Rotatória do } \\
\text { Shopping }\end{array}$ & \begin{tabular}{|c|} 
As fortes chuvas \\
que cairam sobre \\
Såo Carlos \\
deixaram um rastro \\
de destruição. \\
Prefeito Newton \\
Lima Neto disse \\
que agora não tem \\
como o governo do \\
estado deixar de \\
liberar recursos \\
para a conlusão de \\
todo projeto contra \\
enchentes \\
elaborado pela \\
administração \\
minicipal.
\end{tabular} \\
\hline
\end{tabular}




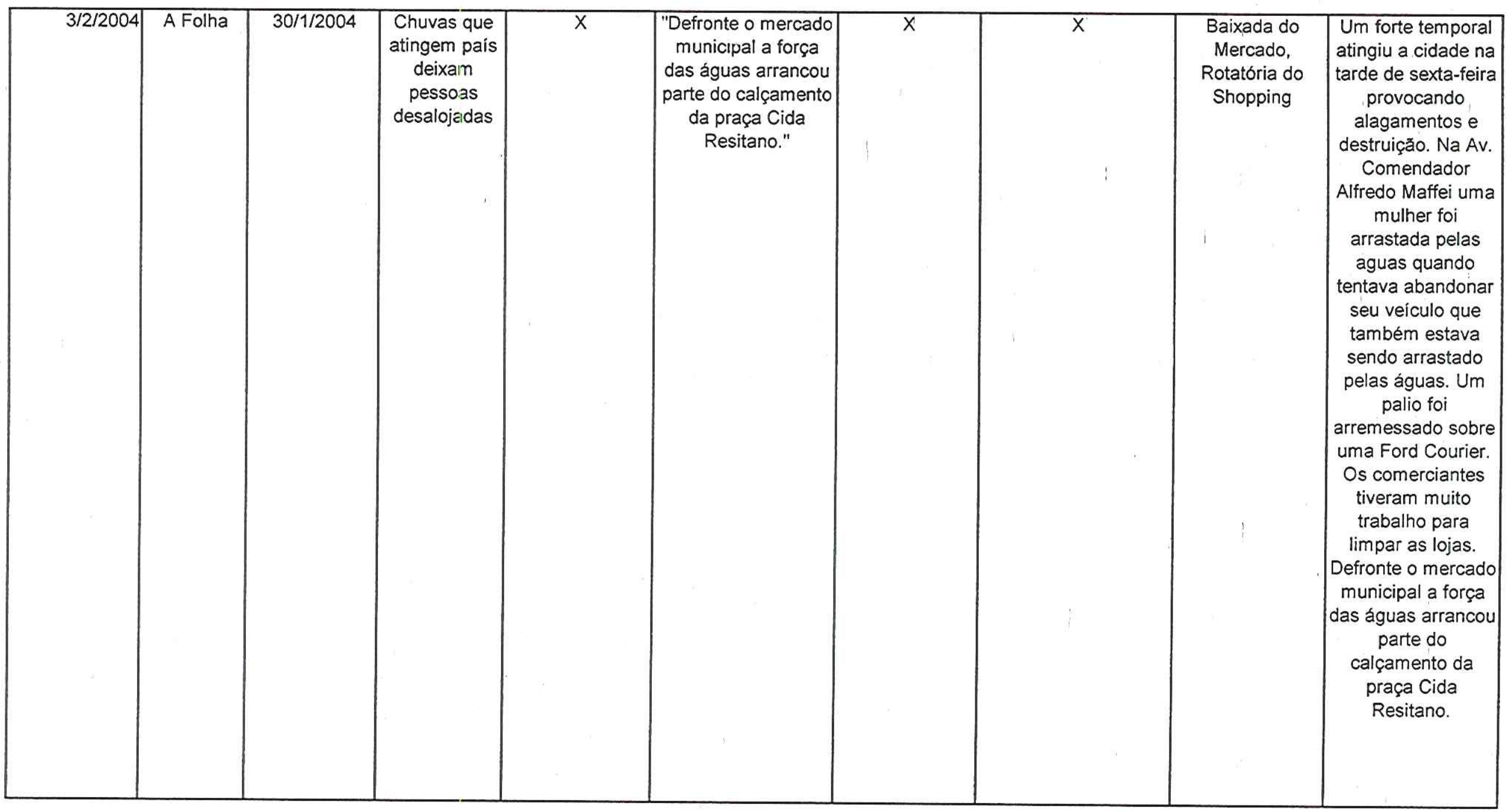




\begin{tabular}{|c|c|c|c|c|c|c|c|c|c|}
\hline $3 / 2 / 2004$ & Primeira Pá & $30 / 1 / 2004$ & \begin{tabular}{|l|} 
\\
\\
Obras \\
recuperam \\
estragos \\
causados por \\
temporal
\end{tabular} & $x$ & $\begin{array}{c}\text { Canos e tubulaçōes } \\
\text { antigos da galeria } \\
\text { localizados na Av. } \\
\text { São Carlos cederam } \\
\text { com a chuva. Na } \\
\text { Rua Episcopal houve } \\
\text { rompimento da rede } \\
\text { de esgoto. Em frete } \\
\text { ao mercado, a forte } \\
\text { chuva arrancou os } \\
\text { bloquetes da praça } \\
\text { construida no fim do } \\
\text { ano. }\end{array}$ & $1 \mathrm{~h}$ & $x$ & $x$ & $\begin{array}{c}\text { A prefeitura } \\
\text { interditou a av. são } \\
\text { Carlos e a Rua } \\
\text { Episcopal, no } \\
\text { trecho } \\
\text { compreendido } \\
\text { pelas Ruas } \\
\text { Geminiano costa e } \\
\text { General Osório, } \\
\text { para obra de } \\
\text { recuperação de } \\
\text { galeria e tubulação } \\
\text { atingidos pela } \\
\text { chuva que inundou } \\
\text { parte da região } \\
\text { central, próximo a } \\
\text { baixada do } \\
\text { mercado. }\end{array}$ \\
\hline $3 / 2 / 2004$ & Primeira Pá & $30 / 1 / 2004$ & \begin{tabular}{|l} 
Obras \\
reparam \\
estragos \\
chuva de \\
feira
\end{tabular} & $x$ & $x$ & $x$ & $x$ & $x$ & $\begin{array}{c}\text { Para recuperar } \\
\text { galeria e tubulação } \\
\text { atingidos pelo forte } \\
\text { temporal da ultima } \\
\text { sexta feira que } \\
\text { inundou parte da } \\
\text { região central, } \\
\text { prefeitura e SAAE } \\
\text { trabalharam ontem } \\
\text { no local. }\end{array}$ \\
\hline
\end{tabular}




\begin{tabular}{|c|c|c|c|c|c|c|c|c|c|}
\hline $16 / 12 / 2004$ & $\begin{array}{l}\text { Primeira } \\
\text { Página }\end{array}$ & $15 / 12 / 2004$ & $\begin{array}{c}\text { Temporal } \\
\text { assusta, mas } \\
\text { não causa } \\
\text { estragos na } \\
\text { cidade? }\end{array}$ & $x$ & $\bar{x}$ & $30 \mathrm{~min}$ & $\mathrm{X}$ & Gregório & \begin{tabular}{|c|} 
Rápido aumento no \\
volume de água no \\
córrego do \\
Gregório após \\
chuva de meia hora \\
assusta moradores \\
e comerciantes. \\
Segundo corpo de \\
bombeiros \\
nenhuma \\
ocorrência grave foi \\
registrada.
\end{tabular} \\
\hline $16 / 12 / 2004$ & $\begin{array}{l}\text { Primeira } \\
\text { Página }\end{array}$ & $15 / 12 / 2004$ & $\begin{array}{l}\text { Temporal de } \\
\text { meia hora } \\
\text { assusta } \\
\text { moradores da } \\
\text { cidade }\end{array}$ & $x$ & $\bar{x}$ & $30 \mathrm{~min}$. & $x$ & Gregório & $\begin{array}{c}\text { Queda de algumas } \\
\text { árvores, inundação } \\
\text { de algumas ruas e } \\
\text { rápido aumento do } \\
\text { nivel de água } \\
\text { devido a forte } \\
\text { chuva. }\end{array}$ \\
\hline $20 / 12 / 2004$ & $\begin{array}{l}\text { EPTV } \\
\text { Central }\end{array}$ & $19 / 12 / 2004$ & $\begin{array}{c}\text { Chuva calusa } \\
\text { alagamentos } \\
\text { em São } \\
\text { Carlo:s }\end{array}$ & $\begin{array}{c}30 \mathrm{~cm} \text { (citado na } \\
\text { notícia) }\end{array}$ & $\begin{array}{c}\text { "Danos aos } \\
\text { comerciantes" }\end{array}$ & $\bar{x}$ & , & $x$ & $\begin{array}{l}\text { Alagamento na } \\
\text { lagoa Serena, } \\
\text { praça Itália, } \\
\text { mercado municipal } \\
\text { e na marginal }\end{array}$ \\
\hline $5 / 1 / 2005$ & $\begin{array}{c}\text { Primeira } \\
\text { Página }\end{array}$ & $4 / 1 / 2005$ & $\begin{array}{c}\text { Chuva causa } \\
\text { alagamento e } \\
\text { transtorno no } \\
\text { trânsito }\end{array}$ & $\begin{array}{l}\text { Cerca de } 10 \mathrm{~cm} \\
\text { (aferido por } \\
\text { observação de } \\
\text { foto) }\end{array}$ & $\bar{x}$ & $\begin{array}{c}\text { Chuvas } \\
\text { começaram a } \\
\text { cair na noite de } \\
\text { segunda-feira e } \\
\text { perduraram } \\
\text { durante toda } \\
\text { terça-feira }\end{array}$ & : & \begin{tabular}{|c|} 
Baixada do \\
Mercado \\
Municipal, Av. \\
Trabalhador São- \\
Carlense \\
(próximo a \\
Rodoviária), \\
Pontilhão da \\
praça Itália
\end{tabular} & $\begin{array}{c}\text { Chuvas causaram } \\
\text { vários pontos de } \\
\text { inundaçăo na } \\
\text { cidade. }\end{array}$ \\
\hline
\end{tabular}




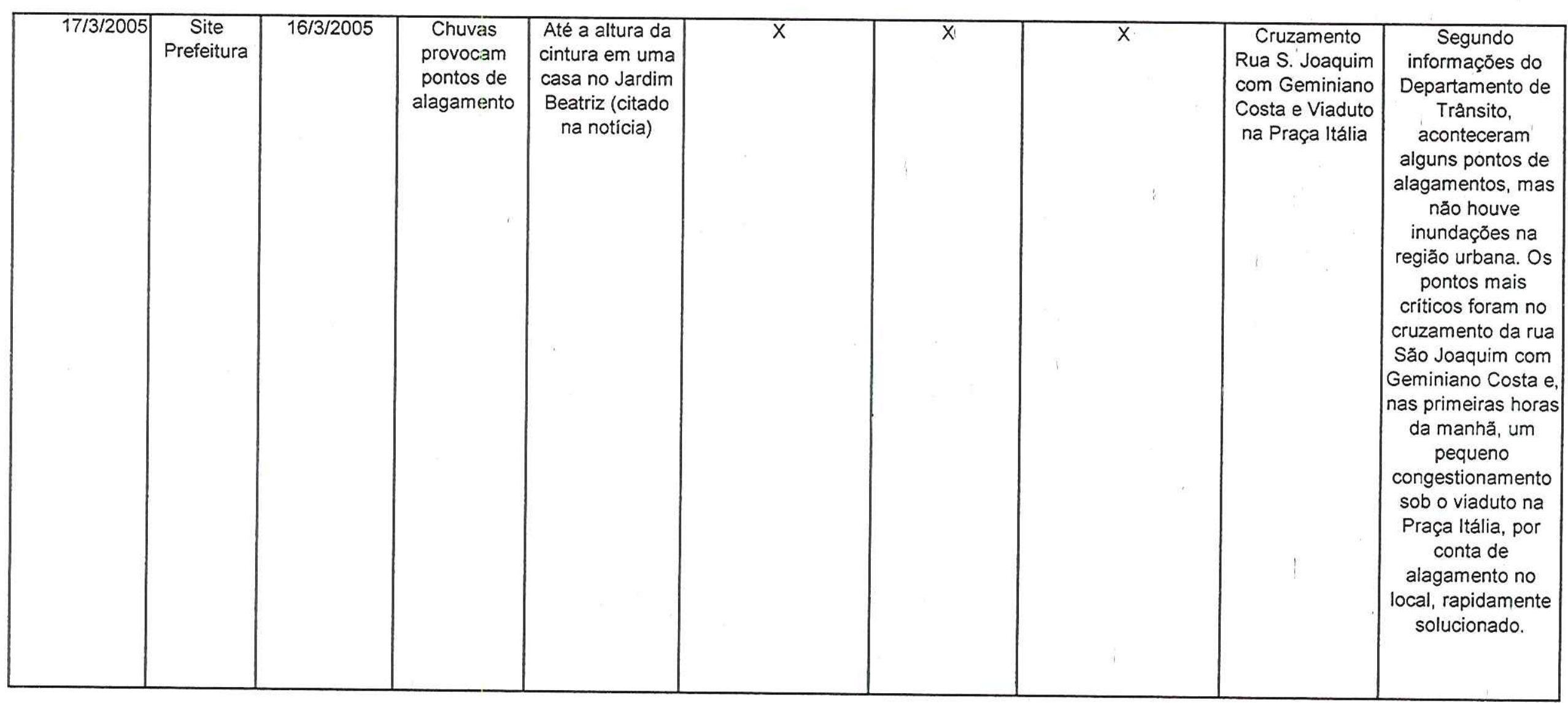




\begin{tabular}{|c|c|c|c|c|c|c|c|c|c|}
\hline $16 / 3 / 2005$ & $\begin{array}{l}\text { EPTV } \\
\text { Central }\end{array}$ & $16 / 3 / 2004$ & $\begin{array}{l}\text { Chuva causa } \\
\text { estragos em } \\
\text { São Carlos }\end{array}$ & $x$ & $\begin{array}{c}\text { Parte de um } \\
\text { barranco desabou na } \\
\text { avenida Marginal. }\end{array}$ & $x$ & $x$ & $x$ & 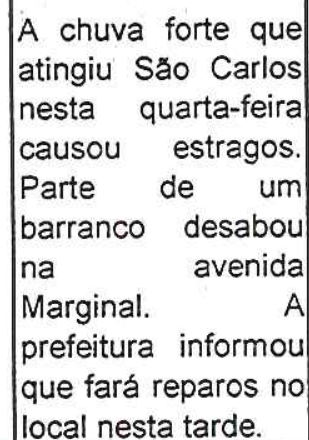 \\
\hline
\end{tabular}

